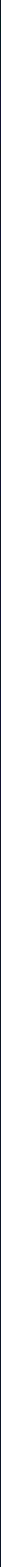




\section{ECCLESIA SEMPER REFORMANDA A CONGREGAÇÃO DOS LÓIOS E A REFORMA DA IGREJA (ITÁLIA, PORTUGAL E ÁFRICA - 1404-1580)}

NUNO DE PINHO FALCÃO 


\section{Título: Ecclesia Semper Reformanda. A Congregação dos Lóios e a Reforma da Igreja (Itália, Portugal é África - 1404-1580)}

Autor: Nuno de Pinho Falcão

Design gráfico: Helena Lobo Design I www.hldesign.pt

Imagem da capa: Escudo de Armas do Reitor Geral dos Lóios - Pontifical do Convento de S. João de Xabregas.

Fotografia de João Loureiro

Coedição: CITCEM - Centro de Investigação Transdisciplinar Cultura, Espaço e Memória

Via Panorâmica, s/n | 4150-564 Porto I www.citcem.org I citcem@letras.up.pt

Edições Afrontamento, Lda. I Rua Costa Cabral, 859 | 4200-225 Porto

www.edicoesafrontamento.pt I geral@edicoesafrontamento.pt

Coleção: Teses Universitárias, n. $^{\circ} 10$

N. ${ }^{\circ}$ edição: 1946

ISBN: 978-972-36-1718-4 (Edições Afrontamento)

ISBN: 978-989-8351-94-4 (CITCEM)

Depósito legal: 450312/18

DOI: https://doi.org/10.21747/9789898351944/cong

Porto, dezembro de 2018

Impressão e acabamento: Rainho \& Neves Lda. I Santa Maria da Feira geral@rainhoeneves.pt

Distribuição: Companhia das Artes - Livros e Distribuição, Lda.

comercial@companhiadasartes.pt

Trabalho cofinanciado pelo Fundo Europeu de Desenvolvimento Regional (FEDER) através do COMPETE 2020 Programa Operacional Competitividade e Internacionalização (POCI) e por fundos nacionais através da FCT, no âmbito do projeto POCI-01-0145-FEDER-007460. 
Aos meus Pais e Irmãos. Aos diletos do meu coração.

À memória das que já não podem ler este livro, mas cuja recordação em mim não se esbate.

À memória de meu tio décimo-sétimo avô, Dom Afonso Anes Nogueira, Bispo de Coimbra e Arcebispo de Lisboa, um dos fundadores Lóios.

Beati mortui, qui in Domino moriuntur amodo. Etiam, dicit Spiritus, ut requiescant a laboribus suis; opera enim illorum sequuntur illos Apocalipse de S. João, 14: 13 


\title{
SUMÁRIO
}

\author{
ABREVIATURAS
}

PAPAS (1404-1580)

Os Lóios e a Reforma da Igreja: Um itinerário de pesquisa 27

$\begin{array}{ll}\text { Estrutura da Obra } & 29\end{array}$

Periodização $\quad 32$

Estado da Arte $\quad 34$

$\begin{array}{ll}\text { Fontes } & 45\end{array}$

$\begin{array}{ll}\text { Bibliografia } & 54\end{array}$

$\begin{array}{ll}\text { Metodologia } & 56\end{array}$

I. LÓIOS: CONTEXTOS GERAIS E MATRIZ CARISMÁTICA

1. Reforma da Igreja na Europa dos sécs. XIV e XV: Entre o ideal e a prática 63

1.1. Reforma: considerações em torno de um conceito $\quad 63$

$\begin{array}{ll}\text { 1.2. Contextos de uma Europa em Reforma } & 70\end{array}$

$\begin{array}{ll}\text { 1.2.1. A Europa da crise: sécs. XIV e XV } & 71\end{array}$

1.2.2. A Itália, de Avinhão a Eugénio IV (1309-1447) 74

$\begin{array}{ll}\text { 1.2.3. O Portugal de Avis } & 83\end{array}$

1.3. O Cisma e a urgência de Reforma 88

1.3.1. 1309 - O Papa em Avinhão $\quad 88$

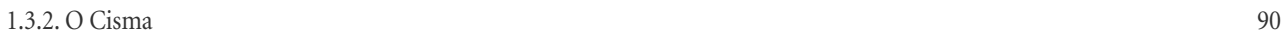

1.3.3 Ecclesia semper reformanda est. Concílios, conciliarismo, autoridade papal e reforma da Igreja 92

2. A Congregação de S. Jorge em Alga de Veneza $\quad 101$

2.1. Origens e Fundadores: particularidades de uma proposta reformista $\quad 102$

2.2. Linhagem e Congregação: o papel da Família no nascimento e consolidação da Congregação de Alga 116

2.3. Eugénio IV (Gabriel Condulmer), a estrutura institucional e a construção material 134

2.3.1. Gabriel Condulmer — Cónego, Bispo e Cardeal: perfil de um jovem reformador 135

2.3.2. Eugénio IV Papa: um pontífice reformista 142

2.3.3. Eugénio IV Papa: a institucionalização da Congregação de S. Jorge em Alga 153

2.4. Lourenço Justiniano e a criação de um ideal espiritual 160

2.4.1. Lourenço Justiniano — Cónego de Alga 161 
2.4.2. Lourenço Justiniano — Bispo de Castello e Protopatriarca de Veneza 167

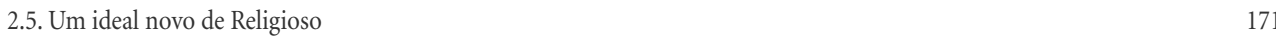

2.5.1. Comunidade de cónegos seculares — Vita Apostolica 175

2.5.2. Congregações de sacerdócio ativo: um modelo para a Igreja Moderna 178

II. LÓIOS: ENTRE O CARISMA E A PRAXIS 183

3. Os Cónegos Seculares de S. João Evangelista e o Carisma da Reforma 185

3.1. In principio erat. As origens Lóias à luz dos movimentos eclesiais no Portugal quatrocentista 185

3.1.1. Movimentos reformistas em Portugal nas primeiras décadas do séc. XV 186

3.1.2. Fundação e Fundadores Lóios em contexto de reforma 202

3.2. Alga como modelo: João Vicente, Afonso Nogueira e a Cúria Romana 210

3.3. Os Lóios, a Congregação de Alga e a Cúria Romana: o carisma reverso 227

4. A Reforma entendida pelos Lóios: Do Claustro e do Século 253

4.1. Carisma e espiritualidade na Congregação de S. João Evangelista 253

4.2. Os Lóios e a administração hospitalar 268

4.3. Um carisma involuntário: os Lóios e a educação 284

4.4. Atuação missionária em África: debates e disputas 294

4.4.1. Os Lóios na missionação africana: um problema por resolver? 295

4.4.2. Evangelizar ou Educar: o modelo Lóio para o Congo e os congoleses 306

$\begin{array}{ll}\text { CONCLUSÃO } & 317\end{array}$

$\begin{array}{lr}\text { FONTES } & 325\end{array}$

$\begin{array}{ll}\text { BIBLIOGRAFIA } & 333\end{array}$

$\begin{array}{lr}\text { ANEXOS } & 349\end{array}$

$\begin{array}{ll}\text { Anexo documental } & 351\end{array}$

$\begin{array}{lr}\text { Quadros } & 369\end{array}$

$\begin{array}{ll}\text { Anexo genealógico } & 388\end{array}$ 


\section{ABREVIATURAS}

ADB Arquivo Distrital de Braga

ADP Arquivo Distrital do Porto

AHHC Arquivo Histórico do Hospital das Caldas

ANTT Arquivo Nacional da Torre do Tombo

ASV Arquivo Secreto Vaticano

AUC Arquivo da Universidade de Coimbra

AVNC Arquivo dos Viscondes de Vila Nova de Cerveira

BA Biblioteca da Ajuda

BAV Biblioteca Apostólica Vaticana

BNP Biblioteca Nacional de Portugal

BPE Biblioteca Pública de Évora

n. Nascimento

P. Papa (eleição)

$\dagger$ Morte 


\section{PAPAS $^{1}(1404-1580)$}

\begin{tabular}{|c|c|c|c|}
\hline Nome & Nascimento & Eleição & Morte \\
\hline Bonifácio IX Tomacelli & ca. 1350 & 2/11/1389 & $1 / 10 / 1404$ \\
\hline Inocêncio VII dei Migliorati & 1336 & $17 / 10 / 1404$ & $6 / 11 / 1406$ \\
\hline Gregório XII Correr & ca. 1335 & $30 / 11 / 1406$ & $18 / 11 / 1417^{2}$ \\
\hline Martinho V Collona & ca.1369 & $11 / 11 / 1417$ & $20 / 02 / 1431$ \\
\hline Eugénio IV Condulmer & 1383 & $3 / 03 / 1431$ & $23 / 02 / 1447$ \\
\hline Nicolau V Parentucelli & $15 / 11 / 1397$ & $6 / 03 / 1447$ & $24 / 03 / 1455$ \\
\hline Calisto III de Borja & $31 / 12 / 1378$ & $8 / 04 / 1455$ & $6 / 08 / 1458$ \\
\hline Pio II Piccolomini & $18 / 10 / 1405$ & $19 / 08 / 1458$ & $15 / 08 / 1464$ \\
\hline Paulo II Barbo & $23 / 02 / 1417$ & $30 / 08 / 1464$ & $26 / 07 / 1471$ \\
\hline Sisto IV della Rovere & $21 / 07 / 1414$ & $9 / 08 / 1471$ & $12 / 08 / 1484$ \\
\hline Inocêncio VIII Cibo & 1432 & $29 / 08 / 1484$ & $25 / 07 / 1492$ \\
\hline Alexandre VI de Borja & ca. 1431 & $11 / 08 / 1492$ & $18 / 08 / 1503$ \\
\hline Pio III Piccolomini & $29 / 05 / 1439$ & $22 / 09 / 1503$ & $18 / 10 / 1503$ \\
\hline Júlio II della Rovere & $5 / 12 / 1443$ & $1 / 11 / 1503$ & $21 / 02 / 1513$ \\
\hline Leão X de Medici & $11 / 12 / 1475$ & $9 / 03 / 1513$ & $1 / 12 / 1521$ \\
\hline Adriano VI Boeyens d'Edel & $2 / 03 / 1459$ & $9 / 01 / 1522$ & $14 / 09 / 1523$ \\
\hline Clemente VII de Medici & $26 / 05 / 1478$ & $19 / 11 / 1523$ & $25 / 09 / 1534$ \\
\hline Paulo III Farnese & $29 / 02 / 1468$ & $13 / 10 / 1534$ & $10 / 11 / 1549$ \\
\hline Júlio III Ciocchi del Monte & $10 / 09 / 1487$ & $7 / 02 / 1550$ & $23 / 03 / 1555$ \\
\hline Marcelo II degli Spannocchi & $3 / 05 / 1501$ & $9 / 04 / 1555$ & $1 / 05 / 1555$ \\
\hline Paulo IV Carafa & $28 / 06 / 1476$ & $23 / 05 / 1555$ & $18 / 08 / 1559$ \\
\hline Pio IV Marignano & $31 / 03 / 1499$ & $25 / 12 / 1559$ & $9 / 12 / 1565$ \\
\hline Pio V Ghislieri & $17 / 01 / 1504$ & $7 / 01 / 1566$ & $1 / 05 / 1572$ \\
\hline Gregório XIII Buoncompagni & $7 / 01 / 1502$ & $13 / 05 / 1572$ & $10 / 04 / 1585$ \\
\hline
\end{tabular}

Fonte: IPPOLITO, 2000.

\footnotetext{
${ }^{1}$ Esta listagem inclui apenas, para o período de vigência cismática, os Papas da obediência romana.

${ }^{2}$ Ainda que novembro de 1417 seja a data de morte de Gregório XII, o fim do seu pontificado está datado de 1415, quando resigna ao Pontificado no Concílio de Constança.
} 
PRÓLOGO

ELVIRA AZEVEDO MEA 
Parece-me bem significativo o início da introdução desta obra: «São infinitas as formas de abordar a História, como infinitas são as formas de cada um de nós abordar a vida. Um velho aforismo diz que à nossa porta começam todos os caminhos, cabe-nos apenas escolher o desejado».

Com efeito o autor, Nuno de Pinho Falcão, no seu processo de formação universitária, que acompanhei de perto, desde a licenciatura, ao mestrado e ao doutoramento, foi abordando a vida com uma forte vontade de vencer, denodo, alegria e vivacidade, demonstrando uma maturidade que só se alcança nesses verdes anos com experiências vivenciais sofridas.

Com uma curiosidade infinita pela História e suas infinitas abordagens, a pouco e pouco ele foi-se inserindo e privilegiando a História Religiosa, Cultural e das Mentalidades, de modo a perceber e compreender cada vez mais a fundo as sendas infindas das vivências espirituais, da religiosidade, com particular incidência nas épocas mais conturbadas e complexas, como o imenso mundo problemático da Reforma.

Foi um caminho difícil de escolher, até porque o Nuno sempre ávido de saber mais e mais, frequentemente enveredava por este ou aquele meandro mais obscuro da História Religiosa e Cultural que era preciso aprofundar.

A História Religiosa ligada à Reforma era, pois, um desafio que entusiasmava, tanto mais que em diferentes perspectivas, contextos e níveis, o desconhecido aparecia a cada passo. Daí o enfoque em autores como Gerhart Ladner, Pierre Chaunu ou Silva Dias, cuja escrita problematizante foi um impulso incentivante.

Em 2005, o Nuno recebe uma bolsa de mérito da Universidade do Porto, que lhe permite inscrever-se no Curso de Mestrado em Estudos Locais e Regionais com o tema Os Azuis no Porto. O Convento Lóio de Nossa Senhora da Consolação (1490-1640).

Esta dissertação possibilitou-lhe fazer emergir a Congregação dos Cónegos Seculares de S. João Evangelista dum desconhecimento geral, focando a sua originalidade, as relações estreitas com a nobreza, já que os seus membros provinham dessa elite, as suas ligações fundacionais à Itália.

Em 2009, ainda antes de acabar o Mestrado, o Nuno de Pinho Falcão recebe mais um prémio, o de Paleografia e Diplomática, concedido pelo Arquivo da Universidade de Coimbra. Desde 2008 que fazia um estágio de técnico superior no Museu de Arte Sacra da Santa Casa da Misericórdia de Penafiel, findo o qual passou a desempenhar a função de técnico superior responsável pelo dito Museu, sempre em dedicação exclusiva.

Em 2010 fez um outro estágio de técnico superior no Museu Regional de Angra do Heroísmo, segundo o mesmo regime.

Numa perspectiva muito abrangente e profunda, é óbvio que a dissertação de Mestrado, a primeira obra de folgo do Nuno de Pinho Falcão, deixava outras questões em aberto, nomeadamente uma visão monográfica e de conjunto dos conventos da Congregação, no contexto da Igreja portuguesa, uma certa acção reformadora em plena época de viragem que urgia aprofundar.

Assim, em 2011, o Nuno Falcão apresentou este projecto de dissertação de Doutoramento, que só então podia concretizar mediante uma bolsa da Fundação para a Ciência e Tecnologia. 
Em 2012 tudo caiu por terra com a dissertação de Doutoramento Os Lóios em Portugal: Origens e Primórdios da Congregação dos Cónegos Seculares de S. João Evangelista (1420-1500) apresentada na Universidade Nova de Lisboa, praticamente com o mesmo tema.

Perante a notícia, o ar atónito dos colegas e de alguns docentes que se apressaram a tentar relativizar a «desgraça», o Nuno, entusiasmado, apresentou um outro projecto que ainda o entusiasmava mais, pois estando estudada a parte institucional, antes obrigatória, podia avançar directamente para um estudo mais problematizante, mais analítico em questões de espiritualidade, podendo então aprofundar a questão de sendo perfeitamente nacional, a Congregação dos Cónegos Seculares de S. João Evangelista, provir dum modelo institucional concebido pela elite eclesiástica italiana de então, próxima do Papado, que apresentava um inequívoco cariz reformista.

Essa característica já vislumbrada durante a preparação do Mestrado, poderia permitir avançar no sentido de verificar a existência, através da acção reformadora dos Lóios na Igreja portuguesa do século XV, duma constante que não só reiteraria a tese de Chaunu acerca da continuidade dos movimentos reformistas da Igreja ao longo do tempo, como a superficialidade da conceptualização e calendarização da Reforma e Contra-reforma.

Simultaneamente podia ainda tocar outras das originalidades da Congregação: a importância da sua vertente secular, o seu projecto de missionação no Congo, a sua competência na gestão de instituições régias, mormente as ligadas à saúde.

Entretanto, a partir de Julho de 2010 o Nuno Falcão já consegue trabalhar no Porto como técnico superior inventariante no projecto de inventariação dos Bens Culturais da Igreja da Diocese do Porto, então ligado ao seu Secretariado Diocesano de Liturgia. Em 2012-2014 é já membro da Comissão Científica de acompanhamento do mesmo inventário de Bens Culturais da Igreja Portucalense.

A dissertação avança, a estadia nos Arquivos do Vaticano ultrapassa as expectativas do Nuno Falcão, pois então apresenta provas de que a Congregação de S. João Evangelista, os Lóios, tal como os Cónegos de Alga a quem estão indissoluvelmente ligados pela sua matriz fundacional, mais do que reformadores foram reformistas por serem reformados.

Como o autor explica na sua conclusão, «ao adoptarem um modo de vida reformado, constituíam-se como agentes de reforma quanto mais não fosse pelo simples exemplo do seu modo de vida».

Assim, de acordo com Pierre Chaunu, constatou-se que a crise da Igreja do século XIV, particularmente o cisma com todas as consequências negativas, proporcionou um consenso de teólogos e outros homens da Igreja, no sentido de avançarem para uma mudança que todos consideravam urgente.

O carisma das Congregações de Alga e de S. João Evangelista, como afirma o autor, «constituiu-se como paradigmático de uma ideia traduzida em esforços (que são eles a própria constituição das Congregações) dirigidos para a recuperação de um valor pré-existente na composição espiritual e material do mundo, que foi o seu ideal de instituírem um modo de vida novo que recuperava (assim o acreditavam) o modo de vida original do Cristianismo».

Era urgente uma reforma in capita et in membris mas não obstante as ligações estreitas com o Papado, o grupo de jovens fundadores da Congregação de Alga começam por reformar-se e reformar 
a Igreja mediante um processo de conversão individual que alastra para o colectivo. Este grupo de clérigos seculares experimenta um novo modo de vida comum, de tipo observante com uma exigência litúrgica particular, uma forte componente pastoral mas com plena liberdade, sem votos solenes.

Este tipo de Congregação, tal como a de S. João Evangelista, foram depois desenvolvidos por algumas das instituições que constituíram a pedra angular da Reforma católica, como os Jesuítas e os Oratorianos.

A pesquisa desenvolvida permitiu reconhecer a ligação regular, o diálogo que se mantém ao longo do tempo entre as duas Congregações, a italiana e a portuguesa, de modo que é num clima de normalidade que surge em 1568 o breve papal que encarregava os Lóios de procederem à reforma das comunidade de Alga, então vivendo uma fase de crise aguda.

Torna-se também muito clara a importância dos Lóios em Portugal, desde a sua vocação muito específica para o culto divino, à participação activa em tentativas de Reforma da Igreja pela família de Avis, enfim o seu carisma e prestígio levam-nos a serem chamados para uma função educativa que ultrapassava completamente a exercida em Santo Elói de Lisboa, desde projectar uma acção missionária a educar os nobres congoleses, a preparar os candidatos para ordens sacras.

Em pleno século XVI os Lóios tornam-se os gestores de várias instituições régias inovadoras, modernas, como a gestão hospitalar e a administração de estruturas de assistência e outras afins, criando ou reestruturando organismos centralizadas, com maior aproveitamento de recursos materiais e humanos, eficazes, transparentes.

O Concílio de Trento que se pautou por demasiadas regras rígidas mais típicas duma Contra-reforma do que dum ambiente conciliatório não se coadunava nem com a liberdade nem com uma concepção e prática de Reforma in capita et in membris das Congregações e Alga e dos Lóios.

Os tempos eram outros mas de modo algum apagaram o seu carisma, influência e uma constante e formidável acção reformadora.

Vale a pena ler esta obra, pois a conceptualização, os contornos e os movimentos de Reforma da Igreja apresentam-se cada vez mais nítidos e precoces. O seu carácter inédito é outra motivação, para além de que está muito bem escrita.

Parabéns Nuno de Pinho Falcão, ficamos à espera da próxima publicação!

Teggiano, 25/07/2018 
NOTA PRÉVIA 
Apesar de revisto e melhor preparado à edição como livro, o trabalho que aqui se apresenta é estruturalmente a tese de doutoramento em História que defendi em julho de 2016 na Universidade do Porto, intitulada A reforma em carisma e ação: A Congregação de S. João Evangelista (Lóios). (Itália, Portugal e África - ca.1420/1580) . $^{3}$

Foi o culminar de um trabalho de pesquisa de quase cinco anos (2011-2016), por sua vez inserido num mais vasto e sistemático interesse científico que tenho dedicado à Congregação dos Cónegos Seculares de S. João Evangelista (Lóios), remontando já a 2005 e à minha dissertação de mestrado, apresentada à mesma Faculdade 4 .

É importante nunca perder de vista este facto, pois ele (mais que qualquer outro) justifica a forma como se estrutura este livro e a particularidade da sua escrita. Uma tese será sempre uma tese, mesmo quando preparado para uma edição mais alargada, e tal poderá o leitor notar no aparato crítico mais elaborado e volumoso, na bibliografia mais dilatada, na solidez monolítica do texto. Pede-se perdão por estas características que poderão obstar a uma leitura mais recreativa e menos fatigante.

Esta edição, além do que representa pessoalmente de reconhecimento do trabalho desenvolvido ao longo do doutoramento, entendo-a como um importante veículo para uma divulgação mais alargada das ideias que nortearam este estudo sobre a Congregação dos Lóios.

Foi meu objectivo contribuir para uma renovada reflexão sobre as reformas religiosas que marcam o final da Idade Média e o início da Idade Moderna, em particular a discussão sobre a sua natureza específica e o alargamento do seu conceito.

Tratou-se de recuperar o trabalho seminal de G. B. Ladner ${ }^{5}$, e do grupo de académicos norte-americanos que seguiu a sua linha de pensamento, e ver as reformas eclesiais quatrocentistas e quinhentistas não como um evento centrado na reforma luterana e nas suas consequências, mas como um fenómeno de longo tempo e com diversas facetas, por sua vez alocável numa ideia cristã de reforma que, segundo Ladner, é identificável desde os primeiros séculos do cristianismo e que faz parte do património espiritual e cultural comum das suas diversas confissões.

O papel das reformas quatrocentistas, e a sua importância enquanto formas próprias de vivência de uma ideia de reforma, e não meros antecedentes das reformas do século seguinte, tiveram em Portugal uma importante vitalidade, no centro da qual podemos identificar a Congregação dos Lóios.

Esta perceção dos Lóios como Congregação de charneira de um universo reformista era já levantada em trabalhos de Silva Dias ou José Adriano de Freitas Carvalho, mas sem nunca ter sido testada numa análise combinatória que juntasse a reflexão teórica do que é o conceito de reforma na Igreja (afinal tanto se fala em reformas religiosas, mas pouco se reflete sobre a efetiva natureza desta ideia e da sua prática) à análise de caso de um grupo específico que se pudesse entender como reformista à luz desse mesmo conceito teórico.

Este foi o âmago de todo o esforço de investigação desenvolvido durante o doutoramento, a sua motivação profunda e o motivo pelo qual a palavra mais frequente desta obra é Reforma! Este último

${ }^{3}$ FALCÃO, 2016.

${ }^{4}$ FALCÃO, 2009.

${ }^{5}$ LADNER, 1959. 
facto, bem salientado no decurso das provas públicas de doutoramento, não deve ser encarado como uma forma de convencer pela repetição, mas apenas a clara centração da análise desenvolvida ao longo destas páginas num tema que se revela fundamental para a compreensão do percurso de uma ideia que, acredito, desempenhou um papel histórico central no universo cristão.

Se esta edição puder almejar algo, que seja o de contribuir para aprofundar e alargar o debate em torno da ideia e da prática reformistas, servindo a ciência como fonte e motor para novas e diversificadas investigações.

Não poderia terminar esta nota prévia sem renovar os agradecimentos que já na tese tive oportunidade de formular, adicionando os que se impõe à presente edição.

Antes de mais o agradecimento ao CITCEM e às Edições Afrontamento, entidades instituidoras do prémio «Teses Universitárias», em cuja edição de 2017 foi contemplada a minha tese doutoral, permitindo a sua presente edição. Depois do longo processo que foi a construção e maturação da tese, é um importante reconhecimento do esforço realizado.

Ao júri das minhas provas doutorais, presidido pelo Prof. Doutor Luís Miguel Duarte, e composto pelos Profs. Doutores Amélia Polónia, Elvira Mea, Isabel Pina, Pedro Tavares e Vítor Teixeira, fica o agradecimento pela forma como contribuíram decisivamente para esse importante momento de transição.

Devo particularizar o agradecimento à Prof. ${ }^{a}$ Elvira Mea, que como orientadora foi a pessoa que mais profundamente acompanhou a década que dediquei ao estudo dos Lóios. Como já escrevi, a tese que deu origem a este livro encerrava em si uma relação exemplar de orientação, patente na generosa dedicação com que a Prof. ${ }^{a}$ Elvira Mea me orientou pelos meandros do mestrado e do doutoramento. Acrescento agora o agradecimento à contínua generosidade que a levou a aceitar prefaciar esta obra, o que muito me honrou.

Ao Prof. Pedro Vilas-Boas Tavares devo também um agradecimento aprofundado, pois são os seus trabalhos sobre os Lóios que estão na base de todo o meu interesse e dedicação a esta Congregação Canonical. Espero que este livro seja um digno penhor de tal dívida.

Ainda no mundo da FLUP, a minha casa desde 2001, agradeço aos professores e investigadores que ao longo destes anos se interessaram por este trabalho e pelo seu autor. Saliento os meus colegas de jornada: a Cátia, a Helena, a Filipa e o Âlvaro, bem como a colega e amiga Patrícia Costa, cuja amizade dura já o tempo que dedico aos Lóios.

Para a realização da tese que deu origem a este livro, recebi ajudas imprescindíveis, de diversa natureza, institucionais e pessoais, que cumpre agradecer com justeza.

À Fundação para a Ciência e Tecnologia, pela concessão da bolsa que tornou possível sustentar materialmente a pesquisa e a frequência do curso de Doutoramento.

Aos arquivos e bibliotecas citados neste livro, em particular a da FLUP, pelos seus serviços tendencialmente exemplares.

À Sr. ${ }^{a}$ Doutora Isabel Castro Pina, pela amabilidade com que acolheu o pedido de consulta da sua tese e a generosidade com que cedeu o ficheiro da mesma. 
Ao Sr. Eng. ${ }^{\circ}$ D. Luís de Azevedo de Vasconcelos e Sousa, que acedeu com grande amabilidade à consulta de documentação do seu arquivo familiar, o dos Marqueses de Ponte de Lima (representantes dos morgadios dos Nogueira).

Ao Rev. ${ }^{\circ}$ Dom Francesco Trolese, OSB, Abade emérito de St. ${ }^{a}$ Justina de Pádua, pelo acolhimento na biblioteca da Abadia, tão proximamente ligada à fundação da Congregação de S. Jorge em Alga, e pela generosa oferta de bibliografia.

Agradeço ainda o acolhimento sincero do Prof. Doutor Gianpaolo Romanato, da Universidade de Pádua e da Pontifícia Comissão de Ciências Históricas.

Por fim os agradecimentos pessoais. O apoio e a amizade da família, dos velhos e dos novos amigos, com quem se partilha (pobres deles!) as alegrias e dificuldades do percurso e que por isso o tornam ainda melhor, fazem brotar do coração uma gratidão luminosa.

À Patrícia Teixeira Santos, aos P.es Joaquim Teixeira e Manuel Amorim, ao João Loureiro (a quem agradeço ainda a imagem que orna a capa deste livro), à Eliana Calado e à Alexandra Cardoso, à Marlene Pinto, ao José Monteiro. À amizade fraterna da Laura Sarmento, da Telma Correia e do meu primo Miguel Martins Costa. À minha prima Bárbara Falcão e à memória da minha tia Isabel Falcão Passos.

Aos Pais. Aos Manos.

Obrigado. 
INTRODUÇÃO 
São infinitas as formas de abordar a História, como infinitas são as formas de cada um de nós abordar a vida. Um velho aforismo diz que à nossa porta começam todos os caminhos, cabe-nos apenas escolher o desejado.

O meu interesse pelos cónegos Lóios tem já uma década, e longo tem sido o caminho que temos trilhado em conjunto: eu no meu papel de investigador, eles no seu de memória histórica, de outros tempos e outras formas de vivência espiritual e religiosa. O meu caminho, escolhido à saída «da minha porta», é voluntário, o deles é imposto pelo desejo do investigador de melhor os conhecer e mais profundamente caracterizar.

Congregação exclusivamente portuguesa, com nove casas conventuais em quatro séculos de existência, número de religiosos que não terá ultrapassado algumas centenas, poderá levar a uma questão quase economicista: qual o real interesse em estudar a Congregação dos Cónegos Seculares de São João Evangelista (padres Lóios)?

Os autores que lhes têm dedicado alguma atenção sustentam a sua importância, enquanto objeto de estudo, na sua ligação à Casa de Avis, na proximidade aos reis e rainhas desta dinastia, no valimento que lhes assegurou proteção, expansão, enriquecimento e um conjunto de encargos espirituais e administrativos de alguma monta.

Destaca-se o seu papel como educadores das elites africanas e o de administradores hospitalares profissionais avant la lettre, com a administração de alguns hospitais régios e da Casa de Bragança, como foram os hospitais real de Coimbra, das Caldas da Rainha, e até o hospital real de Todos os Santos de Lisboa.

No entanto valimento e encargos são resultado de uma realidade estrutural mais profunda da Congregação dos Lóios: a sua natureza de congregação clerical secular de vida comum (que veremos ser, seguindo o modelo de Alga, uma novidade no universo congreganista), de notório perfil reformista.

Creio ser neste ponto que reside a verdadeira resposta à dúvida mencionada, quando consideramos, para além da exiguidade numérica dos seus religiosos e Casas, o seu papel enquanto congregação religiosa reformista.

A sua ligação à congregação de São Jorge em Alga de Veneza coloca os padres Lóios na linha reformista da Itália, em particular de Veneza, do século XV. Alga não foi só um figurino exterior que se adotou, existindo um verdadeiro (re)conhecimento de pessoas e de ideias, de círculos reformadores, que ultrapassaram as dificuldades do espaço e do tempo para estender um modo de vida que se acreditava ser o apostólico, e como tal o original de uma Igreja que se pretende reformar.

Sendo certo que os números em História têm o seu relevo, a exiguidade numérica (em Casas e efetivos) destas congregações não diminui a importância do seu papel na relação com um dos elementos estruturais do pensamento cristão ocidental: a ideia de reforma, entendida na formulação de Gerhart Ladner, no seu The idea of Reform ${ }^{6}$, que nas palavras de José Adriano de Freitas Carvalho, é «um antigo, mas tanto quanto sabemos, ainda não superado, trabalho».

\footnotetext{
${ }^{6}$ LADNER, 1959.
}

${ }^{7}$ CARVALHO, 1995: 638. Não se engana o prof. José Adriano de Freitas Carvalho, para o que basta verificar a vitalidade da escola de Ladner, de que existe um recente testemunho coletivo em BELLITO \& FLANAGIN, 2012b. 
No mesmo artigo de Freitas Carvalho reconhece-se o papel cimeiro dos Lóios na reforma da Igreja no Portugal do séc. XV, assumindo-se (de acordo com o pensamento de Pierre Chaunu sobre as reformas) como exemplo de um dos movimentos reformistas que abrem o período das grandes reformas religiosas do ocidente cristão.

Pensar os Lóios como congregação reformista é contribuir para o resgate da ideia e práticas reformistas da centração dicotómica das lutas entre confissões religiosas de um séc. XVI omnipotente, e de geografias que excluem países católicos que se mantêm genericamente firmes na ortodoxia Romana.

Portugal, pelos Lóios, por outras congregações religiosas (particularmente pelos movimentos de observância), pelos seus Príncipes e por entidades eclesiásticas e laicas, participou ativamente no universo reformista da Europa quatrocentista.

Pretende-se, nas páginas que se seguem, demonstrar este papel dos Cónegos Seculares de S. João Evangelista, à luz do entendimento dos autores citados, perspetivando como o seu ideal de vida e atuação (bem como o dos cónegos de Alga, base matricial e com quem têm um efetivo relacionamento), prefigura com clareza identificável o que vão ser soluções da reforma católica do séc. XVI. 


\section{OS LÓIOS E A REFORMA DA IGREJA: UM ITINERÁRIO DE PESQUISA}

O meu primeiro contacto com os Cónegos Seculares de São João Evangelista, também ocasionalmente chamados Homens Bons de Vilar (sobretudo no período inicial), de Cónegos Azuis ${ }^{8}$, e mais comummente conhecidos como Lóios', teve lugar em 2005 (nos primeiros passos do curso de mestrado em História Local e Regional), com a leitura de um artigo de Pedro Tavares que apresentava uma Congregação religiosa de marcado cariz reformista, que «ao contrário de outras famílias religiosa $[\ldots]$ não conta até hoje, infelizmente, com qualquer estudo monográfico de conjunto» ${ }^{10}$.

Devedor como sou do trabalho de Pierre Chaunu e da sua ideia das reformas em continuidade $^{11}$, foi sempre minha intenção trabalhar (como tive a oportunidade de salientar ${ }^{12}$ ) um tema que tivesse por pano de fundo a questão dos movimentos reformistas na Igreja, maxime a portuguesa, no período de transição da Idade Média para a Moderna, em particular no século que antecede as reformas quinhentistas. $\mathrm{O}$ objetivo era contribuir para um entendimento mais profundo e de longa duração de um movimento reformista que parece extravasar os limites estritos da tradicional historiografia das reformas religiosas.

Desde os primeiros passos de pesquisa, e até ao presente, tenho-me mantido convicto que a Congregação de S. João Evangelista é um caso paradigmático das iniciativas de carácter reformista na Igreja portuguesa quatrocentista, uma relevância que se aprofunda pela ligação fundacional a um movimento reformador mais vasto, centrado na Itália e com indelével ligação ao próprio poder Pontifício.

Em 2011 foi suprida a necessidade premente do «estudo monográfico de conjunto», de que falava Pedro Tavares, com a tese doutoral da Doutora Isabel Castro Pina ${ }^{13}$, que estudou a Congregação de S. João Evangelista, nas suas diversas facetas institucionais, das suas origens (ca. 1420) até ao final do séc. XV.

\footnotetext{
${ }^{8}$ Acerca das diversas designações da Congregação dos padres Lóios, o cronista Francisco de Santa Maria esclarece que os religiosos da sua congregação, ainda antes de terem designação oficial, eram denominados entre os fiéis que os conheciam por «bons homens de Vilar». A primeira designação formal terá sido de Congregação dos cónegos seculares de S. Salvador de Vilar de Frades (da comunidade fundacional) e que o Papa Pio II, a instâncias do rei Afonso V e por pedido de sua mulher a rainha Isabel (grande devota de S. João Evangelista e protetora dos Lóios), transformou em Congregação dos cónegos seculares de S. João Evangelista. A designação de Santo Elói foi originada por abuso, dado terem tomado conta do hospital de Santo Elói em Lisboa, onde estabeleceram a sua primeira comunidade na capital e de onde derivou Lóios (cf. SANTA MARIA, 1697: 235. Veja-se igualmente: TAVARES, 2001a; PINA, 2011: 1, 198 e segs.). Isabel Castro Pina acrescenta alguns outros designativos utilizados em documentos do séc. XV, testemunhando uma variedade que é reflexo de um percurso identitário que se foi construindo no tempo.

${ }^{9}$ A designação de Lóios era já antiga e usual em 1588, quando bula de Sisto V se dirigia aos Cónegos Seculares de S. João Evangelista «vulgo dictorum Loios in Portugalliae et Algarbiorum Regnis» (cf. ANTT - Congregação de S. João Evangelista, Convento de S. João Evangelista de Xabregas, mç. 6, doc. não numerado).

10 TAVARES, 2001 a.

${ }^{11}$ CHAUNU, 2002.

${ }^{12}$ FALCÃO, 2009.

${ }^{13}$ PINA, 2011.
} 
Com esta tese passaram os Lóios a contar com um estudo de fundo institucional, abrindo espaço a investigações de outra natureza. Foi o caso da pesquisa de doutoramento que deu origem a este livro: pensada originalmente como um estudo institucional da Congregação, transformou-se num estudo mais analítico, centrado em refletir questões anteriormente apenas contempladas com breves pinceladas, apesar da importância que assumem para a compreensão da realidade histórica dos Lóios e da sua Congregação.

Nascida no final de um grave contexto eclesial, o do Cisma e da sentida urgência de reforma in capite et membris, não nos podemos deixar enganar pelo facto da Congregação dos Cónegos Seculares de São João Evangelista ser uma Congregação de carácter exclusivamente nacional. Portuguesa na origem e portuguesa em todo o seu percurso (como portuguesa foi para desaparecer em definitivo com a legislação anticongreganista de 1833/34) adotou desde cedo, no entanto, um figurino carismático e institucional concebido para além das lusas fronteiras.

A matriz veneziana de $S$. Jorge em Alga de Veneza, abraçada por motivos que se explanarão no capítulo terceiro, transporta os padres Lóios, logo na sua origem, para o cerne de um movimento eclesial, centrado no norte e centro italianos, de cariz assumidamente reformista e com proximidade fundacional a uma elite eclesiástica que chega ao cume da Igreja: a Cátedra de S. Pedro.

A relação estrutural entre as duas Congregações, bem como as relações que estabelecem com os contextos em que se inserem, são relevantes para compreender a sua origem e desenvolvimento enquanto instituições eclesiais de carácter reformista.

Com base neste entendimento, este estudo centra-se na análise combinatória das características institucionais e carismáticas das duas congregações com o contexto histórico que define as suas pertenças enquanto instituições de cariz reformista. Pretende-se problematizar o surgimento das congregações e as suas características, enquanto instituições que se inserem no contexto histórico mais complexo dos movimentos reformistas na Igreja na transição para a Modernidade e que, por sua vez, estão profundamente imbricados nos contextos mais vastos da política e sociedade europeias.

Trata-se não já de analisar os Lóios como um ente institucional particular e isolado, estudado monograficamente, mas perspetivá-lo como estrutura institucional, com dimensão espiritual, humana e patrimonial, fundada num determinado ideário que, não sendo específica e exclusivamente seu, o coloca em diversos universos de pertencimento, principalmente os de cariz eclesiástico e reformista, tão manifestamente presentes na cristandade ocidental nos sécs. XV e XVI, mas também nos meandros de poder formados em torno da coroa portuguesa da dinastia de Avis.

Em suma, e para sintetizar em apenas uma questão o fio condutor que atravessará todas as páginas desta obra, dando-lhe forma e sentido, e partindo da afirmação de Silva Dias de que os Lóios foram «o protesto mais veemente contra os costumes do clero e a tentativa mais séria da sua reforma, que se fez em Portugal no decurso do século $\mathrm{XV} »^{14}$, atendendo à sua ligação à Congregação de $\mathrm{S}$. Jorge de Alga, e por via desta ao cerne do movimento reformista da Europa pós-cismática, pergunta-se pois: foram os Lóios uma congregação de carisma reformista? Se o foram, como tem sido repetido

${ }^{14}$ DIAS, 1960: 94. 
por diversos autores ${ }^{15}$, de que modo colocaram significativamente esse carisma em prática no Portugal de Avis?

A resposta a esta pergunta, de simples formulação, e que aparenta ter resposta em diversos trabalhos, obrigará no entanto a uma reflexão sobre o conceito de reforma no ocidente cristão, de como este se apresentava no final da Idade Média, e de como se reflete no carisma dos cónegos seculares de Alga e nos de S. João Evangelista de Portugal.

Reforma foi (e él6) no seio da Igreja um conceito operacional central, sustentáculo de dinamismo espiritual e pastoral, mas também institucional e cultural, que se consubstanciou nos diversos movimentos de reforma que a Igreja conheceu desde os seus primeiros séculos.

Este estudo pretende recuperar uma pequena fração do tecido histórico, em que diversos contextos tardo-medievais, de diferentes geografias, se interligaram num dado momento e produziram uma experiência comum sustentada num mesmo entendimento ontológico; procurando demonstrar como o carisma transplantado de Alga de Veneza a Portugal, e que é por natureza um conceito teórico $^{17}$, se converte em prática e vivência reformista no Portugal dos sécs. XV e XVI.

\section{Estrutura da Obra}

Pensada como um reflexo do seu objeto, esta obra organiza-se em duas partes, tantas quantas as Congregações Canonicais que o ocupam, com dois capítulos cada. Em suma, quatro capítulos que nos conduzirão através de uma narrativa que, das pinceladas gerais do universo cristão dos sécs. XIV e XV, nos conduzirá ao universo reformista italiano e, por este, ao português.

Um $1 .^{\circ}$ capítulo de contextualização justifica-se numa obra que coloca no seu cerne não apenas um estudo intrínseco da Congregação dos Lóios, mas o seu aparecimento, desenvolvimento e atuação inseridos num movimento de cariz espiritual e institucional que extravasa os limites do reino de Portugal, a que a Congregação se circunscreveu.

\footnotetext{
${ }^{15}$ Além da afirmação de Silva Dias, a ideia foi repetida por diversos autores. Citando alguns dos mais significativos: José Marques na sua obra sobre a arquidiocese de Braga no séc. XV (MARQUES, 1988: 868); Pedro Tavares em diversos artigos (por ex. em TAVARES, 1999; TAVARES, 2001a: 149 e seg.) e Isabel Castro Pina na sua tese de doutoramento (PINA, 2011).

${ }^{16}$ Só para dar uma nota sobre a questão da reforma na atualidade da Igreja Católica, mesmo depois de em meados do séc. XX se ter vivido um período entendido de reforma geral da Igreja, codificado e generalizado pelo II Concílio do Vaticano, e não entrando no atual pontificado que se apresenta sob signo reformista, já o pontificado de Bento XVI foi visto à luz do conceito, introduzido pelo Pontífice, da hermenêutica da reforma (veja-se: O’MALLEY, 2012; HITCHCOCK, 2008).

${ }^{17}$ Carisma, significando etimologicamente graça ou dom divino, assume-se no universo cristão como sinónimo de dom de Deus, transmitido pela ação do Espírito Santo, e em que se insere, por exemplo, o dom da vida consagrada, a que pertence também a vida claustral ( $v$ d. FALCÃO, 2004). O carisma das ordens e congregações religiosas insere-se assim no quadro mais vasto do carisma da vida consagrada, entendido como implicando a existência de uma chamada (de onde vocação, do latim vocatio, chamamento) a uma vida plena no compromisso com o serviço de Deus e do Seu reino na terra. Assim entendido, o carisma de uma congregação estará diretamente correlacionado com o carisma individual dos fundadores, e que os terá levado a constituir uma estrutura a partir da sua própria vocação. Tal não permite, no entanto, excluir da leitura do carisma o período histórico da fundação, a geografia particular em que ocorre, o meio cultural, a estrutura eclesial em que se desenvolve, as diversas pessoas que se juntaram ao fundador, já que tudo isto contribui para a compreensão do espírito particular de cada ordem ou congregação (cf. FOLEY, 2003).
} 
Focando o estudo na questão das linhas reformistas que atravessaram a história da Europa Ocidental nos sécs. XIV e XV, centrando-o nas relações existentes entre movimentos reformistas na Itália e em Portugal (de que a adoção do carisma de S. Jorge de Alga pelos Cónegos de S. João Evangelista é exemplo cabal), a compreensão da dinâmica social, política e religiosa de uma época marcada pelo tópico da crise e pela construção dos Estados vem sustentar o conhecimento que se pretende construir sobre os cónegos Lóios e as linhas da sua atuação.

Assim far-se-á uma leitura que sendo essencialmente focada sobre Portugal e os Estados Italianos, não deixará de lançar um olhar sobre o enquadramento conjuntural da Europa dos finais da Idade Média, como forma de compreender um ambiente coletivo. Europa, Itália, Portugal e a Igreja nos tempos de Avinhão, do Cisma e dos Concílios, serão os pontos que tratados darão, assim se espera, uma visão de um Ocidente cristão em transformação política, social, económica, religiosa, cultural e espiritual.

No entanto, e procurando estabelecer desde logo qual o conceito operativo de reforma com que esta tese trabalha, abrir-se-á este primeiro capítulo com uma análise do conceito (e da prática) de reforma no mundo cristão nos séculos que antecedem a cronologia deste trabalho. Este ponto é tanto mais importante quanto a ideia de reforma é o escopo teórico da ação de clérigos e leigos do ocidente cristão na transição da Idade Média para a Modernidade e é, como já ficou dito, o elemento central de questionamento deste livro.

Poder-se-á colocar a questão de até que ponto contextos de carácter tão alargado, e aparentemente genéricos, serão de real relevo para resolver o problema que aqui nos ocupa. É uma dúvida que se esclarece facilmente: a Congregação de S. João Evangelista, nascida em Lisboa e de carácter exclusivamente pátrio, está (como tem sido sobejamente afirmado, e se poderá comprovar neste mesmo trabalho) estruturalmente ligada à congregação matricial de S. Jorge em Alga de Veneza. Esta, por sua vez, ainda que nascida num humilde priorado Agostinho, situado numa pequena ilha da laguna veneziana e deixado quase ao abandono pelos seus religiosos, foi alfobre de Papas, cardeais, patriarcas, arcebispos e bispos com um papel relevante no universo italiano quatrocentista.

A imbricação dos cónegos de Alga com o Papado no final do cisma do Ocidente, e nas décadas subsequentes, intimamente conectado com a ascensão de uma linhagem veneziana ao sólio pontifí$\mathrm{cio}^{18}$, coloca-os no cerne da política eclesiástica e secular, da Itália e da Europa, no período do Cisma e no decurso do séc. XV.

A compreensão do contexto específico do aparecimento da Congregação de Alga, nascida num contexto de crise eclesial e numa Itália em crise política e demográfica, obriga a compreender outros contextos com que se interliga.

Uma leitura de conjunto que identifique o séc. XIV (em cujo término se situa a origem da Congregação de Alga), e a 1.a metade do séc. XV como períodos de crise e berço de dinâmicas superadoras, implica uma rápida leitura dos contextos políticos em que se opera a transferência da Cúria

${ }^{18}$ A linhagem dos Correr, Condulmer e Barbo, todos patrícios venezianos, todos parentes, todos ligados à fundação dos Cónegos de Alga. 
Romana para Avinhão, da crise cismática e da sua superação pela ativa participação do Império. França e Império são igualmente as duas geografias políticas que delimitam territorialmente o norte italiano, onde a Congregação de Alga surgirá.

Associar-se-ão os contextos da Itália, primordialmente a dos Estados Pontifícios e da Sereníssima, bem como a do Portugal da dinastia de Avis, que constituem naturalmente os contextos principais de pertença das duas congregações.

O primeiro capítulo terminará no ponto 1.3, onde se fará uma análise da situação particular do Papado no período que se situa da transferência da cúria para Avinhão até aos concílios que marcam a passagem conflituosa do cisma à unidade, concluindo a trabalhar esse conceito que o mundo católico contemporâneo herdou da reforma calvinista, e que dá titulo a este livro: Ecclesia semper reformanda est.

O 2. ${ }^{\circ}$ capítulo direciona-se para o estudo da Congregação de S. Jorge em Alga de Veneza, entendida numa perspetiva institucional integrada nos movimentos reformistas da Igreja dos sécs. XIV e XV.

Pretender-se-á salientar no seu processo de formação e afirmação (tal como depois para os Lóios) as suas pertenças num universo situado entre o pensamento e ação reformistas, por um lado, e um universo de elites aristocráticas e da cúria pontifícia pelo outro. Para tal perspetivar-se-á não só uma análise dos processos constitutivos da Congregação em causa, mas a sua conexão com outros processos similares, com os ambientes eclesiais que se situam num entendimento reformista, e ainda focando o olhar em algumas das personalidades que marcam internamente a sua fundação e organização, particularmente para Alga as figuras de Eugénio IV e Lourenço Justiniano ${ }^{19}$.

A segunda parte desta obra abre com o $30^{\circ}$ capítulo que, à imagem do seu antecessor, irá debruçar-se sobre a constituição e expansão da Congregação de S. João Evangelista, entendendo-a como um movimento eclesial tendencialmente reformista, em contacto com outros movimentos similares e que encontrou fora dos limites nacionais um modelo carismático que adota, com as consequências que se destacarão. As figuras cimeiras voltam a ser objeto de análise, particularmente mestre João Vicente e D. Afonso Nogueira, procurando-se problematizar o papel que cada um assumiu na adoção do modelo carismático de Alga.

Conclui-se num $4 .^{\circ}$ capítulo dedicado à atuação dos Cónegos Lóios e à sua presença na sociedade portuguesa da dinastia de Avis. Será uma análise da sua vivência do ideal carismático e da forma

\footnotetext{
${ }^{19} \mathrm{O}$ primeiro por ter sustentado o crescimento da congregação pela forte proteção dispensada enquanto Cardeal e Papa, o segundo pelo papel que assumiu na constituição da espiritualidade de Alga e pela condução interna da congregação nas suas primeiras décadas. A consciência de tal era já bem patente para os Lóios, que o terão transmitido ao Rei D. Manuel I, que o fez expressar na carta que escreveu ao seu embaixador em Roma D. Miguel da Silva, datada de Lisboa a 15 de junho de ano incerto, mas certamente não anterior a 1515, ano em que chega a Roma (BUESCU, 2010), e em que se escreve que o modo de vida dos Lóios começara: «em as partes de Itallia em a Casa de Sam Jorge d'Allga de Veneza per Grabiell Comdallmario que despois foy Papa Eugenio quarto e per Lourenço Justiniano primeiro Patriarca de Veneza na era de Nosso Senhor de mil e quatrocentos e quatro e creçeram e crecem em numero de Casas e pessoas em vida llouvavell» (cf. ANTT - Congregação de S. João Evangelista, Convento de S. João Evangelista de Xabregas, mç. 15, doc. n. ${ }^{\circ}$ ). Treslado coevo mas não datado, intitulado Carta que el Rey dom Manuel mandou a Roma a dom Migyel que falasse ao Sancto Padre por ha confirmação de nossos privillegios.
} 
como o transpõem para as relações com a sociedade em que se inserem. Abordar-se-ão alguns pontos que, ainda que já tratados, podem ter a ganhar com um aprofundamento de análise.

Entre a teoria e a prática, entre o ideal fundacional e carismático e a realidade da vida quotidiana da Congregação, assim poderemos definir, de modo simplista, aquilo que se pretende estudar neste último capítulo, que se espera constitua um quadro problematizado da ação dos Cónegos Azuis nos seus diversos campos de atuação, e do modo como nestes desenvolveram uma ação caracterizável como de cunho reformista.

Far-se-á uma leitura das atividades desenvolvidas pelos cónegos Lóios ao longo dos sécs. XV e XVI, que extravasam o simples domínio da pastoral e da vida claustral, e que se identificam com aquilo que hoje chamaríamos «atividades socialmente relevantes».

Alicerçados no prestígio institucional que a Congregação tinha junto da Casa Real de Avis e da Casa Ducal de Bragança, os serviços prestados na administração hospitalar (que se assumem como um serviço palatino prestado à Coroa e aos Duques de Bragança, mas que se particularizará na dimensão, relevância e duração) e os serviços educativos prestados no convento lisboeta de St. ${ }^{\circ}$ Elói, que se confundem com os primórdios da ação missionária portuguesa e formação de clero africano, serão objeto de uma análise que procurará antever nestas atividades uma linha de conduta que se pauta não só por uma proximidade ao poder, através da prestação destes serviços que se traduziriam em proteção por parte da Coroa e da aristocracia, mas também a forma de vivência de um ideal interno de sacerdócio ativo, secular mas desenvolvido em estrutura congreganista, que parecem prefigurar outros figurinos institucionais que no séc. XVI, e no contexto das reformas, se tornarão relevantes no universo eclesial católico.

\section{Periodização}

Sendo a História delimitada pela relação do espaço com o tempo, qualquer obra que caia no seu âmbito deve justificar, de modo claro, as suas balizas espácio-temporais. Se nesta obra o espaço se define facilmente pelas áreas ocupadas, e influenciadas, pelas Congregações em estudo, o tempo necessita de uma precisão mais estrita e fundamentada.

Em termos absolutos a Congregação dos Lóios existiu entre a década de 1420 e o ano de 1834, quando a lei de 30 de maio ${ }^{20}$ vem suprimir todas as casas religiosas masculinas, compreendendo a totalidade das Casas e dos cónegos Lóios, que sendo seculares com Congregação passaram a ser seculares sem Congregação.

Em pouco mais de quatro séculos de existência, os Lóios viveram sob o domínio de três dinastias e estiveram presentes em toda a Época Moderna portuguesa. A riqueza histórica destes quatro séculos tornam impossível, de modo claramente percetível, que um único trabalho (ainda mais com o formato inicial de tese) se debruce sobre o período completo de existência, impondo-se um corte temporal coerente com os seus objetivos.

${ }^{20}$ SILVA, 2000. 
A base de partida formal desta obra é a década de 1420 e a fundação da Congregação. É certo que este termo a quo aplica-se exclusivamente aos Lóios, já que a compreensão de contextos, e a própria história da Congregação matricial de S. Jorge em Alga, obrigam a recuar algumas décadas, na tentativa de compreensão do contexto geral e específico, particularmente focados na cristandade ocidental de finais do séc. XIV e inícios do séc. XV, que suscitaram o aparecimento de uma Congregação canonical com as características da Congregação de S. João Evangelista.

Os Lóios surgem no primeiro reinado da Dinastia de Avis, a mesma a que vão estar, desde o princípio, fortemente associados. Os elementos que distinguem e caracterizam a Congregação surgem e desenvolvem-se no consulado dos monarcas Avisenses. A estreita ligação da Congregação com a dinastia torna-se ainda mais patente quando se atenta no facto que as nove casas conventuais da Congregação (os oito conventos/mosteiros/colegiadas ${ }^{21}$ acrescidos do Colégio de Coimbra) foram fundadas ou entregues à Congregação até ao reinado de D. João $\mathrm{III}^{22}$, cronologia que se pode aplicar às entregas de administrações hospitalares, ao cerne da sua atuação enquanto congregação associada à coroa e nobreza cortesã, ao seu papel na educação de jovens africanos e, em suma, ao seu papel como congregação reformista quatrocentista, cuja proposta se lançou, desenvolveu e consumou ao longo dos séc. XV e 1. ${ }^{\text {a }}$ metade do séc. XVI.

O desafio lançado pela reforma protestante, a evolução da Igreja Católica no sentido da ansiada reforma geral in capite et membris, a premência dos tempos que impuseram o tema ao universo da cristandade ocidental, suscitam um amplo debate e uma dinâmica conjuntural que se traduzirá no aparecimento de diversas iniciativas que se emparelham com a grande resposta institucional: o Concílio de Trento.

O período situado entre a década de 1530 e os finais do séc. XVI será fértil em reformas de ordens existentes e criação de novas estruturas congreganistas. Os jesuítas serão caso paradigmático, e ainda que se veja nos Lóios uma prefiguração da Companhia de Jesus e da Congregação do Orató-

\footnotetext{
${ }^{21}$ É tema sobejamente conhecido, no estudo das ordens e congregações religiosas, a questão da nomenclatura a utilizar na identificação das casas de religiosos: mosteiros, conventos ou outros. A definição mais comummente aceite atribui a designação de mosteiros às «ordens monásticas, institutos de vida consagrada sui juris, que praticam a vida contemplativa, estável, separada do mundo» (cf. CHORÃO, 2001), enquanto convento seria a comunidade dos religiosos de ordem mendicante (cf. CHORÃO, 2000), acentuando-se na diferença dos termos a diferença de conceitos e a diversidade das instituições: enquanto no mosteiro foca-se a estrutura espacial, material e institucional que é o mosteiro, no caso do convento acentua-se a instituição humana constituída pelo conjunto de religiosos que forma uma comunidade, o «convento» (do latim conventus, reunião, assembleia, comunidade, cf. Dicionário de Latim-Português, 2001). Apesar disto a exatidão dos termos não foi uma constante, nomeadamente entre os Lóios, que designam os seus assentamentos por casa, mosteiro, convento, colegiada (como comunidades canonicais seculares) e colégio (que se usou para o Colégio de Coimbra, mas também para as outras casas), hospital (no caso de Santo Elói de Lisboa que foi originalmente hospital de merceeiros), ou até designações mistas como casa colegiada. A diversidade de termos utilizados, entre casas Lóias mas também para identificar uma mesma casa, parece demonstrar não só que os designativos para as casas religiosas nem sempre seguem as lógicas instituídas como que os Lóios transmitiam a estes designativos o hibridismo e particularismo institucional que marca a sua história.

${ }^{22}$ Note-se como exceç̃̃es Coimbra e Lamego, ressalvando-se no entanto que o Colégio de Coimbra, construído na década de 1630, vinha substituir uma comunidade Lóia já residente, desde 1548 e por licença de D. João III, no hospital real de Coimbra (que a Congregação administrava), enquanto St. ${ }^{a}$ Cruz de Lamego, fundação de 1596, veio substituir a comunidade que desde 1438 vivia em S. Jorge de Recião (cf. TAVARES, 2001a).
} 
rio $^{23}$, a Congregação de S. João Evangelista vê-se frente a novas estruturas eclesiais mais preparadas para os desafios da Igreja tridentina. Como dita uma velha lei universal, a ascensão de uns constrói-se do declínio de outros.

A novidade da proposta reformista dos Lóios parece ter-se esgotado na evolução dos tempos, e a preferência que a Congregação pode ter tido nos corredores do Paço Real esfuma-se com a própria dinastia de Avis. O declínio nasce das próprias características da instituição e sendo, portanto, estrutural, tende apenas a agravar-se.

Cristalizada no tempo, nas propostas carismáticas, na incapacidade de expansão, a Congregação não gerará dinâmicas substancialmente novas para além de finais do séc. XVI. Revelando-se os Lóios em tudo uma Congregação da Casa de Avis, o termo ad quem desta tese impõe-se por si, com naturalidade, no final da dinastia: 1580.

Entenda-se que o ano da morte do Cardeal-Rei impõe-se como operativo, mas não absoluto. Em muitos casos os temas abordados situar-se-ão até meados do séc. XVI, noutros será necessário passar para além da década de 1580, quando se mostre necessário acompanhar algum processo de longo prazo, ou para recorrer a dados recolhidos e registados em data posterior, mas com interesse para a tese, como acontecerá com o relevante trabalho cronístico do P.e Jorge de S. Paulo ${ }^{24}$, elaborado entre as décadas de 1630 e 1660.

\section{Estado da Arte}

Sendo este livro a publicação de tese doutoral não pode deixar de incluir o que, no meio académico, tornou-se elemento imprescindível: o Estado da Arte, uma reflexão sobre o que de mais significativo tem sido produzido nas áreas sobre as quais o trabalho incide.

Assim, ao perspetivar um estado da arte para este trabalho, identificam-se de imediato duas áreas temáticas a ter em particular consideração, excluindo as de carácter generalista e que se incluem nesta tese com objetivo contextualizante.

A primeira é aquela que se apresenta, sem dúvida alguma, mais vasta, no espaço, no tempo, na diversidade de causas e consequências. Trata-se dos estudos que se dedicam aos movimentos reformistas no seio da Igreja, particularmente os estudos e reflexões sobre as ideias e práticas reformistas nos séculos que marcam a transição da Idade Média para a Modernidade.

A segunda é a que mais se aproxima do tema específico da tese, e que por isso mesmo tem dimensão mais restrita; tratam-se dos estudos sobre a Congregação de São João Evangelista, nosso objeto principal de pesquisa, e que se pode enquadrar no universo mais lato dos estudos sobre as ordens e congregações religiosas católicas, incluindo os que têm tratado da congregação matricial de S. Jorge em Alga de Veneza.

\footnotetext{
${ }^{23}$ Como afirmam Pedro Tavares e José Adriano de Freitas Carvalho (cf. Idem, ibidem).

${ }^{24} \mathrm{Vd}$. o ponto «Fontes».
} 


\section{A reforma como objeto de estudo}

A análise extensiva dos estudos em torno do conceito e prática reformistas no cristianismo ocidental ocuparia bem mais que a totalidade das páginas desta obra. $\mathrm{O}$ tema das reformas é amplamente tratado pela historiografia internacional, ocupando-se de diversos tempos e espaços, diferentes protagonistas e formulações que a ideia de reforma foi assumindo.

É do conhecimento comum que o estudo da reforma enquanto tal associou-se desde cedo ao estudo das reformas ditas protestantes, ou seja, aos movimentos eclesiais que se desenvolvem a partir da década de 1520 e na sequência da ação de Martinho Lutero, gerando uma alternativa institucional à Igreja tradicional, que a partir de então se passa a designar por Católica. Esta visão esteve quase sempre ligada a uma pesquisa histórica que simultaneamente se mesclava com pertenças no campo religioso ${ }^{25}$.

Por associação era identificada uma contrarreforma católica, cuja essência se revelava apenas como movimento interno do mundo católico gerado para combater o avanço das Igrejas reformadas ${ }^{26}$.

Este discurso foi tanto mais importante quanto gerou um quadro mental duradouro, reduzindo o sentido de reforma a um sinónimo das reformas religiosas quinhentistas.

Este sentido era ainda muito recentemente (1988) defendido pelo oxfordiano Alister McGrath, ao afirmar que «the fact remains that the term 'Reformation' is generally accepted as the proper designation for this movement ${ }^{27}$, sustentando que a reforma do séc. XVI se convertera, metonimicamente poderíamos dizer, em apenas reforma, excluindo do entendimento imediato dos académicos as restantes reformas como tal. Reforma seria a do séc. XVI, e não mais ${ }^{28}$.

O autor, não rejeitando a presença da ideia de reforma em outros estágios da história europeia, salienta no entanto a relevância da reforma do séc. XVI, na qual identifica (por esta ordem) quatro movimentos: a reforma luterana, a Igreja Reformada (a instituição que se forma pela ação principal de Calvino, e que como tal se designa vulgarmente por Calvinismo), a reforma radical (o movimento anabatista, presente na Alemanha, Suíça e Holanda) e a reforma católica ${ }^{29}$. Ainda que se debruce essencialmente sobre uma análise comparada do pensamento reformista nas duas principais correntes protestantes (luteranismo e calvinismo), antecedido por uma leitura da crise de autoridade da Igreja no final da Idade Média, e das características do humanismo europeu que se cruzam com a formação do pensamento reformista protestante, demonstra ainda a cristalização de uma visão que encerra o conceito de reforma, no cristianismo ocidental, essencialmente nas reformas protestantes do séc. XVI.

\footnotetext{
${ }^{25}$ Como Dominique Julia faz notar, só na segunda metade do séc. XX é que se percebe entre os historiadores alguma capacidade de afastamento entre o trabalho científico e as profissões individuais de fé, e que foi aliás a base que permitiu renovar os estudos historiográficos numa área dominada por longo tempo por uma historiografia frequentemente de tom apologético (cf. JULIA, 1990: 545).

${ }^{26} \mathrm{Vd}$. o que Alister McGrath diz sobre a questão (MCGRATH, 1988: 6 e segs., particularmente a p. 10, sobre a reforma católica).

${ }^{27}$ Idem, ibidem: 2.

${ }^{28}$ Como o próprio afirma «the twelfth century witnessed a comparable attempt to reform the church in western europe - but the term 'Reformation' is not used to designated this earlier movement» (Idem, ibidem). Desta afirmação discordariam certamente Giles Constable (CONSTABLE, 1996) (ainda que a obra seja de 1996, corresponde a conferências proferidas em Cambridge em 1985); ou Brenda Bolton (BOLTON, 1986), apenas para citar dois nomes que têm trabalhado a reforma no séc. XII. ${ }^{29}$ MCGRATH, 1988.
} 
Note-se que apesar de reconhecer a existência de uma reforma católica, e não já uma contrarreforma ${ }^{30}$, a sua leitura faz uma confessionalização de toda a questão, e encerra a reforma quinhentista numa formulação centrada em processos distintos e separados, numa base em que reconhece a primazia da formulação de todo o processo ao universo protestante.

A leitura dicotómica das reformas, a radical separação dos processos sustentada na fragmentação da unidade eclesial do ocidente cristão, tem vindo paulatinamente a ser posta em questão, como aliás o foi a identificação excessiva de reforma apenas com os processos reformistas do séc. XVI.

Neste campo teve um papel importante a historiografia francesa e a renovação dos estudos de história religiosa, que procuraram antes de mais recuperar a relevância do processo reformista quinhentista na órbita católica.

Será precisamente aos académicos franceses que Isabel Castro Pina irá buscar o cerne da contextualização do seu trabalho sobre os Lóios $^{31}$. Salienta desde logo, e bem, o trabalho pioneiro de Jean Delumeau que, ainda na década de 1960, teve o mérito de ultrapassar a leitura clássica de processos reformistas iniciados apenas no pós-1517, e transpõe a reforma católica da linha da simples reação ao protestantismo.

Na sua obra sobre a reforma protestante, Delumeau identifica, entre os historiadores católicos, o desejo de abandonar o conceito de contrarreforma; algo a que se opõe, não porque considere que este encerre a ação do mundo católico do séc. XVI, mas porque pretende dar a este conceito uma leitura nova, mais estrita e focada. Afirma a existência de uma contrarreforma na medida em que existiu uma contraofensiva católica ao protestantismo, mas que esta é apenas uma parte do reformismo católico: «la Réforme catholique fut infiniment plus large, plus riche et plus profonde que l'action par laquelle Rome combattit le Protestantisme» ${ }^{32}$.

Delumeau não deixa no entanto de centrar toda a questão da reforma no séc. XVI, como resposta espiritual às angústias da medievalidade agonizante ${ }^{33}$ e a um período em que a Igreja terá conhecido diversas crises que não lhe permitiram dar uma resposta adequada à ânsia espiritual das comunidades ${ }^{34}$.

Como Isabel Pina faz notar, o trabalho de Delumeau, bem como de historiadores como Francis Rapp $^{35}$ e André Vauchez, marcam o ponto em que a historiografia começa a rejeitar a clássica justificação da crise moral do clero como causa do aparecimento da reforma protestante ${ }^{36}$. Acentua-se a importância assumida pelos movimentos laicais nos sécs. XIV e XV; Delumeau afirma mesmo que os

\footnotetext{
${ }^{30}$ «It is, however, becoming increasingly clear that the Roman Catholic church countered the Reformation partly by reforming itself from within, in order to remove the grounds of Protestant criticism. In this sense, the movement was a reformation of the Roman Catholic church, as much as it was a reaction against the Protestant Reformation» (idem, ibidem: 11).

${ }^{31}$ PINA, 2011: 35 e segs.

${ }^{32}$ DELUMEAU, 1965: 1.

${ }^{33}$ «La Réforme fut d'abord une réponse religieuse à la grande angoise du Moyen Age finissant» (cf. Idem, ibidem: 48).

${ }^{34}$ Vd. Idem, ibidem: 47 e segs.; DELUMEAU, 1967: 159 e segs.

${ }^{35}$ Notavelmente Pierre Chaunu, de quem se falará adiante, indicará precisamente Delumeau e Rapp como fontes para encontrar uma listagem da bibliografia mais significativa para o tema das reformas do séc. XVI (cf. CHAUNU, 1981 : 13, 14. ${ }^{36}$ PINA, 2011: 35. Já Jean Delumeau (DELUMEAU, 1967: 155) chama a atenção para manifestações de renovação (sublinhe-se que não as apelida de reformadoras) dentro de diversas ordens e congregações religiosas, anteriores a 1517.
} 
reformadores do séc. XVI são herdeiros de toda uma corrente que desvaloriza a hierarquia eclesiástica e promove o laico na vida religiosa ${ }^{37}$. Além das matérias de natureza puramente espiritual e religiosa, salientam a relevância dos contextos, e rejeitam ${ }^{38}$ uma causalidade unívoca do surgimento das reformas do séc. XVI, em prol de uma explicação polifactorial, mas que deve ser encontrada toda ela no domínio da história religiosa e das mentalidades, caminho que a historiografia então traçava ${ }^{39}$.

$\mathrm{O}$ avanço que esta historiografia traz permite recuperar para o debate os movimentos reformistas que antecedem as reformas do séc. XVI. Não deixam no entanto de precisar que «durant cette période [1400-1520], il y eut donc des reformes, mais non une Réforme, car l'impulsion ne venait pas du centre. Seul l'ébranlement du schisme protestant conduisit Rome à repenser sa théologie, à clarifier sa doctrine, à revaloriser le prêtre et les sacrements» ${ }^{40}$.

A perspetiva em causa, ainda que possa ser operativa para o que aqui se trata, ao admitir a existência de reformas no universo eclesial anterior ao séc. XVI, não permite no entanto uma leitura verdadeiramente satisfatória para o questionamento central que nos ocupa.

Se a Congregação de S. João Evangelista é de facto reformista, e com ela necessariamente a de S. Jorge de Alga por ser matriz carismática, e se existe uma conexão imediata com a Santa Sé, que como veremos nos capítulos 2 e 3 será o ponto central de contacto entre as duas instituições, então não será possível aceitar a ideia que Roma está alheada do pensamento e ação reformistas do séc. XV. Simultaneamente, dada a natureza dos processos históricos que envolvem as duas congregações, e apesar do peso e dimensão dos movimentos reformistas do ocidente cristão do séc. XVI, parece lícito questionar a utilização da capital maiúscula para definir os movimentos reformistas desse século.

Será, no entanto, do mesmo alfobre destes académicos que surgirá uma possível resposta para estas inquietações. No seu $O$ Tempo das Reformas ${ }^{41}$ Pierre Chaunu introduzirá uma estimulante leitura dos processos históricos que marcam as reformas religiosas do ocidente cristão na transição da Idade Média para a Modernidade.

Numa pesquisa muito marcada pelas questões da demografia histórica, Chaunu começa por salientar os avanços historiográficos da década de 1960, e de como se tinha em definitivo ultrapassado a ideia das reformas em rutura e se estabelece a ideia de duas reformas em continuidade, em suma, o que resume na expressão «as duas reformas da Igreja» ${ }^{42}$.

\footnotetext{
${ }^{37}$ DELUMEAU, 1967: 162.

${ }^{38}$ Como Delumeau faz no seu Naissance et Affirmation de la Réforme, ao passar criticamente em revista as diversas linhas tradicionais de análise das causas das reformas do séc. XVI, particularmente o arranque da protestante (cf. DELUMEAU, 1965: 257 e segs.).

39 «Ainsi voit-on que la recherche historique actuelle est résolument orientée, en ce qui concerne la Réforme, vers l'étude des doctrines et leurs rapports avec la mentalité des foules du XVI' siècle» (cf. Idem, ibidem: 280).

${ }^{40}$ DELUMEAU, 1965.

${ }^{41}$ CHAUNU, 2002 (edição original francesa de 1975).

${ }^{42}$ Idem, ibidem: 9, 10. De notar como Chaunu faz situar o desenvolvimento desta leitura dos processos reformistas do séc. $\mathrm{XVI}$, entendidos como duas formas da mesma reforma eclesial, dentro do quadro de abertura ecuménica que as diversas igrejas cristãs demonstram por esta época, e que no caso católico se nota com os pontificados de João XXIII e Paulo VI, e na decorrência do II Concílio do Vaticano.
} 
De relevante para o que aqui nos ocupa, a investigação de Chaunu aporta o alargamento da problemática das origens e natureza das reformas. Tendo ainda como fito central as reformas do séc. $\mathrm{XVI}^{43}$, o autor não deixa, no entanto, de alargar o olhar cronológico que dirige a esta temática, e que se verifica desde logo no alcance do arco temporal em que delimita este seu trabalho: 1250-1550 .

Este alargamento, e a advocação que faz do facto de que aquilo que tradicionalmente se chamava a pré-reforma, e em que comodamente se arrumavam as iniciativas reformistas nascidas no interior da Igreja anteriormente a Martinho Lutero e à emergência do universo protestante, constata-se ser afinal um universo bicentenário de correntes reformistas que descreve como «uma riqueza invulgar de correntes de reforma que atravessa a cristandade» ${ }^{44}$.

Ao elevar os movimentos reformistas do séc. XIV e XV à categoria de primeira reforma no ciclo das reformas que marcarão a transição da Idade Média para a Modernidade, Chaunu introduz um conceito operativo que, esse sim, nos permite finalmente fazer uma leitura mais compreensiva do papel das duas Congregações, a de Alga e a de S. João Evangelista, num panorama eclesial quatrocentista marcado por crises internas e externas à Igreja, mas em que se encontram a desenvolver dinâmicas que o séc. XVI estenderá ao conjunto da cristandade.

Não importa neste ponto precisar mais profundamente o conteúdo do pensamento de Chaunu nesta matéria, mas sim reter que a leitura que o autor fez dos processos reformistas em curso nos sécs. XIV e XV será a chave de leitura escolhida, como o já foi na minha dissertação de mestrado, para analisar o percurso dos cónegos de Alga e dos Lóios enquanto reformistas, permitindo assim comprovar a asserção do Prof. Silva Dias, que já em 1960 intuía claramente o papel de relevo dos Lóios como congregação reformista no séc. XV português ${ }^{45}$.

Em relação ao que já, ainda que incipientemente, se discorria na dissertação de mestrado acerca da teoria e práticas reformistas no séc. XV, inteiramente alicerçado em Chaunu, acrescentar-se-á a este pilar teórico um outro pilar originado na escola historiográfica que se desenvolveu a partir do trabalho do historiador austríaco, naturalizado canadiano, Gerhart Burian Ladner.

Com pesquisa que se centra na história da arte, da cultura, das ideias e da Igreja ${ }^{46}$, Ladner foi o percursor, no meio académico norte-americano, de uma escola historiográfica que tem como cerne a questão da ideia e prática reformistas na Igreja.

O seu estudo acerca da ideia da reforma ${ }^{47}$, centrado nos primeiros séculos do cristianismo, tem um carácter que foi considerado, ainda recentemente, seminal ${ }^{48}$ para os estudos que se atêm às ques-

\footnotetext{
${ }^{43}$ Patente não só no Tempo das Reformas, mas também no seu Église, Culture et Société. Essais sur reforme et contre-réforme (cf. CHAUNU, 1981).

${ }^{44}$ CHAUNU, 2002: 11.

${ }^{45}$ DIAS, 1960: 93 e segs. (capítulo A reforma da vida monástica).

${ }^{46}$ Veja-se o que acerca do seu perfil se diz em BELLITTO \& FLANAGIN, 2012a.

${ }^{47}$ LADNER, 1959.

${ }^{48}$ Assim o afirmam BELLITTO \& FLANAGIN, 2012a, mas também o medievalista Louis Pascoe, SJ, que o considera uma das suas principais influências académicas (cf. PASCOE, 2012: 31 e segs.).
} 
tões da reforma no universo religioso, tanto mais que o trabalho em si defende a natureza «cristã» do conceito de reforma no mundo ocidental.

Particularmente relevante o facto de Ladner ter elaborado uma teoria acerca da ideia e prática reformistas que perspetiva a reforma como um dos conceitos centrais do cristianismo, presente em diversas fases da sua história, e que como tal ultrapassa em absoluto qualquer tendência para colar o conceito a um único processo reformista temporal e geograficamente delimitado.

Reforma passa a ser, nesta leitura, um conceito operativo desenvolvido em determinados parâmetros que o permitem identificar como tal, abrindo caminho para que se interpretem pela mesma chave de leitura um determinado conjunto de processos históricos tipologicamente similares, ainda que possam ser cronológica e geograficamente distantes entre si.

Esta assunção, que tal como as ideias de Chaunu se trabalharão melhor no ponto 1.1, está patente nas diversas colaborações no volume ${ }^{49}$ que marca o $50 .^{\circ}$ aniversário da publicação do trabalho central de Ladner, e que demonstram como, dos séculos iniciais da igreja ao séc. XVII, os historiadores desta escola têm trabalho os processos reformistas recorrendo à mesma ferramenta teórica.

De destacar os trabalhos de Christopher Bellitto ${ }^{50}$, que se tem dedicado à Igreja do séc. XIV e $\mathrm{XV}$, com particular relevo para o pensamento e ação reformistas no período final dos Cisma e dos concílios, e que como tal será um dos contributos oriundos desta linha de pesquisa que auxiliará à compreensão de um universo reformista em que Alga e os Lóios se poderão inserir.

Praticamente desconhecido no meio académico português, o trabalho de Ladner e a sua visão da reforma como uma ideia estrutural ao cristianismo foi já salientado para aplicação ao universo reformista português do séc. XV num artigo do Prof. José Adriano de Freitas Carvalho que, já com duas décadas, continua profundamente atual, como o prova a sua muita recente reedição, e a servir de importante ponto de referência ${ }^{51}$.

\section{Estudos sobre ordens e congregações religiosas. Os estudos sobre as Congregações de Alga e dos Lóios}

Mesmo tratando-se de uma congregação de clérigos seculares ${ }^{52}$, os estudos que têm sido desenvolvidos sobre a Congregação de S. João Evangelista incluem-se claramente na área da história das ordens e congregações religiosas, particularmente nos estudos de natureza institucional, patrimonial (entenda-se, património cultural e artístico), cultural, pastoral e espiritual. Inserem-se, pois, numa área de pesquisa profícua, alicerçada na patente relevância que as ordens e congregações tiveram na história portuguesa ${ }^{53}$.

\footnotetext{
${ }^{49}$ BELLITTO \& FLANAGIN, $2012 \mathrm{~b}$.

${ }^{50}$ BELLITTO \& HAMILTON, 2005; BELLITTO, 2008; BELLITTO, 2009, para citar alguns dos seus trabalhos.

${ }^{51}$ CARVALHO, 1995; CARVALHO, 2016.

${ }^{52}$ As particularidades do modelo congreganista dos Lóios serão exploradas ao longo deste livro.

${ }^{53}$ A importância das ordens e congregações religiosas na história portuguesa parece-me por demais evidente, e não carecer de cabal comprovação. No entanto uma leitura dos 3 volumes da História Religiosa de Portugal (AZEVEDO, 2000-2002) e dos 4 volumes do Dicionário de História Religiosa de Portugal (com entradas para todas as ordens e congregações com presença em Portugal, cf. AZEVEDO, 2000-2001), dão uma visão completa do papel e relevância dos regulares na vida portuguesa.
} 
Trata-se de uma área de investigação que tem tido alguma atenção, nas últimas décadas, por parte do meio académico e com resultados importantes, facilmente verificáveis, com recurso a uma pesquisa nos fundos de teses e dissertações das Universidades portuguesas, bem como pelo acesso aos mais recentes repositórios de teses disponíveis on-line, que permitem um contacto facilitado com a produção da Academia.

Sendo vasto, moroso e de relativo interesse uma análise das linhas de pesquisa e dos trabalhos produzidos nesta área, apenas farei aqui menção do que têm sido os estudos em torno das ordens e congregações religiosas na Universidade do Porto, em cujo âmbito desenvolveu-se a tese doutoral que deu origem a este livro, bem como uma leitura rápida sobre algumas linhas de força que nesta temática se desenvolveram nos últimos anos.

A renovação dos estudos históricos em Portugal, iniciada na década de 1960, coincide com a restauração da Faculdade de Letras da Universidade do Porto, e com a criação do seu curso de História ${ }^{54}$. Neste processo não deixa de ser significativo que das primeiras teses de doutoramento defendidas no pós-25 de abril de $1974^{55}$, duas o tenham sido no âmbito da história das ordens e congregações religiosas.

As teses de Eugénio dos Santos ${ }^{56}$ e de Cândido dos Santos ${ }^{57}$, defendidas em 1977, introduziram na academia portucalense os estudos de ordens e congregações religiosas ${ }^{58}$ em linha com o então se fazia nas instituições académicas francesas, nomeadamente seguindo a escola de Jean Delumeau ${ }^{59}$, que orientou estas teses, e que como foi salientado ${ }^{60}$, permitiu introduzir na Faculdade de então, e sobretudo entre os que dedicavam à História Moderna, o «desenvolvimento de uma História das Mentalidades e de uma Sociologia Religiosa $»^{61}$.

Perspetivando a ordem ou congregação como unidade estrutural de referência, introduzem um conceito de instituição que extravasa os grandes fundadores ou reformadores, a crónica apologética que tanto sucesso conheceu no seio das próprias instituições. Estes trabalhos situam-se numa leitura mais vasta e completa das instituições, que pretende incluir uma visão complexa das diversas facetas da vida monástica, incluindo a dimensão material, social, cultural, espiritual e pastoral, carismática;

\footnotetext{
Para uma leitura rápida, veja-se a entrada clero regular, no $1 .^{\circ}$ volume do Dicionário de História Religiosa de Portugal (BARBOSA, 2000).

${ }^{54}$ HOMEM, 1991.

${ }^{55}$ Cf. HOMEM, 2001.

${ }^{56}$ SANTOS, 1982.

${ }^{57}$ SANTOS, 1996.

${ }^{58}$ Atentando no panorama nacional, Maria Helena da Cruz Coelho destaca que o estudo das Ordens e Congregações religiosas são, no panorama da historiografia portuguesa do pós-25 de abril de 1974, o segundo mais profícuo dos subcampos em que se subdivide o campo da História da Igreja. Em 2001 contaria com 387 referências bibliográficas sobre o tema, apenas tomando em consideração os produzidos no âmbito universitário (cf. COELHO, 2001: 359).

${ }^{59}$ Creio não ser necessário justificar a relevância da figura do Prof. Jean Delumeau, nomeadamente no que se refere ao desenvolvimento de estudos em torno da cultura e religião em diálogo com a sociologia religiosa. De notar que é um dos nomes destacados entre os académicos que seguem esta linha na entrada religião no dicionário A Nova História (cf. JULIA, 1990).

${ }^{60}$ HOMEM, 1991.

${ }^{61}$ Idem, ibidem: 238.
} 
em suma, procurando tocar tudo aquilo que possa caracterizar, num determinado espaço e tempo, uma congregação ou convento na relação com o que era a sua identidade (o tal «carisma»).

No campo da História Económica e Social, encontramos o estudo de Aurélio de Oliveira para Tibães $^{62}$, com que se inaugura uma linha de investigação em história rural e agrária que tem por base as instituições monásticas, de onde emergem um conjunto de dissertações de mestrado ${ }^{63}$ que sendo monásticas no seu objeto de investigação (as propriedades de uma determinada casa monástica), não se poderão classificar como de história monástica, entendendo as comunidades apenas ao nível da posse senhorial da terra, da relação que estabelece com a propriedade e com aqueles que a trabalham ${ }^{64}$.

Na sequência, a academia portucalense foi berço de um conjunto de trabalhos que, direta ou indiretamente, se debruçam sobre estas instituições. Destacam-se os trabalhos de Geraldo Coelho Dias (OSB), sobretudo centrados na Ordem de S. Bento, que associados ao seu magistério de anos na Faculdade de Letras inspiraram bem mais que um trabalho ${ }^{65}$; ou a pesquisa em torno das Ordens Militares do Hospital ${ }^{66}$ e de Avis ${ }^{67}$.

Este quadro, necessariamente limitado, deixa muitos trabalhos por mencionar, pretendendo apenas demonstrar brevemente como os estudos das ordens e congregações religiosas tiveram um espaço relevante na produção científica de docentes e investigadores da FLUP, o que se constituiu como capital científico e de conhecimento que favoreceu, e favorece, os estudos nesta temática.

Deixando de parte os estudos genéricos em ordens e congregações, e passando aos trabalhos específicos que têm sido produzidos em torno da Congregação dos Lóios, o universo de produção torna-se decididamente mais reduzido.

Nos anos anteriores à década de 1980 poucos são os trabalhos que se debruçaram, direta ou indiretamente sobre a congregação dos Lóios.

O estudo desenvolvido em 1947, por Eugénio da Cunha e Freitas, sobre o convento Lóio do Porto $^{68}$, ainda que nos tenha dotado de um primeiro trabalho sobre esta casa conventual, avança pouco em matérias de relevo mais geral, nomeadamente no que à congregação e ao carisma se refere.

\footnotetext{
${ }^{62}$ OLIVEIRA, 1979.

${ }^{63}$ Como exemplo citem-se apenas as dissertações produzidas sobre as casas monásticas beneditinas de Ganfei (cf. SILVA, 1993); e de Arnóia (cf. CARVALHO, 1996).

${ }^{64}$ Como tive a oportunidade de salientar na minha dissertação de mestrado: «Um estudo de história monástica, na minha ótica, assenta sobre uma análise de uma comunidade ou congregação religiosa sempre entendida na perspetiva de ser uma unidade orgânica, criada em torno de um ideal de vida, sustentado por meios humanos e materiais suficientes, que busca cumprir o seu carisma fundacional (ou seja o seu objetivo primordial, conferido pelos fundadores $a b$ initio) e que pode ser caracterizada nestes vetores e na análise da sua existência espácio-temporal» (cf. FALCÃO, 2009: 8).

${ }^{65}$ Acerca da importância da influência deste docente, tive já a oportunidade de chamar a atenção na minha dissertação de mestrado. Sobre a sua importante obra, nomeadamente a ligada à história monástica, veja-se o artigo de homenagem que lhe consagrou o Prof. José Marques (MARQUES, 2006).

${ }^{66}$ COSTA, 2000. A tese de doutoramento trilha os caminhos que a dissertação de mestrado já iniciara, e introduz o tema em dissertações de mestrado dirigidas pela autora.

${ }^{67}$ Veja-se, por exemplo, a sua dissertação de mestrado: CUNHA, 1989.

${ }^{68}$ FREITAS, 1947.
} 
Em 1956 Fernando Magano publica, na «Studium Generale» ${ }^{69}$ um artigo sobre a Congregação, cujo enfoque principal recaía sobre uma das obras memorialísticas mais importantes da Congregação, produzida em 1658 pelo Lóio P.e Jorge de S. Paulo ${ }^{70}$ : o Epílogo e Compêndio, cujo relevo Pedro Tavares salientou em artigo ${ }^{71}$.

De 1960 data o já mencionado trabalho de Silva Dias ${ }^{72}$ que, não sendo exclusivamente sobre a Congregação e não dedicando aos Lóios mais que umas páginas, situa claramente a congregação no cerne dos movimentos reformistas do séc. XV em Portugal.

Em 1967 a reedição da História da Igreja em Portugal, de Fortunato de Almeida, menciona os Lóios em leves pinceladas, com as informações mais correntes ${ }^{73}$. No mesmo ano, e no seguinte, a Academia das Ciências de Lisboa edita, em 3 volumes, o manuscrito da crónica do Hospital das Caldas da Rainha, obra do P.e Jorge de S. Paulo, de 1656, em edição do médico e historiador da assistência em Portugal Fernando da Silva Correia ${ }^{74}$.

Esta edição marca o culminar do trabalho de Silva Correia, que morrera no ano anterior ao do início da publicação, na divulgação da história da medicina e da assistência em Portugal, muitas vezes assumindo a forma de artigos publicados em revistas médicas ${ }^{75}$.

Tendo exercido a sua profissão nas Caldas da Rainha, acabará por tomar contacto muito cedo com a obra de Jorge de S. Paulo, que passa a ser uma das suas fontes prediletas e privilegiadas para o estudo do Hospital das Caldas da Rainha, da história da medicina em Portugal do final da Idade Média ao séc. XVII, patente não só na sua frequente utilização, mas também nos rasgados elogios que faz à obra e, sobretudo, ao autor, que dá como exemplo aos médicos do séc. XX pela excelência na administração hospitalar ${ }^{76}$.

Em abono da verdade não se poderá caracterizar o seu trabalho como estando dedicado aos Lóios, já que os Cónegos de São João Evangelista apenas lhe interessam na medida em que: «não se pode estudar a história da administração hospitalar portuguesa nos séculos XVI, XVII e XVIII, sem conhecer os documentos deixados pelos loios, de alguns dos quais, como Jorge de S. Paulo, existem elementos particularmente valiosos» ${ }^{77}$. É notório que o trabalho que desenvolve sobre os Lóios é essencialmente devedor do trabalho de Jorge de S. Paulo, de quem faz a primeira edição completa de um dos seus manuscritos inéditos, mas também do cronista oficial da Congregação, P.e Francisco de Santa Maria ${ }^{78}$.

\footnotetext{
${ }^{69}$ MAGANO, 1956.

${ }^{70}$ Acerca do Padre Jorge de S. Paulo e do seu trabalho cronístico, veja-se o ponto seguinte.

${ }^{71}$ TAVARES, 2001b.

${ }^{72}$ DIAS, 1960.

${ }^{73}$ Cf. ALMEIDA, 1967.

${ }^{74}$ SÃO PAULO, 1967/68. Anteriormente a esta edição completa, Silva Correia tinha já publicado parcelas da obra e utilizado como fonte em diversos artigos e opúsculos.

${ }^{75}$ Caso dos artigos que publicou no «Jornal da Sociedade das Ciências Médicas de Lisboa» (por ex. CORREIA, 1965), ou na «Imprensa Médica», revista publicada no âmbito da Faculdade de Medicina de Lisboa (por ex. CORREIA, 1943).

${ }^{76}$ CORREIA, 1965.

${ }^{77}$ CORREIA, 1961.

${ }^{78}$ SANTA MARIA, 1697.
} 
Em 1975 o franciscano António Domingues de Sousa Costa toma em mãos a entrada Lóios ${ }^{79}$ no Dicionário de História de Portugal, que então se publicava. A sua abordagem, de reduzidas dimensões pela natureza da obra, faz-se essencialmente pelo historiar do processo de fundação e institucionalização da Congregação, com destaque para os atos emanados para tal pela Santa Sé, demonstrando a natural inclinação do editor da Monumenta Portugaliae Vaticana. No mesmo ano José Mattoso produzia uma entrada sobre os Lóios para o célebre Dizionario degli Istituti di Perfezione ${ }^{80}$.

Uma década depois, em 1986, Sousa Costa publica uma obra que tratará criticamente, em três capítulos do seu estudo sobre os Bispos de Lamego e Viseu ${ }^{81}$, as informações existentes sobre o mais importante dos fundadores Lóios: D. João Vicente.

Com este trabalho, Sousa Costa faz uma leitura crítica das informações veiculadas na cronística lóia, nomeadamente com o recurso à documentação de arquivo, portuguesa e italiana (que ele tão bem dominava), dando um importante contributo para a compreensão desta figura central dos Lóios, e da Igreja portuguesa do séc. XV. Este livro de Sousa Costa poderá integrar-se na dinâmica, observável a partir da década de 1980, de trabalhos sobre os Lóios, que se começam a avolumar, de modo sustentado, no meio académico.

Não errarei em afirmar que a primazia deve ser atribuída à dinâmica criada pelos investigadores do Centro Interuniversitário de História da Espiritualidade da Universidade do Porto, a que pertenceu o Prof. Pedro Vilas-Boas Tavares, nome de charneira no estudo dos Lóios e autor de numerosos artigos sobre os mesmos.

Com os seus primeiros trabalhos sobre os Lóios, ainda na década de $1980^{82}$, dedicados a questões de natureza pastoral e doutrinárias suscitadas pelo Regimento de Vida Cristãa do lóio P.e Pedro da Santa Maria, Pedro Tavares anteviu nos Cónegos Azuis a mesma relevância que lhes reconhecera Silva Dias, e que Tavares cita especificamente no seu primeiro trabalho ${ }^{84}$. Seguiu-se um número importante de artigos acerca da Congregação, passando dos trabalhos específicos em torno de uma figura e da sua produção literária para o universo mais vasto da Congregação e de diversos dos seus conventos ${ }^{85}$.

Demonstrando a relevância e constância dos trabalhos desenvolvidos por Pedro Vilas-Boas Tavares em torno dos Cónegos e Congregação de S. João Evangelista, bem como o reconhecimento de tal na Academia, coube-lhe produzir a entrada Lóios no Dicionário de História Religiosa de Portugal ${ }^{86}$. Esta entrada fixou numa obra de grande relevo e circulação as linhas principais da Congregação e um resumo breve do seu percurso histórico. Tornou os Lóios uma realidade mais próxima e inspirou outros trabalhos.

\footnotetext{
${ }^{79}$ COSTA, 1975.

${ }^{80}$ MATTOSO \& SOUSA, 1975.

${ }^{81}$ COSTA, 1986.

82 TAVARES, 1984; TAVARES, 1986; TAVARES, 1988.

${ }^{83}$ SANTA MARIA, 1555.

${ }^{84}$ Cf. TAVARES, 1984: 266.

${ }^{85}$ Destaque-se aqui o convento lóio da Feira a que Pedro Vilas-Boas Tavares dedicou artigos e um livro, de edição da autarquia local (cf. TAVARES, 1991; TAVARES, 2008; TAVARES, 2009).

${ }^{86}$ TAVARES, 2001a.
} 
No mesmo círculo encontramos o trabalho ${ }^{87}$ que José Adriano de Freitas Carvalho dedicou a essa figura tutelar dos Lóios seiscentistas, o P.e António da Conceição, o célebre Beato António, a quem a congregação deve o informal, mas duradouro, renomear da sua Casa generalícia ${ }^{88}$, e Lisboa a nomeação de uma freguesia, a freguesia do Beato.

Um conjunto de outros trabalhos têm sido produzidos por diversos investigadores, em contexto de teses de licenciatura, de mestrado, ou trabalhos científicos de outra natureza, maioritariamente elaborados em torno do que se poderá chamar de historiografia local, e em que destacam os estudos dos Lóios na perspetiva artística e patrimonial, como será o caso da aproximação à livraria e convento dos Lóios do Porto por Eduardo Gonçalves ${ }^{89}$, o estudo de Alves Vinhas para o convento de Vilar de Frades ${ }^{90}$, ou o breve trabalho de Celso Mangucci para o património azulejar dos Lóios em Évora e Arraiolos ${ }^{91}$.

Mais recentemente, e na academia lisboeta, foram desenvolvidos trabalhos que trouxeram um importante contributo para o estudo da Congregação dos Lóios.

A Cristina Sobral deve-se a edição crítica da primeira crónica dos Lóios ${ }^{92}$, ainda quatrocentista, do P.e Paulo de Portalegre, bem como estudos sobre este autor e sobre a sua obra no campo memorialístico e hagiográfico ${ }^{93}$.

Ainda na capital e já no corrente século destacou-se a produção da Doutora Isabel Castro Pina que, com participação na equipa que elaborou o Guia Histórico das Ordens Religiosas em Portugal: das origens a Trento $^{94}$, focou o seu labor científico na Congregação de S. João Evangelista, tema em que produziu diversos artigos ${ }^{95}$ e que culminaram na sua já mencionada tese de doutoramento de $2011^{96}$.

Será em linha com o trabalho destes investigadores, particularmente aqueles mais destacados pela constância, profundidade e dimensão do seu contributo para o conhecimento histórico dos Cónegos Lóios, que esta obra se pretende situar.

\footnotetext{
${ }^{87}$ CARVALHO, 1998.

${ }^{88}$ A Casa generalícia dos Lóios foi, desde o reinado de D. Afonso V, o convento de S. João Evangelista de Xabregas, também chamado de S. Bento de Xabregas, da invocação do oratório existente no local em que se viria a construir o convento. A figura do Padre António da Conceição, beatificado pela força dos seus crentes mas não pela autoridade apostólica, fez com que o seu convento passasse a ser designado como o convento do Beato, nome com que é hoje conhecido e que designa um conhecido espaço particularmente consagrado a eventos empresariais, sociais e culturais que ocupa o velho convento (sic transit...). Existe alguma justiça nesta designação, pois o P.e António da Conceição foi um dos grandes impulsionadores das obras de renovação da igreja e convento, que se estenderam para além da sua vida mortal (cf. Idem, ibidem; TAVARES, 2001a) para a fundação da Casa de Xabregas ( $v d$. PINA, 2011: 137 e segs.).

${ }^{89}$ GONÇALVES, 1991.

${ }^{90}$ VINHAS, 1998.

${ }^{91}$ MANGUCCI, 2013.

92 PORTALEGRE, 2007.

${ }^{93}$ SOBRAL, 1997; SOBRAL, 2003a; SOBRAL, 2003 b.

${ }^{94}$ SOUSA, 2005.

${ }^{95}$ PINA, 2007; PINA, 2009; PINA, 2010.

${ }^{96}$ PINA, 2011.
} 


\section{Fontes}

Dos cartórios e das tradições antigas, e constantes, tirão unica, e forçosamente as famílias sagradas, os documentos para as suas primeiras cronicas, e a estes termos se acha redusido sem remedio todo o Escrittor, que he o primeiro em qualquer assumpto: porque antes da primeira historia não ha outra, e não havendo outra, não resta para onde recorrer, senão para os manuscriptos, e tradições ${ }^{97}$.

Parece que no entender do autor da crónica impressa dos Lóios, Francisco de Santa Maria, o documento de cartório e a tradição constante da Congregação, ou seja, a fonte manuscrita e a memória coletiva ${ }^{98}$ construída, trabalhada e preservada por gerações de Lóios, eram o árduo e sofrido caminho dos cronistas percursores, em que ele se incluía.

Ainda que possamos concordar com o cronista lóio na necessidade imperiosa de utilizar as fontes documentais como base de qualquer estudo histórico, parece-me que dificilmente o hodierno historiador concordará que tal seja um fardo imperioso, e menos ainda que a existência de uma crónica institucional, ou mesmo de outros estudos historiográficos, demitam o investigador do seu trabalho com as fontes originais.

Sendo as Congregações Religiosas instituições detentoras de meios materiais significativos, formadas por elementos humanos que dominam (em grau variado) a cultura escrita, tendo em perspetiva uma existência coletiva de longa duração (que se consubstanciava na existência de sucessivas gerações de religiosos numa mesma casa conventual, por exemplo), desde cedo estas revelaram-se como privilegiadas produtoras de documentação.

A tipologia documental que se pode esperar encontrar, seja para uma ordem ou congregação religiosa, seja para uma simples casa monástica, segue genericamente o que foi a orgânica de vida das comunidades, dos assuntos que as ocupavam e que se centrariam na vivência efetiva de um ideal carismático e na obtenção e gestão dos meios materiais necessários para que tal fosse possível.

É certo que as vicissitudes dos tempos, particularmente gravosas para com instituições que passaram por processos de extinção, como o foram as duas Congregações que nos ocupam, irão necessariamente refletir-se nos vestígios documentais que dessas instituições nos chegaram, conservadas essencialmente em arquivos públicos.

Mercê de trabalhar uma Congregação que teve nove conventos em seis distritos portugueses, com uma ligação fundacional a Itália e participante no primeiro movimento missionário em África, tornou-se necessário empreender uma busca sistemática de fontes que ajudem a obter a resposta à problematização central desta obra, implicando o manejo de documentos espalhados por diversos arquivos e bibliotecas, portugueses e italianos.

Começando pela Congregação de S. Jorge de Alga, a quem cabe a primazia histórica e na orgânica desta obra, nota-se que o seu estudo tem sido efetuado, no que aos estudiosos da Congregação de

${ }^{97}$ SANTA MARIA, 1697: prólogo.

${ }^{98} \mathrm{Vd}$. o que sobre este conceito diz Pierre Nora (NORA, 1990: 451). 
S. João Evangelista se refere, exclusivamente pelo recurso a bibliografia produzida pelos académicos italianos.

Os estudos de Silvio Tramontin e de Giorgio Cracco têm sido amplamente utilizados ${ }^{99}$, revelando no entanto que, pela dimensão reduzida destes trabalhos, à Congregação de Alga se aplicam as palavras de Pedro Tavares sobre a lamentável falta de um estudo monográfico profundo, o que é particularmente verdade quando se considera a existência, malgrado os 348 anos passados sobre a extinção forçada da Congregação de Alga, de fontes documentais suficientes.

Extinta em $1668^{100}$, a Congregação de Alga dispõe ainda hoje de um importante número de fontes originais oriundas dos cartórios da Congregação, particularmente da sua Casa-mãe, conservados no «Fundo Veneto I» do Arquivo do Vaticano, depósito da documentação proveniente da antiga nunciatura apostólica de Veneza, onde os cartórios da Congregação de Alga foram recolhidos após a sua extinção e passagem dos seus bens ao Estado de Veneza. A supressão desta nunciatura, decorrente do desaparecimento da República Veneziana (1797), conduziu o seu arquivo ao Vaticano, incluindo os fundos dos cartórios das Congregações extintas nos territórios da Sereníssima.

Da consulta dos índices foi possível perceber que a documentação existente não só permite um estudo de fôlego, mas também que se podem encontrar alguns documentos do período fundacional que, já conhecidos pelas crónicas e transcrições, têm o enorme valor de permitirem o cotejamento e como tal uma mais acurada crítica de fontes.

Para esta obra utilizaram-se alguns documentos selecionados desse fundo, bem como dos fundos de Miscellanea e Registo de Breves, todos com interesse para fixação dos primeiros passos da Congregação de Alga, mas também do processo de reforma interna que se segue ao Concílio de Trento, em que a Congregação portuguesa participará de diversos modos, como se poderá ver no ponto 3.3.

São documentos emitidos pela chancelaria pontifícia, atos notariais e documentação interna da própria Congregação de Alga, tipologias de documentos que permitem supor a fidedignidade da informação veiculada, não apenas a dos atos formais mas também a dos documentos internos, que pela própria natureza e por serem elaborados para utilização na vida própria da Congregação, permitem aceitar como verdadeiras as informações que plasmam, mesmo aquelas que pretendem apresentar e defender um determinado ponto de vista, como acontece com documentos de natureza judicial, nomeadamente em peças processuais. Apesar desta confissão de fé na boa índole da informação veiculada nos documentos, procurou-se sempre que possível confirmar os dados obtidos por confronto com outras fontes, método básico de pesquisa em História que se aplicou igualmente no tratamento à documentação dos Lóios.

Diferem, nesta matéria, dos registos cronísticos, particularmente aqueles que declaradamente se produziram para dar a conhecer as Congregações a um público externo (como serão o caso das crónicas impressas de Alga e dos Lóios), ou mesmo as crónicas produzidas internamente, mas que partilham com aquelas um mesmo objetivo: apresentar o carácter providencial das suas fundações,

${ }^{99}$ Confira-se na bibliografia de Os Lóios em Portugal (PINA, 2011), bem como nos trabalhos de Pedro Tavares (por ex. TAVARES, 2001a), e ainda $v d$. Nuno Falcão (FALCÃO, 2009).

${ }^{100}$ Para uma breve visão do processo de extinção, veja-se o que se diz no ponto prévio ao capítulo 2 . 
a exemplaridade dos seus religiosos (em particular os fundadores), a superioridade e autenticidade do seu carisma. São pois fontes que, ainda que insuperáveis pela riqueza informativa que carregam, obrigam (como veremos) a algumas cautelas por parte dos investigadores.

Além da documentação que se encontra no Arquivo Vaticano para a Congregação de Alga, deve-se ainda mencionar a existência de um fundo no Arquivo de Estado de Veneza, que não foi possível consultar, mas em que o catálogo ${ }^{101}$ revela a existência de 68 pergaminhos dos cartórios da Congregação.

A consulta a bases de dados de arquivos e bibliotecas italianas permitem perceber que outras fontes se poderiam encontrar para esta congregação, mas que extravasando o tema e os meios desta tese, ficam reservados para quem se determinar a estudar a fundo os cónegos de Alga, um estudo imprescindível para melhor situar o universo reformista veneziano das primeiras décadas do séc. XV.

Mas a recolha de fontes documentais que sustentassem este estudo foi, sem dúvida alguma, mais intensa para o seu objeto principal: a Congregação dos Lóios. A pesquisa fez-se no conjunto de arquivos portugueses que custodiam a documentação sobrevivente da Congregação ${ }^{102}$, genericamente os arquivos públicos dos distritos que albergaram comunidades Lóias: Braga (Arquivo Distrital), Lisboa (Arquivo Nacional da Torre do Tombo, Biblioteca Nacional de Portugal), Évora (Biblioteca Pública Municipal), Porto (Arquivo Distrital e Biblioteca Pública Municipal) e Coimbra (Arquivo e Biblioteca da Universidade). Soma-se a este elenco um conjunto de documentos do Convento Lóio da Feira conservados no Arquivo do município, e a impossibilidade de descortinar o destino do cartório da Casa de St. ${ }^{a}$ Cruz de Lamego e da sua antecessora de S. Jorge de Recião ${ }^{103}$.

Sendo já bem conhecido o fundo do Arquivo Distrital do Porto ${ }^{104}$, e tendo podido consultar, ainda que mais brevemente, os restantes arquivos e bibliotecas mencionados em busca de dados documentais relevantes para ajudarem a responder ao questionamento central deste trabalho, o trabalho de pesquisa e levantamento de fontes centrou-se primordialmente no Arquivo da Torre do Tombo.

A opção preferencial pelo Arquivo Nacional prende-se com um dado relevante: a instituição custodia a documentação sobrevivente das duas Casas Lóias da capital ${ }^{105}$ (para além de um conjunto de documentos pontuais para outras Casas da Congregação), em que se inclui a Casa Generalícia de Xabregas.

Não será apenas pela proximidade destas Casas ao poder Real e senhorial de onde veio maior apoio à Congregação, mas pelo facto de nos seus cartórios se conservar um sólido conjunto documental

\footnotetext{
${ }^{101}$ Consultável on-line, no guia de fundos do arquivo disponível em $<$ http://213.136.75.178/siasve/cgi-bin/pagina.pl?Tipo= riprodinventa rio $\&$ Chiave $=36>$.

${ }^{102}$ Para o que serviu de principal indicador o guia de fontes das ordens religiosas em Portugal, produzido sob a direção do Prof. Bernardo de Vasconcelos e Sousa (cf. SOUSA, 2005: 235 e segs.), associada à experiência de pesquisa em arquivo que transitou do mestrado.

${ }^{103}$ Que Isabel Castro Pina dá por perdida (cf. PINA, 2011: 13).

${ }^{104}$ Cujas 96 unidades de instalação tive, na preparação ao mestrado, oportunidade de analisar ( $v d$. FALCÃO, 2009: 14 e segs.). ${ }^{105}$ A Casa de St. ${ }^{\circ}$ Elói de Lisboa teve grande parte da sua documentação destruída na sequência do terramoto de 1755 . Tal pode-se comprovar, em discurso direto, no tomo I da Colleção de Noticias para servirem de Index do cartório desta Caza de S.to Eloy da Cidade de Lisboa, escrito em 1766 pelo cónego cartorário da Casa, que fora nomeado em 1752 pelo reitor P.e Doutor Manuel de S. Bernardino, e que dá conta nos seus primeiros fólios da grande perda de 1 de novembro de 1755, incluindo dos 2 volumes que para a Casa tinha escrito o P.e Jorge de S. Paulo (cf. ANTT - Congregação de S. João Evangelista, Convento de S. João Evangelista de Xabregas, lv. 28).
} 
que, por incluir o cartório da Casa generalícia, oferece ao investigador as fontes mais relevantes para o estudo das instâncias superiores da Congregação e para as relações desta com diferentes níveis da sociedade. Pelo mesmo motivo note-se que o cartório da Casa fundacional de S. Salvador de Vilar de Frades reúne informação de substancial interesse para os primeiros anos da Congregação.

Como Isabel Pina salientou (e para cuja análise se remete) ${ }^{106}$, a documentação existente para os Lóios seguirá o que, e de acordo com o entendimento generalizado em matéria de documentação de ordens e congregações religiosas, é habitual encontrar em instituições desta natureza e que se dividem em duas grandes áreas: a documentação que se relaciona com o património material das Casas e a sua gestão; e a documentação que corresponde ao governo interno e à vida das comunidades.

Em suma, a documentação segue, como seria expectável, a orgânica das próprias instituições. Neste caso é perfeitamente válido o que escrevi na minha dissertação de mestrado sobre a natureza do estudo de uma comunidade monástica, que é «uma unidade orgânica, criada em torno de um ideal de vida, sustentado por meios humanos e materiais suficientes, que busca cumprir o seu carisma fundacional ${ }^{107}$, ou seja, a existência de uma comunidade religiosa (seja apenas uma casa conventual, seja a unidade integradora de uma ordem ou congregação) constrói-se sobre dois vetores:

1. Institucional - Aquele que compõe o próprio corpo da comunidade e em que se identificam duas dimensões: a propriamente institucional, em que entram as instituições que regem a Congregação e os oficiais que as servem; e a dimensão humana, que compreende o tecido vivo da Congregação e que são os seus religiosos, que geração a geração mantêm vivas as comunidades e permitem a sobrevivência do carisma. Estas duas dimensões da Congregação são geradoras de testemunhos escritos, que no primeiro caso testemunham a existência de todo um aparelho normativo destinado a regular a vida das comunidades, e que no segundo caso registam os marcos principais dos religiosos no espaço e tempo da Congregação a que pertenceram.

Começando pela documentação de cariz normativo e institucional, deve-se em primeiro lugar considerar os documentos que, ainda que emanados de instituições externas à Congregação e a esta dirigidos, são hierarquicamente superiores pela autoridade de que estavam revestidos os emitentes. Trata-se, obviamente, dos documentos emitidos das chancelarias pontifícia e régia, que se consubstanciam essencialmente nos privilégios concedidos à Congregação ${ }^{108}$. Demonstram proteções e redes relacionais, estabelecem os limites em que a Congregação pode desenvolver a sua atuação e são, numa sociedade do privilégio, marca do prestígio dos padres Lóios.

A importância destes privilégios percebe-se desde logo pelo número substancial de documentos originais e treslados destes documentos que se encontram nos cartórios Lóios (em particular nas

\footnotetext{
${ }^{106}$ Cf. PINA, 2011: 12 e segs.

${ }^{107}$ Cf. FALCÃO, 2009: 8.

${ }^{108}$ É certo que de Papa e Rei não vinham apenas privilégios. A relação dos Lóios com estas autoridades dava-se também em contexto de litígios com terceiros, ocasião em que a Coroa e a Santa Sé agiam na vertente de autoridade judicial. Tal explica a existência de sentenças e outras peças judiciais, utilizados nesta obra apenas quando se revelam de interesse para o argumento geral: Não são analisadas profundamente por não constituírem corpo organizado (como acontece com os privilégios) e pelo frequente alcance limitado.
} 
Casas de Xabregas e Vilar de Frades), na importância que era dada à sua sistemática confirmação e pelo empenho da Congregação em reunir e fazer imprimir os privilégios pontifícios ${ }^{109}$. Já as concessões régias nunca passaram a letra de forma, mas podem-se encontrar delas abundantes vestígios nos cartórios Lóios.

Nesta matéria ainda, e como já referia Isabel Pina ${ }^{110}$, existe um particular interesse na numerosa documentação aduzida por Sousa Costa nas suas obras já citadas, a que se poderá somar o recurso pontual à documentação transcrita na Monumenta Henricina ${ }^{111}$.

Sendo, por definição, uma comunidade de clérigos de vida comum, a Congregação dos Lóios tinha na vida comunitária o seu ponto de toque, implicando um conjunto de instituições próprias que dirigissem as diversas Casas, e cada uma destas individualmente.

De facto, um dos pontos fundacionais basilares da Congregação de Alga foi a possibilidade, concedida por autoridade apostólica ${ }^{112}$, da comunidade canonical reunir um capítulo geral anual em que se elegessem os reitores, a quem, pelo espaço de um ano, era atribuída a função de reger as comunidades. Além disso, o capítulo geral tornou-se o espaço próprio para exercer mais uma das concessões apostólicas fundacionais: a de estabelecer normativa própria para o eficaz governo da Congregação, garantindo deste modo um espaço coletivo de decisão nesta matéria e permitindo à instituição responder eficazmente às mudanças dos tempos.

Tratando da gestão das comunidades, elegendo os seus oficiais principais (incluindo reitores, vice-reitores, procuradores, deputados e confessores; no caso dos Lóios, e quando tal se torna parte da sua vida coletiva, a eleição dos provedores e almoxarifes dos hospitais entregues à sua administração), renovando a sua normativa por via de definições, as atas dos capítulos gerais constituem-se como uma fonte de exceção pela riqueza de informações que podem fornecer e constituem-se, a par com as constituições da Congregação impressas em 1540, como o cerne estrutural da normativa dos Lóios.

Para o período cronológico abrangido por esta obra, identificam-se dois volumes de atas capitulares: um ainda para o séc. XV e que abrange o período de 1481 a $1500^{113}$; um outro para o séc. XVI, para o curto período que vai de 1538 a $1545^{114}$.

Trata-se certamente de um número muito reduzido de existências, registos de 28 anos, para um período tão alargado da vida da Congregação. Em século e meio ${ }^{115}$ de vida da Congregação dos Lóios encontramos registos capitulares apenas para $18,7 \%$ do total desses anos.

\footnotetext{
${ }^{109}$ Caso do livro que condensa os principais privilégios que os Papas concederam às Congregações de Alga e dos Lóios, por concessão ou comissão, veja-se pontos 2.3.3. e 3.2. (cf. Livro dos Privilegios concedidos pellos Summos Pontifices..., 1594) e a obra em que se imprimem os privilégios obtidos em Roma pelo P.e Pêro de S. João, veja-se o ponto 3.3. (cf. Diversae Concessiones et Gratiae Concessae..., 1596).

${ }^{110}$ PINA, 2011: 20.

111 ALMEIDA, 1961.

${ }^{112}$ Sobre as primeiras normas estabelecidas para a Congregação de Alga, base institucional do seu modo de vida, estabelecidas pela executória do Bispo Barbarigo, de outubro de 1404, estabelecida com autoridade apostólica de Bonifácio IX e aprovada pelo seu sucessor Gregório XII, veja-se a análise no ponto 2.1.

${ }^{113}$ ANTT - Manuscritos da Livraria, n. ${ }^{\circ} 523$.

${ }^{114}$ ANTT - Manuscritos da Livraria, n. ${ }^{\circ} 186$.

${ }^{115}$ Que vai da sua formalização pelo Papa em 1431 até 1580, ano em que esta obra termina.
} 
A noção da exiguidade dos números torna-se ainda mais patente quando se considera, por exemplo, que só no convento Lóio do Porto existiam, aquando do seu inventário geral pós-dissolução da comunidade, efetuado em 18 de outubro de $1833^{116}, 15$ livros de atas capitulares, entre os capítulos gerais e de atas próprias da Casa do Porto. Destes volumes não sobrevive hoje nenhum ${ }^{117}$.

A insuficiência da amostra não diminui a riqueza descritiva da fonte capitular, assumindo-se como uma janela informativa de relevo para comprovar, desmentir e acrescentar informações veiculadas pela cronística Lóia. Tal poder-se-á comprovar pelo recurso a estas fontes no decurso da II Parte.

Ainda no domínio das fontes produzidos em espaços normativos, nomeadamente no exercício de uma gestão das comunidades e de controlo hierárquico exercido em nome da instituição máxima da Congregação, o capítulo geral, a quem eram apresentados os seus resultados, encontramos a prática das visitações anuais às Casas da Congregação (estabelecido nas constituições ${ }^{118}$ ), de que vieram a resultar a produção dos respetivos livros de visitas. A redação destes livros esteve em uso entre os Lóios pelo menos desde $1491^{119}$, ainda que, como Isabel Castro Pina salienta ${ }^{120}$, não tenham chegado até nós livros de visitas anteriores ao séc. XVII.

A parte das fontes de cariz institucional-normativo e cronístico, a congregação produzia um conjunto de outros documentos que registavam o percurso dos religiosos na vida comunitária: começam nos processos de genere dos candidatos a noviços (nenhum anterior ao séc. XVII ${ }^{121}$ ) e terminam naturalmente nos livros de óbitos dos religiosos, que a par com um conjunto de outros documentos ligados à vida quotidiana das comunidades nos poderiam dar uma ideia mais profunda da vida nos claustros Lóios. Em termos genéricos esta é a documentação que está, para a cronologia desta obra, em falta, uma ausência que poderá decorrer da sua maior antiguidade ou ser uma consequência da sua falta de interesse material, que o teria apenas humano e institucional, o que estava longe do alcance mental das autoridades públicas que tomaram posse destes cartórios após a extinção de 1834 .

2. Material - Nenhuma comunidade religiosa pode perseverar no tempo sem dispor de meios adequados à prossecução dos objetivos de vida comunitária contidos no seu carisma. Esta é uma constatação base, que dificilmente se crê possa ser contestada.

As atividades de gestão material, ao envolverem recursos e implicarem frequentemente um conjunto de direitos e/ou obrigações, tornam particularmente relevante a questão documental que titula

\footnotetext{
116 Cf. ADP - Governo Civil do Porto, Actividades Eclesiásticas, Comissão administrativa dos bens dos conventos extintos, 1. ${ }^{\circ}$ de registo do inventário, C/4/1/3/4815. Informação transcrita como anexo 1 em FALCÃO, 2009: 178, 179.

${ }^{117}$ Sobre esta questão veja-se o que digo em Idem, ibidem: 14 e segs.

${ }^{118}$ Que trata nos seus caps. XII a XV (cf. Statutos e Constituyções dos virtuosos e reverendos padres Conegos azuys..., 1540: fls. XVII a XIX).

${ }^{119}$ Conforme à determinação do capítulo geral desse ano em que «Hordenarom e mandarom que se continue o caderno dos $<$ mandados das > visitações como se começou este ano em que se escrepvam as cousas mais sustanciosas o mais em brevemente que poder ser» (cf. ANTT - Manuscritos da Livraria, n. ${ }^{\circ}$ 523, fl. 51).

${ }^{120}$ PINA, 2011: 18, 19.

${ }^{121}$ Existe um número muito razoável de maços com documentação desta natureza no fundo da Casa de Xabregas na Torre

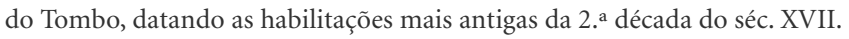


a posse dos bens e direitos conexos e história o seu percurso, constituindo-se como uma ferramenta para a boa gestão.

Na verdade uma nota domina na documentação sobrevivente da Congregação de S. João Evangelista (bem como das demais ordens e congregações religiosas cujas comunidades foram extintas em 1834): a salvaguarda prioritária de documentação com natureza patrimonial, ou que possa de algum modo servir para a gestão dos bens das Casas Lóias que, aquando da sua extinção, passaram aos próprios nacionais.

Sobre o descarte de documentação sem carácter patrimonial tive já a oportunidade de discorrer (no que ao cartório Lóio do Porto se refere ${ }^{122}$ ), demonstrando como, entre o inventário das Casas de 1833-34 e a entrega da documentação sobrevivente pelos serviços de finanças aos arquivos distritais na década de 1930, houve a eliminação de documentação de temática não patrimonial.

Em abono da verdade, e apesar da ausência de estudos desta natureza até ao presente, não faltam fontes relevantes para quem se determinar a estudar o património das Casas Lóias. Os numerosos livros de tombo, de prazos, de sentenças (na sua maioria relacionadas com questões de natureza material), alguns livros de contas, servirão para estudar a riqueza de uma Congregação que, limitada no tamanho, seria dotada de substancial desafogo financeiro sustentado sobre o padroado de igrejas e a posse de bens de raiz. Valha-nos o exemplo da Casa do Porto que era, em 1788 e segundo a opinião do P.e Rebelo da Costa, o convento mais rico da cidade do Porto ${ }^{123}$.

$\mathrm{O}$ interesse relativo da documentação patrimonial para o questionamento central desta tese, bem como a sobrevivência (que ficou patente) de um número suficiente de documentos (os mencionados livros de atas, privilégios pontifícios e régios, itens de correspondência, documentos notariais, memórias ocasionais, etc.) que permitem responder de modo suficiente à problemática que nos ocupa, colocam o interesse central da investigação na documentação institucional e nas fontes cronísticas.

\section{Fontes Cronísticas}

Só em 1697 contaram os Lóios com o seu exemplar de uma das mais comuns características partilhadas pelas ordens e congregações religiosas: a crónica impressa.

Não é com Francisco de Santa Maria, e com o Ceo aberto na terra ${ }^{124}$, que começa a produção cronística entre os Lóios, mas será a primeira vez que declaradamente uma das suas obras memorialísticas tem por objetivo fixar a memória coletiva da instituição, e dos seus religiosos e beneméritos, mais para o exterior do que para o interior da Congregação.

Quando elaborou a sua crónica impressa, Francisco de Santa Maria mencionou o trabalho de quatro cónegos que o tinham antecedido na construção da memória comum: Paulo de Portalegre, João de St. ${ }^{\circ}$ Estevão, Miguel da Cruz e Jorge de S. Paulo ${ }^{125}$.

\footnotetext{
${ }^{122}$ Cf. FALCÃO, 2009.

${ }^{123}$ Cf. COSTA, 1945: 147, 148.

${ }^{124}$ Cf. SANTA MARIA, 1697.

${ }^{125}$ Idem, ibidem: prólogo.
} 
Das obras destes autores, todas elas manuscritas, apenas se conhecem hoje as do primeiro e do último. Sobre estes dois autores, de quem já se tem editado obras e sobre quem já muito se escreveu, abordaremos brevemente os trabalhos com interesse para esta obra, remetendo-se para os referidos trabalhos para maior contextualização.

Paulo de Portalegre, autor do Novo Memorial do Estado Apostólico ${ }^{126}$, a primeira e ainda quatrocentista crónica dos Lóios, conta com uma recente edição organizada por Cristina Sobral que, com Pedro Tavares, se apresenta como uma das investigadoras que a este autor mais se tem dedicado ${ }^{127}$. Esta obra do P.e Paulo, de carácter eminentemente hagiográfico, tem um efetivo valor historiográfico que lhe é amplamente reconhecida e que Castro Pina resume deste modo: «Os objectivos directamente historiográficos entrecruzam-se, na obra, com os de natureza hagiográfica e uns e outros contribuem, com a sua especificidade, para o conhecimento cabal da congregação» ${ }^{128}$.

Este facto, e com as devidas cautelas que esta natureza mista aconselham, tornam este trabalho uma das fontes importantes para melhor conhecer os anos fundacionais dos Lóios.

Jorge de S. Paulo († 1664) será talvez, malgrado a projeção que a figura de Santa Maria conheceu, a figura maior da cronística Lóia da época moderna ${ }^{129}$, de um séc. XVII que neste particular se mostrou de ouro para a Congregação dos Lóios.

Pedro Tavares, no artigo que dedicou a este padre e ao seu trabalho ${ }^{130}$, salienta precisamente a importância do seu legado e a descrição da sua figura, no que concorda Castro Pina, que do autor e sua obra fez uma análise cuidada ${ }^{131}$.

De uma produção de sete obras memorialísticas que lhe atribui Francisco de Santa Maria ${ }^{132}$, encontram-se hoje quatro sobreviventes: o volume do Porto ${ }^{133}$, o da Casa da Feira ${ }^{134}$, o volume do hospital das Caldas ${ }^{135}$ (em que Jorge de S. Paulo foi provedor duas vezes, e em cujo exercício morre em 1664), o único dos seus livros que foi até agora publicado ${ }^{136}$, graças ao Dr. Fernando da Silva Correia, o médico que se converteu no primeiro defensor contemporâneo da importância do testemunho deste cónego Lóio.

\footnotetext{
${ }^{126}$ PORTALEGRE, 2007.

${ }^{127}$ Sobre os trabalhos destes dois autores sobre Paulo de Portalegre (aliás citados nesta tese no ponto Estado da Arte), bem como um resumo problematizado deste autor e sua crónica, veja-se o que diz PINA, 2011: 24-26.

${ }^{128}$ Idem, ibidem: 26.

${ }^{129}$ Ideia que concorda com o que afirma Pedro Tavares «deve dizer-se que este último [Jorge de S. Paulo] foi apenas mais um elo, sem dúvida o mais forte e consistente, na cadeia do memorialismo lóio» (cf. TAVARES, 2001b: 134).

${ }^{130}$ Idem, ibidem.

${ }^{131}$ PINA, 2011: 29-31.

${ }^{132}$ Um livro sobre a Casa de Vilar de Frades, dois sobre St. ${ }^{\circ}$ Elói de Lisboa (desaparecidos no terramoto de 1755), outro sobre a Casa do Porto, a da Feira, o hospital das Caldas e um volume geral sobre a Congregação e que se conservava em Vilar de Frades (cf. SANTA MARIA, 1697: prólogo).

${ }^{133}$ ADP - Monásticos, Convento de Santo Elói do Porto, lv. do Compêndio do cartório, K/19/6-57.

${ }^{134}$ Mais propriamente o treslado do original que se conserva na Biblioteca Municipal da Feira, de onde desapareceu o volume original, conforma revela Pedro Tavares (cf. TAVARES, 2001b: 127).

${ }^{135}$ Cujo original se conserva no Arquivo Histórico do Hospital das Caldas, sob a cota AHHC - SR 003 D 00001 , Livro da fundação deste Real Hospital.

${ }^{136}$ Em edição da Academia das Ciências de Lisboa (cf. SÃO PAULO, 1967/68).
} 
O quarto volume sobrevivente era o segundo volume existente em Vilar de Frades e o de maior alcance por se referir ao conjunto da Congregação. Trata-se do Epilogo e compendio da origem da Congregação de Sam Joam Evangelista e do nacimento, vida e morte dos seus tres fundadores. Da fundação dos nove conventos; das suas rendas; encargos; e prelados; e dos onze hospitais da sua administraçaam; e de outras memorias. Composto, e escrito pello Padre Mestre Jorge de Sam Paulo ${ }^{137}$. Este volume, que Pedro Tavares transcreveu e estudou, espera-se ver brevemente impresso com os competentes estudos, completando por fim o núcleo impresso de crónicas da Congregação.

Como já foi salientado ${ }^{138}$, a riqueza informativa deste volume conservado no Arquivo Distrital de Braga, está fundada num evidente conhecimento dos cartórios da Congregação ${ }^{139}$, o que torna esta obra uma importante fonte para o estudo da Congregação, da sua fundação até meados do séc. XVII. Teve mesmo por primeiro utilizador o cronista oficial da Congregação.

Francisco de Santa Maria (1653-1743), foi (como o mesmo afirma na folha de rosto da sua crónica) cronista geral da Congregação de S. João Evangelista, o primeiro (e único, parece) que se encontra a fazer uso de tal título. Será no exercício de tal cargo que produz a crónica geral dos Lóios, intitulada O ceo aberto na terra. Historia das Sagradas Congregaçoens dos Conegos Seculares de S. Jorge em Alga de Veneza e de S. João Evangelista em Portugal, impressa em Lisboa em $1697^{140}$. Depois da crónica ainda produzirá outras obras de carácter polemista em que defende a sua crónica ${ }^{141}$, bem como alguns volumes de sermões (natural em quem foi pregador régio de D. Catarina de Bragança).

Deixou-nos Francisco de Santa Maria uma obra de estilo grandiloquente (que o fazia considerar o português objetivo do P.e Jorge de São Paulo como «sem estylo» ${ }^{142}$ ), fortemente apologética, típica da sua época e meio, que centra todo o seu esforço em apresentar a sua Congregação como modelar, possuidora de diversas primazias, muito próxima aos poderes instituídos, dotada de religiosos virtuosos e plenos de méritos.

Apesar dos exageros de uma obra que pretende demonstrar superioridade, não podemos ignorar a importância de uma obra memorialística com a dimensão da crónica do P.e Santa Maria, que aporta um número muito relevante de dados e até a transcrição de documentos. Esta posição concorda com o que Castro Pina advoga na sua tese ${ }^{143}$, onde chama no entanto a atenção para variantes introduzidas em textos transcritos, com intuito de promover a Congregação. Nesta matéria, aliás, podemos acrescentar exemplos similares aos que Isabel Pina apresenta ( $v d$. ponto 4.2.), e que se aprofunda ainda mais com toda a problemática relacionada com a primeira missão no reino do Congo (vd. ponto 4.4.).

\footnotetext{
${ }^{137}$ ADB - Manuscritos, ms. 924.

138 TAVARES, 2001b: 123.

${ }^{139}$ Pedro Tavares apresenta-o como o «ingente pesquisador de arquivo» (cf. Idem, ibidem: 138) que Jorge de São Paulo parece ter sido, e que Isabel Castro Pina corrobora (cf. PINA, 2011: 30).

${ }^{140}$ Cf. SANTA MARIA, 1697.

${ }^{141}$ Sobre estas obras e a questão associada veja-se o que escreve Isabel Castro Pina (PINA, 2011: 32 ).

${ }^{142}$ SANTA MARIA, 1697: prólogo.

${ }^{143}$ PINA, 2011: 33.
} 
Francisco de Santa Maria e a sua crónica, bem como os demais cronistas, apesar de serem uma fonte importante e muitas vezes insubstituível para o estudo da Congregação, devem ser sempre lidos com cuidados e, em todos os casos possíveis, cotejados com documentação que permita corroborar, mitigar ou negar o que as crónicas nos dizem.

As mesmas cautelas podem-se aplicar ao outro cronista a utilizar nesta tese, o da Congregação de S. Jorge em Alga, o cónego regular de Alga e bispo de Cittànova na Ístria Giacomo Filippo Tomasini (1595-1655) ${ }^{144}$, autor do Annales Canonicorum Secularium S. Georgii in Alga, publicado em $1642^{145}$.

Apesar das salutares cautelas note-se que o valor do testemunho deste prelado, como Isabel Pina precisou citando Cracco e Tramontin ${ }^{146}$, é corroborado pela fidedignidade das suas informações. Esta é mesma perceção com que fiquei quando, no Arquivo Vaticano e no seu Fundo Veneto I, pude cotejar os documentos originais do cartório de Alga com a transcrição que dos mesmos Tomasini incluiu na sua crónica.

Possivelmente o facto do bispo Tomasini ater-se a situar datas e acontecimentos da sua Congregação, e a transcrever fielmente documentos, esteja na origem do pobre juízo que dele fazia Francisco de Santa Maria, que demonstra bem o escopo principal da sua própria obra: «todo se ocupa, e cança, em referir os capitulos geraes da sua Ordem, e os nomes dos eleytos nelles, e lançar por extenso os Breves Pontificios, e Decretos da Senhoria de Venesa passados a favor da Congregação, e pouco, ou nada mais, com que gastou o papel e a tinta, perdendo (como se diz) o óleo, e a obra, em materia inútil para os leitores, e não de grande gloria para os seus Conegos» ${ }^{147}$.

\section{Bibliografia}

A elaboração deste estudo, para além do recurso às fontes históricas já mencionadas, valeu-se de um conjunto de estudos historiográficos, de diversos autores e temáticas, que se revelaram de interesse para uma compreensão dos contextos gerais e específicos.

Verificou-se inestimável a pesquisa e recolha bibliográfica, pela qualidade e pertinência dos acervos, realizada nas bibliotecas da Faculdade de Letras da Universidade do Porto, Pública Municipal do Porto, do Seminário Maior do Porto, Nacional de Portugal, bem como as bibliotecas Apostólica Vaticana e da Abadia de St. ${ }^{\text {a }}$ Justina de Pádua, em Itália (estas duas particularmente relevantes para as questões relacionadas com a congregação de Alga e o universo reformista italiano).

Além das tradicionais bibliotecas, e rendendo-me às variedades dos tempos, foi possível aceder digitalmente a um importante número de trabalhos, particularmente artigos académicos publicados em revistas científicas e obras impressas de cronologias mais recuadas; recolha operada através dos diversos repositórios disponibilizados pelos serviços da Universidade do Porto e do repositório que é o sítio da Google Books.

\footnotetext{
${ }^{144}$ Para uma biografia do bispo Tomasini veja-se VEDOVA, 1836: 334-345.

145 TOMASINI, 1642.

${ }^{146}$ PINA, 2011: 28.

${ }^{147}$ SANTA MARIA, 1697: prólogo.
} 
Ainda que o acesso facilitado a bibliografia digital implique cuidados redobrados por parte do investigador, para separar o trigo do joio (recorrendo aos termos da parábola), torna possível o acesso a bibliografia internacional que de outro modo dificilmente estaria disponível. Assim se compreende a sua importância numa pesquisa doutoral que trabalha não só sobre uma Congregação italiana, como centra o seu enfoque na questão da reforma e das reformas nos séculos de transição da medievalidade para a modernidade, área de pesquisa que tem desenvolvido escola fora de Portugal, em particular nos Estados Unidos, sob a influência de Ladner, e na Alemanha (neste caso, infelizmente, ficam os seus trabalhos excluídos pelo desconhecimento absoluto da língua de Goethe).

Foi precisamente no acesso a um artigo de uma revista científica on-line que tive um primeiro contacto com as teorias de reforma de Gerhart Ladner, um autor cujas obras não existem em bibliotecas portuguesas e que tão importante se revelou para estabelecer um conceito de reforma, para o período histórico analisado.

A Bibliografia que foi selecionada e recolhida nestas bibliotecas e repositórios digitais poderá ser dividida em três grandes grupos:

1. A bibliografia de carácter geral e contextualizante. Neste grupo incluem-se as obras utilizadas na elaboração do primeiro capítulo da tese, que atendendo à dimensão do objeto de estudo e ao seu carácter generalista se dirigiu para obras de referência, tanto internacionais ${ }^{148}$, como nacionais ${ }^{149}$.

Obras de referência para a História da Igreja tenham-se em conta a História Religiosa de Portugal $^{150}$ e o seu Dicionário ${ }^{151}$, do CEHR-UCP, que pela sua atualidade, qualidade das contribuições e extensividade se apresenta como uma escolha de primeira água.

Existe o pontual recurso a monografias específicas que contribuam para uma melhor compreensão do ambiente histórico em causa, ou que possam de algum modo apresentar dados que auxiliem a análise dos percursos das duas Congregações.

Entre estas obras encontram-se aquelas que deram o suporte teórico principal para desenvolver uma ideia de reforma em que se enquadre o movimento dos Cónegos de Alga e de S. João Evangelista, e que se centra no pensamento de Chaunu e da escola de Ladner.

2. O segundo grupo de bibliografia utilizado corresponde ao segundo capítulo, ou seja, a bibliografia específica sobre a Congregação de S. Jorge em Alga de Veneza, e aquela que de algum modo contribua para melhor definir e compreender o quadro histórico do aparecimento e desenvolvimento desta Congregação.

Tratam-se, particularmente, dos trabalhos de $\operatorname{Tramontin}^{152}$, $\mathrm{Cracco}^{153} \mathrm{e}^{\mathrm{Tassi}}{ }^{154}$, bem como artigos que respeitem direta ou indiretamente à Congregação de Alga e aos seus religiosos, como são os trabalhos dedicados a Eugénio IV e a S. Lourenço Justiniano.

\footnotetext{
${ }^{148}$ ABULAFIA, 2006; JONES, 2000a; ALLMAND, 1998.

${ }^{149}$ COELHO \& HOMEM, 1996; MARQUES, 1987; DIAS, 1998; MATTOSO \& SOUSA, 1997; MAGALHÃES, 1997.

${ }^{150}$ AZEVEDO, 2000-2002.

${ }^{151}$ AZEVEDO, 2000-2001.

152 TRAMONTIN, 1956; TRAMONTIN, 1975; TRAMONTIN, 1984.

${ }^{153}$ CRACCO, 1959; CRACCO, 1960; CRACCO, 1997.

${ }^{154}$ TASSI, 1948; TASSI, 1952.
} 
3. O terceiro grupo de bibliografia é aquele que mais diretamente corresponde ao tema desta obra, ou seja, a produção bibliográfica relacionada com os Lóios.

Como encontramos para a Congregação de Alga, estamos perante dois tipos de trabalhos: os que tratam especificamente da Congregação de S. João Evangelista e trabalhos que, tendo o seu enfoque noutras temáticas, dão contributos válidos para um melhor conhecimento da Congregação.

No primeiro caso destacam-se a tese de Isabel Castro Pina ${ }^{155}$ e os múltiplos trabalhos de Pedro Tavares ${ }^{156}$; no segundo contam-se contributos de diversas naturezas que (como ficou visto no ponto estado da arte) abordam os Lóios colateralmente ao tema central dos seus trabalhos, seja por a Congregação se relacionar com os seus objetos, seja pelo seu objeto de estudos pertencer ao universo da Congregação (caso do estudo da azulejaria dos Lóios).

\section{Metodologia}

Sendo por natureza um labor científico, o trabalho historiográfico tem naturalmente de ser produzido sob rigorosas condições metodológicas que permitam aferir a autenticidade e seriedade do resultado final. É consabido.

O ponto de partida de todo o trabalho está num questionamento de fundo que implica, para ser satisfatoriamente respondido, a construção de um conhecimento novo (ou pelo menos entendido de um modo diferentes em relação a análises anteriores) que sustente a resposta final, seja ela conclusiva (comprovando ou negando a hipótese original) ou inconclusiva.

Perante a problematização fundadora da pesquisa que aqui se apresenta, e o dilema de responder se foram ou não os Lóios uma Congregação reformista e em que termos, procurou-se antes de mais estabelecer teoricamente um conceito válido de reforma. O resultado está patente no ponto 1.1, dedicado precisamente à reflexão sobre o tema da reforma, e que se baseia no trabalho desenvolvido por dois académicos de reconhecido mérito: um representante da escola francesa, Pierre Chaunu, e um académico que faz a ponte entre as escolas germânica e anglo-saxónica, Gerhard Ladner.

Situados entres os campos da história social e quantitativa, história da arte, da cultura e das ideias, e tendo sobretudo em comum a história religiosa, estes dois académicos legaram um entendimento de reforma que se acredita servir perfeitamente aos termos em que foi formulada a problematização desta obra, e nos permitem compreender o universo reformista quatrocentista, de Portugal e Itália.

Com uma questão, e um quadro teórico que sustentasse essa questão, a conclusão foi estruturada a partir de um longo trabalho, que se procurou fosse o mais exaustivo possível, de recolha de fontes e de bibliografia relevantes para a construção de conhecimento.

A bibliografia terá nesta tese um duplo papel: com uma função primordial de contextualização teórica e histórica, para o que é selecionada sobre critérios de qualidade científica e representativi-

\footnotetext{
${ }^{155}$ PINA, 2011.

156 TAVARES, 1984; TAVARES, 1986; TAVARES, 1988; TAVARES, 1989; TAVARES, 1991; TAVARES, 1999; TAVARES, 2001a; TAVARES, 2001b; TAVARES, 2001c; TAVARES, 2003; TAVARES, 2008; TAVARES, 2009.
} 
dade, vamos encontrá-la ocasionalmente a servir de fonte secundária, sempre quando se torne difícil ou impossível recolher as informações que veicula a partir de fontes primárias.

Dos cartórios das Casas Lóias, conservados em arquivos e bibliotecas públicas, bem como de alguns outros fundos documentais que se revelaram de interesse para responder a questões pendentes ou para confirmar informações de fontes secundárias (cronísticas, por exemplo ${ }^{157}$ ), saíram as fontes primárias para esta pesquisa.

Combinando a questão de base e a tipologia de fontes primárias que se reconheceram de interesse elevado (exclusivamente fontes documentais, já que não se identificou outra tipologia de fontes com valor intrínseco) originou-se um percurso de arquivo que permitiu a ampla recolha de dados, os quais foram obtidos por um método simples, mas trabalhoso e demorado: a compulsa sistemática de fundos documentais selecionados por relevantes, com a recolha dos dados pertinentes.

Deste trabalho de arquivo resultou um corpo sólido de dados qualitativos que, incorporados à escrita da tese, são o sustentáculo do texto e, particularmente, das conclusões que se vão obtendo. Tratando-se maioritariamente de informações que não colocam problemas de base em matéria de autenticidade (do documento em si ou da informação que encerra), escusou-se o recurso a outras formas metodológicas de validação ou tratamento da informação.

Apesar disso, e para melhor sustentar o texto historiográfico que foi sendo produzido, procedeu-se ocasionalmente à condensação de informação em quadros (colocados em anexo), perspetivando o enriquecimento da sua análise enquanto dados quantitativos. Será o caso, por exemplo, da contabilização dos privilégios pontifícios concedidos às Congregações, elaborada (a par da sua análise qualitativa) para quantificar este tipo de apoio recebido dos Papas, e a sua variação em intervalos temporais.

Considerando as relações familiares como um dos vetores relevantes para o estudo das duas Congregações, inclui-se em anexo dois esquemas genealógicos que sistematizam as relações familiares da dinastia papal dos Correr-Condulmer-Barbo, de Veneza, e as do fundador dos Lóios D. Afonso Nogueira ${ }^{158}$.

Em matéria de cartografia histórica, visando uma melhor leitura da dispersão no espaço das comunidades religiosas e sua proximidade a centros políticos e religiosos, não foi possível elaborar cartografia para a Congregação de Alga pelo seu desaparecimento tricentenário e pela dificuldade em obter uma eficaz georreferenciação das comunidades. Seria para a Congregação de S. João Evangelista, na realidade o tema da obra, que uma leitura cartográfica se apresentaria mais importante, mas contando já com cartografia elaborada e publicada, remete-se para a sua consulta ${ }^{159}$.

\footnotetext{
${ }^{157}$ Será por exemplo o caso da procura no registo de breves do Arquivo do Vaticano do breve de Pio V que ordena o envio de Lóios a reformar a Congregação de Alga, mencionado pelo cronista Francisco de Santa Maria mas de que não havia vestígios na documentação dos Lóios. Veja-se o ponto 3.3.

${ }^{158} \mathrm{Vd}$. anexo genealógico.

${ }^{159}$ No guia histórico Ordens Religiosas em Portugal: das Origens a Trento, dirigido por Bernardo de Vasconcelos e Sousa (cf. SOUSA, 2005: 238, 239).
} 
Com toda a informação obtida das fontes primárias e secundárias, da sua análise qualitativa e quantitativa, com o recurso à bibliografia, aos quadros anexos e esquemas genealógicos, ao longo dos anos da pesquisa doutoral foi sendo construído o texto historiográfico que, dirigido por um questionamento de base, permitiu chegar à elaboração de uma conclusão, estabelecendo uma tese sobre a presença da ideia e prática de reforma entre os Cónegos Lóios. Este é, pois, o resultado que o leitor tem agora em mãos. 


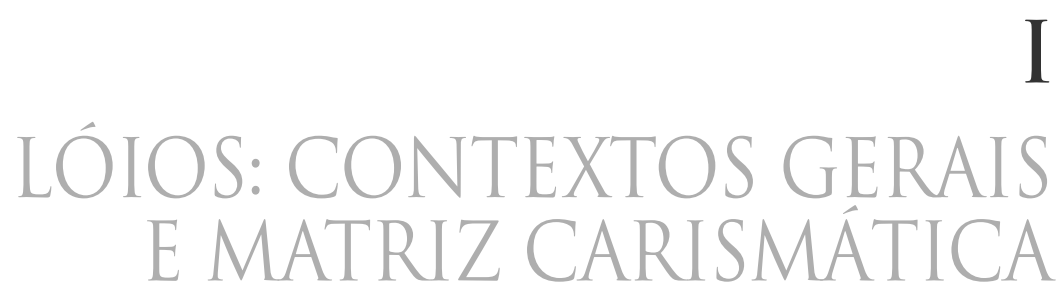


Corria o seculo decimo terceiro depois do parto da Virgem, quando a Christandade se vio em estado tão incerto, e perigoso, que parecia ameaçar ruina o soberano edifício da Igreja Catholica. Cresceo de modo a sempre inquieta ambição dos Principes, que não ficou pedra que não movessem por estender, e levantar cada hum sobre ruinas alheas a grandesa propria. Forão cruéis as guerras, e lastimosos os estragos, que padecerão por aquelles tempos as melhores, e mais florentes provincias da europa, como Hespanha, França, Inglaterra, e mais que todas a infelice Italia, fatalmente cortada, e dividida nas duas inimicissimas facções de Guelfos, e Gibelinos, que $/ / 10$ como dous incendios arrebatados, e violentos, fazião ou desfazião em cinza quanto topavão diante[...]. Os Pontifices, a cuja providencia, e cuidado tocava principalmente buscar remedio a tantas calamidades, vivião ausentes em Avinhão[...].

As Cidades estavão feitas hermos, trocadas em acervos de ruinas as antiguas grandesas; os Mosteyros se vião pela mayor parte convertidos em alojamentos de soldados, e as casas de oração feitas espeluncas de ladrões facinorosos. Os povos não acodião às Igrejas; estas carecião de ministros, e estes, ou seguião sem reparo a turbulência das facções, ou choravão sem remedio os danos dellas $[\ldots]$.

Os frades levados da corrupção dos tempos, e da propensão da natureza, sempre amiga da liberdade, e da sol-//11-tura, rompendo as leys da obediência, e pizando os dictames da rasão, $e$ talvez despindo os habitos, e com elles totalmente a gravidade, e a modestia, vivião, e vagavão à vontade. Nos Clerigos era mayor a dissolução, e o escandalo: porque como homens mais metidos no mundo, e geralmente menos disciplinados, sem resistencia se deixavam levar da corrente, $e$ apenas conservavão em o nome a memoria da sua dignidade; muitos trocando os barretes em capacetes, em espadas os breviários, e em sayas de malha as sotaynas, se fazião soldados ou salteadores, que tudo era a mesma cousa. Andava emfim de revolta o sagrado, e o profano, e tudo com desordem, e confusão summa declinava, e descahia cada vez mais para o precipicio, e ultima ruina.

P.e Mestre Francisco de Santa Maria, $1697^{160}$

${ }^{160}$ SANTA MARIA, 1697: 9 e segs. 


\section{REFORMA DA IGREJA NA EUROPA DOS SÉCS. XIV E XV: ENTRE O IDEAL E A PRÁTICA}

\subsection{REFORMA: CONSIDERAÇÕES EM TORNO DE UM CONCEITO}

a ideia de reforma pode ser definida como a ideia de livres, intencionais e sempre aperfeiçoáveis, múltiplos, prolongados e sempre repetidos esforços feitos pelo homem para reafirmar e aumentar os valores pré-existentes na composição espiritual-material do mundo ${ }^{161}$.

Foi com este parágrafo que Gerhart Ladner delineou, em poucas palavras, o seu entendimento do que é a ideia de reforma na história da Igreja.

Tendo-se dedicado a estudar a presença da ideia reformista na Igreja dos primeiros séculos (até ao séc. VI), particularmente atentando na sua presença em S. Paulo, St. ${ }^{\circ}$ Agostinho e no desenvolvimento do monaquismo ${ }^{162}$, irá defender a importância central desta ideia na história e, o que é ainda mais profundo, na identidade do mundo cristão.

De forma exemplar, Ladner não se furta a previamente ao seu estudo definir o que entende por reforma, elaborando uma chave de leitura que possui a enorme riqueza de não se reduzir a um limite casuístico, mas que pretende ser capaz de abarcar processos históricos com natureza profunda similar, ainda que se possam situar em espaços temporais e geográficos distintos. Ou seja, não se limitou a estudar um fenómeno temporalmente delimitado, mas fê-lo elaborando um quadro conceptual mais vasto, aplicável ao decurso da história bi-milenar do cristianismo.

Ladner intuiu, ao longo de uma vida académica particularmente dedicada e ativa, que existe no cristianismo uma característica constantemente presente, que se pode identificar como identitária.

Como faz notar, a história da humanidade pode (e tem sido) interpretada como uma série de começos, de processos de declínio e renovação que se sucedem entre si. O cristianismo, que sempre se entendeu como cosmogónico, desde cedo se inseriu nesta visão do mundo, lendo-se a si mesmo como expressão de renovação. Para Ladner esta auto compreensão irá marcar não só o domínio religioso mas todos os demais domínios do mundo cristão ${ }^{163}$.

Como o autor assinala de modo preciso, o próprio elemento central da teologia cristã, o processo salvífico da humanidade, desenvolve-se como processo de regeneração, através da morte e res-

\footnotetext{
${ }^{161}$ Tradução livre do original: «the idea of reform may now be defined as the idea of free, intentional and ever perfectible, multiple, prolonged and ever repeated efforts by man to reassert and augment values pre-existent in the spiritual-material compound of the world» (cf. LADNER, 1959: 35).

${ }^{162} \mathrm{Idem}$, ibidem. Ladner afirma no entanto que era seu desejo futuro, nunca concretizado, de trabalhar a questão para além do séc. VI, a persistência da ideia de reforma e de como ela terá passado do domínio puramente ideológico. Apesar de não ter concretizado este desejo, diversos são os trabalhos que utilizam o trabalho de Ladner como fonte de inspiração teórica para a sua investigação, como fica patente pelos contributos para a obra que marca o $50 .^{\circ}$ aniversário da edição da The idea of reform (cf. BELLITTO, 2012b).

${ }^{163} \mathrm{Idem}$, ibidem: 1 e segs.
} 
surreição de Cristo, «For christianity is a great religion of renewal where sin and death are overcome by divine redemption and ressurrection ${ }^{164}$.

Defendendo a ideia de reforma como conceito estrutural do cristianismo, tem o cuidado de precisar que esta no entanto tem uma definição distinta da leitura corrente do conceito, que modernamente seria antes de mais associada à renovação e melhoramento de entidades sociais e de instituições.

Como afirma, na sua origem a ideia cristã de reforma estava profundamente ligada à doutrina Evangélica e Paulina da pessoa humana, ou seja, a ideia cristã de reforma referir-se-ia originalmente à experiência de renovação pessoal em Cristo, do homem renovado à imagem de Deus. Ladner faz notar que ainda que este processo fosse essencialmente individual, ganha cedo na Igreja uma dimensão supra individual, traduzida no aparecimento do mundo monástico.

De interesse para esta obra é o questionamento do autor acerca das múltiplas reformas da Igreja que os historiadores abordam, e se essas manifestações pertencem a uma mesma tendência para a renovação, ou se pelo contrário têm naturezas distintas entre si e não compõem um padrão identitário.

Não dando uma resposta cabal, que seria extemporânea numa obra dedicada aos seis primeiros séculos do cristianismo, Ladner não deixa no entanto de precisar que, apesar da variação da terminologia utilizada, basta citar alguns exemplos (menciona Gregório Magno, Alcuíno, Gregório VII, Bernardo de Claraval, S. Boaventura) para demonstrar como a ideia de reforma se pode encontrar entre os grandes pensadores da Igreja ${ }^{165}$.

A grande questão situa-a não na existência histórica da ideia de reforma, mas na sua natureza exata. Tal será o que ocupa a primeira parte deste seu trabalho seminal ${ }^{166}$.

Ladner afirma categoricamente que a ideia de reforma que ele identifica, e pretende utilizar como ponto de referência para o estudo da história desta ideia no cristianismo inicial e nos tempos subsequentes, pertence ao domínio da ideia geral de renovação, de que é uma das variantes ${ }^{167}$.

Considerando a ideia de reforma como essencialmente cristã na sua origem e desenvolvimento inicial (não negando manifestações anteriores desta ideia no mundo Clássico, sem no entanto terem uma relevância central como no cristianismo), Ladner começa por definir entre os conceitos de renovação aqueles que não são a ideia de reforma que o ocupa. Identifica quatro tipos de ideias de renovação distintas da ideia de reforma:

1. Ideias cosmológicas de renovação - em que se enquadram as teorias da antiguidade sobre ciclos perpétuos de ocorrências similares, em que o início de cada ciclo implicaria forçosamente uma renovação do mundo. No mesmo campo encontram-se os esquemas das idades sucessivas do mundo que, em combinação com elementos apocalípticos do judaísmo e do cristianismo inicial, foram a base das ideias milenaristas de renovação. Estas teorias, de que se podem encontrar diversas formulações,

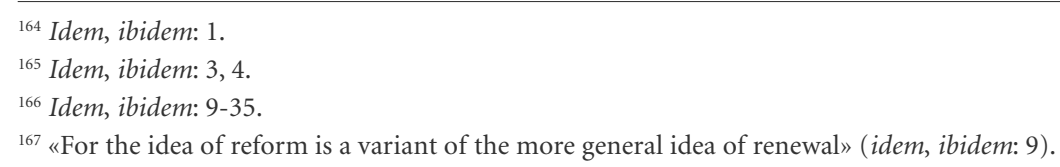


na sua forma mais extrema são, segundo Ladner, incompatíveis com o pensamento cristão. Lapidarmente esclarece: «The idea of reform differs from all cosmologic-deterministic renewal ideas through its element of freedom» ${ }^{168}$.

2. Ideias vitalistas de renovação - Assentam numa analogia com o mundo natural, com as conceções biológicas de desenvolvimento vital. Ladner considera que a ideia de Renascença, que irá acompanhar o ocidente cristão na transição para a Modernidade, radica nesta conceção de renovação, que já tivera uma presença no mundo romano, e a qual teria servido de influência para os pensadores renascentistas. A ideia de uma renovação que implica um carácter de revitalização natural, mesmo no domínio de uma regeneração espiritual, choca com a ideia de reforma sustentada pelo autor na medida em que o elemento natural e vitalista, e como tal determinista, desta ideia de renovação exclui na prática a intencionalidade na construção da proposta reformista ${ }^{169}$.

3. Ideias milenaristas de renovação - Estas ideias, que aparecem por vezes em combinação com as duas anteriores, são definidas por Ladner como utopias messiânico-milenaristas, ideias de absoluto ou de perfeição total. Aqui inserem-se as ideias milenaristas cristãs, fundadas no Apocalipse de João e na tradição do messianismo judaico, com influência de cosmologia oriento-helénica. Além das utopias milenaristas medievais, o autor inclui neste conjunto as ideias de Utopia, revolução ${ }^{170}$ e de progresso contínuo. Estas ideias distinguem-se da ideia de reforma, que segundo o autor tem conservado os elementos essenciais da sua origem nos primórdios do cristianismo, pelo facto desta se caracterizar pela crença na inerradicável imperfeição terrestre e na sua relativa perfectibilização numa dimensão imprevisível.

4. As ideias de conversão, regeneração batismal e de penitência e a sua relação com a ideia de reforma - Para Ladner, apesar das ideias de conversão religiosa e de regeneração espiritual individual através do batismo estarem proximamente ligadas à ideia de reforma, não são no entanto idênticas. Tal deve-se ao facto de a regeneração por via do batismo ser, doutrinalmente, instantânea e não-repetível, contrariamente à ideia de reforma que ocupa o autor, que contém elementos de multiplicidade que envolvem a noção de prolongamento e repetição. Dando exemplos doutrinais, a graça batismal entende-se na partilha pelos cristãos dos méritos da morte e Ressurreição de Cristo, enquanto a ideia de reforma se poderá associar à eucaristia, em que o sacrifício de Cristo se repete no altar, produzindo efeitos repetida e prolongadamente. Ladner faz notar que o sacrifício eucarístico pode mesmo ser entendido como o centro vivificante da reforma cristã, ainda que na sua formulação original, no cristianismo primitivo, tal se possa intuir mais na própria liturgia do que no pensamento explícito dos Padres da Igreja.

\footnotetext{
${ }^{168}$ Idem, ibidem: 16. Itálico no original.

169 «Contrary to all vitalistic renewal ideas, the idea of reform implies the concious pursuit of ends. Wheter reform be predominantly contemplative or active, its starting point is the element of intention rather than of spontaneity, urge or response» (idem, ibidem: 26. Itálico no original).

${ }^{170}$ No que se refere à ideia de revolução, Ladner chama a atenção para que dificilmente se pode considerar este conceito como aplicável à realidade europeia anterior à Época Moderna. Sublinha também que se pode encontrar confusão em alguns autores entre a ideia de revolução e reforma, distinguindo desde logo uma da outra pelo facto da ideia de revolução conter em si a crença de que o destino humano pode ser melhorado de modo violento, total e definitivo (cf. Idem, ibidem: 30).
} 
Depois deste esforço em dizer o que não é reforma, Ladner apresenta a sua já citada definição do que é, precisando que embora esta garanta a possibilidade de definir a ideia de reforma e de estudá-la como um facto histórico, um fenómeno essencialmente cristão na sua origem e desenvolvimento inicial, tal não obriga implicitamente que à ideia corresponda uma realidade efetiva. Ou seja, trata-se para o autor da questão de se os termos contidos na definição se poderem transpor para uma realidade e existir para além de uma dimensão superior; como o próprio expressa: «in short, is there possibility of reform besides changelessness and besides other types of renewal and change?» ${ }^{171}$.

Ladner coloca o ponto final da sua definição de ideia de reforma na noção generalizada de que os grandes eventos que transformam a história dependem de mudanças, ainda que ligeiras e subtis, no domínio das ideias. Com base em tal, diz não ser descabido esperar que a ideia de reforma, pelo seu conteúdo, tenha jogado um papel particularmente importante nas alterações históricas.

A proposta de Ladner, de estudar a reforma antes de mais como uma ideia, e uma ideia estrutural ao pensamento cristão, formada essencialmente no seu seio e que o tem acompanhado secularmente, abre um horizonte de compreensão muito mais vasto do que aquele com que tradicionalmente a historiografia tem abordado as reformas.

Poder-se-á, nesta chave de leitura, lançar um olhar muito mais abrangente sobre os diversos movimentos de reforma existentes no percurso histórico do universo religioso do mundo cristão ${ }^{172}$, nomeadamente perspetivando um conceito de fundo que acompanhe e enquadre numa mesma linha histórica de pensamento diversos momentos e movimentos reformistas. Do mesmo modo permitirá qualificar pensadores e instituições que participam deste universo ideológico da reforma, mesmo quando o seu peso real e imediato no tecido histórico é bastante limitado.

Quão longe esta definição de ideia de reforma nos permite situar em relação à perspetiva de reforma como um movimento maciço que abrangeu o universo religioso cristão do séc. XVI, perspetivando-se na dramática e estrutural alteração dos pressupostos institucionais em vigor até então.

A reforma não é mais uma questão de protestantes e de reação católica, de polarizações religiosas, políticas e sociais, mas entra a ser parte de uma estrutura de pensamento mais vasta no tempo, no espaço e nas manifestações. Entenda-se, não se pretende diminuir a relevância histórica das reformas religiosas quinhentistas, tanto mais que talvez sejam a expressão real mais notável da influência da ideia de reforma no mundo cristão.

\footnotetext{
${ }^{171}$ Idem, ibidem: 35.

${ }^{172}$ A expressão «mundo cristão» pressupõe já por si uma categorização de natureza religiosa. No entanto, e devido ao facto desta definição ter uma aplicação histórica mais vasta, englobando identitariamente o mundo europeu cristianizado (veja-se ainda recentemente os debates em torno da matriz cristã da Europa), precisa-se aqui que neste trabalho se toma o mundo ou universo cristão na sua vertente propriamente religiosa, unitária até aos diversos cismas que foi sofrendo ao longo da sua história, primeiro com a separação da Igreja do Oriente, depois com o nascimento das Igrejas do universo protestante. Acerca da delimitação do «sector religioso, no seio do grande fluxo da história», veja-se o que diz CHAUNU, 2002: 13 e segs.
} 
Pretende-se sublinhar, em linha com Ladner e outros académicos que seguem a sua perspetiva de análise, bem como com aqueles que trilhando outros caminhos alcançam uma similar abertura de perspetivas de análise do pensamento e ação reformistas no mundo cristão, que não se pode ver a reforma apenas pelos resultados maciços resultantes da ação de pessoas e instituições com carácter reformista, mas pela transposição do enfoque de leitura para um enquadramento mais largo, que da análise dos efeitos passe a uma leitura abrangente que envolva as causalidades e os processos históricos que conduzem à efetiva ação reformista.

Esta abertura de lente permitirá igualmente enquadrar no campo do pensamento e ação reformistas indivíduos e coletividades que de algum modo se possam identificar como participantes de uma ideia geral de reforma, como a proposta por Ladner, e que tantas vezes foram ignoradas ou descartadas como tal por se situarem apenas no campo das ideias, ou por os seus esforços terem diminuta repercussão no conjunto eclesial e social.

Na prática Ladner oferece um sustentáculo teórico que permite a inclusão, na história do pensamento e ação reformistas, destes elementos anteriormente ignorados, tendo neste domínio o efeito transformador que em outros domínios da história assumiu o movimento da Nova História ${ }^{173}$.

A sua teoria, que aqui se expôs, conjuga-se com o questionamento central desta obra e permite analisar de modo mais rico a ação dos cónegos de Alga e de S. João Evangelista. Se aos olhos da historiografia tradicional das reformas estas congregações não poderiam ser verdadeiros alfobres reformistas, porque antecediam no tempo as reformas triunfantes do séc. XVI, os avanços historiográficos colocaram-nas posteriormente na arrumação da pré-reforma da Igreja, que Chaunu descreve como «velha problemática, desajeitada na sua formulação, mas útil, da pré-Reforma», não deixando no entanto de salientar que «A pré-Reforma não é, simplesmente, uma reforma à procura de si mesma» ${ }^{174}$.

É neste ponto interessante confrontar, apesar das diferenças de abordagem, a teoria de Ladner e o trabalho de Chaunu, as duas perspetivas de reforma que mais decididamente influenciam esta obra. Juntas acredita-se que possam oferecer solidez ao edifício teórico com que se analisa os Lóios, entendidos como congregação reformista.

Ladner e Chaunu encontram-se em pontos distantes, não só nos horizontes temporais (o primeiro trabalha os primeiros séculos do cristianismo enquanto o segundo trabalha os séculos finais da Idade Média e a Modernidade), mas também nas abordagens, pois se o primeiro trabalha essencialmente com as questões históricas das mentalidades e do universo religioso, destacando-se como historiador da Igreja, já Chaunu tornou-se justamente célebre como um investigador da área da história social e demográfica, tendo (o que aqui nos interessa particularmente) desenvolvido igualmente importantes estudos na área da história religiosa.

\footnotetext{
${ }^{173}$ Note-se que o trabalho de Ladner se situa temporalmente em paralelo com aquilo que Le Goff caracterizou como «uma profunda renovação no domínio científico», em que a História participou de modo consistente e decisivo (cf. LE GOFF, 1990).

${ }^{174}$ CHAUNU, 2002.
} 
Esta aplicação far-se-á, por exemplo, em relação à figura do Papa Eugénio IV (uma das figuras centrais da Congregação de Alga), a quem se tem reconhecido perfil de reformista e de reformador ${ }^{175}$, ainda que não consistentemente. Tendo atingido o lugar mais elevado na hierarquia eclesiástica seria de esperar, do fundador de uma congregação reformista, que levasse a cabo uma ampla política de reformas no interior da Igreja.

A debilidade do poder pontifício que herdou de Martinho V e da crise cismática anterior, mantém o papa veneziano na luta contra a corrente conciliarista na Igreja, representada pelo concílio de Basileia. Partindo do pressuposto que reforma é antes de mais uma ideia e não um (ou múltiplos) processo reformista, podemos então (analisando, como se fará, o pensamento e ação dos fundadores de Alga) colocar Eugénio IV e os seus companheiros de Congregação no universo dos reformistas do séc. XV. Similarmente equacionar-se-á, na mesma chave de leitura, o pensamento e ação dos cónegos Lóios.

Pensar, segundo Ladner e a sua escola, os cónegos de Alga e de S. João Evangelista como reformistas e reformadores, pelo seu pensamento explícito e pelas suas ações, independentemente dos resultados efetivos que possam ter alcançado ${ }^{176}$, permitirá colocá-los no cerne dos movimentos que nos inícios do séc. XV, e na saída da grave crise cismática, procuraram renovar e reformar a vida da Igreja, do clero e dos seus fiéis.

Será aqui o ponto em que os trabalhos desenvolvidos entre os discípulos de Ladner que se dedicam aos séculos finais da Idade Média se encontram com o postulado por Chaunu em O Tempo das Reformas.

Como já foi sendo exposto, o estudo das duas congregações como entes reformistas apenas será possível ultrapassando o eterno problema da centralização das reformas no séc. XVI. Chaunu faz uma leitura abrangente que propõe uma cronologia tricentenária, unindo os séculos finais da medievalidade às primeiras décadas da Modernidade: 1250-1550.

A abrangência cronológica, que o autor explica bem ${ }^{177}$, marca um longo tempo em que situa os eventos fundamentais dos processos reformistas e das transformações intelectuais, espirituais, materiais e técnicas que os permitiram e sustentaram.

Este longo tempo dá-nos uma visão dos processos reformistas distinta daquela que tradicionalmente se sustenta, muito centrada nos processos quinhentistas de rutura, polarização e afirmação identitária dos blocos eclesiais resultantes.

Chaunu oferece, à ideia de duas reformas do séc. XVI (a protestante e a católica), a alternativa de quatro reformas interconectadas entre si, que se situam entre o séc. XIII e o XVI, e na qual atribui

\footnotetext{
${ }^{175}$ WATANABE, 2008.

${ }^{176}$ Como dizia Silva Dias, os Lóios foram «a tentativa mais séria da sua reforma [do clero]». Note-se que ação dos Lóios é analisada como importante, mas não como decisiva. Ou seja, Silva Dias reconhece claramente a natureza reformista da Congregação, mas reconhece que a sua ação reformadora, ainda que importante, foi limitada na Igreja portuguesa quatrocentista (cf. DIAS, 1960: 94).

${ }^{177}$ CHAUNU, 2002: 27 e segs. Note-se que para Chaunu a cronologia correta deveria ser entre 1300 e 1700 , período que para ele é efetivamente o tempo das reformas da Igreja: «Entre 1300 e 1700, na aceção mais vasta e sem dúvida abusiva, situa-se o tempo das reformas da Igreja, e, em torno de uma relação do homem com Deus, todo um sistema de civilização».
} 
a primazia (como já referido anteriormente) aos movimentos de reforma (correntes de reforma na expressão do autor) anteriores à emergência do protestantismo, de uns sécs. XIV e XV particularmente ricos de alterações materiais, sociais, intelectuais e religioso-espirituais, que na sua opinião terão conduzido «por volta de 1500, ao consensus, que não é o da reforma mas, sim, o da sua necessidade» ${ }^{178}$.

Toda a 1. a parte de O Tempo das Reformas é dedicada a expor o que entende por mais relevante nestas alterações, e do modo como estas se combinaram para uma alteração de consciência e de entendimento do mundo que conduzisse ao tal consenso.

A análise de Chaunu e de Ladner e da sua escola permitem estabelecer conceitos de reforma distintos mas complementares para o período a que esta pesquisa se reporta, e deste modo sustentar a proposta de leitura que se faz dos Lóios como uma congregação religiosa efetivamente reformista e com ação reformadora no seio do clero português, mas também na sociedade portuguesa dos sécs. XV e XVI, onde o seu capital reformista foi reconhecido suficientemente para permitir o seu desenvolvimento institucional e conceder-lhe um espaço de ação para além dos limites dos muros claustrais.

Visto como uma ideia, ou visto como uma realidade prática resultante da transformação de mentalidades provocada pela transformação material do mundo, os processos reformistas do séc. XV são, na perspetiva das duas linhas que aqui se seguem, processos históricos com um valor próprio, não dependente dos que se lhe seguem temporalmente.

Deste modo podemos reconstruir a diacronia natural do tempo histórico. Não se pode considerar numa perspetiva histórica correta que a leitura de processos históricos temporalmente anteriores seja feita pela relação que com eles estabelecem processos sucessores. As reformas quinhentistas da Igreja são sucessoras dos processos de reforma dos dois séculos anteriores. Pensar os segundos pelos méritos das primeiras é um erro.

Ainda que os reformadores que antecederam Lutero tivessem na sua ação, naturalmente, uma perspetiva de futuro, dificilmente se poderá considerar que agissem na intenção concreta das mudanças que se vieram a operar nos séculos posteriores. O seu pensamento e ação são dotados de uma consciência e de um valor próprios, inseridos na realidade do seu tempo, enquadrados nos contextos em que se desenvolveram.

Pensar linhas reformistas que se desenvolvem na Europa do séc. XIV e XV obriga, além de refletir sobre os contextos gerais de crise (que Chaunu acentua com o subtítulo do seu livro, A crise da cristandade), a ter em consideração que em outros domínios que não o eclesial (nomeadamente o cultural) outros movimentos de renovação estavam a desenvolver-se.

Não entrando demoradamente sobre a questão da natureza e forma do Renascimento, que no entanto estará presente nesta tese por esta se debruçar parcialmente sobre o norte italiano dos finais do séc. XIV e XV, importa salientar que a Idade Renascimental introduziu, também ela, noções que se podem caracterizar como renovadoras, o que aliás já Ladner, como vimos, salientava ${ }^{179}$.

\footnotetext{
${ }^{178}$ Idem, ibidem: 10.

${ }^{179}$ LADNER, 1959: 16-26.
} 
A noção expressa por Petrarca dos tempos negros, que intermediariam entre o mundo clássico e a sua contemporaneidade do séc. XIV, tem por fundo um entendimento de natureza religiosa, como já foi apropriadamente salientado ${ }^{180}$, e que se insere na longa tradição do pensamento dicotómico de oposição entre luz e escuridão, entre verdade e erro, entre bem e mal, entre eternas salvação ou condenação.

Esta ideia, adotada pelos intelectuais do Renascimento numa apropriação secularizante de uma noção de natureza religiosa, permite no entanto perceber um entendimento, por parte dos homens de cultura italianos dos sécs. XIV e XV, de um desvirtuamento e afastamento de uma realidade inicial, entendida como superior, para o retorno à qual todos os esforços se deveriam orientar.

A semelhança com o pensamento dos reformistas religiosos do período de viragem do séc. XIV para o XV é relevante, ainda mais considerando que ambos usam de base um pensamento com a mesma raiz. A ideia de um novo tempo, que restaura a perfeição do antigo.

\subsection{CONTEXTOS DE UMA EUROPA EM REFORMA}

O excerto de Francisco de Santa Maria, Cronista dos Lóios, em que o autor traça pinceladas de uma realidade em mudança no mundo religioso italiano dos primeiros anos do séc. XIV, expõe um quadro que se tornou bem mais agudo no decurso desse século, mercê de contextos rigorosos.

As mudanças e crises que marcaram os séculos XIV e XV são de particular interesse para a compreensão do que foram as Congregações de S. Jorge em Alga de Veneza e de S. João Evangelista de Portugal, e do seu papel num complexo e longo processo reformista da Igreja.

A Europa trecentista viveu sob o signo da contradição. Considerado pela historiografia ${ }^{181}$ como um século de crises em que a medievalidade estabelece o seu ocaso, está no entanto já impregnado da essência do que será a Modernidade ${ }^{182}$.

$\mathrm{Chaunu}^{183}$ situa mesmo este século no período de charneira em que se constroem as mutações intelectuais, espirituais, sociais e materiais que permitirão, no séc. XVI e XVII, o surgimento de todas as efetivas mutações, nos mais diversos quadrantes, que se situam já numa modernidade de plena maturação, e que estabelecem um quadro que perdurará por alguns séculos. Século de crises, assume-se no entanto como propiciador de mudanças e de construção de novas realidades que precipita.

\footnotetext{
${ }^{180}$ MOMMSEN, 2002: 219 e segs.

${ }^{181}$ Veja-se o terceiro capítulo, intitulado L’Europe en crise 1328-1453, de AA.VV., 1970: 421 e segs. Do mesmo modo o Livro I As grandes provações 1328-1453 de BÉRENGER, 1996. Também a historiografia portuguesa faz eco desta sensibilidade, com um relevo que permite eleger a crise trecentista como marco cronológico, em COELHO \& HOMEM, 1996, e de modo ainda mais claro em MARQUES, 1987; encontrando-se também refletido na segunda parte de MATTOSO \& SOUSA, 1997. 182 «Fin d'un monde ancien et début d'un monde nouveau. La physionomie de l'Europe se transforme aux 14e et 15e siècles. [...] Les deux derniers siècles du Moyen Age représentent une période d'interprétation difficile pour qui considère l'ensemble de l'Europe. D'un côté, à l'Ouest, les régions qui avaiaent le plus beneficie de l'essor des siècles précédents traversent une crise qui entraîne bouleversements et reclassements. D'un autre côté, en Europe centrale et en Europe du Nord-Est, s' affirment de nouvelles forces politiques et économiques. Au Sud-Est, enfin, l'agonie et la disparition de l'Empire byzantin et l'avènement de l'Empire Ottoman donnent ses contous définitifs à l'Europe modern» (CARPENTIER \& LEBRUN, 1990: 194).

${ }^{183}$ CHAUNU, 2002: 9 e segs.
} 


\subsubsection{A Europa da crise: sécs. XIV e XV}

É de crer que o facto mais marcante para a cristandade latina (entendida enquanto comunidade de crentes), no decurso do séc. XIV, terá sido o Grande Cisma da Igreja. A grave crise eclesial que abre insere-se num período de sentimento generalizado de crise, alicerçado na diversidade e relevância das áreas da vida humana em que se fez sentir.

Depois de na viragem do primeiro milénio a Europa ter genericamente (ainda que com maior acuidade no eixo central europeu dominado pela Françç ${ }^{184}$ ) vivido um período de expansão tecnológica, económica e demográfica, com consequências políticas, sociais e religiosas ${ }^{185}$, o mesmo atingirá um ponto culminante nas primeiras décadas do séc. XIV, altura em que diversos fatores provocaram a inflexão para o período que tem sido caracterizado como de «crise».

Um dos elementos da vida europeia mais notoriamente afetado neste período de crise que abrange os sécs. XIV e XV foi o da demografia, que depois de séculos de crescimento entra agora num período de depressão que, em alguns pontos específicos, se poderá mesmo considerar dramático.

As mortes provocadas pela peste, fome e guerra (o temido trio mortal, contra quem se dirigiam também as preces do povo cristão $\left.{ }^{186}\right)$, provocam no decurso do séc. XIV e XV um retrocesso demográfico, uma quebra que segundo os autores levará séculos a recuperar ${ }^{187}$.

A conjugação de fatores, em que as crises agrícolas e as fomes, originadas possivelmente por alterações climáticas e pela incapacidade de alimentar as populações multiplicadas ${ }^{188}$, e que ao longo

${ }^{184}$ Como Chaunu faz notar ao precisar que a França concentrava, nos inícios do séc. XIV, 30\% da população europeia, em 5\% do território europeu (cf. CHAUNU, 2002: 42).

185 «Des trois grandes étapes qui ont conduit l'Europe occidentale à la suprématie mondiale, la période qui va de 1000 à 1300 représente la première $[. .$.$] Cette première croissance a assuré aux hommes de la Chrétienté latine, de plus en plus nom-$ breux, la maîtrise de l'occupation du sol et de la production rurale» (CARPENTIER \& LEBRUN, 1990: 156, vd. igualmente para o mesmo: GRIMAL et al., 1996: 357 e segs.).

${ }^{186}$ A peste, fame et bello líbera nos Dómine, assim se expressa o verso da Ladainha dos Santos, fórmula de oração antiquíssima, constituída por uma série ritmada de súplicas, de solene utilização litúrgica (cf. COELHO, 1950: 29). Já Armindo de Sousa chamava a atenção para este versículo da Litaniae Sanctorum (MATTOSO \& SOUSA, 1997: 285).

${ }^{187}$ Ainda que estas sejam considerações gerais, é notório que tanto a profundidade da quebra demográfica, como o ritmo da sua recuperação, variou consideravelmente por todo o espaço europeu, como aliás variou anteriormente o ritmo de crescimento e a concentração de populações (cf. CARPENTIER \& LEBRUN, 1990: 194 e segs; BÉRENGER et al., 1996: 20 e segs.; CHAUNU, 2002: 46, 47). Mais recentemente a variedade da evolução demográfica foi salientada, seja no espaço ou no tempo, em KLAPISCH-ZUBER, 2000: 126 e segs.

${ }^{188}$ CHAUNU, 2002: 46, 47. Chaunu sublinha o papel das crises agrícolas e das sequentes fomes no decréscimo populacional, em linha com outros historiadores. Para Portugal Oliveira Marques afirma o papel das fomes na crise demográfica portuguesa dos sécs. XIV e XV (MARQUES, 1987: 30 e segs.). No entanto, no seu estudo sobre a Peste Negra e as alterações económicas e sociais decorrentes, Herlihy (1999: 31 e segs.), contraria as correntes historiográficas malthusianas e marxistas postulantes de uma Europa que entra em desequilíbrio nos sécs. XIV e XV por excesso populacional ou por tensão nas relações sociais de dominação. Não recusando uma explicação multifactorial, vem acentuar o papel da Peste e das suas consequências no rompimento do status quo demográfico e social criado nos séculos anteriores. Atendendo à questão das fomes da primeira metade do séc. XIV, sublinha que não terão alterado substancialmente a demografia da sociedade europeia, que aliás se manteve estável nos seus diversos componentes até ao advir da Peste. Paul Freedman (FREEDMAN, 2000: 82 e segs.), também historia as diversas abordagens do problema, no que se refere ao âmbito rural da sociedade, e conclui por uma explicação que integra as três visões previamente enumeradas, acentuando a importância do papel da Peste de 1347/1352, mas não deixando de relevar elementos depressivos na demografia 
do séc. XIV e XV serão periódicas, a par dos efeitos das crises epidémicas de peste, cuja primeira grande manifestação entre 1347-1352 terá reduzido a população europeia em percentagem situada acima das três dezenas ${ }^{189}$, vão ter um efeito devastador na demografia europeia.

No contexto da crise o lugar das crises epidémicas é cimeiro, já que ao afetar dramática, rápida e eficazmente a própria subsistência física das comunidades, é geradora de substanciais alterações das mesmas.

A epidemia de Peste que nos anos centrais do séc. XIV atravessou a Europa, com as suas recidivas ao longo da 2. ${ }^{\text {a }}$ metade desse século e no seguinte, foi considerada como o mais grave desastre natural que afetou a Europa na sua História ${ }^{190}$.

Herlihy advoga para a peste negra, e para a rapidez dos seus efeitos e das alterações que provoca, o papel de um dos principais sujeitos de mudança no mundo tardo-medieval europeu ${ }^{191}$, e adivinha (não na epidemia, mas na resposta da sociedade aos desafios que a mesma lançou) o motor de um conjunto de mudanças que introduzirão no decurso da $2 .^{\text {a }}$ metade do séc. XIV e do séc. XV, o que se parece com as linhas gerais da Modernidade ${ }^{192}$.

\section{Política e Guerra}

Os séculos finais da medievalidade permitem entrever, na orgânica dos Estados europeus, um estádio novo na afirmação dos poderes soberanos: «In this century [séc. XIV], when feudalism died, absolute monarchy everywhere took its first steps» ${ }^{193}$.

anteriores a este fenómeno, bem como as tensões existentes no seio do sistema senhorial. No que respeita ao espaço urbano, Jean-Pierre Leguay (LEGUAY, 2000: 102 e segs.) nota processo similares para o espaço urbano, numa época em que abrangeria apenas 5\% da população europeia. Já Christiane Klapisch-Zuber sublinha que as fomes das primeiras décadas do séc. XIV tiveram alcance limitado, apesar de serem causa direta ou indireta de mortalidade, e de os cronistas e historiadores atribuírem às suas consequências um papel de facilitador na rápida propagação da Peste (cf. KLAPISCH-ZUBER, 2000: 129, 130).

${ }^{189}$ CHAUNU, 2002: 46, 47. Chaunu fala numa cifra global situada entre os 30\% e os 40\%. Em BÉRENGER et al., 1996: 39, a cifra fica-se nuns mais modestos $20 \%$, salientando a variação dos números no espaço europeu. CARPENTIER \& LEBRUN, 1990: 195, inclinam-se para um número entre o quarto e o terço da população europeia morta pela peste de 1347-52. Armindo de Sousa (MATTOSO \& SOUSA, 1997: 283-285), apoiando-se nos estudos portugueses e europeus, acentua bem a questão da variação da mortalidade, sobre a qual intervieram diversos fatores, tanto para Portugal como para o resto da Europa. Oliveira Marques, além de afirmar que a Peste de 1348 foi em Portugal «o grande acelerador da crise», acentua a sua importância para a demografia portuguesa, e alinha pela ideia geral de que um terço da população portuguesa teria perecido nesta primeira manifestação da Peste (cf. MARQUES, 1987: 20 e segs.).

${ }^{190}$ HERLIHY, 1999.

191 «It [a peste] broke the Malthusian deadlock that medieval growth had created and which might have impeded further growth in diferente forms. It guaranteed that in the generations after 1348 Europe would not simply continue the pattern of society and culture of the thirteenth century. It assured that the Middle Ages would be the middle, not the final, phase in Western development» (HERLIHY, 1999: 38).

192 «A more diversified economy, a more intensive use of capital, a more powerful techology, and higher standard of living for the people - these seem the saliente characteristics of the late medieval economy, after it recovered from the plague's initial shock»; «The plague broke the deadlock, and allowed Europeans to rebuild their demographic and economic systems in ways more admissive of further development. Culturally, the plague thinned the cadres of the skilled and learned and reduced their years of servisse; it weakened schools and universities; and it compromised the quality of cultural traditions. But it also prepared the road to renewal» (idem, ibidem: 51, 81).

${ }^{193}$ RIGAUDIÈRE, 2000: 17. 
O Estado conhece um período de construção ${ }^{194}$ que se desenvolve em duas linhas:

A primeira no campo da teoria política e ciência do governo, em que pensadores e homens do Direito vão desenvolver toda uma nova justificação do poder, substituindo a ideia imperial pela legitimidade de pleno poder dos reis nos seus reinos. Esta construção teórica procura enquadrar o fortalecimento das jovens monarquias europeias, enquanto o poder imperial sofre, no decurso da $2 .^{\text {a }}$ metade do séc. XIII, de particular fragilidade ${ }^{195}$.

A segunda linha tem carácter institucional. O ideal de um Rei com plenitude de poderes coloca os soberanos no topo de uma cadeia que lhes confere plena autoridade em matéria legislativa e judicial. Uma perceção mais alargada de poderes, e o seu efetivo exercício, exigem a multiplicação e especialização das instâncias de poder, que levam à primeira grande construção dos aparelhos de Estado. São também uma das causas da criação da fiscalidade permanente, gerando por sua vez toda a estrutura encarregue da cobrança fiscal. O crescimento do aparelho de Estado conduz à necessidade de especialização dos funcionários, e deu origem a especialistas de governo, consubstanciados na burocracia presente nos conselhos dos soberanos, nos seus tribunais e cargos da administração ${ }^{196}$.

Entre as questões de política dinástica e a ambição territorial de soberanos cujo poder, e a forma de o exercer, foi claramente ampliada, a política europeia conhecerá nos séculos XIV e XV alguns períodos de instabilidade, traduzidos em estados de guerra.

A França e a Inglaterra, reinos empenhados em processos de afirmação do poder Real, estão envolvidas por laços de sangue e de vassalidade, que em última análise vão levar ao desencadeamento da Guerra dos 100 anos (1337/38-1453).

A França atingiu no reinado de Filipe IV (†1314), empenhado na consolidação e alargamento do poder real, uma posição segura como o maior e mais influente reino do ocidente cristão $0^{197}$. O seu poder mede-se pela vitória na disputa com a Santa Sé no pontificado de Bonifácio VIII ${ }^{198}$, na transposição da cúria romana para Avinhão, e sequente colocação do Papado na órbita de influência da coroa francesa. Afinal, como expressava quase um milénio antes Ambrósio de Milão: Ubi ergo Petrus, ibi Ecclesia ${ }^{199}$.

O resultado foi o afrancesamento da Santa Sé, que conhecerá um processo de reorganização administrativa importante, dotando-a de uma burocracia altamente especializada e eficaz, que avança no mesmo sentido que a das monarquias: um maior e mais eficaz exercício de poderes, sustentado por uma maior e mais eficaz fiscalidade ${ }^{200}$.

\footnotetext{
${ }^{194}$ Estas considerações são genéricas, e referem-se sobretudo às principais monarquias europeias, nomeadamente França, Inglaterra, Península Ibérica e Império. Ainda assim convém ter em consideração que a diversidade é regra: «Seria ilusório, pelo menos à primeira vista, tentar integrar num esquema uniforme e comum a evolução política do conjunto dos Estados europeus no final da Idade Média. Nesse domínio, a diversidade e os contrastes sobrelevam tudo o mais» (cf. BÉRENGER et al., 1996: 121).

${ }^{195}$ RIGAUDIÈRE, 2000: 18 e segs.

${ }^{196}$ Idem, ibidem.

${ }^{197}$ JONES, 2000b: 388, 389.

${ }^{198} \mathrm{Vd}$. ponto 1.3.1.

${ }^{199}$ No comentário 30 ao Salmo 40 (cf. AMBRÓSIO DE MILÃO, 1842).

${ }^{200}$ CHÉLINI, 1982: 19-62; GUILLEMAN, 1998; Vd. Ponto 1.3.1.
} 
Os processos de consolidação e ampliação de poderes desenvolvidos no reinado de Filipe IV «alors le plus puissant souverain d'Europe ${ }^{201}$, terão acentuado a centralidade e importância da monarquia francesa no conjunto das coroas europeias. Após a sua morte, e rápida sucessão dos seus filhos, a coroa tentará manter, com o apoio da burocracia, a estabilidade das estruturas de poder desenvolvidas ao longo do seu reinado ${ }^{202}$.

Após a morte do último Capeto, e a ascensão de Filipe VI Valois ao trono, a situação tornar-se-á mais complexa pela reclamação, por parte de Eduardo III de Inglaterra, do direito de sucessão como neto de Filipe IV. O resultado é a guerra, o aparecimento de blocos a partir das suas relações com os reinos e potências vizinhos, os quais aproveitarão para mesclar outras conflitualidades, inclusive, durante a crise cismática, as obediências aos Pontífices Avinhoenses e Romanos ${ }^{203}$.

O Sacro Império foi dominado ao longo do séc. XIV e primeira metade do XV pela Casa de Luxemburgo, a qual assegura a dignidade imperial no término de um período de forte instabilidade e fragilização que se segue à morte de Frederico II e à saída de cena da Casa dos Hohenstaufen $(1250)^{204}$. Apesar dos lustros da dignidade Imperial, de que o titular está ainda revestido, e que permitirão a Segismundo (1410-1437205) arvorar-se de autoridade para convocar o Concílio de Constança (onde terá fim o Cisma ${ }^{206}$, os anos finais da Idade Média são de enfraquecimento do Poder Imperial, mas também do poder Pontifício com quem mantiveram sempre relações intensas de apoio ou oposição ${ }^{207}$.

\subsubsection{A Itália, de Avinhão a Eugénio IV (1309-1447)}

Ultrapassados em grande medida os diferendos entre o Império e os Estados Italianos, que tinham marcado os séculos anteriores ${ }^{208}$, a Itália do séc. XIV vive um período de desenvolvimento e

\footnotetext{
${ }^{201}$ CHÉLINI, 1982: 22.

${ }^{202}$ JONES, 2000b.

${ }^{203}$ Idem, ibidem; BÉRENGER et al., 1996: 121 e segs. Veja-se como exemplo a posição de Portugal nestes conflitos, decidida antes de mais de acordo com os ditames e sabores da política nacional, e da sua conjugação com a relação, frequentemente conflituosa, com o reino vizinho (MARQUES, 1987: 316 e segs.).

${ }^{204}$ Para a evolução do Império entre 1200 e 1500, veja-se TOCH, 2006; HERDE, 2000; HLAVÁCEK, 2000 ; SCOTT, 1998.

${ }^{205}$ Se bem que Segismundo apenas seja formalmente Imperador entre 1433, ano em que é coroado por Eugénio IV, e a sua morte em 1437. Entre 1410 (quando eleito para suceder a Ruperto do Palatinado) e 1433 foi Rei dos Romanos (para além de rei da Boémia, Hungria, Croácia, e Eleitor de Brandeburgo).

${ }^{206}$ Apesar do papel desempenhado pelo Imperador Segismundo na superação do Cisma, a sua ascensão e reinado foram marcados por dificuldades internas e externas no exercício da autoridade (cf. SCOTT, 1998).

${ }^{207}$ HERDE, 2000; BÉRENGER et al., 1996: 126-128; GRIMAL et al., 1996: 280 e segs. (Império Carolíngio), 450 e segs., 518, 519 (crise entre Papado e Império pelo domínio no palco italiano no séc. XII e XIII), 523 e segs. (movimento de oposição entre Império e Cidades na Itália — oposição entre Guelfos e Gibelinos). Vd. igualmente WATT, 2006; TOCH, 2006; HERDE, 2000; HLAVÁCEK, 2000.

${ }^{208}$ O Império nunca deixa, pelo menos em teoria, de afirmar o seu direito suserano sobre os territórios italianos, quanto mais não seja como elemento de conexão ao fundamento teórico e histórico do Império, que se pretende remontar ao antigo império romano. Ainda que os imperadores tentem intervir e controlar a Itália ao longo do séc. XIV e XV (frequentemente os imperadores entram em Itália com o objetivo de se fazerem coroar em Roma, fulcral nos processos de legitimação de soberanos eleitos por um colégio), as suas intervenções e exercício de poder em Itália são de efeito limitado e temporário (cf. LAW, 2000).
} 
consolidação do poder dos pequenos Estados e Senhorios, sobretudo em detrimento de um poder imperial e pontifício cada vez mais ausente e ineficaz ${ }^{209}$, bem como de um reino de Nápoles em declínio, após a morte de Roberto de Anjou (1343) ${ }^{210}$.

No início do séc. XIV são notórios os contrastes de um território fragmentado. Se o centro italiano é dominado pelo Património de São Pedro, no norte predominam as repúblicas mercantis governadas por comunas e os senhorios, enquanto o sul vive sobre o ideal feudal da nobreza napolitana e siciliana.

As dezenas de estados autónomos conhecem, ao longo do séc. XIV e XV um decréscimo de número, consequência da atividade expansionista de alguns Estados e de um constante estado de guerra. Papel fundamental têm os Visconti, os Estados Pontifícios, mesmo durante a ausência francesa da Cúria (1305-1377), e o reino napolitano, que vive neste período a conturbada disputa do trono entre a coroa de Aragão e os Anjou.

Se os inícios do séc. XIV parecem ter sido de crescimento no norte de Itália, período de vitalidade económica, comercial e demográfica, artística e literária, em continuação de dinâmicas anteriores, em meados do século a situação vai-se alterar ${ }^{211}$.

O período central do século (1340-1380) terá sido de crise, económica, política e demográfica ${ }^{212}$. Com crises de fome, guerras, mas sobretudo com a peste pelos anos de 1347-49, a Itália terá perdido na primeira metade do séc. XIV cerca de 4 milhões de pessoas, possivelmente um terço da população. Da quebra demográfica não terá havido recuperação significativa ao longo da segunda metade do século ${ }^{213}$.

Como exemplo das dinâmicas de crise, e pelo relevo que assumiu no contexto da Igreja em Itália, e no das Congregações reformadoras em particular, atente-se no estado a que terão chegado numerosos mosteiros, conventos e priorados, privados de efetivos suficientes para a regular vida claustral ou com o claustro em profunda crise moral e vocacional, entregues a comendatários, quando não mesmo anexos a outras casas religiosas, secularizados para paróquias ou simplesmente ermos ${ }^{214}$.

Este processo de crise humana, material e espiritual no seio das ordens religiosas não é exclusivo da Itália, e pode-se encontrar paralelo na restante cristandade ${ }^{215}$, incluindo Portugal ${ }^{216}$. Esta crise do

\footnotetext{
${ }^{209}$ Idem, ibidem: 450 e segs.; BÉRENGER et al., 1996: 124-126.

${ }^{210}$ Sobre o reino napolitano $v d$. VALERI, 1969: cap. 1, mas sobretudo o mais recente trabalho de David Abulafia (ABULAFIA, 2000), que analisa o reinado deste monarca, os seguintes, bem como a situação do reino da Sicília.

${ }^{211}$ MARTINES, 1986: 5-12.

${ }^{212}$ LARNER, 1971: 121 e segs.

${ }^{213}$ MARTINES, 1986. Aliás, no que se refere aos Estados Pontifícios e ao reino de Nápoles, pelo menos, a crise demográfica ter-se-á prolongado, a par das epidemias, ao longo do séc. XV (cf. RYDER, 1998).

${ }^{214}$ Veja-se para Veneza o que diz Antonio Rigon (RIGON, 1997), no seu ponto 10, que abre com a descrição de um quadro desolador generalizado: «Edifici in rovina, conventi desolati, comunità in crisi sono testimonianze di difficoltà materiali e di disorientamento spirituale...».

${ }^{215}$ BÉRENGER et al., 1996: 82 e segs.

216 «A crise dos costumes religiosos e das instituições eclesiásticas afetou praticamente toda a Europa nos fins da Idade Média. Portugal, como era de prever, não escapou à regra» (DIAS, 1960: 33). Vd. sobre isto o que diz Oliveira Marques (MARQUES, 1987: 20 e segs., 223 e segs.).
} 
claustro gerou em si a própria reação, que será de reforma. Será na reforma de mosteiros sem vida regular e reduzidos a igrejas seculares que as Congregações de Alga e de S. João Evangelista vão iniciar materialmente o seu movimento reformista ${ }^{217}$.

Neste contexto italiano são de particular interesse, para esta obra, os Estados Pontifício e de Veneza, pois representam as geografias em que nasce a Congregação de Alga (Veneza), e onde esta se projeta e estende a sua influência carismática para a nascente Congregação dos Lóios (Roma).

\section{Roma e os Estados Pontifícios}

Crise entre as crises terá conhecido, ao longo do séc. XIV, o Património de São Pedro, os Estados Pontifícios da Itália, que durante o longo período do Cativeiro na Babilónia de Avinhão viram afastar-se o seu soberano temporal, foram perpassados por lutas intestinas e tentativas de emancipação de um poder longínquo.

Ocupando sensivelmente o centro da Itália, mediando entre os Estados do norte e o Reino de Nápoles ao sul, os Estados do Papa constituíam o essencial do domínio temporal de um soberano que nunca deixa de tentar afirmar a supremacia do seu poder sobre todo o ocidente cristão ${ }^{218}$.

A crónica instabilidade de Roma e dos Estados Pontifícios é uma preocupação permanente da Cúria Romana em Avinhão, e o mais forte argumento a obstar ao retorno do Papa à Cidade Eterna. A atuação do legado vigário-geral para o Património de São Pedro, Cardeal Albornoz ${ }^{219}$, permitirá em 1377 o retorno da cúria pontifícia a Roma, respondendo aos anseios da corrente que reclamava o retorno do Bispo de Roma à sua Sé220.

Parecia abrir-se um período novo, em que o regresso da Cúria (que se alargara e especializara por influência dos processos de estatização e burocratização da coroa francesa) traria uma natural superação da crónica instabilidade nos Estados Pontifícios. A eleição de Urbano VI (1378), a sequente cisão do Colégio de cardeais com a eleição de um antipapa ${ }^{221}$, que reinará em Avinhão, lançou a Igreja no Cisma e teve, naturalmente, consequências pesadas em Roma e nos Estados Pontifícios.

O Cisma converteu o papado Romano de um sistema monárquico de peso transnacional numa estrutura política de influência reduzida, virtualmente dedicada aos assuntos políticos da península italiana. Mesmo os Estados da obediência Romana aproveitaram o Cisma para atenuar os laços com a

\footnotetext{
${ }^{217} \mathrm{Vd}$. Capítulos 2.1. e 3.1.

${ }^{218}$ Note-se que, nos tempos que antecedem o papado de Avinhão, os Papas passariam largas temporadas fora de Roma, mas em circulação por outras cidades dos seus Estados (cf. ZUTSHI, 2000: 653).

${ }^{219}$ O papel de Gil Alvarez, Cardeal Albornoz, arcebispo de Toledo, enquanto legado e vigário-geral do papa nos seus Estados italianos, o seu esforço em pacificar o território, restaurar a autoridade pontifícia e o funcionamento do aparelho burocrático e fiscal foi de tal ordem que as constituições que estabeleceu para o governo dos Estados Pontifícios estiveram em vigor até 1816 (cf. CHÉLINI, 1982: 44; ZUTSHI, 2000: 656, 657). A ligação da família do Cardeal Albornoz à cúria de Avinhão foi tal que, após a sua morte, o seu primo coirmão Pedro de Luna foi antipapa com o nome de Bento XIII (PIÑEIRO, 2000).

${ }^{220}$ CHÉLINI, 1982: 44, 45; KAMINSKY, 2000: 674 e segs. Como afirmam diversos autores, o retorno a Roma nunca esteve inteiramente afastado da mente dos Pontífices de Avinhão. $V d$. ponto 1.3.1.

${ }^{221}$ Para conceito de antipapa, $v d$. ponto 1.3.2.
} 
Santa Sé, e a burocracia papal (fulcral nas relações com os diversos Estados, para o controlo das Igrejas locais e dos territórios do Estado Pontifício) formada e aperfeiçoada em Avinhão, vai seguir maioritariamente esta obediência, obrigando Roma a reconstituir o seu aparelho burocrático ${ }^{222}$.

O Pontificado de Bonifácio IX demonstra claramente esta conversão, com um Papa inteiramente dedicado ao esforço de domínio sobre os Estados Pontifícios, uma política que sustenta numa fiscalidade agressiva e práticas que violavam os cânones da Igreja ${ }^{223}$.

Este foco sobre a política italiana, e mais particularmente sobre os Estados Pontifícios, com uma aparente desatenção geral do carácter católico, universal, da Igreja, gerará reações em diversas regiões da obediência Romana, descredibilizando o Papado. Estas críticas revelam já geografias que terão um papel preponderante nas reformas protestante do séc. XVI ${ }^{224}$ : Alemanha, Inglaterra (Wycliff), Boémia (Huss). Ao aspeto crítico do Cisma, soma-se a incapacidade dos Pontífices romanos de lidarem com as questões mais profundas da Igreja que fica para além do Património de S. Pedro.

Como um biógrafo de Bonifácio salientou: «le pratiche indegne di un troppo rigido fiscalismo discreditavano la Curia romana, specialmente in Germania, e fecero del pontificato di Bonifacio il simbolo stesso della Chiesa bisognosa di riforma ${ }^{225}$.

As políticas tendencialmente italianizantes de Urbano VI ${ }^{226}$ e de Bonifácio IX asseguraram, por alturas da morte deste último, o almejado objetivo: o controlo de Roma e dos Estados Papais pelo soberano pontífice, ainda que este domínio estivesse na mão de uma rede de senhores, os vigários apostólicos ${ }^{227}$.

A definição do poder territorial em Itália, uma fiscalidade que garantia o funcionamento da Cúria romana, o desejo cada vez mais profundo e generalizado de que o Cisma fosse superado, parecia abrir a possibilidade de os pontificados seguintes, de Inocêncio VII ${ }^{228}$ e Gregório XII ${ }^{229}$, centrarem-se na resolução do Cisma ${ }^{230}$. No entanto, a impossibilidade de garantir em permanência a estabilidade dos Estados Pontifícios, não permitiu que tal empenho fosse constante e decisivo.

\footnotetext{
222 KAMINSKY, 2000: 682 e segs.

${ }^{223}$ Aparecem acusações de simonia, sustentadas sobre a prática comum de venda de expectativas sobre benefícios não vagos, entre outras; menciona-se ainda a forma violenta como se cobravam impostos nos Estados Pontifícios (através dos condottieri que geriam a sua guerra) e as taxas nas dioceses da sua obediência (excomungou 95 prelados por não pagamento dos «serviços» devidos à tesouraria pontifícia) (cf. Idem, ibidem: 684, 685; ESCH, 2000).

${ }^{224}$ Note-se também que as geografias principais dos países da obediência Romana são, em essência (e com exceção do Império que ocupa uma posição central no espaço Europeu), regiões da periferia europeia: Escandinávia, Hungria, Inglaterra, Irlanda, Polónia, ocasionalmente Portugal. Seguem o Papa de Roma também a maioria dos estados e territórios do Império e, por razões óbvias, a maioria da Itália (cf. KAMINSKY, 2000: 678).

${ }^{225} \mathrm{ESCH}, 2000$.

${ }^{226}$ Para a política italiana de Urbano VI $v d$. AIT, 2000. Este Papa, ainda que se debatesse com os mesmos problemas financeiros que o seu sucessor Bonifácio IX para sustentar a guerra italiana, não implementará uma política fiscalista tão severa.

${ }^{227}$ KAMINSKY, 2000.

${ }^{228}$ DE VINCENTIIS, 2000.

${ }^{229}$ ORTALLI, 2000.

${ }^{230} \mathrm{Em}$ ambos os casos o conclave que os elegeu foi precedido por juramento do Sacro Colégio em como o eleito empregaria todos os meios para superar o Cisma, com a sua abdicação se necessário, e convocação de um Concílio Geral (cf. Idem, ibidem e DE VINCENTIIS, 2000).
} 
A eleição de Martinho V marca o regresso à unidade Eclesial. O novo Papa lançar-se-á, assim que entra em Itália, à tarefa de recuperar a plena autoridade sobre os Estados Pontifícios ${ }^{231}$, atividade que se intensifica com a entrada em Roma, em $1420^{232}$. Martinho V foca-se em restaurar em pleno os poderes pontifícios nos vicariatos e comunas sujeitas à Sé Apostólica, em paralelo com a restauração da estrutura financeira e fiscal, a reforma curial, o apoio a algumas reformas que se desenhavam no seio de Ordens religiosas, o reforço das relações com os diversos reinos cristãos e com as igrejas locais, o diálogo com o Cristianismo oriental, de uma Igreja bizantina com quem se procura a plena união ${ }^{233}$.

O pontificado de Martinho V parece ter como fulcro a recuperação plena do prestígio da Sé Apostólica ${ }^{234}$ e o seu papel de relevo no ocidente cristão. O esforço do Papa em devolver a Roma o seu lugar de caput mundi percebe-se até em matérias eminentemente práticas, como os projetos de recuperação do edificado e das estruturas viárias de Roma.

Nascido numa das principais famílias da nobreza romana, os Colonna, Martinho V tinha um bom conhecimento das questões políticas que envolviam os estados pontifícios, mas também uma noção da importância de Roma como sede do Papado e o apoio da sua linhagem para lidar com estas questões. O sucesso do Papa não poderá deixar de ser atribuído a este conhecimento de causa, ao apoio familiar, e ao que parece ser uma natural capacidade diplomática ${ }^{235}$.

Será a esta Roma, que volta a ser a cidade do Papa e cabeça da Igreja, que os fundadores Lóios se dirigem para obter aprovação canónica, e definição carismática, da Congregação. Se o carisma Lóio é veneziano, como o é a Congregação de S. Jorge de Alga, será em Roma que a Congregação portuguesa se decidirá definitivamente por este figurino institucional, e será do Papado que lhe virão nos primeiros anos importantes benesses.

Ao romano Martinho V segue-se o veneziano Eugénio IV. O novo Papa, um dos fundadores da Congregação de Alga, toma logo no início do seu pontificado duas decisões que terão consequências nefastas para a Santa Sé e deitarão por terra a frágil pacificação dos Estados Pontifícios operada pelo seu antecessor.

\footnotetext{
${ }^{231}$ Uma sua biógrafa define assim os desafios do Papa recém-eleito: «Problemi di diversa natura [...] si ponevano com urgenza a Martino, in particolare la ricostituzione dello Stato pontificio, i rapporti com le varie potenze straniere, le prospettive di riforma ecclesiale, la ridefizione dei tributi ecclesiastici, la riorganizzazione degli uffici di Curia» (BIANCA, 2000).

${ }^{232} \mathrm{O}$ demorado regresso do Papa faz-se pela necessidade de negociar com aqueles que exerciam o poder nos territórios Papais da Itália. Martinho V age com prudência e diplomacia, reconhecendo os vigários pontifícios (nobres que detinham a autoridade de territórios sob suserania, mesmo que teórica, da Santa Sé), mas cujo poder e duração vai dedicar-se a moderar (cf. RYDER, 1998: 573, 574).

${ }^{233}$ BIANCA, 2000.

${ }^{234}$ Apesar do pontífice ter ao longo do seu pontificado respeitado as determinações conciliares e evitado confrontos com a corrente conciliarista, o Papa não deixa de procurar por todos os meios recuperar o prestígio e poder da Santa Sé. A dura afirmação de autoridade pontifícia de Eugénio IV, e o seu confronto com a linha conciliarista, não deixa de estar na sequência do pontificado de Martinho V, de quem o Cardeal Condulmer foi até importante colaborador (cf. Idem, ibidem; e HAY, 2000).

${ }^{235}$ RYDER, 1998: 574 e segs.
} 
Intransigente defensor do ideal de supremacia do poder pontifício, senhor de uma forte e indócil personalidade ${ }^{236}$, Eugénio trata, logo após a sua eleição, de afirmar o seu poder sobre o Concílio que o antecessor convocara para Basileia, reconvocando-o para Bolonha ${ }^{237}$, retirando-o de terras (e influências) Imperais e colocando-o numa cidade dos Estados Pontifícios. Simultaneamente toma ações quase imediatas contra o poder que a família de Martinho V tinha em Roma e nos Estados da Igreja, forçando-os a renunciar às benesses obtidas do Papa ${ }^{238}$.

As duas tomadas de posição, que virão a ter resultados inesperados para o pontífice, revelam a sua decisão em afrontar diretamente o que considerava serem as principais ameaças ao seu poder: em Roma e nos Estados Pontifícios, o poder dos Colonna; no plano externo o Concílio e as ideias conciliaristas, que irá combater decididamente.

Os resultados são conhecidos, e irão dominar todo o pontificado: uma parte do concílio de Basileia recusa-se a obedecer à transferência ordenada pelo Papa, continua os seus trabalhos, encaminhando-se ambas as partes para a rutura ${ }^{239}$.

Pior será a situação nos Estados Pontifícios. A debilidade aparente da posição de Eugénio IV na sua relação com o Concilio de Basileia, que é apoiado por diversas coroas europeias, nomeadamente a Imperial, é aproveitada pelos inimigos que o Papa criou nas suas afirmações de autoridade. Os Colonna e a sua influência parecem decair num primeiro momento. O Papa consegue algum controlo sobre Roma, onde em 1433 coroa Segismundo como imperador ${ }^{240}$.

O assédio militar que os Estados Pontifícios sofriam da parte de Milão e Nápoles, a instabilidade criada pelos Colonna, o recrudescimento das tensões com os conciliares de Basileia, a dificuldade de Eugénio IV em garantir a estabilidade interna nos seus Estados, e a sua aparente habilidade de desagradar a (quase) todos, dissipa o capital de boa vontade que o povo romano acumulara nas décadas de ausência da Cúria ${ }^{241}$.

\footnotetext{
${ }^{236}$ Como o referem diversos autores que sobre ele escreveram, baseados na forma voluntarista e intransigente como geriu as principais questões em que esteve envolvido: relações com o Concílio, com as monarquias, a gestão politica dos Estados Pontifícios (cf. Idem, ibidem: 575 e segs.; HAY, 2000); Pierluigi Sartorelli, num artigo que trata particularmente da juventude do pontífice, não deixa de referir a opinião generalizada da sua inflexibilidade e obstinação, se bem que (citando o Joseph Gill, um dos biógrafos de Eugénio IV) leia nestas características tenacidade e fidelidade aos objetivos (cf. SARTORELLI, 1988).

${ }^{237}$ Note-se que Eugénio IV, enquanto Cardeal, foi legado papal em Bolonha, onde seu primo Antonio Correr fora Bispo. Durante a sua estadia legatícia, Cardeal Condulmer conseguiu mesmo obter do bispo da cidade, o futuro Cardeal Albergati (futuro importante colaborador de Eugénio), um convento Agostinho, sem vida regular, para a sua Congregação de Alga (cf. TOMASINI, 1642: 94 e segs; PÀSZTOR, 1960a).

${ }^{238}$ HAY, 2000; WATANABE: 2008: 179 e segs; RYDER, 1998.

${ }^{239}$ WATANABE, 2008: 179 e segs.

${ }^{240}$ A paz com o Imperador datará de 9 de março de 1433. A 21 de maio o imperador entra em Roma, sendo coroado pelo Papa em S. Pedro no dia 31 desse mês (cf. BAV - Manoscritti, VAT.LAT.7167 - Diaria seu acta [Romanorum Pontificum] ab anno 1378 usque ad $1596 . .$.$) .$

${ }^{241}$ HAY, 2000; RYDER, 1998.
} 
A 29 de maio de 1434 uma revolta popular, instigada pelos que se opunham ao pontífice, obriga o Papa a fugir de Roma, vestido de monge, e faz prisioneiro o vice-chanceler (e sobrinho do Papa) Francesco Condulmer ${ }^{242}$.

Eugénio fará recuperar Roma por dois prelados (ambos criados cardeais pelo Papa em paga dos seus serviços) condottieri, Vitelleschi e Trevisano, que garantem o controlo da cidade e a pacificação dos Estados Papais ${ }^{243}$.

Apesar de garantir o controlo dos seus Estados, Eugénio deverá ter consciência da fragilidade da sua posição numa Roma que aparentemente o rejeita. O resultado é o afastamento do Papa, de Roma e do centro da Itália, durante os oito anos seguintes.

Estante sobretudo em Florença e na Ferrara dos Este (feudatários da Igreja, e que serão elevados a Duques em 1472 pelo sobrinho de Eugénio IV, Paulo II), será para estas cidades (primeiro Ferrara e depois Florença) que o Papa transfere o concílio de Basileia, que não se dissolvendo gerará os dois Concílios opostos ${ }^{244}$.

A pacificação de Roma que permite o regresso do Papa na conclusão do Concílio de Ferrara-Florença, coroado pela vinda do Imperador bizantino e pelo ato de união da cristandade, com reconhecimento do Primado do Bispo de Roma, a que se juntará por fim, em 1447, a submissão e concórdia com o Império, permite a Eugénio IV ao morrer (nesse mesmo ano) deixar os Estados Pontifícios numa situação de estabilidade que não foi a marca do seu pontificado.

\section{La Serenissima: a Veneza dos Papas}

Durante todo o séc. XIV as duas potências marítimas da península itálica, Veneza e Génova, disputam o controlo marítimo do comércio no mediterrâneo, culminando na guerra de Chioggia (1378-1381 $)^{245}$ e na vitória veneziana. Além da disputa com Génova, Veneza experimentou sérias dificuldades no mediterrâneo oriental, na disputa com bizantinos e otomanos pelo controlo de rotas marítimas e de entrepostos comerciais ${ }^{246}$. Para a Sereníssima, o séc. XIV não foi um período sereno.

Tendo no mar e no comércio marítimo a base da sua riqueza e do seu poderio, Veneza encontra-se na necessidade de guerrear em mar e terra para garantir o seu domínio territorial e comercial a

\footnotetext{
${ }^{242}$ Idem, ibidem; HAY, 2000; OLIVIERI, 1982a. Watanabe engana-se na data da revolta romana em dois anos, dizendo ser de 1432 (cf. WATANABE, 2008: 180). Apesar do erro, apresenta uma descrição mais pormenorizada dos aspetos dramáticos da fuga do pontífice, num barco que os romanos atingiam com pedras e flechas, retirada das biografias do Papa e inspirada na descrição fornecida por Vespasiano da Bisticci (que segundo Sartorelli terá conhecido Eugénio IV, possivelmente nos anos que o Papa passou em Florença, cf. SARTORELLI, 1988) nas suas memórias (cf. BISTICCI, 1859: 8). Talvez o erro de datação provenha da própria leitura de Da Bisticci, já que o texto do seu manuscrito antecipa a presença no Pontífice em Florença, atribuindo o editor este erro a um lapso na redação.

${ }^{243}$ RYDER, 1998. Ryder equivoca-se ao definir Vitelleschi como um cardeal que se torna condottiero, porque o seu comando militar ao serviço do Papa data ainda de 1434, e a sua criação cardinalícia tem lugar no consistório de 9 de agosto de 1437. Trata-se pois de um condottiero feito cardeal e não o contrário. Parece ser o mesmo caso com o Cardeal Trevisano (cf. HAY, 2000).

${ }^{244}$ Idem, ibidem; RYDER, 1998.

${ }^{245}$ Para as questões da guerra de Veneza com Génova veja-se BALARD, 1997: 87-126.

${ }^{246}$ Cf. DOURMEC, 1997a: 237-250; LAW, 2000.
} 
oriente da península itálica, garantido pela expansão da sua frota naval, capaz de promover o comércio ultramarino e a defesa dos interesses venezianos ${ }^{247}$.

Internamente Veneza vive um conjunto de mudanças políticas e sociais, completando a formação do Estado Patrício, no interior do qual as famílias da elite lutam pelo controlo das instituições políticas e da vida da comunidade. Apesar do chamado «mito veneziano», que apresentava a República Veneziana como um modelo político perfeito assente numa elite coesa e num governo abrangente, Veneza era na realidade uma sociedade com múltiplas estruturas de poder e instâncias sociais com influência política e social de diferentes graus ${ }^{248}$. Em suma, uma sociedade rica e complexa.

Apesar da cidade ter sofrido profundamente com os efeitos da crise pestífera (1347-48), que interromperá os profundos trabalhos de renovação urbana, e do peso do já mencionado clima de guerra, e perante o sentido desejo veneziano de afirmação e expansão, os anos finais do séc. XIV e os primeiros do séc. XV serão marcados pelo apogeu das ambições expansionistas venezianas nos territórios italianos adjacentes ao seu Estado, tendo-se a Sereníssima dedicado a alargar os limites do seu domínio sobre a terraferma ${ }^{249}$.

Esta política, que demonstra a pujança económica e política veneziana, tem o particular relevo (para esta obra) de no seu período de maior vigor anexar ao domínio veneziano as cidades de Vicenza (1404), Verona e Pádua (1405).

Nestas cidades vamos encontrar, entre os anos de 1406 e 1486, a constituição de 8 comunidades da Congregação de Alga $^{250}$, representando uns expressivos 47\% da percentagem total das 17 comunidades que a Congregação teve ao longo da sua existência.

Em Vicenza estabelecem-se duas comunidades da Congregação veneziana em 1407, três anos depois da incorporação desta comuna ao domínio da Sereníssima. Em Pádua o processo ainda é mais rápido, já que no ano imediato à anexação estabelece-se a comunidade de S. João Decollato (Degolado).

Estas são as três primeiras comunidades que os Cónegos de Alga estabelecem para lá da Casa fundacional de S. Jorge, são aprovadas pelo primeiro Papa veneziano, tio dos fundadores de Alga e patrono da nova Congregação, Gregório XII ${ }^{251}$.

Demonstra-se com clareza a identificação da nova Congregação com Veneza, com as suas elites de onde são oriundos os principais cónegos de Alga e com as suas políticas de Estado. Aliás, esta característica da Congregação está patente na sua compreensão como uma Congregação veneziana (mesmo quando se alargou para os Estados Papais e para o reino da Sicília), até ao seu desaparecimento em prol do financiamento da defesa de Cândia pelos venezianos no séc. XVII.

\footnotetext{
${ }^{247}$ DOURMEC, 1997a: 237-250; DOURMEC, 1997b: 617-640.

${ }^{248}$ Cf. CHOJNACKI, 1997: 641-725; CARAVALE, 1997: 299-364.

${ }^{249}$ PAVAN, 1997: 729-781; VARANINI, 1997: 159-236.

${ }^{250}$ Para as fundações da Congregação de Alga veja-se quadro anexo n. ${ }^{\circ} 2$.

${ }^{251}$ Para todas as questões relacionadas com a Congregação de Alga, seus fundadores e fundações, bem como as pertenças sociais no universo veneziano, veja-se o capítulo 2.
} 
A proteção que a Congregação de Alga parece ter gozado, nos primeiros séculos, do Estado Veneziano vê-se, por exemplo, na carta que o Doge Cristoforo Mòro ( $† 1471^{252}$ ) enviou ao seu orador junto do Papa Paulo II (mais um veneziano, ligado familiarmente aos fundadores de Alga), Pietro Morosini, em que relata como, perante acusações de vícios torpes (turpi vitio) apresentadas contra os cónegos de S. Jorge em Alga, avocara a si a causa que já corria, a julgara com o seu conselho, demonstrando-se a inocência dos cónegos e ordenando na sequência perpétuo silêncio, ordenando que do veredicto dê conta ao Cardeal de S. Marcos, Marco Barbo, protetor da Congregação de $\operatorname{Alga}^{253}$.

As instituições políticas venezianas surgem-nos a apoiar movimentos e instituições eclesiásticas do seu território quando se revelam de interesse aos seus projetos, como demonstra a expansão do carisma de Alga nos territórios recém-adquiridos por Veneza, exemplo que se aplica a outras comunidades religiosas e sugere uma política alargada.

Um outro claro exemplo, ainda dentro do universo limítrofe da Congregação de Alga, é o da abadia de St. ${ }^{a}$ Justina de Pádua, que de um comendatário ligado aos poderes paduanos passa, após a incorporação da cidade no Estado Veneziano, a ter por comendatário um patrício, prelado e purpurado veneziano (e fundador de Alga) António Correr. Será depois entregue por um papa veneziano, Gregório XII, a um outro patrício veneziano, Luís Barbo (prior de Alga) para que restaure na abadia a vida regular, resultando no nascimento da observância beneditina que levou o nome de St.a Justina ${ }^{254}$. Nada poderá ser mais demonstrativo da correlação entre os processos políticos e os eclesiásticos, suportada em figuras que fazem a ponte entre os dois universos.

A ligação entre Congregação de Alga e o Estado Veneziano é facilmente compreensível à luz da própria natureza das relações entre Estado e Igreja, sendo que esta última se apresentava, neste período do séc. XIV e XV e nos territórios da Sereníssima, como uma realidade complexa que chegava ao ponto de ter, no interior da própria cidade de Veneza, nada mais e nada menos do que três autoridades ordinárias eclesiásticas com jurisdição.

Como Cracco faz notar ${ }^{255}$, Veneza entendia-se como um estado profundamente cristão, com uma dimensão espiritual importante, num quadro em que a Igreja era compreendida pelos poderes como um elemento institucional da ordem política e social da Sereníssima, cuja atuação devia ser regida pelos interesses coletivos, entendimento que garantia ao Estado o direito de intervenção sobre os assuntos da Igreja e a direção dos eclesiásticos para o que entenderiam ser uma atuação em prol do bem comum.

Esta noção, que se aprofunda quando o regime comunal de Veneza dá lugar ao pleno domínio patrício, é ainda mais importante quando se tem em conta que Veneza procurou sempre afirmar a sua independência em relação à Santa Sé e exigiu, nos seus limites territoriais, um papel na gestão do sagrado. Estamos perante um processo que aponta para outros similares nas monarquias europeias

\footnotetext{
${ }^{252}$ Sobre o Doge Moro veja-se GULLINO, 2012.

${ }^{253}$ Carta datada do paço ducal de Veneza, a 16 de dezembro de 1467 e conservada em ASV - Fundo Veneto I, doc. 1117.

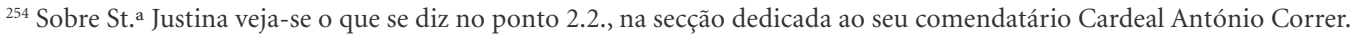

${ }^{255}$ CRACCO, 1997: 957 e segs.
} 
do séc. XIV e XV. Apesar de tudo, e graças às vozes que se levantaram em defesa das liberdades eclesiásticas e da autonomia da Igreja para gerir a sua atuação pastoral (uma das quais a do beato Dominici, que várias vezes nos aparecerá nesta obra), o séc. XV conhecerá em Veneza (e graças também à atuação da Congregação de Alga e suas figuras cimeiras) um sistema relacional entre Igreja e Estado que, na opinião de Cracco, mais do que uma Igreja de Estado, cria uma relação de cooperação em que podemos falar de «una Chiesa vicina allo Stato, o di uno Stato che non sapeva vivere senza la Chiesa ${ }^{256}$.

No decurso do séc. XIV e os primeiros anos do séc. XV (aqueles em que se forma o ambiente reformista veneziano e em que se funda a Congregação de S. Jorge em Alga) Veneza é um estado em aguerrida política de afirmação, que pretende alargar o seu domínio regional e internacional, e cuja pujança e influência se alarga aos domínios da religião.

A pujança da Igreja veneziana é de assinalar, mesmo nos seus confrontos com o Estado, com a crise cismática e as suas complicadas redes de jurisdição ordinária. O vigor do meio reformista veneziano, e do seu universo eclesiástico em geral, está patente até na ascensão dos três primeiros Papas ligados a Veneza alguma vez eleitos, todos do séc. XV, da mesma família e ligados à Congregação de Alga e, no caso de Eugénio IV, indelevelmente ligado à afirmação da Congregação de S. João Evangelista e do seu fundador João Vicente.

\subsubsection{O Portugal de Avis}

Situado no extremo ocidental da Europa, da qual no entanto não estava alheado, o reino de Portugal participará, nos sécs. XIV e XV, das dificuldades que se apresentavam ao ocidente cristão num período centrado na dicotomia crise-transformação.

À semelhança dos seus congéneres europeus, as fomes e pestes não foram estranhas ao povo português. Oliveira Marques ${ }^{257}$ e Armindo de Sousa ${ }^{258}$ chamam atenção para os efeitos combinados da peste (cujos surtos Portugal sentiu com alguma força), das fomes e das guerras ocasionais em que o reino se envolveu com os seus vizinhos peninsulares.

Em Portugal os anos finais da crise cismática, aqueles em que nasce a Congregação de S. Jorge de Alga de Veneza e em que se lançam as sementes da futura Congregação de S. João Evangelista, são marcados pela ascensão da dinastia de Avis.

O reinado de D. João I (1385-1433) encerra em si um período de significativa transformação. Tendo-se iniciado com a ingente necessidade de solidificar a nova dinastia com vitórias militares e a aprovação dos povos em cortes ${ }^{259}$, dedicou os anos sequentes a afirmar formalmente a legitimidade dinástica e a lançar uma nova política de expansão territorial no norte de África, iniciada com a tomada de Ceuta em 1415.

\footnotetext{
${ }^{256}$ Idem, ibidem.

${ }^{257}$ MARQUES, 1987: 15 e segs.

${ }^{258}$ MATTOSO \& SOUSA, 1997: 283 e segs.

${ }^{259}$ Sobre o período do Interregno veja-se Idem, ibidem: 415; MARQUES, 1987: 523 e segs.
} 
Com esta ação, de que o monarca, nem certamente aqueles que o acompanhavam, teriam uma noção das consequências futuras, a Casa de Avis inicia o movimento que marcará a sua memória e caracterizará os 195 anos da dinastia: a expansão marítima ${ }^{260}$.

Com D. João I Portugal entra no séc. XV, o último da medievalidade, tempo de crises políti$\mathrm{cas}^{261}$, económicas e religiosas (numa Igreja em ânsias de reforma ${ }^{262}$ ), de uma sociedade em transformação, com um poder real em afirmação e um Estado cada vez mais presente. O séc. XV português, período de transições, constrói-se nesse binómio de crise-mudança, que marca a transição para a modernidade.

A D. João I, em cuja corte se formaram os principais fundadores Lóios, e à margem da qual se deram os encontros fundacionais da Congregação, sucede o seu filho D. Duarte (1433-1438) que, apesar da curta duração do seu reinado, deu ao reino um governante experiente, pela associação ao governo durante todo o 2. ${ }^{\circ}$ período do reinado de seu pai. Rei informado, dedicado ao seu ofício, metódico; homem culto e, pelo menos na aparência, religioso. Terá sido um apoiante dos movimentos religiosos de cariz reformista, particularmente das observâncias das ordens religiosas, e também figura central da política régia de promoções de reformas ${ }^{263}$, sem no entanto abdicar das posições da coroa na sua disputa com o clero sobre a questão das liberdades eclesiásticas ${ }^{264}$.

A sua sucessão por um Afonso V (1438-81) menor de idade abre caminho a uma década regencial, de sua mãe Leonor (1438-39) ${ }^{265}$ e do tio, o Infante D. Pedro (1439-48).

A figura do Infante D. Pedro. Duque de Coimbra, sobre a qual pesou a danação por vencido em Alfarrobeira, apresenta-se como a de príncipe rico, culto e viajado, preparado para as funções de mando. Durante o seu período regencial tiveram lugar algumas medidas políticas de monta, em matéria legislativa e na expansão marítima, bem como a manutenção da política eclesiástica que vinha dos dois reinados anteriores, e para cuja formulação teria contribuído anteriormente ${ }^{266}$. Morto nos campos de Alfarrobeira, a 20 de maio de 1449, ao seu corpo será negada sepultura condigna, passando depois (e ainda que temporariamente) à custódia dos padres Lóios da Casa de St. ${ }^{\circ}$ Elói de Lisboa, que o Infante entregara à Congregação, e de onde passará ao panteão de Avis na Batalha ${ }^{267}$.

\footnotetext{
${ }^{260}$ Idem, ibidem: 530 e segs.; MATTOSO \& SOUSA, 1997: 415 e segs.

${ }^{261}$ Basta enumerar: a crise com Castela que inaugura a dinastia, a crise regencial após a morte de D. Duarte e que culmina em Alfarrobeira, a instabilidade do período final do reinado de D. Afonso V, a luta de D. João II contra os grandes do reino, em particular os seus cunhados Duque de Viseu e de Bragança.

${ }^{262}$ A crise da Igreja e as tentativas de reforma no séc. XV (por iniciativa régia ou de instituições e figuras da própria Igreja) são perfeitamente consabidas e várias vezes mencionadas nesta obra. Em particular veja-se o clássico resumo de DIAS, 1960; o estado da questão em CARVALHO, 1995; e o que sobre as iniciativas régias de reforma, ou pela coroa apoiadas, diz VENTURA, 1997.

${ }^{263}$ Como se percebe em Idem, ibidem. Veja-se sobre a questão o que se diz no ponto 3.1 .

${ }^{264}$ A biografia recente de D. Duarte pode-se ver em DUARTE, 2005.

${ }^{265}$ Sobre a figura da rainha D. Leonor $v d$. RODRIGUES, 2012.

${ }^{266}$ MATTOSO \& SOUSA, 1997: 421-423; VENTURA, 1997: 60 e segs.

${ }^{267}$ Sobre a questão da sepultura de D. Pedro veja-se o que se diz na biografia da sua filha rainha D. Isabel, protectora dos Lóios (RODRIGUES, 2012: 314 e segs.).
} 
Terá D. Afonso V tido esmerado educação, embasada em moldes «eclesiásticos e itálicos» ${ }^{268}$, recordando os círculos do seu tio D. Pedro, que terá tido natural influência na formação do seu real sobrinho e genro. Tradicionalmente visto como o último rei medieval português, como resumem Mattoso e Oliveira Marques ${ }^{269}$, terá seguido uma política favorável à nobreza e um entendimento expansionista na linha da política cruzadística norte-africana, em detrimento da política de expansão atlântica.

Saul Gomes prefere salientar um reinado marcado por progressos na modernização do Estado e na assistência, defendendo que o propalado desinteresse do Rei pela expansão atlântica não será verdadeiro $^{270}$. Defende que a ideia de um rei medieval, cruzadístico e neo-feudalista estará errada, retirando o soberano do seu enquadramento histórico, de uma sucessão de príncipes da Casa de Avis em que estaria perfeitamente inserido ${ }^{271}$.

O governo de D. João II (1481-1495) irá assentar em dois vetores estruturais ${ }^{272}$ : dedicar-se-á, e logo desde o início do reinado, a consolidar o poder Real face a uma poderosa alta nobreza de que abate os principais elementos, conservando a história a memória dos seus cunhados D. Diogo, Duque de Viseu, que o próprio Rei apunhala mortalmente, e o Duque de Bragança D. Fernando II, que faz executar por justiça ${ }^{273}$.

O segundo vetor do seu reinado é o da política ultramarina, centrado nas viagens de descoberta na costa atlântica de África, e que D. João dirigia já desde o período final do reinado de seu pai. O Rei promove ativamente as viagens de descoberta, ciente do valor da exploração comercial dos territórios africanos.

O pensamento estratégico do monarca leva-o a procurar encontrar em África soberanos a quem Portugal possa aliar-se em prol dos seus interesses, para o que procura obter a conversão dos potentados regionais africanos ao cristianismo e ao modo de vida português. Tenha-se em consideração as relações estabelecidas com o rei do Benim e, a seguir, com o rei do Congo. A conversão deste último, a vinda para Portugal de jovens da elite congolesa para serem educados e o que se lhe segue ( $v d$. o que se diz no ponto 4.4) dá-nos a dimensão da política régia de alianças políticas em África e de assimilação a Portugal, e que genericamente transitará ao reinado seguinte ${ }^{274}$.

$\mathrm{Na}$ alteração de política africana empreendida por D. João II, situar-se-á o ponto em que verdadeiramente se transforma o entendimento que, em matéria religiosa, os portugueses tinham da expansão em África, já que «no fundo, o que está aqui subjacente é o processo evolutivo que, da cruzada, conduz à missionação» ${ }^{275}$.

\footnotetext{
${ }^{268}$ GOMES, 2006: 59.

${ }^{269}$ MATTOSO \& SOUSA, 1997: 419-424; MARQUES, 1987: 557 e segs.

${ }^{270}$ GOMES, 2006: 109 e segs.

${ }^{271}$ Idem, ibidem: 7 e segs.

${ }^{272}$ Estes dois vetores enunciam-se numa recente biografia do Rei (cf. FONSECA, 2005: 7, 8).

${ }^{273}$ Idem, ibidem: 59 e segs. Saliente-se que a mais importante descrição da morte do Duque é feita pelo seu confessor e cónego lóio P.e Paulo de Portalegre, em relato de teor hagiografante (cf. SOBRAL, 1997).

${ }^{274}$ FONSECA, 2005.

${ }^{275}$ Idem, ibidem: 101.
} 
Sem herdeiro legítimo, sucede-lhe o cunhado e primo D. Manuel I (1495-1521) ${ }^{276}$, a quem coube continuar a política expansionista, com a chegada à Índia e consequente ligação marítima da Europa ao subcontinente indiano. Dois anos depois o Brasil. Configuravam-se, no dealbar do séc. XVI, os elementos centrais dos domínios ultramarinos portugueses nos séculos seguintes: África, Índia e Brasil. A política ultramarina portuguesa, que se complexifica significativamente ${ }^{277}$, traz à Coroa portuguesa meios que permitem reformas na administração e a projeção internacional da monarquia.

Pela reforma normativa patente nas Ordenações Manuelinas, a concessão de um conjunto de regimentos a organismos da Coroa, a reforma dos Forais, da burocracia régia e das justiças, procurava o Rei, na senda do seu antecessor, uniformizar e adequar a administração a um reino que se convertia na cabeça de um império pluricontinental ${ }^{278}$.

Retenha-se, para esta obra, o modo como manteve a política de alianças africanas, iniciada pelo seu predecessor, e como a acentuou sistematizando a formação das elites congolesas em Portugal, perspetivando a criação de uma elite educada segundo os moldes europeus e até a preparação de um clero e episcopado africano.

O seu sucessor D. João III (1521-1557), seguindo a lição do pai (e de uma já longa linha de políticas régias de modernização) prossegue com a reforma da administração, que aprofunda, com crescimento exponencial da burocracia régia, da legislação, mas também da corte que acompanha as Reais pessoas. E claro, cresce a despesa e onera-se o erário.

Uma das áreas em que o reinado de D. João III inseriu maiores mudanças foi o da política ultramarina, em que se terá desviado das políticas do reinado de seu pai, com abandono do entendimento manuelino para o império português do Oriente, que apesar disso continuou em construção. É também neste reinado que o Brasil recebe as primeiras estruturas de governo e administração e inicia a exploração do território ${ }^{279}$.

Terá o Rei promovido outras reformas administrativas que visavam melhorar a capacidade de intervenção régia: promoveu o primeiro numeramento da população do reino, para sustentar uma reorganização da divisão administrativa e eclesiástica, patente na criação de novas dioceses ${ }^{280}$.

Em matéria de alargamento do poder régio, e na sua interseção com o universo eclesiástico ${ }^{281}$, podemos situar a instituição do Tribunal da Inquisição, que a Coroa obtém depois de muita insistência diplomática em Roma e apesar das declaradas reticências da Santa Sé. A nova instituição inseria-se na política régia de normalização do tecido social e no controlo de comportamentos heterodoxos ou desviantes à norma ${ }^{282}$.

\footnotetext{
${ }^{276}$ Sobre D. Manuel I veja-se COSTA, 2005.

${ }^{277}$ Idem, ibidem: 145 e segs.

${ }^{278}$ Idem, ibidem: 133 e segs. Veja-se também o resumo de MAGALHÃES, 1997: 443 e segs.

${ }^{279}$ DIAS, 1998: 724-741; BUESCU, 2005: 232 e segs.

${ }^{280}$ Idem, ibidem: cap. 10.1. e 10.2.

${ }^{281}$ Segundo a leitura de Idem, ibidem: 194 e segs.

${ }^{282}$ MEA, 1998: 432-441.
} 
Em matéria religiosa, e numa época de efervescência neste domínio, D. João III revelou-se verdadeiro herdeiro da tradição monárquica portuguesa, não só por manter uma política régia de intervenção e direção dos assuntos eclesiásticos ${ }^{283}$, como de promoção de reformas do universo claustral e de apoio a novas ordens e congregações religiosas de proposta reformista. Sendo certo que o processo de reforma das congregações religiosas no reinado de D. João III prolongava o que fora pensado no reinado de seu pai, a ele deve-se a sua efetiva aplicação, com a intervenção e apoio de outros membros da família Real, em particular os cardeais infantes Afonso e Henrique. Foi um processo que percorreu todo o reinado, e para além deste, com díspares resultados ${ }^{284}$.

Será no seu decurso que uma nova ordem, a Companhia de Jesus, se introduz em Portugal. Se o Rei manterá os seus confessores entre os Franciscanos e os Agostinhos, já a rainha D. Catarina e o seu irmão Cardeal D. Henrique ir-se-ão claramente inclinar para os Inacianos, de cujas fileiras sairá o principal mestre do futuro rei D. Sebastião, o P.e Luís Gonçalves da Câmara ${ }^{285}$. Serão os Jesuítas, figuras maiores do universo da reforma católica do séc. XVI, a prefigurarem-se como a ordem escolhida para o régio patronato das décadas finais da dinastia de Avis.

Será neste universo genérico de reformas e mudanças introduzidas pelo monarca que poderemos situar a reforma da administração hospitalar, de que os Lóios foram a instituição de apoio ao monarca.

A morte de D. João III abre caminho aos dois últimos reinados da dinastia de Avis, de um Rei que reina 21 anos e governa apenas 10, e de outro que reina 2 anos e governa $7^{286}$.

Rei aos 3 anos, a primeira década do reinado de D. Sebastião (1557-1578) é de regências da sua avó, D. Catarina de Áustria, e do seu tio-avô cardeal-infante D. Henrique, mantendo-se no essencial as políticas do reinado anterior, divergindo os regentes na sua maior ou menor proximidade aos interesses espanhóis e no acrisolamento cultural e religioso. Será na regência do cardeal-infante, legado a latere $^{287}$, que se encerra o concílio tridentino (1563), sendo conhecido o perfil de reformista e o apoio do cardeal a esta reunião magna da Igreja e suas reformas ${ }^{288}$, cujos decretos o Papa Pio IV promulgara e que, logo em 1564, Portugal aceita e transpõe para o ordenamento jurídico nacional289.

Atingida a maioridade, D. Sebastião toma as rédeas do governo em janeiro de 1568, abrindo a década do seu governo, no qual o rei demonstraria interesse e empenho, e que será marcado por uma importante atividade governativa e legislativa, dirigida aos mais diversos aspetos da vida nacional ${ }^{290}$.

\footnotetext{
${ }^{283}$ Não podemos deixar de ter em consideração o seu comportamento na questão com D. Miguel da Silva, em particular a sua criação cardinalícia pelo Papa sem a aprovação régia (Veja-se sobre isto BUESCU, 2010).

${ }^{284}$ Cf. DIAS, 1960.

${ }^{285}$ BUESCU, 2005: 218, 219; CRUZ, 2006: 80 e segs.

${ }^{286}$ De facto D. Sebastião foi rei desde a morte de seu avô em 1557 até à batalha de Alcácer Quibir em 1578, mas só tomou as rédeas do poder em 1568. Já o seu tio e sucessor Cardeal D. Henrique, tendo apenas reinado até à sua morte em 1580 , teve no entanto a regência do reino de dezembro de 1562 até janeiro de 1568 (cf. CRUZ, 2006; e POLÓNIA, 2005).

${ }^{287}$ Cf. Idem, ibidem: 84.

${ }^{288}$ Idem, ibidem; POLÓNIA, 1994.

${ }^{289}$ Cf. MAGALHÃES, 1997: 455-458; CAETANO, 1965.

${ }^{290}$ CRUZ, 2006: 157 e segs.
} 
A mais conhecida marca da sua governação foi, no entanto, a sua política de reconstrução do domínio português no norte de África, que culmina em Alcácer-Quibir, onde o D. Sebastião é dado por desaparecido, previsivelmente morto ${ }^{291}$.

As leis dinásticas colocaram a coroa sobre uma cabeça mitrada, a do antigo regente cardeal-infante D. Henrique ${ }^{292}$. O novo Rei assume o trono aos 66 anos de idade, sem herdeiros naturais em virtude do dever de celibato associado ao estado eclesiástico que tinha abraçado em jovem ${ }^{293}$.

Com um longo percurso de numerosos deveres políticos e eclesiásticos, sempre nas mais elevadas posições que o seu nascimento e o seu título cardinalício lhe garantiam, o novo Rei era homem experimentado no mando, conhecedor dos assuntos públicos portugueses, mas que as circunstâncias fizeram reinar em tempos difíceis. $\mathrm{O}$ seu governo centrou-se em resgatar os milhares de portugueses cativos em resultado da batalha e na questão premente da sucessão do trono português, sem solução até ao final do reinado ${ }^{294}$.

O Rei morre a 31 de janeiro de 1580, em Almeirim (onde se reuniam cortes para tratar da questão sucessória), no preciso dia em que completava 68 anos de idade ${ }^{295}$, encerrando assim os 195 anos da Casa de Avis.

\subsection{O CISMA E A URGÊNCIA DE REFORMA}

\subsubsection{9 - O Papa em Avinhão}

O período que medeia entre a reforma gregoriana do séc. XI e a série de eventos que levaram à transferência plena da Cúria Romana para Avinhão, teve por característica a quase constante oposição entre o poder Pontifício e os mais importantes poderes monárquicos ${ }^{296}$.

Neste contexto situa-se o pontificado de Bonifácio VIII (1294-1303) e a controvérsia que manteve com a Coroa francesa, que mais não foi que uma disputa entre o ideal de supremacia do poder pontifício e o da plenitude do poder Real ${ }^{297}$.

A vitória da França sobre o Papado, por via da humilhação infligida a Bonifácio VIII em Anagni (setembro de 1303), resposta à sua bula Unam Sanctam (1302) em que estabelecia «la dernière et la plus parfaite expression de la théocratie pontificale» ${ }^{298}$, resultou na colocação dos Papas na órbita francesa nas décadas seguintes ${ }^{299}$.

\footnotetext{
${ }^{291}$ Idem, ibidem, em particular os caps. 9 e 12 a 14. Resumo abreviado em DIAS, 1998: 749-752.

${ }^{292}$ Sobre o cardeal-rei D. Henrique veja-se a recente biografia de POLÓNIA: 2005.

${ }^{293}$ Amélia Polónia chama precisamente a atenção para o facto de nenhum elemento permitir supor que o cardeal-rei não tenha cumprido fielmente com o dever de celibato clerical (cf. Idem, ibidem: 206).

${ }^{294}$ Sobre a ação governativa $v d$. Idem, ibidem: 194 e segs., para a questão sucessória o seu cap. 5.

${ }^{295}$ Idem, ibidem: 246 e segs.

${ }^{296} \mathrm{Vd}$., resumidamente, BARRACLOUGH, 1972: 73 e segs.; LABOA GALLEGO, 2010: 143 e segs; WINROTH, $2012: 89$ e segs.

${ }^{297}$ CHÉLINI, 1982. Chélini faz uma boa síntese das questões que opõem Papa e Rei, entre papado e monarquia, e do processo que conduz ao seu culminar em Anagni.

${ }^{298}$ CHÉLINI, 1982: 26.

${ }^{299}$ Idem, ibidem: 21-28.
} 
A Bonifácio VIII sucede um efémero Bento XI, a cuja morte o sacro colégio reunirá conclave em Perugia, mercê da crónica instabilidade de Roma. Após 11 meses de vacância é eleito Papa o arcebispo de Bordéus, Clemente V (1305-1314) ${ }^{300}$. Com um pontificado vivido em solo francês, com um esmagador afrancesamento do colégio cardinalício ${ }^{301}$, com a sua colagem à Coroa francesa, lança as raízes do Papado de Avinhão ${ }^{302}$, que de 1309 a 1378 dará à Igreja, sucessivamente, sete Pontífices franceses e que aproximará a administração da Santa Sé à da Coroa francesa ${ }^{303}$.

Tradicionalmente visto numa perspetiva negativa ${ }^{304}$, o papado de Avinhão teve uma menos destacada atuação em prol de ações reformadoras no mundo clerical. Se João XXII (1316-1334) tenta suprir a acumulação de benefícios, já o pontificado de Bento XII (1334-1342) irá assumir uma faceta mais claramente reformista.

Monge cisterciense, o Papa é marcado pelo rigor claustral. Certo da importância da vida monástica como fermento da vida religiosa da Igreja, dirigirá para a sua reforma o essencial da sua ação. Incentiva as ordens religiosas a enviar religiosos para a Universidade, na crença que uma melhor e mais correta formação do clero, principalmente o professo, terá correspondência numa vida eclesial mais perfeita ${ }^{305}$. No mesmo sentido exige um correto exame das capacidades e idoneidade dos candidatos a benefícios ${ }^{306}$.

Entre os seus sucessores destacam-se pelo carácter reformista Inocêncio VI (1352-1362) e Urbano $\mathrm{V}$ (1362-1370), que pontificando em anos duramente marcados pelos primeiros surtos de peste, e pelo início da guerra entre França e Inglaterra, vão ainda assim dedicar atenção à constante tentativa de limitar os abusos beneficiais, bem como ensaiar alguns (tímidos, é certo) esforços na procura de uma melhor preparação e formação do clero, e apoio a processos reformistas no interior de Ordens religiosas ${ }^{307}$.

Com Urbano V dá-se a primeira tentativa de retorno da cúria pontifícia a Roma, retomada pelo seu sucessor Gregório XI (1370-1378), que em 1377 entra em Roma, onde morre em março do ano seguinte ${ }^{308}$.

\footnotetext{
${ }^{300}$ Idem, ibidem.

${ }^{301}$ Em três criações, num total de 24 cardeais, 20 eram franceses, dos quais 13 da Gasconha como o Papa (cf. GUILLEMAN, 1998: 18, 19).

${ }^{302}$ Cidade em que os Papas se instalam definitivamente só em 1316, por decisão de João XXII (cf. Idem, ibidem: 13 e segs, 23 e segs.).

${ }^{303}$ ZUTSHI, 2000: 662 e segs.; GUILLEMAN, 1998 (sobretudo o cap. 3, sobre a centralização financeira e administrativa da Igreja); CHÉLINI, 1982: 53 e segs.; LABOA GALLEGO, 2010: 195 e segs.

${ }^{304}$ GUILLEMAN, 1998: 7-9. Também Chélini entra na discussão dos méritos e deméritos do papado de Avinhão «maintenant que les polemiques sont depuis longtemps éteintes entre Italiens et Français sur les torts et les mérits des papes d'Avignon, il est beaucoup plus facile de fair ele bilan de leur oeuvre. Dans l'ensemble, il est largement positif tant sur le plan profane que dans le domaine purement religieux». CHÉLINI, 1982: 45. Já Petrarca, e antes do Cisma, apostrofaria Avinhão de Babilónia e Inferno, uma visão que seria depois firmada para a posteridade com a célebre expressão «cativeiro da Babilónia da Igreja», como designativo conjunto deste período da História da Igreja (cf. ZUTSHI, 2000: 657, 658).

${ }^{305}$ GUILLEMAN, 1998: 83 e segs.; CHÉLINI, 1982: 41 e segs.

${ }^{306}$ LABOA GALLEGO, 2010: 209, 210.

${ }^{307}$ GASNAULT, 2000; HAYEZ, 2000a.

${ }^{308}$ Acerca desta questão $v d$. Idem, ibidem, bem como o 7. ${ }^{\circ}$ capítulo de GUILLEMAN, 1998.
} 


\subsubsection{O Cisma}

Com a morte de Gregório, e pela primeira vez em mais de sete décadas, é eleito um Papa em Roma e um não francês, o napolitano Urbano VI (1378-1389). Respondia o colégio de cardeais ao opressivo desejo do povo romano de um Papa natural de Roma ou italiano, e cuja veemência servirá como argumento da nulidade da eleição ${ }^{309}$.

O novo Papa entra em colisão com o Sacro Colégio, o qual tenta severamente reformar, assumindo um comportamento despótico, definido como patológico ${ }^{310}$. Quatro meses após a sua eleição a maioria dos Cardeais deixa Roma, declara a eleição nula pela pressão popular e exigem a renúncia do Papa. Perante a sua recusa elegem Papa um cardeal francês, Clemente VII, o qual regressa com os seus apoiantes a Avinhão ${ }^{311}$. A partir desta altura, e durante cerca de quatro décadas, a Igreja estará dividida. É o Cisma ${ }^{312}$.

Apesar de não constituir uma novidade na história da Igreja ${ }^{313}$, o cisma do Ocidente tem como novidade a quebra ampla e duradoura da unidade da Igreja cristã ocidental, com consequências que extravasam o domínio puramente eclesial, e gerando uma crise grave para uma instituição que sempre destacou a importância da unidade e unicidade ${ }^{314}$.

\footnotetext{
${ }^{309}$ KAMINSKY, 2000: 675; LABOA GALLEGO, 2010: 219.

${ }^{310}$ Idem, ibidem; CHAUNU, 2002: 192. Kaminsky não menciona a questão, preferindo acentuar o rigor do Pontífice para com o Sacro Colégio (KAMINSKY, 2000: 676, 677); enquanto Ait, na sua biografia de Urbano VI, menciona as diversas condicionantes de ordem política e o rigor do comportamento do Papa, chamando ainda a atenção para leituras recentes da questão num quadro de crise Eclesial e de espírito reformista em atuação. Não ilude a questão do comportamento do Papa, mas apresenta uma resposta multifactorial para o afastamento entre o Papa e a maioria dos Cardeais (AIT, 2000).

${ }^{311}$ Não confundir com Clemente VII Médicis (1523-1534). É considerado pela Igreja Católica na lista dos antipapas, como aliás os demais Papas da obediência avinhoense e os eleitos na sequência do Concílio de Pisa. O não reconhecimento da validade das suas eleições (que no Cisma a Igreja reserva aos Papas da obediência romana) implica duplicação da numeração de diversos Pontífices (cf. GUYOTJEANNIN, 1994).

${ }^{312}$ Cisma define-se por quebra da unidade da comunhão eclesial, ou seja, da unidade dos cristãos, no mais das vezes na obediência à sua cabeça que é o Papa. Não implica heresia ou heterodoxia, mas apenas (segundo Isidoro de Sevilha) uma divisão da congregação, sem alteração na Fé ou ritos. Já Agostinho e Jerónimo defendiam que o cisma seria apenas uma forma de heresia, com a qual só variava no grau e não na natureza. Tomás de Aquino apresenta o cisma como algo contrário à unidade de Igreja, colocando em causa a comunhão dos seus membros e a relação entre a comunidade eclesial e a sua cabeça, o Cristo e a hierarquia presidida pelo Papa. O cânone 751 define cisma como recusa de obediência ao Papa ou da comunhão com os membros da Igreja. Assim a divisão do corpo eclesial em duas obediências, sem alteração da ortodoxia da Fé mas dividindo a unidade do corpo eclesial constituirá um efetivo cisma (cf. LAWLOR, 2003).

${ }^{313}$ Foi o caso do cíclico aparecimento de antipapas, normalmente apoiados em pequenos grupos eclesiais ou em poderes externos à Igreja (Império, aristocracia, etc.) e que durante algum tempo ocasionavam fraturas na unidade eclesial. Os antipapas surgiram em casos de usurpação violenta do papado, por eleição sucessiva a eleição ilegalmente anulada, por eleição após ilegítima deposição do pontífice anterior, por dupla eleição. Canonistas e historiadores têm considerado como fundamento para um papado ser tido por antipontifical irregularidades na vacância da Sé Apostólica no momento da eleição, irregularidades na eleição ou indignidade e/ou ausência de condições no eleito (cf. GUYOTJEANNIN, 1994; BECK, 2003).

314 «Credo in [...] unam, sanctam, cathólicam et apostólicam Ecclésiam», segundo a fórmula do Credo Niceno-Constantinopolitano. Acentua-se assim a crença na unicidade (unam) e universalidade (catholicam) da Igreja. Para St.o Agostinho estas duas características estavam proximamente unidas e eram complementares, num conceito de unidade que se construía sobre a ideia que a catolicidade se compunha de um corpo e que tinha como contraponto todos os que se situavam «extra ecclesia» (cf. EVANS, 1999). Sobre o Credo vd., por exemplo, MURPHY, 2003 a.
} 
O período de crise cismática, situado genericamente entre as eleições de 1378 e $1417^{315}$, força os povos do ocidente cristão a assistirem ao doloroso drama do digladiar de duas obediências que procuram alcançar o maior número de apoios para se afirmarem como única e verdadeira autoridade pontifícia da Igreja. Os Papas de Roma afirmavam a sua legitimidade na validade da eleição de Urbano VI e na posse efetiva da Sé de Pedro, Roma. Os Papas de Avinhão, pelas alegações de irregularidade das suas eleições, vão sentir a necessidade constante de afirmar a legitimidade das suas pretensões ao sólio pontifício ${ }^{316}$.

O cisma terá uma natural transferência para as alianças e disputas políticas europeias. Um exemplo claro está patente na posição portuguesa e dos demais reinos peninsulares. Se Portugal seguiu a obediência de Avinhão, o interregno e a guerra com Castela (da obediência de Avinhão, como aliada que era da França), a consequente aproximação à Inglaterra ${ }^{317}$, levam D. João I a transferir a obediência portuguesa para Roma, assumindo-se esta decisão como um importante fator político «...el reconocimiento de la autoridad romana terminaría convirtiéndose en el alma del independentismo portugués frente a las ambiciones castellanas ${ }^{318}$. Apesar da afirmação política de apoio da Coroa portuguesa a Roma ter sido um processo lógico de alianças, a situação da Igreja portuguesa não foi tão simples. Dioceses providas pelas duas obediências, um clero dividido, uma situação geral de confusão sustentada sobre as dúvidas iniciais de adesão e pela situação política do reino são uma imagem da crise geral da cristandade ${ }^{319}$.

Note-se porém que não foi apenas ao nível da alta política internacional e da esfera eclesiástica mais elevada que se fez sentir a difícil necessidade de escolher e seguir um pontífice. O cisma colocou um mundo cristão, que não estava habituado a uma crise de unidade com esta gravidade e dimensão, perante escolhas dolorosas e que afetavam não só cerne das suas crenças como diversos níveis da vida social. Foi uma experiência traumática para as comunidades do ocidente cristão, eclesiásticas e laicas, como diversos estudos sobre a matéria parecem demonstrar ${ }^{320}$.

Sendo certo que os momentos de crise andam quase a par com as soluções para a sua superação, e que as soluções para as crises eclesiais se fundam normalmente nos movimentos reformistas da Igreja, não podemos deixar de situar no contexto temporal da crise cismática o surgimento da Congregação de S. Jorge em Alga (que como veremos esteve estritamente associada a uma das obediências).

\footnotetext{
${ }^{315}$ O Concílio de Constança e a sua eleição, em 1417, de Martinho V como Papa da unidade marcam genericamente o fim do cisma, ainda que o Papa de Avinhão Bento XIII de Luna se recuse a aceitar a sua deposição. À sua morte, em 1422, ainda será eleito um sucessor da sua obediência, que renuncia em 1429, encerrando definitivamente o capítulo da obediência de Avinhão (cf. PIÑEIRO, 2000).

${ }^{316}$ Sobre a questão veja-se FLECK, 2009: 239 e segs.

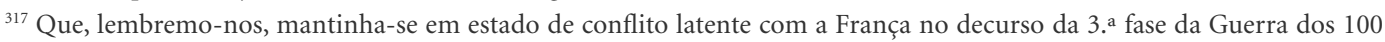
anos, e como tal se coloca do lado contrário ao francês em matéria de obediência, aderindo assim ao Papa de Roma.

${ }^{318}$ Cf. SESA, 2006: 308.

${ }^{319}$ Idem, ibidem: 308 e segs.

${ }^{320}$ Cf. DAILEADER, 2009.
} 
A complexidade da situação, a sua durabilidade, os seus efeitos nefastos na Igreja e na crença da unidade eclesial, levaram a que, ante a irredutibilidade dos pontífices das obediências e dos que os rodeavam, se começassem a levantar vozes em diversos pontos da cristandade exigindo uma resolução. As próprias autoridades políticas, mesmo que instrumentalizando o cisma, evidenciam o desejo de uma resolução, enquanto diversas instituições e personalidades surgem a apresentar propostas.

Um dos exemplos mais significativos dos movimentos em prol da resolução do cisma foi o da Universidade de Paris, liderada pelo célebre reformador e conciliarista Jean Gerson ${ }^{321}$, que nos anos finais do séc. XIV propugnava pelo forçar de uma resolução.

Nos debates em torno da questão, e que têm essencialmente lugar a partir de 1394, delineiam-se as possíveis vias para a resolução do cisma. Se num primeiro momento a obediência de Avinhão considerou (tendo por base a crise de obediência romana) que poderia vencer o lado contrário pela força das armas e conquistar Roma, tal projeto revelou-se impossível, ainda mais quando as obediências se parecem equilibrar.

Da reflexão da Universidade de Paris, e de outros pensadores, eclesiásticos e laicos, que se debruçaram sobre o tema, definem-se as possíveis soluções e que passam, num primeiro momento, pelo necessário entendimento das partes. Sugere-se a negociação direta para obter uma solução, apresentarem-se a arbitragem externa ou a mútua abdicação para eleição de um único pontífice.

A sistemática recusa dos Papas das duas obediências em aceitar estas vias propostas, mesmo com retirada de obediência por parte de alguns estados para forçar uma tomada de posição, conduz à imposição de outra solução e aquela que marcará a Igreja dos primeiros anos do séc. XV até Trento: a via do concílio ${ }^{322}$.

\subsubsection{Ecclesia semper reformanda est ${ }^{323}$. Concílios, conciliarismo, autoridade papal e reforma da Igreja}

A proposta de um concílio geral para ultrapassar a crise cismática aparece nos primeiros anos do cisma, como espaço privilegiado para arbitrar a legitimidade das duas obediências. A fraca adesão dos Papas e dos poderes estabelecidos, bem como dos próprios intelectuais que se debruçam sobre a

\footnotetext{
${ }^{321}$ Sobre Gerson e o seu pensamento e ação reformistas veja-se, nas linhas do entendimento de Ladner, PASCOE, 1973; bem como MEYJES, 1999.

322 STUMP, 2009: 395 e segs.; CHAUNU, 2002: 191 e segs.

${ }^{323}$ Expressão nascida no seio da reforma protestante e que colheu eco no universo católico no contexto do II Concílio do Vaticano. Note-se que a expressão é usada na entrada «aggiornamento» da New Catholic Encyclopedia para sublinhar que o processo reformador e modernizador implantado a partir do Concílio, ainda que discutido nos meios académicos sobre a sua real natureza, profundidade e impacto, se coloca num processo histórico da Igreja que se pode sintetizar nesta expressão latina (cf. BULLMAN, 2010). Bellitto escreve sobre esta expressão o seguinte: «Hans Küng believes the phrase may have its origins in Jean Calvin's thougt or circle in the 16th century; he suggested a study of the phrase itself would be salutary, particularly as the Church was preparing for Vatican II in the early 1960s, but no such study has appeared» (cf. BELLITTO, 2009: 306). Mais recentemente, a 21 de dezembro de 2015, esta expressão foi pedra de toque do discurso que o Papa Francisco dirigiu à Cúria Romana por ocasião dos cumprimentos de Natal.
} 
matéria ${ }^{324}$, coloca-a no final da lista das opções. Será a gradual falência das outras vias para a resolução do cisma que permitirá à via conciliar impor-se ${ }^{325}$.

O recurso à solução conciliar andará então a par com a estruturação de uma corrente conciliarista, que se manterá forte nas primeiras quatro décadas do séc. XV e que se constitui em paralelo com a crise da autoridade pontifícia.

Tradicionalmente convocados pelos Papas, os concílios gerais funcionavam sob sua autoridade. A inexistência de autoridade pontifícia incontestada que o convocasse levou à procura de alternativa que o direito canónico não previa, pensada sob expedientes teóricos preparados por, entre outros, Jean Gerson e Pierre d'Ailly ${ }^{326}$. Gerson, definitivamente um defensor da solução conciliar ${ }^{327}$, sugere a convocação por cardeais das duas observâncias que abandonaram os seus Papas ${ }^{328}$, para que dele saísse a eleição de um Papa incontestado e se superasse a crise estrutural em que a Igreja caíra. O resultado é conhecido, o concílio de Pisa de 1409, que eminentemente eclesiástico e como tal separado de outros poderes com papel na questão cismática, elege mais um pontífice contestado, Alexandre V (logo depois sucedido por João XXIII). A situação agrava-se, com três obediências opostas $^{329}$.

O agravamento do cisma torna a necessidade de uma resolução ainda mais premente. Apesar do concílio de Pisa não ter sido um sucesso, tendo em vista o agravamento da cisão, não colocou no entanto em causa o recurso ao concílio.

Apenas quatro anos passados sobre o concílio de Pisa, o rei dos romanos Segismundo emite um édito, de 30 de outubro de 1413, a convocar concílio geral para cidade imperial de Constança, antecipando-se à bula de convocação que o Papa de Pisa João XXIII emite em 9 de dezembro. Ao Rei dos romanos e ao prestígio da sua coroa dever-se-á o sustentáculo deste concílio e da dinâmica que permitirá ultrapassar a crise cismática ${ }^{330}$.

O concílio de Constança abre, com presidência do Papa de Pisa, a 5 de novembro de 1414. A partir desta data somar-se-ão delegações e o concílio crescerá, convertendo-se no maior concílio medieval da Igreja, a cuja amplitude Stump atribui o seu sucesso ${ }^{331}$.

\footnotetext{
${ }^{324}$ Será por exemplo o caso de Gerson, que estando inicialmente em completo desacordo com a solução conciliar, irá acabar por abraçar a ideia, podendo-se situar a sua transição para a adesão a uma ideia conciliar, ainda que de modo muito ténue, a partir dos anos de 1402 (cf. MEYJES, 1999: 88 e segs.).

325 STUMP, 2009: 398 e segs.

${ }^{326}$ Bispo de Cambrai (cf. RICHARDSON, 2009: 40).

${ }^{327}$ Cf. MEYJES, 1999: 146 e segs.

${ }^{328}$ Estamos perante cardeais das duas obediências que retiraram a sua obediência aos respetivos Papas por estes não cumprirem com as capitulações eleitorais com que ambos (Bento XIII de Avinhão e Gregório XII de Roma) tinham sido eleitos, e que determinavam por questão fulcral dos seus pontificados o fim do cisma, com a sua resignação ao sólio se tal fosse necessário. As sistemáticas recusas de Bento XIII nesta matéria, e o facto de Gregório XII criar novos cardeais romanos (que as mesmas capitulações proibiam), levam estes cardeais a decidirem tomar a questão em mãos, pela promoção de um seu concílio, que reunirá em Pisa (cf. Idem, ibidem; ORTALLI, 2000; PIÑEIRO, 2000; RICHARDSON, 2009: 39 e segs.).

329 OAKLEY, 2006: 193, 194; RICHARDSON, 2009: 43; STUMP, 2009: 401 e segs.

${ }^{330}$ Idem, ibidem.

${ }^{331}$ Idem, ibidem: 403.
} 
Logo em 23 de março de 1415 Gerson, que viera ao concílio com o Cardeal D’Ailly ${ }^{332}$ (aliás seu antecessor como chanceler da Universidade de Paris), prega um sermão em que deixa explícita a ideia que a relação indissolúvel da Igreja é com Cristo, de quem era a noiva, e não com o seu representante, o Papa. No mesmo sermão, onde está presente a sua longamente maturada ideia conciliarista, afirma que existem casos em que o concílio geral se pode reunir sem ser convocado pelo Papa, mesmo que eleito legitimamente, e que a Igreja (ou o concílio geral em sua representação) pode limitar ao Papa o uso do seu poder através do correto conhecimento e utilização da lei canónica; em suma, Gerson recusa a plenitudo potestatis papal, ainda que sem atingir o radicalismo de um Marsílio de Pádua ${ }^{333}$.

Desenhava-se a afirmação da superioridade do concílio sobre o poder papal, com as suas decisões, desde os primeiros dias, a fortalecerem a sua posição enquanto espaço privilegiado para a resolução da crise mas também como órgão supremo da Igreja ${ }^{334}$.

Na sequência do sermão de Gerson, ponto de partida para a autoafirmação do concílio, é emitido (a 30 de março) o decreto Haec sancta, que determinará (entre outras coisas) que Constança é um legítimo concílio geral, cuja autoridade vem diretamente de Cristo, a quem todos devem obedecer, mesmo o Papa, e que se reuniu para dar um fim ao cisma e para reformar a Igreja, in capite et in membris ${ }^{335}$. Expressa-se aqui não só a amplamente sentida necessidade de reforma da Igreja, mas o entendimento (que será de Gerson) que a reforma deve ser antes de mais uma iniciativa do concílio, justificando a futura decisão de concílios periódicos para o bom governo da Igreja e sua reforma ${ }^{336}$.

Com a fuga de João XXIII, que abandona Constança ao sentir que os trabalhos não o favoreciam, o concílio julga-o e depõe-no em maio desse ano de 1415. Em julho, o Papa de Roma Gregório XII envia dois representantes ao concílio: o Cardeal Dominici, que em seu nome proclama bula de convocação do concílio (aduzindo a legitimidade romana à de Segismundo e de João XXIII de Pisa) e Carlo Malatesta ${ }^{337}$ que, na mesma sessão, abdica do sólio pontifício em seu nome ${ }^{338}$. Gregório XII coloca como única condição à sua abdicação que a posição dos cardeais, amplamente criticada e discutida no concílio, fosse respeitada, garantindo assim a sobrevivência da instituição colégio cardinalício ${ }^{339}$.

\footnotetext{
${ }^{332} \mathrm{O}$ qual, apesar de ser criado cardeal por João XXIII, vai logo no início do conclave demonstrar a sua posição em defesa do concílio e da resolução do cisma, ao defender que os cardeais da observância romana deviam ser recebidos e integrados ao concílio nessa condição, gesto aprovado por Segismundo e que tinha por finalidade promover um entendimento diplomática favorável que tornasse aceitável a Gregório XII renunciar ao sólio, como o mesmo já equacionava e como virá a acontecer (cf. Idem, ibidem: 406, 407).

${ }^{333}$ OAKLEY, 2006: 179 e segs., coloca Gerson como um teólogo conservador e cauteloso, cuja obra teve a infelicidade de ser lida sob a perspetiva de posições mais radicais como a de Marsílio de Pádua no séc. XIV, e depois do grave confronto entre papado e concílio ocorrido no pontificado de Eugénio IV.

${ }^{334}$ Idem, ibidem: 195; RICHARDSON, 2009: 44, 45; STUMP, 2009: 410.

${ }^{335} \mathrm{Vd}$. sobre este decreto o artigo de DECALUWE, 2008.

${ }^{336}$ Idem, ibidem: 136 e segs.

${ }^{337}$ Para Stump, Malatesta é uma das pessoas a quem se deveria dar maior crédito pelo papel desempenhado na resolução do cisma, pelo seu papel nas negociações que levam à pacífica abdicação de Gregório XII, e nas tentativas para forçar a abdicação de Bento XIII (cf. STUMP, 2009: 415, 416).

${ }^{338}$ Idem, ibidem: 413 e segs.; RICHARDSON, 2009: 47 e segs.

${ }^{339}$ Idem, ibidem: 48.
} 
Entra-se então nos dois últimos passos para a resolução do cisma: o primeiro foi a deposição formal de Bento XIII de Avinhão, a 26 de julho de 1417 (e ao cabo de um processo aberto em novembro do ano anterior), que certo da sua legitimidade se recusara a abdicar mesmo quando perdera os seus últimos apoios em $1416^{340}$.

O segundo passo inicia-se após ser estabelecida, a 30 de outubro de 1417 e com grande dificuldade, a forma de eleição do Papa. A 9 de novembro inicia-se o conclave e apenas dois dias depois, a 11 de novembro de 1417, é eleito Odo Colonna, Papa Martinho V ${ }^{341}$.

Com a eleição do Papa o concílio entra na sua reta final, sem ter conseguido pôr em marcha a tão desejada reforma geral, por dificuldades diversas incluindo a de entendimento entre diversas visões do que deveria ser essa reforma. Do longo debate em torno da questão (que se inicia logo no verão de 1415) o concílio irá emitir um conjunto de decretos que visavam a reforma da Igreja dirigindo-se aos seus tradicionais problemas: a reforma da administração financeira da Santa Sé e dos excessos da fiscalidade pontifícia (um clássico entre as queixas dos povos cristãos), a reforma in capite, dirigida à cúria romana, nomeadamente com a limitação da autoridade pontifícia e do colégio de cardeais, bem como a moralização do alto clero, e a reforma in membris, dirigida aos demais degraus do universo eclesiástico visando a melhoria da sua formação e a sua disciplinação, bem como aos laicos ${ }^{342}$.

Apesar das dificuldades em obter consensos e em garantir a efetividade de medidas de reforma, a riqueza de sensibilidades reformistas presentes no concílio demonstra até que ponto a necessidade de reforma era amplamente sentida e como estavam em atuação no universo eclesiástico essas sensibilidades, traduzidas em movimentos.

Apontando para o movimento de S. Jorge em Alga, e para o universo reformista veneziano em que se inseria, e sem considerar profundamente a questão, tenhamos apenas em consideração que em Constança atuaram 3 cardeais que lhe estavam ligados: António Correr, Gabriel Condulmer e Giovanni Dominici ${ }^{343}$.

Não lançando o tema da reforma da Igreja, que na leitura de Ladner e da sua escola é um tópico recorrente do universo cristão, o concílio de Constança coloca-o no entanto como uma das questões principais da Igreja, estabelecendo um conjunto de normas que visavam antes de mais dar resolução aos problemas do universo eclesiástico, aquele que mais crise aparentava e que é para quem se dirigem os esforços dos principais movimentos reformistas dos sécs. XIV e XV, como os das observâncias, os dos Cónegos de Alga e de S. João Evangelista em Portugal.

No seu desejo de manter viva a instituição conciliar e de garantir, por ela, um controlo da Santa Sé e promover as reformas necessárias, o concílio de Constança estabeleceu o decreto Frequens, que determinava que se reunissem frequentemente concílios gerais, o primeiro dos quais será o Concílio de Siena de 1423 que, apesar da continuada condenação da decadência do clero, encerrará sem

\footnotetext{
${ }^{340}$ STUMP, 2009: 416 e segs.

${ }^{341}$ Idem, ibidem: 439-441.

${ }^{342}$ Para a questão veja-se a obra de Stump sobre as reformas no concílio de Constança: STUMP, 1994.

${ }^{343}$ Sobre estas figuras, todas ligadas a Gregório XII, veja-se o cap. 2 desta obra.
} 
nenhuma medida notável em matéria de reforma ${ }^{344}$, convocando-se o concílio seguinte para Basileia, em $1431^{345}$.

Durante o seu pontificado, e apesar da debilidade da instituição pontifícia e da força alcançada pelas ideias conciliaristas, Martinho V tentará empreender a reforma curial e do colégio de cardeais (a quem recupera a posição abalada pelas críticas conciliares e que tenta ligar mais estreitamente à autoridade pontifícia), bem como a lenta reconstrução da sua autoridade, a par de outras ações que pretendia concorressem para o bem geral da Igreja e da sua unidade, como a promoção do diálogo com outras igrejas cristãs tendo em vista a união e o auxílio aos movimentos reformistas internos das ordens religiosas ${ }^{346}$.

Em fevereiro de 1431 Martinho V emitia as bulas pelas quais dava poder ao Cardeal Cesarini para em seu nome abrir o concílio geral convocado para Basileia; no dia 20 desse mês o Papa morria. A 3 de março o conclave elegia, à primeira votação, o Papa Eugénio IV, que aprovará as bulas do seu predecessor. O concílio abre a 23 de julho desse ano ${ }^{347}$.

Eugénio IV revelar-se-á um tenaz opositor do concílio de Basileia e da teoria conciliarista que esta encarna, e que vai radicalizando na sua luta com o Papa. Watanabe descreve sumariamente os pontos principais desta luta entre duas conceções de Igreja: a do Papa, que assenta sobre a supremacia absoluta do poder pontifício e numa longa tradição que vinha, pelo menos, desde os tempos da reforma gregoriana; a do concílio, solidificada em torno dos pensadores conciliaristas que deram forma à eclesiologia conciliarista durante o concílio de Constança, também assente numa tradição secular e que afirmava o concílio (enquanto representação da Igreja universal) como o mais alto poder na Igreja ${ }^{348}$.

Considerando o pontífice que o concílio em Basileia tinha pouca adesão tenta, nos seus primeiros tempos, dissolvê-lo ou transferi-lo para Bolonha (território da Igreja, ao contrário de Basileia). Esta tentativa do Papa provoca fortes reações entre os conciliares, escudados no presidente do concílio Cardeal Cesarini. Entre avanços e recuos (assentes na fragilidade da situação de Eugénio IV devida a complicações no palco da política regional italiana), o Papa reconhece a legitimidade de Basileia, não se evitando no entanto o extremar de posições.

A 18 de setembro de 1437 Eugénio, que se mantivera em constante oposição ao concílio e ao plano de reformas que este queria impor ao Papa e à cúria ${ }^{349}$, toma uma posição firme e ordena, sob

\footnotetext{
${ }^{344}$ Os quatro decretos deste concílio dirigiram-se aos utraquistas boémios, às sobrevivências cismáticas de Avinhão (que prossegue para lá da morte de Bento XIII em 1422), aos trabalhos em prol da união com a Igreja Grega e a correção do regime beneficial, cheio de abusos (cf. CHAUNU, 2002: 198).

${ }^{345}$ RICHARDSON, 2009: 50, 51.

${ }^{346}$ Idem, ibidem; BIANCA, 2000.

${ }^{347}$ Idem, ibidem; WATANABE, 2008: 179. Para um bom resumo dos diversos passos do concílio de Basileia e da sua relação com o Papa veja-se os primeiros capítulos de STIEBER, 1978.

${ }^{348}$ WATANABE, 2008.

${ }^{349}$ Como afirma Joachim N. Stieber (STIEBER, 1978: 26 e segs.), o Papa considerava-se particularmente agravado por o concílio reafirmar os actos de Constança que declaravam a superioridade do concílio na Igreja, a sua abolição das expectativas e anatas de benefícios (que afetavam diretamente a tesouraria pontifícia), o facto de determinar a limitação do poder pontifício e a presunção do concílio em dirigir as negociações com a Igreja grega com vista à união e que tinham sido iniciadas e dirigidas por Martinho V.
} 
sua autoridade, que o concílio se transfira a Ferrara e que a reunião de Basileia se dissolvesse (virá a excomungar os resistentes em $1438^{350}$ ). O núcleo do concílio de Basileia recusa-se obedecer ao Papa, declara a sua deposição e em 1439 elege o Duque Amadeu de Sabóia como Papa Félix V, tornando-se o concílio, depois de ser fautor da unidade, fonte de cisma ${ }^{351}$.

O Papa acabará por ter na transferência do concílio para Ferrara, e depois para Florença e Roma, um ponto de viragem que lhe permitirá reforçar a sua autoridade, a qual será reconhecida por quase todas as autoridades da europa cristã, incluindo-se o Imperador e a Igreja grega com quem se fará o decreto de união em 1439. Será aliás nessa ocasião que se apresentará à delegação grega uma declaração sobre o primado Papal, que traduz o essencial do pensamento de Eugénio IV sobre a matéria:

Nós definimos que o santo apostólico e romano Pontífice é o sucessor de Pedro e vigário de Jesus Cristo, cabeça de toda a Igreja e pai de todos os cristãos, também nosso mestre, e que ele detém o primado sobre todo o mundo e que à mesma Sé e Romano Pontífice, em São Pedro, o Príncipe dos Apóstolos, foi dado o poder plenário de prover, reunir, reger e governar toda Igreja ${ }^{352}$.

O concílio de Basileia irá perdendo gradualmente os seus apoios, sobretudo depois de depor o Papa e fazer a Igreja cair em novo cisma. A sua posição cada vez mais marginal, conduz a uma inevitável agonia que dura até 1449, já no pontificado de Nicolau V, perante cuja autoridade o papa de Basileia Félix V renunciará, obtendo um lugar no seu colégio de cardeais. Com o fim inglório de Basileia, e com a vitória clara do concílio de Eugénio IV, a doutrina conciliarista da Igreja parece definitivamente afastada, e assim se manterá na prática até ser ressuscitada nos debates que circundaram o II Concílio do Vaticano.

Watanabe ${ }^{353}$, na lição de Gill, um dos principais biógrafos de Eugénio IV, reafirma a tradicional leitura crítica de um Papa que se opõe tenazmente ao movimento conciliar e procura salvaguardar a tradicional constituição da Igreja, mais por teimosia, simplismo mental, inexperiência, desejo de manter o poder e riqueza do papado, do que por qualquer motivo de natureza puramente eclesial, e que deste modo teria colocado em causa a possibilidade de os concílios colocarem em prática um dos seus pontos de toque: a reforma geral da Igreja.

Ignora-se em Eugénio IV as suas próprias circunstâncias para perceber a sua oposição ao concílio, a sua defesa da autoridade pontifícia e a sua própria ideia e atuação reformistas.

Não entrando no debate das características de personalidade do Papa, o que se conhece da sua atuação não permite supô-lo como simples de entendimento e inexperiente em assuntos da Igreja. Cardeal curial durante 23 anos, primeiro como cardeal de seu tio o Papa de Roma Gregório XII,

\footnotetext{
${ }^{350}$ Idem, ibidem: 43.

${ }^{351}$ Idem, ibidem: 44 e segs. Como DECALUWE, 2008: 123, chama a atenção, a instituição conciliar colocou-se em Basileia nesta irónica posição de, sendo criada para superar o cisma, o retomar ao eleger um anti-papa em confronto com um Papa legitimamente eleito, e para tal usando como elemento central da argumentação o mesmo decreto conciliar de Constança que promovera a unidade eclesial, o Haec sancta.

352 Traduzido da citação inglesa em WATANABE, 2008: 191.

${ }^{353}$ Idem, ibidem: 193.
} 
depois como colaborador de Martinho V, Eugénio IV é, aquando da sua eleição, uma figura provada no governo da Igreja, um homem que conhecia bem a experiência conciliar de Constança,

A experiência do concílio que forçara o seu tio a despir-se da dignidade pontifícia, a natural relação da corrente conciliarista com o universo francês ${ }^{354}$ (estritamente ligado ao papado de Avinhão e à sua obediência durante o cisma, e como tal o «inimigo»), a sua colaboração com Martinho V na recuperação do poder pontifício e em promover reformas efetivas à margem da atuação dos concílios, permite supor com alguma segurança que Eugénio IV era, ao subir ao sólio de S. Pedro e além de um efetivo defensor da eclesiologia do primado de Pedro, um homem que não teria a mínima simpatia pela ideia conciliarista.

Nas críticas à oposição de Eugénio IV ao Concílio de Basileia e ao conciliarismo está latente uma acusação de opor-se igualmente ao capital reformista que o conciliarismo comportaria. Nesta ideia o Papa seria responsável pela incapacidade da Igreja se reformar eficazmente e como tal condenando-a às reformas e cisões do séc. XVI. Esta leitura empobrecida ignora as questões estruturais que subjazem aos acontecimentos posteriores, pois como Chaunu chamou a atenção existem já no conflito entre Basileia e o Papa tomadas de posição de estados europeus, e adesões de pessoas e instituições, que apontam para adesões estruturais que se podem encontrar nas reformas do séc. XVI ${ }^{355}$.

Sendo, como o autor demonstrou, um processo de longo tempo, a emergência de um campo religioso polarizado na Europa quinhentista não pode ser exclusivamente assacado à incapacidade reformadora da Igreja, e menos ainda a um Papa cioso dos seus direitos pontifícios, mas a um conjunto de mutações históricas muito alargadas.

Importa ainda salientar, que Eugénio IV foi, em essência, um eclesiástico reformador (e como tal será analisado no ponto 2.3.), mesmo que o seu entendimento de reforma seja distinto do entendimento dos representantes da corrente conciliarista e se funda principalmente numa ideia mais geral, e historicamente mais antiga, de reforma.

Os grandes pensadores conciliaristas de Constança, como Gerson e d'Ailly, entendiam a reforma da Igreja feita da capite aos membris, ou seja, uma reforma pensada verticalmente e de sentido descendente, implicando que o concílio como autoridade superior proceda (ou faça proceder) à reforma da cúria pontifícia, a partir da qual emanará (por força da sua autoridade) para o demais corpo da Igreja; entendimento que apenas alcançará efetiva realização um século mais tarde, em Trento.

Mas o entendimento destes pais do conciliarismo quatrocentista não era o único. Observe-se, por exemplo, o pensamento de Nicolas de Clamanges, secretário papal da obediência de Avinhão, que situa a base da reforma da Igreja na reforma individual de cada cristão, situando-se assim na tradição mais antiga da ideia de reforma, herdada dos Padres da Igreja, e com raízes no pensamento de S. Paulo e na ideia Paulina de reforma ${ }^{356}$. Para Clamanges a reforma individual dos cristãos, ou seja, a sua

\footnotetext{
${ }^{354}$ A França será o principal sustentáculo de Basileia contra Eugénio IV, e os apoiantes do Papa usam como argumento contra o concílio a sua próxima relação aos interesses franceses (cf. STIEBER, 1978).

${ }^{355}$ CHAUNU, 2002: 198 e segs.

${ }^{356}$ Sobre a questão de Clamanges veja-se BELLITTO, 1999; sobre a ideia Paulina de reforma, e do entendimento de reforma dos Padres da Igreja veja-se a obra de LADNER, 1959.
} 
experiência de conversão em Cristo, era a forma da Igreja se reformar como um todo. Um conceito de reforma baseado num entendimento profundo de Igreja, vista como um corpo vivo formado pelo conjunto de todos os crentes, e que se reformará não pela imposição de reformas externas mas pela adesão a um processo interno, individual e coletivo, de reforma.

Será nesta linha que deveremos situar o entendimento de reforma do Papa Condulmer, que durante o seu pontificado (como antes, durante a sua longa carreira eclesiástica, iniciada como cónego reformador na fundação da Congregação de S. Jorge em Alga) pensará o seu apoio ${ }^{357}$ ou promoção direta de reformas como dirigidas a uma reforma da base eclesial, nomeadamente do seu vasto corpo eclesiástico que importa moralizar e formar. Acreditaria o Papa que, pelo efeito de expansão, iria gradual mas inevitavelmente reformar-se toda a Igreja.

Considerando o apoio do Papa a alguns movimentos observantes, bem como à sua Congregação de Alga e aos seus «filhos» institucionais portugueses, os Lóios, se nos ativermos ao seu empenho em nomear bispos de cariz reformador e exemplar (recorde-se mesmo a sua relação com alguns prelados que serão beatificados e canonizados) e a sua aposta na formação de clérigos ${ }^{358}$, poderemos perceber que a ideia de reforma de Eugénio IV, explicada nos termos de uma ideia de reforma horizontal e não vertical, alcançou um grau de sucesso não desprezível e apresenta a debate algumas das preocupações da reforma tridentina: formação clerical, prelados dignos, reforma interna e observante das ordens religiosas, tudo dirigido em última instância à ação pastoral da Igreja. Poderemos assim eximir Eugénio IV do julgamento de Hudon sobre o papel dos universos reformistas dos primeiros anos do séc. XV, em particular dos conciliares:

The standard interpretation of reform leaders and their initiatives in the fifteenth century at the councils of Constance and Basel finds prelates full of good intentions, but decidedly wanting when it came to action [...] a rather complete failure ${ }^{359}$.

\footnotetext{
${ }^{357}$ No qual devemos inserir o seu apoio aos fundadores Lóios, não só à Congregação, mas também pela escolha de D. João Vicente para Bispo de Lamego e Viseu, dando à Igreja portuguesa um bispo de cariz reformador.

${ }^{358}$ Sobre a atuação reformista de Eugénio IV veja-se o ponto 2.3.

${ }^{359}$ HUDON, 2012: 261.
} 


\section{ACONGREGAÇÃ̃O DE S. JORGE EM ALGA DE VENEZA}

Un vasto e profondo bisogno di riforma affiorava e si imponeva ovunque e non tardò a dare $i$ suoi frutti dapprima in seno ai grandi Ordini Religiosi poi per iniziativa di singoli che davano vita a nuove congregazioni. Cosi nella famiglia domenicana la riforma fu ad opera del beato Dominici, tra i francescani invece il beato Paolo Trinci promosse l'Osservanza regolare. La riforma benedettina si diffuse dall'abazia di S. Giustina di Padova per merito di Ludovico Barbo, patrizio Veneto, raggiungendo di li a poco anche la Spagna e lo stesso Montecassino. Accanto alla riforma le nuove congregazione:

Dei Gesuati per merito del Beato Colombini, degli Alessiani nei Paesi Bassi, delle Oblate di S. Maria, fondata da S. Francesca Romana, l'ordine del Salvatore e della Vergine, per mezzo di S. Brigida di Svezia e sopratutto i Fratelli della vita comune, agostinianni di Windesheim per opera di Gerardo Groot e Fiorenzo Radewiis. Nel 1435 i frati minimi religiosi di S. Francesco di Paola.

$E$ in seno a questo grandioso anelito di rinnovamento interiore che si inserisce il sorgere e il maturare del movimento di San Giorgio in Alga ${ }^{360}$.

Fundada em plena crise cismática, na viragem do séc. XIV para o XV, a Congregação de S. Jorge em Alga de Veneza irá fazer parte do horizonte espiritual da Sereníssima durante pouco mais de dois séculos e meio.

Fundada sob os auspícios da Santa Sé e do Estado Veneziano, com quem terá no séc. XV forte ligação, alicerçada no facto de preencherem as suas fileiras patrícios venezianos e ser fonte de recrutamento de um Papa e diversos prelados, a Congregação de Alga conhecerá a extinção pela ação concorde dos seus sustentáculos originais.

A extinção da Congregação de S. Jorge em Alga, por decisão do Papa Clemente IX, a que se soma a dos Jesuatos e dos eremitas de S. Jerónimo de Fiesole, vem na sequência da dos Irmãos da Cruz (Fratres Cruciferorum) no pontificado anterior (de Alexandre VII, 1655-1667), e surge como resposta ao pedido do Estado Veneziano de ajuda material para a Guerra de Cândia, onde se pretendia defender o domínio de Veneza sobre a ilha de Creta, disputado pelo império Otomano.

Sob o argumento de nas Congregações não vicejar já o vigor inicial, a Bula Romanus Pontifex, de 6 de dezembro de 1668, procede formalmente à extinção destas congregações religiosas italianas, de cariz regionalizante, reservando todos os seus bens à Sé Apostólica. No dia sequente, a bula Cum Nos gravissimis concede à Sereníssima todos os bens não-sagrados das Congregações extintas, existentes em território da república, a que acrescenta (por bula de 17 de dezembro do mesmo ano) os bens que as Congregações possuíssem no reino da Sicília além do Farol (ilha da Sicília) ${ }^{361}$.

\footnotetext{
${ }^{360}$ BARBATO, 1959.

${ }^{361}$ Bullarum Privilegiorum ac Diplomatum Romanorum Pontificum..., 1762: 304-307, 311, 312.
} 
Para a gestão dos processos de extinção destas Congregações, foi determinada a constituição de uma sagrada congregação particular ${ }^{362}$, de cujo trabalho resta no Arquivo do Vaticano, pelo menos, um códice que recolhe informações dos conventos extintos e atas das sessões da congregação particular. Por ele ficamos a saber que aquando da extinção a Congregação de Alga tinha 16 conventos (10 na república de Veneza, 3 nos estados Papais e 3 na Sicília) e 232 religiosos (163 religiosos nos conventos de Veneza, 41 religiosos nos de Roma e 28 nos da Sicília ${ }^{363}$.

Estes dados permitem perceber que, até ao final da sua existência, a Congregação de S. Jorge de Alga foi em essência uma Congregação dos territórios da Sereníssima.

Nascida em plena laguna ${ }^{364}$, erguida sobre as elites patrícias de Veneza, a Congregação de Alga acompanha, e é parte indissociável, da emergência de uma nova dinastia papal que teve um papel determinante na Santa Sé nas décadas de 1400 a 1470.

Foi, em suma, um assunto de família.

\subsection{ORIGENS E FUNDADORES: PARTICULARIDADES DE UMA PROPOSTA REFORMISTA}

\section{S. Jorge em Alga de Veneza - de Priorado a Colegiada}

A data fundacional da comunidade canonical de S. Jorge em Alga poderá ser colocada, sem grandes dúvidas e como o têm feito os diversos estudiosos que dela trataram ${ }^{365}$, no dia 30 de outubro de 1404. Tomasini não hesita e afirma mesmo «atque hoc fuit Congregationis nostrae initium» ${ }^{366}$.

Nesta data, conforme ao teor de ata notarial transcrita pelo cronista da Congregação $0^{367}$, a partir do original existente no arquivo do mosteiro insular, foi executada letra apostólica ${ }^{368}$ do Papa Bonifá-

\footnotetext{
${ }^{362}$ Por oposição às Congregações Romanas, que constituem os dicastérios da Santa Sé, definidos como os grandes ministérios da Santa Sé para auxiliar o Pontífice no governo da Igreja, criados a partir do séc. XVI, sendo o mais antigo o da Inquisição, hoje chamado da Doutrina da Fé. As congregações particulares eram nomeadas para tratar de assuntos específicos e temporalmente limitados (D’ONORIO, 1994).

${ }^{363}$ Cf. ASV - Miscellanea, Armadio VIII, n. ${ }^{\circ} 41$.

${ }^{364}$ Assim define Tramontin o mosteiro de S. Jorge em Alga «una piccola isola tra Venezia e la terraferma» (cf. TRAMONTIN, 1975: col. 155).

${ }^{365}$ Idem, ibidem e TRAMONTIN, 1984: 96 e segs.; Cracco no seu artigo acerca da fundação dos cónegos de Alga, CRACCO, 1959; o cronista da própria Congregação de Alga, TOMASINI, 1642: 24; Tassi também menciona este ato, sem no entanto o sublinhar excessivamente (cf. TASSI, 1952: 15, 16).

366 TOMASINI, 1642: 24.

${ }^{367}$ Idem, ibidem. Este mesmo documento está transcrito no Livro dos Privilégios dos Lóios, onde se imprime carta testemunhável do Vigário Geral do Arcebispado de Lisboa pelo Arcebispo D. Fernando de Vasconcelos, licenciado Pedro Velho, datada de lisboa a 5 de março de 1555, onde se afirma que a pedido do Reitor Geral dos Lóios P.e Diogo da Ressurreição se transcrevem, por maior segurança, a bula de fundação (esta que nos ocupa) e muitas outras. Será deste treslado, que foi declaradamente feito para substituir os originais quando fosse necessário saírem do cartório da Congregação, que se prepara esta versão impressa em 1594 (cf. Livro dos Privilegios concedidos pellos Summos Pontifices..., 1594: fl. 1 e segs.). Saliente-se no entanto que enquanto na transcrição feita por Tomasini do ato original se separe dois documentos (o ato de transformação do mosteiro em igreja secular com capítulo canonical e as Determinações feitas pelo bispo executor para governo da nova comunidade), na versão impressa feita pelos Lóios os dois actos estão fundidos num só, porque impressos a partir de confirmação do Papa Gregório XII de 1407.

${ }^{368}$ Datada de Roma, a 15 de março (Idos) de 1404 (15. ${ }^{\circ}$ do pontificado de Bonifácio IX) (cf. Idem, ibidem: fl. 2v.).
} 
cio $\mathrm{IX}^{369}$, em que o pontífice diz que por Luís (Barbo), prior do mosteiro de S. Jorge em Alga, lhe fora suplicado provimento para o seu desejo de ver reformado o mosteiro ${ }^{370}$, que se encontrava privado de vida claustral regular e com o culto divino gravemente afetado.

O Pontífice ordena ao executor da bula, o Bispo de Kysamos, Ângelo Barbarigo ${ }^{371}$, que se informe pessoalmente sobre o estado do mosteiro e confirme as premissas apresentadas por Luís Barbo, dando-lhe a sua autoridade para que reforme e corrija o mosteiro «in capite quam in membris», com faculdade para ordenar estatutos e constituições, bem como determinar no que respeite ao bem do culto divino, e que esses capítulos ou estatutos possam ser futuramente feitos pelo Bispo de Castelo e com o cabido do mesmo mosteiro ${ }^{372}$.

Ângelo Barbarigo dá conta que no mosteiro, além do Prior Luís Barbo, residiam apenas os frades agostinhos Honorato de Veneza e Luís de Florença, os quais não viviam em observância regular. Aliás os dois frades eram apenas conversos tacitamente professos, ou seja, pertenciam aquele grupo de homens que abraçava a vida claustral sem chegar a fazer a profissão solene de votos, e que se colocava num patamar inferior aos dos religiosos professos $^{373}$.

Diz o prelado não se esperar dos Agostinhos que providenciassem a reforma do mosteiro e da sua vida regular, pelo que, depois de conferenciar com o Prior Luís Barbo e outros homens veneráveis, e tendo afastado a hipótese do mosteiro ser reformado por religiosos de outras ordens ou congregações regulares, atendendo a que Marino Quirino e os seus associados clérigos seculares viviam no mosteiro com grandes virtudes e graves costumes, reformando-o, decide por exercício da autoridade apostólica, com o consenso do prior, transformar o antigo mosteiro, cabido e igreja em igreja secular colegiada, de cónegos seculares, com a obrigação de vida comunitária, incluindo os ofícios divinos (de dia e de noite).

Nada muito diferente de outros atos notariais em eventos similares, em que igrejas de mosteiros ou conventos sem adequada vida regular são secularizadas, no caso presente com o objetivo de ser reformada pela constituição de uma colegiada de clérigos seculares. Este será o processo mais comum pelo qual a futura Congregação de Alga tomará posse das suas diversas casas, um processo que se encontrará na Congregação dos Lóios, no que às primeiras casas conventuais respeita ${ }^{374}$.

É difícil não ver semelhanças com a secularização do mosteiro beneditino de S. Salvador de Vilar de Frades, em Barcelos, que o Arcebispo de Braga D. Fernando da Guerra, a 28 de fevereiro de 1425 , reduz a igreja secular e entrega a mestre João Vicente ${ }^{375}$. Esta secularização de igreja que se

\footnotetext{
${ }^{369}$ Já então desaparecido, porque falecido em Roma no primeiro dia desse mesmo mês de outubro de 1404 (cf. ESCH, 2000 ). ${ }^{370}$ «Quare pro parte dicti Prioris qui ut asserit ad reformationem ipsius monasterii ferventer anhelat» (cf. Livro dos Privilegios concedidos pellos Summos Pontifices..., 1594: fl. 1 e segs.).

${ }^{371}$ GUALDO, 1964a. Acerca da posição deste prelado no universo familiar da linhagem dos Correr/Condulmer/Barbo, veja-se em anexo esquema genealógico n. ${ }^{\circ} 1$.

${ }^{372}$ Livro dos Privilegios concedidos pellos Summos Pontifices..., 1594: fl. $2 \mathrm{v}$.

${ }^{373}$ Acerca dos irmãos conversos veja-se DONOVAN, 1908.

${ }^{374}$ Veja-se, em anexo, os quadros anexos n. ${ }^{\text {os }} 2$ e 4, que resumem as fundações das casas das Congregações de Alga e dos Lóios. ${ }^{375}$ ADB - Monástico, Lóios, Mosteiro de Vilar de Frades, lv. 12, fl. 107. Transcrito em anexo documental, como doc. n. ${ }^{\circ}$ 1. Isabel Castro Pina na sua tese (PINA, 2011: 103) menciona a data e o ato de redução de Vilar pelos cronistas Jorge de São Paulo e Francisco de Santa Maria. No entanto o original ainda existe, e atesta a fidedignidade, reportada aos documentos de cartório, do trabalho de Jorge de São Paulo.
} 
converterá em primeira casa e futura sede geral da Congregação será considerada pelo cronista Lóio Francisco de Santa Maria, tal como aconteceu para a de Alga em 1404, ponto fundacional dos Lóios ${ }^{376}$. Algumas diferenças (como por exemplo a igreja ser entregue em benefício a João Vicente e não constituída em colegiada para um grupo de religiosos) implicam uma leitura própria.

O processo de secularização de mosteiros despovoados ou em crise grave, associado ao fenómeno dos comendatários, são bem demonstrativos da crise sentida no mundo monástico dos sécs. XIV e XV e para a qual se dirigiu uma parte importante dos esforços reformistas destes séculos ${ }^{377}$.

$\mathrm{O}$ ato notarial prossegue com a instituição canonical da nova comunidade, composta por um não desprezível conjunto de 17 homens, sete sacerdotes: os venezianos António Correr, Gabriel Condulmer, Estevão Morosini e Francisco Barbo, o paviense Mateus de Strata, o milanês Romano de Rudello e o estiense Luca Fillipi; seis diáconos: os venezianos Marino Quirino, Miguel Condulmer e Lourenço Justiniano, os cremonenses João de Picenardi ${ }^{378}$ e Simão de Persico, o paviense Jerónimo de Mussis; quatro subdiáconos: os venezianos Marcos Condulmer, Domingos Morosini e Ângelo de Ser Donato e o paviense Agostinho de Gastaldi.

A enumeração das presenças ao ato fundacional pode ser descritiva e até parecer fastidiosa, no entanto esta listagem será fulcral para salientar algumas das características mais relevantes da Congregação de Alga, algumas das quais veremos depois replicadas na Congregação dos Lóios.

Diz o Bispo de Kysamos que por sua autoridade, e por espontânea renúncia do prior Luís Barbo, extingue o priorado regular, transferindo-o e criando-o em priorado de cónegos seculares, para quem faz transitar tudo o que em direito pertencia ao agora extinto priorado agostinho, no espiritual como no temporal, e dando aos cónegos posse corporal.

Ao prior Luís Barbo reserva a dignidade de prior com 1/3 dos rendimentos de S. Jorge em Alga. No entanto o título era apenas uma cortesia, Barbo estava afastado da direção da igreja e comunidade, que seria regida por vigário eleito pelos cónegos, com mandato anual, que apesar de não poder usar do título prioral, detinha toda a autoridade de um verdadeiro prior secular ou reitor.

Fazendo uso da faculdade concedida pelo Papa de ordenar estatutos para a comunidade, o bispo Barbarigo determina um conjunto resumido de regras para a vida da comunidade, que o cronista da Congregação precisa em 12 pontos:

1. Que os cónegos tivessem voz em capítulo para eleger vigário, que depois de Barbo deixar a dignidade prioral passaria a ser titularmente prior secular ou reitor.

\footnotetext{
376 «entendeo [João Vicente] que naquele sitio [mosteiro de Vilar de Frades] era o Senhor servido, que a nova Congregação se fundasse, e firme neste pensamento, declarou ao Arcebispo [D. Fernando da Guerra] que aceitava a Igreja, na qual logo foi colado» (cf. SANTA MARIA, 1697: 218). Isabel Castro Pina também o coloca como parte fulcral do processo fundacional (cf. PINA, 2011).

${ }^{377}$ Acerca disto veja-se as considerações gerais em PENCO, 1984: 3 e segs. Acerca da crise da igreja em Portugal veja-se DIAS, 1960; MARQUES, 1987, cap. VIII, acerca da secularização de mosteiros veja-se o caso bracarense descrito em MARQUES, 1988.

${ }^{378}$ Pertencente a uma das famílias nobres de Cremona, com longa tradição no mundo eclesiástico, incluindo diversas prelazias monásticas e episcopais (veja-se TIRABOSCHI, 1815: 63, 64).
} 
2. Que o reitor secular eleito pela maior parte do capítulo comece, sem mais solenidades, a governar e reger por um ano contínuo com cura espiritual e temporal, com todo o poder e autoridade ordinária que têm os priores perpétuos de locais seculares e regulares. Terminado o ano do seu governo que seja absolto do cargo e eleito outro para o seu exercício.

Com estas duas primeiras determinações o prelado garante à comunidade de cónegos do mosteiro de Alga a autoridade para elegerem entre si um superior que os governe. Estabelece a natureza dessa autoridade, que equipara aquela que o direito concedia aos priores perpétuos. De qualquer modo, e desejando certamente evitar possíveis abusos, determina período certo para o exercício do reitorado, um ano. Foi norma estruturante na vida das duas Congregações, a das prelaturas anuais, posteriormente convertidas em trienais ${ }^{379}$.

De notar que o articulado deste texto refere-se sempre ao prelado do mosteiro como "prior secular ou reitor», com a variante «reitor ou prior secular», salientando deste modo que o mosteiro de priorado pudesse ser também convertido em reitorado ${ }^{380}$.

Poderá parecer preciosismo de linguagem, no entanto a precisão dos termos reveste-se de importância. Se o priorado se refere essencialmente a uma dignidade própria do claustro, nascida no seio do mundo regular ${ }^{381}$, ainda que com tradição nas colegiadas seculares ${ }^{382}$, já o reitorado tendeu sempre a ser uma designação da igreja secular, referindo-se à administração delegada no governo de uma igreja sem cura de almas (ou seja, que não é uma igreja paroquial ou de uma casa conventual), de uma instituição (caso dos reitores das Universidades) ou até de eclesiásticos e leigos nomeados para o governo de cidades ou regiões, por exemplo, nos antigos Estados Pontifícios ${ }^{383}$.

\footnotetext{
${ }^{379} \mathrm{~A}$ regra da anualidade das reitorias, estabelecida nesta executória, mantém-se em Alga até 1587, já depois da Congregação ter passado a ser de cónegos regulares, por uma determinação de Pio V que introduz os mandatos trienais (cf. TOMASINI, 1642: 597). Entre os Lóios, segundo Jorge de S. Paulo na sua listagem dos Gerais da Congregação (ADP - Monásticos, Convento de Santo Elói do Porto, lv. do Compêndio do cartório, K/19/6-57), as reitorias passaram a ser trienais a partir de 1612 . Se em Alga parece ter existido alguma rotatividade no exercício dos reitorados (como se poderá facilmente ver por uma leitura da crónica de Tomasini), para os Lóios Isabel Pina salienta o contrário, um exercício de reitorias concentrado em algumas pessoas, que cumpriam com a norma que lhes permitia serem anualmente eleitos até três mandatos sucessivos, podendo voltar a ser eleitos depois de um ano de pausa (cf. PINA, 2011: 225 e segs.).

${ }^{380}$ Para simplificação do texto, e atendendo a esta dupla designação constante de "prior» e «reitor», e atendendo a que o título reitoral será o preferencial no percurso histórico das duas congregações, utilizar-se-á preferencialmente este termo na explicitação do conteúdo das determinações do Bispo de Kysamos.

${ }^{381} \mathrm{O}$ título prioral é por natureza um título associado ao exercício de cargos de superior em comunidades de religiosos. Era utilizado com este sentido já no séc. VI, nomeadamente na Regra de S. Bento onde aparece sete vezes. Foi usada e divulgada pelos cluniacenses, aplicada aos superiores escolhidos pelos abades dos mosteiros para os auxiliar no governo da comunidade (substituindo os termos praepositi e decani). O seu uso manteve-se até hoje entre beneditinos e cistercienses, passando a outras ordens religiosas, como os premonstratenses, cartuxos, dominicanos, agostinhos (daí o seu uso em S. Jorge em Alga, como priorado agostinho), carmelitas e servitas; o seu uso estendeu-se ainda às ordens militares (cf. DONAHUE, 2003).

${ }^{382}$ Cf. RODRIGUES, 2000b.

${ }^{383}$ Do latim regere, reger, o título reitoral é identificado com três usos no Código de Direito Canónico: reitor de igreja, sacerdotes encarregues de igrejas não-paroquiais, não capitulares e nem anexas a casas religiosas, e que sendo escolhido por pessoa ou instituição tem ainda assim de ter confirmação episcopal, estando impedido de celebrar funções reservadas ao ordinário paroquial ou diocesano, ainda que possa celebrar solenemente; reitor de seminário ou colégios de clérigos, em
} 
A Congregação de Alga nasce num priorado secularizado, e o seu superior irá manter o título prioral por um vinténio. Segundo o cronista de Alga, será em 1424 (20 anos depois da executória) que os cónegos decidem, e numa fase em que a expansão da Congregação exigia nova dinâmica organizacional, estabelecer um superior geral, agregado ao governo do mosteiro de S. Jorge de Alga ${ }^{384}$.

No ano seguinte (1425), e poderemos supor que no contexto que determinou a decisão anterior, elege-se o superior que pela primeira vez aparece documentado como reitor de S. Jorge em Alga e geral da Congregação ${ }^{385}$. A assunção desta designação, que será constante entre os Lóios, parece que se pode enquadrar no que será a constituição definitiva da Congregação de S. Jorge em Alga, impondo-se como congregação de clérigos seculares regidos por superiores eleitos entre si $^{386}$, e como tal deve ser encarada como uma afirmação institucional e não um preciosismo de linguagem.

Prosseguindo com as determinações do Bispo Barbarigo:

3. A instituição e destituição dos cónegos é feita pelo reitor e capítulo. Os candidatos devem ter pelo menos 18 anos de idade, estar à experiência por 1 ano contínuo, e aprovados por maioria do capítulo.

4. Os bens e rendimentos são comuns e o seu uso está a arbítrio do reitor.

5. Vive-se vida comum, dormindo em dormitório e comendo em refeitório, só se ausentando os cónegos da comunidade com licença do reitor.

6. Os que se ausentem sem licença ficam a arbítrio do reitor e capítulo para serem punidos ou expulsos.

7. As vestes devem ser as determinadas, nem muito longas nem muito curtas. O número de religiosos deve ser taxado pelas possibilidades.

8. Se algum religioso for descoberto com bens e se não corrigir depois de 3 admoestações, fica a arbítrio do reitor e capítulo para ser privado do canonicato e expulso.

9. Devem congregar-se nas horas canónicas para celebrar o ofício divino conforme o uso da cúria romana.

\footnotetext{
que a função é inerente ao cargo de superior, e que no caso dos seminários, por virtude de isenção da jurisdição ordinária paroquial, permite ao reitor a administração dos sacramentos; reitor de universidade, cuja designação advém do facto de exercerem nas instituições uma função de regência que tradicionalmente era de natureza eclesiástica e delegada. Historicamente podem-se encontrar dois outros usos para além dos previstos na normativa da Igreja: os reitores que exerciam um mandato administrativo e político atribuído pela Santa Sé nos seus territórios, ou (e o que aqui nos interessa) a sua utilização pelos superiores de algumas congregações religiosas, como foi o caso dos Clérigos da Madre de Deus de Lucca (nascida como congregação de clérigos seculares), e das congregações de que este livro se ocupa (cf. MURPHY, 2003b; MEEHAN, 1911). ${ }^{384}$ TOMASINI, 1642: 110.

${ }^{385}$ Luca de Este, designado como reitor no documento que regista a admissão de Bartolomeu de Canalli, e em que é designado como «reitor geral da sociedade de S. Jorge em Alga da diocese de Castelo» (cf. ASV - Fundo Veneto I, doc. 1024). $V d$. igualmente, em anexo, o gráfico 1, em que se elenca os superiores do mosteiro de Alga de 1404 a 1447.

${ }^{386}$ Note-se que o título reitoral foi, em contexto congreganista, assumido particularmente pelas instituições que se afirmavam (pelo menos fundacionalmente) como seculares, caso, por exemplo, dos Clérigos Regulares da Mãe de Deus de Lucca, que foram fundados como congregação de clérigos seculares, sem votos solenes (apenas os tinham simples), e que assim se mantiveram até o Papa Gregório XV os «regularizar», impondo-lhes votos solenes (cf. CARMICHAEL, 1908).
} 
10. Permite-se aceitar laicos a título de dedicados a Deus, conversos ou oblatos, solteiros e com mais de 18 anos, honestos, a quem é atribuído o estatuto de conversos e devem viver sem bens próprios e em comum, sendo recebidos para servir nos trabalhos manuais.

11. Se algum dos habitantes (cónego, conversos, laicos dedicados a Deus, oblatos) for filho da perdição e iniquidade, e sem emenda, fica a arbítrio do reitor e capítulo a expulsão.

12. Que o reitor, com o capítulo, tivessem autoridade plena para fazerem novas constituições, e corrigir, adicionar ou diminuir as existentes, sempre com o objetivo do aumento do culto divino, honestidade clerical, «et pro observatione huiusmodi reformationis institutionis et statutorum $»^{387}$.

Estes dois documentos encerram em si diversos pontos relevantes para a compreensão histórica da Congregação de Alga, e por inerência para a da Congregação de S. João Evangelista. Em primeiro lugar marca a entrega formal do mosteiro que será a pedra angular da Congregação, e que (como vimos) será desde 1424 a sua casa generalícia.

Em segundo lugar, a entrega do mosteiro aos 17 clérigos é o primeiro reconhecimento formal do seu modo de vida, ao qual se dá o formato institucional de colégio de cónegos, clérigos seculares, com obrigação de vida e património comum e de satisfação coletiva em coro das horas canónicas, como fica patente naquela que será a terceira vertente a sublinhar: a de uma primeira estruturação normativa da novel congregação, registada nos doze pontos supra e que definirá as linhas mestras futuras da Congregação italiana e da portuguesa. São, em suma, a definição inicial e institucionalização de um carisma.

Note-se ainda um pequeno ponto revelador dos objetivos dos fundadores de Alga em constituir uma congregação autónoma, e como para tal concorreu a sua rede de apoios: o Papa Bonifácio, na sua letra apostólica, concede ao Bispo de Kysamos a faculdade de ordenar estatutos pelos quais a nova comunidade se reja, o que como vimos foi levado a cabo, indicando que futuramente estes poderiam ser feitos pelo prelado diocesano, o Bispo de Castelo, com o cabido de S. Jorge em Alga. Ora, como se pode ver no ponto 12 (e último) das determinações do Bispo de Kysamos, verifica-se que o prelado executor concentra toda a faculdade futura em matéria normativa nos religiosos do mosteiro, excluindo o ordinário diocesano.

Primo de dois dos fundadores (António Correr e Gabriel Condulmer) e sobrinho do homem que com toda a probabilidade obteve do Papa a letra apostólica (o patriarca Ângelo Correr), Ângelo Barbarigo parece favorecer a autonomia futura dos clérigos de S. Jorge em Alga. A sua proximidade a este universo familiar será, 4 anos depois, demonstrada pela sua criação cardinalícia pelo tio Ângelo Correr, então já Papa Gregório XII, no segundo consistório para criação de cardeais que este Papa reuniu em setembro de $1408^{388}$.

\footnotetext{
${ }^{387}$ TOMASINI, 1642: 36.
}

${ }^{388}$ GUALDO, 1964a. 
Isabel Pina aventa a hipótese ${ }^{389}$, não sendo possível conhecer ao certo o memorial e constituições que Afonso Nogueira (um dos Lóios fundadores) obteve dos Cónegos de Alga em 1427 para a sua congregação, de a sua natureza não estar longe do plasmado no capítulo II dos Estatutos e Constituições Lóios ${ }^{390}$.

A comparação do capítulo com o texto transcrito por Tomasini e com as confirmações de Gregório XII e Eugénio IV impressas no Livro dos Privilégios (que as identifica como confirmação da primeira regra da Congregação de Alga), permite concluir pela validade dessa hipótese, ainda mais se considerarmos que a 16 de junho de $1470^{391}$ se pedia em Roma a transcrição destes atos, reconhecendo-se o seu interesse e validade, tanto no domínio institucional e memorialístico das Congregações (como ata fundacional e identitária de Alga), como certamente no domínio de uma normativa estrutural que se mantinha essencialmente inalterada. Saliente-se ainda que, em 1594, os dois atos de 1404 serão os documentos escolhidos para abrir o Livro dos Privilégios que os Lóios fazem imprimir, como já em 1540 tinham sido fonte para o capítulo II dos Estatutos.

A renúncia que Luís Barbo faz deste mosteiro ${ }^{392}$ de que era comendatário desde 1397, marca um ponto de inflexão na vida deste eclesiástico e dos 17 clérigos a quem o entregou, cujos caminhos, que certamente se terão cruzado anteriormente (ou não fosse o núcleo central oriundo do patriciado urbano veneziano), ir-se-ão em definitivo cruzar nas décadas seguintes, de Veneza até ao trono de São Pedro.

\section{Luís Barbo, o Priorado de Alga e a Congregação canonical}

A figura de Luís Barbo, célebre como prelado monástico e diocesano de cariz reformador, tem sido alvo de diversos estudos ${ }^{393}$ que salientam as diversas fases e facetas do seu percurso, incluindo as que mais nos interessam e ocupam, que são as que se situam entre 1397 e 1404 enquanto prior do mosteiro de Alga, e as suas relações com os cónegos de Alga para além deste horizonte cronológico.

O seu percurso parece feito das mesmas angústias e dos mesmos anseios com que se fez o percurso dos fundadores da congregação de Alga e, a cerca de 2 milhares de quilómetros, o percurso dos fundadores Lóios.

\footnotetext{
${ }^{389}$ PINA, 2011: 116.

${ }^{390}$ Statutos e Constituyções dos virtuosos e reverendos padres Conegos azuys..., 1540. Acerca desta edição veja-se o que diz o Rei Dom Manuel II no $2 .^{\circ}$ volume do seu Livros Antigos Portuguezes, que abre precisamente com este impresso (cf. MANUEL II, 1932: 3 e segs.).

${ }^{391}$ Será desta transcrição que se faz a impressão no bulário dos Lóios (cf. Livro dos Privilegios concedidos pellos Summos Pontifices..., 1594).

${ }^{392}$ É certo que a plena renúncia de Luís Barbo será posterior, com toda a probabilidade de 1409, quando é nomeado Abade de S. Justina de Pádua por Gregório XII, o que implicou a sua renúncia ao priorado titular e rendimento anexo que os atos de 1404 lhe asseguravam, e permitindo a eleição de Lourenço Justiniano como primeiro prior eleito dos cónegos e congregação de S. Jorge em Alga (cf. TOMASINI, 1642: 77 e segs.); no entanto os atos de 1404, como ficou visto no seu articulado, marcam em definitivo a entrega do mosteiro aos 17 religiosos que são constituídos como cabido e comunidade, com posse e poderes decisórios.

${ }^{393}$ TASSI, 1952; PRATESI, 1964; as diversas participações em TROLESE, 1984a.
} 
Filho de Marco Barbo, nobre veneziano, Luís Barbo era em 1397 um jovem clérigo da diocese de Castelo $^{394}$, com cerca de 16 anos de idade ${ }^{395}$. A 15 de março desse ano o Papa Bonifácio IX concedia-lhe, certamente em resposta a uma súplica, o priorado do mosteiro Agostinho de S. Jorge em Alga de Veneza.

As letras apostólicas, além de suprirem o defeito de idade, declaram claramente que o priorado de Alga, ainda que tivesse religiosos não professos, carecia de prior e vida regular. Afirmam que o jovem Barbo, e os demais religiosos, teriam demonstrado desejo de professar na vida canonical dos Agostinhos, o que no entanto se coloca ao seu arbítrio «si eam sponte emittere vellet» ${ }^{396}$; o pontífice tem o cuidado, no entanto, de declarar que devia ser tido como expressamente professo na ordem dos cónegos Agostinhos, para poder tomar posse do priorado e sem embargo de poder ser colado em outros benefícios.

Tassi lê, no desejo manifestado por Barbo, uma fórmula institucional para justificar formalmente a concessão de um priorado agostinho a um elemento externo à Ordem, o que deduz do facto da executória não mencionar em ponto algum a profissão de votos ${ }^{397}$.

Se o jovem Barbo não desejaria professar nos Agostinhos, a concessão deste priorado despovoado deve-se certamente ao movimento natural das elites de garantir à sua prole destinada à carreira eclesiástica benefícios que lhe garantissem influência e bem-estar material ${ }^{398}$. Os 2000 florins de ouro de rendimento e o título prioral, mencionados nas letras apostólicas, eram o primeiro degrau que os Barbo garantiam a este jovem clérigo ${ }^{399}$.

As lógicas comendatárias eram então bem comuns, ainda que os seus efeitos se fizessem sentir nefastamente na vida da Igreja e começassem a gerar reações ${ }^{400}$.

\footnotetext{
${ }^{394}$ A diocese de Castelo, do séc. VIII, era a circunscrição eclesiástica diocesana da cidade de Veneza. Dependia eclesiasticamente do Patriarcado de Grado (sucessor do Patriarca de Aquileia que já no séc. VI tinha jurisdição sobre esta região), e tinha a sua sede na basílica de S. Pedro de Castelo. Na Veneza dos sécs. XIV e XV o bispo diocesano não era no entanto a única autoridade eclesiástica com autoridade na cidade e diocese. Além dele viviam e tinham as suas igrejas em Veneza o próprio Patriarca de Grado, que se retirara da sua cidade e instalara a sua sede na igreja veneziana de S. Silvestre, o Patriarca Latino de Constantinopla, título criado na sequência da IV cruzada (1204), reservado aos venezianos e cuja sede estava na cidade lagunar desde o fim do Império Latino de Constantinopla e o Primicério da Basílica de S. Marcos, o primeiro cónego do cabido desta igreja que servia de capela ducal de Veneza e era considerada em tudo isenta da jurisdição eclesiástica, só dependendo do Doge (o que explica que só aquando da supressão da República de Veneza é que se extinga esta estrutura eclesiástica e a Basílica de S. Marcos, como igreja principal de Veneza, possa tornar-se a catedral da cidade, que até então era S. Pedro de Castelo). Esta multiplicação de autoridades prelatícias na cidade não só aumentava o dinamismo eclesiástico da mesma, como também criava problemas jurisdicionais na mesma medida (cf. RANDO, 1992; CRACCO, 1997 para as questões da relação entre a Igreja e o Dogado, nomeadamente no que se refere à Basílica de S. Marcos; RIGON, 1997).

${ }^{395}$ Assim o identifica a Letra Apostólica de Bonifácio IX, datada de Roma nos idos (15) de março de 1397, inserida no ato executório levado a cabo pelo prior de St. a Maria dos Cruciferários a 2 de abril do mesmo ano (cf. ASV - Fundo Veneto I, doc. 951.

${ }^{396}$ Idem, ibidem.

397 TASSI, 1952: 17.

${ }^{398} \mathrm{Na}$ mesma linha de interpretação vai, além de Tassi, TRAMONTIN, 1984: 95.

${ }^{399}$ Assim também o afirma PRATESI, 1964.

${ }^{400}$ Nas palavras de Penco: «Rimane, ad ogni modo, il fatto che, insieme con l'isolamento, la comenda constituì il grande nemico contro cui si impegnò a combattere il movimento riformistico del tempo» (PENCO, 1984: 16).
} 
Luís Barbo não teria então, certamente pela jovem idade e integração nas lógicas tradicionais próprias da sua classe, grandes preocupações de natureza espiritual ou reformadora. Como Tramon-

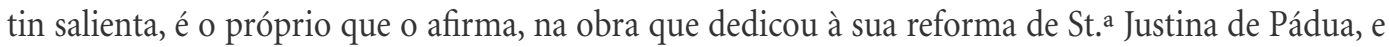
em que diz que a sua conversão de vida teve lugar a partir de 1403, com o contacto mais estreito com o núcleo de clérigos fundadores da Congregação de Alga ${ }^{401}$. Deste contacto de Luís Barbo com os cónegos de Alga (de que fazia parte o seu irmão Francisco Barbo) veio-lhe também toda a sua carreira eclesiástica como abade, bispo e legado papa ${ }^{402}$.

Luís Barbo é testemunho vivo do papel reformista da Congregação de S. Jorge em Alga, ao reconhecer neste grupo, então em processo fundacional, um substrato espiritual e material que o inspirou a desenvolver um pensamento e ação marcada e reconhecidamente reformistas, fulcral na reforma da ordem beneditina (a partir da abadia de St. ${ }^{a}$ Justina de Pádua e da congregação que dela se formou ${ }^{403}$ ), bem como da diocese de Treviso que Barbo dirigiu como bispo diocesano ${ }^{404}$.

Não se conhece muito o percurso do jovem prior entre 1397 e 1404, pensa-se que terá permanecido na residência familiar onde continuou estudos humanísticos, antes de cursar direito canónico em Pádua ou Bolonha ${ }^{405}$. Não se sabe igualmente como e quando entrou em contacto com o grupo fundacional dos cónegos de Alga, sobre cuja origem e desenvolvimento anterior à concessão de Bonifácio IX de 1404, e da sequente executória de Ângelo Barbarigo, existem dúvidas e o testemunho único do cronista Tomasini.

\section{Fundação e Fundadores da Congregação de Alga}

Os diversos autores que trataram a Congregação, com o seu cronista à cabeça, tenderam tradicionalmente a acentuar o papel das três figuras que nas décadas seguintes aos anos fundacionais, e já fora dos claustros de Alga, mais se destacaram: Gabriel Condulmer, que se sentou no trono de S. Pedro como Eugénio IV; o seu primo Cardeal António Correr, bispo de Bolonha, e Lourenço Justiniano, protopatriarca de Veneza e santo da Igreja ${ }^{406}$.

Tomasini atribui toda a responsabilidade fundacional aos primos Correr e Condulmer, a quem se juntariam num grupo inicial Estevão Morosini, Marino Quirino, Mateus de Strata, Lucas e Filipe de Este, João de Picenardi e Francisco Barbo (o já mencionado irmão de Luís Barbo). Reconhecem-se

\footnotetext{
${ }^{401}$ Idem, ibidem: 95, 96.

${ }^{402}$ Nesta linha o afirma Tassi, quando inicia o livro que lhe dedica a dizendo que para perceber ideia da reforma de St. ${ }^{\text {a Jus- }}$ tina de Pádua que Luís Barbo empreende como abade, obriga antes de mais a pensar S. Jorge em Alga e a sua congregação. Menciona também toda a relação que Barbo manterá com membros da congregação de Alga, incluindo com o papa Eugénio IV, que muito o favorecerá (TASSI, 1952: 13 e segs.).

${ }^{403}$ TROLESE, 1984b.

${ }^{404}$ PESCE, 1984.

${ }^{405}$ PRATESI, 1964.

${ }^{406}$ Caso de TASSI, 1952: 13 e segs; TRAMONTIN, 1975: col. 154 e 155, tendo o cuidado de associar o nome de Marino Quirino, que irá ainda salientar mais em TRAMONTIN, 1984: 97. Já o cronista dos Lóios Francisco de Santa Maria menciona 3 fundadores principais, os primos Correr e Condulmer, a que acrescenta o seu tio o Patriarca Ângelo Correr (cf. SANTA MARIA, 1697: cap. IX e seguintes do livro único).
} 
os nomes dos atos de 1404, mas desconhece-se o papel de cada um, para além do que a crónica nos revela.

Apesar de parecer óbvio que a valorização do papel desempenhado pelos primos Correr e Condulmer poder dever-se à sua projeção futura mais do que ao efetivo papel desempenhado nos primeiros anos da Congregação de Alga, os dados que a crónica e a documentação sobrevivente aduzem parecem concordar com esta versão.

Se tomarmos por verdadeiro o testemunho de Tomasini, os dois primos Correr e Condulmer lideraram, possivelmente a par com Marino Quirino, o grupo fundador da Congregação de S. Jorge em Alga, num processo que parece ter seguido um figurino estrutural que se encontrará replicado nos passos fundacionais dos Lóios.

Jovens clérigos seculares, oriundos essencialmente do patriciado, entre os quais se pode encontrar formação universitária ${ }^{407}$, integrados numa Igreja que se encontrava em pleno processo cismático, traduzindo uma Europa em crise, constroem uma solução de vida comunitária nova, acreditando replicar o modo de vida dos primeiros entre todos os cristãos, os Apóstolos ${ }^{408}$.

O estado da Igreja, e do seu clero, era então uma preocupação dominante, a que se associava a consciência da necessidade de superar a crise cismática e empreender a reforma geral. Enquanto em janeiro de 1394 a Universidade de Paris, a pedido da Coroa francesa, debatia quais as soluções para a resolução institucional do cisma ${ }^{409}$, pelos mesmos anos (segundo Tassi, que situa os inícios da Congregação por volta de 1395 , na tradição de Tomasini ${ }^{410}$ ) na laguna veneziana um conjunto de jovens sente o anseio de uma vida religiosa mais perfeita, através da qual anteveem a possibilidade de reforma da Igreja.

O ponto inicial estará, como nos Lóios de 1420, nos encontros destes jovens, oriundos da mesma classe e frequentadores dos mesmos círculos ${ }^{411}$, participantes do mesmo anseio de uma vivência espiritual mais forte, um caminho mais perfeito para a santificação pessoal e coletiva «Il loro ideale era di stabilirsi in un luogo appartato per vivere in comune presso una chiesa, secondo un serio programma di santità ecclesiastica $»^{412}$.

A crónica de Alga salienta bem, no impulso inicial que reúne os primos, e estes aos seus companheiros da primeira hora da Congregação, o papel dicotómico entre um mundo que se considera

\footnotetext{
${ }^{407}$ Entre aqueles cujo percurso se conhece melhor, Antonio Correr e Gabriel Condulmer, sabe-se serem formados em Pádua. (Veja-se TASSI, 1952: 14; SARTORELLI, 1988; PAPADOPOLI, 1726).

${ }^{408}$ Como se pode ler na proto crónica lóia, do P.e. Paulo de Portalegre, «a nossa vida e modo de viver traz o seu inicio e fundamento da vida dos apóstolos d'u trazem fundamento todos os bons e religiosos stados» (cf. PORTALEGRE, 2007: 67). Acerca desta questão $v d$. melhor ponto 2.5. da tese.

${ }^{409}$ KAMINSKY, 2000: 686 e segs.

${ }^{410}$ TASSI, 1952: 16.

${ }^{411}$ «Il grupo era costituito la maggior parte da persone provenienti da famiglie di alta posizione sociale, alcuni provvisti di benefici ecclesiastici, e tutti iniziati alla vita ecclesiastica» (TASSI,1952: 13); "questo gruppo primitivo restava infatti in una cerchia limitatissima di famiglie veneziane, e erano vari membri delle stesse famiglie, ai quali si accompagnarono pure alcuni forestieri, cioè provenienti da altri stati fuori del domínio veneto» (Idem, ibidem: 15).

${ }^{412}$ Idem, ibidem: 13.
} 
decadente e licencioso, inimigo das virtudes cristãs, e um afastamento do mundo que permitirá a aproximação a Deus e a prática facilitada das virtudes ${ }^{413}$.

Entre os debates e reflexões de cariz espiritual, cuja natureza certa se desconhece, podemos supor com algum grau de certeza que, além da reflexão sobre a crise moral da Igreja e sociedade do seu tempo, terão estes jovens fundadores introduzido o topos tradicional dos reformistas: a procura de um ideal de vida cristão que, inevitavelmente, se identifica com um retorno ao modo de vida das primeiras comunidades cristãs, a vera vita apostolica ${ }^{414}$.

Este debate, que se tornará um elemento carismático e identitário a partir do momento em que os Cónegos de Alga, e depois deles os Lóios, assumem viverem num espírito comunitário diretamente alicerçado no modo de vida dos apóstolos, aponta e enquadra-se no conceito de ideia de reforma que Ladner definiu.

A formação do que acreditam ser um novo modo de vida comunitária ${ }^{415}$ acerca-se do conceito de esforços «livres e intencionais», que resultarão de um processo que os fundadores empreendem coletivamente e na sequência de uma reflexão que, poderemos supor com propriedade, se centrará simultaneamente no processo de conversão individual e da natural consequência de uma melhoria generalizada na condição espiritual e moral da Igreja.

Reportando-se a um conceito matricial do cristianismo primitivo, que se acredita ser um tempo carismaticamente mais verdadeiro pela proximidade temporal ao mistério central do Cristianismo, que é a Encarnação, encontramos a reafirmação e aumento (pela nova forma de vida religiosa) dos «valores pré-existentes no composto espiritual-material do mundo».

O sucesso fundacional, a construção gradativa da congregação ao longo do séc. XV ${ }^{416}$, o empenho de diversos dos seus religiosos não só na construção da sua congregação, mas também na transposição do seu carisma para a sociedade, através do exemplo de vida e do digno desempenho de funções eclesiásticas e pastorais ${ }^{417}$, completam o enquadramento do movimento de Alga na ideia

\footnotetext{
413 TOMASINI, 1642: 4 e segs.

${ }^{414}$ Esta ideia do cristianismo do período apostólico e dos primeiros séculos (nomeadamente no que se refere à influência do pensamento dos Padres da Igreja) é um eixo estrutural do pensamento reformista cristão. Pode-se encontrar, e apenas como exemplos, no pensamento do Papa Gregório VII e da sua reforma (cf. GRANT, 2012: 61 e segs.), no pensamento dos hussitas presentes no Concílio de Basileia em 1433, ao apresentarem os quatro artigos que condensam o seu pensamento reformista e que dizem estarem de acordo com a Igreja primitiva (cf. CHRISTIANSON, 2012: 124 e segs.), ou como fundamento carismático apresentado pelos cónegos agostinhos Premonstratenses nos concílios quatrocentistas (cf. HYLAND, 2012 : 170 e segs.). Vauchez salienta o papel que este conceito assumirá no Ocidente medieval dos séculos XI a XIII, nomeadamente quando o sistema monástico pré-existente se revela incapaz de responder às demandas da sociedade (cf. VAUCHEZ, 1985: 65 e segs.).

${ }^{415}$ Como veremos no ponto 2.5., existe novidade na estrutura institucional dos cónegos de Alga, que introduzem a ideia de congregação de clérigos seculares, que depois terá desenvolvimentos, no período tridentino, com congregações da mesma natureza e na variante de congregações de clérigos regulares.

${ }^{416}$ Patente nas diversas fundações de novas casas (quadro anexo n. ${ }^{\circ}$ 2), pelos privilégios obtidos da Santa Sé (quadro anexo n. ${ }^{\circ}$ ) e pelo facto de se assumir como um importante alfobre de prelados e pontífices.

${ }^{417}$ Aqui notem-se, como veremos, as concordes opiniões da exemplaridade de vida de Eugénio IV, António Correr, Lourenço Justiniano e Maffeo Contarini, bem como as diversas iniciativas de carácter reformista que estes prelados levarão a cabo nos seus governos.
} 
de reforma de Ladner, ao apresentarem um processo de fundação e de crescimento institucional com os «sempre aperfeiçoáveis, múltiplos, prolongados, sempre repetidos esforços», que se podem encontrar num movimento coletivo que consegue, através de um processo dinâmico e gradativo, institucionalizar um novo modo de vida e através dele atuar na Igreja e na sociedade em que insere.

Tomasini colocou no ano de 1400 a data inicial do movimento que viria a ser a Congregação de $\mathrm{Alga}^{418}$. Ainda que a viragem de século seja data demasiado perfeita, até porque coincidiu com Ano Santo $^{419}$, o certo é que os autores situam as suas origens no período que medeia entre 1395 e 1402, como Tramontin mais recentemente precisou ${ }^{420}$.

Sabe-se que o grupo seria composto por clérigos de pouca idade. António Correr seria dos mais velhos, nascido provavelmente em $1369^{421}$, contaria na viragem do século 31 anos de idade. Seu primo Gabriel Condulmer era substancialmente mais novo, nascido entre 1381 e $1383^{422}$, e como tal com uma idade entre os 17 e 19 anos em 1400. Em matéria de carreira eclesiástica percebe-se esta juventude, mas em simultâneo o compromisso com o estado eclesiástico, pois como visto na executória de 1404, o grupo fundacional era composto por clérigos nos três estádios das ordens sacras.

Tomasini e a sua crónica defendem que a Congregação de Alga começa com os primos Correr e Condulmer a decidirem retirar-se do mundo, com o objetivo de dedicarem-se a uma vida espiritualmente estruturada em torno da oração e do estudo divino, sem as distrações e os perigos morais que uma vida no século acarretaria ${ }^{423}$.

Menciona como primeiras adesões as de Estevão Morosini e de Marino Quirino. Aqui alguns historiadores que trataram dos fundadores de Alga chamam a atenção para a figura de Quirino, nascido de nobre família veneziana, tendo por irmã Querina, mãe de Lourenço Justiniano, que viria a juntar-se a seu tio na Congregação ${ }^{424}$.

\footnotetext{
418 TOMASINI, 1642: 2.

${ }^{419}$ Como destaca Mons. Sartorelli (SARTORELLI, 1988).

${ }^{420}$ «Non si sa con essateza neppure l'anno della sua costituzione: si va infatti dalla fine del'300 al 1404, passando per quasi tutti gli anni intermedi: dal 1395 circa proposto dal Tassi al 1402 ritenuto più probabile dal Cracco che valuta soprattutto la giovanissima età dei primi aderenti» (TRAMONTIN, 1984: 91). Monsenhor Sartorelli (SARTORELLI, 1988) chama a atenção para o facto de numa procuração datada de novembro de 1401, passada a António Correr para administração do priorado de St. ${ }^{\circ}$ Agostinho de Vicenza, Gabriel Condulmer dar como morada a sua residência paterna no quarteirão de S. Leonardo de Veneza, demonstrando que nesta data os dois primos ainda não residiriam em comunidade no mosteiro de Alga. ${ }^{421}$ François-Charles Uginet (UGINET, 1983), diz que teria nascido a 14 de janeiro de 1369, o que segundo Sartorelli (SARTORELLI, 1988), seria baseado na informação prestada pelo sobrinho protonotário Gregório Correr, depois IV Patriarca de Veneza, que sobre o tio escreveu De vita et obitu beatae memoriae Antonii episcopi Ostiensis soliloquium ad Deum (cf. PRETO, 1983).

4221383 diz Denys Hay (HAY, 2000), seguindo a versão mais tradicional; já Sartorelli inclina-se para data anterior a este ano, por já ser presbítero em 1404, e tendo em consideração que o Concílio de Viena precisara anteriormente os 25 anos como idade mínima para a ordenação sacerdotal, e não querendo acreditar na existência de uma dispensa para ordenação, que sempre é uma hipótese válida para quem já em 1400 era cónego de Verona (cf. SARTORELLI, 1988).

${ }^{423}$ TOMASINI, 1642: 4 e segs.

${ }^{424}$ Conforme expressa o seu biógrafo Guiseppe del Torre (DEL TORRE, 2007). No entanto o seu primeiro biógrafo, o sobrinho Bernardo Justiniano, declara que Marino Quirino seria primo, e não irmão, de sua mãe Querina Quirino (cf. JUSTINIANO, 1628: cap. I).
} 
Tramontin ${ }^{425}$, depois de salientar que há quem atribua o papel principal da fundação aos primos Correr e Condulmer (Tassi) ou particularmente a Gabriel Condulmer $\left(\operatorname{Cracco}^{426}\right)$, opina que deveria atentar-se em Marino Quirino, salientando um importante dado documental que vai para além das considerações de Tomasini na sua crónica: o facto da executória de 1404 mencionar destacadamente o nome de Quirino, ainda que nessa data fosse apenas ordenado de diácono.

O bispo Barbarigo, ao referir-se pela primeira vez aos clérigos que irão constituir o capítulo canonical de S. Jorge de Alga, fá-lo dizendo «Qua propter scientes venerabilis viros Marinum Quirino et socios eius Clericos seculares, qui ad praesens trahunt moram in supradicto monasterio [...]» ${ }^{427}$. E mesmo Tassi, ainda que sustente o papel fundacional dos primos Correr e Condulmer, não deixa de salientar Marino Quirino, destacando-o e chamando a atenção para a importância de o ter em consideração $^{428}$.

A conclusão é simples: entre a escassez de fontes, a crónica institucional do bispo Tomasini e os trabalhos que sobre Alga foram sendo produzidos (particularmente os de Tassi, Cracco e Tramontin), não é possível conhecer as datas fundacionais senão num intervalo de tempo que vai de 1395 a 1403 (data em que Barbo diz ter iniciado a sua conversão de vida pela relação com a comunidade que foi viver no seu mosteiro de Alga).

O mesmo nível de dúvida paira sobre o fundador ou fundadores: António Correr, Gabriel Condulmer, Marino Quirino, um ou mais, senão mesmo todos, quem são os verdadeiros fundadores do movimento dos cónegos seculares de S. Jorge em Alga?

A verdade é que, tal como acontecerá nos Lóios em relação à identificação e real papel dos fundadores e datas certas de início da vida comunitária, existem mais dúvidas do que certezas entre os investigadores, que se veem na contingência de circunscreverem-se às informações contidas nas crónicas, e ao pouco que se pode obter da documentação.

As informações contidas nos atos emanados das chancelarias episcopais, e que pela primeira vez nos dão uma certeza acerca da cedência de igrejas secularizadas que se converterão em primeira casa das novas congregações, serão as informações mais seguras, e estabelecem-se como terminus ad quem fundacionais. Assim as já citadas executória de 1404, para S. Jorge em Alga, e a carta de secularização e

\footnotetext{
${ }^{425}$ TRAMONTIN, 1984: 91, nota de rodapé n. ${ }^{\circ} 1$.

${ }^{426}$ Notavelmente o primeiro cronista dos Lóios, padre Paulo de Portalegre, atribuía já em 1468-69, o papel central na fundação da congregação de S. Jorge em Alga a Gabriel Condulmer (cf. PORTALEGRE 2007: 69 e segs.). Este será um caso, apesar da proximidade aos tempos fundacionais, em que se percebe que o destaque futuro de Condulmer poderá ter atuado como veículo de projecção a posteriori em relação ao seu real relevo em eventos anteriores à sua promoção ao cardinalato e ao papado. Note-se neste caso que tal se poderá considerar pela influência das relações de Gabriel Condulmer com o fundador lóio João Vicente, e de como este influenciará a visão de Paulo Portalegre, como o mesmo admite ao mencionar as longas conversas que este prelado mantinha com ele enquanto jovem cónego (cf. Idem, ibidem: 82, 83).

${ }^{427}$ TOMASINI, 1642: 26; Livro dos Privilegios concedidos pellos Summos Pontifices..., 1594.

${ }^{428}$ «In questo gruppo [dos fundadores] una figura rimasta nell'ombra, ma che sembra da pori in linea più avanzata, è marino Quirini, lo zio materno di S. Lorenzo Giustinian. Anche nell'esecutoriale del vescovo di Kisamos Marino era il capogruppo. Nel De initiis il Barbo riporta le difficoltà da lui frapposte alla sua accettazione di S. Giustina, ed erano parole di una persona grave ed anche attempata. Nella biografia di S. Lorenzo Giustinian egli appare un autentico maestro di vita spirituale» (cf. TASSI, 1952: 16).
} 
concessão de 1425 para o mosteiro de S. Salvador de Vilar de Frades, emitidas pelo bispo de Kysamos e pelo arcebispo de Braga, são os primeiros documentos verdadeiramente relevantes para atestar o início efetivo e sustentado das vidas em comunidade.

As notícias que as crónicas dão acerca de experiências anteriores vividas em comunidade demonstram a natureza construtiva e evolutiva da formação das congregações a partir de grupos informais de clérigos que se dedicavam coletivamente à meditação espiritual e aspiravam a uma vida comunitária mais perfeita.

No caso veneziano a crónica fala de uma possível primeira experiência no mosteiro beneditino de S. Nicolau do Lido ${ }^{429}$, então privado de vida regular em consequência dos danos provocados pela guerra de Chioggia e para onde se teriam retirado os futuros cónegos em busca do afastamento do mundo que não teriam no primeiro local de agrupamento: a residência de Ângelo Correr, patriarca Latino de Jerusalém, tio de António Correr e Gabriel Condulmer ${ }^{430}$.

No caso português, e como veremos, as tentativas de vida comum anteriores ao assentamento inicial em Vilar de Frades terão passado pela igreja dos Olivais em Lisboa e pela de St. ${ }^{a}$ Maria de Campanhã no Porto, localizadas em áreas periurbanas das duas cidades, sobressaindo a partilha de características iniciais com o movimento de Alga: o isolamento comunitário em espaço próximo, mas independente, de aglomerado urbano ${ }^{431}$.

Estas primeiras experiências que conduzirão ao nascimento da Congregação de Alga levam-nos a atentar no papel desempenhado pelas relações familiares, já que cronistas e historiadores não deixaram de salientar laços de parentesco entre alguns dos fundadores.

O caso de Marino Quirino e de Lourenço Justiniano foi já mencionado, e a influência do tio no sobrinho, que decide juntar-se à comunidade nascente, parece bastante óbvia. O papel de Justiniano como prelado da Congregação e prelado diocesano, e o seu papel na construção de um determinado pensamento espiritual, patente nas suas numerosas obras, dão-nos uma visão rápida da importância destas ligações familiares.

A relação de Ângelo Correr com António Correr, Gabriel Condulmer e Ângelo Barbarigo, todos eles participantes, de uma forma ou outra, nos primeiros anos de vida da Congregação e determinantes para a institucionalização da Congregação, com a concessão de privilégios e bens materiais, obriga a um olhar mais aprofundado.

\footnotetext{
${ }^{429}$ Como se pode verificar em SARTORELLI, 1988, o mosteiro beneditino de S. Nicolau do Lido ficava numa zona então afastada da cidade, cujas características se adaptariam de tal modo a uma procura de vida espiritualizada e afastada do mundo que tinha sido escolhida para a instalação de uma Cartuxa, a cartuxa de St. ${ }^{\circ}$ André do Lido (cf. CORNELIO, 1749: 137 e segs.).

${ }^{430}$ TOMASINI, 1642: 13 e segs., 70 e segs.

${ }^{431}$ Acerca desta questão veja-se o que dizem os cronistas Lóios: PORTALEGRE, 2007: 88 e segs.; S. Paulo, 1967-1968: Epílogo e Compêndio (ADB - Manuscrito, n. ${ }^{9}$ 924, fl. 138 e segs.; SANTA MARIA, 1697: 209 e segs.).
} 


\title{
2.2. LINHAGEM E CONGREGAÇÃO: O PAPEL DA FAMÍLIA NO NASCIMENTO E CONSOLIDAÇÃO DA CONGREGAÇÃO DE ALGA
}

\begin{abstract}
Il successo dei celestini ${ }^{432}$ deve molto al fatto che essi riuscirono, fin dal 1406, a portare le loro istanze di riforma fino ai massimi vertici della Chiesa, soprattutto grazie all'elezione pontificia di uno dei loro fondatori, Angelo Correr, divenuto papa nel 1406 con il nome di Gregorio XII. Egli portò con sé a Roma Antonio Correr e Gabriele Condulmer, suoi nipoti ben presto creati cardinali, dando così inizio a una «dinastia» di papi veneziani che continuò con l'ascesa al soglio pontificio del Condulmer e giunse a compimento nel 1464 con il papato del nipote di quest'ultimo, Pietro Barbo (Paolo II) ${ }^{433}$.
\end{abstract}

É reconhecido o papel da família, e do conceito de linhagem, nas elites europeias tardo-medievais e modernas. Numa época em que o nascimento era frequentemente o ponto de entrada e o justificativo de pertença ao mundo da nobreza, e num estado como o Veneziano em que o exercício do poder era dominado pelo patriciado, que de entre si elegia o seu governante primus inter pares, o Doge, a linhagem era um forte elemento identitário ${ }^{434}$.

A pertença ao patriciado veneziano tornou-se ainda mais relevante durante o séc. XIV e XV, na sequência do processo de encerramento (serrata) do Conselho Maior da Sereníssima à aristocracia mais recente e que, apesar de não ter um efeito absoluto, definiu os limites da aristocracia veneziana e do seu poder. Foi um processo cujos reais efeitos e perenidade de alcance a investigação tem vindo a mitigar, sugerindo ser mais um mito historiográfico do que como um real processo histórico, ainda que com efeitos no que se refere ao reforço da aristocracia veneziana governante ${ }^{435}$.

Apesar da importância do poder patriarcal no seio da elite patrícia de Veneza, o lugar das mulheres, ainda que secundário nas lógicas das linhagens e do poder, ganha relevo ao longo do séc. XIV, quando no esquema de enclausuramento do patriciado a linhagem feminina assume uma proeminência quase paralela à da ascendência masculina, graças à preocupação de garantir boas alianças matrimoniais, e à possibilidade das mulheres nobres gerirem o destino de parte dos seus bens dotais ${ }^{436}$.

Associando estas alterações ao papel da mulher enquanto educadora dos filhos, e como tal com espaço para influenciar a sua descendência varonil para não se ater exclusivamente à tradição patrilinear

\footnotetext{
${ }^{432}$ Do mesmo modo que os Lóios foram chamados de Azuis pela cor do hábito, os Cónegos de Alga foram designados por Celestinos (de azul celeste).

${ }^{433}$ Guiseppe del Torre (DEL TORRE, 2007), na biografia que escreve de Lourenço Justiniano, descreve deste modo a relação entre a Congregação de Alga e a linhagem papal dos Correr, Condulmer e Barbo.

${ }_{434}$ «In merito al ceto nobile è stato chiarito che nel secolo XIV i vincoli familiari erano di duplice natura: da un canto si riferivano alla famiglia mononucleare, composta dai genitori e dai figli, a volte estesa anche ai fratelli celibi dei genitori, dall'altro alla cosiddetta "ca'», il gruppo consanguineo — cioè — che riconosceva di discendere da un capostipite comune e portava lo stesso cognome. Un'articolazione, questa, che era poi ulteriormente arricchita da una terza componente, quella del «ramo» familiare al quale facevano capo, all'interno della stessa ca', più famiglie mononucleari. Nella sua triplice accezione la famiglia costituiva l'ordinamento di base che tutelava i cittadini e, di conseguenza, stabiliva per loro diritti e doveri; e i vincoli di solidarietà legavano i nobili in tutti e tre i gradi familiari» (cf. CARAVALE, 1997).

435 «tra il tardo Trecento e il primo Quattrocento una seconda ondata legislativa riformula in modo più preciso e lungimirante la definizione istituzionale della nobiltà» (cf. CHOJNACKI, 1997).

${ }^{436}$ CHOJNACKI, 2002.
} 
da aristocracia veneziana, tornou-se possível que, através da influência materna, os patrícios gerassem relações de apoio e proximidade com as suas linhagens maternas. Como Chojnacki fez notar, estas relações consubstanciaram-se frequentemente na relação dos jovens patrícios com os tios maternos que favoreceram o alargamento e aprofundamento das linhas de apoio aos jovens patrícios na vida pública ${ }^{437}$.

Esta tendência, estudada sobretudo no que se refere a relações de género e política de alianças matrimoniais, pode-se também verificar nos casos em que os jovens patrícios não são votados ao serviço público da Sereníssima, mas ao estado clerical.

Uma rápida leitura da genealogia da dinastia papal de Correr-Condulmer-Barbo permite perceber de imediato a validade desta premissa. Gregório XII Correr é tio materno de Eugénio IV Condulmer, que por sua vez foi tio materno de Paulo II Barbo. Mais do que isso, Gregório XII promoveu toda a carreira eclesiástica de Eugénio IV, e elevou-o ao cardinalato; o mesmo processo ocorrerá com Pietro Barbo (Paulo II).

O apoio dos tios maternos foi, no que se refere a esta dinastia veneziana de Papas, fulcral para o seu desenvolvimento. Surgida no seio do patriciado veneziano, replica pois os processos sociais que este engendrou no seu percurso histórico.

Como afirma Tomasini acerca de Beriola Correr, irmã de Ângelo Correr, mãe de Gabriel Condulmer e avó de Pietro Barbo: «Ita clarissima foemina et omnibus seculis celebris beriola, raro felicitatis exemplo, fratrem, filium ac nepotem Summos Pontifices vidit» e acrescenta acerca das linhagens que ela uniu ao casar com Angelo Condulmer: «haec itaque Corrariorum et Comdulmeriorum felix coniunctio Venetae Urbi primam ac Summam Sacrae dignitatis gloriam attulit» ${ }^{438}$.

\section{Ângelo, Cardeal Correr - Gregório PP XII}

A figura tutelar desta dinastia de Papas e altos prelados, feita das relações familiares forjadas entre três linhagens do patriciado veneziano, os Correr, os Condulmer e os Barbo, é Ângelo Correr, que como quarto e último pontífice da obediência romana do cisma, foi também o primeiro Papa veneziano da Igreja, tio do segundo e tio-avô do terceiro ${ }^{439}$. Esta circunstância, bem como a noção de que a sua carreira eclesiástica abre caminho a todo o desenvolvimento desta dinastia de Papas venezianos, obriga a um olhar sobre este homem que, não tendo sido em momento algum um Cónego de Alga, é colocado pelo cronista dos Lóios como «primeiro e principal fundador da Congregação de S. Jorge em Alga ${ }^{440}$.

Nascido numa família do patriciado veneziano, em meados de trezentos, Ângelo Correr é destinado à carreira eclesiástica, tendo estudado Teologia em Bolonha. Alcança em 1377 o deado da Sé de Corone (diocese grega, território então em mãos venezianas) por recomendação do Senado da Sereníssima ao Papa Gregório XI ${ }^{441}$.

\footnotetext{
${ }^{437}$ Idem, ibidem: 190.

${ }^{438}$ TOMASINI, 1642: 3.

${ }^{439} \mathrm{Vd}$. em anexo esquema genealógico n. ${ }^{\circ} 1$.

${ }^{440}$ SANTA MARIA, 1697: 36 e segs.

${ }^{441}$ ORTALLI, 2000.
} 
Já no cisma, em 1379/1380, é eleito bispo de Castelo, e como tal ordinário de Veneza. Novamente deve a nomeação ao Senado veneziano, que exerce o direito de apresentação dos prelados dos seus territórios, sujeito apenas a sancionamento pontifício. Com esta nomeação Correr passa a estar em posição de manter contactos mais fortes com a cúria, destacando-se sempre pela sua adesão ao partido romano do cisma ${ }^{442}$.

Parece ter sido prelado de cariz reformador, como demonstrará o facto de ter recebido da parte de Catarina de Siena as felicitações pela sua eleição, pouco antes da morte desta figura maior do movimento reformista italiano do séc. XIV ${ }^{443}$.

Significativamente é a primeira figura apontada por Rigon quando trata da reforma monástica em Veneza na viragem do séc. XIV para o XV. Menciona que, como Bispo de Castelo, Ângelo Correr faz publicar em 1383 uma constituição diocesana em que denuncia os problemas que grassavam no mundo monástico feminino, levando pouco depois à intervenção do papa Urbano VI, que ordena ao Patriarca de Grado a reforma de todos os mosteiros de religiosas dos territórios da sua jurisdição ${ }^{444}$.

A preocupação demonstrada pelo Bispo Correr, ainda que de resultados limitados, demonstra claramente uma sensibilidade que podemos classificar como reformista, e que entendia o mundo regular veneziano como, a exemplo de outros, estando em crise.

A sensibilidade reformista do prelado parece demonstrar-se, para além de tomadas de posição como a relatada, pelas relações que estabelece com grupos reformistas que se desenvolvem na Veneza das décadas de 1380 e 1390, e no apoio que dará aos seus sobrinhos e ao grupo fundador da Congregação de Alga.

As relações que Correr manteve com os seguidores de Catarina de Siena e reformistas da Ordem dos Pregadores que, na década de 1390, se recolhem a Veneza, são neste contexto altamente esclarecedoras e de grande importância. Menciona-se a presença de dois importantes reformadores do universo dominicano, Tommaso di Antonio Caffarini (um dos autores da legenda de St. ${ }^{\text {a Catarina de }}$ Siena) e o beato Giovanni Dominici ${ }^{445}$.

Dominici instala-se em Veneza em 1388, como leitor de Teologia na escola dominicana do convento de S. João e S. Paulo. Como afirma Alce, ao falar brevemente da reforma dominicana dos séc. XV e XVI, em que Dominici é a figura central da reforma dos conventos venezianos «Il concetto di riforma è una constante nella storia dei domenicani, intendendo per riforma l'osservare «ad unguem» quanto è scritto nelle costituzioni ${ }^{446}$.

Dominici promoverá na década seguinte, com Raimundo de Cápua ${ }^{447}$, uma reforma da sua Ordem, começando pelos três conventos de Veneza ${ }^{448}$. Como Cracco salienta, este empenho reforma-

\footnotetext{
${ }^{442}$ Idem, ibidem.

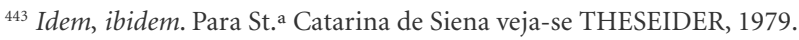

${ }^{444}$ RIGON, 1997.

${ }^{445}$ CRACCO, 1997. Beatificado por Gregório XVI em 1832 (cf. CRACCO, 1963).

${ }^{446}$ ALCE, 1984.

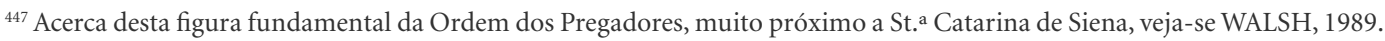

${ }_{448}$ Os dominicanos tinham já albergado internamente tentativas de reforma, nomeadamente em meados do séc. XIV na província de Aragão, de parcos resultados pela oposição claustral (cf. VARGAS, 2012).
} 
dor estendia-se para além da Ordem dos Pregadores, e encontra apoio em diversos níveis da sociedade veneziana, laica, secular e regular. Entres os apoios (em que se podem mencionar os franciscanos ou o governo veneziano) destaca-se o da hierarquia eclesiástica, que para Cracco se consubstancia no apoio de Ângelo Correr ${ }^{449}$.

A ação reformista de Dominici, que se traduziu na reforma claustral e na pregação (própria do carisma dominicano) ter-se-á também feito sentir no ensino e na direção de consciência. Neste contexto pode-se aventar a possível influência do dominicano num outro Correr, António, sobrinho do Bispo Ângelo e futuro fundador da Congregação de Alga, que fez os seus estudos na escola dominicana do convento de San Zanipolo ${ }^{450}$. É elevada a probabilidade do tio, que terá o papel fundamental na construção da sua carreira eclesiástica ${ }^{451}$, ter também participado na escolha desta escola, em que Dominici atuava ativamente na construção de um círculo reformista.

Se mais indícios não houvesse das relações do círculo de Giovanni Dominici com a linhagem dos Correr/Condulmer/Barbo bastaria apenas chamar a atenção para que, em maio de 1408 Ângelo Correr, já papa Gregório XII, cria em consistório os seus quatro primeiro cardeais, escolhidos entre pessoas da maior proximidade, premiando a sua fidelidade e dotando-os de uma posição em que melhor o pudessem ajudar num pontificado difícil ${ }^{452}$, que tinha a expressa obrigação de dar resolução ao cisma. Estes novos purpurados são os seus sobrinhos (e fundadores de Alga) António Correr e Gabriel Condulmer, a que se unem Giovanni Dominici e Jacopo del Torso ${ }^{453}$.

Em 1390 Ângelo Correr é eleito por Bonifácio IX patriarca de Constantinopla, aumentando o seu prestígio e preeminência de grau no universo eclesiástico, bem como os rendimentos de que dispunha; o que concertado garante um aumento de influência do novo patriarca, doravante presença assídua na cúria romana, onde estabelece relações com o Cardeal Cosmato dei Megliorati ${ }^{454}$, o qual eleito Papa o irá, em junho de 1405, elevar ao cardinalato ${ }^{455}$.

Será no período em que é Patriarca de Constantinopla, com residência em Veneza, que Ângelo Correr irá dar o seu apoio ao núcleo fundador da Congregação de Alga.

\footnotetext{
${ }^{449}$ CRACCO, 1963.

${ }^{450} \mathrm{O}$ mesmo que S. João e S. Paulo em veneto. Ildefonso Tassi (TASSI, 1952: 14), menciona esta frequência escolar, tal como o seu biógrafo François-Charles Uginet (UGINET, 1983), certamente baseados na já mencionada biografia da autoria do sobrinho Gregório Correr.

${ }^{451}$ Como se depreende dos diversos autores que trataram António Correr, direta ou indiretamente, nomeadamente os seus biógrafos que já se foram citando.

${ }^{452}$ Como o interpreta um dos biógrafos do Papa (cf. ORTALLI, 2000).

${ }^{453}$ Que já fazia parte do círculo de Ângelo Correr de longa data, como o afirma o seu biógrafo (BARBALARGA, 1990). Acrescenta acerca do consistório: «Sentendo di non godere più dell'appoggio di gran parte del Collegio cardinalizio, tra cui sempre più numerosi divenivano i fautori di un concilio che ponesse termine allo scisma, Gregorio XII si risolve il 9 maggio 1408 a creare quattro nuovi cardinali, che scelse tra i suoi più fedeli sostenitori: il fratello Antonio Correr, vescovo di Bologna, il Iacopino del Torso, Gabriele Condulmer, vescovo di Siena, il domenicano Giovanni Dominici», note-se no entanto que se equivoca, chamando irmão ao sobrinho António Correr e não identificando nessa qualidade a Gabriel Condulmer.

${ }^{454}$ Acerca deste cardeal, depois Papa Inocêncio VII, veja-se DE VINCENTIIS, 2000.

${ }^{455}$ ORTALLI, 2000.
} 
Segundo uma tradição veiculada pela cronística de Alga ${ }^{456}$ e dos Lóios ${ }^{457}$, «ho Spiritu Sancto que primeiro espertara ao dito Gabriel [Condulmer] inflamou ao reverendissimo padre ho senhor Angelo Corareo bispo da diocesi Castelanensi pera que recebesse benignamente aos ditos padres em suas pousadas e paço episcopal» ${ }^{458}$.

Esta informação, veiculada nos Statutos e Constituyções dos Lóios, radicar-se-ia na Memória que na segunda metade da década de 1420 D. Afonso Nogueira teria trazido de Itália. Verdadeira ou não, era, ainda em vida da maioria dos seus intervenientes, parte da memória que se construía acerca da fundação da Congregação de S. Jorge em Alga.

No elevado grau de incerteza existente sobre os primeiros passos dado pelos fundadores da Congregação até à formação da comunidade canonical de $1404^{459}$, e até na dúvida da identificação absoluta dos principais fundadores, parece no entanto claro que Ângelo Correr, fundador de uma poderosa linhagem eclesiástica de altos prelados e Papas, escrita entre tios e sobrinhos, teve um papel de animador e promotor.

Tassi afirma mesmo: «il suo contributo all'origine del movimento deve essere stato grande, come ispiratore, come legislatore e come esempio di vita sacerdotale integra e virtuosa ai suoi nepoti. Egli, osservando la vita devota dei nepoti, li spinse alla vita comune e diede loro i principi con i quali unirsi», e com grande lógica conclui «Certo egli li invitò nel suo palazzo, e non poteva essere solo per dar l'allogio, ma puré una iniziazione ed una direttiva ${ }^{460}$.

Mais recentemente Tramontin, ao mencionar o pouco conhecimento e dificuldade em identificar as influências diretas do movimento de Alga, refere destacadamente o Patriarca Correr, antepondo-o a outras influências, como a do grupo que gravitava em torno do beato Dominici, ou dos camaldulenses $^{461}$.

O apoio de Ângelo Correr, em diversos momentos e posições por si ocupadas, ao grupo fundacional da Congregação de Alga parece ser um natural alargamento do apoio dado aos seus sobrinhos. Acentue-se o papel que desempenhou na vida de ambos, refletindo nos seus parentes dedicados à vida eclesiástica o sucesso que alcançou na sua própria carreira, abrindo caminhos e

\footnotetext{
${ }^{456}$ TOMASINI, 1642: 12.

${ }^{457}$ SANTA MARIA, 1697: 14. Francisco de Santa Maria parece ter no essencial seguido a lição do cronista de Alga Tomasini. Esta informação não é no entanto necessariamente veiculada por todos os cronistas: o primeiro cronista lóio, Paulo de Portalegre, escrevendo sete décadas depois dos acontecimentos, não menciona em ponto algum a residência dos fundadores de Alga no palácio do Patriarca Correr, ainda que sustente ter sido a força animadora de Gabriel Condulmer na fundação (cf. PORTALEGRE, 2007: 69).

${ }^{458}$ Statutos e Constituyções dos virtuosos e reverendos padres Conegos azuys..., 1540: fl. $1 \mathrm{v}$.

${ }^{459} \mathrm{O}$ beneditino Ildefonso Tassi é neste ponto muito claro: «Non è facile descrivere l'origine del movimento [dos Cónegos de Alga]. Il raconto dello storico della congregazione Iacopo Filippo Tomasini non soddisfa la nostra esigenza storica» (cf. TASSI, 1952: 13).

${ }^{460}$ Idem, ibidem: 22.

${ }^{461}$ TRAMONTIN, 1984: 91. Refere-se à influência dos beneditinos camaldulenses de Murano, cuja ordem será depois, em inícios do séc. XVI (aprovação em 1523), reformada pela criação de uma corrente observante que dará origem à Congregação de Eremitas Camaldulenses de Monte Corona, cujo fundador será um membro da mesma família Justiniana de onde veio Lourenço Justiniano, Paulo Justiniano (cf. FIORI, 1729, e o mais recente TABACCHI, 2001).
} 
permitindo um rápido progresso, em consonância com lógicas de linhagem e de poder típicas do patriciado veneziano.

O papel por si desempenhado na vida dos seus sobrinhos assume uma relevância e proximidade que se poderá ler, por exemplo, na memória que um seu sobrinho-neto, o protonotário Gregório Correr (n. 14/09/1409, †30/11/1464), patriarca eleito de Veneza, faz das suas próprias relações com o seu tio António Correr e deste com o tio Ângelo.

De acordo com o que descreve, as relações eram filiais, traduzindo-se mesmo no uso do nome «pai» para designar estes dois clérigos e a sua relação com os seus sobrinhos. Dirigindo-se a Deus, diz Gregório que chora a morte de António Correr «Patris mei, non quidem Patris carnis meae, sed in tua pietate Patris, et ideo verius Patris» ${ }^{462}$. Poder-se-á supor que António Correr replicara na relação com o seu sobrinho Gregório, cuja carreira apadrinhou ${ }^{463}$, o padrão de comportamento que aprendera com o seu tio Ângelo. De modo similar, Sartorelli, ao falar dos primeiros anos de Gabriel Condulmer e da morte precoce de seu pai, apresenta o tio Ângelo Correr como a figura que assume na vida do sobrinho um papel de cuidador, e de possível substituto da figura paterna, promovendo os seus estudos e, com toda a probabilidade, encaminhando-o para a carreira eclesiástica ${ }^{464}$.

Da sua aproximação à cúria romana, e da sua elevação ao cardinalato por Inocêncio VII, Ângelo Correr conseguirá obter, depois da morte deste, a sua eleição ao sólio de S. Pedro.

Entra o Cardeal Correr no conclave a 18 de novembro de 1406, dele sairá o Papa Gregório XII a 30 desse mesmo mês. Foi o terceiro conclave em cisma dos cardeais da obediência romana e é dominado pela necessidade de se alcançar uma resolução ao enorme rasgão aberto na túnica inconsútil de Cristo. Ante tão premente necessidade, que por toda a cristandade ocidental se exigia, os 14 cardeais reunidos decidem que aquele que vier a ser eleito se compromete a renunciar ao pontificado, se tal for necessário, para o fim do cisma.

Gregório XII, no primeiro consistório público, confirmará solenemente esta decisão do conclave $^{465}$, que cumprirá futuramente, em 1415, depois de aberto o concílio de Constança.

Tendo enviado o Cardeal Dominici, o dominicano reformista de Veneza, para em seu nome proclamar a bula de abertura do concílio, dando-lhe assim o sancionamento eclesiástico da obediência romana e recuperando algum centralismo depois da marginalização que sofrera a partir de $1409^{466}$,

${ }^{462}$ CORRER, 1757.

${ }^{463}$ A influência será tal que, segundo o seu biógrafo, tendo de escolher entre permanecer laico e prosseguir uma carreira prestigiante que lhe assegurava as suas origens patrícias e permitia a excelência da sua formação humanística, ou seguir uma carreira eclesiástica como aquela a que o seu tio Cardeal António o influenciava, Gregório acabou por optar por esta (cf. PRETO, 1983).

${ }^{464}$ SARTORELLI, 1988.

${ }^{465}$ Note-se que no entanto não respeitará a outra decisão dos cardeais, de que o novo Papa fizesse incidir todos os seus esforços na resolução do Cisma, para o que não deveria aumentar o colégio de Cardeais. Gregório XII acabará por, ao fim de 2 anos de pontificado, e ao sentir a premente necessidade de apoios de confiança para o trabalho a que se propunha, criar 14 novos cardeais, em dois consistórios no ano de 1408. O aprofundamento da crise cismática a partir da eleição do Papa de Pisa, em 1409, acabou por condicionar futuras criações de cardeais (cf. ORTALLI, 2000; KAMINSKY, $2000: 692$ e segs.). ${ }^{466} \mathrm{Com}$ o afastamento dos cardeais do sacro colégio que o tinham elegido, e que o abandonam em protesto pela nomeação que fez de novos cardeais (cf. Idem, ibidem). 
Gregório XII encarrega Carlo Malatesta ${ }^{467}$ de apresentar em seu nome, e em prol da resolução do cisma por eleição de um novo Papa, a sua renúncia ao trono pontifício. Estamos a 4 de julho de $1415^{468}$.

A 20 de julho de 1415, depois de ter notícia de que o Concílio recebera a sua renúncia ao pontificado, Gregório reúne o seu último consistório, no decurso do qual depõe as insígnias pontifícias e reveste-se da púrpura cardinalícia que o Concílio, em reconhecimento da sua adesão (patente no sancionamento ao Concílio e na renúncia) lhe concedera novamente, com o título de cardeal-bispo do Porto, o primeiro na hierarquia a seguir ao $\mathrm{Papa}^{469}$. Novamente Cardeal Ângelo Correr, ocupará desde então, e até à sua morte em outubro de 1417, a função de legado na marca de Ancona ${ }^{470}$.

O apoio de Ângelo Correr aos seus sobrinhos António Correr e Gabriel Condulmer, primeiro enquanto bispo, patriarca e cardeal e depois, numa circunstância bem mais destacada, como Papa da obediência romana, associado ao papel destacado que os dois primos terão na Igreja nas décadas seguintes à renúncia do tio que lhes abriu as portas da carreira eclesiástica, converteu-se especificamente em apoio dispensado à jovem congregação de S. Jorge em Alga. A circunstância de apoios cruzados entre os membros desta linhagem concorreu para elevar e sustentar, entre os cronistas e historiadores, os dois primos (e por vezes o seu tio) ao papel de principais fundadores da congregação ${ }^{471}$.

\section{António, Cardeal Correr (1369-1445)}

Mox Venetiis Monasterio se abdidit [António Correr] cum paucis Clericis non quidem professione, sed humilitate, et saeculi contemptu, Monachus. Ibi jejuniis, \& orationibus vacans, ardens tua, \& proximi caritate quotquot ei donabas, hortationibus, et (quod magis movebat) exemplo suo ad frugem melioris vitae trahebat ${ }^{472}$.

\footnotetext{
${ }^{467}$ Carlo Malatesta (1368-1429), senhor de Rimini em 1385, por sucessão de seu pai, foi reitor da Romagna pela Santa Sé. Importante condottiero, foi em 1387 nomeado gonfaloneiro da Igreja, pelo Papa Urbano VI. O seu serviço como comandante militar dos Papas da obediência romana foi relevante, tendo sido um dos principais apoiantes de Gregório XII, pelo qual desenvolveu diversos esforços e desempenhou alguns encargos, como o de representar e defender o Papa no concílio de Pisa de 1409, e que se traduziu finalmente na sua escolha para apresentar a renúncia no concílio de Constança. Retenha-se ainda que teve (para além do seu papel como político e militar), a par com a sua mulher Isabel Gonzaga (filha de Luís II, senhor de Mântua), um forte empenho religioso, traduzido em forte vida espiritual e no apoio a ordens religiosos novas e em reforma, de que o seu empenho na resolução do cisma dá uma visão (cf. FALCIONI, 2007).

${ }^{468}$ Cf. ORTALLI, 2000.

${ }^{469}$ A renúncia e o seu sequente regresso ao cardinalato recuperaram, em 2013, a figura de Gregório XII, nos meios académicos, eclesiásticos e na imprensa, na sequência da renúncia do Papa Bento XVI. Último pontífice a renunciar antes do Papa Ratzinger, a uma distância de 598 anos, Gregório alcançou então fama inesperada. A diferença de posições assumidas pós-renúncia (Gregório retornando ao estado anterior à eleição, e Bento mantendo-se como Papa, a que se acrescentou o título de emérito, mas ainda substancialmente conetado à ideia do pontificado romano) criou algumas dúvidas, apesar de compreensível pela diferença de circunstâncias históricas que separam estes dois Papas.

${ }^{470}$ Cf. ORTALLI, 2000.

${ }^{471}$ Monsenhor Sartorelli, fazendo uma análise da questão, e muito baseado em Tassi, conclui também pelo papel desempenhado a par pelos dois primos (cf. SARTORELLI, 1988). Condensa assim a opinião generalizada dos académicos que desde a década de 1950 escreveram sobre o assunto.

${ }^{472}$ CORRER, 1757: 16. É deste modo que o seu sobrinho Gregório Correr descreve o movimento fundacional de S. Jorge em Alga e o seu modo de vida.
} 
Em cariz hagiografante, Tomasini exalta nos jovens primos Correr e Condulmer o desejo precoce de abandonar o mundo e os seus vãos encantos ${ }^{473}$, um anseio reformista que se entende na natureza original do conceito na leitura de Ladner, de uma reforma individual e coletiva em Cristo, implementada na reforma moral do clero, e que se traduziria, pelo exemplo e ação pastoral, nos diversos níveis do mundo eclesial.

Trata-se de uma opção espiritual individual assumida por estes jovens, e pelos que os acompanharão, e que não podemos conhecer verdadeiramente na medida em que nenhum dos dois deixou testemunho pessoal do que os moveu nos anos fundacionais da Congregação de Alga. Restam-nos os testemunhos de terceiros e os indícios que se podem encontrar no seu percurso de vida, para tentar descortinar as motivações matriciais.

A opção pela vida retirada e em comunidade parece poder intuir-se com mais certezas em relação ao mais velho dos primos, António Correr, que o sobrinho descreveu como homem desprendido dos bens terrenos, abstinente, caridoso, puro de coração, tudo com uma humildade que lhe era peculiar e que manteve intacta mesmo quando revestido da púrpura cardinalícia, «comites raro visas in Romana Curia ${ }^{474}$.

Gregório Correr acentua particularmente a sua atenção para com os mais pobres e, em tom também hagiográfico, louvando a paciência com que o cardeal suportou a longa doença que o acompanhou nos anos finais da sua vida.

Nascido, cerca de $1369^{475}$, na patrícia família dos Correr, António começou a sua formação escolar no convento dominicano de S. João e S. Paulo de Veneza, tendo depois, e seguindo a tradição da aristocracia veneziana e da sua linhagem, prosseguido os seus estudos na Universidade de Pádua, onde se formou em ambos os Direitos ${ }^{476}$.

O sobrinho ${ }^{477}$ menciona que, ainda jovem, sentiu atração por experiências espirituais, talvez influenciado pelo ambiente criado por Dominici e pelos reformadores dominicanos, e que o terão levado, em 1392, a uma passagem pelos Jesuatos, ordem de recente fundação ${ }^{478}$. Esta passagem, que

\footnotetext{
${ }^{473}$ Veja-se o que diz TOMASINI, 1642: 4 e segs.

${ }^{474}$ CORRER, 1757: 17.

${ }^{475}$ De acordo com a informação veiculada pelo seu sobrinho protonotário Gregório Correr, que o dá falecido com 76 anos de idade a 19 de janeiro de 1445 (cf. Idem, ibidem: 23). Monsenhor Sartorelli (SARTORELLI, 1988), chama a atenção no entanto para outra fonte (uma das crónicas dos Jesuatos) que o dão como nascido em 1374.

${ }^{476}$ TASSI, 1952: 14; UGINET, 1983. Foi precedido nesta frequência pelo seu primo Ângelo Barbarigo, o mesmo bispo de Kysamos que presidirá à executória de 1404, que fez estudos jurídicos em Pádua de 1375 a 1383, tendo-se formado em Direito Canónico. Já o tio de ambos Ângelo Correr teria estudado Artes em Pádua, bem como Gabriel Condulmer, que a crónica da Universidade dá como colega de seu primo António (cf. PAPADOPOLI, 1726: 12,13, 16, 163, 164, 266, 267).

${ }^{477}$ CORRER, 1757.

${ }^{478}$ Os Jesuatos foram fundados em Siena em meados do séc. XIV pelo beato Giovanni Colombini, patrício casado, dedicado ao comércio e à vida pública da sua cidade, que em 1355 passa por um processo de conversão pessoal. Abdica dos seus bens, deixa a família e dedica-se com alguns seguidores a uma vida de pobreza, assistência aos pobres e doentes, oração e penitência. O grupo acabará suspeito de heterodoxia (acusam-nos de fraticellismo pela forma radical como adoptam e pregam o despojamento material e se mortificam) pelo que Colombini obterá do Papa Urbano V, em 1367, a sua aprovação como congregação de laicos, ainda que com mitigação à pobreza extrema que os jesuatos então praticavam, imposta pela hierarquia eclesiástica. O seu carisma, que é o do fundador, é o da experiência da procura e transformação em Cristo, um processo de conversão pessoal que funda sobre S. Paulo e os Padres da Igreja, indo assim ao cerne da ideia reformista (cf. PIAZZONI, 1982).
} 
a ser verdadeira não terá sido muito prolongada ${ }^{479}$, parece demonstrar os seus anseios espirituais e a sua filiação desde jovem em movimentos reformistas, ainda mais numa congregação que tem sido associado aos Cónegos de Alga ${ }^{480}$.

No mesmo ano em que tio Ângelo é promovido ao patriarcado (1390), António recebe do Papa a sua eleição como Deão de Corone, a mesma que marcara o início da carreira eclesiástica de seu tio, benesse que Ângelo Correr obtém para António com o mesmo fito com que, 13 anos antes, tinha sido alcançada para si ${ }^{481}$.

Em setembro de 1396, António Correr recebe a primeira das ordens sacras, o subdiaconado, para o que concorrera como título, segundo Tassi, o benefício na diocese de Corone ${ }^{482}$. Nos anos seguintes receberá os dois graus seguintes da ordem sacerdotal, pois vamos encontrá-lo como presbítero na executória de 1404.

Neste percurso, de estudante em Veneza, de formado em Pádua e, por fim, de clérigo, percebe-se que o percurso de António Correr fez-se paulatinamente. A frequência, desde jovem, de meios reformistas determinam escolhas futuras, mas pode-se validamente questionar se a eleição do estado clerical foi vocação de primeira hora.

Se as preocupações de natureza espiritual de António Correr são notórias desde cedo, a escolha de uma carreira eclesiástica não parece tão precoce. A falta de informação para as primeiras décadas da sua vida é uma constante, e deve-se ter cuidado com a retórica do sobrinho Gregório Correr, que promove a memória do tio enquanto sacerdote e prelado.

Dois dados permitem questionar uma vocação clerical precoce: o primeiro são os contactos com o Jesuatos, então ainda uma congregação de laicos, e que se colocam como ponto inicial do seu percurso carismático, antes ainda de qualquer ordenação; o segundo é o facto de António Correr receber a primeira das ordens sacras já com 27 anos de idade (em 1396), uma idade algo tardia se atendermos ao facto de que o seu primo Gabriel, cerca de 14 anos mais novo, não ter recebido as ordens muito depois ${ }^{483}$.

Apesar de a sua adesão ao estado eclesiástico ter sido opção mais tardia que a de alguns dos colegas de Congregação ${ }^{484}$, e ainda que se possa ler no quadro da influência do seu tio Ângelo Correr (e talvez do primo Ângelo Barbarigo, desde 1385 bispo de Kysamos ${ }^{485}$ ), não parece existir motivo para

\footnotetext{
${ }^{479}$ Como Sartorelli chama a atenção, ao afirmar que em 1396 ao ser ordenado de sub-diácono, figura apenas como deão da diocese de Corone, dignidade que recebera em 1390, e de que teria certamente de renunciar se perseverasse entre os jesuatos (cf. SARTORELLI, 1988).

${ }^{480}$ PIAZZONI, 1982.

${ }^{481}$ Esta é a leitura do seu biógrafo: «Scelse la vita ecclesiastica per incoraggiamento dello zio Angelo Correr. Quest’ultimo, nominato patriarca di Costantinopoli, il 28 settembre 1390 gli procurò il decanato di Corone in Grecia di cui egli stesso era stato titolare fino al 1380 e che poi era riuscito a mantenere vacante con vari cavilli, fino al raggiungimento della maggiore età canonica del nipote.» (cf. UGINET, 1983).

${ }^{482}$ TASSI, 1952: 13.

${ }^{483}$ Note-se que Gabriel Condulmer em 1404 é já também mencionado como sacerdote, contando então apenas 21 anos de idade. ${ }^{484}$ Já se mencionou o seu primo Gabriel, mas também se poderia mencionar o caso de Lourenço Justiniano, que em 1404 teria 23 anos e ordens de diácono (cf. DEL TORRE, 2007).

${ }^{485}$ GUALDO, 1964a.
} 
duvidar do que parece ser uma decisão já madura, que coincide com uma visão exigente do ministério sacerdotal que se poderá encontrar na Congregação de Alga, e cujo carisma assentará na reforma e santificação do povo de Deus pela reforma e santificação do clero e do culto por ele prestado.

A adesão de António Correr a este ideal de sacerdócio encontra-se no seu percurso de vida, conforme o testemunho do seu sobrinho Gregório, que com ele viveu 14 anos, inclusive na cúria romana, e mesmo descontando seu o exagero encomiástico.

A imagem do prelado altamente espiritualizado ${ }^{486}$, despojado e caritativo, fortemente dedicado ao culto divino e ao serviço da Igreja, transparece não só do que saiu da pena de Gregório Correr, mas de diversos outros testemunhos, todos concordes, como já se afirmava em 1761 «omnium opinione sanctissime vixit...» ${ }^{487}$.

Valhamo-nos do importante testemunho de um coetâneo (nascido em 1421), que sendo certo que conheceu pessoalmente o Papa Eugénio IV ${ }^{488}$ poder-se-á supor com segurança que terá conhecido o seu primo António Correr, ou dele teve segura notícia ${ }^{489}$. Trata-se de Vespasiano da Bisticci, livreiro, escritor e humanista toscano, que na obra biográfica de mais de uma centena de pessoas ilustres com quem contactou ao longo da sua vida (1421-1498), descreve o Cardeal António Correr nos seguintes termos:

Messer Antonio [...] fu di santissima vita, e nella gioventù si fece frate insieme com Papa Eugenio, in uno luogo in Vinegia[sic] che si chiama Santo Giorgio d'Alga. Fu mosso proprio da smisurato amore che aveva alla cristiana religione e alla salute dell'anima sua. [...] Fini la vita sua santissimamente», e termina Bisticci dizendo: "Questi sono di quegli prelati che aveva la Chiesa di Dio, degni di eterna memoria! ${ }^{490}$

A biografia delineada por Uginet é consideravelmente menos encomiástica mas, e ainda que sem o benefício do conhecimento pessoal e aproximado dos testemunhos quatrocentistas, apresenta-se bastante mais segura do ponto de vista documental e crítico.

\footnotetext{
${ }^{486} \mathrm{O}$ seu sobrinho sublinha a importância que António Correr dava à leitura e meditação das obras de S. Paulo e dos Padres da Igreja, com relevância para St. ${ }^{\circ}$ Agostinho, entre outras leituras espirituais, referência importante feita por uma personagem com uma bem radicada formação humanista (PRETO, 1983), e sublinhando a relevância da biblioteca que o cardeal reuniu e que legaria ao mosteiro de S. Jorge em Alga (cf. CORRER, 1757: 21). Acerca da biblioteca do Cardeal e do seu legado ao mosteiro de Alga veja-se BARBATO, 1959, que faz notar que estas eram as principais fontes da espiritualidade de S. Jorge em Alga na fundação e primeiras décadas, com uma significativa biblioteca (hoje perdida, devido ao fogo que a consumiu em 1716) que se ficou a dever em grande medida a doações dos seus antigos religiosos: António Correr, Eugénio IV, o Patriarca Maffeo Contareno e de um Cardeal de Óstia (possivelmente o mesmo António Correr, o único cónego de Alga que teve esta sede suburbicária). A relevância da biblioteca foi tal que dela saíram livros por empréstimo, por exemplo para Marino Contareno, Bispo de Kotor e de Treviso. ${ }^{487}$ QUERINI, 1761: 24. O Autor, Cardeal Querini, que produziu diversas obras historiográficas, teve dois cargos ligados ao livro e à produção intelectual: o de Bibliotecário da Santa Igreja (responsável pela Biblioteca Vaticana), e o de Prefeito da Congregação do Index (cf. Idem, ibidem: 418 e segs.).

${ }^{488}$ Conforme o declara Monsenhor Sartorelli no seu opúsculo sobre o Papa Condulmer (cf. SARTORELLI, 1988). Provavelmente tal referir-se-á aos períodos em que o Papa Eugénio residiu em Florença, onde inclusive fez reunir o concílio e onde recebeu o Imperador Bizantino (cf. HAY, 2000).

${ }^{489}$ Também Correr, e durante o pontificado do seu primo, teve estadias em Florença, nomeadamente participando no concílio (cf. UGINET, 1983).

${ }^{490}$ BISTICCI, 1859: 120, 121, 123.
} 
Acentua o percurso eclesiástico do seu biografado, diretamente correlacionado com o do seu tio, Ângelo Correr, a quem António deve o decanato de Corone e Gabriel, em 1400, um canonicato na Sé de Verona ${ }^{491}$. Será entre a obtenção destes benefícios e a eleição de Ângelo Correr a Papa Gregório XII (1406) que se situará o ponto fundacional da Congregação de Alga e a permanência dos dois primos no claustro.

O curto espaço de tempo que medeia entre os primeiros passos e a saída de Correr e Condulmer para a cúria romana não deixam no entanto de ser de uma importância extrema, por marcarem uma ligação que, nas décadas seguintes, permitirá a fixação e aumento do carisma de Alga, cuja vida presente e futura se sustentará no sucesso da linhagem papal que leva, pela primeira vez, venezianos ao sólio de S. Pedro.

Com a eleição de Gregório XII, e ainda antes de serem feitos cardeais no primeiro consistório do seu tio, António e Gabriel são chamados a Roma e promovidos na carreira eclesiástica. Não se sabe a data certa em que os primos Correr e Condulmer abandonam o claustro de Alga, mas fazem-no certamente em data muito precoce da vida da congregação.

Este afastamento, já no início de $1407^{492}$, quando a congregação de Alga estava ainda nos seus inícios e contava apenas dois mosteiros (um deles recém-adquirido ${ }^{493}$ ), em fase incipiente de expansão e estruturação administrativa e normativa, não só não significou o desligamento dos dois primos em relação às comunidades de cónegos, mas pelo contrário marcou o ponto de viragem que permitiu que esta nova forma de vida religiosa, de clérigos seculares de vida comum e sem votos, sobrevivesse à complexidade da situação eclesial dos anos finais do cisma, e alcançasse uma estruturação mais sólida e uma expansão sustentada que se construirá ao longo do séc. $X V^{494}$.

A 26 de fevereiro de 1407 António Correr é sagrado bispo de Modon no Vaticano pelo tio Gregório XII, com assistência (entre outros) do seu primo homónimo bispo de Asolo ${ }^{495}$.

No mês seguinte, março de 1407, é transferido à Sé de Bolonha, da qual só mais tarde tomará posse, mantendo-se na cúria romana onde será referendário, tesoureiro papal e camerlengo, o que o colocou no vértice da administração curial e como um dos principais apoios do seu tio em Roma, que o escolhe por representante nos contactos que em 1407/08 mantiveram as obediências romana e avinhoense, tendo em vista a mútua renúncia.

António manteve-se próximo do tio, possivelmente o seu mais importante colaborador, acentuado pela sua criação cardinalícia a 19 de maio de 1408. Teve missões de legado à Alemanha, Inglaterra e Irlanda, em busca de apoios mais fortes para Gregório XII. O resultado parece não ter sido o

\footnotetext{
${ }^{491}$ SARTORELLI, 1988.

${ }^{492}$ Em fevereiro António Correr está em Roma, onde é consagrado Bispo (cf. UGINET, 1983).

${ }^{493}$ O mosteiro de S. João Degolado de Pádua, recebido do seu Bispo em julho de 1406.

${ }^{494}$ Note-se que são 17 casas da Congregação de Alga, adquiridas entre 1404 e 1496, na sua maioria (13 casos) até à morte do fundador Eugénio IV. $V d$. quadro anexo n. ${ }^{\circ} 2$.

${ }^{495}$ Um dominicano que fora nomeado para esta Sé em inícios de 1406, demonstrando o valimento desta linhagem no seio da cúria romana (aquando da sua eleição Gregório XII tinha pelo menos 2 sobrinhos já bispos, além dos dois sobrinhos que em Alga fundavam uma congregação), a sua forte ligação à carreira eclesiástica, mas também (neste caso em particular) evidenciando ainda mais a ligação ao círculo reformista da observância dominicana de Veneza( $v d$. TASSI, 1952: 14; UGINET, 1983).
} 
melhor e, na opinião do biógrafo, nos anos finais do pontificado verifica-se um afastamento, de que a relação não recupera até à abdicação.

Em novembro de 1415, já depois da abdicação do seu tio, António Correr e seu primo Gabriel, com quem neste período terá mantido uma ação fortemente concertada, juntam-se ao concílio de Constança, onde apoiam o partido de Segismundo, Rei dos Romanos ${ }^{496}$.

Com a eleição de Martinho V, e apesar do novo Papa ter sido um dos cardeais da obediência romana que abandonaram Gregório XII em 1408, o Cardeal Correr retorna a Roma e aos ofícios curiais. Terá gozado do favor do Papa Colonna, que lhe deu diversos e importantes cargos, que remunerou com benefícios.

Morto Martinho V, em 1431, sucede-lhe o primo de Correr, Gabriel Condulmer, agora Papa Eugénio IV. A relação estreita de ambos, como fundadores de Alga, como cardeais colaboradores de seu tio, com uma mesma estratégia no concílio de Constança que lhes garantisse um papel futuro numa Igreja em que o seu tio se convertia em figura de passado que se queria ultrapassar, não terá prosseguido nos anos que se seguem.

O biógrafo do Cardeal Correr salienta diversos pontos que opõem os primos, um deles certamente com grande peso para Eugénio IV, a adesão de Correr, em 1432, ao concílio de Basileia, contra a vontade e sentimento de seu primo, que já então se confrontava com o concílio na tentativa de reafirmar a autoridade pontifícia ${ }^{497}$.

Correr participará no concílio de abril de 1433 até setembro de 1434, quando se reúne ao seu primo, que entretanto fora constrangido a fugir de Roma pela instabilidade e se refugiara em Florença, onde viria a convocar o seu próprio concílio. O reencontro florentino parece marcar a reconciliação entre os dois fundadores de Alga, tendo no entanto Correr mantido uma presença mais discreta nos assuntos da Igreja, provavelmente devido ao seu estado de saúde debilitado, que o sobrinho Gregório menciona ${ }^{498}$ e que se percebe do pedido que faz em 1437 para dispor dos seus bens em testamento ${ }^{499}$.

Depois da longa carreira eclesiástica, de bispo e cardeal, regressa aos claustros de Congregação de Alga, onde transcorrem os últimos anos da sua vida. Depois de dispor dos seus bens, recolhe ao mosteiro de S. João Degolado de Pádua, acompanhado da sua biblioteca ${ }^{500}$, e onde terminará os seus dias a 19 de janeiro de 1445. Corpo e biblioteca repousarão depois no mosteiro de S. Jorge em Alga, cabeça da sua Congregação ${ }^{501}$.

Além de ser um dos fundadores deste novo modo de vida, de clérigos seculares de vida comum, com os quais se manteve ligado mesmo para além da sua saída para a cúria romana, e para além do seu próprio exemplo de vida, António Correr demonstrou ser um homem que se situou entre os círculos contemporâneos que propugnavam pela reforma da Igreja, sendo ele próprio motor de reforma.

\footnotetext{
${ }^{496}$ Idem, ibidem.

${ }^{497}$ Idem, ibidem.

${ }^{498}$ CORRER, 1757: 13, 14 (morte), 17 e segs. (fala das condições de saúde nos últimos anos de vida).

${ }^{499}$ UGINET, 1983.

${ }^{500}$ Acerca desta biblioteca $v d$. BARBATO, 1959.

${ }^{501}$ TOMASINI, 1642: 260 e segs.; CORRER, 1757: 20 e segs.; UGINET, 1983.
} 
Já foram mencionados os seus contactos reformistas anteriores a Alga, nomeadamente a sua formação entre os dominicanos observantes, importa destacar outros contactos, outros apoios, outras atuações, que deixam antever em António Correr o clérigo reformista.

Do período fundacional de Alga, e da convivência comum entre 1403 e 1406, ficou o contacto com Luís Barbo. Se, como defendem Tassi, Pratesi e Tramontin ${ }^{502}$, só é possível compreender a reforma de Luís Barbo em St. ${ }^{a}$ Justina de Pádua e em Treviso pelas suas relações estruturais com Alga, do mesmo modo só se pode compreender a reforma de St. ${ }^{a}$ Justina de Pádua, e a criação da observância beneditina que se lhe seguiu, pelas relações que parecem ter existido entre Barbo e António Correr.

Após a sua eleição a Papa, e do lançamento mais eficaz da carreira eclesiástica dos sobrinhos Correr e Condulmer ${ }^{503}$, Gregório XII concede-lhes os meios necessários para sustentar a sua nova posição, recorrendo à plenitude do sistema beneficial, com benefícios eclesiásticos efetivos (pela concessão de dioceses, seja como prelados ou administradores), mas também pela concessão de mosteiros em comenda.

A António Correr Gregório XII entrega, a 21 de agosto de 1407, a comenda da paduana abadia beneditina de St. ${ }^{a}$ Justina, que não estando privada de vida claustral, passava então por uma grave crise: «La desolazione dell'ambiente, l'esiguità dei monaci, il quasi impossibile controlo del patrimonio fondiario e la disastrosa situazione dei benefici ecclesiastici dipendenti dal monastero ${ }^{504}$, a que não era estranho o controlo da abadia pela elite paduana que, em 1404, era vencida por Veneza e afastada do poder ${ }^{505}$.

A nomeação de Correr a comendatário de St. ${ }^{a}$ Justina abre um novo período para a abadia. Residente na cúria romana, António Correr parece ter mantido intacto o que podemos considerar ser um entendimento reformista da Igreja, e que enquanto comendador implicava uma efetiva preocupação com as comunidades que lhe estavam consignadas ${ }^{506}$.

No caso específico de St. a Justina, que terá sido uma das primeiras comunidades a ser-lhe dada em comenda, e atendendo ao grau de crise em que se encontrava mosteiro e comunidade, Correr procura uma solução institucional que não só garanta uma mais eficaz gestão patrimonial (que se rever-

\footnotetext{
502 TASSI, 1952: 13: «È una premessa necessária per capire le idee di S. Giustina parlare di S. Giorgio in Alga. Sono i precedenti obbligati di un movimento spirituale, che si estese per tutta la nostra penisola» (PRATESI, 1964), «L'esempio dei canonici secolari contribuì efficacemente alla formazione spirituale dei Barbo e proprio nel contatto con questo gruppo di ecclesiastici ferventi vanno ricercati i germi della sua azione futura» (TRAMONTIN, 1984: 91 e segs.). Tramontin, ainda que não rejeite esta influência, coloca-a no entanto como um de três pilares da construção espiritual de Luís Barbo; são os outros dois as correntes reformistas que existiam na Veneza da passagem do séc. XIV ao XV (como visto um dos elementos destacados na formação de Alga) e a própria personalidade e ação de Luís Barbo.

${ }^{503}$ Como já foi mencionado, o cuidado de Ângelo Correr em promover a carreira dos seus sobrinhos, e de lhes obter benefícios eclesiásticos que a sustentassem, é anterior à sua eleição ao sólio, no entanto ganha uma magnitude imcomparável depois do conclave de 1406 .

${ }^{504}$ TROLESE, 1984b: 110. Trolese descreve o estado da abadia aquando da tomada de posse da abadia por Luís Barbo, em 1409.

${ }^{505}$ Cf. TASSI, 1952: 34 e segs.

${ }^{506}$ Assim o afirma Tassi: «Affidatagli la badia padovana, il degno prelato, non dimentico dei principi riformatori professati a s. Giorgio, cercava il modo migliore per restituire a nuova vita il monastero. Sono noti dallo scritto del Barbo gli sforzi ed i tentativi del santo cardinale» (cf. Idem, ibidem: 35, 36).
} 
teria em seu proveito), mas que devolvesse ao mosteiro o seu papel enquanto comunidade religiosa e centro de espiritualidade.

Depois de ter obtido do tio, em março de 1408, que a comunidade fosse entregue aos beneditinos de Monte Oliveto ${ }^{507}$, para a «reformationem dicti monasterii in spiritualibus et temporalibus» ${ }^{508}$, não concretizada por motivos não inteiramente esclarecidos ${ }^{509}$, vamos encontrar o Papa Gregório XII a emitir seis documentos, todos datados de Rimini a 20 de dezembro de 1408, com os quais abre o caminho à posse de Luís Barbo e inicia o processo de reforma da comunidade que resultará na criação de uma congregação beneditina observante: reverte a doação da abadia aos Olivetanos sob o argumento de não tomarem a devida posse; revoga a comenda de António Correr; promove Luís Barbo, prior de S. Jorge em Alga ${ }^{510}$, a Abade de St. ${ }^{a}$ Justina de Pádua com obrigação de mudar de hábito e professar na Ordem de S. Bento; comunica aos monges de St. ${ }^{a}$ Justina a eleição do seu novo abade; reserva para o Cardeal Correr metade dos rendimentos da abadia e nomeia os bispos de Castelo e Siena (Gabriel Condulmer) e o abade de S. Miguel de Murano para superintenderem o pagamento anual de rendas ao Cardeal Correr.

Desta massa documental, bem como de outras fontes, os investigadores que se têm debruçado sobre Barbo e a sua reforma ${ }^{511}$ concluíram que em relação a St. ${ }^{a}$ Justina existiu por parte de António Correr, particularmente como comendatário, e do seu primo Gabriel Condulmer ${ }^{512}$, o exercitar de influências junto de seu tio para promover a entrega da abadia a Luís Barbo. Nada de surpreendente, sabendo nós até que ponto a história da congregação de Alga se constrói no jogo das relações familiares e de grupo social.

Um pormenor desta concessão, bem como o resultado futuro da presença de Luís Barbo em St. ${ }^{a}$ Justina de Pádua e em Treviso, demonstram o alcance reformista destes documentos. Por um lado temos a revogação da comenda de António Correr sob a abadia, em troca de uma pensão anual sobre os seus rendimentos (afinal o objetivo da sua comenda), decisões que evidenciam que o Cardeal Correr transfere toda a autoridade sobre a comunidade. Esta decisão, que dá a Barbo a plena liberdade de atuação enquanto abade, associada ao conhecimento pessoal que dele tinham Gregório XII e os sobrinhos, permite concluir com algum grau de certeza que se esperava de Luís Barbo uma eficaz reforma da comunidade, que correspondeu de modo pleno, e para além do expectável.

\footnotetext{
${ }^{507}$ Então ainda uma jovem congregação, nascida em Siena com carácter original eremítico, por ação de S. Bernardo Tolomei (cf. BUCHOUD, 2009).

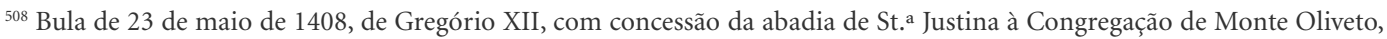
com reserva de uma renda anual para o comendatário António Correr (Transcrita em CATTANA, 1984: 323, 324).

${ }^{509}$ Cattana faz uma análise dos diversos motivos que podem ter resultado para este insucesso, conjugando os de natureza religiosa aos de natureza política, numa época em que Veneza tentava consolidar o seu domínio sobre Pádua (cf. Idem, ibidem: 312 e segs.).

${ }^{510}$ Por esta bula se comprova que Luís Barbo nunca chegou a entrar na Congregação de S. Jorge em Alga, pois menciona-o como prior expressamente professo na Ordem de St. ${ }^{\circ}$ Agostinho (cf. Idem, ibidem: 327).

${ }^{511}$ Caso de TASSI, 1952; PRATESI, 1964, as diversas contribuições em TROLESE, 1984a.

512 Tassi, de acordo com o testemunho do próprio Barbo, advoga que a ideia original terá vindo de Condulmer, que a apresentou ao tio e primo como solução para levar a cabo a reforma da abadia de St. ${ }^{\text {a }}$ Justina, que se apresentava urgente (cf. TASSI, 1952: 37 e segs.).
} 
Assim António Correr (e depois Gabriel Condulmer já como Papa, atendendo aos diversos e relevantes encargos que atribuiu a Luís Barbo, elevando-o ao episcopado ${ }^{513}$ ) além de ser uns dos fundadores de uma congregação tida por reformista, apresenta-se como parte ativa no processo que conduz ao nascimento de uma das observâncias reformadoras da ordem que está na origem do monaquismo ocidental, a Ordem de S. Bento.

A atuação de Correr neste caso, e cujo resultado se poderá considerar altamente satisfatório se entendido dentro de uma lógica de urgente necessidade de reforma de comunidades religiosas na senda de uma reforma eclesial mais vasta, será recuperado futuramente em benefício da Congregação de S. Jorge em Alga, quando em 1419 o cardeal vai renunciar à comenda do mosteiro do St. ${ }^{\circ}$ Anjo Gabriel de Verona, desprovido de vida regular, para que nele se estabelecesse um colégio de cónegos seculares de $\mathrm{Alga}^{514}$, o quinto mosteiro da Congregação e o primeiro que recebe depois do núcleo fundacional de 4 mosteiros, recebidos entre 1404 e 1407, obtidos sob a ação protetora de Gregório XII. Com esta doação do Cardeal Correr, que o recebera já do Papa Martinho V (em dezembro de 1417) e não de seu tio Gregório XII, inicia-se a segunda fase da vida da Congregação, aquela que é marcada pela plena maturidade dos seus fundadores Correr e Condulmer, o período em que não estão já sob a proteção de seu tio.

A atuação fundacional em Alga, o apoio a pessoas e instituições de carácter reformador, o constante exemplo de vida que nos remete para o conceito de reforma da Igreja pela formação e santificação do clero, a inserção em redes reformistas (além das suas ligações de juventude, o biógrafo menciona a amizade com os santos João de Capistrano (OFM), Bernardino de Siena (OFM) e Antonino de Florença $\left.(\mathrm{OP})^{515}\right)$, tornam António Correr o exemplo de um reformador dos círculos de Alga e da Igreja italiana do final do Cisma.

\section{A terceira geração e a influência do ideal reformista de Alga}

O percurso de António Correr é representativo de percursos similares desta linhagem, em que se constroem destacadas carreiras eclesiásticas através de uma economia de influências familiares, e sustentada no poder e prestígio que Veneza construiu no palco italiano e europeu dos sécs. XIV e XV, influência que pela primeira vez se faz chegar a um papado romano que, no quadro do cisma, se apresenta declaradamente italianizado.

De uma linha de influência que emerge em Ângelo Correr, e onde gravitam dois sobrinhos bispos anteriores à sua eleição ao pontificado (Ângelo Barbarigo, Bispo de Kysamos, e António Correr, bispo de Asolo), vamos encontrar o alargamento a outros sobrinhos no período pós-eleição: assim os fundadores de Alga António Correr e Gabriel Condulmer serão elevados ao episcopado, e pouco depois catapultados para o colégio de cardeais, a par do seu primo Ângelo Barbarigo.

António Correr e Gabriel Condulmer replicarão o mesmo sistema de proteção familiar, que em simultâneo criava uma rede familiar de apoio à sua própria ação (caso de Gregório XII, que ao

${ }^{513}$ Cf. Idem, ibidem; PRATESI, 1964.

${ }^{514}$ Cf. TOMASINI, 1642: 91 e segs.

${ }^{515}$ UGINET, 1983. 
nomear os três sobrinhos cardeais procurou, mais que num exercício de nepotismo, assegurar uma rede familiar de apoios no exercício do pontificado):

- António Correr com Gregório Correr, protonotário apostólico e efémero quarto patriarca de Veneza ${ }^{516}$;

- Gabriel Condulmer com Francesco Condulmer, cardeal $^{517}$ e Marco Condulmer, patriarca de Grado, e ainda com Pietro Barbo (de quem foi tio materno, mantendo a tradição de influência colateral matrilinear na construção destas carreiras eclesiásticas), Cardeal e Papa Paulo II. Nos quatro casos os biógrafos destacam que a carreira eclesiástica se constrói pela influência de seus tios ${ }^{518}$.

Realce-se neste jogo de influências familiares, e para demonstrar que a Congregação de Alga, nascida no seio desta importantíssima linhagem eclesiástica do final do cisma, teve para os seus fundadores mais que um papel fugaz, um dado revelador: estes quatro sobrinhos estiveram ligados, por influência dos seus tios, de modo mais ou menos comprometido, aos claustros da Congregação de Alga.

Gregório Correr (n. 14/09/1409, †30/11/1464), humanista e defensor da reforma eclesial (ainda que nem sempre, e com consequências negativas para si, de acordo com o entendimento reformista de seu primo Eugénio IV), terá forçosamente vivido nos claustros do convento de S. João Degolado de Pádua quando acompanhava o seu tio nos últimos tempos de vida, do outono de 1443 a janeiro de 1445 .

A sua passagem por Alga dá-se já em idade madura, quando o seu espírito está formado, no entanto parece que a ligação com o tio, imbuído do espírito de Alga e da reforma da Igreja, terá tido influência na formação do seu pensamento ${ }^{519}$.

Francesco, Cardeal Condulmer (n. ca. 1390, †30/10/1453), por influência do tio Gabriel, instala-se entre os cónegos de S. João Degolado de Pádua, enquanto estuda Direito na universidade. de Pádua, e para além das ligações com os cónegos, fica a inserção em círculos ligados a Luís Barbo, então abade de St. ${ }^{a}$ Justina de Pádua, o que demonstra mais uma ligação entre Barbo e Gabriel Condulmer, de quem o sobrinho Francesco será o principal colaborador durante o pontificado ${ }^{520}$.

O seu biógrafo acentua, na sua longa ação como cardeal curial e principal colaborador do tio, e para além das numerosas missões diplomáticas e resolução de questões administrativas em que

\footnotetext{
${ }^{516}$ PRETO, 1983. Note-se que se poderá fazer um paralelismo entre os diversos altos e baixos da carreira eclesiástica de Gregório Correr e os da carreira do seu tio e protetor. Apesar disso acabará por alcançar um desejado título episcopal, e logo o de Patriarca de Veneza, de que não tomará posse por morrer. O título patriarcal de Veneza esteve profundamente ligado à Congregação de Alga, já que os seus dois primeiros titulares foram seus cónegos (S. Lourenço Justiniano e o seu discípulo Maffeo Contarini), e o quarto era sobrinho e primo dos fundadores Correr e Condulmer.

${ }^{517}$ Curiosamente, o seu biógrafo faz notar que Francesco Condulmer continuou a tradição familiar de construção de redes de apoio à sua linhagem nos meios curiais, no caso através da promoção da carreira eclesiástica de seu primo (e sobrinho-neto de Eugénio IV) Lorenzo Zane, discípulo de Lorenzo Valla, e que foi Arcebispo de Spalato e Bispo de Bréscia (cf. OLIVIERI, 1982a).

${ }^{518}$ PRETO, 1983; OLIVIERI, 1982a; OLIVIERI, 1982b; MODIGLIANI, 2000.

${ }^{519}$ PRETO, 1983.

${ }^{520}$ OLIVIERI, 1982a.
} 
aplicava a sua cultura jurídica, o seu papel em prol da reforma das instituições eclesiásticas, nas quais assume uma postura decididamente pastoral.

Como bispo de Verona (1438), e apesar de não residir na diocese pelos ofícios curiais que gradualmente aumentavam em número e relevância, procura implementar o pensamento reformista de seu tio Eugénio IV, traduzido particularmente na moralização e formação do clero, para o que institui um fundo destinado à formação de jovens clérigos.

Será na formação clerical e no acentuar da dimensão pastoral que se vai desenvolver a reforma de Francesco Condulmer, que caminha a par de seu tio que em Florença fundara, em 1436, um colégio para formação de clérigos. Francesco Condulmer, como o tio, antecede, nas palavras do biógrafo, as preocupações dos reformistas do final do séc. $X V^{521}$.

Marco Condulmer (n. ca. 1405-1408, † ca. 1460), aquele que mais diretamente esteve ligado à Congregação de Alga, tendo a pedido do tio Cardeal Gabriel Condulmer entrado na congregação no mosteiro fundacional de S. Jorge em Alga. Dele sairá ainda muito jovem, chamado a Roma por seu tio para integrar o seu séquito.

A eleição do tio marca um novo ponto na carreira eclesiástica de Marco, que ainda em vida de Martinho V tinha obtido, por sua influência, a diocese de Avinhão (ainda recentemente residência do papado) e o território francês que a Igreja tinha sob sua soberania. A nomeação e atuação de Condulmer não foi pacífica e levou à sua transferência para o governo de Bolonha, onde acabou envolvido em lutas intestinas.

Retornado à cúria, foi eleito Arcebispo de Tarantasia, Patriarca de Grado e, por fim, Patriarca de Alexandria. Teve diversas missões em vida do tio, uma das quais de grande alcance para os interesses deste Papa, como legado a Constantinopla para tratar da união das Igrejas Latina e Grega, a cujo decreto de união esteve presente, em 1439, no concílio de Florença. A sua carreira parece ter entrado num impasse após a morte de Eugénio ${ }^{522}$.

Pietro Barbo, Papa Paulo II (n. 23/02/1417, P. 30/08/1464, †26/07/1471), foi da sua geração o mais bem-sucedido, ao atingir a tiara pontifícia, onde substituiu Pio II.

Deveu, tal como os seus primos Condulmer, a sua carreira eclesiástica ao tio Gabriel. Protonotário com 19 anos, cardeal e bispo com 23 (em 1440), manteve um papel destacado na cúria mesmo depois da morte do tio, talvez motivado pelas boas relações que parece ter tido com Nicolau V Parentucelli e com Calisto III Bórgia, mas também do apoio ocasional do Estado Veneziano, a que Barbo corresponderá, quando Papa, com uma política filo-veneziana. Bispo de Vicenza em 1451, acabará por ser eleito Papa no conclave de 1464.

\footnotetext{
${ }^{521}$ Idem, ibidem. «Alcune lettere della fine del 1441 inviate dal Condulmer al Consiglio comunale veronese — il quale si era fatto portavoce delle diffuse critiche al provvedimento pontificio - mettono in luce gli elementi più significativi del problema: la cultura del clero affiancata da un legame rinnovato, su fondamenti evangelici, non solo fra il pontefice ed i vescovi, ma anche fra questi e le comunità a cui venivano preposti. Era un'importante anticipazione della problematica "pastorale» che verso la fine del '400 verrà ripresa in una prospettiva generale di rinnovamento della Chiesa. Il Condulmer di questi progetti diviene un elaboratore importante».

${ }^{522}$ OLIVIERI, 1982b.
} 
Na tradição de Eugénio IV, Paulo II dedicará grande esforço à afirmação do poder pontifício (a corrente conciliarista era ainda forte, mesmo na cúria), nomeadamente na construção de uma imagem simbólica da dimensão majestática do poder pontifício, traduzida na magnificência pública da cúria e no recurso constante aos símbolos de poder, de que o uso público e constante do triregnum papa ${ }^{23}$ é exemplo.

Afasta-se de seu tio precisamente na falta de uma ideia tão clara e tão forte da importância e da necessidade da reforma da Igreja. Retenha-se apenas que um dos seus mais próximos colaboradores, Rodrigo Arévalo, autor de obras de defesa da supremacia do poder e autoridade pontifícia, nas quais plasma a linha de pensamento do próprio pontífice, irá sustentar que qualquer reforma da Igreja deve ter origem na iniciativa do $\mathrm{Papa}^{524}$.

Este pensamento do colaborador de Paulo II expressa o que foi o dilema do pontificado de Eugénio IV: a crença da necessidade de reforma da Igreja, mas (ante um poder pontifício que se apresenta fraco no pós-cisma e perante um conciliarismo triunfante) a incapacidade de aceitar que se faça sem ou em detrimento da autoridade do Papa.

Não estando diretamente ligado à Congregação de Alga, sem ter passado pelos seus claustros, ainda assim será Paulo II a dar aos cónegos (a seu pedido) como juízes conservadores o patriarca de Veneza e o abade de S. Jorge Maior de Veneza (mosteiro reformado pela congregação de St. ${ }^{a}$ Justina de Pádua ${ }^{525}$ ). A eles o Papa cometerá, com os 12 cónegos mais velhos da congregação, a revisão dos costumes da Congregação, que se assume como a sua primeira revisão normativa ${ }^{526}$.

Paulo II promoveu a carreira do seu parente, Marco Barbo (n. 1420, $\dagger$ 1491), Bispo de Treviso, Vicenza e Patriarca de Aquileia, que faz Cardeal de S. Marco (o seu próprio título cardinalício). Foi protetor da Congregação de Alga, prolongando as relações estabelecidas pela linhagem fundacional entre a Santa Sé e a Congregação veneziana ${ }^{527}$. Era Marco Barbo sobrinho de Luís Barbo (que o antecedera na cátedra de Treviso), e terá sido um prelado austero, figura relevante na cúria, a quem chegou a ser dado encargo na reforma da Ordem dos Hospitalários. Ainda que tenha acumulado benefícios eclesiásticos, parece ter encarado o sistema de comenda com o carácter de seriedade no eficaz apoio às comunidades, de que se pode encontrar o exemplo do priorado de S. Tiago de Pontida, em Bréscia, onde introduziu os monges da abadia de St. ${ }^{a}$ Justina, da reforma de seu tio.

\footnotetext{
${ }^{523}$ Segundo o biógrafo, Paulo II teria predilecção pelo uso da tiara pontifícia que seu tio Eugénio IV mandara buscar a Avinhão, e que segundo a tradição fora a que o imperador Constantino dera ao Papa Silvestre I como testemunho da entrega do poder de imperium à Igreja. Esta escolha é tanto mais interessante quanto em 1440 Lorenzo Valla demonstrara a falsidade da doação constantiniana, mas revela até que ponto este Papa, como o tio, pretendiam reconstruir uma frágil autoridade pontifícia (cf. MODIGLIANI, 2000). ${ }^{524}$ Idem, ibidem.

${ }^{525}$ Que já integrava o conjunto de 4 abadias beneditinas que em 1419, por bula de Martinho V, deram origem à Congregação de St. ${ }^{a}$ Justina (cf. FOIS, 1984: 231).

526 TOMASINI, 1642: 332 e segs.

${ }^{527}$ Como foi identificado na carta do Doge Cristoforo Mòro ao orador de Veneza Pietro Barbo, de 16 de dezembro de 1467 (cf. ASV - Fundo Veneto I, doc. 1117), em que menciona como protetor da Congregação o Cardeal de S. Marcos, que então era Marco Barbo (cf. GUALDO, 1964b).
} 
Como patriarca de Aquileia Marco Barbo tentou restaurar a disciplina eclesiástica entre os seus clérigos, tendo celebrado concílio provincial. Partilhava do entendimento de Paulo II e de Eugénio IV sobre a direção de onde deveria vir a reforma da Igreja:

Le sue sollecitudini non avevano solo per oggetto gli istituti avuti in commenda, ma si allargavano a tutta la Chiesa, di cui auspicava una energica riforma, a partire dal suo capo, il pontefice; per questo sosteneva la necessità che fossero creati buoni cardinalij28.

\subsection{EUGÉNIO IV (GABRIEL CONDULMER), A ESTRUTURA INSTITUCIONAL E A CONSTRUÇÃO MATERIAL}

\section{Eugénio IV}

Gabriel Condulmer, Cardeal presbitero do título de São Clemente, no dia 3 de março ano de 1431, no mosteiro de Santa Maria Sopra Minerva de Roma foi eleito em Sumo Pontífice, dia XI desse mês frente à Basílica de São Pedro foi coroado, cerca da aurora do dia 23 de fevereiro do ano de 1447, no palácio Vaticano partiu para o Senhor ${ }^{529}$.

Assim se exprime um códice da Biblioteca Vaticana para registar os dados extremos do pontificado de Eugénio IV.

Por sua vez, os Diaria de Roma informam-nos que a 19 de fevereiro de 1431 Martinho V sofre uma apoplexia; morre no dia seguinte. A 1 de março os cardeais reúnem-se em conclave em Santa Maria sopra Minerva, onde dois dias depois Gabriel, Cardeal Condulmer, é eleito Papa, tomando o nome de Eugénio IV. O Diário Romano regista ainda que a 11 desse mês o Papa é coroado na sua Sé, a basílica de $\mathrm{S}$. João de Latrão ${ }^{530}$.

O novo pontífice, como vimos, não é estranho ao sólio pontifício, onde antes dele, e no período final do Cisma, pontificou o seu tio Gregório XII. O seu pontificado não estará isento de controvérsias, e será igualmente assombrado pelo fantasma do cisma, de um Duque Amadeu de Sabóia, que o concílio de Basileia, em aberta oposição a Eugénio IV, elegerá Papa Félix V, o último antipapa da Igreja ${ }^{531}$. Não deixa de ser paradigmático que a principal luta do pontificado de Eugénio seja contra o concílio e contra a ideia conciliarista, a mesma que tinha dado resolução à crise cismática.

Sobrinho de um Papa que renunciou perante o concílio, Eugénio IV procura restaurar a plenitude da potestade pontifícia perante a mesma instituição, e o resultado será uma inversão de tendên-

\footnotetext{
${ }^{528}$ Idem, ibidem.

${ }_{529}$ Traduzido livremente do latim original: «Eugenius IV. Gabriel Condolmerius presb. Card. Tit. Sancti Clementis die 3 Martii anno 1431 in Monasterio Sanctae Mariae supra Minervam Romae in Summum Pontificem eligitur, die XI eiusdem mensis antefores Basilicae Beati Petri coronatur, die 23 februarii circa auroram anno 1447 in Palatio Vaticano migravit ad Dominum» (cf. BAV - Manoscritti, VAT.LAT.12131).

${ }^{530}$ BAV - Manoscritti, VAT.LAT.7167 - Diaria seu acta [Romanorum Pontificum] ab anno 1378 usque ad 1596... Difere do documento anterior que afirma ter sido o Papa coroado frente à basílica de São Pedro.

${ }^{531}$ BLACK, 1998.
} 
cias: do concílio dos três Papas a Igreja passa ao Papa com dois concílios ${ }^{532}$. Mas sobre esta questão o ponto 1.3.3. deixou já uma visão clara.

As complexidades do pontificado de Eugénio IV, que parece a muitos títulos ter sido um pontificado difícil, são relevantes para perceber o modo como um homem austero, com um percurso associado a uma determinada ideia de reforma da Igreja, acabará por não conseguir, atingido o vértice da pirâmide eclesiástica, empreender uma reforma mais alargada do que aqueles esforços reformistas que se conseguem identificar no seu pontificado, e de que o apoio às Congregações de Alga e de Vilar de Frades (que de S. João Evangelista só a partir de 1461) é um dos mais relevantes exemplos.

\subsubsection{Gabriel Condulmer - Cónego, Bispo e Cardeal: perfil de um jovem reformador}

Gabriel Condulmer terá nascido em Veneza em $1383^{533}$, filho de Ângelo Condulmer, mercador veneziano de nobreza não muito certa ${ }^{534}$, e de Beriola Correr, ela sim de indiscutível extração patrícia, e irmã do então bispo de Castelo, Ângelo Correr.

Os diversos autores que se debruçam sobre a sua vida, desde os cronistas mais antigos aos biógrafos contemporâneos ${ }^{535}$, acentuam que o evento determinante da sua infância e juventude foi a morte precoce do seu pai, o que permitiu que Ângelo Correr, então já um prelado em via ascendente, ocupasse o lugar de figura paterna na vida do seu sobrinho. À semelhança do que fizera com António, Ângelo Correr lança cedo as bases da carreira eclesiástica de Gabriel.

Estudará Filosofia e Teologia ${ }^{536}$, em data incerta, na Universidade de Pádua, na mesma zona onde se pensa que possa ter nascido ${ }^{537}$, já que a região de Pádua era uma das escolhidas da elite veneziana para as suas propriedades na terra ferma.

Em 1400, e como aconteceu com António Correr, Gabriel obtêm da influência do tio Ângelo Correr, então já Patriarca de Constantinopla, o primeiro degrau da sua carreira eclesiástica: a conces-

\footnotetext{
${ }^{532}$ Entenda-se, do concílio de Constança com três obediências papais (Gregório XII Correr de Roma, Bento XIII de Luna de Avinhão e João XXIII Cossa de Pisa), passa-se no pontificado de Eugénio IV a ter os dois concílios simultâneos, o de Basileia que fora ainda convocado por Martinho V, e o concílio de Ferrara-Florença que o próprio Eugénio convoca, como transferência do de Basileia.

${ }^{533}$ Esta tem sido a data mais tradionalmente aduzida, nomeadamente pelo mais recente biógrafo (HAY, 2000). Monsenhor Sartorelli (SARTORELLI, 1988), inclina-se para 1381, argumentando com a convicção pessoal de que o facto de ser presbítero em 1404 obrigaria a que, caso fosse nascido em 1383, tivesse sido ordenado muito antes dos 25 anos prescritos pelo Concílio de Viena. Esta convicção estará incorreta, na medida em que, como relembra Hay, quando nomeado bispo de Siena pelo tio Gregório XII em 1407, Gabriel Condulmer teve de ser dispensado pelo facto de ainda não ter os 25 anos de idade necessários para alcançar esta dignidade, concluindo-se que o ano de 1383 é, com toda a probabilidade, o ano efetivo do seu nascimento.

${ }^{534}$ Denys Hay (HAY, 2000), afirma-o nobre veneziano, já Sartorelli (SARTORELLI, 1988) diz que os Condulmer eram uma família distinta já na Veneza tribunícia, e de que um ramo seria elevado ao patriciado em 1381, sendo que no entanto Gabriel pertenceria a um ramo que só em atingiria este patamar em 1554.

${ }^{535}$ No $1 .^{\circ}$ caso o contemporâneo Giovanni da Bisticci (BISTICCI, 1859: 6), ou o Cardeal Querini (QUERINI, 1761: 6), no 2. Denys Hay (HAY, 2000); Monsenhor Sartorelli (SARTORELLI, 1988).

${ }^{536}$ PAPADOPOLI, 1726: 167.

${ }^{537}$ Idem, ibidem; SARTORELLI, 1988.
} 
são, pelo Papa Bonifácio IX, de um canonicato na Sé de Verona, a que se somará no ano seguinte a comenda do mosteiro de St. ${ }^{\circ}$ Agostinho de Vicenza ${ }^{538}$.

A sua participação na fundação de Alga faz-se ainda muito jovem, pois encontramo-lo na passagem de século e no seu primeiro benefício eclesiástico pelos 16/17 anos de idade.

Se em António Correr reconhece-se a opção de vida clerical como uma decisão de maturidade, a de seu primo Gabriel, com quem parece ter estado mais ou menos emparelhado, é uma opção de fundo que se pode atribuir não só à influência do tio Ângelo mas também a uma inclinação juvenil que já Bisticci deixou registada ${ }^{539}$ e de que dá testemunho, certamente mais autorizado, Luís Barbo, que do futuro Papa escreveu «quid ab infantia reformare deformata anxie concupivit» ${ }^{540}$.

Com António Correr, e depois com os outros fundadores de Alga, sob a figura tutelar de seu tio o patriarca Ângelo Correr, o jovem Gabriel Condulmer participa ativamente na formação da nova comunidade canonical, semente da Congregação.

Clérigo secular, consciente da crise da Igreja e da necessidade de reforma, Gabriel participava dos debates dos círculos reformistas, não só dos integrados pelos membros da sua família e que resultariam na fundação da comunidade de Alga, mas também pela proximidade que terá tido a uma outra figura reformista, Bartolomeu de Roma ${ }^{541}$.

Bartolomeu de Roma (n. ca. 1350, †22/09/1430), iniciou a sua vida religiosa como clérigo secular. Pensa-se que pouco depois da sua ordenação presbiteral tornou-se notável pregador itinerante, centrado particularmente na região lombardo-veneta, onde terá tido forte influência em meios reformistas, particularmente os que já se mencionaram ${ }^{542}$.

A sua pregação centrar-se-ia principalmente na reforma da Igreja, particularmente a do universo eclesiástico, não poupando nem os Papas às suas censuras. Pregador e reformador, foi igualmente asceta e místico e um influenciador importante daquele grupo de jovens clérigos que em Alga iniciavam um novo modo de vida ${ }^{543}$.

Podemos imaginar o peso que a pregação de Bartolomeu de Roma, toda centrada na reforma da Igreja e do clero, poderá ter tido no jovem Gabriel, que no testemunho de Barbo estaria desde cedo atento a estas questões.

\footnotetext{
538 TOMASINI, 1642: 6; TASSI, 1952: 14.

539 «Mori il padri, sendo lui molto giovane, e lasciollo molto ricco di beni temporali; in modo che, conosciuta a buon' ora la miseria di questa vita, volle solvere i tenaci legami de beni temporali delle ricchezze di questo infelice mondo, e dette per amor di Dio Ducati venti mila. Dispensati i beni temporali, determino volere essere erede di beni eternali [...] Entrati in questo luogo [S. Jorge em Alga] attesono a farsi perfetti nella vita spirituale» (cf. BISTICCI, 1859).

${ }^{540}$ Passagem do seu «De initiis Congregationis Sanctae Justinae de Padua», citado em TASSI, 1952: 15.

${ }^{541}$ Assim o afirma o biógrafo de Bartolomeu de Roma ZAFARANA, 1964; já TASSI, 1952, chamara a atenção para a importância das relações entre António Correr, Gabriel Condulmer e Ludovico Barbo com Bartolomeu de Roma, que seria uma das fontes de inspiração para a fundação da Congregação de S. Jorge em Alga e depois para a reforma de St. ${ }^{a}$ Justina de Pádua.

542 ZAFARANA, 1964.

${ }^{543}$ TASSI, 1952: 23, 24.
} 
A ligação de Gabriel Condulmer, bem como de António Correr e de Luís Barbo, com Bartolomeu de Roma é atestada em crónica que descreve a sua vida, e que os elege como principais exemplos (pela ordem aqui usada) das conversões obtidas pela sua pregação ${ }^{544}$.

Um exemplo da proximidade entre Bartolomeu e Gabriel é o mosteiro de St.o Agostinho de Vicenza, que em 30 de junho de 1399 é secularizado pelo bispo diocesano e entregue como benefício com obrigação de cura de almas a Bartolomeu de Roma, que no entanto só o manterá brevemente ${ }^{545}$. Em 1401 o benefício passa a Gabriel Condulmer, que apesar de absente terá no entanto utilizado os seus rendimentos para financiar a comunidade de S. Jorge em Alga. Após a sua partida para Roma e nomeação para o colégio de Cardeais, Gabriel irá, em 1408, entregar este benefício ao cónego de Alga Lourenço Justiniano, com objetivo (cumprido) de o transformar em comunidade da Congregação ${ }^{546}$.

Sabendo nós que a sucessão de Condulmer por Justiniano se dá com o objetivo de manter St. ${ }^{\circ}$ Agostinho e os seus rendimentos na órbita de Alga, podemos questionar se a sucessão de Bartolomeu de Roma por Condulmer, em 1401, terá tido objetivos similares.

Uma possibilidade, já que o percurso deste priorado vicentino parece desenhar-se, nas primeiras décadas do séc. XV, nas relações destes seus três beneficiados que o colocarão no caminho da reforma, ou como afirma Cracco: «Bartolomeo da Roma, Gabriele Condulmer e Lorenzo Giustiniani nel giro di circa trent'anni non soltanto riformarono il monastero di S. Agostino, ma consizionarono anche larghi strati della vita religiosa italiana ${ }^{547}$.

Nos anos em que se fundava a comunidade de Alga, Bartolomeu de Roma reforma os cónegos regulares agostinhos, a partir do priorado de St. a Maria de Frigionaia, em Luca, onde atua a partir de 1401 (coincidindo com a transferência do benefício vicentino para Condulmer) e onde instaura uma reforma cujas linhas mestras, como já se fez notar ${ }^{548}$, se mescla com as de Alga: vida comum, solenidade litúrgica, apostolado e exigente vida espiritual. Duas formas de vida canonical, coetâneas, dirigidas por figuras com percursos interligados, num ideal reformista comum.

A reforma dos cónegos regulares terá um avanço mais rápido que a de S. Jorge em $\mathrm{Alga}^{549}$, no número de casas religiosas reformadas, mas também institucionalmente, antecipando-se aos cónegos de Alga na organização da Congregação e na obtenção do Papa das confirmações e privilégios que solidificam a reforma, processo que com os cónegos de Frigionaia se dá durante o pontificado

\footnotetext{
${ }^{544}$ Trata-se da Cronaca Antiqua dos Cónegos Regulares de St. a Maria de Frigionaia (hoje Cónegos Regulares Lateraneneses), citada em FONSECA, 1984: 298.

${ }^{545}$ Já não o deterá em 3/01/1400 (cf. Idem, ibidem).

${ }^{546}$ Idem, ibidem: 297, 298; CRACCO, 1960.

${ }^{547}$ Idem, ibidem.

${ }^{548}$ FONSECA, 1984: 299 e segs.

${ }^{549}$ Neste ponto discorda-se de Isabel Castro Pina (PINA, 2011: 212), que defende que institucionalmente a Congregação de Alga avança mais rapidamente do que a observância dos cónegos regulares agostinhos. Como se verá no ponto 2.4.1., a executória de 1404 marca a constituição de uma colegiada, não da Congregação, que será de ca. 1424, depois da institucionalização da Congregação de Frigionaia, que em 1421 é aprovada por Martinho V. Um confronto com o processo de aprovações e concessões de privilégios pela Santa Sé (que em relação a Alga se fará no ponto 2.3.3.) demonstra bem que esta construção, que para Frigionaia foi feita por Martinho V, para Alga é obra de Eugénio IV.
} 
de Martinho V (ainda que os primeiros privilégios sejam de Gregório XII), e que na Congregação de Alga será um processo do pontificado de Eugénio IV ${ }^{550}$.

Da ligação e proximidade carismática dos cónegos regulares a Gabriel Condulmer encontram-se exemplos posteriores à sua eleição, de que o biógrafo salienta dois muito relevantes ${ }^{551}$ : a entrega da abadia camaldulense de Fiesole aos cónegos regulares durante a estadia do Papa em Florença e, em 1445, a escolha dos cónegos regulares para reformarem a comunidade encarregue da mais importante basílica de Roma, S. João de Latrão. A entrada dos cónegos regulares, agora designados Lateranenses, na basílica primacial de Roma (onde estarão apenas até à década de 1470), bem como as tentativas goradas do Papa de os fazer entrar em S. Pedro, demonstram o apreço de Eugénio IV por esta congregação, que escolhe para reformar as duas principais igrejas do cristianismo ocidental.

Nota-se assim que os anos iniciais da vida eclesiástica de Gabriel Condulmer, mesmo antes de iniciar a fulgurante carreira curial, foram muito fortes na formação do espírito do jovem clérigo.

As influências do jovem Condulmer foram as mesmas que Tassi e Cracco ${ }^{552}$ identificam para a Congregação de Alga: Ângelo Correr, Bartolomeu de Roma, e Giovanni Dominici, ou seja, os ciclos reformistas que se desenhavam na Veneza de finais do séc. XIV, centrada em figuras do clero e das prelaturas seculares, mas também (e principalmente) nas observâncias das ordens e congregações religiosas, em que no caso presente se destacam as dos Dominicanos e dos cónegos regulares Agostinhos, mas em que, na opinião de $\mathrm{Cracco}^{553}$, poderá estar também presente a observância franciscana, cujas características nota no ideal de vida perseguido pelos cónegos de Alga, e à qual Gabriel estará ligado particularmente depois da sua eleição para o sólio de S. Pedro ${ }^{554}$.

Com esta reflexão sobre as influências e as relações do jovem Gabriel Condulmer pretende-se salientar dois importantes factos: o estar desde cedo associado a círculos reformistas, em que ele próprio participou como fundador da Congregação de Alga, e o facto de esta sua ligação não ser circunstancial mas estrutural, mantendo-se para além da sua juventude, nos anos de estadia na Cúria Romana e durante o seu pontificado, podendo-se descortinar nas medidas que toma e nos apoios que concede como Cardeal e Papa.

Obtemos assim uma leitura mais rica e complexa da entrada do carisma de Alga na Congregação de S. João Evangelista, operada essencialmente a partir das relações de Eugénio IV com D. João

\footnotetext{
${ }^{550}$ FONSECA, 1984.

${ }^{551}$ HAY, 2000. Note-se no entanto que neste ponto Hay erra ao afirmar que o interesse de Eugénio IV pelos cónegos regulares agostinhos se deve ao facto de o Papa ter sido um deles, o que de facto não foi.

552 TASSI, 1952: 10 e segs., 22 e segs.; CRACCO, 1959: 70 e segs.

${ }^{553}$ Idem, ibidem.

${ }^{554}$ Observância é um conceito que etimologicamente aponta para a atenção particular e rigorosa de um referencial, que no caso das ordens e congregações religiosas se entende ser o cumprimento estrito e rigoroso do carisma e das regras fundacionais da instituição, entendendo-se deste modo que se recupera a pureza e a originalidade carismática que se perdera ou degradara no decurso do tempo. A observância é por isso um movimento de reforma dentro do conceito estabelecido por Ladner, ao reafirmar os valores pré-estabelecidos, a que acresce naturalmente a evolução dos tempos, já que uma observância não negará à partida a experiência comunitária adquirida no percurso histórico da sua ordem ou congregação, mas antes procura o reafirmar dos elementos identitários originais, normalmente identificados. Sob a questão genérica das observâncias veja-se o resumo estabelecido por Isabel Castro Pina na sua tese: PINA, 2011: 42 e segs.
} 
Vicente, que deixa assim de ser entendida isolada e fortuitamente e insere-se num contexto complexo de redes reformistas, em que por processos de (re)conhecimento os fundadores portugueses agregam-se a um movimento similar italiano, participando do capital carismático, institucional e espiritual, da Congregação de Alga.

Apesar da sua ligação permanente à comunidade de S. Jorge em Alga e sua Congregação, Gabriel Condulmer (tal como seu primo António) residirá nos seus claustros num período muito limitado, interrompido pela eleição do tio ao papado. Gregório XII chama a Roma um Gabriel ainda cónego da Sé de Verona, de imediato nomeado protonotário apostólico e tesoureiro pontifício, a que depois acrescenta o bispado de Siena para que o tio o elege, com dispensa por não ter a idade mínima de 25 anos de idade ${ }^{55}$. Pouco depois, e no primeiro consistório que seu tio celebra, Gabriel Condulmer é elevado ao cardinalato, com o título de S. Clemente.

Após a sua elevação ao cardinalato, e apesar do seu comprometimento com as obrigações curiais, Gabriel Condulmer não se desliga da comunidade de Alga e do que a circundava. Logo no ano de 1408, em que é feito cardeal, e de acordo com o testemunho de Luís Barbo ${ }^{556}$, no meio da dificuldade sentida pelo tio Gregório XII e pelo primo Cardeal António Correr de encontrar quem levasse a cabo a reforma da abadia beneditina de St. ${ }^{a}$ Justina de Pádua, será Gabriel Condulmer a sugerir Luís Barbo como a figura indicada para, professando na ordem beneditina e eleito abade da comunidade, levar a cabo a reforma que a abadia, importante centro agregador de relíquias notáveis, necessitava.

Como Tassi nota ${ }^{557}$, trata-se não só de uma escolha motivada pelo conhecimento mútuo dos tempos de S. Jorge em Alga e da relação próxima que Barbo manteve com os dois primos Condulmer e Correr ${ }^{558}$, mas o reconhecimento das qualidades de Barbo como reformador, das quais irá sustentadamente dando conta ao longo da sua vida, e que fará com que Condulmer venha a ter nele, após a sua eleição, um importante colaborador.

Além da escolha de Barbo ter tido a intervenção direta e pessoal de Condulmer, está também intrinsecamente ligada à comunidade de S. Jorge em Alga, de onde Luís Barbo era ainda prior titular, de onde sai para o seu novo encargo e de onde o acompanham dois dos cónegos da comunidade ${ }^{559}$ que, a par de dois noviços beneditinos camaldulenses ${ }^{560}$, irão constituir o grupo que acompanha 0 novo abade na sua entrada em St. ${ }^{\mathrm{a}}$ Justina ${ }^{561}$.

Ao propor uma figura próxima a si e que, pelo convívio de pelo menos 5 anos de vida comum com os cónegos de S. Jorge em Alga, estava formada no espírito da congregação que fundara, Gabriel

\footnotetext{
${ }^{555}$ HAY, 2000.

${ }^{556}$ Citado por TASSI, 1952: 37.

${ }^{557}$ Idem, ibidem: 37 e segs.

${ }^{558}$ No que são constantes aqueles que sobre Barbo escrevera: idem, ibidem; TRAMONTIN, 1984: 102; PRATESI, 1964.

${ }^{559}$ Para Trolese um dos cónegos seria Pedro Barbo, irmão do próprio Luís Barbo, a quem nomeará em 1409 seu procurador para certos assuntos (cf. TROLESE, 1984b: 111).

${ }^{560}$ Da comunidade de Murano que Tramontin identificava como uma as inspirações reformistas da comunidade fundacional de S. Jorge em Alga (cf. TRAMONTIN, 1984: 91).

${ }^{561}$ PRATESI, 1964.
} 
Condulmer e a Congregação participam na reforma da abadia de St. ${ }^{a}$ Justina de Pádua e no aparecimento futuro da reforma da ordem beneditina ${ }^{562}$, marcada pelo nascimento da observância ${ }^{563}$, já que Luís Barbo:

portava com sé a S. Giustina tutto S. Giorgio in Alga nello spirito e nella mentalità. Giunse alla sua badia com un'esperienza matura di vita spirituale e con una formazione interiore completa e profonda. Aveva trovato nel programma di S. Giorgio il pieno compimento della sua sete di perfezione religiosa e di santita ${ }^{564}$.

Mas a ligação de Condulmer à Comunidade de S. Jorge em Alga durante o seu cardinalato, seja sob Gregório XII, seja sob Martinho V, não se verifica apenas na promoção de personalidades ligada aos seus claustros, mas diretamente na promoção do seu carisma e da particularidade do seu figurino institucional de congregação de cónegos seculares, que começa a desenhar-se nestes anos.

A mais relevante nota deste apoio encontra-se logo em 1407, ano em que transita para a cúria romana, quando entrega à congregação, então com duas comunidades (S. Jorge em Alga e S. João Degolado de Pádua ${ }^{565}$ ), dois mosteiros que recebera em comenda e que estavam privadas de vida regular: o priorado de St. ${ }^{\circ}$ Agostinho de Vicenza (já mencionado e que será inicialmente entregue a Lourenço Justiniano), e a abadia beneditina de S. Fermo e Rustico da mesma cidade ${ }^{566}$. Estas cedências feitas por Condulmer à Congregação, que serão uma prática regular no seu pontificado, demonstram desde cedo a vontade expressa de favorecer o crescimento do carisma de Alga.

Além da cedência direta poderemos questionar-nos se o Cardeal Condulmer, ou em hipótese o seu primo Cardeal Correr ${ }^{567}$, terá utilizado potencialmente alguma da sua influência na concessão à Congregação de Alga dos mosteiros de S. Gregório de Bolonha e de S. Tiago de Monselice (Pádua), feitas respetivamente em abril de 1419 e dezembro de 1420 pelos bispos diocesanos Nicolau Albergati e Pedro Marcello.

Do último conhecem-se esforços para a reforma dos claustros, de que a entrega de mosteiro de Monselice a Alga é apenas um dos exemplos ${ }^{568}$, podendo-se supor que esta doação advenha do conhecimento de proximidade resultante do facto de ser veneziano e bispo de uma diocese em cuja sede

\footnotetext{
${ }^{562}$ Que na opinião de Tassi era um objetivo de Luís Barbo no momento do seu ingresso em St. ${ }^{a}$ Justina e na Ordem de S. Bento: «Il Barbo era andato a S. Giustina con un programma definitivo nelle linee generali, a riformare cioè, restaurando l'osservanza della regola benedettina» (cf. TASSI, 1952: 43).

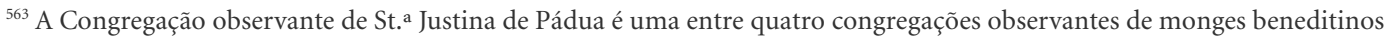
instituídas no séc. XV, a par com as de S. Bento de Valladolid, de Bursfeld e de Chezal-Benoît, revelando-se até que ponto se sentia neste século a necessidade de reformar os monges negros de S. Bento, com movimentos similares e coetâneos em Itália, Espanha, Alemanha e França. Acerca destas congregações veja-se DIAS, 2001: 142 e segs.; FOIS, 1984.

${ }^{564}$ Idem, ibidem.

${ }^{565}$ Cf. quadro anexo n. ${ }^{\circ} 2$.

${ }^{566}$ Idem, ibidem.

${ }^{567}$ Que em janeiro de 1419 abdicava da sua comenda no mosteiro do Santo Anjo de Verona para nele ser constituída uma colegiada da Congregação (idem, ibidem).

${ }^{568}$ Pietro Marcello, 2007.
} 
tinham (tal como o bispo) estudado os principais fundadores de Alga e onde a Congregação estabelecera em 1406 a segunda comunidade ${ }^{569}$.

De Nicolau Albergati, austero cartuxo eleito bispo de Bolonha em 1417, sabe-se que Condulmer o tinha em boa conta e com ele terá tido proximidade funcional, primeiro como legado pontifício em Bolonha (1423-24) e depois como colegas no colégio de cardeais para o qual Albergati entrou em 1426. Após o conclave de 1431 o Cardeal Albergati será um próximo colaborador de Eugénio IV, em missões de natureza diplomática, incluindo espinhosas missões nos concílios de Basileia e de Ferrara-Florençç ${ }^{570}$.

É possível que as relações do bispo de Bolonha com o círculo de Alga fossem anteriores à presença do Cardeal Condulmer na cidade, pois em 1419 Albergati tinha já conhecimento suficiente dos Cónegos de Alga, então apenas com quatro comunidades situadas nos Estados de Veneza, para lhes entregar um mosteiro. Tomasini afirma textualmente que a entrega do priorado deve-se à influência de Gabriel Condulmer ${ }^{571}$, e de facto a redução de S. Gregório de Bolonha a igreja secular e entrega aos Cónegos de Alga, feita por Albergati, tem aprovação pontifícia dada pelo Legado Cardeal Condulmer, em março de $1424^{572}$.

Entre 1407 e 1415 Gabriel dedica-se ativamente ao serviço do tio Gregório XII na cúria romana. A precipitação da questão cismática, com a convocação do Concílio de Constança, a adesão do tio ao concílio e sequente renúncia ao pontificado, leva a que o Cardeal Condulmer se junte, em novembro de 1415, ao concílio, onde segundo o biógrafo do primo António Correr irá ter com este estratégia concertada, objetivando a permanência no colégio de cardeais, a integração dos cardeais da obediência romana no concílio e, sobretudo, na escolha do futuro Papa ${ }^{573}$.

A eleição de Martinho V permitiu-lhe, como acontecera com António Correr, manter um papel de relevo no colégio de cardeais e na cúria romana. Será escolhido pelo Papa Colonna para Legado pontifício na marca de Ancona e em Bolonha, cargo que ocupará nos anos de 1420 a 1424, altura em que regressa a Roma ${ }^{574}$, afastado da legacia aparentemente por ter desagradado ao Papa pelas suas simpatias pró-florentinas na disputa entre Florença e Milão, contrariando as ordens de neutralidade; será substituído por Louis Aleman, que será seu firme opositor no concílio de Basileia, e promoverá neste a sua destituição ${ }^{575}$.

A falta de notícias para os anos seguintes permite supor que, após incorrer no desagrado pontifício, Gabriel terá mantido em Roma a vida comum de um cardeal de cúria, sem sobressaltos, nem eventos de destaque. Será nestes anos que contactará com o português mestre João Vicente, fundador dos lóios, que em Roma procurava sólida estrutura institucional para o movimento de clérigos seculares de vida comum que, com Afonso Nogueira e outros, fundava em Portugal. Mas isso já será outra história.

\footnotetext{
${ }^{569}$ Cf. quadro anexo n. ${ }^{\circ} 2$.

${ }^{570}$ PÀSZTOR, 1960a.

${ }^{571}$ TOMASINI, 1642: 94.

${ }^{572}$ Idem, ibidem: 111 e segs.

${ }^{573}$ UGINET, 1983.

${ }^{574}$ PICOTTI, 1932.

${ }^{575}$ PÀSZTOR, 1960b.
} 


\subsubsection{Eugénio IV Papa: um pontífice reformista}

A eleição do Cardeal Condulmer, a 3 de março de 1431, abre um caminho novo para a Congregação de S. Jorge em Alga, que depois de ter visto como Papa um dos seus protetores fundacionais, Gregório XII, tinha agora no seu sobrinho Gabriel um pontífice saído dos seus claustros, dos quais fora um dos principais fundadores.

Ao definir de um modo rápido as linhas principais do seu pontificado, Denys $\mathrm{Hay}^{576}$, um dos seus recentes biógrafos, salienta antes de mais a luta constante do Papa Eugénio IV para afirmar a autoridade pontifícia a dois níveis: a nível regional, onde procura garantir a pacificação e posse indisputada de Roma e dos Estados Pontifícios, que o leva a confrontar, logo após a sua eleição, a família do seu antecessor, os Colonna, processo longo e difícil que culmina com a revolta dos romanos em $1434^{577}$ e consequente fuga do Papa (disfarçado de monge beneditin ${ }^{578}$ ). A questão só terá resolução quase no final do pontificado, permitindo ao Papa regressar a Roma, depois de ter passado a maior parte dos 16 anos do seu pontificado noutras cidades italianas, com particular destaque para Florença e para Ferrara, onde terão lugar as sessões do seu concílio.

Num nível mais alargado, e destacando-se como a grande luta do pontífice no plano universalista da Igreja, temos a oposição do Papa ao concílio de Basileia, reunido sob convocatória do seu antecessor, intransigente na defesa do conciliarismo e que entra numa espiral que culmina na deposição do Papa e na eleição do último antipapa da história ${ }^{579}$.

Estas duas questões marcam determinantemente o pontificado de Eugénio IV. Nascido no Cisma, profundamente ligado a este como cardeal de uma das obediências, a sua carreira eclesiástica esteve irremediavelmente ligada ao tio Papa que viu resignar perante o concílio, obrigando-o a redefinir o seu papel enquanto cardeal e a sua participação nas novas redes de poder eclesiástico que emergem da resolução do Cisma e da eleição de um novo Papa. Poder-se-á supor o impacto que a renúncia de Gregório XII e o triunfo da solução conciliar terão tido em Eugénio IV ${ }^{580}$, e como tal compreender que, após a sua eleição, o Papa Condulmer rejeite o movimento conciliarista e os conciliares de Basileia.

\footnotetext{
${ }^{576}$ HAY, 2000.

${ }^{577}$ Note-se que os Colonna eram uma das mais importantes famílias da elite romana, e que o seu poder em Roma e nos Estados Papais, já tradicionalmente grande, incrementara durante o pontificado de Martinho V. Eugénio IV, consciente do domínio dos Colonna sobre o Lácio (alicerçado no poder próprio e em rede de alianças), considera que a melhor forma de garantir a sua autoridade ante um poder tão forte seria confrontá-lo diretamente. O resultado dificilmente será o esperado pelo Papa: os Colonna ripostam e fomentam, nos anos seguintes à eleição de Eugénio, a constante instabilidade em Roma e no Lácio. A ação brutal do comandante do Papa, o futuro Cardeal Giovanni Vitelleschi, contra os Colonna e seus aliados estará na origem da revolta de Roma, de 1434, que obrigará o Papa a fugir da cidade (cf. Idem, ibidem).

${ }^{578}$ Aliás Tassi sublinha este facto, num artigo que escreve sobre um dos colaboradores de Eugénio IV o beneditino Cardeal Giovanni de Primis, salientando a relação do Papa com os beneditinos da Congregação de St. ${ }^{a}$ Justina (a que o cardeal pertencia), e afirmando «nel 1434 furono i monaci che salvarono la vita al Pontifice che foggiva da Roma, sallevatasi gli contro, vestito anche lui da monaco» (cf. TASSI, 1948).

${ }^{579}$ Sobre o concílio de Basileia e a sua relação com o Papa Eugénio IV existem diversas obras que se podem consultar, destacam-se GILL, 1959; STIEBER, 1978; as diversas contribuições em AA.VV., 2008.

${ }^{580}$ A impossibilidade histórica de conhecer em profundidade a dimensão psicológica de Eugénio IV, que não deixou testemunho sobre a renúncia do tio e a supremacia temporária do concílio sobre o pontífice romano, não impede algumas suposições. A experiência dos anos finais do cisma e sua superação, conjugada com os anos de cúria romana, que o tornaram
} 
Ainda que para os expoentes do concílio de Basileia o Papa Eugénio IV figurasse como uma encarnação do demónio ${ }^{581}$, opinião diversa tiveram os que com ele privaram ${ }^{582}$. Bisticci, que conheceu o Papa no período em que este viveu na sua cidade natal de Florença, traça de Eugénio IV uma biografia (que é, saliente-se, a primeira biografia da série que dedica aos homens ilustres do seu tempo) em que o descreve nestes termos:

Messer Gabriello Condulmeri, che fui di poi papa Eugenio IV, di nazione viniziano, è stato uomo di santissima vita e costumi ${ }^{583}$.

Aprofunda a descrição do Papa Condulmer em termos que demonstram a viva impressão que Eugénio IV provocaria sobre aqueles que com ele se encontravam:

Non passerò qui io non dica delle condizioni di papa Eugenio, di grandíssima autorità. In prima egli era grande della persona, di belíssimo aspetto, macilento e grave, e di grandíssima riverenza a vederlo, in modo che non era ignuno che, per la grande autorità che egli aveva in sè, lo potesse guatare. Serbava maravigliosamente l'autorità del pontífice ${ }^{584}$.

Da descrição que faz do Papa Eugénio emerge a imagem do homem austero, de hábitos regrados e frugais ${ }^{585}$, liberal em dar audiências a quem as pedia e a distribuir esmola pelos mais neces$\operatorname{sitados}^{586}$.

Bisticci estabelece uma imagem de Eugénio IV que está de acordo com a definição que tem sido feita do modo de vida da Congregação de Alga. Descreve a simplicidade e austeridade da vida do Papa, a sua caridade, a sua devoção e dedicação à oração mental e à observância das horas canónicas com os seus religiosos de câmara, em simultâneo descreve a magnificência e solenidade da liturgia nas principais cerimónias pontifícias, bem como a grandeza e dignidade hierática que o mesmo apresentava em público ${ }^{587}$.

É difícil não encontrar paralelo na descrição que Tramontin dá da Congregação de Alga:

experimentando não só no governo da Igreja como o introduziram nas questões complexas da política italiana, criaram em Eugénio a convicção profunda da necessidade de ao Papa ser assegurada a supremacia em toda a Igreja, construção teórica a que o pontífice e os membros da sua entourage se aplicam decididamente. Sobre a questão $v d$. WATANABE, 2008.

${ }^{581}$ Foi, por exemplo, como o identificou o teólogo e conciliarista espanhol Juan de Segóvia, um dos principais opositores de Eugénio IV e da cúria romana (que conhecia bem, desde o pontificado de Martinho V) como defensor do concílio e do conciliarismo, tendo sido uma das figuras mais diretamente envolvida na deposição de Eugénio pelo concílio e a eleição de Félix V (cf. MANN, 1996).

${ }^{582}$ Assim pelo menos supõe Msr. Sartorelli (cf. SARTORELLI, 1988).

${ }^{583}$ BISTICCI, 1859: 6.

${ }^{584}$ Idem, ibidem: 16.

${ }^{585}$ Salienta que o Papa não bebia vinho, apenas água açucarada e com um pouco de canela e comia moderadamente (um só prato por refeição, simples) (cf. Idem, ibidem: 16, 17).

${ }^{586}$ Idem, ibidem.

${ }^{587}$ Idem, ibidem. 
La sua originalità stava [...] nella sintesi della vita devota, umile e solitaria, unita alla solennità della vita corale, dell'ufficiatura e della liturgia; l'umiltà di una vita nascosta e semplice, con una nobilità di contegno e di mentalità che riteneva molto dell'ambiente patrizio e signorile dal quale provenivano i fondatori ${ }^{588}$.

O testemunho de Bisticci poderá ser infamado de suspeito por parcial na descrição de uma figura que claramente admira. Corrobore-se com o testemunho de um humanista que dificilmente se poderá considerar como próximo a Eugénio IV, ainda que tenha sido um dos seus sucessores na Sé de Roma: Eneias Silvio Piccolomini, o futuro Papa Pio II.

Piccolomini, que na juventude esteve ligado a Basileia e à corrente conciliarista (chegou a ser secretário do antipapa Félix V), passou ao serviço do Imperador Frederico III, abandonando o conciliarismo e participando ativamente na reconciliação entre a Santa Sé e o Império. Esteve com Eugénio IV pelo menos duas vezes: em 1445, numa primeira missão diplomática (altura em que obtém do Papa o perdão pelo seu passado de conciliarista) e em janeiro de 1447, quando profere ante o Papa e o consistório a oratio que abre caminho à obediência do Império ao Papa, derradeira vitória de Eugénio ${ }^{589}$.

Depois da morte do Papa, e da eleição do sucessor, Piccolomini, que acompanhara em Roma os acontecimentos integrado na missão diplomática imperial, escreve uma carta a Frederico III em que narra como vira o Papa Eugénio nos últimos dias de vida:

165v. Eugenius in solio sedebat gravis, ac omni veneratione dignissimus Pater ${ }^{590}$.

Uma vez mais salienta-se a dignidade hierática do pontífice, que transmitia uma viva impressão, que Piccolomini acentua descrevendo o modo corajoso como o Papa enfrentava a doença e os últimos dias da sua vida.

Um pontífice digno, austero, moderado nos hábitos, em guerra constante com todos aqueles que de algum modo pusessem em causa a suprema potestade Papal, e cujo pontificado Piccolomini resume deste modo:

Vix Pontificem invenies sub quo plura et adversa, et secunda contigerint. Is Concilium congregavit, dissolvitque. Is bella quamplurima gessit, vicit, atque succubuit, sententiam depositionis $/ / 187 v$ sub nomine Concilii adversus se perpessus est, et ipse deponentes deposuit. Adversarium et competitorem in Pontificatu habuit, Neutralitas eo Pontifice (res nova et inusitata) coepit. Perdidit Alemaniam, et recuperavit. Graecos ad unionem redegit. Iacobitis Evangelium ignorantibus legem dedit, adversus Turcas classem missit, legatosque Juliano in Husitas potestatem praebuit. Sigismundo Cesari prius bellum intulit, post diadema concessit. Archiepiscopos, Episcoposque dignitate

\footnotetext{
588 TRAMONTIN, 1975: col. 155.

${ }^{589}$ PELLEGRINI, 2000.

${ }^{590}$ ASV - Miscellanea, Armadio II, n. ${ }^{\circ}$ 2, fl. 158 e segs. Transcrição setecentista do original da oratio enviada por Piccolomini a Frederico III e intitulada Aeneas Silvii Piccolomini Senensis Federici Rom. Regis secr.rii et Oratoris, De morte Eugenii Quarti et Coronatione Nicolai Quinti Summorum Pontificum Oratio.
} 
privavit, nec Cardinales, nec electores Imperii reliquit intactos. Sanctum Nicolaum de Tolentino canonizavit, Romae captus est, fugit, rediit, Marchiam perdidit, recuperavitque, //188 Brassium in agris iacentem excommunicatum mortuum absolvit. Ioannem Vitellescum sublimem fecit, post capi, qui mortem in carcere obiit. Bononiam recuperavit, post amisit. Regi Aragonum infestus fuit, post illi Regnum confirmavit. Venetorum prius amicus, deinde suspectos habere coepit ${ }^{51}$.

Mas de todas estas aparentes contradições do pontificado de Eugénio IV, nascidas das dificuldades em que o seu governo da Igreja se desenvolveu, e em que a sua conhecida obstinação de carácter ${ }^{592}$ parece ter desempenhado um papel, Piccolomini resume por fim:

Alti cordis fuit, sed nullum in eo magis vitium fuit, nisi quia sine mensura erat, et non quod potuit, sed quod voluit aggressus est ${ }^{593}$.

Entre a admiração de Bisticci, e o respeito admirativo de Piccolomini nascido (quase que podemos supor que a contragosto) da inteireza moral e da impressionante figura deste pontífice austero, concorda-se na construção de uma imagem que se poderá associar sem dúvidas à do homem que desde jovem abraçou o estado eclesiástico com um reconhecido empenho na reforma da Igreja, que para ele sempre foi antes de mais a reforma do clero.

A este respeito, o mais relevante para esta obra, sigamos o testemunho de Bisticci que, entre as características do pontificado de Eugénio IV, destaca precisamente no papa Condulmer a sua faceta de reformador:

Istando la sua Santità a Firenze in questo modo, attendeva com ogni diligenza a riformare la Chiesa, e fare che i religiosi stessino à termini loro, e di conventual fargli osservanti, giusto alla possa sua ${ }^{594}$.

Fica claro, por olhar de um coetâneo, que a dedicação de Eugénio à reforma da Igreja (que, como Bisticci bem expressa, se confunde com a reforma do clero) era característica bem vincada da sua personalidade, e como tal incluída com destaque na sua biografia.

Mesmo num período particularmente difícil do seu pontificado, em que recolhe a Florença depois de ter fugido de Roma, Eugénio IV não deixa de dedicar-se à reforma eclesiástica, com particular empenho em favor das observâncias, como a dominicana e a beneditina de St. ${ }^{a}$ Justina de Pádua

\footnotetext{
${ }^{591}$ Idem, ibidem: fl. 187-188.

${ }^{592}$ Msr. Sartorelli analisa diversos autores sobre esta questão da personalidade do Papa Condulmer, e prefere concluir, com o seu biógrafo Joseph Gill que a obstinação do pontífice possa ser lida como tenácia e fidelidade aos objetivos, considerando que como tal deve ser tida por virtude e não defeito (f. SARTORELLI, 1988). Deixando de parte a questão dos vícios e virtudes, que é matéria de moral mais que historiográfica, fica no entanto registada a opinião corrente de que o carácter do Papa tinha um importante grau de inflexibilidade e determinação.

${ }^{593}$ ASV - Miscellanea, Armadio II, n. ${ }^{\circ}$ 2, fl. 188.

${ }^{594}$ BISTICCI, 1859: 9.
} 
(a que os fundadores de Alga estavam ligados), mas também dos franciscanos, que apoiou pelo empenho direto de S. Bernardino da Siena. Bisticci não deixa de registar as reformas de comunidades religiosas florentinas promovidas pelo Papa, e conclui: «Mentre visse papa Eugenio, attese, como è detto, a riformare luoghi d'uomini come di donne» ${ }^{595}$.

O empenho do pontífice em promover a reforma da Igreja, que Tassi classificou como uma «premurosa sollecitudine» ${ }^{596}$, aparece-nos assim na natural continuidade do seu percurso como jovem reformador fundador da Congregação de Alga.

Na senda do que Bisticci deixou registado, Tassi ${ }^{597}$ acentua a característica típica do pensamento reformista de Alga e dos seus expoentes máximos Eugénio IV, Lourenço Justiniano, António Correr e Luís Barbo ${ }^{598}$ : reforma da Igreja pela reforma do clero, seja ele regular, seja ele secular. Aconselha a leitura dos Registri Vaticani n. 360 a 384, do pontificado de Eugénio IV, para perceber amplamente o papel das medidas reformistas durante o seu pontificado e que se plasmam na documentação da sua chancelaria.

Para Tassi está assim claro que a ideia de reforma que movia Eugénio IV era a mesma que desde jovem movia Gabriel Condulmer, e que este desenvolvera nos anos em que, nos claustros de Alga, fundava uma nova Congregação ${ }^{599}$.

Hay releva, na dimensão reformista do pontificado de Eugénio ${ }^{600}$, a reforma da cúria e o apoio às observâncias das ordens. Nota que o Papa, apesar de ter assinado com os demais cardeais as capitulações eleitorais que antecederam o conclave ${ }^{601}$, irá posteriormente rejeitar este programa, que apesar de ser de natureza reformista colocava o foco da reforma no concílio e no aumento do poder do colégio de cardeais ${ }^{602}$. Eugénio IV apenas seguirá a ideia de alargamento do colégio de cardeais, segundo o entendimento do concílio de Constança que defendia que devia representar a Igreja na sua diversidade.

Se Martinho V criou cardeais de cinco nacionalidades (7 italianos, 5 franceses, 3 espanhóis, 1 inglês e 1 boémio ${ }^{603}$ ) o Papa Condulmer cria cardeais de 9 distintas origens (13 italianos, 4 franceses,

\footnotetext{
${ }^{595}$ Idem, ibidem: 11.

${ }^{596}$ TASSI, 1948.

${ }^{597}$ Idem, ibidem.

${ }^{598}$ Não sendo um expoente da Congregação de Alga Luís Barbo é um expoente formado na Congregação, como se pode concluir dos trabalhos sobre ele e que mencionam a importância dos fundadores da Congregação de Alga na formação do seu espírito reformista, bem como a relação estrutural que terá com os cónegos, mesmo depois da sua saída de Alga (cf. TASSI, 1952: parte I; TRAMONTIN, 1984).

599 TASSI, 1948.

${ }^{600}$ Que associa ao passado claustral do Papa que, erradamente, diz ter sido cónego professo agostinho. Erro muito comum entre os que escrevem sobre Eugénio IV, provocado não só pela ligação próxima aos cónegos Lateraneneses e a Bartolomeu de Roma, mas também por a Congregação de Alga ter professado no séc. XVI a regra Agostinha ( $v$ d. ponto 3.3.), alterando o carisma inicial e abrindo caminho a equívocos.

${ }^{601}$ Determinavam a convocação do concílio, a reforma da Igreja «in capite et membris», o alargamento internacional do colégio dos cardeais e a partilha de parte da potestade com este acerca das capitulações eleitorais veja-se RICHARDSON, 2009: 86 e segs.

${ }^{602}$ HAY, 2000.

${ }^{603}$ Trata-se aqui das criações próprias de Martinho V, e não do reconhecimento que fez de cardeais criados pelos anti-papas do Cisma (cf. CARDELLA, 1793a: 31 e segs.).
} 
3 espanhóis, 2 bizantinos, e um cardeal de Portugal, Inglaterra, Baviera, Polónia e Hungria ${ }^{604}$ ), incluindo dois cardeais bizantinos, no consistório de 1439, cuja nomeação alicerça um dos grandes esforços do pontificado: a união das Igrejas Latina e Oriental, de resultados efémeros (pela resistência da Igreja Oriental e pelo colapso do Império Bizantino em 1453), mas que reverberou largamente no imaginário do ocidente cristão e marcou o ponto em que o concílio do Papa se sobrepõe ao concílio de Basileia ${ }^{605}$.

Dos cardeais bizantinos destaca-se Bessarione ${ }^{606}$, a quem o Papa entrega o monacato bizantino (monges de S. Basílio) presentes em Itália, que o cardeal reunirá em capítulo geral na sua igreja titular em Roma (a que já reformara o culto com o apoio do Papa), prevendo uma reorganização material e uma reforma da vida religiosa. A Eugénio IV deverá os meios e autoridade para que pudesse empreender tal reforma, mas também para o apoio que dará aos franciscanos, de quem será protetor, particularmente os observantes ${ }^{607}$.

A enumeração dos apoios dados por Eugénio IV a figuras e comunidades reformistas prossegue. Mencione-se os camaldulenses, em reforma presidida pelo seu geral (e colaborador de Eugénio) Ambrogio Traversari6 ${ }^{608}$, ou o apoio pontual aos Olivetanos, com entrega de uma abadia beneditina sem vida regular para que a reformassem ${ }^{609}$.

Relevante a relação com a observância franciscana, a quem o Papa dispensa proteção e benesses e que se personaliza nas relações com duas das suas principais figuras: João de Capistrano ${ }^{610}$ e Bernardino de Siena ${ }^{611}$; que recebem do Papa proteção e sustentáculo para a sua missão, e dele são colabora-

\footnotetext{
${ }^{604}$ Idem, ibidem: 61 e segs. Para Carol Richardson (RICHARDSON, 2009: 82 e segs.), o alargamento geográfico da cooptação dos membros do colégio de cardeais deve-se antes de mais à necessidade sentida pelo Papa Eugénio IV de garantir e firmar os apoios dos poderes locais italianos ou dos príncipes cristãos.

${ }^{605}$ Note-se que os contactos aprofundados com o império Bizantino visando a união das duas cristandades vinham já do pontificado de Martinho V, compreensíveis num período em que a superação de cismas era o assunto do momento. A Eugénio IV cabe o mérito de os concluir com êxito, sobrepondo-se em toda a linha ao concílio de Basileia, que pretendia tomar em mãos as negociações (cf. GILL, 1959).

${ }^{606}$ O Cardeal Bessarione, monge oriental, intelectual, homem de corte e metropolita de Niceia, integra a comitiva grega ao concílio de Ferrara-Florença, onde pronuncia discurso inaugural, no qual participa ativamente e com claro esforço conciliador, e a quem coube (com o Cardeal Cesarini) proclamar o acto de união entre as duas Igrejas. Criado cardeal pelo Papa Eugénio, estabelece-se na cúria romana, onde se dedica antes de mais aos dois grandes empenhos da sua vida: a defesa da união entre as duas cristandades e a luta contra os Otomanos, que acabarão por conquistar o império Bizantino. Será colaborador próximo de Nicolau V, assumindo-se como figura relevante da cúria romana (cf. LABOWSKY, 1967).

${ }^{607}$ Idem, ibidem.

${ }^{608}$ HAY, 2000.

${ }^{609}$ FAGGIONI, 1986.

${ }^{610}$ Hélène Angiolini (ANGIOLINI, 2001) não deixa de registar o bom acolhimento que Capistrano e os observantes receberam do Papa Eugénio IV, salientando o seu papel como colaborador do Papa em matérias de reforma, mas também as numerosas em missões curiais e inquisitoriais que cumpre para o Pontífice.

${ }^{611}$ MANSELLI, 1967. As relações entre Eugénio IV e Bernardino da Siena não terão tido a proximidade das relações com Capistrano a quem o Papa recorreu amíude em serviço da Santa Sé. No entanto o biógrafo salienta que Eugénio protegeu Bernardino de acusações inquisitoriais de heresia, apoiou-o na sua atividade e, por duas vezes, tentou elevá-lo ao episcopado (nas dioceses de Ferrara e Urbino), o que recusou.
} 
dores em diversas missões. Do mesmo modo os encontramos (pelo menos Capistrano ${ }^{612}$ ) em relação com outras figuras centrais da Congregação de Alga: o Cardeal António Correr e Lourenço Justiniano. A relação do Papa com Capistrano terá sido tal que atribui-se a este último a intervenção decisiva para que a Observância obtenha de Eugénio IV, em 1446, a autonomização dos conventuais ${ }^{613}$.

Entre o apoio que Eugénio IV, durante o seu pontificado, dá aos claustros devem evidenciar-se aqueles a que mais duradouramente está ligado, e que são os mesmos a que os Lóios irão estar mais próximos na origem: a Congregação de Alga e a observância Beneditina iniciada em St. ${ }^{a}$ Justina de Pádua por Luís Barbo.

O jovem Condulmer terá tido uma estrita responsabilidade na formação do espírito reformista de Luís Barbo (como um dos fundadores de Alga) e o papel central na sua escolha, por Gregório XII

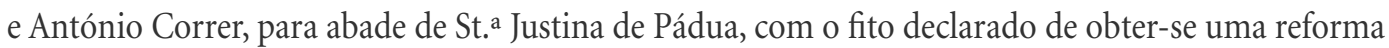
desta importante instituição monástica.

Para Tramontin ${ }^{614}$ a Congregação observante de St. ${ }^{a}$. Justina, na forma como surge nas bulas confirmatórias de Martinho V e Eugénio IV, destaca-se pela síntese entre a tradição monástica beneditina e os costumes dos mendicantes e das novas congregações religiosas, em que se destacariam os cónegos de Alga. Estes seriam a influência mais relevante pelo conhecimento direto que Barbo tinha do seu modo de vida, fruto dos anos de vida comum.

Essa influência dos cónegos lagunares encontrar-se-ia, por exemplo, na preferência por pequenas comunidades (mais facilmente controláveis e menos permeáveis aos desvios), na autoridade central do capítulo geral (organismo que para os beneditinos era recuperado de bula de Bento XII de 1336) onde tinha lugar a eleição de superiores e dos oficiais, com cargos de duração anual, e ainda na dependência das várias casas em relação à primeira de entre elas ${ }^{615}$, que se assume como cabeça da Congregação ${ }^{616}$.

A relação do Papa Eugénio com a reforma de St. ${ }^{a}$ Justina foi sempre e antes de mais a relação com Barbo, que se transporá dos claustros para a cúria e para a mitra de Treviso ${ }^{617}$.

Se o Cardeal Condulmer já influenciou ${ }^{618}$ a concessão por Martinho V, em 1419, da bula Ineffabilis $^{619}$, que marca a constituição formal da Congregação de St. ${ }^{a}$ Justina $^{620}$, e se depois foi seu cardeal

\footnotetext{
${ }^{612}$ No caso de Capistrano menciona-se a sua nomeação para, a par com o Bispo de Castelo Lourenço Justiniano, visitarem os Jesuatos e julgarem da sua ortodoxia; bem como o seu encontro com António Correr em Verona em 1438, mencionando o biógrafo de Capistrano o apoio em cúria que Correr dava à observância franciscana (cf. ANGIOLINI, 2001).

${ }^{613}$ Cf. Idem, ibidem.

${ }^{614}$ TRAMONTIN, 1984: 103 e segs.

${ }^{615}$ Como de pode ver na Congregação dos Cónegos Seculares, em que o mosteiro de S. Jorge em Alga manteve essa preeminência, como casa generalícia. Era similar entre os Lóios, em que a Casa de Vilar de Frades foi cabeça da Congregação até que por bula de Pio II de março de 1461 ( $v d$. quadro anexo n. ${ }^{\circ}$ 3), e a pedido do rei D. Afonso V, transfere esta preeminência para o mosteiro de S. João Evangelista de Xabregas.

${ }^{616}$ TRAMONTIN, 1984: 104.

${ }^{617}$ Como se poderá verificar em TASSI, 1952, e em diversas contribuições de TROLESE, 1984a.

${ }^{618}$ Como refere o biógrafo de Barbo, PRATESI, 1964.

${ }^{619}$ Para o resumo da qual veja-se WITTERS, 1984.

${ }^{620}$ FOIS, 1984: 231 e segs.
} 
protetor, ou promoveu a reforma da Basílica de S. Paulo Extramuros por monges de St. ${ }^{\mathrm{a}}$ Justina $^{621}$, a sua eleição a Papa acentua e aprofunda esse apoio, desde logo com a confirmação mais ampla da nova congregação observante (1432).

O apoio do Papa Eugénio percebe-se no contexto dos seus apoios a pessoas e instituições refor-

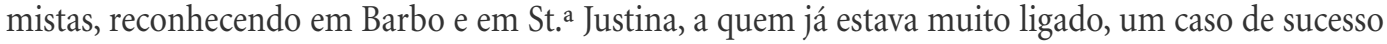
na reforma e de introdução feliz do movimento observante.

Ante a necessidade de encontrar apoios firmes para o exercício político e pastoral do seu difícil pontificado, bem como recrutar colaboradores de confiança ${ }^{622}$ que partilhassem do seu entendimento de Igreja, Eugénio IV escolhe na Congregação de St. ${ }^{a}$ Justina alguns próximos colaboradores. Mencionem-se três exemplos:

- Luís Barbo - A proximidade de longa data aprofunda-se logo após a eleição de Eugénio IV, que entrega a Luís Barbo encargos da mais alta confiança. De 1432 a 1434 será legado do Papa ao concílio de Basileia, onde desenvolve importantes contactos diplomáticos para o pontífice ${ }^{623}$, que em 1436 o nomeia para, com o bispo dominicano Tommaso Tommasini Paruta ${ }^{624}$, ser visitador apostólico no patriarcado de Aquileia.

Em 1437 Eugénio escolhe-o para a diocese de Treviso, onde será bispo reformador, nomeadamente para com o seu clero diocesano, que pretende de vida morigerada. Na linha da ação de Eugénio IV, que fundara em Florença, Bolonha e Pistoia colégios para a formação dos futuros clérigos, Barbo funda uma instituição similar em Treviso ${ }^{625}$.

Pesce faz notar que, nos anos que se seguem a 1435, Eugénio IV e Barbo pensam e põem em prática o seu entendimento de formação escolar, moral, pastoral e litúrgica dos futuros clérigos, em paralelo com as sessões do concílio de Basileia que trataram da reforma do clero. Nos anos que se seguem às fundações de Eugénio IV (de 1436) e de Barbo (de 1437) diversos bispos criarão instituições similares; Pesce menciona 6 casos até ao ano da morte do Papa, todos ligados a Eugénio e/ou a Luís Barbo ${ }^{626}$.

\footnotetext{
${ }^{621}$ PRATESI, 1964.

${ }^{622}$ Nota-se em Eugénio a necessidade sentida por seu tio Gregório XII de se rodear de colaboradores da mais estrita confiança, pelo que recorre ao apoio de sobrinhos que promove na carreira eclesiástica, ou de amigos próximos da juventude (como Luís Barbo). Tal está na origem, quase coetânea, de acusações de nepotismo, que Bisticci afasta, ao afirmar que o Papa apesar de se rodear de parentes nunca os tinha favorecido com bens do estado temporal da Igreja (cf. BISTICCI, 1859: 17).

${ }^{623}$ PRATESI, 1964.

${ }^{624}$ Um outro colaborador de Eugénio IV, pertencente à Ordem dos Pregadores, ao grupo observante veneziano, sobre quem veja-se AGOSTINI, 1739. Bispo de Recanati e Macerata, foi escolhido por Eugénio IV para visitar os Camaldulenses em 1435 (cf. TASSI, 1948).

${ }^{625}$ PESCE, 1984: 140 e segs.

${ }^{626}$ Como Lourenço Justiniano em Veneza, o Cardeal Francesco Condulmer (sobrinho do Papa) em Verona, Albergati em Bolonha (cf. Idem, ibidem: 144,145). Acrescente-se o colégio fundado pelo Cardeal de Primis (outro colaborador próximo de Eugénio) na Catânia, por supressão de um priorado beneditino sem vida claustral e com as rendas aplicadas ao sustento e formação de clérigos pobres (cf. TASSI, 1948).
} 
- Giovanni di Primis, cardeal $(† \text { 1449 })^{627}$ — Bolseiro na Universidade de Pádua, onde estuda Direito e Teologia, é influenciado pela reforma de Barbo em St. ${ }^{a}$ Justina e endossa o hábito negro. Prior de S. Paulo Extramuros (entregue à Congregação pelo Cardeal Condulmer) em 1427, foi o grande fautor da renovação desta basílica romana. Foi em 1438 Abade de St. ${ }^{a}$ Justina e em 1436 e 1445 Geral da Congregação.

Reconhecidamente homem próximo a Eugénio IV, que lhe atribuiu diversas missões, nomeadamente como visitador de ordens e congregações, instituições caritativas e até dioceses, onde atuava de acordo com os pressupostos reformistas do pontífice. Em 1441 chegou a ser encarregue do governo de Montecassino (então ameaçado pela guerra de sucessão do trono de Nápoles).

Em 1444 foi nomeado legado e visitador geral à Sicília, cuja Igreja ainda não teria recuperado das consequências do período cismático. São-lhe concedidos poderes muito amplos, demonstrando a confiança do Papa na sua atuação. Entre as missões de que estava encarregue estaria promover a entrada da observância beneditina nos mosteiros sicilianos.

Na sequência desta legação, e na sua última criação, Eugénio IV concede a di Primis o barrete cardinalício, e entrega-lhe a administração da diocese de Catânia, onde o novo cardeal tinha removido o bispo diocesano, após inquirição, pela sua inépcia ${ }^{628}$.

Na relação do cardeal com o Papa, Tassi resume a relação do Papa com a Congregação de St. ${ }^{a}$ Justina e conclui que: "Oltre ai collaboratori, S. Giustina dava tutto il suo appogio di grande organismo religioso ${ }^{629}$.

- Os monges de Câmara do Papa - Sem o destaque de Barbo e De Primis, os monges beneditinos observantes de serviço à Câmara do Pontífice demonstram até que ponto o Papa Eugénio estava ligado a esta congregação, bem como à dos cónegos de Alga.

Aveva al suo governo in camera sua quattro religiosi: dua dell'ordine di Santa Giustina, che è la badia di Firenze, e dua degli Azzurini, di quello ordine fu papa Eugenio; avevavi uno secolare prete, tutte degne persone. Con questi quattro diceva l'ufficio el dì e la notte [... $]^{630}$.

Pode-se imaginar a relevância desta escolha do Papa, que com estes religiosos partilhava os seus dias e as suas devoções. Pequeno indicador, mas que comprova a ligação estrutural de Eugénio IV, ao longo da sua vida, às reformas que ajudou a criar.

Na relação com o clero secular Eugénio IV parece ter tido duas preocupações, a mais importante das quais o provimento das mitras diocesanas (pelo menos em Itália, para onde se dirigia o principal da sua atuação, já que desde cisma a política da Santa Sé se tinha regionalizado profundamente) em prelados com pronunciado perfil pastoral e reformador.

Basta citar, para exemplo, os casos que se referem de nomeações episcopais por Eugénio IV: Luís Barbo para Treviso, Lourenço Justiniano para Castelo (Veneza), o duplo convite a Bernardino

\footnotetext{
${ }^{627}$ Para a biografia do Cardeal de Primis veja-se FODALE, 1991.

${ }^{628} \mathrm{Idem}$, ibidem; para as relações com Eugénio IV e atividade reformista na colaboração com este veja-se TASSI, 1948.

${ }^{629}$ Idem, ibidem: 16.

${ }^{630}$ BISTICCI, 1859: 18.
} 
de Siena para Ferrara e Urbino, ou ainda a nomeação do dominicano Antonino de Florença ${ }^{631}$ para arcebispo da sua cidade; só nesta curta listagem mencionam-se três futuros santos da Igreja, sublinhando a escolha de prelados com perfil próximo ao modelo ideal da Igreja: a santidade. Retenha-se ainda a nomeação, por Eugénio IV, do fundador dos Lóios, mestre João Vicente, para as dioceses de Lamego e Viseu.

Além do provimento de prelados de cariz reformista e dotados de exemplaridade moral e pastoral, Eugénio preocupou-se com o melhoramento da formação do clero, preocupação que se encontrará posteriormente, já como medida estruturante, no Concílio Tridentino ${ }^{632}$.

A atuação de Eugénio IV nesta matéria teve efeitos concretos, ainda que localizados, na preparação dos clérigos. Destaca-se a reforma profunda da universidade de Roma e a aplicação dos rendimentos dos benefícios vagantes da Sé de Verona na fundação de uma escola para formação de clérigos, a par dos colégios fundados e já aqui mencionados ${ }^{633}$.

Pesce, ao definir a dimensão reformista da ação diocesana de Barbo, que para ele seguia o entendimento do Papa Condulmer, sustenta que a ideia e a prática reformista do pontificado de Eugénio IV deverá ser lida a partir do conceito estabelecido pelo teólogo dominicano alemão Johannes Nider, observante associado a Raimundo de Cápua que, apesar das suas simpatias conciliares, traçará na sua obra Formicarius um retrato de reforma e reformista que se poderá aplicar integralmente ao Papa ${ }^{634}$.

Nider acreditava que o grande conceito de reforma «in capite et in membris» era de tal modo genérico e abrangente que se tornava uma fórmula estereotipada, abstrata e ineficaz. Defendia a necessidade de deixar os grandes conceitos e começar a desenvolver qualquer ação no tecido vivo da Igreja seguindo o exemplo da formiga, atuando pouco a pouco com paciência e tenacidade, construindo a reforma de modo gradual e crescente, como a formiga constrói o formigueiro, robustecendo e aumentando, recomeçando após derrocada:

Così di fatto Eugenio IV intendeva lavorare, iniziando la riforma da qualche monastero; un gruppo di cenobi riformati avrebbe tracinato altri sulla stessa via; poi il movimento di bonifica si sarebbe allargato penetrando nelle città e nei borghi; $i$ vescovi provenienti da

\footnotetext{
${ }^{631}$ Santo Antonino de Florença (n. 1389, † 1459), arcebispo de Florença nomeado pelo Papa Eugénio em 1446 (a cuja morte Antonino estará presente no ano seguinte), pertencia à Ordem dos Pregadores, proximamente associado aos reformistas dominicanos, particularmente ao beato Giovanni Dominici, sendo um promotor da observância na Toscana. O seu perfil foi o de um reformista, de que é exemplo a sua nomeação por Pio II para fazer parte da comissão encarregue de preparar e pensar a reforma da Igreja, abortada pela dedicação do pontífice à causa da cruzada contra os otomanos (cf. ADDARIO, 1961).

${ }^{632}$ Trento vincou a importância da formação do clero secular, nomeadamente com a obrigatoriedade de instituir seminários diocesanos para dar aos futuros padres a formação mínima para o desempenho do seu múnus pastoral. Veja-se para o caso português PAIVA, 2000: 213 e segs. Como já se fez notar esta norma do concílio, apesar de ter tido um papel importante, não encerra em si novidade ou radicalidade assinalável, apenas sintetiza e generaliza o que já era uma preocupação anterior (cf. VENARD, 1994: 319, 320).

${ }^{633}$ HAY, 2000. O autor defende no entanto que o entendimento do Papa nesta matéria era tradicional.

${ }^{634}$ PESCE, 1984: 153, 154.
} 
ordini religiosi osservanti avrebbero esteso tale operazione nelle loro diocese. Acrescenta Pesce: Eugenio IV non vedeva la riforma in astratto, ma nella dimensione concreta, nelle forme di attuazione allora possibiliti35.

Fica assim claro que a perspetiva de reforma do Papa estava longe do conceito de uma reforma vertical, de sentido descendente, como em grande medida será a reforma preconizada por Trento, onde o Concílio pensa e prepara a reforma como um grande edifício normativo que se impõe triunfantemente ao conjunto da Igreja.

Eugénio IV, defensor do poder absoluto do pontífice e descrente da instituição conciliar, compreenderia a reforma como um conceito exponencial, talvez concebível circularmente, em que a partir de algumas iniciativas centrais (como as que o próprio Papa promove com objetivo de colocar em ação processos reformistas) se obtêm resultados que vão alargando o seu alcance, por anéis sucessivos e crescentes de impacto.

Apesar da situação da Igreja no seu conjunto não melhorar significativamente ao longo do séc. XV, as diversas pequenas reformas que a ação combinada das observâncias regulares, apoiadas por diversos pontífices (de que Eugénio IV é um bom exemplo), as ações empreendidas pelos próprios Papas e por diversos prelados de cariz reformista, geraram um capital reformador no interior da Igreja que se converteu no ponto de partida para esta pensar a sua grande reforma construída em Trento e a partir de Trento.

Neste ponto o caso de Alga é um dos paradigmáticos, porque desenvolve uma solução congreganista nova e própria, cujos elementos distintivos se poderão encontrar nas novas fundações do séc. XVI, nas congregações de clérigos regulares e seculares.

Não sendo aqui possível, mais aprofundadamente, analisar as complexidades do pontificado de Eugénio IV, fica no entanto patente a forma como entendeu, e atuou, em prol da reforma da Igreja. Ao fim de 16 anos de pontificado, limite que (segundo lenda registada por Bisticci) lhe fora previsto por uma figura misteriosa que o visitara nos claustros de Alga da sua juventude e lhe professara a tríplice tiara, o Papa Eugénio morre, corria o mês de fevereiro de 1447. Vespasiano da Bisticci descreve os seus últimos momentos, rico no sabor demi-milenar e em que a parcialidade não choca demasiado:

Sendo malato, si conobbe morire, e attese a tutte quelle cose a che attende uno fedelissimo cristiano, come lui $i^{636}$.

Regista o último pensamento do Papa para a vida que deixara ao abandonar Alga:

sospirando disse: o Gabriello, ch'era il nome suo, quanto sarebbe suto meglio per la salute dell'anima tua, che tu non fussi mai suto nè papa nè cardinale, ma fussiti morto nella tua Religione $^{637}$ !

\footnotetext{
${ }^{635}$ Idem, ibidem: 154.

${ }^{636}$ BISTICCI, 1859: 20.

${ }^{637}$ Idem, ibidem.
} 
E conclui o biógrafo:

Presi tutti i sacramenti della Chiesa, rendè lo spirito al suo Redentore, santissimamente com'era vivuto. E questa fu la fine di si degno Pontefice, lume e ornamento della Chiesa di Dio ${ }^{638}$.

\subsubsection{Eugénio IV Papa: a institucionalização da Congregação de S. Jorge em Alga}

Tem sido objetivo desta obra situar a fundação da Congregação de Alga num contexto reformista específico, marcada por algumas figuras que lhe deram estrutura carismática e institucional, que a definia como forma particular de vida congreganista. Entre estas destacar-se-ão as de Eugénio IV Condulmer como construtor institucional e Lourenço Justiniano como construtor (ou melhor dizendo redefinidor ou refundador) carismático.

O empenho fundacional de Gabriel Condulmer nos claustros de Alga, e o apoio constante que manteve depois de os abandonar para integrar a cúria romana, cresce com a sua eleição, quando promove o aumento do número de comunidades da Congregação e concede um conjunto de privilégios que concluem o seu edifício institucional normativo, e por ela da Congregação dos Lóios a quem passam por concessão.

- Entrega de mosteiros e casas religiosas - As fundações de Alga têm duas características muito destacadas e que nos indicam a natureza da própria Congregação:

1. As comunidades de Alga são, desde a origem e quase na totalidade ${ }^{639}$, instituídas sobre fundações anteriores, tanto da Ordem dos cónegos de St. ${ }^{\circ}$ Agostinho como da Ordem de S. Bento, sem vida claustral regular.

A secularização das comunidades e a sua constituição em colégio de cónegos seculares, processo preferido para posse destas comunidades (fossem adquiridas por entrega direta dos pontífices ou por renúncia dos comendatários), é assim a reforma de uma comunidade monástica no extremo da decadência, ou seja, quando perdeu qualquer característica de comunidade regular.

A Congregação de Alga é reconhecida, pelos doadores das casas da Congregação, como uma instituição cujo carisma se adequa à reforma de comunidades em crise, e neste caso com preferência em relação à observância das mesmas Ordens ${ }^{640}$.

2. As comunidades da Congregação são estabelecidas todas no decurso do séc. XV, entre 1404 e 1496. Dado particularmente relevante para perceber os limites temporais do crescimento da Congregação, e que marcará a sua capacidade de se assumir como escolha para reforma ou fundação de comunidades.

\footnotetext{
${ }^{638}$ Idem, ibidem.

${ }^{639}$ Apenas duas comunidades são fundadas de origem na Congregação de Alga: a comunidade de S. Salvador em Lauro de Roma, fundada pelo patrocínio do Cardeal Orsini em 1468 e a de S. Roque de Vicenza em 1486, oferta da própria comuna vicentina (cf. TOMASINI, 1642).

${ }^{640}$ Resta saber o motivo desta preferência: se por uma preferência pelo carisma de Alga, se pela dificuldade material e humana das observâncias beneditinas e agostinha de reformarem estas comunidades.
} 
Esta limitação temporal do processo expansionista da Congregação de Alga, que antecede em quase meio século o movimento reformista do Concílio Tridentino, coloca algumas questões difíceis de responder.

A falta de estudos aprofundados sobre a Congregação de Alga não permite perceber as motivações do processo de estagnação e decadência. Tramontin defendia ${ }^{641}$ que a decadência foi um processo de meados do séc. XVII, no entanto é anterior e já patente em meados do séc. XVI, quando o Papa Pio V, por Breve de março de 1568, ordena ao geral dos Lóios que envie 6 ou 8 cónegos para reformarem a Congregação de $\mathrm{Alga}^{642}$, na mesma época em que uma crise interna obriga o pontífice a nomear um vigário-geral e visitadores para a Congregação ${ }^{643}$ e a ordenar a Fr. Paulo Emanuel de Verona ${ }^{644}$ que faça visita por autoridade apostólica ${ }^{645}$.

Estas duas características, que encontraremos parcialmente replicadas entre os Lóios, permitem perceber, pelo quadro de fundações de comunidades da Congregação de Alga ${ }^{646}$, que o Papa Condulmer é o maior responsável pela sua entrega e que o cerne das fundações, fossem ou não da sua responsabilidade ${ }^{647}$, situam-se temporalmente até ao final do seu pontificado, já que apenas quatro das comunidades se instituíram após a sua morte.

A ligação do Papa à Congregação que fundou, a sua ação direta e indireta em prol da sua expansão, atinge um ponto culminante na sua relação com mestre João Vicente, quando consegue assegurar que o grupo fundacional dos Lóios assuma o carisma de Alga, e que consolida com a eleição episcopal de João Vicente e a concessão de confirmações e privilégios que asseguram à Congregação portuguesa a possibilidade de subsistir.

- Construção do quadro normativo e de privilégios - A natureza hierárquica da Igreja, pirâmide cujo vértice superior é o Papa, fonte de autoridade, de privilégios e de proteção, implicou historicamente que as formas de vida religiosa em si geradas, para existirem legalmente, procurassem junto do pontífice a confirmação do seu modo de vida.

Do mesmo modo, e numa sociedade ocidental dominada por uma economia relacional de privilégios, procurava-se junto do Papa a concessão destes, visando o aumento de direitos, a isenção de outras autoridades e a atribuição de alguns poderes próprios.

\footnotetext{
${ }^{641}$ TRAMONTIN, 1975.

${ }^{642}$ ASV - Indice Brevi 749, fl. 214. Para esta questão $v d$. também o ponto 3.3.

${ }^{643}$ Por Breve de 21 de julho de 1568 (cf. ASV - Segreteria dei Brevi, SEC.BREV.REG. N. o 11, fl. 20). A nomeação é feita entre religiosos da Congregação.

${ }^{644}$ Que Tomasini afirma ser frade dominicano (cf. TOMASINI, 1642: 529).

${ }^{645}$ Como se pode ver nas instruções dadas para a visita, ASV - Miscellanea, Armadio II, n. ${ }^{\circ} 34$.

${ }^{646} \mathrm{Vd}$. quadro anexo n. ${ }^{\circ}$.

${ }^{647}$ Das 17 comunidades da Congregação de Alga, 5 são entregues diretamente pelo Papa Condulmer, duas enquanto cardeal e três durante o seu pontificado (cf. Ibidem). Além das comunidades que o Papa entregou diretamente existem as que entram na congregação pela sua influência. Hipótese que já foi levantada para conventos que entram na órbita da Congregação antes da sua eleição, mas que se pode verificar com mais alguma certeza para o caso dos três conventos que Afonso V de Aragão, rei da Sicília, entrega a Henrico de Simone e que constituirão o ramo siciliano da Congregação de Alga, que Tomasini atribui à influência de Eugénio IV na adoção do carisma (cf. TOMASINI, 1642: 179 e segs.).
} 
Entre as aprovações e confirmações de modos de vida, a concessão de privilégios (e o recurso à Santa Sé, e seus representantes, para arbitrar conflitos sobre o seu uso), constrói-se o aparelho normativo e a rede de privilégios que envolve a instituição, escudando-a de intervenções externas mas determinando-lhe os limites de atuação.

É um processo gradual, que a Congregação de Alga, bem como os Cónegos Lóios, tiveram que percorrer. Uma análise desse processo, pelas confirmações e privilégios concedidos pela Santa Sé, permite a leitura do processo em si e a identificação de dados relevantes, como os limites temporais e os principais agentes envolvidos.

O quadro anexo n. ${ }^{\circ} 3$ condensa o essencial da informação sobre os diplomas pontifícios que estruturaram o modo de vida das Congregações de Alga e de S. João Evangelista, já que a aprovação da comunidade de Vilar de Frades ad instar de S. Jorge em Alga implicou a comunicabilidade de privilégios, que no entanto Eugénio IV concede explicitamente ${ }^{648}$.

A sua construção ${ }^{649}$ é feita com diplomas que vão de 1404 (ano da Letra fundacional de Bonifácio IX) a 1580 (términus desta obra), a partir de duas fontes impressas: o Livro dos Privilegios concedidos pellos Summos Pontifices, à Congregação de S. João Evangelista ${ }^{650}$, de 1594, e a Crónica da Congregação de Alga, que regista (e geralmente transcreve) os privilégios concedidos pela Santa Sé ${ }^{651}$. Além destas fontes, o quadro completou-se com o recurso pontual à Monumenta Portugaliae Vaticana ${ }^{652}$.

Tipologicamente incluem-se um conjunto de documentos distintos ${ }^{653}$ que outorgam benefícios às Congregações, categorizáveis em privilégios por concessão ou comissão ${ }^{654}$, bem como as confirmações dos mesmos concedidas pelos pontífices em resposta aos pedidos das Congregações, que procuravam garantir a sua posse contínua e segura.

\footnotetext{
${ }^{648}$ Como se pode ver na concessão de 18 de maio de 1431, que concede aos Lóios, por comissão, os privilégios da Congregação de Alga e da Ordem de S. Jerónimo (cf. quadro anexo n. ${ }^{\circ} 3$ ).

${ }^{649}$ Não exaustiva, já que estarão excluídos à partida todos os privilégios que tenham carácter particular ou temporário, que por isso não foram registados nas duas obras que serviram de fonte, bem como aqueles que à data da sua elaboração (1594 para os Lóios, 1642 para os Cónegos de Alga) já não estivessem em uso.

${ }^{650}$ Livro dos Privilegios concedidos pellos Summos Pontifices..., 1594.

${ }^{651}$ Note-se que estas duas fontes permitem cotejamento de fontes para os diplomas concedidos à Congregação de Alga. É possível perceber que a crónica de Tomasini não tem por fonte o Livro dos Privilegios dos Lóios, que regista frequentemente nos protocolos e escatocolos o espaço e o tempo em que são pedidos os documentos, notoriamente treslados de originais pertencentes aos cartórios Lóios. Estes elementos, ausentes na versão de Tomasini, (que no entanto conhecia a edição dos Lóios, TOMASINI, 1642: 177) parecem confirmar a sua afirmação de que trabalhou com os cartórios de Alga, então ainda íntegros.

${ }^{652}$ COSTA, 1970.

${ }^{653}$ Por comodidade usa-se a designação genérica de «Privilégios», ainda que nem todos os documentos se constituam como tal, por representar a maioria tipológica e pelo facto de todos os documentos serem, em última análise, em benefício das instituições a que são concedidos.

${ }^{654}$ Os privilégios eclesiásticos concedidos pela Santa Sé podem ser concedidos aos beneficiários direta e expressamente, caso em que a sua tipologia será concessão, ou por comissão, quando se atribui a instituição, comunidade ou pessoa o usufruto de privilégio concedido a terceiros (cf. BOUDINHON, 1911).
} 
Em matéria de intervenientes criou-se duas categorias: concessores (aqueles que usando de autoridade própria ou delegada concedem os privilégios) e beneficiários (ou privilegiados, aqueles a quem o benefício é concedido ou usufruem dos seus efeitos ${ }^{655}$ ).

Ao último grupo pertencem as Congregações de Alga e de S. João Evangelista, mas também os Jerónimos (como Ordem, ou por privilégios concedidos a certas comunidades), cujos privilégios passaram por comissão aos Lóios $^{656}$. Ainda que se registem documentos das três instituições note-se que o fito será sempre os Lóios, já que das três instituições é aquela a quem todos os documentos dizem respeito, por concessão ou comissão ${ }^{657}$.

Gráfico 1. N. ํ de privilégios em uso nas Congregações de Alga e dos Lóios, por beneficiário

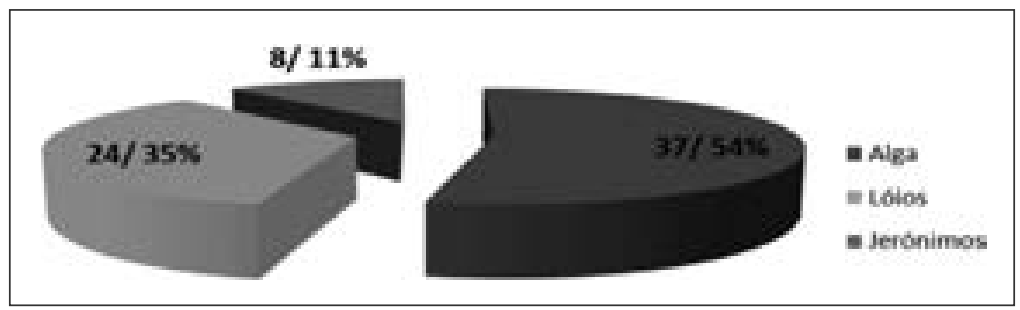

O gráfico 1 permite perceber que num conjunto identificado de 69 documentos com aprovações, determinações, privilégios e confirmações, a maioria foi concedido à Congregação de S. Jorge em Alga, em percentagem que ultrapassa os 50\%. Os documentos correspondentes aos Jerónimos estarão certamente sub-representados, já que apenas foram incluídos no Livro dos Privilegios aqueles que os Lóios utilizavam.

Não surpreende o destaque da Congregação de Alga, não só porque das suas fileiras emergiu o Papa que foi a principal fonte destes privilégios, mas também porque sendo uma Congregação italiana tinha maior proximidade ao centro da cristandade. Era em Roma, que estava a sua comunidade de S. Salvador em Lauro, cujo reitor é mencionado a intervir diretamente na obtenção de uma confirmação, único (além dos cardeais protetores) mencionado em tal situação ${ }^{658}$.

\footnotetext{
${ }^{655}$ Preferiu-se a designação concessor e beneficiário para os intervenientes nos documentos em detrimento de outras designações correntes, na perspetiva de que os termos utilizados se aproximarão mais da essência destes documentos, ou seja, de que alguém, no usufruto da sua autoridade, concede a terceiros um determinado privilégio, graça, confirmação, etc., que o irá beneficiar de algum modo.

${ }^{656}$ Concedido consecutivamente, em resposta a súplicas apresentadas pelos Lóios, por Martinho V a 18/10/1430 e 20/01/1431, e por Eugénio IV a 18/05/1431 (cf. quadro anexo n. ${ }^{\circ}$ 3). A sua inclusão, com 7 documentos, está sempre ligada aos Lóios de cujo Livro dos Privilegios foram retirados.

${ }^{657}$ Já que aos Lóios foi concedido o usufruto dos privilégios dos demais e não o contrário. No entanto, em 1596, é concedido aos Lóios um privilégio que Iacobo Tomasini (TOMASINI, 1642: 631), avoca para Alga, alegando a aplicação inversa da concessão por comissão dos privilégios de Alga aos Lóios. Tratando-se da primeira vez que tal acontece, incluiu-se este privilégio no quadro anexo n. ${ }^{\circ}$, ainda que extravase a cronologia.

${ }^{658} \mathrm{Vd}$. quadro anexo n. ${ }^{\circ} 3$, docs. de 4/12/1523, 13/02/1538 e 23/05/1547.
} 
A importância da proximidade à cúria romana para obtenção de privilégios e graças espirituais não é desprezível, como se poderá ver nos Lóios pelo esforço para fazerem representar os seus interesses na Cidade Eterna, com os resultados que se percebem pelos números que aqui se apresentam, ainda que certamente mitigados e excluindo períodos posteriores de igual obtenção de graças e privilégios.

Gráfico 2. N. ${ }^{\circ}$ de Privilégios em uso na Congregação de Alga e Lóios, por concessor

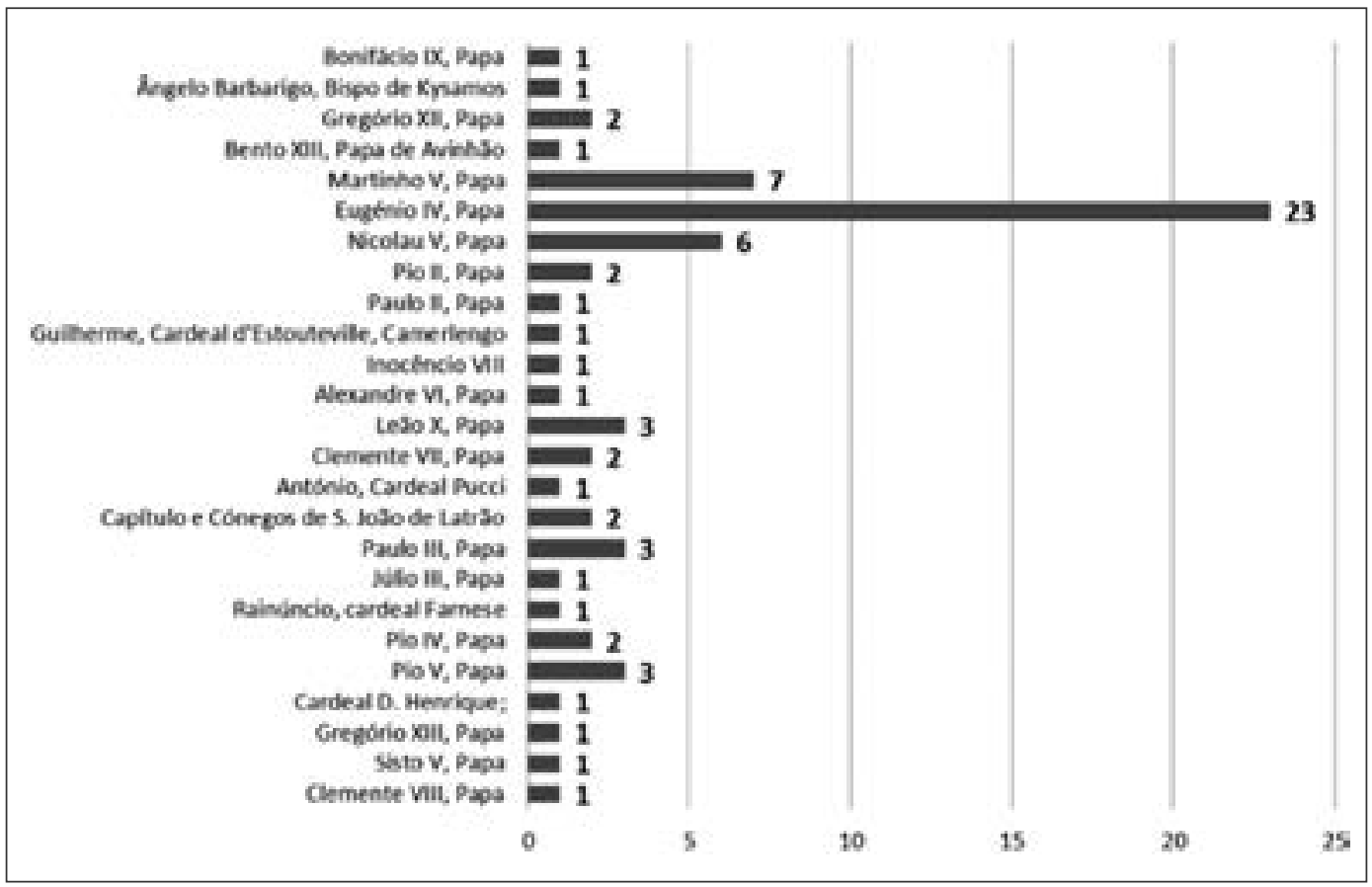

Para além dos beneficiários dos privilégios, importa conhecer os seus concessores. Uma análise do gráfico 2 permite afirmar que estes reduzem-se praticamente aos Papas, fonte de privilégios na Igreja, a que se associam ocasionalmente altos prelados, que intervêm quase sempre por seu mandato. Um caso excecional quebra esta regra: o do capítulo e cónegos da Basílica de S. João de Latrão que concedem, a título próprio, que a Congregação dos Lóios possa gozar, por comissão, dos privilégios que os Papas lhes atribuíram ${ }^{659}$.

Uma leitura rápida permite perceber que Eugénio IV foi a principal figura, no seu pontificado de 16 anos, da construção do edifício normativo e de privilégios das duas Congregações, podendo ainda supor-se a sua intervenção na obtenção das confirmações e privilégios anteriores ao seu pontificado.

Confirma-se assim a ideia, que aqui se tem sustentado, de que o Papa Condulmer foi o alicerce institucional da Congregação que fundou, e de que esse processo é, como a constituição material das

${ }^{659}$ Cf. Livro dos Privilegios concedidos pellos Summos Pontifices..., 1594: 63v. e segs. 
comunidades da Congregação de Alga, um processo da primeira metade do séc. XV, como facilmente se percebe ao analisar o gráfico n. ${ }^{\circ} 3$.

Gráfico 3. N. de privilégios em uso nas Congregações de Alga e Lóios, em intervalo de tempo

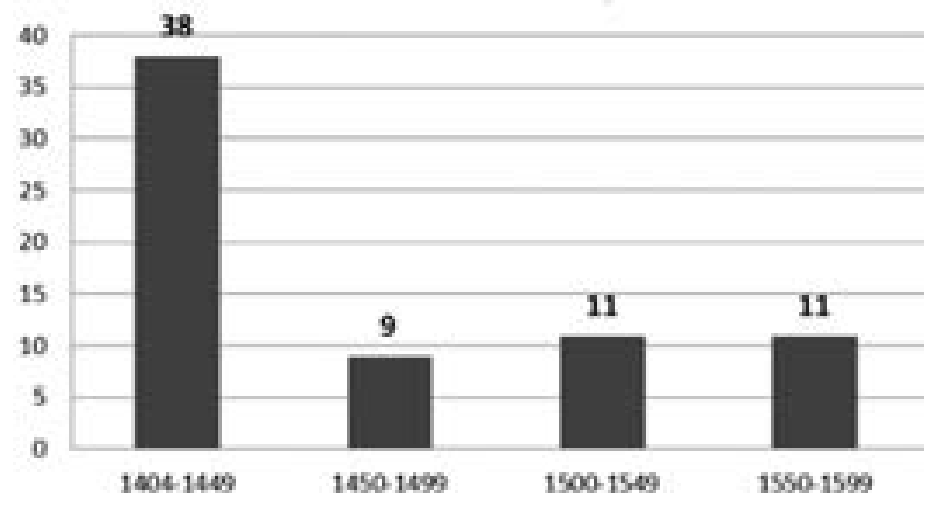

Esta leitura aprofunda-se ainda mais quando se individua no tempo (gráfico n. ${ }^{\circ}$ 4) os privilégios concedidos à Congregação de Alga, acentuando-se a identificação da primeira metade do séc. XV como o grande momento de receção de privilégios por Alga.

Dos vinte privilégios que a Congregação de Alga recebe até 1449 (e que corresponde a mais de $50 \%$ do total dos privilégios registados para o período em análise), 16 são concedidos por Eugénio IV nos 16 anos do seu pontificado, representando $80 \%$ dos privilégios concedidos ao capítulo e Congregação de Alga nos primeiros 45 anos da sua existência, e 43\% do total que receberão até ao final do séc. XVI. Mais significativo, de Martinho V (antecessor de Eugénio e, como se nota no gráfico 2, o segundo maior concessor identificado) a Congregação de Alga não recebeu nenhum privilégio.

Até à eleição de Eugénio IV registam-se para Alga quatro documentos: a Letra de Bonifácio IX e a executória do Bispo Barbarigo, ambas de 1404, a confirmação de Gregório XII dos dois documentos anteriores e um privilégio dos cónegos tomarem ordens com qualquer bispo em comunhão com a Santa Sé, ambos de $1407^{660}$.

Vinte e quatro anos depois, a 6 de dezembro de 1431, Eugénio IV, por meio de duas Letras, confirma as instituições de comunidades feitas por autoridade dos seus antecessores, as determinações estabelecidas por Barbarigo, a isenção do ordinário, e a possibilidade de receberem igrejas para novas colegiadas, bem como todos os privilégios, liberdades, imunidades e indulgências concedidas à Congregação pelo predecessores, e por outras autoridades, alargando às demais Casas ligadas a Alga, e aquelas que o vierem a ser ${ }^{661}$.

\footnotetext{
${ }^{660}$ Cf. quadro anexo n. ${ }^{\circ} 3$.

${ }^{661}$ Idem, ibidem. Por estes documentos é possível perceber que neste hiato de tempo foi concedida a isenção do ordinário e a faculdade de receberem novas igrejas para estabelecer comunidades, bem como um número desconhecido de privilégios pelos Papas e outras autoridades.
} 


\section{Gráfico 4. Privilégios concedidos à Congregação de Alga, em intervalo de tempo}

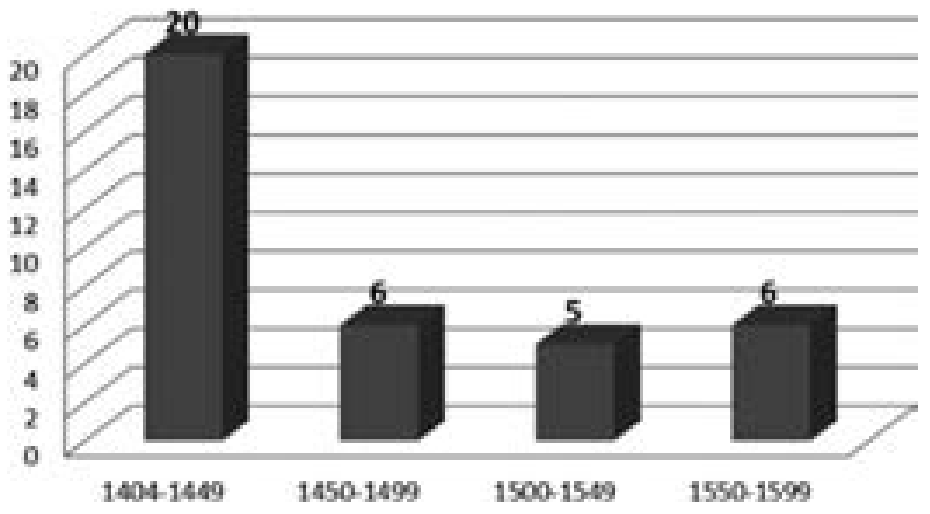

Nos anos seguintes Eugénio IV concede privilégios e uma nova confirmação geral ${ }^{662}$. São privilégios de natureza fiscal e financeira ${ }^{663}$; litúrgica e sacramental ${ }^{664}$, incluindo de natureza absolutória ${ }^{665}$ e indulgenciária ${ }^{666}$; de natureza normativa ${ }^{667}$ e até judicial ${ }^{668}$.

Com este Papa constrói-se a estrutura de privilégios e isenções da Congregação de Alga. Nos dezassete documentos sequentes à morte de Eugénio IV registados por Tomasini oito correspondem a confirmações ${ }^{669}$, enquanto nos restantes destacam-se seis concessões de dois Papas profundamente ligados à reforma Tridentina: Paulo III e Pio V. Se o primeiro concede privilégios por concessão e de natureza espiritual ${ }^{670}$, o segundo irá, no período pós-conciliar, mitigar as alterações sofridas pela Congregação de Alga, forçada a tomar votos perpétuos e a viver sob a regra de St.o Agostinho, determi-

${ }^{662}$ Concedido a 6/12/1437, e que inclui a confirmação do usufruto de todos os privilégios que cabem aos clérigos seculares.

${ }^{663}$ Isenção de décimas (de 6/2/1432 e 17/10/1446) ou de qualquer imposição fiscal eclesiástica (de 7/6/1442), perdão de taxas em dívida à Câmara Apostólica (de 25/10/1446).

${ }^{664}$ Possibilidade de receberem ordens sacras de qualquer bispo católico nas suas Casas (de 23/12/1431), licença para celebrarem os ofícios divinos em tempo de interdito, secretamente (19/7/1440).

${ }^{665}$ Privilégios de escolherem entre si confessores, com faculdade para absolverem de todos os casos, mesmo os reservados ao Bispo ou à Santa Sé (com excepção dos pecados de homicídio voluntário, mutilação de membros e bigamia), de absolverem de votos de peregrinação a Roma ou Compostela, e mesmo de votos de entrar na vida regular, sob obrigação de entrar na Congregação e nela perseverarem (privilégios de 23/5/1437, 19/7/1440, 15/9/1440).

${ }^{666}$ Privilégio de altar privilegiado com as indulgências das igrejas estacionárias de Roma (de 29/8/1440).

${ }^{667}$ Determinação de que o reitor de Alga e os seus cónegos possam prover cargos vacantes na Congregação entre capítulos gerais, sem necessidade de outra confirmação (de 17/1/1446), privilégio da Congregação poder forçar os que saíam da Congregação a largar o hábito em prazo de 15 dias, com recurso ao braço eclesiástico e secular se necessário (de 22/9/1446).

${ }^{668}$ Isenção, de todos os religiosos da Congregação, da autoridade inquisitorial, seja instituída pelo ordinário ou pela Santa Sé (de 21/1/1440).

${ }^{669}$ Confirmações gerais ou específicas: de Nicolau V, de Pio II, de Inocêncio VIII, de Leão X, de Clemente VII, Júlio III, Pio IV. ${ }^{670}$ Concede (23/01/1537) por comissão os privilégios da Congregação Cassinense (a mesma fundada por Luís Barbo em St. ${ }^{a}$ Justina de Pádua, que altera a sua designação depois da entrada da abadia de Montecassino), a que acrescenta a concessão aos Cónegos de Alga, laicos e familiares as indulgências da mesma Congregação (13/02/1538), e o privilégio das igrejas da Congregação de Alga terem altar privilegiado (23/05/1547). 
nando ${ }^{671}$ que possa gozar dos privilégios e preeminências concedidos pelos predecessores, incluindo os que pertenciam especificamente aos cónegos seculares.

Fica claro o compromisso de Eugénio IV com a Congregação que ajudou a fundar. Promoveu o alargamento do seu espaço de atuação pela concessão de priorados e mosteiros onde se instituem novas colegiadas, construiu o essencial do seu edifício normativo e de privilégios, que norteou a Congregação na sua vida interna e a situou na relação com outras entidades eclesiásticas e com a sociedade em geral.

- Promoção da disseminação do Carisma de Alga — Como se depreende da sua atuação junto de clérigos (e dos movimentos que já lhes estavam associados) que integra ao carisma de Alga: foi o caso de Henrique Simone e o ramo siciliano da Congregação; de dois clérigos que iniciam vida comum em St. ${ }^{a}$ Maria Anunciada de Sturla (Génova), confirmada pelo Papa em 1435 e unidos à Congregação de Alga em 1437, de que se separarão em 1451, no contexto de crise diplomática entre Génova e Veneza ${ }^{672}$; e o de mestre João Vicente e a Congregação de S. Salvador de Vilar de Frades.

Mas não só nas três frentes supra mencionadas se esgota a relação do Papa Condulmer com os cónegos de Alga. Outros indícios demonstram até que ponto a Congregação se manteve como parte da sua vida e atuação, configurando certamente uma das instituições cuja natureza coincidia com a visão reformista de Eugénio IV.

A Congregação foi ocasionalmente espaço de recrutamento de colaboradores do Papa, mas também espaço de formação privilegiado para membros da sua linhagem.

Citaram-se os dois cónegos de Alga que, a par de dois monges de St. ${ }^{a}$ Justina, constituíam a câmara de Eugénio IV, e que com ele viviam quotidianamente, numa posição de notável proximidade. Relembre-se os seus sobrinhos que passaram por Alga: o Cardeal Francesco Condulmer ${ }^{673}$, que viveu entre os cónegos de Pádua, e o patriarca Marcos Condulmer ${ }^{674}$, que tendo entrado pela influência de seu tio na Congregação irá sair dela para o acompanhar na cúria, onde foi seu colaborador.

Cite-se, por fim, duas figuras com particular relevo enquanto prelados claustrais e diocesanos reformistas, saídos dos claustros onde atuaram na renovação de vida para dirigirem dioceses onde aplicaram, com considerável fama, os princípios que os regiam, a ponto de um deles ser elevado às honras dos altares. Se de Luís Barbo, reformador dos monges negros e formado espiritualmente no âmbito reformador de Veneza e da nascente Congregação de Alga já muito aqui se falou, olhemos agora para Lourenço Justiniano, o cónego e Geral de Alga, pai espiritual da Congregação.

\subsection{LOURENÇO JUSTINIANO E A CRIAÇÃO DE UM IDEAL ESPIRITUAL}

[Lorenzo Giustiniani] si ritira nell'isola di S. Giorgio in Alga, dove alcuni giovani sacerdoti veneziani, preceendo simili istituzioni della riforma cattolica, senza alcuna regola, per lo meno

\footnotetext{
${ }^{671}$ Por três pvivilégios datados de 11/12/1569, 23/12/1569 e 22/05/1571.

${ }^{672}$ Conforme descreve TOMASINI, 1642: 224, referindo-se a notícias que obteve do cartório da sua Congregação.

${ }^{673}$ OLIVIERI, 1982a.

${ }^{674}$ OLIVIERI, 1982b.
} 
di quele tradizionali, si erano riuniti per attendere allo studio e alla preghiera, alla santificazione propria e della società $\grave{6}^{65}$.

O V centenário da morte de Lourenço Justiniano, em meados do séc. XX, tornou-o alvo de interesse dos investigadores e da Igreja veneziana. Os estudos, que evidenciam a sua dimensão espiritual e reformadora, percurso de vida e ação prelatícia, tiveram um amplo incentivo do Patriarca Angelo Giuseppe, Cardeal Roncalli ${ }^{676}$.

O interesse do futuro João XXIII pelo seu antecessor no patriarcado, e o sentido que os autores deram aos trabalhos realizados, revela o apelo que a figura do protopatriarca teria para os tempos modernos.

Terá a memória histórica do primeiro patriarca veneziano, homem de reforma(s) e de espiritualidade suscitado no seu sucessor, futuro Papa do Concílio e da reforma da Igreja, algum espírito de emulação? Será que o percurso do prelado quatrocentista se enquadrava de modo particular no quadro mental que guiou o percurso de Roncalli?

Não cabe aqui a resposta destas questões complexas, mas ajudam a perceber como a figura de Lourenço Justiniano, fulcral na espiritualidade inicial de Alga, e de forte marca reformista como religioso de claustro e como patriarca, deixou um sentido indelével, que sobreviveu por mais de cinco séculos e teve a capacidade de apelar a figuras cimeiras de movimentos reformistas de épocas e contextos muito diferentes.

\subsubsection{Lourenço Justiniano - Cónego de Alga}

Tinha Lourenço Justiniano o perfil-tipo do cónego de Alga dos tempos fundacionais. Nascido, cerca de 1381, numa das mais antigas Casas do patriciado veneziano, destacada particularmente nos sécs. XIV e XV ${ }^{677}$, era sobrinho materno de Marino Quirino, o cónego de Alga que figura em primeiro lugar na executória do Bispo Barbarigo.

Entra jovem na Congregação (segundo Tassi em $1400^{678}$ ), depois de uma juventude pouco conhecida $^{679}$. Na sua primeira biografia ${ }^{680}$, escrita pelo sobrinho Bernardo Justiniano, desenha-se a imagem de um jovem patrício de precoce vocação religiosa, sublinhando-se o papel de Marino Qui-

\footnotetext{
675 TRAMONTIN, 1956: 11.

${ }^{676}$ Conforme se pode ver no seu prefácio a TRAMONTIN, 1956, em obra que iniciava uma colecção dedicada à figura do $1 .^{\circ}$ patriarca veneziano. O incentivo do Cardeal Roncalli foi também a base para a tese do Pe. Napoleone Barbato sobre as fontes da doutrina ascética de S. Lourenço Justiniano, conforme a carta do mesmo ao patriarca, entretanto já eleito Papa João XXIII, e que se conserva com o exemplar da obra que remeteu ao Papa e que se conserva na Biblioteca Vaticana (cf. BARBATO, 1959; BAV - R.G.Dattil.158). No mesmo sentido vai o testemunho de Ângelo Favero, que menciona a influência de João XXIII, desde os tempos do patriarcado, no impulso aos estudos sobre Lourenço Justiniano (cf. FAVERO, 1966).

${ }^{677}$ DEL TORRE, 2007.

${ }^{678}$ TASSI, 1952.

${ }^{679}$ DEL TORRE, 2007.

${ }^{680}$ Desta biografia existe versão impressa, latina, a abrir a edição das suas obras completas, em JUSTINIANO, 1628. Os Lóios tinham tradução em português a abrir o manuscrito da tradução de uma das suas obras, o Livro da Regra e Perfeição da Conversação de monges (ANTT - Manuscritos da Livraria, n. ${ }^{\circ}$ 513, fl. 1-19). Com probabilidade trata-se do original ou cópia
} 
rino na sua construção, mas descrevendo-a em termos que permitem perceber no autor a vontade de demonstrar sinais de predestinação e construir uma imagem de santidade que pretende comprovar ${ }^{681}$.

As fontes para os seus anos de cónego em Alga não são abundantes e, com exceção da biografia do seu sobrinho Bernardo, genericamente indiretas.

Percebe-se, como Tramontin sublinha ${ }^{682}$ e pelo papel de Marino Quirino em o conduzir ao grupo fundador de Alga, que Lourenço Justiniano não pertence ao núcleo absoluto de fundadores de Alga, ainda que se integre no seu conjunto fundacional. Surge já mencionado, como diácono (contava então 23 anos), na executória de $1404^{683}$, primeira institucionalização da colegiada, e tem um papel de primeiro plano nas três primeiras décadas da Congregação, talvez o mais destacado entre os nomes citados na executória e que perseveraram nos claustros de Alga ${ }^{684}$.

Couberam-lhe alguns marcos importantes: foi o primeiro superior da Comunidade de Alga (ainda com o título prioral) eleito depois da renúncia ${ }^{65}$ de Luís Barbo. Segundo Tomasini, a 2 de setembro de 1409, e seguindo o costume eclesiástico nesta matéria, os cónegos reuniram-se «...per sonum campane in capitolo eiusdem Ecclesiae et monasterii [...]» onde, depois de evocado o Espírito Santo (certamente pelo hino de Veni Creator Spiritus e sua oração, que encontramos prescrito para o capítulo geral dos Lóios $\left.^{686}\right)$, Lourenço Justiniano foi eleito prior por unanimidade ${ }^{687}$.

Nas décadas seguintes, e até ao fim do pontificado de Eugénio IV, período para o qual se elaborou um quadro descritivo dos reitores de S. Jorge em $\operatorname{Alga}^{688}$, percebe-se que dois nomes se destacam, o de Lourenço Justiniano e o daquele que considerado o seu principal discípulo e sucessor (tanto em Alga como no Patriarcado de Veneza), Maffeo Contarini ${ }^{689}$.

\footnotetext{
da tradução desta obra atribuída à Infanta D. Catarina, filha do rei D. Duarte, conforme diz a página de rosto da sua edição impressa, feita em Coimbra por Germão Galhardo em 1531, mas que tem omissa esta biografia (cf. JUSTINIANO, 1531).

${ }^{681} \mathrm{Vd}$. capítulo I in ANTT - Manuscritos da Livraria, n. ${ }^{\circ}$ 513, fl. 3v. e segs. É provável que esta biografia fosse pensada para integrar o processo de canonização do patriarca, que o mesmo Bernardo Justiniano promoveu (cf. PISTILLI, 2002).

682 TRAMONTIN, 1984: 91.

${ }^{683}$ Livro dos Privilegios concedidos pellos Summos Pontifices..., 1594: fl. 1 e segs.

${ }^{684}$ Conhecem-se os destinos de António Correr e Gabriel Condulmer, chamados à cúria romana. De Marino Quirino, que sabemos envolvido na escolha de Luís Barbo para St. ${ }^{a}$ Justina (este menciona uma conversa com ele sobre a aceitação deste novo encargo, cf. TRAMONTIN, 1984: 102), o seu nome aparece com frequência na crónica, mas sempre como cónego, nunca tendo sido eleito para prelazias.

${ }^{685}$ Não parece existir traços de uma renúncia formal ao título prioral de Alga, que no entanto é tácita quando professa entre os beneditinos.

${ }^{686}$ Nesta matéria os Lóios guiavam-se pelo cerimonial comum da Igreja. A eleição, feita em capítulo fechado, é antecedida pela missa do Espírito Santo, e iniciada pelo hino de Veni Creator Spiritus, em que se pede a intervenção de Deus pelo Seu Espírito na eleição que irá ter lugar (cf. Statutos e Constituyções dos virtuosos e reverendos padres Conegos azuys..., 1540, fl. XIIv. e XIII). 687 TOMASINI, 1642: 79. O cronista não descreve o modo de eleição de Lourenço (calcula-se pela ausência de acta documental), que no entanto deduz-se da acta da eleição do seu imediato sucessor, Juliano de Manerbio, de onde foi retirada a citação que se inclui (cf. ASV - Fundo Veneto I, doc. 973). A cronologia da eleição de Lourenço comprova-se por procuração conservada nos fundos do cartório de Alga, datada de 8/7/1410, em que Lourenço surge como prior da comunidade (cf. ASV - Fundo Veneto I, doc. 969).

${ }^{688} \mathrm{Vd}$. quadros anexos n. ${ }^{\circ} 1$ e $1 \mathrm{~A}$.

${ }^{689}$ Cf. MENEGHETTI, 1983.
} 
Entre a sua eleição a superior em 1409 e 1433, o ano em que deixa os claustros de Alga, e num universo de vinte eleições que foi possível identificar ${ }^{690}$ para este período, Lourenço ocupou o priorado/reitorado da Congregação por sete vezes, o superior que mais tempo ocupou esta função neste período, 35\% do total.

Um outro marco: Lourenço foi, em 1424, o primeiro Geral eleito da Congregação, ao cabo de um processo, não devidamente esclarecido, em que os padres passam a entender-se como Congregação com um Geral. Tomasini sugere que, ante o crescimento do número de Casas (em 1424 seriam já sete) e a necessidade de as reger, entenderam os cónegos que seria necessário eleger um geral ${ }^{691}$. De facto a crónica não regista para os anos anteriores a esta alteração outra eleição anual que não fosse a do superior do mosteiro de Alga, passando pós-1424 a mencionar anualmente os superiores eleitos para cada comunidade.

A conclusão parece óbvia: até ao capítulo de 1424 não se pode afirmar a existência em absoluto de uma Congregação, mas sim um conjunto de comunidades que se filiam a uma comunidade principal, a de S. Jorge em Alga.

Esta conclusão também se colhe da leitura da letra de Gregório XII ${ }^{692}$, de 1407, que reduz o mosteiro de S. João Degolado de Pádua e o constitui em colegiada de cónegos, em que não menciona uma Congregação de Alga, mas nominalmente os cónegos de Alga que vão constituir o novo colégio. O mesmo padrão na concessão de St. ${ }^{\circ}$ Agostinho e S. Fermo e Rustico de Vicenza (1407), entregue diretamente em comenda a Lourenço Justiniano, ou a concessão por Nicolau Albergati do mosteiro de S. Gregório de Bolonha (1419), em que menciona os «venerabilium virorum Canonicorum Secularium monasterii, sive Ecclesiae S. Georgii de Alega», constituídos como colegiada da nova comunidade $^{693}$.

Será preciso esperar por 23 de dezembro de 1431 para que, no privilégio que Eugénio IV concede aos cónegos de se poderem ordenar com qualquer bispo católico, encontremos a designação de «Congregatione S. Georgii in Alga...» ${ }^{694}$.

A conclusão impõe-se: o entendimento das comunidades de Alga como Congregação, com um Geral (que será o reitor de S. Jorge em Alga) e um superior em cada comunidade afiliada a esta instituição, é algo que se organiza a partir do capítulo geral de 1424, e será a partir desta data (senão mesmo a partir de $1431^{695}$ ) que se poderá entender como tal.

É, pois, manifestamente impreciso situar na executória de 1404 a instituição da Congregação ${ }^{696}$, já que apenas foi a instituição de uma colegiada. A Congregação, essa, será fruto da dinâmica de cres-

\footnotetext{
${ }^{690}$ Não se encontra informação para os anos de 1411 e 1412, 1417, 1423.

${ }^{691}$ TOMASINI, 1642: 109 e segs.

${ }^{692}$ Transcrita em Idem, ibidem: 58 e segs.

${ }^{693}$ Cf. Idem, ibidem: 94-96.

${ }^{694}$ Idem, ibidem: 130-132.

${ }^{695}$ Quando encontramos a designação em uso em documentos de Eugénio IV.

${ }^{696}$ Como faz Isabel Pina quando afirma que a Congregação foi canonicamente erigida pela executória de 1404 (cf. PINA, 2011: 213). De facto foi instituída uma comunidade canonical já de facto preexistente, e nada mais, como bem salienta Monsenhor Sartorelli (cf. SARTORELLI, 1988).
} 
cimento da comunidade de Alga, multiplicada num número crescente de colegiadas e que vai evoluindo numa crescente organização interna, em que a figura de Lourenço Justiniano parece ter tido um papel central ${ }^{697}$.

Este dado dá-nos a dimensão orgânica e gradual do processo constitutivo da Congregação e ajuda-nos a compreender de um modo mais claro o processo constitutivo da Congregação dos Lóios, os seus avanços e recuos, as suas vicissitudes e as suas hesitações.

Da vida do cónego Lourenço Justiniano, para além das suas funções de superior, temos a imagem que Bernardo Justiniano legou, de um homem austero, frequente em jejuns, vigílias e mortificações, exercitado em virtudes e na oração ${ }^{698}$. Diz um dos seus biógrafos:

Il suo prestigio gli veniva senza dubbio da una scelta di vita ispirata all'assoluta povertà $e$ alla castità, rivolta interamente alla preghiera e alla riflessione sulla Scrittura ${ }^{699}$.

Será como figura exemplar, como prelado reformista e como autor de literatura espiritual que Lourenço Justiniano marcará a Congregação de Alga, a dos Lóios, a Igreja de Veneza, e a Igreja universal de que se tornará santo.

A obra literária de Lourenço Justiniano, de dezoito obras ${ }^{700}$, está influenciada pelo seu percurso de vida, e traduzi-lo-án ${ }^{701}$. Identificam-se duas linhas mestras, aquelas a que dedicou a sua vida: a perfeição interior e a perfeição de governo; linhas que inserem-se no entendimento de reforma da Congregação de Alga e do Papa Eugénio IV, centradas na reforma pessoal e na necessidade de prover a Igreja de bons prelados e pastores.

Esta produção literária tem sido dividida em dois períodos distintos, separados pelo ano de 1433, em que é eleito bispo de Castelo. A primeira fase, iniciada em 1419, corresponde ao período claustral, traduzido pela natureza prevalentemente monástica dos temas, de uma relação individual com Deus. A segunda fase, já produzida quando bispo, tem uma natureza pastoral, preocupando-o principalmente o papel dos prelados ${ }^{702}$.

Nas obras do primeiro período Lourenço Justiniano trabalha temas caros à reforma de Alga: a Igreja primitiva como modelo para a reforma (como se lê no seu Lignum vitae), mas também o primado da vida comunitária ou a necessidade de que a profunda renovação da Igreja tenha por base a Sagrada Escritura e os cânones da Igreja primitiva, retornando às fontes originais da Igreja como forma de ultrapassar a crise do universo eclesiástico ${ }^{703}$.

\footnotetext{
${ }^{697}$ Concorda-se com Tassi, que diz sobre Lourenço Justiniano «realizzò ulteriormente l'organizzazione dell'istituto in congregazione, della quale egli fu il primo rettore generale...» (cf. TASSI, 1952: 17).

${ }^{698} \mathrm{Vd}$. capítulo II e III in ANTT - Manuscritos da Livraria, n. ${ }^{\circ} 513$, fl. 4v. e segs.

${ }^{699}$ DEL TORRE, 2007.

${ }^{700}$ Cf. JUSTINIANO, 1628.

${ }^{701}$ COSTANTINI, 1960.

${ }^{702}$ Idem, ibidem.

${ }^{703}$ DEL TORRE, 2007. Aliás um tema caro aos reformistas de diversas épocas (veja-se para os reformadores do séc. XI o que diz VAUCHEZ, 1985: 70 e segs.).
} 
A produção de Lourenço Justiniano, cónego e reitor, é o espelho da espiritualidade de S. Jorge em Alga, em que se forma e de que é em simultâneo formador.

La spiritualità profunda restò la caratteristica riscontrata tra i Canonici Secolari di S. Giorgio. Usciti di li papa Eugenio IV, il card. Antonio Correr, il patriarca di Venezia S. Lorenzo Giustinian e l'abate riformatore e poi vescovo Ludovico Barbo, pure in mezzo alle cure della loro vita pastorale e gli affari, rimasero eminentemente degli asceti: furono qualificati dal loro forte spirito di preghiera e dalla loro vita racolta e solitaria ${ }^{704}$.

Já foram analisadas as fontes inspiradoras da fundação de Alga, centradas nas linhas em que se formaram Correr, Condulmer, Barbo e Justiniano e que constituem o capital reformista da Veneza de finais do séc. XIV e do séc. XV.

Foi sugerida ${ }^{705}$ a influência da devotio moderna dos Países Baixos, nomeadamente dos Irmãos de Vida Comum e Congregação canonical de Windesheim ${ }^{706}$. Na tentativa de explicar o movimento canonical reformista italiano, e atendendo à ligação dos fundadores de Alga a Bartolomeu de Roma e à reforma dos cónegos agostinhos de Frigionaia, pretendeu-se ver a influência dos agostinhos reformados dos Países Baixos na reforma canonical italiana. É uma leitura redutora, que exclui a dinâmica própria dos movimentos reformistas italianos da passagem do séc. XIV para o XV ${ }^{707}$ e que procura dar uma resposta rápida ao problema da génese dos movimentos de reforma em Itália.

É mais provável que, ante um contexto geral de crise eclesial, se tenham gerado em distintas geografias movimentos e respostas similares. Assim se compreende o movimento dos cónegos Lóios que, ante anseios espirituais e eclesiais comuns aos dos seus congéneres italianos, trilham percursos similares, que culminam na adesão ao carisma de Alga.

Os autores que mais se debruçaram sobre a Congregação de Alga e a sua espiritualidade, Tassi ${ }^{708}$, $\mathrm{Cracco}^{709}$ ou Tramontin ${ }^{710}$, não incluem nas suas leituras a devotio dos Países Baixos.

Barbato, ao estudar as fontes de Lourenço Justiniano ${ }^{711}$, critica a ideia de uma relação direta com o movimento dos Países Baixos, mas admite a existência de semelhanças, nomeadamente ao nível da sua espiritualidade, que poderá ser entendida no seu conjunto como uma expressão do que será a devotio moderna, da qual diz:

\footnotetext{
${ }^{704}$ TASSI, 1952: 21.

${ }^{705}$ Giovanni Mantese (apud SARTORELLI, 1988) defendia que a força das relações culturais e comerciais entre o norte da Itália e os Países Baixos pressupunha um válido influxo da Devotio em Alga, o que já afirmara Henry Watrigant (WATRIGANT, 1919: 4) dizendo mesmo que Alga fora parte da Congregação de Windesheim.

${ }^{706}$ Para os Irmãos de Vida Comum e para a Congregação de Windesheim veja-se POST, 1968. Sobre a questão da devotio pode-se sempre ver o resumo feito por CHAUNU, 2002: 101 e segs.

${ }^{707}$ Para ter uma noção rápida das linhas de reforma em actuação no mundo regular italiano veja-se o que diz PENCO, 1991: 20, além do seu capítulo introdutório em PENCO, 1984.

708 TASSI, 1952.

${ }^{709}$ CRACCO, 1959, critica abertamente a ideia de influência flamenga no movimento de Alga.

710 TRAMONTIN, 1975; TRAMONTIN, 1984.

${ }^{711}$ BARBATO, 1959.
} 
Per comprendere meglio questa spiritualità non bisogna considerarla avulsa da quel più vasto moto di riforma che [...] investi tutta l'europa cattolica in quell'ultima metà del'300 e che ebbe i suoi esponenti migliori in seno agli ordini religiosi. [...] Gli autori concordano nel presentare la Devotio Moderna come reazione alla mistica tedesca, la quale, tesa a speculazioni arditissimei prestava facile ocasione a svigotire la vita dei monasteri deviandola e inaridendola nelle inutili sottigliezze. Da ciò il suo carattere pratico che segna un retorno alla spiritualità affettiva; cosi chè mentre com l'Eckart assistiamo allo spettacolo dell'anima che nella mistica della passione e della Trinità tende al finale dimenticarse e perdersi in Dio fino quasi ad abolire i confini tra creato ed increato, com Ruysbroeck la mistica segna un deciso orientamento di moderazione nell'esercizio esterno della carità ${ }^{712}$.

A teologia de Lourenço Justiniano encontra-se entre a tradição medieval e os novos caminhos que então se desenhavam, em proximidade tipológica à teologia da devotio, tendo por principal inovação a construção de um pensamento que não se desenvolve apenas no domínio metafísico, mas que se projeta sobre a dimensão prática da vida do cristão: «...forse sta proprio qui la grandezza di Lorenzo: saper adattare la Teologia alla pratica tanto da fare una pratica morale ed ascética veramente teologica» ${ }^{713}$.

Apesar de não excluir a escolástica (em particular o Tomismo), foi principalmente influenciado pela patrística, em particular St. ${ }^{0}$ Agostinho $^{714}$ (segundo o desejo de retorno às fontes do cristianismo), aproximando-se à devotio moderna no ponto em que Alga e os cónegos renanos são influenciados pela mesma patrística. Note-se até o conhecimento da obra de Ruysbroeck ${ }^{715}$, de que figurava uma obra na biblioteca de Gregório XII, e que pelo seu sobrinho António Correr passou à biblioteca de $\operatorname{Alga}^{716}$.

Ante um ideal reformista de Alga que se tem identificado com a ideia da conversão pessoal no caminho da santificação coletiva, a produção de literatura espiritual saída da pena de Lourenço Justiniano situa-se como o ponto em que a ideia reformista das primeiras gerações de Alga, e que reúne diversas tendências que marcam o horizonte espiritual da Sereníssima dos finais da Idade Média, se converte num corpo teológico escrito, através do qual terá influência que extravasa largamente o espaço e tempo em que nasceu. De todos os exemplos que se poderiam dar retenha-se o da Congregação de S. João Evangelista.

A tradução para português de uma das obras em que Lourenço Justiniano defende a superioridade da vida consagrada em comunidade, em que teoriza sobre a necessidade de conversão pessoal para a abraçar, dos perigos que a rodeiam, das dificuldades de reger as comunidades (de que Lourenço

\footnotetext{
${ }^{712}$ Idem, ibidem.

${ }^{713}$ FAVERO, 1966: VI.

${ }^{714}$ Idem, ibidem; BARBATO, 1959. Estes autores estudam a teologia de Lourenço Justiniano e, no caso de Barbato, situam-na nos claustros de Alga, nomeadamente por uma análise das fontes da sua espiritualidade através da reconstituição das livrarias de Alga e de alguns religiosos que lhe estavam ligados.

${ }^{715}$ Sobre Ruysbroeck, uma das influências espirituais de Windesheim veja-se, por ex. SCULLY, 1912.

${ }^{716}$ BARBATO, 1959.
} 
podia falar com pleno conhecimento), da necessidade da constante formação do espírito e exercício das virtudes para nela perseverar, etc. ${ }^{717}$, é feita, naturalmente, em contexto Lóio, na década de $1460^{718}$.

Será no entanto a sua edição impressa, por Germão Galharde em Santa Cruz de Coimbra, em abril de $1531^{719}$, que será verdadeiramente revelador do reconhecimento que a obra literária de Lourenço Justiniano encontrou, afirmando-se fora do circuito carismático dos claustros das Congregações de Alga e dos Lóios e assumindo-se como autor de literatura espiritual com uma proposta aliciante para um universo mais vasto.

O Infante D. Henrique (futuro Cardeal-Rei) teria dado conta a D. Dionísio, prior de Santa Cruz de Coimbra, da existência da tradução manuscrita na livraria dos Lóios de St.o Elói de Lisboa, tendo este decidido promover a sua impressão ${ }^{720}$; corria o quarto ano da reforma do mosteiro crúzio e este era o primeiro prior eleito pela comunidade depois da reforma que, por vontade de D. João III, empreendera o jerónimo Fr. Brás de Braga ${ }^{721}$.

Ao analisar esta reforma Silva Dias vê (ainda que sem indícios sólidos) «clarões de Windesheim com lampejos de Renascença» ${ }^{722}$, lamentavelmente não citando a impressão da obra de Lourenço Justiniano entre as fontes que inspiraram a reforma de St. ${ }^{a}$ Cruz.

Não discutindo a influência que Windesheim possa ter tido nesta reforma, o que Silva Dias procura claramente demonstrar, é interessante nela situar a edição imprensa da tradução portuguesa de obras de Lourenço Justiniano. Permite-nos colocar a teologia do santo veneziano entre os referenciais teóricos de outros movimentos reformistas que não aqueles que ele próprio integrou, e em simultâneo permite-nos alargar os referenciais sobre os quais se construiu a reforma de Santa Cruz de Coimbra, ultrapassando os limites da sua própria área carismática.

\subsubsection{Lourenço Justiniano - Bispo de Castello e Protopatriarca de Veneza}

Se a entrada de Lourenço Justiniano nos claustros de Alga é um ponto basilar da sua vida, o segundo virá da eleição de Eugénio IV a Papa. Na escolha que o Papa Condulmer tenta fazer de prelados diocesanos com perfil de pastores e de reformadores, e depois da transferência do bispo Malipiero de Castello para Vicenza em maio de $1433^{723}$, elege Lourenço Justiniano para a cátedra veneziana.

O novo bispo, então com 52 anos de idade, e cerca de 30 de claustro, parece ter resistido a uma nomeação que vinha alterar por completo o seu percurso de vida, o qual tinha maturado nas três

\footnotetext{
${ }^{717}$ Cf. JUSTINIANO, 1531. Para além do Livro da regra e perfeição da conversação de monges, esta edição inclui o Livro da vida solitaria, que Justiniano escreve sobre a opção de vida eremítica. Nota-se, no confronto, que a preferência de Justiniano está na vida em comunidade orientada segundo princípios com vista a uma ideia de santificação.

${ }^{718}$ Será a tradução que é atribuída à Infanta D. Catarina, princesa de Avis próxima à Congregação.

${ }^{719}$ Conforme se pode ver no cólofon da obra (cf. JUSTINIANO, 1531).

${ }^{720}$ Idem, ibidem.

${ }^{721}$ DIAS, 1960: 105 e segs.

${ }^{722}$ Idem, ibidem: 111.

${ }^{723}$ CANZIAN, 2007, sugere que a eleição do bispo pelo cabido de Vicenza tenha tido influência de Eugénio IV, sobrepondo-se ao sistema de probae que permitia ao governo veneziano escolher os prelados do seu Estado e libertando a cátedra de Castello para prover num bispo próximo a si, Lourenço Justiniano.
} 
décadas de Congregação e que, como se depreende da leitura da sua produção literária da primeira fase, considerava a forma mais elevada de vida.

A edição das suas obras ${ }^{724}$, bem como a crónica de Tomasini ${ }^{725}$, transcrevem as cartas que Eugénio IV e Justiniano teriam trocado na ocasião. A 11 de maio de 1433 o Papa comunica a Lourenço a eleição para bispo de Castello, exortando-o a aceitar e dizendo que por ele Veneza receberia palavra (entenda-se magistério), autoridade e exemplo. Prevendo a recusa, o Papa apela para a sua obediência e, citando S. Gregório, diz-lhe que mesmo que não desejasse tal nomeação não lhe pertence recusá-la.

Lourenço responde com protesto da sua indignidade para tal cargo, aproveitando para salientar que era diocese com clero desordenado, espaço de muitos vícios, de lutas constantes entre os poderosos, e perguntando como poderia ele, depois de 30 anos de claustro e procurando sempre afastar-se dos assuntos mundanos, ser bom prelado.

A resposta de Eugénio é clara, prometendo-lhe o auxílio dos seus irmãos, o seu e o da Santa Sé. Relembra-lhe o que para ele representaria a prelatura: «... Simulque considera, quod non regnum suscipis, sed ministerium Christi, non honorem, sed onus, non divitias, sed dispensationem multiformis gratiae Dei ${ }^{726}$, concluindo a sublinhar (é certo que se poderá tomar em conta de argumento de persuasão) a admiração que a comunidade de Alga tinha por ele, e que dava a dimensão da sua pessoa: «Leva in circuitu oculos tuos et vide. Omnes isti congregati sunt, venerunt tibi» ${ }^{727}$.

Lourenço aceita e é consagrado bispo de Castello a 15 de setembro de $1433^{728}$ ordinário de 90 mil almas e da cidade que é cabeça de um dos principais estados italianos.

O seu governo terá, segundo o biógrafo, seguido a normativa geral que o Papa dera a diversos bispos nomeados naquele período: restaurar a autoridade episcopal pela presença, cumprindo o dever de residência (questão central em Trento) e encarnando integralmente o papel de pastor, provendo à guia e liderança moral das comunidades e do seu clero.

O governo de Lourenço Justiniano parece evocar o que serão os governos dos bispos reformadores do séc. XVI: reforma e formação do clero, reorganização e reafirmação normativa por via de sínodos, residência e acompanhamento pastoral ${ }^{729}$.

O seu episcopado está marcado nos extremos pela realização de reuniões magnas do clero. Pouco depois de subir à cátedra de Castello, Lourenço reúne sínodo diocesano, dedicado antes de mais a morigerar o universo eclesiástico, para o que aliás promove uma recolha de velhas e novas disposições referentes à disciplina do clero. A morte surpreende-o na organização de um concílio provincial, o primeiro do patriarcado veneziano e com o qual pretende, novamente, extirpar os abusos já conhecidos ${ }^{730}$.

\footnotetext{
${ }^{724}$ JUSTINIANO, 1628.

725 TOMASINI, 1642: 141 e segs.

${ }^{726}$ Idem, ibidem: 147.

${ }^{727}$ Idem, ibidem: 147, 148.

${ }^{728}$ TRAMONTIN, 1956: 12.

${ }^{729}$ DEL TORRE, 2007.

730 TRAMONTIN, 1956.
} 
A preocupação de Lourenço com o seu clero, de cuja crise e dissolução se queixava ao Papa Eugénio $^{731}$, marcará genericamente o seu governo. Reforma o capítulo da sua catedral, exigindo a residência e vetando o acumulamento de benefícios pelos cónegos, de forma a garantir que o culto divino fosse devidamente celebrado ${ }^{732}$.

A exemplo do Papa Eugénio e de outros prelados reformistas a este ligados, funda um colégio para a formação de clérigos pobres, em que Tramontin coloca a raiz do seminário de Veneza ${ }^{733}$. Interveio, por delegação do Papa, na reforma de comunidades monásticas masculinas e femininas, em que procura restaurar a disciplina e observância ${ }^{734}$.

Aos deveres de reformador do clero, Lourenço juntou a prática caritativa e assistencial, atingindo o apogeu durante a peste de 1447, onde a sua atuação suscitou universal aplauso e lhe terá valido o reconhecimento de virtudes de santo ainda em vida. O resultado é que nas pestes (mencionam-se as de 1476, 1480, 1630) será à intercessão de Lourenço Justiniano que a Sereníssima encomendará o pedido de ajuda divina ${ }^{735}$.

Mantendo como bispo o norteamento de vida dos tempos de claustro, Lourenço Justiniano permanece um homem ascético e, ainda que de modo mais limitado pelo peso das obrigações prelatícias, prossegue com a sua produção literária, que agora dedica ao seu ofício pastoral de prelado diocesano.

A primeira obra produzida após a eleição transmite a visão pastoral que tinha do múnus episcopal; as suas últimas três obras, produzidas entre a elevação ao patriarcado e a morte, obras da maturidade prelatícia, mudam o foco da eclesiologia tradicional de Lourenço, baseada nos caminhos de perfeição (interior e no exercício do governo de comunidades) para se centrar na importância da autoridade e da hierarquia na vida da Igreja.

Esta alteração nasce das circunstâncias do seu episcopado e poderão ser consideradas em dois níveis: o pessoal e local, demonstrando a dificuldade que Lourenço Justiniano teve como prelado para solidificar a sua autoridade e impô-la a um clero nem sempre dócil; o geral, marcado pelas dificuldades sentidas pelo Papa Eugénio IV nas suas relações com o concílio de Basileia e na afirmação da autoridade pontifícia, de que Lourenço foi sempre importante defensor e ponte de ligação entre o Papa e a República de Veneza ${ }^{736}$.

Depois da morte de Eugénio IV, e numa reforma das circunscrições eclesiásticas, Nicolau V extingue o Patriarcado de Grado (cuja sede estava em Veneza) transferindo o título patriarcal para a diocese de Castello que é também extinta, convertendo-se assim na nova unidade eclesiástica que é o patriarcado de Veneza ${ }^{737}$.

\footnotetext{
${ }^{731}$ BARBATO, 1959.

732 DEL TORRE, 2007.

${ }^{733}$ TRAMONTIN, 1956: 13.

${ }^{734}$ DEL TORRE, 2007.

${ }^{735}$ Idem, ibidem; TRAMONTIN, 1956: 13.

${ }^{736}$ DEL TORRE, 2007.

${ }^{737}$ Deste modo resolviam-se os problemas jurisdicionais existentes em Veneza pela presença de mais do que um prelado diocesano com jurisdição local (cf. RIGON, 1997).
} 
Lourenço torna-se então o primeiro Patriarca da Sereníssima (protopatriarca como surge na bibliografia), elevado a metropolita e como tal com jurisdição alargada ${ }^{738}$. Será na sequência desta alteração que pensa o sínodo provincial que preparava quando morre, a 8 de janeiro de 1456, abençoando a sua diocese: «Benedica il Signore il mio popolo, cui si degni di conservare e di accrescere sempre più l'amore, la pace, la concordia ${ }^{739}$.

Patrício de Veneza e prelado da Igreja, Lourenço torna-se o santo do Estado Veneziano, que promoverá a causa da sua canonização, em que empenhará a sua diplomacia junto da Santa Sé e obtendo do Papa Sisto IV a abertura do processo em $1472^{740}$.

Beatificado em 1524 por Clemente VII, será preciso esperar pelo primeiro Papa veneziano depois da abertura do processo (depois da dinastia Correr-Condulmer-Barbo) para a sua canonização, a 16 de outubro de 1690, por Alexandre VIII Ottoboni (cujo primeiro título cardinalício fora o convento de Alga em Roma, S. Salvador em Lauro $)^{741}$.

Ocorrida já depois da extinção dos cónegos de Alga, e aquando das oblações da missa da canonização, estes serão representados pelo seu último procurador-geral, D. Scipione Pochidori e por um outro filho espiritual de Lourenço Justiniano: o cónego Lóio P.e António de S. Carlos, procurador em Roma da Congregação de S. João Evangelista.

$\mathrm{O}$ relevo da figura de S. Lourenço Justiniano enquanto prelado reformista levou a que Jedin o incluísse como uma das quatro principais figuras que, no contexto do movimento reformador que situa no período tardo-medievo, elaboraram sobre o perfil do prelado ideal, construindo um entendimento posteriormente aprofundado e generalizado pelos pensadores da reforma quinhentista da Igreja, e praticado pelos prelados do período pós-tridentino (destacando a figura de Carlos Borromeo em Milão) ${ }^{742}$.

Menciona em particular uma das obras de Justiniano do período episcopal, o De institutione et regimine praelatorum, que coloca na linha da Devotio pela referência direta à Sagrada Escritura, sem passar pela autoridade dos Padres da Igreja (aos quais no entanto Justiniano não era de todo indiferente), para definir as virtudes de um pastor de almas.

Acentua que Lourenço Justiniano centra o ideal de prelado na perfeita imitação dos Apóstolos, concedida pela Graça e que se manifesta na perfeição da conduta, num processo interno de perfeição, «Per Giustinini tutto è concentrato nell'uomo interiore» ${ }^{743}$.

${ }^{738}$ Idem, ibidem; DEL TORRE, 2007.

739 TRAMONTIN, 1956: 14, que segue o que se encontra em JUSTINIANO, 1628: cap. XI da «Beati Laurentii Iustiniani Vita». Difere da tradução portuguesa, em que este capítulo surge resumido e em que se omite estas últimas palavras (cf. ANTT Manuscritos da Livraria, n. ${ }^{\circ}$ 513, fl. 18-19).

${ }^{740}$ Giorgio Cracco (CRACCO, 1997), sintetiza a herança de Lourenço, que para ele faz a ponte entre o prelado modelo desejado por Roma, e o patrício modelo desejado por Veneza, estabelecendo uma ponte entre interesses nem sempre concordantes: «Lorenzo Giustiniani, il servo di Dio non dello Stato, che dopo la sua morte fu celebrato come «decoro» di Roma e insieme di Venezia, come ecclesiastico santo e insieme patrizio ideale; e per il quale lo Stato stesso, sul finire del Quattrocento, chiese al papato l'onore della canonizzazione: in nome di Dio e della pátria. In fin dei conti, gli ideali di Andrea Dandolo non erano del tutto tramontati».

${ }^{741}$ DEL TORRE, 2007; ROSSI, 1690.

${ }^{742}$ JEDIN ALBERIGO, 1985.

${ }^{743}$ Idem, ibidem: 23. 
A relevância do seu exemplo foi tal que a sua biografia, escrita pelo sobrinho Bernardo, será traduzida do latim a italiano por encomenda do bispo de Bergamo ${ }^{744}$ Luigi Lippomano, conciliar de Trento, prelado reformador e núncio em Portugal e na Polónia ${ }^{745}$, revelando o apelo que a sua vida e escritos tinham para os reformadores do séc. XVI.

\subsection{UM IDEAL NOVO DE RELIGIOSO}

... est une société de prêtres séculiers, qui ne prononcent donc pas de voeux. Elle constitue une instituition originale et sans equivalente ${ }^{746}$.

Esta descrição sintetiza admiravelmente a essência do modo de vida da Congregação de Alga e dos Lóios; no entanto a autora descreve a Congregação do Oratório.

Já Cracco, ao tratar dos fundadores de Alga (outros autores semelhantes seguiriam a mesma linha) sublinha precisamente a dimensão secular dos cónegos e de como tal introduz uma novidade e capacidade de dinâmica na sua ação pastoral:

quei giovani furono preti, e non monaci: preti che scelsero di vivere dentro il mondo, da «secolari», in mezzo alla gente, tutti dediti alla cura delle anime. L'Institutio canonicorum del 30 ottobre 1404 - il primo vero documento che qualifichi la nascente congregazione - non lascia dubbi circa il carattere «clericale» del movimento [...] Non solo preti, ma anche preti speciali, canonici. Difatti vollero vivere in comune e in perfetta povertà, come gli apostoli, secondo il modello della Chiesa primitiva: per essere appieno «servi di Dio» e pastori di anime. E sappiamo che lo furono davvero: andando nelle chiese e nelle parrocchie più disastrate, mostrando nei fatti come farle rinascere, tra lo stupore dei fedeli che spesso avevano perso il ricordo del buon prete $e^{747}$.

\section{Sociedade de padres seculares}

Sociedade - assim se definiam, em documentação dos primeiros tempos, os cónegos de S. Jorge em Alga e os cónegos Lóios. Em 1404 a executória do bispo Barbarigo menciona por duas vezes a expressão socios: referindo-se a António Correr, Gabriel Condulmer e os outros sócios, e mais à frente a Marino Quirino «et socios eius clericos seculares» ${ }^{748}$.

A mesma expressão aplicou-se aos padres Lóios: logo em 1427 na concessão de súplica de Martinho $V^{749}$, mas também em duas concessões de Eugénio IV, da entrega do hospital de St.o Elói de

\footnotetext{
744 TRAMONTIN, 1956.

${ }^{745}$ KOLLER, 2005. Veio precisamente a Portugal para anunciar o Concílio e convidar os prelados portugueses. Será um dos presidentes do concílio durante o seu segundo período. Foi ainda autor de literatura dogmática e hagiográfica, pensados para servirem de subsídios para o clero. Retenha-se ainda que por via da mulher de seu pai (que não sua mãe, por ser filho ilegítimo) estava ligado à família Justiniano.

${ }^{746}$ GERHARDS, 1998: 430.

${ }^{747}$ CRACCO, 1997.

748 TOMASINI, 1642: 23, 26.

${ }^{749}$ Em que concede plena remissão dos pecados in articulo mortis aos reitores e presbíteros presentes e aos que futuramente forem «de illorum commercio et societate» (cf. COSTA, 1970: 223).
} 
Lisboa aos Lóios, que designa como «societati certorum presbyterorum secularium sub obedientia et correctione venerabilis fratris nostri Ioanis Visensi, tunc Lamacensis Episcopi in ecclesia Sancti Salvatoris de Vilar de Frades» ${ }^{750}$.

Desenha-se a natureza institucional das Congregações de Alga e de S. João Evangelista. Nascem como associações (no sentido objetivo do termo e no institucional) de clérigos seculares que procuravam, em comum, a santificação individual e coletiva, da comunidade claustral e da comunidade eclesial em que se inserem e que servem.

Cracco enfatiza o trabalho pastoral dos cónegos de Alga, como outros autores que sobre eles se debruçam ${ }^{751}$, dando-nos a dimensão do papel da Congregação enquanto instituição religiosa, pela pregação, direção de consciência ${ }^{752}$ e desvelada dedicação à liturgia (afinal as mais relevantes funções do clero secular), a par com a centralidade da oração e da meditação ${ }^{753}$. Resumindo «essere sacerdoti ma sacerdoti di grande educazione como patrizi, di preghiera solenne come monaci, di contemplazione profondissima come eremiti, d'apostolato serratissimo come popolani [...] un sacerdozio non monastico, tuttavia coordinato; un sacerdozio in vita comune, tuttavia nella libertà» ${ }^{754}$.

Em essência estamos no que, e a arrepio da afirmação de Gerhards sobre um Oratório singular entre as sociedades de sacerdotes seculares, foi definido como uma sociedade de padres seculares com vida comum sem votos, um dos três tipos de associações para a santificação do clero, a par com as sociedades regulares (de votos solenes) e as sociedades sem votos nem vida comum (essencialmente confrarias de clérigos seculares) $)^{755}$.

De padres Seculares - Tem sido sublinhado que a primeira característica que ressalta entre os membros da colegiada instituída em 1404 é que todos os novos cónegos eram ordenados de ordens maiores, estabelecendo a natureza sacerdotal da comunidade.

Característica de tal modo vincada que as Constituições dos Lóios, pelas quais supomos as de Alga, determinam especificamente no seu capítulo XIX, que trata do provimento dos cónegos e irmãos e dos comissos, que «declaramos e avemos por conegos tam somente os que tiverem ordeens sacras scilicet sacerdotes, diáconos e subdiáconos» ${ }^{756}$.

Congregação de Clérigos em vida comum, com este figurino introduz-se um modelo, que os cónegos acreditam fundado na tradição mais antiga da Igreja, que encontrará grande expansão no século seguinte, quando as congregações de clérigos, regulares e seculares, se convertem no modelo preferencial para as novas fundações, nomeadamente aquelas que mais irão marcar a Igreja Moderna e tridentina.

\footnotetext{
${ }^{750}$ Livro dos Privilegios concedidos pellos Summos Pontifices..., 1594: fl. 57, 57v.

751 TASSI, 1952: 20, 21; TRAMONTIN, 1975; TRAMONTIN, 1984.

${ }^{752}$ Daí a importância das concessões pontifícias em matéria absolutória, $v d$. quadro anexo n.o 3 .

${ }^{753}$ Note-se nesta matéria a importância da obra de Lourenço Justiniano, que a par de Luís Barbo e do seu método de meditatio, trabalham activamente num modus orandi de importante difusão (cf. TRAMONTIN, 1984: 100; CALATI, $1984: 55$ e segs.).

${ }^{754}$ Texto de Giuseppe de Luca, citado em TRAMONTIN, 1984: 94, 95.

755 BROU, 1937.

${ }^{756}$ Statutos e Constituyções dos virtuosos e reverendos padres Conegos azuys, 1540: fl. XXv. Para a caracterização dos sete graus de ordenação veja-se COELHO, 1950: I, 590 e segs.
} 
Deve-se, no entanto, perceber que a Congregação de Alga (tal como a dos Lóios) constituiu-se num processo de alguma duração e não como uma realidade imediatamente criada e institucionalizada. Retoma-se a questão: a executória de 1404, ainda que seja o ponto fundacional da Congregação, não marca a sua constituição, mas a de uma colegiada de cónegos, instituição singular, para a regência da qual o executor apostólico institui um conjunto de normas, com faculdade de os cónegos criarem novas futuramente.

Esta distinção, que pode parecer preciosista, pressupõe dois elementos relevantes para a fundação da Congregação de Alga, e que permitem estabelecer similitudes com a fundação da Congregação dos Lóios: intencionalidade e gradatividade.

Intencionalidade - Em relação à qual convém precisar desde já dois postulados:

- o primeiro é o da inexistência de documento que permita sustentar que a intenção dos fundadores de Alga fosse, ab initio, fundar uma congregação canonical com a estrutura que esta veio a assumir. É o que se supõe do facto da Congregação de Alga só se organizar como tal a partir de1424, bem como da noção de que só com Eugénio IV se constitui o cerne do seu aparelho normativo e de privilégios; até 1431 a Congregação de Alga apenas conta, a nível institucional, com a sua constituição em canonical, com as determinações do Bispo Barbarigo e a aprovação que deste ato faz o Papa Correr.

- o segundo é que nada faz supor, ao contrário dos Lóios que terão tido dúvidas iniciais sobre o modelo institucional a adotar (chegando a pensar na regra dos agostinhos ${ }^{757}$ ), que os fundadores de Alga tivessem dúvidas sobre o que pretendiam instituir: uma comunidade de cónegos seculares, de vida e bens em comum, dedicados ao serviço de Deus e da Igreja que pretendem reformar pelo exemplo de vida.

Os Cónegos de Alga, com o seu novo modo de vida e a recusa em adotar modelo de vida comunitária previamente instituído, fazem uma afirmação, consciente e assumida, de colocarem-se à margem de um universo regular em crise institucional e de recrutamento, moral e material, que se converte em crise de prestígio e que o torna alvo de numerosas críticas e ataques, particularmente no confronto da Igreja Católica com as Igrejas Reformadas do séc. XVI ${ }^{758}$.

A consciência da escolha é acentuada pela decisão de não integrar nenhuma das reformas observantes que se construíam, e com as quais tinham grande proximidade.

Escolhem ser cónegos (certamente este figurino institucional, graças à abertura dada por Bonifácio IX ao bispo de Kysamos para reformar o priorado de Alga ad libitum, terá sido pensada e conversada entre o executor e os novos cónegos) e escolhem ser seculares, o que só podem fazer em liberdade e plena consciência da sua escolha, porque dificilmente alheios da reforma dos cónegos

\footnotetext{
${ }^{757}$ Como se depreende da súplica ao Papa Martinho V, de outubro de 1430 (cf. COSTA, 1970: 581, 582), e como bem salientaram CARVALHO, 1995: 654, 655; TAVARES, 1999: 5; PINA, 2011: 114.

${ }^{758}$ Uma visão resumida da situação das instituições regulares para o final da Idade Média pode-se ver em BONNET, 1968: 62 e segs.
} 
regrantes de St. ${ }^{o}$ Agostinho que Bartolomeu de Roma dirigia, e ao qual S. Jorge em Alga, como priorado agostinho, poderia ter facilmente aderido.

Gradatividade - Sabe-se que o nascimento de uma ordem ou congregação dá-se sob a ação de um (ou mais) fundador e é definida pelo carisma que este lhe associa e que norteará a instituição, a par com a confirmação da autoridade eclesiástica e a normativa associada, e que no conjunto definem a natureza geral e específica da instituição.

O carisma tende a tornar-se, findo o período fundacional, um elemento estável na vida da instituição (ainda que mutável quando sujeito a interpretação), mas a sua construção, em que se inserem todas as condicionantes do tempo e lugar que marcam o percurso dos fundadores ${ }^{759}$, é por natureza um processo dinâmico, baseado antes de mais num sentido de ânsia ${ }^{760}$, ânsia de perfeição, sentido de natureza espiritual que muitas vezes escapa às grelhas da análise historiográfica.

As biografias de fundadores de ordens e congregações permitem-nos perceber como a constituição do carisma é dinâmica, maturando a experiência espiritual pessoal, que alargam à comunidade de confrades que os acompanham nos primeiros tempos.

Vive-se normalmente uma experiência de conversão (caso de Francisco de Assis ${ }^{761}$ ou de Inácio de Loyola) ou sente-se na Igreja a necessidade de uma nova forma de atuação (como acontece com Domingos de Gusmão ${ }^{762}$ ou Filipe de $\mathrm{Neri}^{763}$ ), não raramente acompanhado de uma transformação radical de vida e a assunção de um conjunto de princípios norteadores (o tal carisma) que se entende como dom transcendental e como uma via para a salvação própria e da comunidade eclesial em que, direta ou indiretamente, se repercutem as consequências reais e espirituais da aplicação do carisma.

Em suma, trata-se de um processo, e um processo que durará mais ou menos tempo, com dinamismo que poderá mesmo passar para lá da vida dos fundadores (muito se tem a dizer sobre se alguns fundadores foram ou não autores das suas ordens ou congregações), e cujas vicissitudes dependerão desse mesmo dinamismo.

No caso da Congregação de Alga têm-se debatido os fundadores e as influências, mas não se tem olhado o processo e analisado aquilo que ele nos revela.

\footnotetext{
${ }^{759}$ FOLEY, 2003.

${ }^{760}$ «Ânsia» parece-me ser a palavra que melhor descreve o processo pelo qual os fundadores carismáticos se sentem impelidos a uma mudança de vida e à ação fundacional que resulta na nova instituição. É ânsia de encontrar caminho no percurso salvífico, aproximar-se da transcendência e alcançar o fito último do cristão, a salvação eterna para a alma pelo percurso individual e pela expansão do reino de Deus na terra. A ideia de ânsia está plasmada em artigo de José Adriano de Freitas Carvalho, testemunhando o processo interno que leva os reformadores a transformar ideia de reforma em ação reformista (cf. CARVALHO, 1995).

${ }^{761}$ RUSCONI, 1997.

${ }^{762}$ Que já clérigo e cónego da Sé de Osma, envolvido na luta contra o catarismo, sente a necessidade de um corpo de pregadores teologicamente preparados, que estará na origem do que virá a ser a Ordem dos Pregadores. Para uma biografia resumida do santo veja-se, por ex., TUGWELL, 1996.

${ }^{763}$ Filipe de Neri fundará o Oratório ao cabo de uma já longa vida eclesiástica, toda ela feita de experiências espirituais e dinamismo religioso (cf. CISTELLINI, 1989: vol. 1).
} 
Tassi afirma, em relação à Congregação de Alga, «I suoi ideali di santità, di solitudine, di preghiera, di meditazione, non erano nuovi; non era nuovo il suo ideale di vita comune dei chierici» ${ }^{764}$ situando a novidade na forma como integram estas características. Tassi não desenvolve a questão em profundidade, no entanto a leitura dos passos dados pelos cónegos lagunares leva-nos a perceber que de uma solução institucional que efetivamente não é nova (a instituição colegiada) ir-se-á criar uma solução nova, marcante nos tempos subsequentes, traduzida nas congregações de sacerdócio ativo, regular ou secular. Neste ponto aprofunda-se o sentido de novidade que Tassi parece ter querido restringir.

Recusando a ideia de uma congregação «canonicamente erigida a 30 de outubro de $1404{ }^{765}$, propõe-se que nessa data foi instituída uma comum colegiada de cónegos seculares, como tantas se conheceram na órbita católica medieval e moderna, e de que o número em Portugal foi significativo até ao séc. XIX ${ }^{766}$. Esta sim é a solução institucional de vida comum dos clérigos em que os cónegos de Alga se inserem e sem novidade.

À colegiada de S. Jorge em Alga irão juntar-se outras igrejas secularizadas e constituídas em colégio de cónegos. Será o número de casas unidas e a necessidade de uma organização mais avançada que conduzirá a que, em 1424, se nomeie pela primeira vez um reitor-geral, o reitor de Alga, e reitores para as demais casas da Congregação.

Neste ponto diferem as Congregações de Alga e a dos Lóios, pois se aqueles se tornam Congregação quando a pressão de gerir em uníssono sete colegiadas assim o impõe, os Lóios serão Congregação quando apenas contam com uma única Casa, a de S. Salvador de Vilar de Frades. Benefícios de adotar um carisma já instituído, que nos obriga no entanto a repensar o papel de Alga em S. João Evangelista.

Com as numerosas concessões de Eugénio IV ficará concluído o edifício da Congregação dos Cónegos Seculares de S. Jorge em Alga, que procurando viver de um modo novo os velhos modelos canonicais irá inaugurar um percurso fecundo das congregações de clérigos regulares e seculares.

\subsubsection{Comunidade de cónegos seculares - Vita Apostolica}

A multidão dos que haviam abraçado a fé tinha um só coração e uma só alma. Ninguém chamava seu ao que lhe pertencia, mas entre eles tudo era comum. Com grande poder, os Apóstolos davam testemunho da ressurreição do Senhor Jesus, e uma grande graça operava em todos eles.

Atos dos Apóstolos ${ }^{767}$

Acreditavam as Congregações de Alga e de S. João Evangelista que o seu modo de vida era o dos tempos primitivos da Igreja, a Igreja dos Apóstolos. Assim o afirma Paulo de Portalegre na sua

\footnotetext{
${ }^{764}$ TASSI, 1952: 21.

${ }^{765}$ PINA, 2011.

${ }^{766}$ RODRIGUES, 2000a.

${ }^{767}$ Atos dos Apóstolos, 4: 32-33.
} 
crónica, inspirando-se certamente no memorial da Congregação de Alga que viera de Itália com Afonso Nogueira ${ }^{768}$.

Pensamento fundacional ou construção justificativa posterior, o certo é que a referência aos tempos apostólicos e à ideia da Vita Apostolica não é nova e estava já então profundamente ligada ao mundo canonical. Já no contexto de reforma da vida religiosa do séc. XI encontramos um movimento de retorno a fontes originais, do pensamento clássico e do cristão dos primeiros séculos. Ante a necessidade de reforma eclesial, reconhece-se na primitiva comunidade cristã de Jerusalém, cuja memória se conservava nos Atos dos Apóstolos, uma dimensão de autenticidade que lhe vinha de ter sido vivida pelos apóstolos (daí Vita Apostolica) e como tal estar próxima ao anúncio salvífico de Cristo ${ }^{769}$.

Para Vauchez não se trata da descoberta destes textos, mas a leitura nova que deles se faz, quando no contexto da reforma gregoriana se questiona a ideia que a sucessão da vita apostolica estava no modo de vida dos monges. Tenta-se alargar ao clero secular a ideia de vida e posse comum, sem grande sucesso, com o objetivo de o reformar. Desta tentativa emergirão, entendendo-se como herdeiros da vida apostólica, os cónegos regulares ${ }^{770}$.

Cónegos são, por definição, clérigos que participam de um colégio dedicados ao solene culto divino em catedral ou igreja colegiada. As suas origens estarão nos sécs. IV e V, quando a Igreja tolerada (e depois oficial) começa a estruturar-se institucionalmente, altura em alguns bispos organizam vida comum para os clérigos das suas catedrais. Nos sécs. VIII e IX sente-se a necessidade de regular este modo de vida com normativa ${ }^{771}$.

A reforma gregoriana é acompanhada pelo surgimento do canonicato regular, impulsionado por Papas que apelam sistematicamente a uma vida comum mais estrita, na senda da tradição evangélica ${ }^{772}$. O apoio de bispos reformadores, de reis e senhores, sustentará o canonicato regular e transformará o séc. XII no século dos cónegos ${ }^{773}$, com a reforma regular de cabidos de catedrais e de colegiadas e a criação de novas comunidades e congregações. A distinção entre os dois modos de ser cónego, secular e regular, dá-se logo em 1059, e é feita pela posse individual de bens, vetada aos regulares ${ }^{774}$.

As congregações canonicais regulares, como instituições clericais, procuravam dotar a Igreja de um clero digno e preparado, para servir o culto divino e desenvolver atividade pastoral nas suas igrejas e nas paróquias e missões que lhe eram adscritas.

O reconhecimento pelo Papa Urbano II, em 1090, de que a vida canonical era um modo de vida apostólico, e de que o sacerdócio era (ou podia ser) um estado de perfeição equiparável ao da vida monástica (até então visto como única via de perfeição), atribui ao sacerdócio uma nova autoridade moral,

\footnotetext{
${ }^{768}$ Cf. PORTALEGRE, 2007. $\mathrm{Vd}$. o que sobre isto diz SOBRAL, 2003b.

${ }^{769}$ VAUCHEZ, 1985: 70, 71.

${ }^{770}$ Idem, ibidem.

771 SMITH, 1953; GERHARDS, 1998: 135. Trata-se da regra de Chrodegang de Metz e as determinações do concílio de Aix-

-la-chapelle, baseadas na tradição dos padres da Igreja e nos concílios.

${ }^{772} \mathrm{Vd}$. o que sobre isto diz VAUCHEZ, 1985: 70.

${ }^{773}$ SMITH, 1953.

${ }^{774}$ GERHARDS, 1998: 135.
} 
que será nos séculos seguintes uma marca fulcral da Igreja, e que atinge o apogeu em Trento e na sua promoção da ordem sacerdotal.

O séc. XIII e a emergência de novos movimentos religiosos, como os mendicantes (com quem competem pelo mesmo público-alvo, a população das cidades), abre o caminho da decadência. Entre mosteiros despovoados, entregues a comendatários ou secularizados, é notória a crise entre os cónegos regulares $^{775}$.

Neste contexto nasce a Congregação de Alga, fundada num priorado agostinho em regime de comenda e que é reduzido a igreja secular ${ }^{776}$. Os cónegos da nova comunidade determinam-se a viver como os apóstolos, conforme a descrição dos Evangelhos ${ }^{777}$, com vida e bens em comum, garantindo o culto divino e a cura das almas.

Com a comunidade de Alga vamos encontrar a superação da definição que vigorava desde o sínodo romano de 1059: comunidade de cónegos seculares sem votos solenes, vão no entanto habitar em comum, com dormitório e refeitório, sem outros bens que não aqueles que pertencessem à comunidade $\mathrm{e}^{778}$.

O objetivo dos cónegos é patente, procuram a vida perfeita em comunidade mas sem as imposições da vida regular que considerariam estar na origem da crise eclesial: a profissão solene de votos, porque impedia a comunidade de dispensar religiosos cujo comportamento fosse considerado indigno $^{779}$; a prelatura perpétua dos superiores, que colocaria a comunidade por tempo indeterminado nas mãos de uma só autoridade ${ }^{780}$. Nas palavras de Tassi: «sembra dalle fonti che avessero la preocupazione di evitare gli abusi che si erano avverati nei vari ordini religiosi, anche quando fossero divenuti soggetti indegni; la prelatura dei superiori e la loro inamovibilità, anche quando si fossero manifestati incapaci o peggio» ${ }^{781}$.

Tomam o figurino institucional que se encontra nos movimentos reformistas vizinhos da Congregação de St. ${ }^{a}$ Justina $^{782}$ ou dos Cónegos Regulares de Frigionaia ${ }^{783}$ : superiores eleitos anualmente

\footnotetext{
${ }^{775}$ Idem, ibidem.

${ }^{776}$ Note-se que em paralelo com o desenvolvimento das reformas dos cónegos regulares, como a dos cónegos regulares de Frigionaia em Itália e, antes deles, a reforma dos cónegos de Windesheim, centrais na corrente mística renana e onde, com probabilidade, se produziu uma das obras cimeiras da espiritualidade cristã do ocidente tardo-medieval, a Imitatio Christi, que Pierre Chaunu (CHAUNU, 2002: 101 e segs.), defende ser influência marcante na espiritualidade de final da Idade Média e do movimento da devotio moderna.

777 Vd. supra citação dos Atos dos Apóstolos.

${ }^{778}$ Como aliás afirma a nota memorial que antecede as actas capitulares de 1538 a 1545 (cf. ANTT - Manuscritos da Livraria, n. ${ }^{\circ}$ 186, que no fl. 5), entre as disposições dos Estatutos de Alga em uso entre os Lóios, diz taxativamente: «Item mandamos que as rendas sejão comuas e que não aja ahi propiadade e que todos comão em hum refeitoyro e todos durmão em hum dormitório e que todos vão ao officio divino ao coro somente a algum que o Reictor der licemsa por causa de alguma necessidade». ${ }^{779}$ Uma leitura das determinações anexas à executória de 1404, mencionadas supra (ponto 2.1.), permitem perceber este dado rapidamente, tão só se observe a sua repetição nos pontos $3,6,8,11$.

${ }^{780}$ E que se vê pelo facto de os priores de Alga serem desde o início providos por eleição anual, tomando a posse mal eleitos, sem necessidade de formalidades (como seria o caso de um superior que recebesse bênção abacial, ou tivesse de ser confirmado, ou tomasse posse solene do seu priorado ou reitorado, tudo situações que o ligariam e dariam direitos sobre o cargo).

${ }^{781}$ TASSI, 1952: 21.

782 TRAMONTIN, 1984: 104.

${ }^{783}$ FONSECA, 1984: 300 e segs.
} 
por capítulo, que se afirma como a autoridade superior da instituição, onde se produz a normativa e tomam as decisões mais relevantes das comunidades. Resta saber quem influenciou quem.

Outra característica fundacional, e que os afasta da tradição monástica da stabilitas locis, é a mobilidade dos cónegos ${ }^{784}$, que permite à Congregação gerir os seus religiosos, transferindo-os entre as casas de acordo com o que os interesses internos aconselhassem.

Estamos perante uma solução mista de colegiada de cónegos seculares, com características institucionais aligeiradas que garantiam à comunidade flexibilidade de adaptação às circunstâncias de tempo e local, mas com vida em comunidade plena e ausência de bens privados.

O que prendia os cónegos à Congregação? Nada senão a intenção de perseverar, e enquanto esta durasse. Estariam apenas sujeitos a votos simples, como defendem Isabel Pina e Pedro Tavares para os Lóios ${ }^{785}$, e como depreende-se da leitura dos Estatutos e Constituições nos pontos que tratam na admissão dos religiosos ${ }^{786}$, mencionando a promessa que faziam e que está de acordo com a definição de votos simples ${ }^{787}$.

Esta liberdade, que permitiu que alguns deixassem o claustro de Alga ou dos Lóios para ocuparem outros lugares no universo eclesiástico ${ }^{788}$, tornou-se num elemento institucional identitário relevante cujos contornos só se conhecerão verdadeiramente no pontificado de Pio V, quando a aplicação das disposições tridentinas sobre o clero força os cónegos seculares a transformarem-se em regulares para manterem íntegra a sua forma de vida de cónegos de vida e bens comuns. Sinal dos tempos: enquanto os cónegos de Alga aceitam professar os três votos solenes debaixo da regra de St. ${ }^{\circ}$ Agostinho, serão os cónegos Lóios a propugnar em Roma pela sobrevivência do seu modo de vida canonical $^{789}$.

\subsubsection{Congregações de sacerdócio ativo: um modelo para a Igreja Moderna}

Será o modelo congreganista que nasce com os Cónegos de Alga, e não o modo de vida canonical que professam (que levou Tassi a considerá-los sem novidade aparente senão na forma) que coloca as duas Congregações num plano de pioneirismo diretamente ligado às congregações clericais que se tornam uma realidade estrutural da Igreja Moderna.

É certa a pré-existência de congregações de clérigos regulares, como as de cónegos regulares, é certa a pré-existência de numerosas igrejas colegiadas de clérigos seculares, mas será em Alga pela primeira vez que um conjunto de comunidades de clérigos viventes colegialmente e que estão agregadas

\footnotetext{
${ }^{784}$ Algo comum entre os Lóios, e que era decidido nos últimos dias do capítulo geral anual, como revelam as actas capitulares que se conservam. No caso da Congregação de Alga encontramos vestígios da mobilidade interna na crónica de Tomasini, nos pontos em que menciona as eleições e a mobilidade de cónegos entre casas para assumir reitorias, ou mesmo para tomar posse de novas casas (como acontece com Lourenço Justiniano quando vai para St. ${ }^{\circ}$ Agostinho de Vicenza) (cf. TOMASINI, 1642). ${ }^{785}$ PINA, 2011: 214; TAVARES, 1999.

786 Statutos e Constituyções dos virtuosos e reverendos padres Conegos azuys..., 1540, caps. XXIV e XXVIII.

${ }^{787}$ VEERMEERSCH, 1912.

${ }^{788}$ Só como exemplo lembrem-se as três grandes figuras de Alga António Correr, Gabriel Condulmer e Lourenço Justiniano, e entre os portugueses Afonso Nogueira (que se verá no ponto 3.2.).

${ }^{789}$ Veja-se ponto 3.3 .
} 
a uma que se assume como matricial, a de S. Jorge em Alga, se constituem como uma congregação de cónegos seculares.

A definição que encontramos para Alga, que aqui se tem analisado e aprofundado, enquadra-se perfeitamente em duas tipologias de vida comunitária que até hoje se têm associado à Igreja tridentina e pós-tridentina: as congregações de clérigos regulares e as sociedades (ou associações) de padres seculares de vida comum e a cujo universo pertencem as congregações cujo perfil os autores têm antevisto nos Lóios ${ }^{790}$.

As primeiras têm sido definidas como uma criação canónica original cuja prioridade absoluta é o sacerdócio de vida ativa, com todas as atividades associadas ao múnus sacerdotal. Ainda que adotem elementos próprios do universo monástico, nomeadamente a profissão de votos solenes e a vida comunitária, a centralidade do sacerdócio como elemento próprio carismático vem contrariar a tradição monástica ${ }^{791}$.

O carisma destas instituições era restaurar a dimensão moral e a qualidade formativa do clero para uma mais eficaz ação pastoral. Regulares pelos votos solenes e observância de uma regra, o seu compromisso com o sacerdócio verifica-se na opção pelo uso da sotaina secular em detrimento de um hábito regular, enquanto adaptam a lectio divina e os ofícios corais à necessidade de tempo para a cura de almas e outras atividades como o ensino (em que algumas se notabilizarão), que entendem como um prolongamento da sua atuação.

As dimensões das congregações de clérigos regulares, com exceção da Companhia de Jesus, foi reduzida em número de religiosos e de janela temporal de fundações, que não ultrapassam os inícios do séc. XVII, e que parece marcar o seu fim enquanto proposta institucional de modo de vida religioso ${ }^{792}$; no entanto, e ainda que bastasse o sucesso da Companhia de Jesus ${ }^{793}$ para sustentar a relevância e sucesso das congregações clericais num século marcado por uma reforma que foi fermento de novas congregações ${ }^{794}$, a verdade é que muito mais se poderia aduzir em defesa destas congregações que introduzem no mundo monástico um carisma essencialmente ativo, cujo foco não seja o laus perene, mas a ação pastoral entendida num sentido lato, sustentada sobre um forte dinamismo no altar, no púlpito, no confessionário, nas escolas e universidades, nas cortes seculares e eclesiásticas, nas missões extraeuropeias, nas academias de ciências e de letras, e em qualquer espaço onde considerassem necessário o serviço da Igreja.

No mesmo séc. XVI encontra-se a fundação das sociedades de padres seculares de vida comum, que constituir-se-ão, segundo a opinião do P.e Brou, para obviar a dispersão e isolamento do clero

\footnotetext{
${ }^{790}$ Pedro Tavares vê características que futuramente se encontrarão nos Jesuítas (TAVARES, 1986: 24 e segs.), José Adriano Carvalho identifica a proximidade ao Oratório (cf. CARVALHO, 1995: 655), com quem de facto os cónegos de Alga e os Lóios partilharam forma institucional de sociedade de clérigos seculares.

${ }^{791}$ GERHARDS, 1998: 157-159. Entrada Clercs réguliers.

${ }^{792}$ Idem, ibidem, dá uma listagem destas instituições e suas fundações: Teatinos em 1524, Barnabitas em 1530, Somascos entre 1534 e 1540, Jesuítas em 1540, Camilianos em 1582/86. Em 1574 e 1617 fundam-se como seculares os Clérigos da Mãe de Deus de Lucca e os das Escolas Pias (Piaristas), que se convertem em regulares em 1584 e 1621, respectivamente.

${ }^{793}$ Como tão bem sustenta Chaunu, aduzindo o dado numérico que não engana, numa congregação que de cerca de mil efetivos em 1556 ultrapassa já os quinze mil em 1625 (cf. CHAUNU, 1981: 401).

${ }^{794}$ Idem, ibidem: 389.
} 
secular, oferecendo-lhes os recursos da vida comum. Refere que no séc. XVI encontram-se traços em Itália de um razoável número de sociedades de preti reformati, mas que o tempo fez desaparecer ou passar ao mundo regular (como os clérigos regulares da Mãe de Deus de Lucca ou os Piaristas) ${ }^{795}$.

Esta solução institucional, que terá no Oratório o seu expoente, para além da fundação na Áustria de um instituto seiscentista ${ }^{796}$, conhecerá um segundo momento de expansão na multiplicação de institutos religiosos do séc. XIX e XX.

Brou não especifica as características do modo de vida destas sociedades de clérigos seculares do séc. XVI, que estabelece como ponto inicial deste modo de vida, pelo que a melhor forma de aproximação será na análise do Oratório de Filipe Neri.

Construído sobre a ação de um sacerdote e seus apoiantes, a Congregação do Oratório é fundada no termo de um processo gradual (e voltamos à ideia de gradatividade presente na constituição da Congregação de Alga), através do qual o padre fundador, Filipe Neri, constrói um entendimento de sacerdote e de sacerdócio secular, enquadrado no pensamento tridentino, maturado por diversas experiências espirituais iniciadas no eremitismo e continuadas na ação pastoral em contexto de irmandades e confrarias; período fecundo em que lançou as sementes do Oratório e manteve contacto estreito com os fundadores de outras congregações clericais, nomeadamente com Inácio de Loyola e os Jesuítas, ou Giovanni Leonardi, fundador dos clérigos seculares da Mãe de Deus de Lucca ${ }^{797}$.

Formado sobre uma espiritualidade muito similar à que encontra em S. Jorge em Alga, marcada por exemplo pelos Doutores da Igreja, pela Imitatio Christi, por St. ${ }^{a}$ Catarina de Siena ou Ubertino da Casale ${ }^{798}$, o crescimento do grupo de sacerdotes e leigos em torno de Filipe Neri conduz a uma organização mais estável, estabelecida por Gregório XIII em 1575, e que se afirma como uma companhia clerical secular com as funções próprias destes clérigos: celebrar a missa e o culto divino, pregar e praticar obras de piedade $\mathrm{e}^{799}$.

Cistellini recusa a ideia generalizada de que o Oratório seja uma solução institucional nova, reconhecendo que não só Filipe Neri conhecia comunidades de vida comum seculares (menciona comunidades femininas da sua Florença natal), como a ideia de radicar as comunidades de clérigos seculares nos tempos apostólicos, pela constituição de um movimento dedicado a recuperar a Ecclesiae primitivae forma, tinha precedentes longínquos na Igreja, que grupos como os preti reformati recuperavam naqueles anos ${ }^{800}$.

Congregação de clérigos seculares, sem votos solenes, alicerçada sobre o múnus sacerdotal, inteiramente dedicada à pastoral e ao culto divino. Novamente poderíamos estar a resumir a Congregação de S. Jorge em Alga ou de S. João Evangelista.

\footnotetext{
${ }^{795}$ BROU, 1937.

${ }^{796} \mathrm{O}$ Instituto dos clérigos seculares viventes em comum, fundado por Barthélemy Holzhauser em 1642 (cf. Idem, ibidem). Note-se no nome o uso das mesmas expressões, com sentido de descrição de natureza institucional, que se encontrará nos Lóios: «seculares viventes em comum».

${ }^{797}$ CISTELLINI, 1989.

${ }^{798}$ Idem, ibidem: 103 e segs. (Confrontar com BARBATO, 1959).

${ }^{799}$ CISTELLINI, 1989: 184 e segs.

${ }^{800}$ Idem, ibidem: 194 e segs.
} 
Cistellini não menciona os Cónegos de Alga, e dificilmente se pode situá-los entre as inspirações da nova Congregação do Oratório, tanto mais que o período da sua constituição corresponde ao período em que a decadência da Congregação de S. Jorge em Alga se torna mais patente, com a sua forçada regularização. No entanto importa aqui deixar registado que entre as duas formas de Congregações de clérigos seculares, uma de sacerdotes e a outra de sacerdotes com título canonical, existe uma proximidade de modo de vida muito forte, e que o conhecimento mútuo é altamente provável, já que Filipe Neri, sacerdote incardinado na diocese de Roma, tinha em S. Salvador em Lauro um exemplo patente de uma congregação de clérigos seculares de vida comum.

Olhando as fundações de congregações clericais, tanto as seculares como as regulares, não pode deixar-se de apreciar como a Congregação de Alga se apresenta como uma ponta de lança que, da antiga instituição canonical, se organiza em moldes novos ou renovados e transfere essa ideia nova de congregação clerical ao séc. XVI e à modernidade.

Deste ponto de vista os Cónegos de Alga, e os Lóios, apresentam uma faceta clara de renovação que, sendo medieval no tempo de origem, encerra já estruturas próprias da modernidade, assumindo-se como movimentos que institucionalmente promovem essa transição.

Congregações de clérigos, onde o múnus sacerdotal é centro e carisma, culminam a evolução de um pensamento que se foi construindo em torno da importância do sacerdócio ativo, digno e preparado, que Trento sintetiza e impõe, mas cujas principais medidas encontramos já em aplicação na Congregação de Alga e no pontificado de Eugénio IV.

Foi um longo processo de evolução do entendimento do sacerdócio, que podemos supor com raízes no canonicato regular medieval, que se construirá gradualmente e que irá atingir a plenitude no decurso da reforma quinhentista da Igreja, quando o concílio tridentino legisla em matéria sacerdotal, sustentando a particularidade deste estado obtido pela ordenação, e esforçando-se por alargar e impor as disposições que visam a exigência moral e formativa do universo sacerdotal ${ }^{801}$.

O trabalho que congregações como as dos cónegos regulares, dos cónegos seculares de Alga e de S. João Evangelista e das novas congregações clericais do séc. XVI, vinham realizando em prol da promoção do sacerdócio como via de perfeição e essência do múnus pastoral da Igreja alcança, por fim, um reconhecimento universalmente imposto pela cúpula eclesiástica, e que irá converter nos séculos seguintes a Igreja Católica numa Igreja de sacerdotes.

${ }^{801}$ HOLMES \& BICKERS, 2006: 195. Para a aplicação em Portugal das disposições tridentinas veja-se o que diz PAIVA, 2000. 


\section{II \\ LÓIOS: ENTRE O CARISMA E A PRAXIS}




\section{OS CÓNEGOS SECULARES DE S. JOÃO EVANGELISTA E O CARISMA DA REFORMA}

O estudo da constituição, consolidação e expansão da Congregação de S. João Evangelista tem sido objeto de diversas análises. Destacam-se as de Pedro Vilas-Boas Tavares e de Isabel Castro Pina, que a par de alguns aportes de outras obras e autores (em que se pode salientar o trabalho de Sousa Costa para a figura de D. João Vicente ${ }^{802}$, a análise de José Marques para a relação e disputas com o arcebispo de Braga D. Fernando da Guerra ${ }^{803}$ ou ainda o que Eduardo Borges Nunes deixou escrito sobre a relação com o abade D. Gomes ${ }^{804}$ ), fixaram de modo muito completo (e até onde as fontes existentes o autorizam) as origens e desenvolvimento da Congregação dos Lóios.

Um redizer do que por estes autores já foi dito seria necessariamente uma repetição, e como tal desnecessário. Importa pois situar a constituição da Congregação dos Lóios, a fundação das suas comunidades e a sua presença na sociedade portuguesa dos sécs. XV e XVI numa linha que integre a sua natureza carismática específica, alargando-se igualmente a questões e períodos que ainda não tenham tido uma análise aprofundada.

A leitura da Congregação e das suas relações de pertença que aqui se propõe, pretende-apenas ser um contributo para a ampliação do conhecimento e compreensão das especificidades dos Cónegos Lóios, do seu entendimento de reforma, da sua natureza carismática e da sua atuação no claustro e no século, situando-a não só nos seus contextos nacionais, mas também no universo eclesiástico de que participa ao assumir um carisma extranacional e cuja origem e natureza, novidade e relevância foi já sendo fixado no decurso desta obra.

A proposta é que sigamos, nas próximas páginas, um caminho de análise que nos conduza à compreensão do enquadramento e do papel desempenhado pelos Cónegos de S. João Evangelista, não só pela sua promoção da reforma eclesiástica, mas também pelas relações que manteve com a matriz de Alga, com a Coroa portuguesa e com a Casa de Bragança, e pelas responsabilidades que estas thes aportaram no plano educativo e no universo da administração hospitalar, revelando o reconhecimento de valor da proposta carismática dos Lóios.

\subsection{IN PRINCIPIO ERAT. AS ORIGENS LÓIAS À LUZ DOS MOVIMENTOS ECLESIAIS NO PORTUGAL QUATROCENTISTA}

A fundação do que virá a ser a Congregação dos Cónegos Seculares de S. João Evangelista, nas décadas de 1420 e 1430, situa-se num período histórico particularmente dinâmico em que um entendimento geral de crise se mescla já com as formas da sua superação.

\footnotetext{
${ }^{802}$ COSTA, 1986: cap. V a VII.

${ }^{803}$ MARQUES, 1988.

${ }^{804}$ NUNES, 1963.
} 
Já se refletiu brevemente sobre a importância que estes anos tiveram para Portugal, mas importa ter em permanente consideração a situação geral da Igreja portuguesa neste período, já que será no seu seio que mestre João Vicente, e os seus companheiros, trarão à luz a nova Congregação.

$\mathrm{O}$ artigo que José Adriano de Freitas Carvalho dedicou aos movimentos de reforma na Igreja portuguesa do séc. XV ${ }^{805}$ é para esta questão de relevante interesse. Ainda que decline a responsabilidade na escolha do seu título, Freitas Carvalho centra a sua análise sobre dois eixos particularmente felizes que parecem congregar o essencial dos movimentos reformistas da Igreja portuguesa quatrocentista: anseios e limites.

O cruzamento destes dois eixos apresenta-se como uma chave de leitura que permite ler com clareza os movimentos reformistas do séc. XV, e que pode aplicar-se não só ao caso português, mas à generalidade da Igreja cristã ocidental.

Ante um contexto de crise eclesial, traduzido desde logo na crise do universo clerical, os sécs. XIV e XV assistem à emergência de diversos movimentos que, entendidos de um modo genérico, teriam em comum o desejo de reformar o universo eclesiástico tendo por referencial a ideia de recuperar uma essência espiritual, traduzida num modo de vida, que se corrompera ou perdera de todo; nas palavras de Freitas Carvalho: «a reformatio, como um anseio permanente e tentativas mais ou menos logradas, atravessou o século $[\mathrm{XV}]_{»^{806}}$.

Já antes encontrávamos em Silva Dias um juízo taxativo sobre a crise da Igreja portuguesa deste período, na qual no entanto insere as diversas iniciativas de sinal contrário, em que os Lóios foram destacados como a mais séria tentativa de inverter o que se apresentava como uma crise moral do clero ${ }^{807}$.

Freitas Carvalho chama a atenção para a necessidade de rever o entendimento do conceito e das práticas reformistas no Portugal de 1400 e, tanto quanto parece pela primeira vez (e possivelmente de modo singular até agora), chama a atenção para o trabalho de Ladner e para o seu conceito de «ideia de reforma ${ }^{808}$.

Significativamente alia esta chamada de atenção a uma citação de Chaunu, do seu $10^{\circ}$ volume do Tempo das Reformas, que define as reformas do séc. XV como o momento em que, mais do que empreender a reforma geral necessária, se estabelece o consenso da necessidade dessa reforma; deste modo associando (num artigo considerado de referência para a temática das reformas quatrocentistas) o pensamento dos dois autores que este trabalho elegeu como seus principais substratos teóricos.

\subsubsection{Movimentos reformistas em Portugal nas primeiras décadas do séc. XV}

Portugal parece ter participado de um modo significativo, malgrado todos os exemplos negativos que se possam avocar sobre o laxismo do universo eclesiástico português (seja masculino ou feminino, secular ou regular), nos movimentos reformistas que no séc. XIV e XV encontram-se em

\footnotetext{
${ }^{805}$ CARVALHO, 1995. Este trabalho fundamental foi atualizado e republicado pelo CITCEM em 2016 (cf. CARVALHO, 2016).

${ }^{806}$ CARVALHO, 1995: 637.

${ }^{807}$ DIAS, 1960: 94 e segs.

${ }^{808}$ CARVALHO, 1995: 638, 639.
} 
atuação na cristandade ocidental, procurando dar uma resposta ao sentimento generalizado de crise eclesial.

Estes movimentos atuantes em Portugal vão, a exemplo do que se passa no demais ocidente cristão, introduzir a questão da reforma, ensaiar algumas soluções e preparar o universo eclesiástico e laico nacional para as reformas mais profundas que o séc. XVI desenvolveráan ${ }^{809}$

Neste desiderato, a Igreja portuguesa parece seguir o entendimento reformista que está presente na fundação da Congregação de Alga e na de S. João Evangelista e que enforma a sua atuação: a reforma do clero é o ponto de partida da reforma da Igreja e por esta de todos os cristãos. A reforma moral, a observância canónica e a espiritualidade litúrgica e devocional abrem o caminho para uma reforma individual e coletiva e inserem-se assim ativamente no processo salvífico ${ }^{810}$.

Oliveira Marques ${ }^{811}$ e Armindo de Sousa ${ }^{812}$ acentuam brevemente os caracteres mais importantes da Igreja portuguesa do séc. XIV e XV. Mencionam as largas diferenças entre um corpo eclesiástico desigual em posição e meios, com base na sua origem social e nas diversas hierarquias que a própria instituição cria no seu interior ${ }^{813}$. Um clero que na sua maioria tinha uma deficiente preparação intelectual e religiosa, um universo eclesiástico em que as redes de interesses eram, a todos os níveis, muito fortes e em que os exercícios de padroado colocavam os provimentos eclesiásticos em mãos e em interesses distintos dos que exigiam a natureza pastoral dos ofícios.

O absentismo e a simonia, a incontinência de quem era obrigado ao celibato e à castidade, levaram Armindo de Sousa a exprimir um juízo definitivo e lapidar: «Diz-se que os clérigos tiveram uma vida moral péssima nos séculos XIV e XV. E tal parece ter sucedido» ${ }^{814}$.

Este era o quadro geral, amplamente conhecido e que, como tal, dispensa maior aprofundamento. Mas é precisamente por existir um quadro generalizado que podemos entender de crise, por evidenciar práticas contrárias aos valores morais e espirituais que a Igreja defendia e propunha ao universo eclesiástico e à comunidade dos crentes, que percebemos com grande simplicidade a emergência simultânea de diversos movimentos eclesiais que visavam promover a alteração deste panorama, por meio de uma reforma da Igreja que é, antes de mais, uma reforma dos clérigos. Afinal, se perdidos andam os pastores, perdidas andarão as ovelhas.

\footnotetext{
${ }^{809}$ Um resumo da situação da Igreja portuguesa e da aplicação de reformas pode ser visto no capítulo que Elvira Mea escreveu para a Nova História de Portugal e que significamente se intitula A Igreja em Reforma (cf. MEA, 1998).

${ }^{810}$ Acerca destas questões em Portugal veja-se, por exemplo, o trabalho de Maria de Lurdes Correia Fernandes (FERNANDES, 2000), que historia brevemente a questão da reforma para os séculos da modernidade no universo eclesiástico nacional. Também Margarida Garcez Ventura, na sua obra sobre a relação entre a Casa de Avis e a Igreja (até meados do séc. XV), identifica o mesmo entendimento entre os príncipes desta dinastia (cf. VENTURA, 1997: 51 e segs.).

${ }^{811}$ MARQUES, 1987: 365 e segs.

${ }^{812}$ MATTOSO, 1997: 356 e segs.

${ }^{813}$ Armindo de Sousa identifica cinco formas de hierarquização, identificadas a partir das fontes e de Fortunato de Almeida: hierarquia de prestígio, de sagração (que talvez fosse melhor denominar de ordenação, já que a sagração está reservada aos Bispos, e cuja identificação parece algo duvidosa pelo menos no que se refere ao primeiro grupo que identifica), de dignidade, de jurisdição e de religião (cf. Idem, ibidem: 357).

${ }^{814}$ Idem, ibidem: 361.
} 
No Portugal dos sécs. XV e XVI a reforma foi antes de mais, como aliás se observou fora do espaço nacional, uma proposta das ordens e congregações religiosas, e particularmente dos movimentos de observância de que o séc. XIV e XV foram ricos.

Podemos citar exemplos nesta matéria, todos consabidos e mais ou menos estudados pelos autores $^{815}$, mas que demonstram até que ponto no Portugal quatrocentista, aquele em que os clérigos tiveram a tal péssima vida moral, desenvolveram-se propostas reformistas criadas e pensadas no seio de ordens e congregações já existentes e naquelas que então se constituíam.

Pela sua precocidade e pelo papel de primeira água que desempenha, alicerçada na relevância que alcança, nomeadamente no favor régio, mencione-se desde logo a observância franciscana, introduzida em Portugal nos finais do séc. XIV ${ }^{816}$. Também os Dominicanos, Beneditinos, Cistercienses e Agostinhos tiveram as suas tentativas mais ou menos bem-sucedidas de reforma claustral ${ }^{817}$.

A atuação destes diversos movimentos de observância em Portugal, e o seu enquadramento no âmbito de movimentos similares, foi já analisado como contexto ao movimento dos Lóios por Isabel Castro Pina ${ }^{818}$ pelo que se escusa uma análise mais aprofundada que se remete para a sua tese doutoral, bem como para as outras obras que aqui se vão citando.

A referência aos movimentos de observância em Portugal nas primeiras décadas do séc. XV, bem como as nascentes Ordem de S. Jerónimo (cujo percurso em muito nos poderá recordar o dos Lóios $^{819}$ ) e movimento dos eremitas da Serra de Ossa (que virão a constituir-se como Congregação em finais do séc. XV e unem-se à ordem de S. Paulo primeiro eremita ${ }^{820}$ ), é no entanto de suma importância quando considerada em contexto e na relação mais ou menos próxima que estes movimentos tiveram nas primeiras décadas da Congregação de S. João Evangelista.

Este florescimento de iniciativas de natureza reformista que se podem encontrar a atuar no Portugal das primeiras gerações da dinastia de Avis tem a possibilidade de desenvolver-se graças ao apoio que, de um modo generalizado e em maior ou menor grau, a Coroa concede a estes movimentos, baseado num entendimento desenvolvido no seio da Casa de Avis sobre o papel que ao Rei pertence na promoção da reforma eclesiástica.

A análise que sobre esta matéria nos dá Margarida Garcez Ventura ${ }^{821}$, no seu estudo sobre as relações entre Coroa e Igreja e o debate em torno da questão das liberdades eclesiásticas, demonstra bem como a coroa portuguesa tinha, na primeira metade do séc. XV, um pensamento teórico estruturado sobre a Igreja e o seu papel na sociedade portuguesa.

Esta construção teórica, construída no seio da monarquia de Avis, favorece o fortalecimento do poder Real pelo entendimento alargado do ofício régio, que entendido como delegação do poder

\footnotetext{
${ }^{815}$ Em resumo mencionam estas iniciativas (e apenas para enumerar as obras mais utilizadas aqui) DIAS, 1960; MARQUES, 1987; MATTOSO \& SOUSA, 1997; FERNANDES, 2000.

${ }^{816}$ Sobre a observância fransciscana em Portugal, o seu papel e relevo enquanto proposta reformista veja-se TEIXEIRA, 2004.

${ }^{817}$ DIAS, 1960; FERNANDES, 2000.

${ }^{818}$ PINA, 2011: cap. I.3 e I.4.

${ }^{819}$ Acerca do surgimento e da presença dos Jerónimos em Portugal veja-se a tese de Cândido dos Santos, SANTOS, 1996.

${ }^{820}$ Sobre os eremitas da Serra de Ossa e a sua Congregação veja-se FONTES, 2012.

${ }^{821}$ VENTURA, 1997.
} 
divino leva a que se encontre entre os primeiros governantes desta dinastia a ideia de que ao Rei cabia, pelo seu ofício, a responsabilidade de garantir o bom governo do seu reino e a pacífica convivência entre os diversos estratos sociais em prol de um bem comum $^{822}$.

Por este entendimento a coroa reclama autoridade sobre o universo eclesiástico sempre e quando se torne necessário corrigir abusos ou intervir para garantir que o clero cumpra com as obrigações que, no esquema social, se lhe atribuem e com as quais cumpre uma função coletiva, de direção moral e espiritual da comunidade de crentes e de súbditos.

No projeto político dos primeiros soberanos de Avis, e enquadrado no seu entendimento do papel que à Igreja cabia representar no conjunto da sociedade, encontra-se a consciência de uma necessária reforma para que esta cumpra o que se entendia ser, como Garcez Ventura resume a partir do pensamento expresso pelo Rei D. Duarte, a «obrigação dos clérigos e outros religiosos: oração, ensino, direcção espiritual e administração dos sacramentos aos fiéis» ${ }^{823}$.

Esta síntese das obrigações do universo clerical, formulada de acordo com o pensamento dos primeiros governantes de Avis, os reis D. João I e D. Duarte e o Infante D. Pedro ${ }^{824}$, bem como o eco das críticas dos mesmos, e do círculo que os rodeia, ao estado moral dos clérigos e à sua insuficiência no cumprimento destas obrigações que lhes são assacadas, sustentam a intervenção da Coroa em prol da reforma da Igreja portuguesa, que é a reforma do seu clero.

A intervenção basear-se-á no entendimento de reforma da própria Coroa, o qual se poderá definir (de acordo com a leitura que Margarida Garcez Ventura faz do pensamento e da atuação dos Príncipes de Avis) como uma mudança individual para melhor, um caminho de renovação moral e espiritual, particularmente no que se refere aos clérigos pela insistência num comportamento moral adequado à sua específica condição clerical (insistência repressiva, como se poderá verificar na normativa destes reinados para esta matéria), na importância de uma adequada formação para o exercício do múnus pastoral e sacramental (nomeadamente na direção de consciência), no exercício de boas obras, no desapego das temporalidades tão contrárias a quem deve perseguir as matérias de espírito, na insistência (pelo menos teórica) a que o provimento de prelazias e outras dignidades se faça por princípios meritocráticos ${ }^{825}$.

Note-se que, em termos genéricos, este conceito de reforma não se afasta substancialmente das principais propostas reformistas que na mesma época se debatiam, e ocasionalmente se tentavam pôr em prática.

Uma comparação com as ideias e práticas que se encontram, por exemplo, entre os círculos reformistas em que se insere a Congregação de S. Jorge em Alga, nomeadamente as iniciativas de reforma propostas por Eugénio IV (o Papa que governará a Igreja no período final do reinado de D. João I, todo o reinado de D. Duarte e na regência do Infante D. Pedro), permite perceber que as ideias de

\footnotetext{
${ }^{822}$ Idem, ibidem: 75 e segs.

${ }^{823}$ Idem, ibidem: 40.

${ }^{824}$ Nomeadamente na sua célebre carta de Bruges, de que se falará neste capítulo.

${ }^{825}$ Note-se que num período em que o fenómeno dos comendatários proliferava vamos encontrar o Infante D. Pedro a defender que as prelazias claustrais fossem providas por via eleitoral (cf. VENTURA, 1997: 63).
} 
reforma centrais que norteiam estes príncipes portugueses são aquelas que preocupam diversos níveis da própria Igreja e que, como visto, centravam-se na melhoria da condição moral do clero, da sua formação, na reforma dos claustros, na escolha de prelados dignos para dioceses, ordens e congregações religiosas e seus conventos.

Aparte os considerandos e variantes de natureza mais política que religiosa que possam existir no entendimento da Coroa sobre a reforma da Igreja, poderemos considerar que a maior diferença entre o seu pensamento reformista e aquele que se debate e organiza no interior da própria instituição está na centralidade da questão: se para a Coroa a reforma da Igreja é matéria de importância mas apenas como mais uma das áreas de intervenção de um poder Real que se pretende afirmar e fortalecer, enquadrado numa lógica coletiva de que a Igreja é um dos elementos, já para a instituição em si, nomeadamente para os pontífices e prelados de cariz reformista e para os diversos movimentos de natureza similar, a questão da reforma é central.

Esta aparente similaridade de pontos de vista entre a Coroa e os diversos movimentos reformistas com atuação em Portugal tornaram possível que, apesar dos indícios de tensão existentes entre a hierarquia eclesiástica portuguesa e a Coroa ${ }^{826}$, encontremos os príncipes de Avis a participarem de modo ativo nas diversas iniciativas reformistas que o país conheceu no séc. XV.

Garcez Ventura $^{827}$ distingue na política régia duas distintas linhas de ação em prol da reforma da Igreja. Uma dessas linhas é a atuação régia que se poderá caracterizar como de apoio às reformas que grupos, personalidades ou instituições eclesiásticas promovem, e nas quais se inclui prevalentemente o apoio às observâncias e às novas fundações de ordens e congregações religiosas. Neste caso temos a Coroa a dar apoio a propostas reformistas exógenas à própria instituição monárquica.

A outra linha de atuação de carácter reformista da dinastia de Avis, na primeira metade do séc. $\mathrm{XV}$, é endógena à própria Coroa, e trata-se do que Garcez Ventura chama de "promoção ativa da reforma», e que encontra como intenção de D. João I e D. Duarte no segundo quartel do século ${ }^{828}$.

Nestas duas linhas de atuação, que consubstanciam a política régia nesta matéria, poderemos encontrar a presença da nova congregação dos Lóios, e dos seus fundadores, em participação direta ou indireta, tornando possível perceber até que ponto a novel Congregação e os seus religiosos foram reconhecidos como proposta reformista, de acordo com os critérios então vigentes, com um valor intrínseco que os tornavam dignos de atenção, apoio e utilização como agentes de promoção de reforma.

Atentando para já na segunda linha mencionada, a das políticas de reforma ativamente promovidas pela coroa, vemos que as mesmas, para Garcez Ventura, se centrarão nas atividades de reforma que a Coroa entrega ao beneditino português radicado em Itália D. Gomes, monge que professara

\footnotetext{
${ }^{826}$ Margarida Garcez Ventura menciona nomeadamente as tensões geradas entre a Coroa e os Bispos pela ingerência normativa e governativa da Coroa em matérias que os prelados consideravam não pertencer à Coroa e que feririam as liberdades eclesiásticas, pelas quais se manteve ao longo dos reinados que a autora estuda uma longa e áspera querela entre Coroa e Mitras. De notar que esta questão complexa ultrapassa mesmo a aparente coincidência de pontos de vista entre a Coroa e os promotores da reforma da Igreja, já que vamos encontrar o próprio fundador dos Lóios, D. João Vicente, a assumir (como Bispo de Lamego) a defesa das liberdades eclesiásticas (cf. VENTURA, 1997: cap. I [para D. João Vicente veja-se as p. 32 e segs.]).

${ }^{827}$ Idem, ibidem: 64.

${ }^{828}$ Idem, ibidem: 64.
} 
na abadia de St. ${ }^{a}$ Justina de Pádua, onde o já nosso conhecido Luís Barbo era Abade e promovia a reforma observante dos monges negros de S. Bento, e que na década de 1420 dirigia o mosteiro de St. ${ }^{a}$ Maria de Florença ${ }^{829}$.

O percurso de D. Gomes em Itália e Portugal, nomeadamente como prelado monástico reformista e como colaborador régio nesta matéria, está amplamente estudado por Borges Nunes e Sousa $\operatorname{Costa}^{830}$, o que Margarida Garcez Ventura chamava precisamente à atenção quando dizia analisar esta figura numa perspetiva nova (a da sua articulação com a questão das liberdades eclesiásticas e com uma determinada política régia) mais do que como uma novidade de conhecimento ${ }^{831}$. Do mesmo modo a novidade que aqui se pretende trazer é mais de enquadramento do que de conhecimento, já que sobre a relação entre Lóios, D. Gomes e a política reformista da Coroa já falaram diversos autores ${ }^{832}$.

Gomes Anes, português de Lisboa que Borges Nunes supõe filho de um notário ${ }^{833}$, terá ainda jovem refeito os passos do seu ilustre conterrâneo, o franciscano Fr. António, e foi até Pádua, para estudar Direito, correria o ano de 1409. No mesmo ano e cidade deu-se, como visto, a passagem do mosteiro beneditino de St. ${ }^{a}$ Justina da comenda do Cardeal Correr ao governo do abade regular Luís Barbo.

Os primeiros recrutas da casa beneditina em reforma, e onde viria a constituir-se a observância beneditina da futura Congregação Cassinense, terão sido estudantes da universidade paduana, certamente participantes dos anseios espirituais e religiosos que dominavam aqueles anos e que aderiam assim ao projeto de reforma que Luís Barbo constituía e em que a Congregação de Alga tinha um importante papel.

Em $1413^{834}$ o estudante de Direito Gomes Anes entra no noviciado de St. ${ }^{a}$ Justina, onde professará em janeiro de 1414, no mesmo mês e ano que dois outros portugueses, que dão conjuntamente bom exemplo da circulação lusitana em Itália, nomeadamente nesta região do Veneto, e do eco que o apelo destes movimentos de observância tinham entre estes jovens escolares (o que eram pelo menos dois dos três jovens portugueses) $)^{835}$.

$\mathrm{O}$ percurso de D. Gomes nos anos seguintes à sua profissão faz-se entre mosteiros beneditinos ligados a St. ${ }^{a}$ Justina, com uma passagem episódica pela cartuxa, que Borges Nunes considera como um «sintoma saudável de apuramento espiritual» ${ }^{836}$, certamente pelo rigor que o modo de vida cartusiano implicava e que era reconhecido neste meio reformista italiano, como vimos acontecer entre os fundadores de Alga, e em particular o seu expoente espiritual Lourenço Justiniano ${ }^{837}$.

\footnotetext{
${ }^{829}$ Idem, ibidem: 64 e segs.

${ }^{830}$ NUNES, 1963; COSTA, 1963.

${ }^{831}$ VENTURA, 1997.

${ }^{832}$ NUNES, 1963: 354 e segs.; COSTA, 1986; PINA, 2011: 56 e segs.

${ }^{833}$ NUNES, 1963: 21.

${ }^{834}$ Na primeira metade desse ano segundo COSTA, 1963: 74.

${ }^{835}$ NUNES, 1963: 28, 29.

${ }^{836}$ Idem, ibidem: 29.

${ }^{837}$ Que aparece a relacionar-se intimamente com a Cartuxa veneziana, do mosteiro de St. André do Lido, mosteiro agostinho (mais um...) que depois de um período de crise sem regular vida claustral acabará por ser entregue aos cartuxos pelo governo veneziano, para ser reformado, graças à intercessão de um outro importante reformista, franciscano, que aparece em íntimo contacto com Lourenço Justiniano, com o Cardeal Correr e com o Papa Eugénio IV (que o pensou para ocupar cáte-
} 
Será um outro processo pessoal de conversão e reforma que levará D. Gomes a assumir o título prioral e a reformar uma casa monástica: como Borges Nunes descreve o abade Guasconi da abadia de St. ${ }^{a}$ Maria de Florença (la Badia di Firenze), nobre a quem a família obtivera o benefício de um importante mosteiro sem vida regular (a comunidade teria 3 monges), parece ter passado um processo interior que o conduz ao desejo de ver a sua comunidade, até então apenas fonte de rendimento, reformada segundo o vigor autêntico da observância da regra de S. Bento.

Difícil não ver na história do abade de Florença as similitudes com a própria história de Luís Barbo, a quem o abade recorre no desejo de ter o seu mosteiro reformado por monges de St. ${ }^{\text {a Justina }}{ }^{838}$.

A história de Guasconi e da sua reforma de abade temporal a reformador é marginal mas revela, desta vez em Florença, o alcance não desprezível das ideias e das tentativas de reforma do mundo clerical regular e secular que então estavam em atuação, a interligação que se criava entre sujeitos reformistas para lá das distâncias geográficas (no caso entre a Toscana e o Veneto) e em que pessoas e instituições distintas se parecem reconhecer pela partilha do mesmo anseio de reforma. Ajuda também a compreender o universo em que Gomes Anes se movia, que o formou e no qual os Lóios serão participantes futuros.

Em outubro de 1418 chegam à abadia de Florença 16 monges de St. ${ }^{a}$ Justina, que D. Gomes liderava como prior claustral, e que Borges Nunes afirma condensar na sua pessoa o pleno controlo da vida da comunidade. A Guasconi resta apenas o título, honra e precedências de abade, resultado do desejo expresso de Luís Barbo que exigia a autonomia da sua comunidade monástica da autoridade abacial que os chamara ${ }^{839}$.

Encontramos novamente na atuação de Luís Barbo em St. a Justina a influência e o ensinamento dos Cónegos de S. Jorge em Alga. A autonomia que a comunidade canonical da executória de 1404 estabelecera, e que apenas deixara a Barbo formalmente o título prioral, tinha por base o entendimento da absoluta necessidade de autonomia interna e externa da comunidade para se governar, de modo a evitar interesses e intromissões de comendatários e para garantir a capacidade dos cónegos para desenvolverem e implementarem o seu entendimento de vida comunitária.

Este mesmo desiderato justificará o desejo constante da isenção do ordinário, que os cónegos de Alga e os Lóios obterão da Santa Sé, e que ocasionará conflitos pelos tempos ${ }^{840}$. Barbo aprendeu a lição dos seus primeiros anos de vida e aplica-a na observância beneditina.

dras diocesanas): Bernardino da Siena. Lourenço Justiniano, durante o seu episcopado, concederá ao mosteiro privilégios e doações em prol do culto divino (cf. CORNELIO, 1749: 135 e segs.).

${ }^{838}$ NUNES, 1963: 33-40.

${ }^{839}$ Idem, ibidem: 41 e segs.

${ }^{840}$ Como se poderá ver numa leitura na crónica de Tomasini para Alga (cf. TOMASINI, 1642); no caso dos Lóios encontram-se exemplos nas diversas crónicas que se têm mencionado. Retenha-se, como exemplo, a questão com D. Fernando da Guerra (antes de mais uma disputa em torno da isenção dos cónegos e Casa de Vilar da autoridade do prelado, que o não quer aceitar), bem como os diferendos com diversos prelados portugueses (como os Bispos do Porto ou de Évora) que se podem encontrar facilmente na documentação sobrevivente das comunidades, como se poderá ver em relação ao Porto o que diz Jorge de S. Paulo no seu Compêndio do Cartório (que escreveu durante o seu reitorado nesta casa, cf. ADP - Monásticos, Convento de Santo Elói do Porto, lv. do Compêndio do cartório, K/19/6-57), ou, na perspetiva oposta à dos Lóios, e já para o final do séc. XVII, os diversos documentos que no arquivo do bispo do Porto (e depois Arcebispo de Braga e Lisboa) D. João de Sousa se conservam na Biblioteca da Ajuda, e que nos dão a dimensão das disputas por preeminências e isenções 
Em 1419, ano da aprovação da Congregação De Unitate de St. ${ }^{a}$ Justina, Gomes Anes é eleito pelos monges para substituir Guasconi, entretanto falecido ${ }^{841}$.

Nas décadas de 1420-30, que serão complexos na vida da Congregação de St. ${ }^{a}$ Justina (de que a abadia de Florença se separará temporariamente ${ }^{842}$ ), Gomes Anes dedica-se em geral ao governo da sua abadia. Certo é que a sua escolha de professar o hábito negro num mosteiro italiano de observância não tornou D. Gomes um estranho ao seu país, que visitará e de onde receberá monges. Até 1426, a abadia de Florença recebeu seis monges portugueses, os quais mormente provenientes da nobreza e dos ambientes de corte, revelando como a reforma observante beneditina que em Florença D. Gomes liderava reverberava nos meios cortesãos portugueses. Será nos contactos com Portugal que D. Gomes se insere na política régia de reforma, na tentativa de introduzir a observância beneditina em Portugal e na fundação dos Lóios.

Borges Nunes e Sousa Costa registam uma primeira estadia do abade D. Gomes em Portugal, nos anos de 1424 e 1426, acompanhado de um grupo de 17 dos seus monges ${ }^{843}$, e depois disso numa nova vinda, entre 1435 e 1437, enviado ao rei D. Duarte como legado do Papa Eugénio IV, com a particular missão de defender perante o Rei a posição do pontífice contra a do concílio de Basileia, envolvendo-se igualmente na projetada reforma da Igreja portuguesa ${ }^{844}$.

Voltará em definitivo em 1441 nomeado Prior de Santa Cruz de Coimbra por bula de Eugénio IV de 12 de agosto, e eleito prior pela comunidade no ano seguinte, esperando-se dele atuação reformista não só em St. ${ }^{a}$ Cruz mas em outras comunidades, como parece seria o desejo do regente D. Pedro e para o que receberá pontuais comissões pontifícias. Será neste priorado que morrerá em $1459^{845}$.

O resumo da ação reformista de D. Gomes em Itália, sintetizada por Borges Nunes e Sousa $\operatorname{Costa}^{846}$, bem como o prestígio que por ela terá alcançado, permitem perceber que fosse encarregado de missões de reforma no seu país natal, com o qual mantinha importantes relações epistolares ${ }^{847}$, ser-

\footnotetext{
que se geravam ainda nesta época entre a mitra portuense e o convento lóio desta cidade, e de como o prelado procurava activa e sistematicamente obter em Roma decisões que lhe fossem favoráveis, quando não tentava intervir mais activamente na comunidade pela nomeação de um reformador para o convento (cf. BA - 51-IX-30).

${ }^{841}$ NUNES, 1963: 47 e segs. Sobre a Congregação de St. ${ }^{a}$ Justina veja-se WITTERS, 1984.

${ }^{842}$ Borges Nunes descreve longamente os diversos passos desta questão, das razões do afastamento e do empenho do papa Eugénio IV, que procurava manter íntegra a observância beneditina que Barbo criara e promovia (cf. Idem, ibidem: cap. 6). ${ }^{843}$ Idem, ibidem: 111; COSTA, 1963: 79 e segs. Desta viagem dá também notícia o salvo-conduto que lhe concede o herdeiro D. Duarte em novembro de 1425 (cf. ALMEIDA, 1961: 104, doc. 56).

${ }^{844}$ COSTA, 1963: 83 e segs.

${ }^{845}$ Idem, ibidem: 93 e segs.

${ }^{846}$ Idem, ibidem: 107 e segs.; NUNES, 1963, particularmente a parte V.

${ }^{847}$ A epistolografia do abade D. Gomes Anes, que deixou uma impressionante massa documental que se situará entre as décadas de 1420 e 1440, constitui-se como uma notável fonte para o estudo das redes de relacionamento deste prelado português, incluindo troca de correspondência com as elites eclesiásticas e laicas do seu tempo, particularmente as portuguesa e italiana, destacando-se as relações com os membros da dinastia de Avis. Desta documentação, conservada em Florença, está prometida uma edição portuguesa, que será de elevado interesse para quem trabalhar as relações entre Portugal e Itália no séc. XV, questões de reforma eclesial, entre outras inúmeras possibilidades de investigação. Foi recentemente publicado um
} 
vindo de figura de referência em Itália para a Coroa e para as elites nacionais, que a ele recorriam para encaminharem os seus assuntos ou para lhe recomendarem pessoas do seu serviço ${ }^{848}$.

É nítido que a presença de Gomes Anes no seu país de origem teve lugar sob o signo da reforma da Igreja, o mesmo sob o qual reconhecidamente decorreu a sua vida, como se percebe do facto dos Papas Martinho V e Eugénio IV, bem como a Coroa Portuguesa, a ele recorrerem para o desempenho de missões de natureza reformista, ao mesmo tempo que o abade cultivava relacionamentos com outras figuras e movimentos reformistas do seu tempo, em que se podem contar os fundadores Lóios $^{849}$.

Quando em $1425^{850}$ o rei D. João I e o seu filho D. Duarte ${ }^{851}$ fazem suplicar ao Papa Martinho V que concedesse o mosteiro beneditino de S. João de Alpendurada (então em regime de comenda entregue ao bispo de Mégara) para que fosse reformado na observância beneditina, informa que o convento era para acolher a comunidade de 18 monges e seu abade (que seria D. Gomes Anes) que fizeram vir de Itália para levar a cabo, em Portugal, a reforma dos monges negros ${ }^{852}$.

Revela-se aqui o desejo régio de querer ativamente promover uma reforma eclesiástica em Portugal, começando pela tentativa de introduzir a observância beneditina que crescia em Itália mas ainda não chegara ao limite ocidental da Europa.

Este desejo consubstanciará, conforme ao entendimento de Margarida Garcez Ventura, a tal promoção ativa de reforma dos primeiros soberanos de Avis, e seria tanto mais importante quanto a importância, tradição, número e património dos mosteiros beneditinos portugueses, e a notória crise a que muitos deles chegaram, sem regular vida claustral e entregues a comendatários ${ }^{853}$. Note-se apenas que se a primeira Casa da Congregação de Alga foi um priorado agostinho, a primeira Casa dos Lóios (Vilar de Frades) foi um mosteiro beneditino sem regular vida claustral.

Apesar de partir da Coroa, e de contar com a concordância pontifícia (que parece ter sido concedida apesar de alguma oposição curial ${ }^{854}$ ), a missão revelou-se de complexa execução, com resultados escassos ou nulos, que não interessa aqui historiar e de que os autores e obras aqui citados tratam já em profundidade. Importa apenas, em relação ao abade D. Gomes e às suas atividades de reforma, ressaltar dois pontos fundamentais:

indíce analítico dos 2 volumes do Codex Ashburnham 1792 da Biblioteca Medicea Laurenziana de Florença, que agrega esta documentação (cf. ELBL, 2014; ELBL, 2015).

${ }^{848}$ Basta analisar o índice supra mencionado para perceber até que ponto esta afirmação se revela verdadeira.

${ }^{849}$ COSTA, 1963: 120 afirma mesmo: «Durante o seu governo, o abade português [...] não se ocupou apenas do progresso e reforma da sua abadia. Chegou a receber encargo da visita e reforma de muitos mosteiros e conventos de diversas Ordens». Borges Nunes também analisa a questão na parte $\mathrm{V}$ do seu trabalho, como já mencionado supra.

${ }^{850} \mathrm{O}$ ano depreende-se da data da concessão da súplica, 30 de maio de 1425, como informa Sousa Costa (cf. Idem, ibidem: 123).

${ }^{851}$ Garcez Ventura afirma que, apesar do nome do Rei figurar na súplica, a vinda inicial de D. Gomes deve-se a D. Duarte (cf. VENTURA, 1997: 65).

${ }^{852}$ COSTA, 1963: 123 e segs.

${ }^{853}$ Para a crise são eloquentes os casos mencionados por Silva Dias (cf. DIAS, 1960: 47 e segs.).

${ }^{854}$ COSTA, 1963: 127 e segs. 
1. Gomes Anes foi reconhecido no seu tempo pelo seu carácter de reformista, o qual formado no espírito da reforma de Luís Barbo e da Congregação de St. a Justina de Pádua estava indelevelmente ligado ao ideal reformista que os sustentava: o círculo reformista veneziano, em particular o do movimento de S. Jorge em Alga.

Como se confirma pelos dados aduzidos por Borges Nunes e Sousa Costa, D. Gomes Anes foi além do mais um relevante colaborador de Eugénio IV em matérias de reforma (e não só), inserindo-se sem grandes dúvidas na categoria dos clérigos reformadores de que, como visto no capítulo anterior, o Pontífice se rodeou e que utilizou em diversos encargos do governo da Igreja.

2. A sua atividade reformista em Portugal parece ter por base o desejo da Coroa Portuguesa em promover ativamente a reforma do universo eclesiástico nacional, principiando por uma das ordens mais antigas presentes em território nacional e uma que apresentava maiores sinais de crise.

Parece claro que os Príncipes de Avis manteriam um conhecimento não desprezível do que, em matéria de reforma eclesiástica e de desenvolvimento dos movimentos de observância, acontecia para além das fronteiras nacionais. Neste conhecimento incluir-se-ia a atividade da observância beneditina italiana, a que pertencia Gomes Anes.

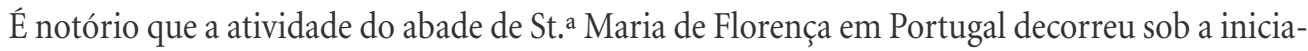
tiva e amparo da Coroa, o que naturalmente promoveu próximas relações entre o abade, os membros da Família Real e os seus cortesãos. Em particular retenha-se que os mais próximos colaboradores de D. Gomes na sua primeira estadia, os monges portugueses Estevão de Aguiar e Fernando Falcão (com quem aliás D. Gomes se desentenderá posteriormente, certamente por iniciativas autónomas que estes tomam ${ }^{855}$ ), eram de origem nobre ${ }^{856}$.

Ante estes dois pontos é possível estabelecer com segurança que, nos anos em que se fundava a futura Congregação dos Lóios, havia em relacionamento com a Coroa e a Corte portuguesas um representante da observância beneditina de St. ${ }^{a}$ Justina, que apesar de vir de Florença transportava em si toda a essência do movimento gerado por Barbo na Abadia Paduana.

A existência das relações de Gomes Anes com os fundadores Lóios está consideravelmente registada na documentação sobrevivente, seja a que se conserva nos importantes volumes epistolográficos do abade ${ }^{857}$, seja em outra documentação em que o abade aparece em relacionamento com os Lóios,

\footnotetext{
${ }^{855}$ Tratam desta questão Sousa Costa (cf. COSTA, 1963: 127 e segs.) e Garcez Ventura (cf. VENTURA, 1997), e pode-se verificar no epistolário de D. Gomes como levou à excomunhão destas duas figuras, e como por eles intercedeu D. Duarte (cf. ELBL, 2014: 68) em carta que transcreve o padre Sousa Costa, na obra supra mencionada, p. 138 e segs.

${ }^{856}$ No caso de Fr. Fernando Falcão, e apesar de não se poder encontrar a sua efetiva filiação em Felgueiras Gaio (talvez o genealogista que mais profundamente tratou da família Falcão) é muito possível que esteja ligado a Gonçalo Anes de Abreu, pai de João Falcão de Abreu (casado com D. Branca de Sousa, filha de D. Lopo Dias de Sousa, Mestre da Ordem de Cristo), cavaleiro do Infante D. Pedro e Alcaide-mor de Mourão, e de D. Álvaro de Abreu, Bispo de Évora, que eram homens integrados nos círculos da corte portuguesa, circulando entre a linhagem dos Abreus e dos Sousa (cf. GAIO, $1939 \mathrm{a}$ : 76 e segs; em GOMES, 1995, vejam-se as informações respeitantes à família dos Sousas e dos Abreus; e o artigo de SOVERAL, 2004, que trata a descendência de D. Lopo Dias de Sousa).

${ }^{857}$ Neste caso é de salientar a troca de cartas com dois dos fundadores Lóios Afonso Nogueira e Martim Lourenço (cf. NUNES, 1963: 354 e segs.; COSTA, 1986).
} 
particularmente quando, em 1437, é preconizado com o fundador dos Lóios mestre João Vicente para a visita geral e reforma do clero em Portugal ${ }^{858}$.

A escolha destes dois prelados, o abacial e o episcopal, pensada entre o rei D. Duarte e o Papa Eugénio IV, é perfeitamente demonstrativa do reconhecimento que as duas figuras tinham aos olhos destes dois soberanos, o régio e o pontifício, como a de clérigos reformadores, dignos de estrita confiança para o desempenho de missão tão relevante.

Aparentemente os méritos reformistas de Gomes Anes e João Vicente não encontraram o mesmo acolhimento entre os principais prelados do reino, que os consideraram indignos de os visitar e corrigir, particularmente considerando que o colégio episcopal português incluía prelados entre os quais «tres sunt de genere regali et alii de nobili genere procreati» ${ }^{859}$.

Os percursos destes dois eclesiásticos, o de Gomes Anes enquanto monge e abade da observância beneditina, o de João Vicente enquanto figura central da fundação da Congregação de S. João Evangelista e enquanto bispo reformador em Lamego e Viseu ${ }^{860}$, estão ligados pela partilha de um mesmo referencial carismático de base.

Apesar das evidentes diferenças entre os modos de vida religiosa que as duas figuras representam, une-as a semente comum do universo reformista veneziano, particularmente a experiência que os fundadores da Congregação de Alga e Luís Barbo desenvolveram no mosteiro lagunar.

Parece, pois, poder-se afirmar com alguma segurança que existe uma raiz comum entre os projetos reformistas em que a Coroa portuguesa empenhou o abade D. Gomes Anes (seja a reforma observante dos beneditinos, seja a pensada reforma geral do clero português) e o projeto reformista desenvolvido pelas primeiras gerações de cónegos Lóios.

É patente que numa mesma linha de pensamento e de atuação conjugam-se (sob o ideal reformista que se desenvolveu a partir da experiência veneziana da viragem para o séc. XV) o papado de Eugénio IV, a ação governativa de D. Duarte, Infante e Rei, o percurso dos fundadores Lóios e em particular o de João Vicente, e a reforma observante de St. ${ }^{a}$ Justina e de Luís Barbo personificada em Gomes Anes.

Esta conclusão, de claro alcance, permitirá agora ao leitor perceber a importância do esforço de caracterização da ideia de reforma da Congregação de Alga e a descrição do universo eclesiástico em que esta se inseriu, e que foi construída ao longo de todo o $2 .^{\circ}$ capítulo desta obra.

Não é apenas pelos Lóios, mas certamente muito por eles, que as linhas de reforma italianas, particularmente as venezianas, se fazem presentes em Portugal, atuando mesmo com o declarado apoio régio, e visando fazer transpor ao nosso país uma experiência reformista que, na mesma época, se tenta ainda fazer implementar no palco italiano.

\footnotetext{
${ }^{858}$ Cf. COSTA, 1963: 144 e segs.

${ }^{859}$ Texto da exposição que os procuradores do episcopado português apresentaram ao Papa Eugénio IV em protesto pela escolha do bispo de Lamego D. João Vicente e o abade de Florença Gomes Anes para visitarem e reformarem o clero português, transcrita por Sousa Costa em COSTA, 1986: 264-266. Nesta exposição os prelados consideram como uma indignidade o serem visitados por reformadores de inferior origem social, não se coibindo igualmente de colocar em causa o seu perfil moral.

${ }^{860}$ Como se percebe no que sobre as suas prelazias escreveu Sousa Costa em Idem, ibidem.
} 
De todos os membros da Casa de Avis o primeiro que de um modo claro apoia a Congregação de S. João Evangelista, malgrado as tentativas cronísticas de fazer remontar esse apoio a D. João I ${ }^{861}$, e apesar da boa valência que D. João Vicente terá tido, enquanto bispo de Lamego, junto do rei D. Duarte ${ }^{862}$, é o Infante D. Pedro (1392-1449), Duque de Coimbra, regente do reino por morte de seu irmão e na menoridade do sobrinho (e genro) Afonso V.

Não é difícil perceber na figura do Infante D. Pedro ${ }^{863}$ os motivos que levaram este príncipe de Avis a apoiar a nova Congregação canonical que se reduzia, no momento em que o Infante assume a regência do Reino (1439864), a duas Casas colegiadas, situadas no interior norte e centro do reino ${ }^{865}$.

Homem que se tem considerado de sólida formação e cultura, viajado, em particular com uma presença nas principais cortes europeias e norte de Itália, onde o Rei dos romanos Segismundo o faz senhor da Marca de Treviso, esteve aí em contacto com as correntes reformistas que então atuavam no norte italiano, e que se pode verificar (por exemplo) nas relações que manteve com o abade Gomes Anes (patente logo no facto de o primeiro biógrafo de Gomes Anes dedicar a sua obra ao Infante D. Pedro ${ }^{866}$ ).

Tal como seu pai e irmão Duarte ${ }^{867}$, o Infante D. Pedro tinha um entendimento claro sobre a necessidade de reforma do universo clerical português, o qual é coincidente com os tópicos centrais de reforma eclesiástica que se debatiam na Europa da primeira metade do séc. XV, em particular com os que encontramos presentes no pensamento e ação do pontificado de Eugénio IV e nas propostas fundacionais das Congregações de S. Jorge em Alga e dos Lóios.

Esta similitude de pontos de vista pode-se encontrar, para o Infante D. Pedro, patente no que deixou escrito, por exemplo, na sua célebre carta de Bruges de 1425/26, dirigida ao seu irmão D. Duarte ${ }^{868}$. Os pontos de contacto são vários e centrais.

${ }^{861}$ De acordo com o que diz o P.e Jorge de S. Paulo no cap. 48 do seu Epílogo, ao afirmar que D. João I teria tornando patente a mestre João Vicente o seu sentimento por não estar a Congregação dos Lóios fundada quando se decidira a construir o mosteiro da Batalha, porque se assim fosse não o teria entregue aos Dominicanos mas faria dele a cabeça da Congregação. Apesar deste relato parecer improvável deixa-se aqui registado (cf. ADB - Manuscritos, ms. 924, p. 209).

${ }^{862}$ Cf. COSTA, 1986.

${ }^{863}$ Sobre o Infante D. Pedro existem diversos trabalhos, mas não uma biografia definitiva, como afirmava um dos autores que mais trabalhou a sua figura, o Prof. Baquero Moreno (cf. MORENO, 1997), e que tem demonstrado a relevância e riqueza desta figura cuja memória está indelevelmente marcada e determinada pela sua morte nos campos de Alfarrobeira e pela damnatio memoriae a que foi votado. Para a sua figura vejam-se, por exemplo, MORENO, 1979; FERREIRA, 1981; DUARTE, 2005; GOMES, 2006; RODRIGUES, 2012; o resumo de Armindo de Sousa em MATTOSO \& SOUSA, 1997: 421-423, e a de Oliveira Marques em MARQUES, 1987: 552 e segs.

${ }^{864}$ Cf. RODRIGUES, 2012: 197.

${ }^{865}$ Vilar de Frades (Barcelos, Arcebispado de Braga) e Recião (Diocese de Lamego).

${ }^{866}$ Veja-se o que sobre isto dizem NUNES, 1963: 93, 169, 181, 238, 283, 352; COSTA, 1963. Ainda que estes dois autores não teorizem longamente sobre as relações entre o Infante e o Abade, notem-se as referências à integração de D. Gomes no séquito de D. Pedro numa viagem a Roma em 1428; as relações que mantiveram à distância, até de natureza material; a sua vinda definitiva como reformador de St. ${ }^{a}$ Cruz de Coimbra, por iniciativa da Coroa e em período regencial de D. Pedro.

${ }^{867}$ Conforme ao que descreve Margarida Garcez Ventura, que situa a sua obra precisamente no período da governação de D. João I, D. Duarte e da regência de D. Pedro. Aliás não deixa de notar o peso do pensamento e actuação do Infante D. Pedro sobre a Igreja e a reforma eclesiástica, não só para o período do seu efetivo governo como regente, mas antes disso pelos conselhos que deixou a seu irmão Duarte, desde pelo menos a Carta de Bruges de 1425/26 (cf. VENTURA, 1997 : 60 e segs.). ${ }^{868}$ Texto transcrito em ALMEIDA, 1961: 140 e segs. 
Seja a questão do provimento de dignos prelados:

E porque a bondade dos prelados faz grande emenda em os súbditos e estes igoalmente não saom feytos em vosa tera senam per voso consentymento e autoridade, pareçeme, senhor, que deveis de ter maneyra como em vosa tera os aja bons e feytos direitamente. - matéria sobre a qual já tinha escrito, a pedido do próprio D. Duarte, como o mesmo declara - E, de como eu entendo que se ysto devia fazer vos leixey hum escrito que fyz, per voso mandado ${ }^{869}$.

Seja a questão de uma necessária melhoria no recrutamento e formação do clero, desde logo ao chamar a atenção para o excesso de menoritas que não pretendiam ordenar-se de ordens maiores (ou seja, procurariam apenas os benefícios e isenções do estado clerical) ou que nem sequer possuíam os conhecimentos mínimos de latim:

e porque vos, senhor, sabeis quão pouco serviço de Deus he e grande embargo a vosa justiça os muytos clérigos de ordens menores..., sugerindo correcção para o problema: [...] devieis de ter maneira que nom dessem [os prelados] ordens senão a homem que quisesser ser cleriguo, fazendothe [...] certo que filharia as ordens sacras [...] [e que além disso não as dessem] a nhũa pessoa que não sayba falar latym ${ }^{870}$.

A questão da correta preparação do clero passa também pela sugestão de uma reforma da Universidade e pela criação de colégios, que o Infante sugere à imagem dos estabelecidos em Oxford e Paris, do mesmo modo que sugere a criação de colégios pelos bispos e cabidos diocesanos e pelas ordens religiosas, para formação do seu clero ${ }^{871}$. Estas fundações teriam como consequência, segundo o Infante, que:

crecerião os leterados e as sciencias e os senhores acharião donde tomassem cappellães honestos e entendidos; e, quando taes promovessem, naom serião desditos. Ealem dysto, se seguyria que vos acharieis leterados pera officiaes da justiça. [...] E destes verião bons beneficiados, que serião bons electores e des hy bons prelados, bispos e outros ${ }^{872}$.

Apesar de ser notório no discurso do Infante D. Pedro que a melhoria da formação redundaria, antes de mais, em proveito da Coroa e Nobreza, dotando-os de um corpo clerical competente para o serviço do Estado, para o provimento de cargos e dignidades eclesiásticas e ainda para o serviço particular das suas capelanias, encontramos uma correlação direta destas medidas com o que virá a ser a atuação de Eugénio IV e do grupo de prelados que o apoiam.

\footnotetext{
${ }^{869}$ Idem, ibidem: 141.

${ }^{870}$ Idem, ibidem.

${ }^{871}$ Idem, ibidem: 142. Nota o editor do texto, em nota de rodapé, que apesar das propostas de reforma do ensino universitário e da criação de colégios pelas ordens religiosas, nem o Infante D. Pedro, nem o Rei seu irmão, chegaram alguma vez a aplicar tais medidas.

${ }^{872}$ Idem, ibidem.
} 
Como visto no ponto 2.3.2, a este Papa deveu-se a reforma da Universidade de Roma e a criação de colégios diocesanos que preconizaram a futura instituição dos seminários, medida que os prelados a ele ligados tiveram o cuidado de reproduzir.

Antes de chegar ao universo do clero regular o Infante deixa ainda um conselho sobre a administração das albergarias e capelas, sugerindo ao monarca que tenha maior atenção sobre aqueles a quem é entregue a sua administração, que em Portugal seria, genericamente e segundo o Infante, danosa para o serviço de Deus e o bem comum $^{873}$. Demonstra-se como a preocupação pela administração das instituições assistenciais que ocupará tão fortemente o rei D. João II (e que se verá no reinado de D. João III a passar pelos Lóios) era já uma preocupação do Infante seu avô.

Como já foi salientado, apesar de ser notória a diferença de finalidades entre a atuação reformista dos príncipes de Avis e do universo eclesiástico, encontra-se uma similitude de entendimentos e uma capacidade não desprezível de mútua colaboração que terá redundado em mútuo benefício.

Mesmo perspetivando que a atuação da Coroa portuguesa em prol de uma reforma eclesiástica tivesse por objetivo resolver problemas estruturais do clero, para que este corpo social cumprisse o mais fielmente possível com as obrigações que lhe pertenciam no entendimento que a monarquia tinha da sociedade, não deixamos de encontrar referências no pensamento do Infante D. Pedro que permitem supor que o Príncipe estava imbuído, nesta matéria, não apenas do sentido político do Estado, mas também de um entendimento religioso da ação reformista da Coroa sobre a Igreja.

Esta ideia está bem vincada, em particular no parágrafo com que o Infante conclui a primeira parte da sua carta, dedicada à Igreja portuguesa, dizendo a seu irmão Duarte:

Senhor, de vos em estas cousas que a igreja pertencem filhardes autoridade, se o fizeseis com tyrania ou temporal cobiça, eu não seria em conselho, e averia por mal a quemquer que o fizese; $e$, se o fizerdes com entenção de fazer serviço a Deus e com acordo dos prelados e doutros homens sesudos, que a voso parecer sejam de boa conciencia, eu entendo que ele vos dar por elo bom galardão ${ }^{874}$.

Nas linhas que o Infante dedicou aos que considerava serem «a muyto principal parte da spiritualidade, que são os religiosos» ${ }^{875}$, nota-se de imediato que o ponto de partida é o da sua propalada crise, já tão mencionada, patente nos conselhos que D. Pedro dá ao seu irmão D. Duarte de usar de particular rigor com os regulares, obrigando-os a um modo de vida austero, sem tempos ociosos, com prelados dignos que sejam escolhidos por eleição e não comendatários:

Prelado antre os fraires nunqua o seja senão o que for inlecto; e, se algum vier per carta, nam curem delo, senão se prouver aos frayres ${ }^{876}$.

\footnotetext{
${ }^{873}$ Idem, ibidem: 143.

${ }^{874}$ Idem, ibidem.

${ }^{875}$ Idem, ibidem: 143.

${ }^{876}$ Idem, ibidem.
} 
É nítido, no pensamento expresso nesta carta, que o Infante D. Pedro alinha o seu entendimento do universo regular com as preocupações dos movimentos observantes. Não será de admirar se tomarmos em consideração que D. Pedro, como um número muito razoável de príncipes da Casa de Avis, vai procurar junto dos ramos observantes das Ordens dos Frades Menores e dos Pregadores os seus diretores de consciência ${ }^{877}$. A proximidade espiritual da Casa de Avis às Observâncias e a própria política régia de apoio a estas linhas de reforma das Ordens religiosas, justificará o patronato que da Coroa veio a estas instituições.

Atentando no caso particular do Infante D. Pedro, como figura particular da Casa de Avis cuja dimensão intelectual e política foi de primeiro relevo, sabemos que teve por confessores conhecidos dois religiosos da Ordem dos Pregadores: Fr. João Verba ${ }^{878}$, que o auxiliará na produção do Livro da Virtuosa Benfeitoria ${ }^{879}$, a que se seguirá, já no período regencial, Fr. Afonso de Évora ${ }^{880}$.

A ligação de D. Pedro aos Pregadores e em particular ao seu confessor Fr. João Verba, como a de seu pai que lhes entregara o mosteiro que mandara construir na Batalha como grande obra de reinado e de dinastia (de que será o panteão ${ }^{881}$, e a de seus irmãos que tiveram dominicanos como confessores e pregadores ${ }^{882}$, teve um papel não desprezível no seu percurso.

Como António Dias Dinis salientou nos artigos que dedicou ao confessor do Infante (em particular o segundo, em que pela primeira vez identificou este eclesiástico como dominicano ${ }^{883}$ ), D. Pedro teve com o dominicano Fr. João uma relação de grande proximidade e uma colaboração de primeira água.

Já bacharel de Teologia em 1412, licenciado antes de 1418, terá entrado no serviço do Infante cerca de $1415^{884}$. A pedido de D. Pedro ao papa Martinho V este conceder-lhe-á, em 1423, o título de capelão pontifício e o priorado do mosteiro Agostinho de S. Jorge de Coimbra em regime de comenda ${ }^{885}$. Demonstra-se assim a valência que este confessor tinha junto do Infante, que na carta que acompanha o seu livro da Virtuosa Benfeitoria declara expressamente a relevância da sua colaboração na produção da obra $^{886}$, a que acresce um papel como colaborador literário também do próprio D. Duarte, futuro rei ${ }^{887}$.

A proximidade de Fr. João Verba ao seu principesco confessado terá levado, segundo Dias Dinis, a que não só integrasse (naturalmente, dado as suas funções) a comitiva do Infante no seu périplo internacional, como a tomar possivelmente parte, pelo menos como inspiração, na elaboração da carta de bruges que aqui já se tratou brevemente ${ }^{888}$.

\footnotetext{
${ }^{877}$ Para um resumo esclarecedor sobre esta questão veja-se MARQUES, 1993.

${ }^{878}$ Sobre o dominicano Fr. João Verba veja-se DINIS, 1956; DINIS, 1957.

${ }^{879}$ DOM PEDRO, 1940.

${ }^{880}$ MARQUES, 1993: 56.

${ }^{881}$ Sobre a posição dos dominicanos portugueses no apoio à causa do Mestre de Avis, e a sequente relação de apoio que os membros da nova dinastia mantiveram com eles, em particular D. João I, pode-se ver um resumo em GOMES, $2009: 264$ e segs.

${ }^{882}$ MARQUES, 1993: 56 e segs.

${ }^{883}$ Cf. DINIS, 1957.

${ }^{884}$ Idem, ibidem.

${ }^{885}$ Letras pontifícias transcritas em Idem, ibidem: 486 e segs.

${ }^{886}$ Cf. DOM PEDRO, 1940; DINIS, 1956: 463 e segs.

${ }^{887}$ Idem, ibidem; DINIS, 1957.

${ }^{888}$ DINIS, 1956: 439.
} 
As hipóteses apresentadas por Dias Dinis sobre a relação deste dominicano com o Infante D. Pedro, bem como a ligação estrutural deste Infante com a Ordem dos Pregadores, permitem supor (ainda que não possamos situar com certeza Fr. João Verba ${ }^{889}$ e Fr. Afonso de Évora entre os dominicanos observantes) que os círculos dominicanos da observância, que se apresentam como parte do ambiente reformista em que se formou a futura Congregação de S. João Evangelista ( $v d$. o ponto seguinte), foram participados pelo Infante D. Pedro, o primeiro membro da Casa Real portuguesa a objetivamente apoiar uma fundação Lóia.

É na já mencionada preocupação do Infante D. Pedro, registada na sua Carta de Bruges, sobre a necessidade de prover as instituições de alma com cariz assistencialista de bons administradores, que poderemos situar a entrega de uma destas instituições, o hospital de S. Paulo, S. Clemente e St.o Elói aos padres da Congregação de S. Salvador de Vilar de Frades.

Isabel Castro Pina sugere ${ }^{890}$ que o Infante se teria decidido pela entrega do hospital de St. ${ }^{\circ}$ Elói (como era e ficou conhecida a instituição) aos Lóios por sugestão do seu último provedor, o cónego Lóio Rodrigo Amado, que o Infante D. Pedro escolhera para substituir um provedor acusado de incumprir com os deveres do seu cargo ${ }^{891}$. Do padre Rodrigo Amado pode-se afirmar a sua proximidade ao bispo D. João Vicente, já que em 1432 aparece associado proximamente ao Bispo fundador, citado num documento como seu clérigo familiar ${ }^{892}$.

A entrega da gestão de St. ${ }^{\circ}$ Elói a Rodrigo Amado, cónego Lóio e muito próximo a João Vicente, não poderá deixar de ser lida como operada num círculo relacional de poder, mas também integrada num entendimento de reforma do universo religioso português que o Infante D. Pedro deixou patenteado na sua obra escrita e transpôs para decisões de governo, de que esta entrega é um cabal exemplo, e que demonstra o reconhecimento do carisma Lóio, como carisma de reforma, junto dos príncipes de Avis.

Este esforço encontrará um particular interlocutor em Gabriel Condulmer que, já Papa, converte o ideal reformista da sua Congregação de Alga e do universo veneziano numa das linhas de atuação do seu pontificado.

Conjugava-se pois a política pontifícia e a política régia portuguesa de reforma eclesiástica, que não visando necessariamente os mesmos objetivos, orientam-se sob um mesmo ideal e interligam-se mutuamente, tendo por intermediários privilegiados dessa interlocução Gomes Anes e João Vicente.

\footnotetext{
${ }^{889}$ Fr. João Verba pertenceria à comunidade conventual de S. Domingos de Lisboa, casa não reformada pela observância, mas onde fora religioso Fr. Vicente de Lisboa, que segundo Fr. Luís de Sousa, teria sido antigo provincial, confessor e pregador de D. João I, que fundaria e seria superior do convento de S. Domingos de Benfica, convento que seria (com o mosteiro da Batalha) uma das duas casas masculinas da observância dominicana em Portugal, centrada nestas duas novas fundações intimamente ligadas à Casa Real (cf. SOUSA, 1767: 83 e segs; MARQUES, 1993: 56).

${ }^{890}$ PINA, 2011: 135.

${ }^{891}$ TAVARES, 1999: 13, 14.

${ }^{892}$ Cf. Livro dos Privilegios concedidos pellos Summos Pontifices..., 1594: fl. 19. Desta proximidade fala também SANTA MARIA, 1697: 737, 738.
} 
Nunca é despiciendo relembrar as súplicas concedidas por Eugénio IV em março de 1445, de confirmação da união de Vilar de Frades e extinção da causa com o arcebispo de Braga, bem como a redução do número de merceeiros a sustentar em St. ${ }^{\circ}$ Elói de Lisboa, em resposta a súplica com as premissas informadas pelo regente D. Pedro mas suplicada pela sua filha rainha D. Isabel e pelos Cónegos Lóios ${ }^{893}$.

A fundação da Congregação que virá a ser de S. João Evangelista aparece assim em pleno diálogo com planos distintos, mas complementares, do universo político e eclesiástico português e italiano, assumindo-se com os seus religiosos como uma instituição de particular relevo na implantação (possível) de uma determinada ideia de reforma.

\subsubsection{Fundação e Fundadores Lóios em contexto de reforma}

A fundação dos Lóios e os seus fundadores (João Vicente, Martim Lourenço, Afonso Anes Nogueira e João Rodrigues, acrescidos de um conjunto de outros clérigos que se podem encontrar como fazendo parte da primeira geração de Lóios) foi analisada num conjunto de obras, aqui amplamente citadas, em que se destacam os trabalhos de Sousa Costa, de Pedro Vilas-Boas Tavares e Isabel Castro Pina, cuja tese teve por particular objeto as origens e as primeiras décadas da Congregação, incluindo necessariamente os seus fundadores ${ }^{894}$.

O trabalho realizado por estes autores não deixa, felizmente, muito por dizer sobre a fundação e os fundadores dos Lóios, pelo que o contributo que sobre esta matéria se pode aduzir vai no sentido de uma maior problematização e da tentativa de melhor situar na relação com o movimento reformista veneziano que lhe servirá como referencial carismático.

A mais antiga crónica dos Lóios, a de Paulo de Portalegre, descreve as fundações das Congregações de Alga e de S. João Evangelista centrando-as nas figuras de um fundador (ou instituidor, como também o designa) que, em cada uma das instituições, atua como um suscitador de vocação e cuja iniciativa se traduz no congregar de um grupo fundacional. Trata-se de Gabriel Condulmer em S. Jorge em Alga e João Vicente entre os cónegos portugueses ${ }^{895}$.

Esta descrição, que se pretende modelar em torno destas figuras, objetiva não só salientar o papel que as duas figuras possam ter tido na efetiva fundação das primeiras comunidades das respetivas congregações, mas refletem também, e com maior grau de certeza, o papel que desempenharam após a constituição dessas comunidades fundacionais.

Como se sublinhou em relação à fundação da Congregação de Alga, o papel de Gabriel Condulmer como fundador único, ou principal, dificilmente se pode comprovar. Será a sua atuação enquanto Cardeal e Papa que o converte na figura mais importante para a expansão dos cónegos seculares venezianos, pela doação de Casas, pela promoção do carisma e pela concessão de privilégios.

\footnotetext{
${ }^{893}$ Sousa Costa dá por anos destas súplicas 1446 no texto da sua obra sobre os bispos de Lamego, mas os documentos que transcreve em nota têm o ano de 1445, (cf. COSTA, 1986: 333 e segs.), o que concorda com os treslados impressos no Livro dos Privilegios concedidos pellos Summos Pontifices..., 1594: fl. 20 e segs., 57, 57v.

${ }^{894}$ COSTA, 1986; TAVARES, 1999; TAVARES, 2003; PINA, 2011.

${ }^{895}$ Cf. PORTALEGRE, 2007: cap. 1-3, 5 e segs.
} 
Em relação a João Vicente importa tentar perceber se a sua preponderância como fundador, na obra de Paulo de Portalegre, alicerça-se num papel determinante exercido desde os primeiros momentos da nova Congregação ou se é um espelho do seu longo percurso à frente dos destinos da Congregação dos Lóios, aliado à sua eleição para o episcopado por Eugénio IV e que tão importante se revelou como forma de dotar esta figura de um poder e autoridade que servisse de amparo institucional às primeiras gerações de cónegos seculares Lóios.

É notória a similitude de papel desempenhado por estas duas figuras nas suas congregações, e explica-se assim a evidente comparação entre Gabriel Condulmer e João Vicente que subjaz à crónica de Paulo de Portalegre, e que podemos fundar na natureza hagiografante da sua produção literária ${ }^{896}$.

Avançando no tempo, encontramos a cronística seiscentista dos Lóios a transpor-se da análise fundacional unicentrada a uma leitura tripartida que, ainda que não esteja ausente em Paulo de Portalegre ${ }^{897}$, aparece então de um modo mais aprofundado e com evidente e declarada interpretação simbólica, tanto no caso português como no italiano.

Encontramos o padre Jorge de S. Paulo a sustentar, no cap. 46 do seu Epílogo, o tríplice protagonismo fundacional da Congregação de São João Evangelista em Mestre João Vicente, D. Afonso Anes Nogueira e no Doutor Martim Lourenço ${ }^{898}$, estabelecendo uma lição que será seguida, por sua vez, pelo cronista oficial da Congregação, padre Francisco de Santa Maria ${ }^{899}$.

Estes dois autores do séc. XVII seguirão a mesma lógica, que se encontra plasmada em Paulo de Portalegre, de situar a crónica institucional da Congregação sob uma perspetiva de sabor hagiográfico, com uma análise do seu percurso histórico fundada não apenas na atuação dos agentes humanos mas perspetivada sob a influência de uma intervenção divina que determina os acontecimentos e que leva a que sejam entendidos como parte do projeto salvífico para a humanidade, um passo mais no retorno do homem a Deus, como o definia Basílio de Cesareia:

Dei ac Servatoris nostri circa hominem dispensatio, revocatio est a lapsu, reditusque ad Dei familiaritatem ab alienatione quam induxit inobedientia ${ }^{900}$.

Assim Jorge de S. Paulo vai explicar a sua opção na eleição das três figuras fundacionais não apenas no plano de uma realidade histórica de facto mas, declaradamente, tendo por escopo uma

\footnotetext{
${ }^{896}$ Sobre a questão da obra hagiográfica e de sabor hagiográfico de Paulo de Portalegre tratar-se-á um pouco mais no ponto seguinte.

${ }^{897}$ De facto o Padre Paulo de Portalegre, apesar de centrar o cerne da sua descrição da fundação Lóia sobre a figura de João Vicente (como evidente paralelo de Gabriel Condulmer), não deixa de precisar que a fundação se sustentara sobre três «pilares» que perseveraram nas fileiras da Congregação desde os primeiros dias e ao longo dos anos das suas vidas: João Vicente, Martim Lourenço e João Rodrigues (cf. PORTALEGRE, 2007: 95). Vd. igualmente o que diz Isabel Castro Pina sobre esta questão (PINA, 2011: cap. II, ponto 2, p. 75 e segs.).

${ }^{898}$ ADB - Manuscritos, ms. 924, p. 202 e segs.

${ }^{899}$ SANTA MARIA, 1697: 209 e segs.

${ }^{900}$ Cf. BASÍllo MAGNO, 1751: cap. XV, n. ${ }^{\circ} 35$, p. 15; e que se poderá traduzir por «O desígnio de Deus nosso Salvador consiste em levantar o homem da sua queda e fazê-lo voltar à intimidade divina, libertando-o da alienação a que o levara a desobediência».
} 
adequação da fundação Lóia à simbólica do número três (para o que faz uma breve análise do carácter particularmente espiritual, místico e até histórico deste número $\left.{ }^{901}\right)$, acentuando o carácter providencial da fundação da sua Congregação, de que procura evidências no seu processo constitutivo.

Não podemos deixar de ter em atenção que o bispo Tomasini, na sua crónica impressa em 1642 (que Jorge de S. Paulo conhecia bem como se depreende das menções que lhe faz) colocou a fundação da Congregação de S. Jorge em Alga sobre três pares de ombros (Condulmer, Correr e Justiniano ${ }^{902}$ ), podendo supor-se que o cronista português pretendia não só seguir a lição do cronista da Congregação de Alga para a descrição da fundação italiana, como acentuar as similitudes de processos fundacionais, transpondo-o para as três figuras que elege como centrais na fundação da Congregação de S. João Evangelista.

Ultrapassando a leitura de Paulo de Portalegre dos três pilares perseverantes dos primeiros dias da Congregação, Jorge de S. Paulo constrói uma leitura própria do papel desempenhado pelos três fundadores que entende serem as verdadeiras raízes dos Lóios e que vai alicerçar na Teologia mística e na sua via (ou itinerário) para a perfeição, que se estende por três níveis: a via purgativa, a via iluminativa e a via perfectiva (ou unitiva), sobre as quais teólogos como S. João da Cruz ${ }^{903}$ teorizavam, mesclando-a com comparação de natureza médica, ao apresentar a Igreja em crise como um corpo biológico e a nova Congregação como o seu remédio, metáfora que considera particularmente feliz pela condição do fundador João Vicente.

A Mestre João Vicente, médico e fundador principal, atribui Jorge de S. Paulo o papel de via purgativa, que preparou o corpo eclesial para ser curado dos vícios e maus costumes da alma, no caso com o enxerto deste novo ramo que é a congregação canonical.

Afonso Anes Nogueira, nobre e futuro prelado, situa o autor na via iluminativa, ao trazer de Itália o carisma da Congregação de S. Jorge em Alga (a regra e modo de vida, como expressa o autor), que iluminou os padres fundadores e que serviu de bom remédio para o corpo que João Vicente purgara.

Ao Doutor Martim Lourenço, pregador, atribuiu a via perfectiva, pois pela sua doutrina e pregação encaminhou as almas, dentro e fora da sua Congregação, para a união com Deus. Como o define Isabel Castro Pina. «Martim Lourenço encarnava, se assim se pode dizer, a vertente letrada e erudita dos fundadores. Sacerdote, latinista, pregador da corte, confessor de D. Fernando e teólogo culto» ${ }^{904}$.

É claro o propósito de Jorge de São Paulo, neste ponto como em diversos outros do seu labor cronístico sobre os Lóios, em situar a fundação da Congregação num plano superior ao humano, demonstrando que esta estava destinada a trazer à Igreja um substrato reformista que se situa na recuperação do que entendiam ser o modo de vida comunitário original do cristianismo, aquele que os Apóstolos teriam partilhado entre si, a vera vita apostolica.

\footnotetext{
${ }^{901}$ Idem, ibidem: 203.

902 TOMASINI, 1642.

${ }^{903}$ Sobre o itinerário espiritual em S. João da Cruz, e a sua relação com o conceito de contemplação, veja-se o artigo do P.e Carreira das Neves (cf. NEVES, 1992).

${ }^{904}$ PINA, 2011: 83.
} 
Assim entre a versão de Paulo de Portalegre e a de Jorge de S. Paulo apercebemo-nos que na questão da identidade dos fundadores Lóios não está apenas implicada a verdade histórica de facto, mas também uma construção histórico-hagiográfica trabalhada pelos memorialistas da Congregação, de que já encontrávamos o exemplo da Congregação de Alga e da figura de Marino Quirino, cujo papel fundacional foi obscurecido pelo papel posterior desempenhado pelos primos Correr e Condulmer e pelo seu sobrinho Lourenço Justiniano.

Uma achega mais à questão: quando D. Manuel I decide intervir a favor dos Lóios junto da Santa Sé, a pedido expresso do Geral dos Lóios Jerónimo da Vidigueira, escreve ao seu representante em Roma, D. Miguel da Silva (futuro Cardeal de Viseu), uma carta em que começa por sumariar a fundação das duas Congregações.

Nesta carta ${ }^{905}$, o Rei afirma que a Congregação «em nossos reynos foy ynstituida pello reverendo padre mestre Joham que depois foy bispo de Lameguo e finalmente de Viseu dito dom Joham da boa memoria e por dom Afonso Nogeyra que depois foy Arcebispo de Lixboa que trouxe a forma do habito e regra daquelles padres de Itallia com outros padres reverendos e notavens que hordenaram esta Comgregaçam de Villar de Frades do arcebispado de Bragua» ${ }^{906}$.

Resumindo: quando o Geral da Congregação pede ao Rei a sua intervenção em defesa da isenção dos Lóios da autoridade dos ordinários diocesanos, apresenta-lhe um sumário histórico da fundação da Congregação, e da sua matriz italiana, certamente no escrito da «enformaçam» que o monarca diz ter-lhe sido apresentada pelo P.e Jerónimo e pela Congregação, e na qual se apresenta como fundadores da Congregação Mestre João Vicente e D. Afonso Nogueira e outros padres não especificados.

À distância de cerca de 9 décadas sobre a fundação dos $\operatorname{Lóios}^{907}$, e numa informação ao Rei que não procuraria assumir o carácter de relato de exemplaridade de uma crónica hagiografante, mas antes pretenderia ser mais objetivamente informativa, seria já memória corrente na Congregação que a figura principal da fundação dos Lóios era, sem dúvida, D. João Vicente, mas que a par deste nome um outro mereceria uma especial menção: o de D. Afonso Nogueira.

Podemos certamente questionar-nos se a menção ao nobre lisboeta se deverá não a uma efetiva relevância fundacional mas à sua posterior condição de Bispo de Coimbra e Arcebispo de Lisboa, mas dada a natureza do relato e o seu objetivo parece-nos menos provável, e tanto mais que a mesma dúvida se poderia aplicar a mestre João Vicente.

A reter que apesar do nome de Afonso Nogueira ser mencionado a par do de João Vicente, este é mencionado sem quantitativo da sua intervenção fundacional (o que transmite uma ideia de totalidade) enquanto o contributo de Nogueira é especificado como sendo o daquele que trouxe de Itália o hábito e modo de vida da Congregação de Alga, sugerindo-se assim uma hierarquia de papéis. Se em Paulo de Portalegre o seu transporte carismático não lhe valeu o ser elevado a sustentáculo institucio-

\footnotetext{
${ }^{905}$ ANTT - Congregação de S. João Evangelista, Convento de S. João Evangelista de Xabregas, mç. 15, doc. n. ${ }^{\circ} 8$. Treslado coevo mas não datado, intitulado Carta que el Rey dom Manuel mandou a Roma a dom Migyel que falasse ao Sancto Padre por ha confirmação de nossos privillegios, transcrito no anexo documental A, doc. A1.

${ }^{906}$ Idem, ibidem: fl. 1 (não numerado).

${ }^{907}$ Sobre a datação desta carta de D. Manuel I, que tem registada dia e mês mas não o ano, veja-se o ponto 3.3.
} 
nal, já para Jerónimo da Vidigueira e para os cónegos de finais da década de 1510 Afonso Nogueira merecia um destaque quase igual ao de João Vicente.

A abordagem de Isabel Castro Pina, de analisar e situar um conjunto de nomes de clérigos que compõe o grupo fundacional, à imagem por exemplo do que Tassi e Tramontin fazem para a Congregação de Alga, é sem dúvida a abordagem mais rica à fundação da Congregação, ao passar do fundador ao universo fundacional; no entanto o que aqui se problematiza é a tentativa de estabelecer uma hierarquia fundacional que nos permita perceber como se evidenciaram, na memória construída da Congregação, as figuras de João Vicente e Afonso Nogueira, aquelas que no período fundacional tiveram um contacto privilegiado com o carisma da Congregação de Alga, e que como tal se entendem por figuras estruturantes ${ }^{908}$.

À parte a questão dos fundadores principais, e de uma hierarquia fundacional, existe um outro aspeto do processo fundacional que deve ser ponderado na comparação com a Congregação de S. Jorge em Alga.

A crónica de Paulo de Portalegre, e perante a dificuldade constante de conseguir uma noção precisa e clara dos primeiros passos que conduzem à fundação de uma ordem ou congregação (como já ficou visto para Alga), apresenta uma descrição do processo que conduziu dos primeiros encontros entre figuras fundacionais à constituição da Congregação pelas letras de Eugénio IV. Desta descrição, e do seu paralelo com a documentação de arquivo pertinente, deu já conta circunstanciada Isabel Castro Pina no cap. II da sua tese ${ }^{909}$. Ressaltemos apenas a descrição dos primeiros passos e a sua correlação com o que se descreve, e o que se sabe da Congregação de Alga.

Segundo Tomasini os jovens primos Gabriel Condulmer e António Correr, destinados que estavam ao estado eclesiástico, sentiram em determinado momento (que como ficou visto poder-se-á situar nos anos finais do séc. XIV) o desejo de retirarem-se de um mundo incerto, corrupto e cheio de enganos, procurando a «vitae solitariae securitate» ${ }^{910}$.

Salienta nos jovens, o cronista de Alga, as suas amplas virtudes e o modo como se determinavam a seguir um modo de vida retirado do mundo e dedicado ao serviço de Deus, o qual iniciado na casa de seu tio, o Patriarca Ângelo Correr, acabaria por passar a uma vida mais retirada num mosteiro da laguna, S. Jorge em Alga, onde foi estatuída em 1404 uma colegiada de cónegos seculares com os 17 jovens clérigos que o movimento já integrava. Concorda esta versão de 1642 com os termos que podemos encontrar na descrição da fundação veneziana apresentada por Paulo de Portalegre ${ }^{111}$ e que não desdiz a que se conserva no início dos Estatutos e Constituições ${ }^{912}$ dos Lóios.

\footnotetext{
${ }^{908}$ Sendo certo que o terceiro fundador apresentado por Jorge de S. Paulo, o P.e Martim Lourenço, que já Paulo de Portalegre apresentava por um dos três pilares da congregação (cf. PORTALEGRE, 2007: 95), que pertenceria ao grupo fundacional da primeira hora e perseverou na Congregação, manteve relações com os círculos reformistas italianos, ou pelo menos com o seu representante Abade Gomes Anes, como nos podemos perceber pela sua correspondência mantida entre os dois (cf. NUNES, 1963: 357 e segs.).

${ }^{909}$ PINA, 2011: 65 e segs.

${ }^{910}$ Cf. TOMASINI, 1642: 4.

911 PORTALEGRE, 2007: 69 e segs.

${ }^{912}$ Statutos e Constituyções dos virtuosos e reverendos padres Conegos azuys..., 1540.
} 
Note-se que das três descrições, a da cronística de Alga, a da crónica portuguesa e a dos Estatutos lóios (que poderá ser a do primeiro memorial que veio de Alga), será a descrição de Paulo de Portalegre a que mais acentua a dimensão carismática da fundação veneziana, ao afirmar que os fundadores (que personaliza apenas em Gabriel Condulmer), perante a crise do sacerdócio secular e o desejo de seguir uma vida mais autêntica e próxima de Deus, se determinaram a instituir «este noso modo de vida novo e per reformaçãão e antiguo per fundação ${ }^{913}$.

Salienta o P.e Paulo de Portalegre, nesta curta expressão, os dois elementos centrais que definem a ideia de reforma na conceção Ladneriana ${ }^{914}$, pois ao elemento original cuja pureza se procura restaurar «o seu modo de vida antiguo per fundação» se junta o enriquecimento pela sua atualização «pois o seu modo de vida novo e per reformação».

A proximidade carismática destes cónegos seculares a esta conceção de reforma é tal que advogariam que o seu modo de vida se fundava diretamente no modo de vida dos tempos apostólicos, seguido pela comunidade cristã de Jerusalém fundada pelos Apóstolos, de que os cónegos venezianos seriam «as primeiras colunas da segumda reedefiqaçãão da vida apostolica» ${ }^{915}$, período no qual, segundo o pensamento de Ladner, se expressaria pela primeira vez (no pensamento de S. Paulo e na ideia Paulina de reforma) a expressão cristã de ideia de reforma ${ }^{916}$.

Reforma é aliás a palavra mais usada por Paulo de Portalegre para exprimir os dois movimentos que historia, falando sempre da recuperação de um modo de vida original dos cristãos, a vera vita apostolica, uma característica comum a muitos movimentos reformistas, mas que pela primeira vez aparecerá numa comunidade de clérigos seculares.

Tendo-se identificado as duas congregações como percursoras das instituições de clérigos seculares de vida comum, podemos também estabelecer que Alga e os Lóios são o ponto de transição da ideia de reforma baseada na recuperação de um modo de vida apostólico, mais próximo às raízes do cristianismo, que até então se expressara essencialmente no seio do universo puramente regular, deixando o universo do clero secular, pela grande variedade das suas situações e pela sua proximidade a um mundo entendido como corrompido, num limbo que o mantinha distanciado do caminho da perfeição ${ }^{917}$.

\footnotetext{
${ }^{913}$ PORTALEGRE, 2007: 69.

${ }^{914}$ Relembre-se que esta: "pode ser definida como a ideia de livres, intencionais e sempre aperfeiçoáveis, múltiplos, prolongados e sempre repetidos esforços pelo homem para reafirmar e aumentar os valores pré-existentes no composto espiritual-material do mundo» (LADNER, 1959: 35); ou seja situa-se nos esforços para recuperar (reafirmar, reformar, restaurar) um determinado valor (que seria o modo de vida original dos cristãos), mas com o acréscimo de algo novo (aumentar).

915 PORTALEGRE, 2007: 71.

${ }^{916}$ Veja-se o que se diz no ponto 1.1 .

917 Tenha-se presente que já os movimentos canonicais regulares se diziam herdeiros do ideal de verdadeira vida apostólica, que no entanto se expressava em comunidades regulares professas (veja-se o que sobre a questão diz VAUCHEZ, 1985). Do mesmo modo Giles Constable sintetizava como para os pensadores cristãos na passagem de milénio, no qual inclui o próprio Papa Urbano II (1088-1099), a sua maioria com origem nos claustros, defendiam que a vida monástica era a imagem da verdadeira vida apostólica, pelo que nos sécs. XI e XII reforma era entendida antes de mais como um fenómeno dos claustros, que nesses séculos entendiam estar a passar por uma renovação, devolvendo os mosteiros às ideias de afastamento do mundo e morigeração de costumes (cf. CONSTABLE, 1996: 17 e segs.; 44 e segs., 296 e segs.).
} 
Com os cónegos de Alga e com os Lóios afirma-se que ao clero secular, vivendo em comum mas sem profissão de votos, que procura afastar-se do mundo mas que ao mesmo tempo se dedica a servir a comunidade de crentes pelo serviço do seu ministério sacerdotal, pertence também o caminho cristão mais perfeito, traduzido na recuperação do modo de vida original dos cristãos.

Esta nova conceção da vida dos apóstolos como a de uma comunidade que partilha vida e bens livremente, sem qualquer outra imposição (como era a profissão solene entre os regulares), baseada na descrição da vida da comunidade original de Jerusalém exarada no livro dos Atos dos Apóstolos, assume-se como a marca da sua identidade, a linha principal do seu carisma, como terá expressado o geral dos Lóios ao rei D. Manuel I e que monarca resumiu na sua carta a D. Miguel da Silva:

a sua regra e ordem de vida fora instytuida por Nosso Senhor Ihesus Chrispto e seus Apostollos segundo que he escrito que era a elles huma avontade e querer e todallas cousas the eram communhas e se dava a ca $<$ da $>$ hum segundo sua necessidade, e per esto modo se nomeava esta Comgregaçam estado apostollicall, do quall estado per muitos tempos fora perdida a memoria delle e finallmente hobra do Spiritu Sancto se viera a retromar em as partes de Itallia em a Casa de Sam Jorge d'Allga de Veneza per Grabiell Comdallmario que despois foy Papa Eugenio quarto e per Lourenço Justiniano primeiro Patriarca de Veneza ${ }^{918}$.

Fica bem patente que os Lóios reclamavam, tal como certamente o fariam os Cónegos de Alga, para a sua Congregação a efetiva recuperação de um modo de vida original das primeiras comunidades eclesiais, assumindo-se como um movimento de reforma na plenitude de um conceito amplo de reforma aplicado ao universo cristão, que se tem operacionalizado nesta obra a partir da definição de Ladner.

A descrição que Paulo de Portalegre (que aqui poderemos considerar não apenas como o primeiro memorialista dos Lóios que foi ${ }^{919}$, mas também no mais antigo memorialista conhecido que trata da Congregação de $\mathrm{Alga}^{920}$ ) apresenta para as duas fundações, que se afiguram como processos muito semelhantes baseados numa mesma ânsia de uma vida espiritual e comunitária mais estrita e verdadeira, pode ser lida de dois modos: ou se baseia numa factualidade real que o memorialista Lóio expressa e estamos perante dois movimentos que, quase em simultâneo, se desenvolvem distanciados mas embasados num mesmo entendimento de Igreja e de reforma; ou Paulo de Portalegre constrói uma explicação da fundação lóia a partir dos primeiros passos da Congregação de Alga.

Seguindo a regra que nos autoriza a aceitar por verdadeiros testemunhos que não sejam contrariados por qualquer outro elemento documental, consideremos que a descrição do memorialista Lóio está conforme a uma realidade histórica objetiva, no que em relação a Alga está de acordo com

\footnotetext{
${ }^{918} \mathrm{Vd}$. anexo documental A, doc. A1.

${ }^{919}$ Como já o definia Pedro Tavares em TAVARES, 2003.

${ }^{920}$ Já que para esta Congregação não se conhece, até ao presente, uma obra de cronística anterior à crónica de Tomasini de 1642. Do mesmo modo tenha-se em consideração que Paulo de Portalegre tem a particularidade de ser o memorialista cronologicamente mais próximo aos factos e de ainda ter conhecido os fundadores lóios, algo de que Tomasini não se podia arrogar para Alga.
} 
a versão que posteriormente apresentará Tomasini na sua crónica e que é aceite pelos historiadores italianos que se debruçaram sobre a questão ${ }^{921}$.

Em suma, em Veneza como em Lisboa (como aliás em todo o universo cristão ocidental) sentia-se a crise da Igreja e do universo eclesiástico. Entre jovens clérigos seculares surgiram figuras que sentiam a necessidade de reformar o seu próprio universo eclesiástico.

Em Veneza como em Lisboa esses grupos de jovens, onde pontificavam algumas figuras destacadas (para Paulo Portalegre são Gabriel Condulmer e João Vicente), prontificam-se a iniciar uma experiência de vida comum, de comunidade de clérigos dedicada antes de mais a viver o carisma próprio da sua condição, que seria a do serviço litúrgico e pastoral.

Em Veneza como em Lisboa aparecem-nos figuras tutelares que darão animação e consistência material à execução deste novo ideal de vida: para Alga foram o patriarca Ângelo Correr e o prior de S. Jorge Luís Barbo, para os Lóios serão Lourenço Anes prior de S. Julião (que animaria João Vicente a perseverar), o prior de St. ${ }^{a}$ Maria dos Olivais de Lisboa (onde permitiria que se estabelecesse a primeira comunidade), o bispo do Porto D. Vasco (que lhes alcançou que se estabelecessem provisoriamente em St. ${ }^{a}$ Maria de Campanhã) e, por fim, o Arcebispo de Braga D. Fernando da Guerra, que daria em benefício ${ }^{922}$ a João Vicente aquela que virá a ser a primeira Casa dos Lóios, S. Salvador de Vilar de Frades ${ }^{923}$.

A tomarmos por verdadeiro o que Paulo de Portalegre afirma sobre a intencionalidade original dos fundadores de Alga e dos Lóios, e o modo direto como as intenções fundacionais reverberariam no ideal carismático das Congregações, estamos perante movimentos que se construíram sobre uma conceção de reforma que se funda numa recuperação superadora do passado, numa estrutura que condensa um passado superior a recuperar pela criação de algo novo. Trata-se de uma notória confirmação de que o carisma de Alga e dos Lóios se insere plenamente no conceito de ideia de reforma apresentado por Ladner, e numa tradição cristã multisecular.

Mas uma pergunta estruturante fica pendente: quando é que o carisma de Alga aparece aos fundadores Lóios como modelo da sua Congregação? Em 1426-27 quando Afonso Nogueira obtém as primeiras confirmações e os elementos identitários da Congregação que traz para Portugal, como tradicionalmente se situa ${ }^{924}$ ? Já anteriormente, nos contactos com Gomes Anes na sua presença em Portugal de 1425? A resposta a esta questão poderá ser respondida de um outro modo, considerando as relações entre os fundadores Lóios e a matriz italiana, que se tratarão no ponto seguinte.

\footnotetext{
${ }^{921}$ No que se refere à estrutura dos factos e dos objetivos dos fundadores, já que sobre estes e o papel efetivamente representado por cada um existem as diferenças que já se puderam salientar no capítulo 2.

${ }^{922}$ Como de pode ver nos termos da carta, de 1425, em que o Arcebispo nomeia João Vicente para o benefício do mosteiro de Vilar de Frades, que fora secularizado por falta de vida regular (cf. anexo documental, doc. 1).

${ }_{923}$ Para estes movimentos veja-se o que sobre a matéria já foi dito nesta tese, bem como o que afirma, nos seus diversos capítulos, P.e Paulo de Portalegre (PORTALEGRE, 2007).

${ }^{924}$ Logo desde Paulo de Portalegre que se situa em Afonso Nogueira e nesta sua viagem a entrada do carisma de Alga entre os Lóios (cf. Idem, ibidem: 91, 92). A mesma informação estava na mencionada carta de D. Manuel I a D. Miguel da Silva, bem como em Jorge de S. Paulo (no seu Epílogo, cf. ADB - Manuscritos, ms. 924, p. 176, 177) e Francisco de St. ${ }^{a}$ Maria (SANTA MARIA, 1697: 228).
} 


\subsection{ALGA COMO MODELO: JOÃO VICENTE, AFONSO NOGUEIRA E A CÚRIA ROMANA}

"Ad instar Rectoris et Canonicorum Sancti Georgii in Allega Venetiarum»" ${ }^{25}$ - à semelhança do Reitor e Cónegos de S. Jorge em Alga de Veneza - esta expressão, frequente em documentação pontifícia que se refere à Congregação de S. João Evangelista, representa um reconhecimento de uma realidade de facto no que se refere à ligação matricial da Congregação portuguesa à italiana.

A constatação desta relação, que parece ser estrutural (no sentido mais pleno da palavra), comporta um questionamento natural: como é que em Portugal, e de modo quase simultâneo ${ }^{926} \mathrm{com}$ a constituição da Congregação de Alga em Itália, vamos encontrar o carisma de vida comunitária de sacerdócio secular ativo, que os cónegos venezianos desenvolviam, a ser escolhido e implementado como modelo da nova Congregação portuguesa? Esta pergunta encerra em si uma pergunta mais direta. De que modo o carisma de Alga chegou aos fundadores portugueses e porque o escolheram.

Os vários autores que se têm debruçado sobre os Lóios historiaram o processo de constituição da Congregação e de escolha do carisma institucional de Alga, destacando-se neste ponto o trabalho de Sousa Costa (pela adução de numerosa documentação pontifícia e dos arquivos diocesanos ${ }^{927}$ ), os artigos de Pedro Tavares ${ }^{228}$ e particularmente a tese de Isabel Castro Pina ${ }^{929}$, que sobre a questão faz a mais extensa análise, com reflexão sobre a bibliografia que na matéria foi sendo produzida.

Ao que estes e outros autores já disseram, aporte-se o questionamento aqui formulado, entendendo a escolha do modelo institucional de Alga pelos Lóios como um processo dinâmico em que, num contexto de contacto, se reconhecem similitudes que levam à escolha ou aceitação de um carisma essencialmente italiano (ou melhor dizendo veneziano) pelos fundadores Lóios.

Existem similaridades entre o movimento de Alga e o dos Lóios que explicam a adoção do modelo institucional de Alga para enformar o movimento português, e que permitem perceber como o fenómeno reformista, a ânsia de uma vida espiritual mais perfeita e de uma Igreja reformada tinha, em diferentes geografias do mundo cristão mas em cronologias similares, expressões institucionais comuns.

\footnotetext{
${ }^{925}$ Como se expressa a bula de Pio II de 1461 que aprova a entrega do mosteiro de Xabregas à Congregação, altera a sua invocação para S. João Evangelista e o torna casa generalícia, ao referir-se aos padres Lóios: «canonicos saeculares congregationis Sancti Salvatoris de Villar de Frades Bracharensis Diocaesis ad instar Rectoris et Canonicorum Sancti Georgii in Allega Venetiarumin communi viventium» (cf. Livro dos Privilegios concedidos pellos Summos Pontifices..., 1594: fl. 24v.).

${ }^{926}$ Como ficou visto a constituição e estruturação principal da Congregação de S. Jorge em Alga dá-se entre 1404 e 1424 (ou seja, da data da executória à nomeação do $1 .^{\circ}$ Geral no capítulo geral de 1424 ), depois de um período embrionário situado dos últimos anos de 1300 a 1404 . Na Congregação dos Lóios o período embrionário estará na primeira metade da década de 1420, a primeira consolidação segue-se à concessão de Vilar de Frades de 1425 e concretiza-se com as concessões pontíficias de Eugénio IV obtidas a partir de 1431. Isabel Castro Pina define também 1425 e 26 de abril de 1427 (data da concessão por Martinho V da primeira súplica dos fundadores para que lhe seja confirmada a concessão da Casa de Vilar de Frades e modo de vida à semelhança da de S. Jorge em Alga) como as datas que separam o período de «...fase transitória de experimentação [...]» e a fundação propriamente dita que seria ditada pelo processo que é lançado pela concessão de 1425 e pela primeira aprovação pontifícia em 1427 (cf. PINA, 2011: 65 e segs., 99 e segs.).

927 COSTA, 1986.

928 TAVARES, 1999; TAVARES, 2003.

${ }^{929}$ PINA, 2011: cap. II e III.
} 
A nova Congregação portuguesa, e segundo a leitura que tem sido feita, terá dado os seus passos fundacionais de um modo absolutamente autónomo em relação a qualquer influência ou interferência do movimento canonical de Alga.

Como Castro Pina sustenta e analisa na sua tese, o contexto fundacional dos Lóios é a Lisboa de cerca 1420, do Portugal de Avis em que diversas correntes de reforma, principalmente as de observâncias, estão ativas e lançam no universo eclesiástico e secular o tema da urgência e necessidade de reforma, em consonância com o que acontecia em outras geografias do ocidente cristão.

Esta análise, que permite perceber de um modo muito concreto como se explica nos contextos os primeiros passos do grupo de jovens clérigos que virá a constituir a Congregação, aborda apenas brevemente a questão da adoção do modelo de Alga ${ }^{930}$, ainda que identifique os agentes que parecem, na análise que se pode fazer da crónica e da documentação que é conhecida, os fundamentais para essa escolha: o abade de St. ${ }^{a}$ Maria de Florença D. Gomes Anes e Afonso Anes Nogueira. Já lá chegaremos.

Os diversos cronistas Lóios, desde Paulo de Portalegre a Jorge de S. Paulo e a Francisco de Santa Maria $^{931}$ (os dois cronistas seiscentistas seguindo de modo generalizado a lição do seu antecessor quatrocentista), concordam sobre os elementos essenciais dos anos fundacionais da Congregação, e por eles podem-se supor os passos iniciais dos padres fundadores.

Uma leitura dos cronistas, e perante a ausência de documentação significativa para os primeiros anos do movimento, permite aplicar aos Lóios o que sobre Alga escreveu Tassi, «Non è facile descrivere l'origine del movimento ${ }^{932}$, frase originada na escassez natural de fontes para os primeiros anos do movimento. $\mathrm{O}$ mesmo autor aconselha, referindo-se a Tomasini e à sua crónica, a não colocar inteira fé no que o cronista deixou registado e que nem sempre se confirmaria nas fontes nem nos rigores das exigências dos estudos históricos ${ }^{933}$.

A descrição cronologicamente mais próxima à fundação, e escrita por um Lóio que ainda conheceu alguns dos fundadores, é a que o P.e Paulo de Portalegre deixou no seu Novo Memoria ${ }^{934}$, obra que (como a sua moderna editora crítica precisou) se assume como a primeira crónica dos Lóios. Esta é a principal fonte para os anos fundacionais, como o define Cristina Sobral ${ }^{135}$, como podemos verificar na tese de Castro Pina ${ }^{936}$ e para que tinha anteriormente chamado à atenção Pedro Tavares ${ }^{937}$.

Como já aqui se focou, e malgrado a quase total ausência de fontes não cronísticas, a similaridade que se pode encontrar nos passos fundacionais dos dois movimentos deixa ao investigador duas hipóteses: ou considera este facto como suspeitoso e lê na obra de Paulo de Portalegre um desejo de

\footnotetext{
${ }^{930}$ Idem, ibidem: 107 e segs.

${ }^{931}$ PORTALEGRE, 2007: 1. ${ }^{\text {a }}$ parte, cap. 5 e segs; ADB - Manuscritos, ms. 924; SANTA MARIA, 1697.

932 TASSI, 1952: 13.

${ }^{933}$ Idem, ibidem: 13 e segs.

${ }^{934}$ PORTALEGRE, 2007.

${ }^{935}$ Idem, ibidem. Já antes da edição crítica do Memorial do P.e Paulo de Portalegre, Cristina Sobral escreveu sobre esta obra e sobre a sua relevância (SOBRAL, 2003a; SOBRAL, 2003b).

${ }^{936}$ PINA, 2011, veja-se o que diz no ponto 2 da Introdução, bem como a utilização que faz desta crónica no decurso da tese. 937 TAVARES, 2003.
} 
conformar a história fundacional dos Lóios à da Congregação matricial de Alga, ou dá como verdadeiro o testemunho do cónego quatrocentista e sustenta a existência da expressão comum de um mesmo anseio de carácter reformista entre a Itália e Portugal dos inícios do séc. XV.

Cristina Sobral, falando da obra de Paulo de Portalegre e particularmente sobre as suas obras sobreviventes, nomeadamente o que escreveu sobre a morte do Duque de Bragança D. Fernando II, cujos últimos momentos o Padre Paulo acompanhou e de que deixou relatos com claro carácter hagiografante, bem como as suas obras desaparecidas (em que se destacaria um Flos Sanctorum, de que sobreviveu uma vida de St. ${ }^{\circ}$ António de Lisboa), deixa perceber claramente estarmos perante um autor com perfil de latinista e uma clara tendência para os textos de natureza hagiográfica ${ }^{938}$.

A tendência hagiografante do autor poderia sugerir o desejo de construir este texto memorialístico de acordo com regras que não as de uma mera descrição histórica, mas que pretenderia demonstrar (com os elementos centrais da sua narrativa) que as Congregações de Alga e dos Lóios se inseririam na natural sucessão da vida apostólica e de que a sua fundação se coloca claramente no desenrolar do projeto salvífico, objetivando a salvação do povo de Deus e sendo divinamente sustentada contra forças malignas que pudessem obstar.

Paulo de Portalegre, como depois dele Jorge de S. Paulo ${ }^{939}$ e Francisco de St. ${ }^{a}$ Maria ${ }^{940}$, colocam o percurso histórico da Congregação numa dinâmica em que Deus e o diabo intervêm como agentes, e em que os padres da Congregação são participantes de um projeto mais vasto de santificação:

Na análise do discurso hagiográfico no Memorial haverá, assim, que distinguir os percursos hagiográficos individuais [...] e o percurso hagiográfico colectivo, notando o modo como os primeiros se articulam e sucedem de forma a construir uma demonstração de santidade colectiva que proteja a Congregação de ataques políticos como o que, pela segunda vez em 1468, teve de defrontar ${ }^{941}$.

Cristina Sobral identifica no texto de Paulo de Portalegre, mesclado com o sentido hagiográfico da narrativa, uma necessidade de afirmação (efetuada em termos de especial proteção divina e santidade individual e coletiva) que servisse os objetivos de afirmação da Congregação, nomeadamente no seio da disputa que a Congregação mantinha com os Arcebispos de Braga.

Estas intencionalidades identificáveis na produção da obra, e às quais o investigador deve estar atento, não implicarão no entanto que se descarte o testemunho daquele que é, em essência, o primeiro cronista dos Lóios.

\footnotetext{
${ }^{938} \mathrm{Vd}$. o que diz em SOBRAL, 1997; SOBRAL, 2003b; PORTALEGRE, 2007.

${ }^{939}$ As suas referências à actuação do demónio e, principalmente, à intervenção de Deus, predestinação de fundação e santidade pessoal e colectiva dos religiosos são uma constante nas suas obras cronísticas, particularmente no seu «Epílogo e Compêndio» que escreveu para a casa de Vilar de Frades (cf. ADB - Manuscritos, ms. 924), mas que já antes estava bem patente no livro que escreveu para a Casa do Porto (cf. ADP - Monásticos, Convento de Santo Elói do Porto, lv. do Compêndio do cartório, K/19/6-57).

940 SANTA MARIA, 1697.

${ }^{941}$ PORTALEGRE, 2007: 36
} 
Aceitando o que escreveu sobre os primeiros passos de mestre João Vicente e dos seus companheiros, e descontando exageros de linguagem e o louvar dos seus méritos morais e espirituais, ficamos com uma imagem dos passos iniciais do movimento que dará origem à Congregação dos Lóios e que importa comparar com o que já ficou dito sobre a fundação de Alga.

Reza o Novo Memorial que João Vicente, nascido em Lisboa era «filho de bõas pessoas, mais famosas per bondades que per geraçã $\rangle^{942}$, que ainda que não sendo nobres estariam no entanto associados aos Castro, senhores de Cadaval, de cujo 2. ${ }^{\circ}$ senhor, D. João de Castro ${ }^{943}$, seria colaço mestre João Vicente, possivelmente servindo a própria mãe de João Vicente como ama do fidalgo.

Pela relação de João Vicente com o 2. ${ }^{\circ}$ senhor de Cadaval consegue-se perceber dois factos substanciais da sua vida e da Congregação: a inserção em círculos cortesãos e o seu acesso à formação universitária e à carreira eclesiástica com posse de benefícios.

Como Isabel Castro Pina salientou ${ }^{944}$, esta ligação com D. João de Castro coloca João Vicente na proximidade da corte, nomeadamente nos círculos formados em torno da futura Casa de Bragança onde D. João de Castro casa a sua filha em 1428.

Do casamento de D. Joana de Castro, filha e herdeira de D. João, resultam duas das principais Casas Nobres portuguesas, as quais estão entre os principais apoios dos Lóios e são fonte da sua presença no Alentejo: a Casa de Bragança, pelo casamento da referida D. Joana com o que virá a ser 2. Duque, D. Fernando; e o ramo secundário dos Braganças que tem origem no quarto filho do casal, D. Álvaro, que recebendo por sua mãe a sucessão de seu avô D. João de Castro, receberá o senhorio de Cadaval e será a raiz da Casa ducal criada do mesmo senhorio, e pai de D. Rodrigo de Melo, fundador e dotador do convento Lóio de Évora ${ }^{945}$.

Esta relação de mestre João Vicente com D. João de Castro, que Paulo de Portalegre nos apresenta, poderá (com plausibilidade) ser fonte e marcar o início das relações dos fundadores Lóios, e em particular de João Vicente, com os círculos cortesãos e com as Casas senhoriais que maior apoio darão à Congregação, relações que encontraremos replicadas em outros fundadores, nomeadamente com Afonso Nogueira.

Além do papel que estas relações assumem na introdução dos Lóios aos círculos de poder que sustentarão a sua proposta de reforma, a ligação de mestre João Vicente a D. João de Castro assume-se também como uma possível explicação material para o desenvolvimento de uma carreira académica pelo fundador dos Lóios, com estudos preparatórios em Artes e a formação em Medicina, que cursou na Universidade então sediada em Lisboa ${ }^{946}$.

\footnotetext{
${ }^{942}$ Idem, ibidem: 79.

${ }^{943}$ Sobre este fidalgo e sua filha casada com D. Fernando I, 2. ${ }^{\circ}$ Duque de Bragança, veja-se SOUSA, 1946-1955: vol. V, 64, 65; CUNHA, 1990: 36 e segs.

${ }_{944}$ PINA, 2011: 77.

${ }^{945}$ Sobre D. Álvaro e a Casa de Cadaval de que é origem veja-se o que diz D. António Cateano de Sousa (SOUSA, 1946-1955: vol. X, 1 e segs.).

${ }^{946}$ Isabel Castro Pina analisa substancialmente a questão do currículo seguido por mestre João Vicente e da Universidade em Lisboa (cf. PINA, 2011: 76 e segs.).
} 
A formação superior perspetivava ao jovem uma posição social mais segura, desejo que Paulo de Portalegre atribui particularmente aos pais de João Vicente e ao seu colaço e protetor D. João, de quem seria próximo e querido: «E alem do que seus padres davão em ho estudo, este [D. João de Castro] avia delle especial carguo e desejava muito de ho acrecemtar. E asi o fazia per obra» ${ }^{947}$, e será a este nobre que poderemos atribuir, hipótese que não será grandemente ousada, a obtenção de um benefício eclesiástico para João Vicente, quando este se decide a seguir a carreira eclesiástica.

$\mathrm{O}$ valimento de mestre João Vicente com o seu colaço D. João de Castro poderá ainda ser explicação para outro importante (ainda que complicado) apoio fundacional dos Lóios, o do Arcebispo de Braga D. Fernando da Guerra.

Ler o apoio deste prelado no contexto de redes sociais em que João Vicente (senão mesmo outros fundadores) se inseria estruturalmente, ultrapassando-se a explicação alicerçada apenas nas curas médicas do fundador Lóio (que são, para o cronista Francisco de Santa Maria, a única explicação aparente para o fundador dos Lóios estabelecer contactos e redes relacionais ${ }^{948}$ ) permite-nos alargar e qualificar o sistema de relações e apoios e o seu papel nos primeiros passos da nova Congregação.

De facto, e um dado que não tem sido particularmente relevado pelos historiadores, o Arcebispo de Braga e D. João de Castro eram primos segundos, já que ambos descendiam de um importante nobre castelhano: D. Pedro Fernandes de Castro, dito o da Guerra.

D. Fernando era bisneto de sua filha D. Inês de Castro pelo primeiro dos filhos que esta teve com o rei D. Pedro I, o Infante D. João; já D. João de Castro era neto do irmão de D. Inês, D. Álvaro Pires de Castro, Conde de Viana e de Arraiolos ${ }^{949}$. Esta relação de parentesco, que começa a ser algo afastada no tronco genealógico dos Castros, não deixa de ser um fator a ter em conta, ainda mais que é percetível no ramo do arcebispo D. Fernando (que bastardo) a assunção da herança familiar dos Castros com o uso, registado desde seu pai, do apelido «da Guerra», resgatado da alcunha do seu bisavô D. Pedro de Castro.

Além de parentes entre si e (no caso de D. Fernando) parentes do rei D. João I, os primos João de Castro e Fernando da Guerra foram reconhecidamente figuras protegidas do primeiro Rei da

\footnotetext{
${ }^{947}$ PORTALEGRE, 2007: 81.

${ }^{948}$ Esta é sem dúvida a principal explicação do P.e Santa Maria para justificar a relação de João Vicente com as figuras mais gradas que se lhe associaram, caso do Bispo do Porto D. Vasco (que teria concedido aos Lóios um primeiro assentamento na cidade do Porto, como se pode ver em FALCÃO, 2009: 98, 99), do mencionado Arcebispo de Braga D. Fernando da Guerra, do Cardeal Condulmer (depois Papa Eugénio IV), além do acompanhamento médico preferencial que faria aos príncipes da Casa de Avis (cf. SANTA MARIA, 1697: 215, 217, 226, 227, 565, 566). Malgrado a sanha curativa que encontramos plasmada no cronista, e que servirá como fonte para outros trabalhos (por exemplo CORREIA, 1961), vemos Sousa Costa a colocar algumas dúvidas ao exercício por João Vicente do cargo de físico régio de D. Duarte (cf. COSTA, 1986: 190). Com a ausência de dados documentais que confirmem ou neguem estas afirmações nota-se que a principal fonte nesta matéria foi (como em muitas outras informações) a crónica de Paulo de Portalegre, em que se menciona a ciência médica de João Vicente (que seria admirada na corte, e que ele terá aplicado quando residiu no Porto), as curas de Fernando da Guerra e de Gabriel Condulmer, mas não a do bispo do Porto, cuja relação atribui ao conhecimento da corte (cf. PORTALEGRE, 2007: 84, 89, 90, 99).

${ }^{949}$ GOMES, 1995: 74 e segs.; SOUSA, 1946-1955: vol. X, 1 e segs. (Casa de Cadaval); vol. XII, 365 e segs. (Infante D. João e sua descendência); para o arcebispo D. Fernando veja-se o que José Marques no cap.I da sua tese sobre o governo do mesmo no arcebispado de Braga, MARQUES, 1988.
} 
dinastia de Avis, e figuras relevantes da sua corte nos anos anteriores e da fundação da Congregação dos Lóios $^{950}$.

D. Fernando da Guerra integrou o desembargo régio de D. João I a partir de 1416, como conselheiro e chanceler-mor (1416-18), de que foi o último desembargador clérigo ${ }^{951}$. Ainda que pareça ter sido pouco interveniente nos trabalhos do desembargo ${ }^{952}$, não se deixa de acentuar a sua presença e envolvimento com a corte régia, a qual sustentou, através da proteção de D. João I, a sua ascensão à mais elevada prelatura do reino, uma «caminhada ascendente que D. Fernando da Guerra fez, à sombra de D. João I, para o episcopado, até ocupar, finalmente, a Cátedra Arquiepiscopal de Braga ${ }^{953}$.

D. João de Castro vinha de um ramo familiar que estivera parcialmente (ainda que de modo ambíguo) associado ao partido de D. João mestre de Avis no período do Interregno. Não foi o caso de seu pai D. Pedro de Castro que se retirou para Castela entre 1384 e 1388, mas que regressando ao reino acabará por receber de D. João I o senhorio de Cadaval e Peral.

A reentrada destes Castro no favor régio do Mestre de Avis tornado Rei, permite que seus filhos João e Fernando (deste último descenderão os Castro condes de Monsanto e marqueses de Cascais) desenvolvam percursos significativos como cortesãos da nova dinastia. A adesão da linhagem à Casa de Avis reforça-se com o casamento de D. João com a viúva do célebre jurista João das Regras, e ainda mais profundamente quando a filha do casal casa-se com o herdeiro sobrevivo do primogénito de D. João I, Fernando $2 .^{\circ}$ Duque de Bragança ${ }^{954}$.

A presença, com altos e baixos, dos Castro na corte portuguesa, assinalável desde o reinado de D. Afonso IV e acentuada no reinado de Pedro I pela ligação a Inês de Castro, assegura-lhes um papel de primeiro relevo, que levou mesmo Rita Costa Gomes a situá-los entre as oito mais importantes linhagens da nobreza cortesã medieval portuguesa ${ }^{955}$.

A ligação de João Vicente a dois dos representantes desta linhagem, e o apoio que terá recebido de ambos nos anos fundacionais dos Lóios, parecem ser a justificativa mais plausível para a sua presença nos círculos cortesãos, onde podermos supor que tenha estabelecido relações, nomeadamente com outras figuras fundacionais. Será mesmo uma explicação preferível a uma hipotética aproximação aos príncipes de Avis anterior à sua elevação ao episcopado, nomeadamente como físico régio, que Sousa Costa não excluindo declaradamente considera, no entanto, como duvidosa ${ }^{956}$.

Da ligação de João Vicente a D. João de Castro poder-se-á perspetivar, com grande probabilidade, uma proteção e a inserção numa rede social privilegiada que será importante para o percurso do fundador dos Lóios e para a futura Congregação. É o que se infere da crónica de Paulo de Portalegre que, apesar de querer (dada a natureza e finalidade do texto) acentuar o desejo do jovem João

\footnotetext{
${ }^{950}$ Idem, ibidem; GOMES, 1995: 90.

${ }^{951}$ HOMEM, 2010.

${ }^{952}$ HOMEM, 1990: 299.

${ }^{953}$ MARQUES, 1988: 61.

${ }^{954}$ GOMES, 1995: 76; CUNHA, 1990: 36, 37.

955 GOMES, 1995: 64, 65.

${ }^{956}$ COSTA, 1986: 190 e segs., 261.
} 
Vicente de se afastar das seduções de uma vida de privilégios a que a proteção do seu colaço faria a sua família aspirar, não deixa no entanto de acentuar a importância desta relação.

É de crer, provavelmente sem grande erro, que a obtenção do benefício de um reitorado paroquial, bem como a procura de outros benefícios mais rendosos, por parte de João Vicente poderá fundar-se nestas suas relações de proximidade e suporte que mantem com este ramo da Casa dos Castro.

De facto, o mais antigo documento que se conhece para mestre João Vicente, e cujo conhecimento se deve ao labor científico do P.e Sousa Costa, é a concessão em 3 de janeiro de 1418 de uma súplica apresentada ao recém-eleito Papa Martinho V por João Vicente, que se apresenta como reitor da paroquial de Santiago de Tremês da diocese de Lisboa, mestre em Artes e Medicina, e em que lhe suplica sobre canonicato e prebenda na diocese de Coimbra ${ }^{957}$.

Nos dados documentais datados de 1418 registados pelo P.e Sousa Costa para João Vicente, e no comentário que faz, encontramos uma informação muito relevante cujo pleno alcance passou despercebido ao douto historiador franciscano, bem como aos autores que têm utilizado a sua obra.

Trata-se de uma informação que vai diretamente ao cerne da questão do modo como os fundadores Lóios poderão ter entrado em contacto com o carisma de Alga e com o círculo reformista que o rodeava e em que se inseria, permitindo-nos antecipar com algum grau de segurança, e em quase uma década, os relacionamentos de João Vicente e dos primeiros Lóios com as correntes reformistas italianas desenvolvidas no universo veneziano.

Sousa Costa sustenta como provável, ante outras súplicas apresentadas em seu nome, que em 1418 João Vicente andasse pela cúria pontifícia. Dá como evidência para esta suposição o facto de o Papa afirmar, na concessão de uma súplica de 28 de maio de 1418, que anteriormente lhe concedera (em 28 de janeiro desse ano) uma outra súplica sobre um canonicato em Lisboa com expectativa de prebenda, concessão que fizera em atenção ao dominicano e Cardeal de Ragusa D. João Domingues, prelado que teria assim um papel de apoio e intermediação na concessão desta súplica ao nosso jovem clérigo ${ }^{958}$.

Será talvez a tradução do nome do Cardeal de Ragusa que não permita uma imediata identificação do prelado em causa, tanto mais que não se tem significativamente perspetivado o movimento dos Lóios em contexto e relação com o movimento de Alga e do universo reformista em que este se inseria, resultando num maior desconhecimento das figuras que nestes se envolviam.

Em 1418 era cardeal da Igreja e Arcebispo de Ragusa ${ }^{959}$ o beato Giovanni Dominici (João Domingues em português ${ }^{960}$ ) Banchini, grande figura da observância dominicana, nomeadamente

\footnotetext{
${ }^{957}$ COSTA, 1986: 191, 192.

${ }^{958}$ Idem, ibidem.

959 Daí a designação de Cardeal de Ragusa, de onde era arcebispo. A tradição de designar os cardeais pela sé que ocupavam ou pela sua origem era muito forte no séc. XV, por isso encontramos Eugénio IV e Pio II a serem chamados cardeais de Siena (como bispos desta cidade, e o último por ser natural do seu domínio) ou Paulo II cardeal de Veneza.

${ }^{960}$ Curiosamente Sousa Costa identifica-o como João Domingues na sua obra sobre os bispos de Lamego e Videu, mas já no artigo que escreve sobre D. Gomes chama-o João Dominici (cf. COSTA, 1963: 59).
} 
em Veneza, estreitamente ligado ao papa Gregório XII (que o criou cardeal) e aos sobrinhos deste pontífice, e seus colegas no colégio cardinalício, que foram fundadores da Congregação de Alga e suporte, no caso de Eugénio IV, dos primeiros passos dos Lóios. Trata-se do mesmo Cardeal Dominici, observante dominicano e dos círculos reformistas dos fundadores de Alga de que já se tratou anteriormente.

Estamos pois perante a declarada intervenção, junto do Papa Martinho V (de quem foi breve mas importante colaborador ${ }^{961}$, como tinha sido de Gregório XII), de um purpurado reconhecidamente reformista e da linha veneziana, a favor de um mestre João Vicente que se supõe estar então junto da cúria pontifícia a tratar de questões beneficiais.

A intervenção do Cardeal de Ragusa ocorre precisamente quando o cardeal se encontrava de partida para duas importantes missões legatícias ao serviço do Papa: ao Rei dos Romanos Segismundo e ao seu irmão Venceslau IV da Boémia (representantes do poder Imperial) para tratar com eles da premente questão hussita, bem como à Grécia para tratar da união entre as duas cristandades ${ }^{962}$.

Poder-se-á considerar esta circunstância meramente fortuita? Ante a escassez de dados documentais que nos expliquem o modo como um carisma reformista italiano se introduz em Portugal pela fundação de uma nova congregação, é lícito colocar de parte um indício tão importante de relacionamento entre a principal figura fundacional dos Lóios e um dos expoentes do círculo reformista veneziano, ainda mais um que é apontado como figura inspiradora e formadora dos fundadores de Alga?

Tem sido considerado, por todos os que se debruçam sobre a fundação dos Lóios, que os primeiros contactos dos fundadores com a matriz carismática de Alga se dão por ocasião da estadia de Afonso Nogueira em Itália, em 1426-27963, onde entre outras coisas teria ido procurar junto da Santa Sé a confirmação da secularização e entrega da casa de Vilar de Frades a João Vicente, bem como uma forma institucional para a comunidade nascente e a renúncia de Vilar de Frades na nova comunidade estabelecida canonicamente.

Como refere Sousa Costa ${ }^{964}$ e se pode verificar nos documentos que aduz no seu Monumenta Portugaliae Vaticana ${ }^{965}$, em abril de 1427 é apresentado ao Papa Martinho V uma súplica dos clérigos e presbíteros que em Portugal vivem ao modo, usos e costumes dos clérigos e presbíteros da igreja de S. Jorge em Alga de Veneza ${ }^{966}$.

\footnotetext{
${ }^{961}$ CRACCO, 1963.

${ }^{962}$ Idem, ibidem.

${ }^{963}$ Não se podendo precisar com inteira certeza as datas da presença de Afonso Nogueira em Itália, poder-se-á afirmar que chega a Roma antes de 8 de junho de 1426, data em que apresenta (com seu irmão Gomes) uma súplica ao Papa Martinho para alargar outra já concedida antes (cf. COSTA, 1970: 123, súplica 988), e regressará a Lisboa cerca de um ano depois, tendo embarcado em Florença a 26 de junho de 1427 e chegado a Lisboa a 14 de agosto, como nos informa Borges Nunes (cf. NUNES, 1963: 358).

${ }^{964}$ COSTA, 1986: 193 e segs.

${ }^{965}$ COSTA, 1970: 222, 223, 236, 237.

966 «clericis et presbyteris in regno Portugalie ad modum, usum et consuetudinem clericorum et presbyterorum in ecclesia sancti Gerorgii dAlega in Venetiis Castellane diocesis» (cf. Idem, ibidem: 223).
} 
Seria esta súplica, que a comprovada presença de Afonso Nogueira na cúria romana permite supor com segurança ter sido apresentada por ele $^{967}$, que marcaria o ponto inicial em que o carisma de Alga se encontra assumido pela comunidade fundacional dos Lóios, que aparece a pedir a confirmação da cedência de Vilar de Frades pelo arcebispo D. Fernando da Guerra, dando conta daquilo que as crónicas já informavam: que na igreja e mosteiro de Vilar a comunidade fundacional pretendia estabelecer a sua primeira Casa estável, já que eles "per prius certa carebant mansione ${ }^{968}$ ».

Nesta matéria, e socorrendo-nos da documentação vaticana apresentada por Sousa Costa nos seus trabalhos ${ }^{969}$, no que diz Eduardo Nunes da relação de D. Gomes com os Lóios ${ }^{970}$ e na análise que Castro Pina faz da questão na sua tese ${ }^{971}$, podemos estabelecer uma análise do período de aprovações pontifícias da futura Congregação de S. João Evangelista, que se situa entre 1427 e 1431 e entre as viagens de Afonso Nogueira e João Vicente à cúria romana.

Diz-nos a documentação ${ }^{972}$ que Afonso Nogueira, na viagem que empreende a Roma em 1426-27 com alguns membros da sua família, impetrará do Papa as primeiras aprovações pontifícias para o grupo fundacional, então já instalado em S. Salvador de Vilar de Frades, entre outras súplicas que o futuro arcebispo apresenta, relacionadas com a sua linhagem ${ }^{973}$.

Terá sido no decurso desta viagem, segundo a lição do cronista Paulo de Portalegre, que Afonso Nogueira terá contacto com o modelo de Alga que, por sua iniciativa, trás para Portugal:

se foy [Afonso Nogueira] a Italya ainda em sua grande honestidade e forte pẽndença, que em sua mãcebia fortemente soportou, e ainda cõ emtenção de aprender e asi o fez, ca indo-se a Italia, a Bolhonha, per algũ tenpo esteve no estudo. E desi foe visitar os Irmãos de Italia [i.e. os cónegos da Congregação de Alga] e elle trouxe de la o abito e capa azull (que antes nõ custumavão senão pardo) e outrosi trouxe as Constituições daqueles padres. E retornãdo a esta tera, achou mestre Johanne, Martĩ Lourenço e Joam Rodriguiz cõ algũs outros em esta casa de Vilar de Frades, os qoaes receberão delle as sobreditas cousas ${ }^{974}$

Pelo testemunho do padre Paulo pode-se atribuir a esta viagem de Afonso Nogueira, que podemos datar de 1426-1427 (ainda que com motivos diferentes dos que o de frequentar o estudo em Bolonha ${ }^{975}$ ) o momento em que os elementos centrais da identidade da Congregação de Alga são

\footnotetext{
${ }^{967}$ COSTA, 1986: 206 e segs.

${ }^{968}$ COSTA, 1970: 223.

${ }^{969}$ Idem, ibidem; COSTA, 1986.

${ }^{970}$ NUNES, 1963: 354 e segs.

${ }^{971}$ PINA, 2011: pontos 2 a 4 do cap. III.

${ }^{972}$ COSTA, 1970: súplicas 1131-1132, 1149-1150.

${ }^{973}$ Como revela com algum detalhe o P.e Sousa Costa (COSTA, 1986: 193 e segs.). Sobre a linhagem de Afonso Nogueira, de que se pode ver um resumo genealógico em anexo (esquema genealógico n. ${ }^{2}$ 2), vejam-se os trabalhos de Mário Farelo (FARELO, 2007; FARELO, 2008; FARELO, 2012).

${ }^{974}$ PORTALEGRE, 2007: 91.

${ }^{975}$ Sousa Costa, que tem um estudo sobre portugueses estudantes em Bolonha no séc. XV (COSTA, 1990), não menciona Afonso Nogueira como estudante em Bolonha. Note-se igualmente que os dados que aduz no seu estudo sobre os bispos de
} 
materialmente passados à comunidade fundacional dos Lóios. Assim, além do hábito azul distintivo ${ }^{976}$, Afonso Nogueira terá trazido, de modo sistematizado, os textos fundamentais normativos da Congregação de Alga, cuja natureza já se abordou no ponto 2.1.

A mesma opinião expressou, certamente seguindo a lição do primitivo cronista mas com um menos apurado sentido da ordem temporal (neste caso antepondo na narrativa a viagem a Itália de João Vicente, que terá lugar em 1430-31, à de Afonso Nogueira), o cronista encartado Francisco de Santa Maria:

voltou D. Afonso Nogueira de Italia, e levou ao convento, e Padres de Villar as constituições, e habito, que trouxera de Venesa dos Conegos da Congregação de S. Jorge em Alga, tão famosa e celebrada naquele tempo, que attrahio, e arrebatou a devoção, e espirito deste ilustre Portuguez, a ir ver com os olhos as maravilhas, com que a fama lhe enchia, e atroava os ouvidos. Foi, vio, e admirou, ficando tão namorado da cor, e forma do habito, tão edificado do modo, e reforma da vida daquelles padres, que se resolveo em trazer aos seus as ideas, e noticias de huma, e outra cousa, com desejo, e intento, de que abraçassem ambas. Achou esta especiosa novidade, universal aceitação, e aplauso nos Padres de Villar, os quaes logo avisarão ao Mestre João que procurasse confirmar a sua Congregação de Portugal à maneira da Congregação de S. Jorge em Alga ${ }^{977}$.

Acentua-se ainda mais, na descrição do Padre Santa Maria, o papel de Afonso Nogueira como responsável do conhecimento e adoção do modelo de Alga. Transmite-se-lhe declaradamente toda a iniciativa nesta matéria de figurino institucional, de que terá tido o primeiro conhecimento em Itália, que trouxe para Portugal e que depois disso os fundadores aceitaram e fizeram aprovar em Roma por mestre João Vicente, que nesta formulação aparece como uma figura passiva que faz aprovar em Roma a escolha que entre Itália e Portugal fizeram Afonso Nogueira e os outros padres fundadores.

A formulação de Francisco Santa Maria está genericamente incorreta, pois não só não concorda inteiramente com os dados e espírito da crónica de Paulo de Portalegre, como está flagrantemente em

Lamego e Viseu (COSTA, 1986), bem como a descrição dos passos de Afonso Nogueira em Itália que é deixada por Borges Nunes (NUNES, 1963: 355 e segs.) não parecem grandemente compagináveis com a necessária demora que uma estadia de estudo comportaria (veja-se por exemplo a estadia escolar de de D. Fernando da Guerra nas Universidades de Bolonha e Pádua, onde ingressou nunca depois de fevereiro de 1408 e onde permanecerá até ca. 1414 (cf. MARQUES, 1988: 51 e segs.). Note-se que Francisco de Santa Maria aduziu um outro motivo, o da visita dos lugares santos de Itália, em particular os de Roma (cf. SANTA MARIA, 1697: 219), mais de acordo com a súplica apresentada por Afonso Nogueira e seu irmão Gomes Nogueira ao Papa Martinho V, em 8 de junho de 1426, em que na sequência do pedido de licença (recusada) para peregrinarem à Terra Santa, e que o pontífice comutara em visitas a igrejas de Roma, pedem que seja a concessão alargada aos familiares que os acompanham (cf. COSTA, 1970: 123, súplica 988).

${ }^{976}$ De onde uma das designações informais dos Lóios, como dos cónegos de alga, de Cónegos Azuis. Segundo a tradição das Congregações a cor do hábito teria origem num desejo (afirma-se que divinamente revelado) em honrar a Virgem Maria (já que o azul é de facto a sua cor distintiva, mesmo em liturgia, cf. GUERREIRO, 2001), informação veiculada na crónica de Tomasini (cf. TOMASINI, 1642: 42 e segs.), bem como nas crónicas portuguesas, a começar na de Paulo de Portalegre (cf. PORTALEGRE, 2007: 96, 97).

977 Cf. SANTA MARIA, 1697: 228. 
desacordo com os trabalhos que mais recentemente analisam a questão da fundação lóia ${ }^{978}$. O cronista ignoraria por certo as súplicas que Afonso Nogueira apresenta em 1427 e as hesitações de escolha de uma estrutura institucional que se percebem até 1431, e de que Isabel Castro Pina faz uma análise nos pontos 2 a 4 do cap. III da sua tese ${ }^{979}$.

Tendo o P.e Sousa Costa identificado as seis primeiras súplicas que pelos fundadores Lóios são apresentadas, quatro em 1427 (na prática duas súplicas, pois ambas compreendem num só pedido duas súplicas distintas mas intercorrelacionadas ${ }^{980}$ ) e duas em 1430-31 ${ }^{981}$, correspondendo aos períodos em que Afonso Nogueira e João Vicente estão na cúria romana, entramos diretamente no questionamento sobre o modo como o modelo de Alga, até então exclusivamente italiano (e pode-se acrescentar exclusivamente do Veneto, com a exceção da comunidade de Bolonha) entra no conhecimento e nas opções do grupo de clérigos portugueses que intentava seguir novo modo de vida comum.

Saliente-se de novo a dificuldade de, nesta matéria, ter certezas profundas. Castro Pina, na senda do que se percebe pelos trabalhos de Borges Nunes e Sousa Costa ${ }^{982}$, e pelo que Pedro Tavares já aventava num seu artigo ${ }^{983}$, apresenta uma proposta de análise que enquadra de modo muito satisfatório a escolha do modelo de Alga e o processo que o grupo fundacional dos Lóios parece viver de indefinição institucional.

Será à influência do abade D. Gomes que se faz acolher o conhecimento da Congregação reformista de Alga, de quem o fundador da observância beneditina em que este abade português Gomes se inseria, o nosso conhecido Luís Barbo, escrevia em 1440, que «religiosissime vivunt et plura per diversas mundi partes monasteria sive ecclesias reformaverunt et in praesenti reformant ${ }^{984}$.

A relação de D. Gomes com os padres fundadores está amplamente documentada, pela epistolografia remanescente do abade de Florença e que Eduardo Nunes e Sousa Costa amplamente utilizam nas suas obras ${ }^{985}$. Conhece-se o papel que desempenhou a auxiliar Afonso Nogueira na concessão das súplicas na cúria, como na tentativa de obter dos Cónegos de Alga os documentos principais atinentes ao seu modo de vida, e em busca dos quais Afonso Nogueira terá passado uma estadia na Casa de Alga, que Borges Nunes calcula em cerca de quatro meses e meio ${ }^{986}$, e na qual podemos supor que tenha aprofundado a aproximação ao modo de vida de Alga.

Não podendo questionar o papel fulcral que Afonso Nogueira tenha tido nesta matéria, o que se afigura como problemático é a atribuição (muito marcada em Francisco de Santa Maria, e em menor grau nos seus antecessores memorialistas lóios) a uma circunstância casual da viagem de Afonso Nogueira a Roma a escolha de um figurino institucional, de que se não teria conhecimento prévio de

\footnotetext{
${ }^{978}$ Veja-se os trabalhos já amplamente citados: COSTA, 1986; TAVARES, 2001a; TAVARES, 2003; PINA, 2011.

${ }^{979}$ Idem, ibidem: 107-118.

${ }^{980}$ COSTA, 1970: 222, 223, 236, 237; súplicas 1131-1132, 1149-1150.

${ }^{981}$ Idem, ibidem: 581, 582, 596, 597, súplicas 1619, 1637.

${ }^{982}$ NUNES, 1963; COSTA, 1986.

983 TAVARES, 2001a.

${ }^{984}$ Citado em TRAMONTIN, 1984: 93.

${ }^{985}$ NUNES, 1963; COSTA, 1986.

${ }^{986}$ NUNES, 1963: 356.
} 
relevo e feita à margem do restante grupo de jovens clérigos a que pertencia e em que a figura principal seria a de João Vicente.

Esta viagem plasma já o padrão que marcará a ligação de Afonso Nogueira com a Congregação ao longo dos anos. Afonso Nogueira, membro de uma família cortesã com ligações ao desembargo e ao conselho régios, além de uma presença notória nas dignidades eclesiásticas ${ }^{987}$, estará fortemente ligado aos destinos da sua linhagem, em que tinha «...suas grosas, temporalidades e morgados [...]»" ${ }^{988}$, e que anteporá à sua pertença à Congregação, da qual no entanto (como veremos) nunca se desligará totalmente.

Estando em Itália em viagem de cariz familiar, como se depreende de ser feita em companhia de seus irmãos Rui (o administrador do morgadio familiar) e Gomes, de apresentarem súplica com matéria referente à herança de seu pai e por se determinaram a fazer peregrinação conjunta à Terra Santa ${ }^{989}$, Afonso Nogueira e os seus familiares parecem ter aproveitado para apresentar um conjunto de outros pedidos que nos permitem antever nesta viagem um alcance mais profundo e alargado que simplesmente tratar dos assuntos do grupo fundacional dos Lóios.

De facto depois de uma primeira súplica relacionada com a comutação do seu voto de peregrinação à Terra Santa ${ }^{990}$, vemos serem deferidas a 19 de junho de 1426 um conjunto de três súplicas ${ }^{991}$, todas com diferentes impetrantes mas ligados entre si, permitindo-nos supor que foram apresentadas pelo mesmo grupo de pessoas, os irmãos Nogueira, cujo cerne da viagem a Itália seria servir os interesses da sua família e, pontualmente, o serviço da Coroa.

Assim a Rui, Afonso e Gomes Nogueira concede o Papa a graça de serem isentos de certas cláusulas testamentárias de seu pai, Afonso Nogueira, do conselho do Rei e do Infante D. Duarte e alcaide de Lisboa; ao conde de Vila Real D. Pedro de Meneses, sogro de Rui Nogueira ${ }^{992}$, concede dispensa de impedimentos de consanguinidade e de afinidade paras as suas filhas legítimas Beatriz e Leonor, ambas casadas em casas de sangue real por bastardia (Beatriz com D. Pedro de Noronha, 2. ${ }^{\circ}$ conde de Vila Real ux iure; Leonor com D. Fernando II, 3. ${ }^{\circ}$ Duque de Bragança, o confessado do P.e Paulo de Portalegre); ao Infante D. Duarte, de cuja casa Rui Nogueira era cavaleiro ${ }^{993}$, um conjunto de súplicas apresentadas para os eremitas da Serra de Ossa (indulto de altar portátil, faculdade de escolher confessor e isenção de dízimos).

Parece pois que a estadia em Roma de Afonso Nogueira não está especificamente associada aos Lóios, mas a uma viagem com objetivos mais vastos e que se estabelecem em vários níveis: assuntos

\footnotetext{
${ }^{987}$ De que se poderá fazer uma rápida leitura no esquema genealógico n. ${ }^{\circ}$ 2, em anexo.

${ }^{988}$ PORTALEGRE, 2007: 91.

${ }^{989}$ Como se pode ver nos trabalhos já citados de COSTA, 1986: 193 e segs.; NUNES, 1963: 355 e segs.

${ }^{990}$ Cf. COSTA, 1970: 123, súplica 988.

${ }^{991}$ Idem, ibidem: 131-134, súplicas 999, 1000, 1001-1005 (conjunto de súplicas correlacionadas).

${ }^{992}$ Casado com a sua filha ilegítima D. Aldonça de Meneses, conforme indica o seu testamento de 8 de outubro de 1429 , de que se conserva treslado não autenticado do séc. XVIII no arquivo dos Viscondes de Vila Nova de Cerveira (cf. AVNC - Morgado de St. ${ }^{a}$ Ana, cx. 5, doc. 44).

${ }^{993}$ Conforme indica a carta régia de D. João I, de 28 de julho de 1426, em que se determina os direitos e rendimentos da alcaidaria de Lisboa, em que por morte de Afonso Anes Nogueira provera o seu filho Rui Nogueira, cavaleiro do Infante D. Duarte (cf. ALMEIDA, 1961: 129).
} 
do morgadio, assuntos da família alargada, assuntos da Coroa. A estes assuntos terá Afonso Nogueira, que neste período se inseria ainda naturalmente no grupo de clérigos de João Vicente ${ }^{994}$ (ainda incipiente e ainda fluído), numa pertença que parece mesclar com a integração nas lógicas da sua linhagem, introduzido as primeiras súplicas da futura Congregação, que pediam ao Papa conjuntamente a confirmação da secularização e entrega do mosteiro de Vilar de Frades pelo Arcebispo D. Fernando da Guerra, bem como graças de natureza penitencial e indulgencial, e beneficial ${ }^{995}$.

Não sendo impossível (já que as súplicas nesta matéria são concedidas em abril e junho de 1427, quando se sabe que Afonso Nogueira estava em Itália desde pelo menos junho do ano anterior) que o conhecimento da matriz de Alga venha da estadia italiana de 1426-27 de Afonso Nogueira, ou tenha sido informada por Gomes Anes na sua visita a Portugal em 1424-26, o certo é que quando se apresentam as primeiras súplicas deste grupo afirma-se que a comunidade é de «clericis et presbyteris in regno Portugalie ad modum, usum et consuetudinem clericorum et presbyterorum in ecclesia sancti Georgii dAlega in Venetiis» ${ }^{996}$, expressão que poderá ser uma forma de retórica curial, mas que parece no entanto indicar uma prévia e consciente existência de vida comunitária de clérigos sob a forma de vida da Congregação de Alga.

Se as relações com o abade Gomes Anes parecem ser uma boa explicação para a aproximação ao carisma de Alga (ainda que o carisma específico deste português tenha sido o da observância beneditina) por parte dos fundadores Lóios, trata-se de uma explicação de clara natureza circunstancial, já que nenhum documento existe que declaradamente expresse a promoção do carisma de Alga e do universo reformista veneziano por parte deste prelado.

Nesta medida gostava de propor uma outra explicação circunstancial, a qual no entanto possui o mérito de aprofundar a ideia de uma inserção dos fundadores dos Lóios, em particular a figura de mestre João Vicente, no universo reformista veneziano.

Como anteriormente se mencionou, os primeiros documentos da chancelaria apostólica sobre mestre João Vicente são de 1418, quando o futuro fundador dos Lóios aparece detentor de um benefício eclesiástico, ainda não ordenado de sacerdote mas já doutor em artes e medicina ${ }^{997}$.

A súplica de 28 de janeiro de 1418 permite supor João Vicente, como já se disse, em contacto direto e sob o patronato de uma das figuras mais relevantes do movimento observante dominicano, um dos pilares do universo reformista veneziano, inspirador e colaborador dos fundadores da Congregação de Alga.

Com estes predicados poderemos supor, ainda com maior propriedade do que para o abade Gomes Anes ${ }^{998}$, que o Cardeal Dominici possa ter apresentado a João Vicente a forma de vida de Alga,

\footnotetext{
${ }^{994}$ Pelo menos encontramos neste período Martim Lourenço, em carta ao abade Gomes Anes, a designá-lo por «nosso irmão» (cf. NUNES, 1963: 357), enquanto vemos o próprio Afonso Nogueira a impetrar súplicas pelos clérigos e presbíteros que em Portugal vivem segundo o modo da Congregação de Alga.

${ }_{995}$ Cf. COSTA, 1970: súplicas 1131-32, 1149-50.

${ }^{996}$ Idem, ibidem: 223, súplica 1131.

${ }^{997}$ Cf. COSTA, 1986: 191, 192.

${ }_{998}$ De facto podemos questionar-nos da efetiva proximidade do abade beneditino à Congregação de Alga, pois como refere Borges Nunes, baseado na correspondência de Gomes Anes, quando se torna necessário mediar com a comunidade de
} 
ou pelo menos colocando-o em contacto com os seus antigos discípulos e colegas purpurados, fundadores da Congregação de Alga, António Correr e Gabriel Condulmer.

Será importante recuperar neste contexto a informação veiculada por Paulo de Portalegre, que nos informa que uma das primeiras inclinações espirituais de João Vicente foi para a observância dominicana, em particular a nova comunidade de S. Domingos de Benfica, cabeça da observância em Portugal, onde terá mantido proximidade aos dominicanos Fr. Mendo e Fr. João de Moura $^{999}$, na qual teria tentado entrar para a vida religiosa, intenção a que no entanto se terá oposto o seu pai ${ }^{1000}$.

Esta nova casa de S. Domingos de Benfica tinha a particularidade de ter sido fundada pelo Dr. João das Regras (que nela está sepultado), de quem era viúva a mulher de D. João de Castro, o protetor de João Vicente, encerrando este círculo relacional que une o fundador Lóio à observância dominicana.

Esta ligação, que Fr. Luís de Sousa não deixou de registar (declaradamente a partir do testemunho do Novo Memorial ${ }^{1001}$ ), apresentada por Paulo de Portalegre para demonstrar a inclinação de juventude de João Vicente à vida religiosa e reformada, poderá ser uma chave de leitura para explicar a sua inserção no círculo do Cardeal Dominici, e por este a sua aproximação ao universo reformista veneziano e aos clérigos seculares de S. Jorge em Alga.

Teria já João Vicente na mente e no espírito o exemplo de Alga quando, na Lisboa de 1420 a que retorna, reúne com Afonso Nogueira, Martim Lourenço e os demais clérigos fundadores para debater a crise da Igreja e para tentar iniciar uma vida comum, em moldes que nos recordam desde o início os do mosteiro lagunar?

A hipótese não é de todo descabida e explicaria o tom em que se formularam as primeiras súplicas apresentadas por Afonso Nogueira, bem como o grande empenho em obter os elementos estruturais do modo de vida de Alga (norma, hábito, cerimonial), que levou o fidalgo lisboeta a passar mais de quatro meses na comunidade veneziana.

Esta possibilidade permite simplificar, muito para além da causalidade em curas médicas, a aproximação de João Vicente ao Cardeal Gabriel Condulmer quando, em 1430, o fundador dos Lóios e reitor da Igreja de Vilar de Frades (que o arcebispo de Braga lhe cedera em benefício em 1425) surge em Roma a impetrar a Martinho V duas súplicas: uma de outubro de 1430 em que pede para, com a comunidade de clérigos de seculares que estavam em Vilar de Frades, professarem na Ordem de St. $^{\circ}$ Agostinho ${ }^{1002}$; a segunda de janeiro de 1431, em que abandonam a ideia de professar solenemente

S. Jorge em Alga a obtenção da sua documentação carismática, o abade de Florença recorre não diretamente à comunidade mas a um outro abade beneditino da observância, o abade de S. Jorge Maior de Veneza (cf. NUNES, 1963: 355, 356).

${ }^{999}$ Fr. João de Moura, escolar em Paris, foi vigário geral da observância dominicana e confessor da rainha D. Leonor de Aragão, mulher de D. Duarte (cf. MARQUES, 1993).

${ }^{1000}$ PORTALEGRE, 2007: 81, 82.

${ }^{1001}$ SOUSA, 1767: 113 e segs.

${ }^{1002}$ Cf. COSTA, 1970: 581, 582, súplica 1619. São aliás os termos desta súplica, que colidem com as súplicas de 1427 em que declaram viver segundo o modo de vida de S. Jorge em Alga, que leva à já mencionada noção de um período de indefinição institucional no período fundacional da Congregação, situado entre 1427 e 1430. 
entre os Agostinhos, afirmando viver religiosamente segundo a regra evangélica na igreja de Vilar de Frades, pedindo a confirmação da sua secularização e para se governarem por prior anual com confirmação do ordinário, ainda que não mencionando em ponto algum a Congregação de Alga ${ }^{1003}$, que só voltará a ser explicitamente mencionada já no pontificado de Eugénio IV, quando em maio desse ano confirma os termos da concessão de janeiro, acrescentando-lhe o gozo dos privilégios da Congregação de Alga (que soma aos dos Jerónimos) ${ }^{1004}$.

Os avanços e recuos do modelo institucional da Congregação foram situados por Isabel Pina ${ }^{1005}$ na problemática da relação com o arcebispo D. Fernando da Guerra, a qual se funda essencialmente na isenção da autoridade ordinária diocesana que a comunidade de Vilar obteria ao constituir-se como Congregação a exemplo de Alga, colocando-se fora da intervenção do prelado diocesano, cuja autoridade em Alga era já excluída, como vimos, na executória de 1404.

Esta é sem dúvida a melhor leitura possível para a questão, já que na mira do prelado bracarense não estaria, quando reduz a igreja de Vilar de Frades a secular e institui nela como beneficiado a João Vicente (sem qualquer menção aos seus seguidores), a alienação de quaisquer tipo de direitos sobre a igreja e mosteiro de Vilar de Frades, fosse o direito de padroado (que pertencia à mitra bracarense), fosse o das diversas obrigações que marcavam a submissão à autoridade ordinária, e que D. Fernando da Guerra deixou bem patentes no ato de redução do mosteiro de Vilar ${ }^{1006}$.

As dúvidas aparentes sobre a adoção plena do modelo de Alga não parecem, pois, fundadas sobre uma dúvida estrutural em relação ao modo de vida dos cónegos seculares de vida em comum, mas na dificuldade, para um grupo ainda incipiente e sem Casa própria, em enfrentar um prelado diocesano que era, além de prole régia e de grande poder, altamente cioso da plena extensão dos seus poderes e autoridade prelatícia ${ }^{1007}$.

Será preciso a eleição de um Papa oriundo dos claustros de Alga, e da próxima relação que já estabelecera com mestre João Vicente, para se alcançar uma solidez de apoios que permitisse aos fundadores Lóios assumir-se como plena e autónoma estrutura congreganista, dotada de privilégios que a colocam imediata à Santa Sé, permitindo-lhe seguir o seu percurso carismático livremente.

Começando com a já mencionada concessão de 18 de maio de 1431, o Papa Eugénio IV abre o período de vida institucional efetiva da que se converterá em Congregação de S. João Evangelista. Entre 1427 e 1449 os Lóios recebem da Santa Sé o cerne do seu corpo de privilégios (seja por comissão ou concessão), já que até meados do século se contam $50 \%$ dos privilégios alcançados nos cerca de 160 anos que este trabalho abrange ${ }^{1008}$.

\footnotetext{
${ }^{1003}$ Idem, ibidem: 596, 597, súplica 1637.

${ }^{1004}$ Livro dos Privilegios concedidos pellos Summos Pontifices..., 1594: fl. 16 e seguinte.

${ }^{1005}$ PINA, 2011: 114-118.

${ }^{1006}$ ADB - Monástico, Lóios, Mosteiro de Vilar de Frades, lv. 12, fl. 107. Transcrito em anexo documental, doc. n. ${ }^{\circ} 1$.

${ }^{1007}$ Marca de personalidade que fica claramente patente de uma leitura da tese do Prof. José Marques (cf. MARQUES, 1988).

${ }^{1008}$ Dados obtidos a partir do quadro anexo n. ${ }^{\circ}$.
} 
Gráfico 5. Privilégios concedidos à Congregação dos Lóios, em intervalo de tempo

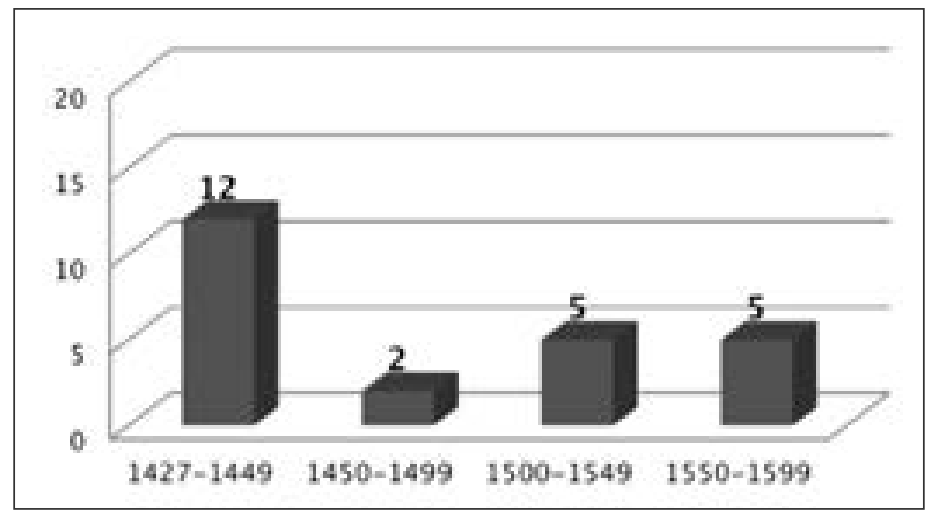

A estruturação normativa, a construção de uma rede de privilégios eclesiásticos, o consequente alargamento da capacidade afirmativa da Congregação, a construção de uma rede de apoios instituída ao mais alto nível e favorecida pelas próprias redes de origem dos fundadores, será altamente facilitada pelo apoio do Papa Condulmer e pelo seu desejo de expansão do carisma de Alga, com cujo processo de afirmação, consolidação e estruturação normativa e de privilégios os Lóios têm muitas semelhanças.

A mais notória diferença entre os dois processos assenta no facto dos Lóios terem, com o percurso dos seus irmãos de Alga, aprendido a atalhar caminho, pois se em Alga existe uma diferença de 20 anos entre a executória do bispo Barbarigo e a efetiva constituição de uma Congregação, os Lóios constituem-se como Congregação à curta distância de pouco mais de meia década (que vão da entrega de Vilar de Frades em 1425 à concessão de Eugénio IV de maio de 1431), e contando apenas com uma comunidade.

Esta dinâmica que o Papa Eugénio IV promove, em paralelo com a que encontramos em Alga, tem um ponto importante, enquanto forma de afirmação institucional, na eleição episcopal de mestre João Vicente para a diocese de Lamego, que tem lugar a 7 de maio de $1431^{1009}, 11$ dias antes da emissão da concessão já mencionada.

Releve-se a sua eleição episcopal por dois motivos:

O primeiro dos motivos é de interesse geral, já que a nomeação do novo bispo português configura-se claramente como uma das primeiras nomeações de prelados reformistas que o Papa Eugénio IV faz, de acordo com a sua política de escolha de dignos prelados.

Eleito bispo de Lamego pelo Papa a 7 de maio de $1431^{1010}$, apenas dois meses e quatro dias após a eleição do próprio Eugénio, esta nomeação antecede em muito a escolha de Lourenço Justiniano para Veneza (1433) ou de Luís Barbo para a mitra de Treviso (1437), aproveitando o Papa esta diocese vaga em Portugal para a prover em alguém que manifestamente reconhece como detentor de um perfil

${ }^{1009}$ COSTA, 1986: 226 e segs.

${ }^{1010}$ Idem, ibidem: 185. 
que está de acordo com o que entendia dever ser um prelado diocesano. Uma leitura dos capítulos de Sousa Costa sobre o governo episcopal de João Vicente permite perceber como Eugénio IV se socorrerá do prelado português para algumas missões de monta ${ }^{1011}$.

O segundo motivo é a força que esta eleição confere doravante a João Vicente, e aos fundadores Lóios, para solidamente sustentarem o seu modo de vida e avançarem para a sua expansão.

O bispo de Lamego, depois de Viseu (em 1444), manterá ao longo da sua vida (que só terminará em 1463) o principal papel na nova Congregação ${ }^{1012}$ e, como Isabel Pina já salientou ${ }^{1013}$, ainda que lhe sejam entregues dioceses de pouco relevo na escala das cátedras episcopais portuguesas (nota-se aqui o peso da falta de berço nobre de João Vicente, que mesmo a valência dos Castro não podia suprir), a autoridade de que passa a estar revestido dota-o de outros meios de intervenção e coloca-o em círculos mais elevados, onde os poderes se exercem. Será também da sua autoridade ordinária que advirá a segunda Casa da Congregação, Recião, na diocese de Lamego ${ }^{1014}$.

Do universo dos principais fundadores será Afonso Nogueira a atingir o mais algo grau na hierarquia eclesiástica, nas mitras de Coimbra e Lisboa, dioceses de primeiro plano, que alcança mercê da sua origem e do seu percurso.

O homem que primeiro trouxe de Itália os elementos estruturais do carisma de Alga, possibilitando aos cónegos portugueses estruturarem o seu modo de vida a partir das linhas da reforma veneziana, deixou cedo a comunidade fundacional.

A morte de seu irmão Rui Nogueira, em $1432^{1015}$, torna Afonso Nogueira herdeiro dos importantes morgados que a sua família tinha em Lisboa, sediados na igreja de S. Lourenço, e cuja posse ocupou Afonso Nogueira por mais de um ano ${ }^{1016}$.

O futuro prelado passa então a estar responsável pelo importante património da sua família, não podendo perseverar numa Congregação que proíbe a posse de bens individuais; não parece crível, no entanto, a hipótese formulada por Jorge de S. Paulo de Afonso Nogueira ter desejado renunciar os morgados na Congregação, que não aceitaria pelo peso que a sua gestão pudesse implicar ${ }^{1017}$. A escolha de Afonso Nogueira terá sido plena e consciente, vencendo o homem nobre e de Corte sobre o clérigo de vida comum.

\footnotetext{
${ }^{1011}$ Idem, ibidem: caps. VI, VII.

${ }^{1012}$ De que passou a ser "protector e conservador do Colégio e Conversação da companhia dos clérigos chamados cónegos seculares viventes em comum do mosteiro de Vilar de Frades», nos termos de um documento da Congregação em que é citado, a doação do oratório de Altentejo, no termo de Óbidos (cf. ANTT - Congregação de S. João Evangelista, Convento de S. João Evangelista de Xabregas, mç. 18, doc. n. ${ }^{\circ}$ 4). Sobre este oratório e seus eremitas, que passará à posse da Congregação, trata FONTES, 2009.

${ }^{1013}$ PINA, 2011: 119 e segs.

${ }^{1014}$ Idem, ibidem: 133, 135; COSTA, 1986: 267, 268.

${ }^{1015}$ Que morrera assassinado (cf. MORENO, 1980: 925).

${ }^{1016}$ Conforme se depreende do acto notarial de posse de bens datado de 10 de novembro de 1433, em que Afonso Nogueira, que afirma por morte de seu irmão Rui ter herdado todos os seus morgados, dos quais muitos bens tinham sido sonegados, e que ele se dedicava a recuperar a posse desses bens (cf. AVNC - Morgado de St. ${ }^{a}$ Ana, cx. 1, doc. 11).

${ }^{1017}$ ADB - Manuscritos, ms. 924, p. 178.
} 
Jorge de S. Paulo, como antes dele Paulo de Portalegre ${ }^{1018}$, sustentam que Afonso Nogueira manteve boas relações com a Congregação. Assim parece ter sido, mantendo-se mesmo a relação próxima com João Vicente, como se supõe quando, na sequência da nomeação de Nogueira para notário apostólico $^{1019}$, encontramos o bispo de Lamego D. João presente no juramento que o novo notário faz no mosteiro de S. Bento de Xabregas (futura Casa generalícia dos Lóios), a 7 de setembro de 1442, perante o executor D. Estevão de Aguiar, Abade de Alcobaça ${ }^{1020}$.

Os fundadores Lóios, assumindo conscientemente o modelo carismático de Alga, conhecido e escolhido nas deambulações de jovens clérigos que procuravam um modo de vida mais próximo do cristianismo inicial, e como tal espiritualmente mais perfeito, integraram-se numa linha de reforma que passou a unir o norte italiano a Portugal, propondo nova forma de vida para os clérigos seculares, cuja reforma propugnavam.

Alga, mesmo que longínqua, não terá sido na fundação dos Lóios apenas um referencial distante, mas uma proposta abraçada e implementada em partilha carismática, de que se encontram os ecos nos cronistas e na futura defesa que os Lóios farão do seu modo de vida.

As quatro figuras fundacionais que se mencionaram, Eugénio IV, Lourenço Justiniano (através da sua obra escrita), João Vicente e Afonso Nogueira, são exemplo desse espaço de contacto entre matriz e filiada, ou melhor dizendo, entre congregações irmãs como se definiriam nos testemunhos patentes na crónica de Tomasini.

Mas para lá dos anos fundacionais, Alga e Lóios manterão relações que demonstram a importância dessa partilha carismática e um mútuo reconhecimento de uma pertença comum, que se entende estrutural, e que como tal obrigará sempre a pensar os Lóios na sua referência a Alga, a Veneza e ao seu universo reformista quatrocentista.

\subsection{OS LÓIOS, A CONGREGAÇÃO DE ALGA E A CÚRIA ROMANA: O CARISMA REVERSO ${ }^{1021}$}

Este ponto caberia igualmente bem inserido entre os capítulos dedicados à Congregação de Alga. Do mesmo modo poderia ter um outro título, mais descritivo talvez, como Relações entre a Congregação de S. Jorge em Alga e de S. João Evangelista de Portugal, já que das relações entre as duas faces de um mesmo carisma ir-se-á tratar.

\footnotetext{
1018 Idem, ibidem; PORTALEGRE, 2007: 91, 92.

${ }^{1019}$ Concedida pelo Papa Eugénio IV, por bula datada de Florença a 17 de julho de 1441 (cf. AVNC - Morgado de St. ${ }^{a}$ Ana, cx. 1, doc. 22 .

${ }^{1020}$ Cf. AVNC - Morgado de St. ${ }^{a}$ Ana, cx. 1, doc. 16.

${ }^{1021} \mathrm{O}$ título deste ponto inspira-se num conceito que se tem introduzido no campo dos estudos das missões: a ideia de missão reversa (reverse mission), que identifica o processo pelo qual missionários naturais de territórios identificados anteriormente como espaço de missão pelas Igrejas cristãs da Europa e América do Norte, vêm desempenhar o seu múnus pastoral num ocidente norte-atlântico em crise vocacional. Numa utilização livre aplica-se a expressão reversa para significar a relação entre a Congregação de Alga e a de S. João Evangelista, que de matriz-filiada, passa a reformanda-reformadora.
} 
Outro título se poderia sugerir - Congregação de Alga: de matriz a reformada, já que se pretende descrever e analisar a forma como nas (poucas) relações que se sabe terem existido entre as Congregações de Alga e dos Lóios encontramos uma inversão de papéis, quando a relação de matriz carismática com filial reverte-se e vemos a congregação portuguesa receber mandato pontifício para a reforma da sua matriz italiana.

Das relações inicias entre os fundadores Lóios e a matriz italiana conhece-se o que ficou escrito no ponto anterior, em particular os contactos estabelecidos por Afonso Nogueira na sua viagem a Itália nos anos de 1426-27, a que se segue a viagem de mestre João Vicente à Cúria Romana em que, apesar de não podermos garantir uma relação direta com uma comunidade da Congregação de Alga (a Casa romana dos Cónegos de Alga, S. Salvador em Lauro, só será fundada em $1468^{1022}$ ), podemos situar os contactos privilegiados com os fundadores da Congregação italiana Gabriel Condulmer e Ângelo Correr, então cardeais residentes na Cúria, bem como com os cónegos de Alga que pudessem estar na sua órbita (relembre-se a descrição que Da Bisticci fazia dos dois cónegos que integravam o pessoal de câmara de Eugénio IV).

Estas estadias em terras italianas, de 1426-27 e 1430-31, asseguradas por duas figuras centrais da Congregação portuguesa e que encerram em si mesmas um processo de escolha definitiva de carisma, de obtenção dos seus elementos normativos-carismáticos mais significativos e da aprovação da suprema autoridade eclesiástica, bem como a constituição da nova Congregação como ente absolutamente autónomo da sua matriz italiana (pois sendo os Lóios ad instar da Congregação de Alga, nunca foram dela dependentes), permitiria aos Lóios desenvolverem o seu percurso histórico, segundo o modelo de Alga, de modo inteiramente autónomo, sem necessidade de contactos com a sua matriz institucional. E de facto assim parecia ter sido genericamente o caso, com exceção de alguns dados que a cronística foi aduzindo ${ }^{1023}$ e os historiadores relevando ${ }^{1024}$.

É certo que em História nem sempre as aparências presentes do que foi o passado correspondem inteiramente ao que as fontes podem revelar. Nesta matéria podemos dizer que (apesar dos aparentes silêncios) a soma dos dados cronísticos com os elementos esparsos que se podem recolher na documentação sobrevivente dos Lóios, nos permitem afirmar que ao longo dos sécs. XV, XVI e XVII as Congregações de S. João Evangelista e de S. Jorge em Alga mantiveram contactos esporádicos, que esses contactos tiveram por palco privilegiado Roma, onde a Congregação portuguesa enviou com alguma frequência os seus cónegos como procuradores junto da Santa Sé, e que nesse contexto de encontro os Lóios obtinham do relacionamento com os Cónegos de Alga diversas modalidades de colaboração.

Pelos dados documentais que se puderam coligir, demonstrar-se-á a existência efetiva destes momentos de contacto entre as duas Congregações, seja à distância por troca de correspondência,

\footnotetext{
${ }^{1022} \mathrm{Vd}$. quadro anexo n. ${ }^{\circ} 2$.

${ }^{1023}$ Refere-se aqui o caso do envio de cónegos Lóios a Itália, por ordem pontifícia, com o objetivo de reformarem a Congregação italiana, de que Francisco de Santa Maria deixou impressa memória na Crónica (cf. SANTA MARIA, $1697: 290$ e segs.). ${ }^{1024}$ E que se centram particularmente na missão Lóia de 1568, que podemos encontrar resumida de modo muito claro em TAVARES, 1999: 7.
} 
seja por contactos presenciais em Itália (i.e. Roma), em que se consubstancia o mútuo reconhecimento e a partilha carismática, que culminará com a tentativa de reforma de Alga por cónegos Lóios, e na estrita defesa do modo de vida original das Congregações durante as tentativas de imposição de votos solenes e que ditará que a pureza matricial se mantenha apenas entre os Cónegos Seculares portugueses.

A análise dos dados far-se-á na crença que estes momentos de mútuo relacionamento demonstram dois factos: o primeiro (e o mais óbvio) é que ao contrário do que inicialmente se suporia, e apesar da distância, as duas Congregações da mesma raiz carismática mantinham contactos entre si; o segundo (que decorre do primeiro) é que existe nestas relações, e até por parte da Santa Sé, um reconhecimento implícito de uma identidade comum que une os cónegos portugueses e italianos, que se traduz no apoio mútuo (com evidente ganho para a Congregação portuguesa) e que salienta o mais importante elemento matricial: o carisma.

Sustenta-se assim, para além do período fundacional da Congregação dos Lóios, uma forte radicação do modo de vida seguido pelos Cónegos num carisma reformador nascido na Veneza dos primeiros anos de 1400, reconhecido e aceite pelo movimento português nascido na Lisboa de 1420, como um modo de vida mais perfeito, herdado dos tempos evangélicos do cristianismo e que se assume, enquanto modo de vida, como dedicado a reformar o corpo clerical e, por ele, a Igreja.

\section{Relação epistolar entre os Cónegos de Alga e os Lóios}

A natureza de uma relação epistolar, alicerçada na troca de cartas pessoais ou institucionais, muitas vezes marcada pelo imediatismo do seu conteúdo, bem como pela sua fragilidade material, resulta frequentemente no sistemático desaparecimento dos seus vestígios.

Esta realidade encontra-se patente para os Lóios, em que o número de documentos epistolares que sobreviveram entre a documentação conservada dos seus cartórios é residual. Atenhamo-nos, pois, aos exemplares que se identificaram.

Em matéria de testemunhos epistolares que evidenciem de modo direto e claro as relações que ocasionalmente se construíam entre as Congregações de Alga e de S. João Evangelista podem-se encontrar dois testemunhos que, ainda que situados fora da cronologia proposta para esta tese, se incluem pelas referências a eventos anteriores e pelo valor testemunhal que encerram.

Tratam-se do testemunho epistolar sobrevivente do cónego lóio P.e Mestre Pêro de S. João Garcês, procurador da sua Congregação em Roma entre 1594 e 1600, e a troca epistolar mantida entre os Cónegos portugueses e os italianos que o cronista de Alga, Tomasini, inclui na sua crónica de S. Jorge em Alga.

O primeiro dos testemunhos, ainda que epistolar, poderia (e até com mais propriedade) entrar na 2. ${ }^{\text {a }}$ parte deste capítulo, já que é propriamente uma troca de cartas entre cónegos Lóios e que descrevem circunstâncias de uma efetiva e presencial estada em Roma. Determinou-se colocá-lo em primeiro lugar pelo peso das informações que revela, e por nos dar indicações sobre outras relações epistolares. 
Do P.e Pêro de S. João sabemos hoje o que dele deixou escrito o P.e Jorge de S. Paulo no seu Epílogo:

${ }^{712}$ O 7.0 Doutor na faculdade Theologica foy o Pe. Pero de S. João Garces ${ }^{1025}$ que leo dous cursos de Artes doutorado na Universidade de Roma, sendo ${ }^{1026}$ com muitas graças espirituais para a Congregação e para o Collegio quazi 200 mil reis de renda nos sette benefícios da / ${ }^{13}$ Igreja de S. Leonardo da Atouguia <e 130 mil reis pella união perpetua da Igreja de Fiães a Lamego > feneçeo em o convento de St. ${ }^{\circ}$ Eloy sendo deputado da Inquisição ${ }^{1027}$.

Resume-se laconicamente aquilo que foi a missão romana deste padre lóio, que parece ter aproveitado o seu tempo na capital do catolicismo não só para tratar dos assuntos da sua Congregação mas também para progredir nos estudos, obtendo da Universidade de Roma a borla doutoral em Teologia.

Pêro de S. João Garcês terá nascido no Porto ${ }^{1028}$, que Felgueiras Gaio dá por terra dos seus pais, no seio de uma família a que a carreira eclesiástica não seria desconhecida, já que o seu tio materno padre João Garcês foi abade de Valbom ${ }^{1029}$, e um dos filhos de sua tia Catarina Garcês ${ }^{1030}$, Rui Gomes Golias, foi vigário geral e provisor nas dioceses do Porto e Braga, ao serviço de D. Rodrigo da Cunha ${ }^{1031}$.

A escolha pela vida religiosa na Congregação de S. João Evangelista parece nascer das ligações de família com os Lóios, mas também com alguma probabilidade da proximidade geográfica da origem

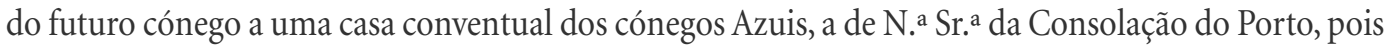
como anteriormente já tive oportunidade de salientar ${ }^{1032}$, existe uma correlação importante entre a localização dos conventos da Congregação e as localidades de origem dos cónegos Lóios.

\footnotetext{
1025 Trata-se do «Pedro de S. João Loio», que Felgueiras Gayo dá por filho de Isabel Garcês e António Ferraz, do Porto (S. João da Foz) (cf. GAIO, 1939b: tomo XVI, 59).

${ }^{1026}$ Segue-se um texto escrito sobre outro, sendo que o original foi repetido mais à frente, e o que foi rescrito por cima e se referiria certamente ao facto de este padre ter sido Procurador-Geral em Roma, está obliterado.

${ }^{1027}$ ADB - Manuscritos, ms. 924, p. 712, 713.

${ }^{1028}$ Suposição confirmada pela disposição do capítulo geral de 1594 que o decide enviar a Roma (cf. ANTT - Congregação de S. João Evangelista, Convento de St. ${ }^{\circ}$ Elói de Lisboa, lv. 15, fl. 130). Já o P.e Diogo Barbosa Machado o dá por natural de Arouca e falecido no convento lóio do Porto em 1640 (cf. MACHADO, 1752: vol. III, 586).

1029 GAIO, 1939b: tomo XVI, 59.

${ }^{1030}$ Esta sua tia Catarina Garcês foi casada com André Gomes Golias, e ambos tinham a sua sepultura e dos seus herdeiros no corpo da igreja do convento dos Lóios do Porto, como aliás acontecia com a tia-avó do nosso cónego, Isabel Dias Garcês, que foi casada com João Fernandes, cidadão do Porto, e a quem pertencia o padroado da capela de S. João Baptista da mesma igreja (cf. FREITAS, 1947: 50 e segs., e 72, 73). Segundo o que se pode depreender do que diz Felgueiras Gaio, o P.e Pêro de

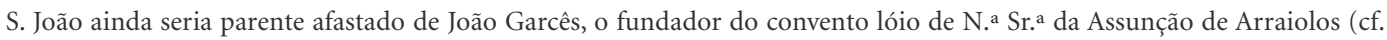
GAIO, 1939b: tomo XVI, 57-59, 64).

${ }^{1031}$ Idem, ibidem: tomo XV, 113.

1032 FALCÃO, 2009: cap. 5.1, 135 e segs. Neste capítulo propus uma metodologia de aproximação ao universo dos cónegos lóios pela utilização de um tipo específico de fontes que, apesar de não conter a riqueza informativa dos livros de obituário ou dos processos de entrada na congregação (que como pude então salientar só existem para cronologias iniciadas no séc. XVII) permite uma abordagem quantitativa ao universo de cónegos, à frequência anual de entrada e sua origem geográfica:
} 
A 28 de maio de 1594 «emlegeo o cap. ${ }^{\text {[ }}$ [geral da Congregação dos Lóios] ao padre mestre Pêro de S. João do Porto para yr a Roma aos negoçios da ordem» ${ }^{1033}$.

Dos resultados desta sua viagem ficou testemunho impresso na obra que reúne um conjunto importante (pela quantidade e profundidade das concessões obtidas e pelo curto período de tempo de que são datados) de diplomas pontifícios que, em resposta às suas súplicas, o Padre Pêro de S. João obteve do Papa Clemente VIII ${ }^{1034}$. Do corpo de 32 concessões do Papa, obtidas até novembro de 1596, o Procurador-geral dos Lóios faz imprimir em Roma um volume agregador ${ }^{1035}$.

Mas não só de um volume impresso, e das parcas informações dos cronistas, se faz a memória histórica da estadia na Cidade Eterna do P.e Pêro de S. João. De facto, e como competiria a um representante delegado da Congregação, o cónego Garcês foi dando conta gradual dos seus passos em cartas que, de Itália, enviava ao Geral dos Lóios.

Estas cartas, relatórios da sua missão romana, devem ter constituído um importante fundo epistolar $^{1036}$, de que hoje se identificam 6 exemplares inseridos num volume de agregação documental.

Das seis cartas remanescentes, uma está em particular mau estado de conservação, sendo que as restantes foram transcritas e constituem o cerne do anexo documental A, intitulado Cartulário de Roma, e onde se registam documentos de particular interesse para a compreensão das relações da Congregação com a corte de Roma e dos privilégios que dela obtinha, e das relações ocasionais com a sua matriz italiana.

trata-se de seis listas nominais cronologicamente situadas entre a fundação da Congregação e 1640. Da análise possível dos dados, e apesar das dificuldades metodológicas associadas que na dissertação de mestrado pude identificar, destacam-se algumas conclusões em relação às origens geográficas dos padres: num universo de 679 religiosos foi possível descobrir origem geográfica em 470 casos $(69,2 \%$ do total) e concluir-se que os lóios recrutavam em todo o país, mas essencialmente nas localidades em que estão presentes ou que lhe ficam próximas. Conclui-se que o recrutamento lóio faz-se em larga escala no meio urbano. Só em Lisboa, Porto, Coimbra, Lamego, Évora (tudo cidades onde existem conventos lóios), Braga e nas vilas de Guimarães e Vila do Conde (com Vilar de Frades nas proximidades), registam-se 257 lóios, 54,7\% do total, o que obriga as outras 107 localidades identificadas a partilharem os restantes 45,3\% de religiosos. O valor desta abordagem metodológica ao universo dos cónegos foi posteriormente confirmada pela tese de Isabel Castro Pina, que num processo similar a aplicou à reconstituição do universo canonical da congregação, ainda que não se debruçando numa análise quantitativa aprofundada dos dados obtíveis (cf. PINA, 2011: 275 e segs.).

${ }^{1033}$ ANTT - Congregação de S. João Evangelista, Convento de St. ${ }^{\circ}$ Elói de Lisboa, lv. 15, fl. 130.

${ }^{1034}$ Francisco de Santa Maria, alargando os dados apresentados por Jorge de S. Paulo, sugere que a ampla concessão de benesses obtida de Clemente VIII por Pêro de S. João seria o resultado da boa valência alcançada pelo lóio junto deste Papa. Não é possível perceber se a afirmação desta boa aceitação é fundada em algum dado substancial ou apenas na observação dos resultados obtidos e impressos (que parecem sugerir essa valência de Pêro de S. João, mas que se poderá atribuir a outros meios, como se verá) e no desejo de promover a Congregação e a sua influência em meios curiais (cf. SANTA MARIA, 1697: 524)

${ }^{1035}$ Cf. Diversae Concessiones et Gratiae Concessae..., 1596. Utilizou-se para esta tese o exemplar que se conserva no fundo da Nunciatura de Lisboa do Arquivo do Vaticano (ASV - Nunziatura di Lisbona, n. ${ }^{94}$ ), se bem que existem exemplares em bibliotecas portuguesas.

${ }^{1036}$ Nas suas cartas é possível identificar a aplicação posterior de um sistema de numeração. A última carta, em sucessão cronológica, está marcada com o número 46, o que nos permite supor que este é o número mínimo de cartas que, no espaço de 5 anos, foram remetidas de Roma por Pêro de S. João. O número de cartas no entanto não seria muito maior, pois esta carta, datada de 7 de março de 1600, é remetida para anunciar o seu muito eminente regresso a Portugal (cf. ANTT - Congregação de S. João Evangelista, Convento de S. João Evangelista de Xabregas, mç. 22, doc. numerado como 46). 
De um modo particular deve-se salientar a primeira carta que de Roma o P.e Pêro de S. João envia ao seu Geral, pelo conjunto de informações que revela, ou que confirma, sobre as relações entre a Congregação de Alga e a dos Lóios, sobretudo se tivermos particular conta que neste período já a Congregação italiana tinha sido forçada a abandonar a sua natureza de congregação de clérigos seculares e professava os votos solenes sob a regra de St. ${ }^{\circ}$ Agostinho.

Diz o P.e São João que assim que chegou a Roma, a 19 de outubro ${ }^{1037}$, se dirigiu «a este nosso mosteiro de S. Salvador...» ${ }^{1038}$, referindo-se à Casa de S. Salvador em Lauro, comunidade da Congregação de Alga em Roma. Esta simples frase demonstra desde logo que, no entendimento do procurador dos Lóios e certamente da sua Congregação, existia em relação à comunidade de $\mathrm{S}$. Salvador em Lauro, e obviamente por extensão à restante Congregação de Alga, um sentido efetivo de pertença, malgrado o tempo, a distância e as vicissitudes.

Significativamente reconhecia-se na Casa romana de Alga um porto próprio de abrigo, para onde o procurador da Congregação dos Lóios se dirigiu, onde foi recebido «com tanta charidade» pelos cónegos, sendo que o prior da Casa o «agazalhou de sorte que parecia Vossa Paternidade», como afirma Pêro de S. João ao seu Geral.

Era o procurador dos Lóios portador de uma carta do seu Geral, então o Padre Bartolomeu da Conceição (que nesse ano iniciara o primeiro dos seus três generalatos ${ }^{1039}$ ), em que pedia ao prior de S. Salvador em Lauro que Pêro de S. João fosse recebido a residir com a sua comunidade.

O superior da Casa romana da Congregação de Alga acedeu ao pedido e disponibilizou cela, lugar no refeitório e um religioso (que fora prior da Casa de S. Salvador e Geral de Alga) por companheiro ${ }^{1040}$; em suma, a pedido do Geral dos Lóios era o procurador da Congregação admitido a viver com a comunidade italiana como se fosse um dos seus religiosos ${ }^{1041}$.

\footnotetext{
${ }^{1037}$ ANTT - Congregação de S. João Evangelista, Convento de S. João Evangelista de Xabregas, mç. 22, doc. 6, não numerado; $v d$. anexo documental A, doc. A2. Pelo facto da carta não estar completa, faltando-lhe os últimos fólios, não é possível conhecer a data em que foi escrita, mas apenas o dia e mês da chegada do P.e São João a Roma, porque o declara no corpo do texto. Tratar-se-á do ano de 1595, em que 19 de outubro calhou uma quinta-feira, conforme ao que diz a carta, e não o ano de 1594 que sugere a informação capitular. Esta noção é corroborada pela sua carta datada de 17 de outubro de 1599, em que afirma estar a 2 dias de completar 4 anos da sua chegada a Roma (cf. ANTT - Congregação de S. João Evangelista, Convento de S. João Evangelista de Xabregas, mç. 22, doc. numerado como 42; vd. anexo documental A, doc. A 5.

${ }^{1038}$ ANTT - Congregação de S. João Evangelista, Convento de S. João Evangelista de Xabregas, mç. 22, doc. 6, não numerado. ${ }^{1039}$ Conforme informa a listagem dos gerais dos Lóios, feita pelo P.e Jorge de S. Paulo (ADP - Monásticos, Convento de Santo Elói do Porto, lv. do Compêndio do cartório, K/19/6-57, lista dos Gerais dos Lóios, fl. 1055 e segs.).

${ }^{1040}$ Segundo o costume da Congregação, e para obviar os inconvenientes que pudessem advir dos cónegos andarem sozinhos fora das suas Casas, determinara-se que os religiosos andassem em pares, tendo cada cónego o seu companheiro. Os capítulos gerais mencionam-nos amíude (por exemplo referindo-se aos companheiros que acompanham os oficiais da Congregação nas suas deslocações) e é mencionado no cap. XLIV das Constituições dos Lóios (cf. Statutos e Constituyções dos virtuosos e reverendos padres Conegos azuys..., 1540: fl. XXXI e verso).

${ }^{1041}$ Apesar deste acolhimento na sua carta de 17 de outubro de 1599 o P.e Pêro de S. João dá conta da sua necessidade de dinheiro para médicos e botica que acudam à sua persistente doença, já que no mosteiro de S. Salvador em Lauro apenas lhe davam pousadas e pão "que ate o vinho compro» (cf. ANTT - Congregação de S. João Evangelista, Convento de S. João Evangelista de Xabregas, mç. 22, doc. numerado como 42).
} 
À distância de mais de um século e meio sobre as fundações, e mesmo com a forçada profissão dos Cónegos de Alga na regra de St. ${ }^{o}$ Agostinho, existia ainda em 1595 um mútuo reconhecimento entre as duas congregações que levava os cónegos italianos a receberem um congénere português no seio da sua comunidade ${ }^{1042}$.

O sentido da unidade entre as duas congregações fica patente quando Pêro de S. João comenta a felicidade dos cónegos romanos ao saberem que o principal assunto que o levava a Roma era obter da Santa Sé licença para celebrarem liturgicamente o beato Lourenço Justiniano, santo comum das duas Congregações e que então tinha o seu culto circunscrito a Veneza, excluindo não só as Casas Lóias como as comunidades de Alga de outros estados italianos.

A assimilação do padre português foi completa no dia sequente à chegada quando a comunidade providenciou que lhe fosse feito hábito azul segundo a forma romana. E mesmo que o hábito (segundo a sabedoria popular) não faça o monge, não se poderá negar que, neste caso, o hábito fez o cónego.

Pêro de S. João nesta sua primeira carta, e além da descrição da sua chegada, enuncia os principais assuntos que o levaram à Corte do Papa, e que são um espelho genérico dos assuntos que tradicionalmente os Lóios procuravam tratar em Roma. De um modo mais alargado percebemo-nos mesmo que são, tipologicamente, o mesmo tipo de assuntos que ocupava os Lóios institucionalmente e que facilmente se poderá perceber pela leitura e análise da normativa de base (as constituições da Congregação ${ }^{1043}$ ), bem como aquela que foi sendo produzida pela sua mais alta instância, o capítulo geral, e que se conserva nos livros de capítulos gerais da Congregação sobreviventes ${ }^{1044}$, ou nas compilações das definições produzidas nesses mesmos capítulos ${ }^{1045}$.

Assim depois de descrever a sua visita ao agente régio em Roma, lança-se o procurador dos Lóios a expor os assuntos que tratará em Roma:

- assuntos de natureza estritamente religiosa, em que os de carácter litúrgico, porque apropriados a uma congregação de clérigos seculares dedicados carismaticamente ao solene culto divino, têm uma presença forte. Destaque-se a sua obrigação de confirmar, com os cardeais da Sagrada Congregação dos Ritos ${ }^{1046}$, um cerimonial da Congregação que os Padres Miguel do Espírito Santo e Agostinho da Trindade tinham preparado;

- assuntos de natureza institucional, em que se destacam as tentativas de alargar o universo Lóio pela instituição de novas comunidades canonicais, mas em que a gestão das comunidades

\footnotetext{
${ }^{1042}$ Não será pouca coisa a recepção, no seio da comunidade, de alguém que na prática pertence e pertencerá a uma outra Congregação. Pensando no caso dos Lóios é significativa a decisão do capítulo geral de 1482 que proibia que se recolhesse nas Casas religioso de outra Ordem ou Congregação, nem que viessem de fora para prestar qualquer serviço na liturgia ou no ensino que obrigasse a uma estadia (cf. ANTT - Manuscritos da Livraria, n. ${ }^{\circ}$ 523, fl. 5).

${ }^{1043}$ Cf. Statutos e Constituyções dos virtuosos e reverendos padres Conegos azuys..., 1540.

${ }^{1044}$ Cf. ANTT - Manuscritos da Livraria, n. ${ }^{\circ}$ 523; ANTT - Manuscritos da Livraria, n. ${ }^{\circ}$ 186; ANTT - Congregação de S. João Evangelista, Convento de St. ${ }^{\circ}$ Elói de Lisboa, lv. 15.

${ }^{1045}$ Veja-se o artigo de Pedro Tavares sobre a matéria, em que se transcreve uma compilação de definições produzidas entre 1478 e 1572 (TAVARES, 2001c).

1046 É o que se supões da expressão «com os cardeais a que isto pertence». A Sagrada Congregação dos Ritos, a quem pertencia regular todas as questões relacionadas com o culto divino, fora instituída por Sixto V em 1588 (cf. D’ONORIO, 1994).
} 
existentes tem também um papel ${ }^{1047}$. Junte-se ainda a procura de confirmação da normativa e dos privilégios, sobre os quais o P.e S. João nos deixa um indício mais das relações existentes entre as duas Congregações, ao sugerir que os documentos lhe sejam enviados de Portugal «per via de Veneza, dirigindo ao Padre Geral [de Alga] ou por via de quem lá achar e parecer melhor ${ }^{1048}$. De relevar ainda a sua menção a novas constituições da Congregação, que estariam para ser aprovadas e aceites em capítulo geral, e que nesse caso se imporia a confirmação pela Santa Sé, informando-nos de uma tentativa efetiva de renovar a normativa base da Congregação, que se sabe não concretizada, pelo facto absolutamente demonstrativo de os primeiros anos do séc. XIX ainda vigorarem as Constituições impressas em $1540^{1049}$;

- assuntos relacionados com a administração e gestão do património temporal da Congregação.

Destacam-se as questões relacionadas com a gestão dos padroados paroquiais das suas Casas, com obrigações ao fisco apostólico de que se procurava remissão; ou a procura de uma resolução para a questão de poderem ou não as Casas fazerem aforamentos por prazos de enfiteuse. Pormenor curioso é o da sua oferta para servir de intermediário no comércio de livros que o capítulo geral autorizara os reitores de Vilar de Frades e do Porto a empreenderem, em pequena escala. Revela-nos esta correspondência, verdadeira janela para a vida quotidiana dos Lóios, um nova faceta destes religiosos: a do reitor-mercador de livros.

Uma leitura das demais cartas ${ }^{1050}$ que se conservam do procurador dos Lóios e que se puderam identificar ${ }^{1051}$, e aparte as considerações sobre a sua pobre saúde (afirma, em novembro de 1599, estar doente há 14 meses ${ }^{1052}$ ), permite perceber que, quatro anos passados sobre a chegada de Pêro de S. João a Roma, a tipologia de assuntos a que se dedicava mantinha-se inalterada.

Para a sua Congregação obteve o desejado ofício de S. Lourenço Justiniano, por ele preparado e que afirma ter estado mais de 3 anos para ser aprovado pela Santa Sé1053.

\footnotetext{
${ }^{1047}$ Neste caso específico tinha o P.e Pêro o encargo de obter do Papa a concessão das letras apostólicas sobre a transferência do mosteiro de S. Jorge de Recião para o de Santa Cruz de Lamego, que instituía o Dr. Lourenço Mourão Homem (cf. ANTT - Congregação de S. João Evangelista, Convento de S. João Evangelista de Xabregas, mç. 22, doc. 6, não numerado).

${ }^{1048}$ Cf. ANTT - Congregação de S. João Evangelista, Convento de S. João Evangelista de Xabregas, mç. 22, doc. 6, não numerado. 1049 Já que em 1804 se reimprimiam em Lisboa as constituições de 1540, por Simão Tadeu Ferreira (cf. Estatutos e Constituições dos Cónegos Azuis da Congregação de S. João Evangelista, 1804). De facto, o capítulo geral de 1592 determinara a reforma dos Estatutos, corrigindo e retirando o que já não estava em uso (cf. ANTT - Congregação de S. João Evangelista, Convento de St. ${ }^{\circ}$ Elói de Lisboa, lv. 15, fl. 68v.).

1050 Todas transcritas no anexo documental A, docs. A2 a A7.

${ }^{1051} \mathrm{O}$ facto de o sistema de numeração aplicado às cartas nos permitir supôr a existência de, pelo menos, 46 cartas, somado à identificação de apenas 7 exemplares que se conservam no mesmo volume de agregação documental, coloca a hipótese de existirem outras cartas da estadia romana do P.e S. João não identificadas, nomeadamente em documentos cuja indicação de mau-estado não permitiu a consulta.

${ }^{1052}$ ANTT - Congregação de S. João Evangelista, Convento de S. João Evangelista de Xabregas, mç. 22, doc. numerado como 43, transcrito em anexo documental A, doc. A6.

${ }^{1053}$ ANTT - Congregação de S. João Evangelista, Convento de S. João Evangelista de Xabregas, mç. 22, doc. numerado como 44, transcrito em anexo documental A, doc. A7.
} 
Revela-se também como a Congregação servia de intermediária aos patronos das suas Casas quando estes pretendiam obter de Roma privilégios espirituais; é o que se pode inferir quando Pêro de S. João afirma a impossibilidade de obter um segundo altar privilegiado para a Casa da Feira, onde já haveria um (o altar de S. Sebastião ${ }^{1054}$ ), conforme ao que seria o desejo de D. Maria [de Gusmão ${ }^{1055}$ ], a quem também não se poderia satisfazer os pedidos em matéria de indulgências pois, estando na eminência do Ano Santo de 1600, todas as indulgências não pertencentes ao ano jubilar, seriam suspensas, advertindo também para que nas igrejas da Congregação não se publiquem as indulgências ordinárias de cada Casa ${ }^{1056}$.

A quase ilegível carta seguinte, datada de 7 de março de $1600^{1057}$ anuncia o seu eminente regresso a Portugal e o fim da sua longa (e poderemos acrescentar produtiva) estadia na cúria romana e entre os Cónegos de Alga.

As suas referências ao relacionamento estreito com os cónegos da comunidade de Roma são de indesmentível interesse e encontram um eco ainda maior por conterem a primeira informação documental, extra o breve pontifício que o ordena e a crónica Lóia que o regista, que comprova a efetiva ida a Roma da missão de cónegos Lóios que, cerca de 1568, foi tentar a reforma dos Cónegos de Alga, no complexo período que marcou a transição da Congregação italiana de secular a regular.

O segundo exemplo de comunicação epistolar que identifica uma relação de comunicabilidade entre as duas Congregações, o cronologicamente mais recente (e derradeiro vestígio desta relação escrita entre as duas Congregações) e talvez o mais acessível, porque dado a letra de forma, é o das cartas transcritas na crónica de Alga pelo bispo Tomasini.

Tomasini descreve a fundação da Congregação portuguesa longamente, e revelando um conhecimento aprofundado dos elementos principais da história da Congregação dos Lóios, elementos que lhe terão sido transmitidos pelo Cónego Lóio Belchior da Graça, de Matosinhos ${ }^{1058}$, residente em Roma como representante da sua Congregação, que lhe teria dado as notícias exatas de que se socorre ${ }^{1059}$.

\footnotetext{
${ }^{1054}$ Que fora obtido de Clemente VIII já por intermédio do P.e Pêro (ver TAVARES, 2008: 215, 216).

${ }^{1055}$ A referência à Casa da Feira, permite supor esta D. Maria como D. Maria de Gusmão, filha do $1 .{ }^{\circ}$ Conde de Vila Franca e condessa da Feira pelo seu casamento com o 5. ${ }^{\circ}$ Conde D. João Pereira, sendo padroeiros da Casa Lóia da Feira (cf. o que sobre esta senhora e o padroado dos Condes da Feira nos Lóios da sua vila diz TAVARES, 1991; TAVARES, 2008 e TAVARES, 2009.

${ }^{1056}$ ANTT - Congregação de S. João Evangelista, Convento de S. João Evangelista de Xabregas, mç. 22, doc. numerado como 44, transcrito em anexo documental A, doc. A7

${ }^{1057}$ ANTT - Congregação de S. João Evangelista, Convento de S. João Evangelista de Xabregas, mç. 22, doc. numerado como 46. ${ }^{1058}$ Trata do P.e Belchior da Graça, de Matosinhos, que o cronista Francisco de St. ${ }^{\text {a Maria }(S A N T A ~ M A R I A, ~ 1697: ~ 527, ~ 528) ~}$ diz graduado in utroque iure pela Universidade de Salamanca, Protonotário Apostólico, três vezes enviado pela Congregação a Roma (uma das quais seria aquando da sua menção na obra de Tomasini). Em Roma teria estudado línguas orientais (hebreu, caldeu, síriaco, árabe e grego), sendo discípulo do maronita Ibrahim Al-Haquilani, ligado ao Colégio Maronita de Roma (cf. O’NEILL, 2001: 847) e de Canachio Rossi, um jesuíta grego educado no Colégio Grego de Roma (cf. FRAZEE, 1983: 92, 93). Diogo Barbosa Machado afirma-o filho do coronel João Monteiro Leão e de Beatriz de Brito Soares, aprofunda a nota biográfica do cronista Lóio e elenca as suas obras; e informa que faleceu na Casa de St. ${ }^{\circ}$ Elói de Lisboa a 20 de abril de 1650 (cf. MACHADO, 1741: 492, 493).

1059 TOMASINI, 1642: 159.
} 
Os conhecimentos de Tomasini eram tão profundos que ao descrever as diversas Casas Lóias menciona qual o reitor em exercício ${ }^{1060}$, mas também revela conhecer os documentos principais da Congregação, seja os seus Estatutos e Constituições impressos, sejam as edições de privilégios pontifícios de 1594 (Lisboa) e de 1596 (edição romana de Pêro de S. João Garcês) ${ }^{1061}$.

Entrando na dimensão epistolar, transcreve Tomasini a carta que a 15 de julho de $1593^{1062} \mathrm{o}$ Geral dos Lóios P.e Miguel do Espírito Santo ${ }^{1063}$ escreveu ao reitor de S. Salvador em Lauro (nas vésperas portanto do envio do P.e Pêro de S. João), que começa por salientar a benevolência que os cónegos romanos muitas vezes tinham demonstrado para com os seus irmãos portugueses, notando como a distância em nada prejudicava a quem tanto partilhava. Afirma o Geral dos Lóios que apesar dos mosteiros de Alga não dependerem dos Lóios, nem vice-versa, não se pode negar serem filhos dos mesmos pais: Eugénio IV, António Correr, Lourenço Justiniano e todos os demais padres que lhes legaram o seu modo de vida.

Expondo o motivo da sua carta, Miguel do Espírito Santo revela que escreve na sequência da determinação do capítulo geral para que se informasse em Roma sobre o estado do processo de canonização de Lourenço Justiniano, que o Estado Veneziano fazia correr na cúria, se dele já havia um ofício que se pudesse celebrar e se já era a sua imagem representada, pois também os Lóios desejavam venerar esta figura maior da sua espiritualidade ${ }^{1064}$.

A resposta, do reitor geral de Alga Daniel Rosa, reforça a ideia da mútua filiação entre as duas Congregações, expõe os termos em que se celebrava Lourenço Justiniano (nos territórios de Veneza, com ofício de confessor, por indulto pontifício que a Sereníssima tinha) e conclui com um resumo da situação de regularização da Congregação e uma descrição institucional da mesma (número de Casas e sua localização), fazendo supor que as relações entre as duas Congregações rareavam por estes anos.

Para além das cartas de 1593, e quase a terminar a sua crónica, Tomasini transcreve ainda uma troca de cartas que ele mesmo manteve com o geral dos Lóios entre 1637 e $1639^{1065}$, cuja carta original enviara pelo embaixador do rei de Espanha em Veneza (estamos no período final da união dinástica).

\footnotetext{
${ }^{1060}$ Informação que se pode confirmar, por exemplo, em relação à Casa do Porto, já que no triénio de 1639-41 (quando se ultimava a crónica de Tomasini) era efetivamente regida pelo P.e Jorge de S. Paulo (veja-se o que digo em FALCÃO, 2009: 144), a quem Tomasini faz um rasgado elogio (cf. TOMASINI, 1642: 174).

${ }^{1061}$ Idem, ibidem: 177. Cita mesmo os Estatutos lóios a partir do seu original em língua portuguesa (ainda que com alguns erros de transcrição) quando refere que aos cónegos não pertence a direcção das religiosas Justinianas da Galiza, pois lhe estava vedado a direcção de comunidades femininas, de acordo com os termos citados de Statutos e Constituyções dos virtuosos e reverendos padres Conegos azuys..., 1540: cap. XXIV, fl. XXIIv., XXIII.

1062 TOMASINI, 1642: 618-620.

1063 Trata-se do P.e Miguel do Espírito Santo, do Porto, que entrou na Congregação em 1554, foi reitor do Porto de 1582 a 1584, Geral de 1592 a 1594 e morreu em 1598 (cf. ADP - Monásticos, Convento de Santo Elói do Porto, lv. do Compêndio do cartório, K/19/6-57, lista dos Gerais dos Lóios, fl. 1055 e segs.).

${ }^{1064}$ Note-se que esta carta comprova bem o interesse da Congregação na veneração de Lourenço Justiniano já em finais do séc. XVI, e não apenas um interesse que surgiria após a sua canonização de 1690, como afirma erradamente Celso Mangucci (MANGUCCI, 2013).

1065 TOMASINI, 1642: 701 e segs.
} 
Nas cartas ao geral dos Lóios, Tomasini afirma que as duas Congregações estavam há 44 anos sem manter contacto, desde a carta de Miguel do Espírito Santo de $1593^{1066}$, e que estando ele a tratar dos Anais da sua Congregação, lhe pedia transmitisse as informações mais importantes referentes à Congregação portuguesa (número de Casas, sua descrição, pessoas notáveis, etc.), acrescentando que, apesar de saber que os cónegos portugueses reconhecem como autores comuns os mencionados na carta de 1593, desconhece os termos em que se baseia tal afirmação.

A resposta do Vigário-geral dos Lóios Miguel do Espírito Santo ${ }^{1067}$, de abril de 1639, a todos os títulos cordial e fraterna, explica que a descrição pedida seria difícil colocar por escrito, dada a amplitude do assunto, encarregando o Lóio P.e Melchior da Graça de lhe transmitir pessoalmente todas as informações, de forma a informar uma obra a que chama já os Annales nostrae Congregationis.

Termina o superior português dizendo que não só reconhecem os Lóios os três pilares fundacionais já mencionados (dos quais afirma desejar ver Lourenço Justiniano canonizado), como apresenta por sua vez o Lóio António da Conceição ${ }^{1068}$, o «beato» António, cuja causa de beatificação a Congregação portuguesa tratava de introduzir na cúria romana ${ }^{1069}$.

Estes dois exemplos de relação epistolar demonstram, com alguma substância, a sua importância. Para além destes dois exemplos principais, porque mantidos a alto nível e com objetivo claramente institucional, outros exemplos pontuais podem ser apresentados, no contexto da cronologia deste trabalho, e que se inserem no enquadramento de uma relação escrita que unia as duas geografias de um mesmo carisma, testemunhando até que ponto se mantinham em contacto as duas Congregações.

O primeiro desses exemplos, apresentados por ordem cronológica, não será talvez o mais demonstrativo das relações entre Congregações, mas é altamente informativo da importância dos assuntos romanos dos Lóios, e de como estes estavam dispostos a recorrer a qualquer autoridade que pudesse favorecer os seus intentos junto da cúria romana.

Que ocasionalmente a Coroa portuguesa peticionava em Roma pelos Cónegos Lóios não é um facto desconhecido: pode ver-se quando Eugénio IV, em 1440, concede a súplica apresentada pelo infante D. Pedro para que o hospital de St. ${ }^{\circ}$ Elói de Lisboa passasse à Congregação; em 1445, quando o mesmo Papa responde a duas súplicas da rainha D. Isabel e da Congregação em que, entre outras concessões, determina que a causa que corria entre os Lóios e o Arcebispo de Braga seja extinta, com anulação das penas eclesiásticas por ele cominadas ${ }^{1070}$; em 1451, quando Nicolau V, na extinção de

\footnotetext{
${ }^{1066}$ No que aliás erra, já que pelo menos houve, documentadamente, o contacto mantido por Pêro de S. João com a comunidade de Roma entre 1595 e 1600.

${ }^{1067}$ Trata-se do P.e Miguel do Espírito Santo, natural de Vila do Conde, que entrou nos Lóios em 1599 e faleceu em 1645. Apesar de identificado como Reitor geral na crónica de Tomasini, foi na realidade Vigário-geral, título com que substituiu no triénio de 1636-1639 o Geral eleito P.e Vicente da Ressurreição, falecido pouco depois de eleito (cf. ADP - Monásticos, Convento de Santo Elói do Porto, lv. do Compêndio do cartório, K/19/6-57, lista dos Gerais dos Lóios, fl. 1055 e segs.).

${ }^{1068}$ Sobre o cónego António da Conceição, o beato António, veja-se o que diz Francisco de Santa Maria na sua crónica dos Lóios e o artigo de José Adriano de Freitas Carvalho (cf. CARVALHO, 1998).

${ }^{1069}$ TOMASINI, 1642: 704-706.

${ }^{1070}$ É interessante notar que numa disputa que envolvia o confronto com o mais poderoso senhor eclesiástico do reino, e em matéria que era de natureza puramente eclesiástica, os Lóios não deixaram de recorrer a uma das suas régias protectoras, certamente com a intenção de dar mais força à sua súplica.
} 
causa que corria entre os Lóios e o Arcebispo, declara ter ouvido o testemunho favorável de Afonso e Isabel reis de Portugal; em 1461, quando Pio II concede, a pedido do rei D. Afonso V e de acordo com os últimos desejos de sua mulher a rainha D. Isabel, a ereção da Casa de S. João Evangelista de Xabregas como comunidade canonical e como cabeça da Congregação ${ }^{1071}$.

Será neste contexto que encontramos um exemplo direto (que não uma informação exarada nos documentos enviados à Santa Sé ou emitidos da sua chancelaria) do recurso, pela Congregação dos Lóios, ao canal diplomático da Coroa Portuguesa para obter de Roma a concessão de privilégios, confirmações, isenções, e demais concessões obtíveis da Santa Sé; exemplo ainda mais significativo quando atendemos ao facto de a Coroa Portuguesa surgir a apoiar declaradamente os Lóios contra um dos principais prelados diocesanos portugueses, o Bispo de Évora.

No cartório de Xabregas conservou-se o treslado de uma carta ${ }^{1072}$ (transcrita no anexo documental A, doc. A1) que o rei D. Manuel I terá enviado a D. Miguel da Silva, seu representante em Roma, em $1517^{1073}$. Da mesma carta, e seguindo de modo quase integral a mesma lição do treslado conservado no cartório de Xabregas, encontramos o treslado que da mesma carta se conservou na chancelaria de D. Manuel e que hoje integra a Coleção do Corpo Cronológico da Torre do Tombo ${ }^{1074}$.

Nesta carta o monarca não só elabora com algum detalhe sobre a fundação e carisma dos Lóios (informações veiculadas pelo Geral dos Lóios, que peticionava pelo apoio régio na matéria) como ordena ao seu embaixador que faça saber ao Papa o bom modo de vida dos Lóios, em cujas Casas «Nosso Senhor he muyto servido dellas e que todos sam pessoas de vida de toda honestidade e bom exemplo e que sam feytos hos hoficios divinos com grande devaçam» ${ }^{1075}$.

Era pretensão régia que o Papa Leão X, ante os méritos dos Cónegos Lóios e do serviço que faziam à comunidade cristã, reconhecesse os privilégios de isenção da Congregação Lóios, que eram postos em causa pelas determinações do V Concílio de Latrão (1512-1517), que Leão X promul-

\footnotetext{
${ }^{1071}$ Informações retiradas do articulado dos privilégios pontifícios da Congregação, conservados no seu Livro dos Privilegios concedidos pellos Summos Pontifices..., 1594, e sistematizadas em anexo a esta tese no quadro anexo n. 3.

${ }^{1072}$ Cf. ANTT - Congregação de S. João Evangelista, Convento de S. João Evangelista de Xabregas, mç. 15, doc. n. ${ }^{\circ}$ 8. Treslado coevo mas não datado, intitulado Carta que el Rey dom Manuel mandou a Roma a dom Migyel que falasse ao Sancto Padre por ha confirmação de nossos privillegios. Desta carta existe uma versão na crónica do P.e Francisco de Santa Maria (cf. SANTA MARIA, 1697: 322, 323), que no entanto diverge em diversos pontos da versão quinhentista que aqui se cita e que por isso se optou por transcrever e colocar em anexo.

${ }^{1073} \mathrm{O}$ documento conservado no cartório de Xabregas está datado de 15 de junho, mas sem indicação de ano. Certo é que terá de situar-se entre 1516 e 1520, intervalo que se obtêm pela aplicação de três datas conhecidas: a nomeação formal de D. Miguel da Silva dos inícios de 1515 (cf. BUESCU, 2010: 144) como termo a quo e a morte do rei D. Manuel (em dezembro de 1521) como termo ad quem. No entanto a menção que o Rei faz do Geral dos Lóios P.e Jerónimo (da Vidigueira) permite situar esta carta em torno do $3 .^{\circ}$ e último período de governação deste prelado, entre 1517 e 1519, conforme informa o P.e Jorge de S. Paulo (cf. ADP - Monásticos, Convento de Santo Elói do Porto, lv. do Compêndio do cartório, K/19/6-57, lista dos Gerais dos Lóios, fl. 1055 e segs). O ano de 1517 obtém-se da datação do treslado da carta conservado no Corpo Cronológico, que apresentando mês e ano distinto (7 de dezembro) oferece no entanto um ano para a carta: 1517 (cf. ANTT - Corpo Cronológico, parte I, mç. 22, doc. 131).

${ }^{1074}$ Idem, ibidem.

${ }^{1075}$ ANTT - Congregação de S. João Evangelista, Convento de S. João Evangelista de Xabregas, mç. 15, doc. n.o 8., fl. 2 não numerado.
} 
gara $^{1076}$, e em cujas determinações estava a revogação da isenção das Ordens e Congregações religiosas da autoridade do ordinário. Em particular desejava o Rei que se obtivesse a revogação de uma bula e provisão que o bispo de Évora obtivera do Pontífice contra a Casa Lóia de S. João de Évora e que, segundo o Rei, tinha por base a inimizade entre o prelado eborense e o Conde de Tentúgal, padroeiro da igreja e convento dos Lóios de Évora ${ }^{1077}$.

O texto, como se poderá ver em anexo, sugere o empenho régio na tentativa de obter em Roma para os Lóios a confirmação da sua isenção e a derrogação dos documentos que em contrário o Papa tinha emitido. Percebe-se que numa disputa entre o bispo de Évora e os Lóios o que estava verdadeiramente em causa era o confronto entre dois grandes senhores, nomeadamente dois membros da Casa de Bragança ${ }^{1078}$, e que como tal os Lóios tenham compreendido a sua incapacidade de obter em Roma o que pretendiam, recorrendo ao favor régio.

Esta carta do Rei ao seu representante em Roma é também o culminar um processo mais vasto, pelo qual os Lóios procuram colocar-se sob a proteção estrita do Venturoso. É o que se pode concluir da leitura do treslado da carta de D. Manuel I, datada de Almeirim a 12 de março de $1516^{1079}$, em que o Rei declara que pelas pendências existentes entre os prelados diocesanos portugueses e os Cónegos Lóios sobre o serem isentos do ordinário e imediatos ao Papa, determinara que os Lóios apresentassem perante o seu Conselho e Desembargo as provas documentais dessa isenção, as quais vistas nestas instâncias e tendo sido apresentadas aos prelados, ordena o Rei aos Bispos que reconheçam os Lóios por isentos e imediatos ao Papa ${ }^{1080}$.

A esta questão pertence ainda a concessão de Leão X de 1518, em que se determina serem os Lóios isentos da obrigação da participarem em procissões, e a sua confirmação de Clemente VII, de novembro de 1523. Este último documento é dirigido ao reitor da Casa Lóia de Évora e afirma especificamente ser concedida pela tentativa do bispo de Évora de obrigar os cónegos a participarem nas procissões extraordinárias (contra o teor do privilégio de Leão X), tendo no processo dessa imposição excomungado a comunidade, pena que o Pontífice anula, bem como a qualquer outra pelo bispo cominada ${ }^{1081}$.

Mas para além do recurso à Coroa, e suas redes diplomáticas, como agente promotor dos seus assuntos na cúria romana, os padres Lóios também recorreram à rede constituída pelos seus irmãos carismáticos, numa dimensão que as cartas de Pêro de S. João fazem supor, e bem mais profunda do que a crónica de Tomasini faz crer.

\footnotetext{
1076 Sob o V Concílio de Latrão veja-se VENARD, 1994.

1077 Sobre esta disputa trata o cronista Francisco de Santa Maria na sua obra (cf. SANTA MARIA, 1697: 318 e segs.).

${ }^{1078} \mathrm{O}$ bispo de Évora era D. Afonso de Portugal, filho de D. Afonso de Bragança, Marquês de Valença, e neto do $1 .^{\circ}$ Duque de Bragança; o conde de Tentúgal era D. Rodrigo de Melo, Marquês de Ferreira em 1533, filho de D. Álvaro de Bragança, senhor de Cadaval, e neto de D. Fernando I, 2. ${ }^{\circ}$ Duque de Bragança (cf. CUNHA, 1990: 36 e segs.).

1079 Conservada no cartório de Xabregas em treslado de 13 de março desse ano (cf. ANTT - Congregação de S. João Evangelista, Convento de S. João Evangelista de Xabregas, mç. 15, doc. n. ${ }^{\circ}$ 6).

${ }^{1080}$ Esta não terá sido a primeira vez que o rei emitiu uma determinação neste sentido. Segundo a listagem dos privilégios e mercês régias que os Lóios tinham para confirmação na Junta das Confirmações aquando da morte do rei D. José I, segundo o que relata o juiz Luiz Rebelo Quintela, estaria entre elas uma carta de D. Manuel I a ordenar aos Bispos que tivessem os Lóios por isentos e imediatos (cf. ANTT - Congregação de S. João Evangelista, Convento de S. João Evangelista de Xabregas, mç. 24, doc. n. ${ }^{\circ} 1$ ).

${ }^{1081}$ Privilégios contidos no Livro dos Privilegios concedidos pellos Summos Pontifices..., 1594, resumido no quadro anexo n. ${ }^{\circ} 3$.
} 
Em 1538 um exemplo da relação entre os Lóios e a Congregação de Alga, particularmente (pelo óbvio motivo de ser a comunidade da Congregação veneziana que está junto da Santa Sé) com a sua comunidade de S. Salvador em Lauro: D. Francesco Mauro, cónego secular de Alga da comunidade romana, aparece a representar o Geral e cónegos Lóios no pedido de treslado em pública-forma do privilégio concedido pelo Papa Paulo III à Congregação de Alga do usufruto dos privilégios que Eugénio IV concedera à Congregação Cassinense ${ }^{1082}$.

É um exemplo relevante, pois encontramos neste caso específico um cónego de Alga, residente na comunidade de Roma, a representar a Congregação de S. João Evangelista, que o constituiu seu procurador, para obter o treslado de um privilégio que no ano anterior ${ }^{1083}$ o Papa tinha concedido à Congregação de Alga e que passava à portuguesa pelo privilégio de comunicabilidade.

Este simples facto de natureza administrativa é revelador de um necessário sistema relacional entre as duas Congregações, que se traduziu na comunicação de Itália para Portugal sobre a obtenção deste novo privilégio, de janeiro de 1537, e de Portugal para Itália com a constituição de um procurador para obter um treslado formal do mesmo para que os Lóios o pudessem utilizar e avocar em direito se necessário, o que foi feito antes de 10 abril de 1538, data de produção do documento. Podemos supor que estas relações se possam ter intensificado em 1539-1540, quando podemos situar uma ida de procuradores Lóios a Roma ${ }^{1084}$.

Dois documentos conectados entre si, de 1556 e 1558, demonstram o valor das relações epistolares mantidas entre as duas Congregações, que ainda que provavelmente não fossem sistemáticas (como se poderá deduzir da distância e pela ausência de um maior número de dados documentais na matéria) parecem ter-se revestido de alguma substância, sustentada no mútuo reconhecimento da partilha carismática. Confirmam a impressão deixada pelo documento anterior de que os Lóios tinham na proximidade dos Cónegos de Alga à Santa Sé, em particular a comunidade de S. Salvador em Lauro, uma instância intermediária de apoio nos corredores da cúria romana.

O primeiro dos documentos não é propriamente uma carta, ainda que certamente tenha sido produzido num contexto de prévia troca de correspondência dos Lóios com a comunidade de S. Salvador em Lauro (como sugere o segundo documento): trata-se da pública forma de uma comissão, redigida pelo notário apostólico Sebastião Rodrigues no convento de S. João Evangelista de Xabregas, a 12 de agosto de 1556 e pela qual o reitor geral dos Lóios, P.e Diogo da Ressurreição, com o reitor de St. ${ }^{\circ}$ Elói de Lisboa e com o vice-reitor de Xabregas, bem como os demais padres deputados ${ }^{1085}$, elegem por protetor da sua Congregação ao Cardeal de St. ${ }^{a}$ Maria in Via.

\footnotetext{
${ }^{1082}$ Idem, ibidem: fl. 68, resumido no quadro anexo n. ${ }^{\circ} 3$.

${ }^{1083} \mathrm{O}$ privilégio está datado de $10 .^{\circ}$ das calendas de fevereiro de 1537, ou seja, 23 de janeiro desse ano (cf. Idem, ibidem: fl. 72. ${ }^{1084}$ Conforme a nota registada nas despesas da Casa de Xabregas apresentadas em maio de 1540 no capítulo geral reunido nessa mesma Casa, e em que se menciona os gastos que foram "para os procuradores que forão a Roma» (cf. ANTT - Manuscritos da Livraria, n. ${ }^{\circ}$ 186, fl. 60v.).

1085 Tratar-se-ão dos padres deputados eleitos em capítulo geral para auxiliar o geral no governo da sua casa generalícia de Xabregas (conforme previsto nas Constituições dos Lóios, cf. Statutos e Constituyções dos virtuosos e reverendos padres Conegos azuys..., 1540: cap. LXXVI, fl. XLIIIv., XLIV), acrescido do reitor de St. ${ }^{\circ}$ Elói, agregado pela relevância do assunto.
} 
Trata-se de Giacomo Cardeal Puteo (ou del Pozzo), jurista formado por Bolonha que fez carreira como auditor do Tribunal da Sacra Rota (de que foi decano), Arcebispo de Bari, Prefeito do Supremo Tribunal da Assinatura Apostólica e do Tribunal do Santo Ofício, protetor do reino da Polónia, da Ordem de Malta e da Ordem do Carmo, tendo morrido nomeado Legado do Papa ao Concílio de Trento ${ }^{1086}$. Percebe-se, pelos dados da sua biografia, a relevância deste cardeal, que a amizade do Papa Júlio III elevou ao cardinalato e o colocou a superintender os principais tribunais da Santa Sé.

Na comissão em que comunicam ao Cardeal del Pozzo a sua eleição como protetor dos Lóios, como aliás já o era da Congregação de S. Jorge em Alga (o documento que seguimos menciona-o como protetor da Ordem de S. Salvador em Lauro, i.e. da Congregação de Alga), pedem os cónegos portugueses que aceite a eleição e que proceda em relação aos assuntos da Congregação de S. João Evangelista de acordo com o que a Igreja prescreve aos cardeais protetores, nomeadamente do modo como tratava os assuntos respeitantes às comunidades de Alga ${ }^{1087}$.

Não foi possível encontrar nos cartórios Lóios a resposta do cardeal protetor, nem uma referência ao seu nome na crónica do Bispo Tomasini (em que apenas se menciona o seu antecessor, Cardeal Gambara $^{1088}$ ). Um outro documento, no entanto, permite supor que aceitou o encargo e aprofunda a noção que temos do relacionamento entre os cónegos portugueses e italianos, além de aumentar o nosso conhecimento sobre a forma prática de atuar na cúria romana da década de 1550 .

Uma carta, em língua italiana, escrita de Roma a 4 de outubro de 1558 pelo cónego de Alga D. Gioanpiero Alisandrinello (assim se assina) e dirigida ao P.e João de St. a Maria, reitor do hospital de Coimbra, em que dá conta de estar em Roma retido pela questão dos quindénios e anatas, que espera resolver em proveito dos Lóios. Diz ainda que escreveu ao Geral dos Lóios ${ }^{1089}$ dando conta das conversas com o cardeal protetor, que encontrou disposto a favorecer os Lóios como fazia com os seus congéneres italianos.

Trata-se certamente do Cardeal del Pozzo, que já encontramos no exercício do cargo de protetor de Alga em 1556 e que só morrerá em 1563 1090 , e a quem o cónego de Alga Alisandrinello, que atua claramente como procurador dos Lóios, sugere que a Congregação portuguesa fizesse uma doação de mil escudos, garante da boa vontade do purpurado em relação à sua protegida e os quais, promete, trariam posteriormente grande benefício aos Lóios ${ }^{1091}$. Resta saber se os Lóios aceitaram a sugestão.

\footnotetext{
${ }^{1086}$ CARDELLA, 1793b: 314-315.

${ }^{1087}$ Cf. ANTT - Congregação de S. João Evangelista, Convento de S. João Evangelista de Xabregas, mç. 22, doc. n.o 1.

1088 TOMASINI, 1642: 497, sobre o Cardeal Gambara, antigo núncio em Portugal, França e Inglaterra, veja-se CARDELLA, 1793b: 222, 223.

${ }^{1089}$ Que nesse ano era o P.e Bernardo de Cristo, da Guarda. Entrou na Congregação em 1518, foi reitor do Porto em 1528-29, Geral em 1547-49 e 1557-59. Terá sido confessor de D. João III, da Rainha sua mulher e dos Infantes D. Luís e Cardeal D. Henrique (cf. ADP - Monásticos, Convento de Santo Elói do Porto, lv. do Compêndio do cartório, K/19/6-57, lista dos Gerais dos Lóios, fl. 1055 e segs.)

${ }^{1090}$ CARDELLA, 1793b: 315.

${ }^{1091}$ Cf. ANTT - Congregação de S. João Evangelista, Convento de S. João Evangelista de Xabregas, mç. 22, doc. n.o 5.
} 


\section{Os Cónegos Lóios em Roma: a Cúria e a Congregação de Alga}

Sabe-se que em 1437 o Chantre de Braga Vasco Rodrigues, que já então se contaria entre os cónegos Lóios, passa por Itália no percurso para a Terra Santa. Visita duas cidades onde existiam Casas da Congregação de Alga: a cidade fundacional de Veneza e Bolonha, esta última onde se encontrava então a cúria pontifícia de um cónego de Alga, Eugénio IV. Poder-se-á supor, ainda que sem informação cabal, que tenha mantido contacto com as comunidades da Congregação de S. Jorge em Alga ${ }^{1092}$.

Do mesmo modo as notícias para os anos seguintes demonstram que de um modo regular os Lóios faziam passar a Itália, mais particularmente à Corte de Roma, alguns dos seus cónegos com o objetivo de procurarem obter da Santa Sé privilégios e confirmações de diversa natureza.

Assim sabemos que em abril de 1448, e como procurador da sua Congregação, o P.e João de Arruda ${ }^{1093}$ está em Roma, onde pede a transcrição em pública-forma de um privilégio de Martinho $\mathrm{V}^{1094}$; em agosto de 1451 a congregação era ainda representada pelo mesmo João de Arruda, agora em companhia do P.e Fernando de Pombeiro ${ }^{1095}$.

Provavelmente regressará uma terceira vez a Roma, como aliás Paulo de Portalegre refere, na segunda metade da década de 1450, como podemos supor por uma carta datável (criticamente e com elevado grau de probabilidade) de 21 de julho de 1456, enviada de Roma pelo P.e Vasco Fernandes, clérigo da Casa dos Duques de Bragança, ao P.e Diogo Anes, abade de Chorente, morador em Barcelos, e em que menciona João de Arruda como estando na Cidade Eterna ${ }^{1096}$.

As viagens de João de Arruda terão certamente implicado um contacto direto com alguma das comunidades de Alga, já que segundo o testemunho de Paulo de Portalegre a ele se ficou a dever a mais completa versão que a Congregação teve do Cerimonial de Alga e do seu Memorial, desempenhado um papel importante na organização da liturgia própria das Casas Lóias ${ }^{1097}$, cuja importância numa Congregação em que a liturgia ocupa um lugar central e uma dimensão carismática, não podemos deixar de acentuar. E de facto o cronista afirma que «ficando la Joam de'Aruda com os nosos Imãos de Italia per alguns dias, por sua recriação e repouso» ${ }^{1098}$.

Aquele padre Fernão [Álvares] de Pombeiro que em 1451 estava em Roma com João de Arruda é o padre Batista, tio de Paulo de Portalegre, que o seu sobrinho ${ }^{1099}$ e Francisco de Santa Maria ${ }^{1100}$

\footnotetext{
${ }^{1092}$ COSTA, 1986: 280 e segs.

${ }^{1093}$ De João de Arruda diz o P.e Paulo de Portalegre que seguiu jovem a carreira eclesiástica, tornando-se grande conhecedor de liturgia, tendo chegado a ser mestre de capela do Infante D. Fernando, filho de D. João I. Pelo relacionamento que teria com Martim Lourenço decidiu ingressar na Congregação. Diz que foi muito dedicado aos assuntos da Congregação, em serviço da qual se deslocou três vezes a Roma (cf. PORTALEGRE, 2007: 151 e segs.).

${ }^{1094}$ Livro dos Privilegios concedidos pellos Summos Pontifices..., 1594: fl. 28v.

${ }^{1095}$ Idem, ibidem: 42.

${ }^{1096}$ ADB - Monásticos, São Salvador de Vilar de Frades, lv. 24, fl. 57.

${ }^{1097}$ PORTALEGRE, 2007: 153.

${ }^{1098}$ Idem, ibidem: 134.

${ }^{1099}$ Idem, ibidem: 140, 141.

${ }^{1100}$ SANTA MARIA, 1697: 734-736.
} 
colocam em Roma, ao serviço da Congregação, duas vezes: a primeira na viagem com João de Arruda em $1451^{1101}$, a segunda para tratar de assuntos dos Lóios e do Duque de Bragança D. Afonso, no decurso da qual terá morrido, sendo sepultado em St. ${ }^{a}$ Maria Maior.

Também o P.e Paulo de Portalegre terá passado por Roma ao serviço da sua Congregação, e a caminho da Terra Santa, em data que Cristina Sobral fixou entre 1469 e $1471^{1102}$; viagem que se repetirá em 1488, na opinião de Jorge de S. Paulo e corroborado na ausência de Paulo de Portalegre no capítulo geral desse ano (e do ano seguinte), desta vez a serviço do rei D. João II ${ }^{1103}$.

Os exemplos que aqui se aduzem, e que se baseiam essencialmente na cronística e em alguns dados pontuais de documentação pontifícia (e em que uma análise dos registos de súplicas poderia preencher certamente com mais informações ${ }^{1104}$ ), não fornecem dados mais precisos sobre estas missões romanas dos Lóios, e apenas pontualmente apontam para uma relação de contacto com os Cónegos de Alga, que como ficou visto sabemos terem lugar e importância não desprezível.

As missões romanas, pela importância institucional, pela distância, pelo custo, seriam encaradas na Congregação com efetivos cuidados que começavam logo em território nacional, onde as missões seriam pensadas e debatidas, aprovadas em capítulo geral. Era ainda em Portugal que se pensava na melhor forma de se tentar garantir à partida o sucesso dessas missões. Alguns documentos permitem sustentar esta ideia.

Um treslado ${ }^{1105}$ da doação do padroado da igreja de S. Pedro de Alenquer, concedida pela rainha D. Leonor (que o retira do padroado das Senhoras Rainhas), em documento datado de Xabregas a 27 de março de 1494, à Casa Lóia de S. João de Xabregas, tem registado no verso uma «ementa das cousas que desejamos de corte [de Roma]», aproveitando-se certamente a viagem que um representante dos Lóios faria a Roma para obter do Arcebispo de Lisboa, Cardeal D. Jorge da Costa, a confirmação desta doação (como a Rainha pedia no ato notarial e que o cardeal concederia $\left.^{1106}\right)$.

Na ementa elencam-se 13 pontos a tratar: o primeiro trata da reforma dos privilégios da Congregação e a nomeação de juízes executores; 5 referem-se a questões de natureza material e beneficial,

\footnotetext{
${ }^{1101}$ O que concorda aliás com a cronologia dos acontecimentos que o supõem a entrar na Congregação pouco depois de Alfarrobeira, colocando o sobrinho como noviço em St. ${ }^{\circ}$ Elói de Lisboa (que Cristina Sobral calcula em 1449-1450) antes de partir para Roma (cf. PORTALEGRE, 2007: 24, 25).

${ }^{1102}$ Idem, ibidem: 25.

${ }^{1103}$ Para esta questão e sua cronologia $v d$. Idem, ibidem: 25, 26.

${ }^{1104}$ Era, aliás objetivo desta tese uma análise do fundo de registo de súplicas do Arquivo de Vaticano, a efetuar numa segunda missão de pesquisa e levantamento documental a este arquivo romano. A alteração operada em 2012-13 nas regras aplicáveis às bolsas de doutoramento (nomeadamente aos períodos de pesquisa no estrangeiro) tornaram materialmente inviável uma segunda estadia em Roma, impossibilitando este desiderato.

${ }^{1105}$ ANTT - Congregação de S. João Evangelista, Convento de S. João Evangelista de Xabregas, mç. 14, doc. não numerado.

${ }^{1106}$ Conforme se pode inferir da comissão por ele passada, em carta datada de Palestrina a 23 de julho desse ano de 1494 , ao bacharel Afonso Gil, seu provisor no arcebispado de Lisboa, par unir a igreja de S. Pedro de Alenquer à Casa de Xabregas quando vagasse (cf. ANTT - Congregação de S. João Evangelista, Convento de S. João Evangelista de Xabregas, mç. 14, doc. não numerado). Na referida ementa, aliás, um dos tópicos era precisamente a obtenção da comissão cardinalícia para a anexação da igreja de Alenquer.
} 
enquanto outros 7 são assuntos de natureza espiritual, indulgencial e litúrgica ${ }^{1107}$; em suma os assuntos que tradicionalmente os Lóios levavam a Roma.

Outro exemplo da preparação dos assuntos a tratar em Roma é o que está patente em duas cartas, de 4 e de 6 de outubro de 1542, enviadas pelos Lóios D. Agostinho Ribeiro ${ }^{1108}$, então já bispo de Lamego, e João de Nazaré, reitor da Casa de Recião, ao Reitor Geral dos Lóios e em que tratavam da melhor forma de obter do Papa a anexação do padroado de uma paróquia à Casa de Recião ${ }^{1109}$.

Pelas cartas ficamos a saber que os Lóios de Recião se aconselharam com um João Faberte, pessoa tida por experiente em questões relacionadas com a cúria romana, que se percebe também (pelo contraste entre as duas cartas) intermediar a questão entre o Bispo (que o enviara a Recião) e a Congregação, ao afirmar-se que teve um papel importante em obter de D. Agostinho Ribeiro não a doação do padroado (que era desejo e iniciativa do Bispo), mas em convencê-lo a assumir o pagamento de todas as despesas com as letras apostólicas de anexação.

Escolha muito acertada, já que podemos identificar este João Faberte com o bacharel João Foubert, cónego da Sé do Porto ${ }^{1110}$, que D. António Caetano de Sousa coloca como capelão régio de D. João III ${ }^{1111}$, e que sabemos ter estado em Roma onde serviu na missão diplomática portuguesa no tempo do embaixador D. Miguel da Silva ${ }^{1112}$.

O desejo do Bispo de Lamego de unir um padroado à Casa de Recião da sua Congregação (que, retenhamos, foi mosteiro entregue aos padres Lóios pelo fundador da Congregação, e seu predecessor na cátedra lamecense, D. João Vicente), bem como as diligências que Bispo e Reitor tomavam, parecem ter tido bom acolhimento do Geral a quem se comunicavam, conforme ao teor da carta do reitor João de Nazaré, em resposta a uma que recebera do Geral ${ }^{1113}$.

Sábia foi a precaução do Bispo de Lamego, bem como do Reitor da Casa de Recião, em procurarem opinião abalizada sobre a melhor de obter de Roma o que pretendiam; sobretudo se tivermos em conta que o bispo D. Agostinho Ribeiro era visto na cúria pontifícia como um homem de simples entendimento e pouco dado a rasgos intelectuais (apesar de ter sido reitor da Universidade de Coimbra):

\footnotetext{
${ }^{1107}$ Em que se insere uma ordem para que o procurador que for a Roma se informe do modo como se celebrava segundo o rito romano, em particular da disposição do cálice e da hóstia na missa.

${ }^{1108}$ Sobre este prelado, 1. ${ }^{\circ}$ bispo de Angra (1534-1540), Bispo de Lamego (1540-1549), 2. ${ }^{\circ}$ reitor da Universidade regressada a Coimbra, Geral da sua Congregação de S. João Evangelista, veja-se o que dizem SANTA MARIA, 1697: 919 e segs.; bem como um breve resumo para o seu governo nos Açores em COSTA, 2009: 11; ou sobre o seu governo em Lamego COSTA, 1982: 26,30 .

${ }^{1109}$ ANTT - Congregação de S. João Evangelista, Convento de S. João Evangelista de Xabregas, mç. 22, doc. n. ${ }^{\circ}$ 8. Caderno de documentos avulsos cozidos entre si, e em que se integram as duas cartas citadas como $1 .^{\circ}$ e $2 .^{\circ}$ documentos na sua ordenação interna.

${ }^{1110}$ Como revela FERNANDES, 2011 quando o menciona como pai de Carlos Foubert, cónego da Sé de Lamego e prior da igreja de Argoncilhe.

${ }^{1111}$ Cf. SOUSA, 1742: 787.

${ }^{1112}$ De que dá exemplo a correspondência que mantém com o Rei D. Manuel I e seus oficiais e que se conserva na $1 .^{a}$ parte do Corpo Cronológico da Torre do Tombo.

${ }^{1113}$ ANTT - Congregação de S. João Evangelista, Convento de S. João Evangelista de Xabregas, mç. 22, doc. n. ${ }^{\circ} 8$. Carta datada de Recião a 23 de novembro de 1542 , e que é o $5 .^{\circ}$ documento do caderno de avulsos em que se insere.
} 
Il vescovo di lamacho e religioso delli azurri di S.to Giorgio in Alga Venetiars. huomo assiu simplice di poche littere nom di mala natura ${ }^{114}$.

Pela mesma época, em 1543, encontramos o capítulo geral dos Lóios a mandar ao reitor e deputados da Casa do Porto que ponham em execução a bula recentemente obtida de Paulo III ${ }^{1115}$, em que o Papa isenta os Lóios das visitações do ordinário ${ }^{1116}$. A preocupação da cúpula da Congregação não é apenas obter e manter os privilégios concedidos pela Santa Sé mas também vê-los em execução, dando verdadeiro sentido a este esforço coletivo da Congregação em prol da construção de uma economia de privilégios que sustente a sua autonomia e lhe permita desenvolver os seus fins últimos, que são aqueles que desde a fundação se contêm no seu carisma ${ }^{1117}$.

Em agosto de 1559 um novo indício indireto da presença de procuradores Lóios em Roma. Em carta ${ }^{1118}$, o Cardeal Carafa, juiz executor dos Breves, afirma ter-lhe sido apresentada pelo Geral e Cónegos Lóios uma carta do Cardeal Rainúncio Farnese, penitenciário-mor, a si dirigida e em que trata de questões sobre a nomeação, pela Congregação, de vigários para igrejas anexas e a liberdade de estabelecer estipêndio para os capelães, o que o Cardeal Carafa concede visto a carta e de acordo com o que de viva voz ouvira aos Lóios, que não sendo naturalmente o geral e toda a Congregação, significará com toda a probabilidade mais um dos seus cónegos procuradores em Roma.

\section{As reformas tridentinas e as tentativas de regularização}

Será no contexto do final do concílio de Trento, e num período de aparente crise da Congregação de Alga, que os Lóios aparecem a ter o mais próximo e relevante contacto direto com os seus irmãos de carisma.

A situação institucional da Congregação de S. Jorge em Alga era, na década de 1560 e antes da imposição definitiva de votos perpétuos que virá a ocorrer por disposição de Pio V de 17 de novembro de $1568^{1119}$, de crise e aparente fragilidade. Nesta matéria é de particular interesse o breve do mesmo Papa datado de 1 de abril de $1567^{1120}$, dirigido ao Geral e Cónegos da Congregação de S. Jorge

\footnotetext{
${ }^{1114}$ Citação retirada das instruções dadas ao núncio nomeado para Portugal em 1542, Luigi Lippomano, bispo coadjutor de Bérgamo (sobre este prelado veja-se o artigo já citado de KOLLER, 2005), e que se podem ver em ASV - Miscellanea, Armadio II, n. ${ }^{\circ} 49$, fl. 195.

${ }^{1115}$ ANTT - Manuscritos da Livraria, n. ${ }^{\circ}$ 186, fl. 158.

${ }^{1116}$ Não foi possível encontrar concessão pontifícia sobre esta matéria específica, no entanto poder-se-á tratar da concessão de 1537 em que Paulo III concede a Alga o usufruto dos privilégios da Congregação Cassinense, em que esta isenção está incluída (cf. Livro dos Privilegios concedidos pellos Summos Pontifices..., 1594: fl. 68 e segs.).

1117 Outros exemplos se poderiam aduzir, por exemplo no capítulo geral do ano seguinte, em que diversos mandados ordenam aos reitores que promovam a execução de privilégios obtidos e, num caso, determina que em determinada bula de Paulo III (não especificada) seja analisada com profundidade, recorrendo a bons letrados (cf. ANTT - Manuscritos da Livraria, n. ${ }^{\circ} 186$, fl. $177 \mathrm{v} ., 178$.

${ }^{1118}$ Datada de Roma a 30 de agosto de 1559 (cf. NTT - Congregação de S. João Evangelista, Convento de St. ${ }^{\circ}$ Elói de Lisboa, lv. 17).

1119 Transcrita em TOMASINI, 1642: 537 e segs.

${ }^{1120}$ ASV - Fundo Veneto I, n. ${ }^{\circ} 1353$.
} 
em Alga de Veneza, em cujas entrelinhas poderemos descortinar as questões que subjazem à transformação desta Congregação de secular em regular.

Neste breve o Pontífice começa por deplorar a existência de cónegos de comportamento repreensível, que cometeriam inclusive delitos que previam a expulsão da Congregação, o que quando acontecia, e de acordo com os termos constitucionais da mesma, previa-se que mantivessem o hábito de clérigos seculares e recebessem da Congregação certo pecúnio, resultando em que os clérigos desviantes passassem ao século como presbíteros seculares e com escândalo do povo cristão.

Revogando esta disposição, considerada branda e em desprestígio do sacerdócio, o Papa endurece as penas aos cónegos infratores e declara, o que é mais significativo, que apesar de ter tolerado que os cónegos de Alga se ordenassem sem património e que pudessem sair da Congregação sem causa legítima, o que era contra os Cânones e as disposições do Concílio Tridentino, e tendo em consideração que ao seu ofício pastoral cabia prover nestas matérias, determina que doravante os clérigos que deixassem a Congregação de Alga, ou dela fossem expulsos, ficassem suspensos a divinis ${ }^{1121}$, até serem absoltos da mesma suspensão pelo Pontífice Romano.

Neste breve apercebemo-nos de duas questões que serão centrais na vida das duas Congregações nos anos que se seguem ao final do Concílio de Trento, e que resultarão na alteração da estrutura carismática-institucional fundacional na matriz italiana de S. Jorge em Alga, que os cónegos portugueses lograrão preservar intacta até à sua extinção em 1834: se por um lado temos a argumentação, por parte de Pio V, que a Congregação de Alga (ou pelo menos algum dos seus cónegos) estava em estado de degradação moral e disciplinar, a que a sua normativa e os seus prelados não atalhavam de modo eficaz; pelo outro encontramos a declaração expressa que a característica central do carisma de Alga, a sua qualidade de congregação de clérigos seculares de vida comum, sem património próprio e sem profissão solene de votos, estava em desacordo com a normativa da Igreja, em particular com aquela que recentemente fora emanada do Concílio tridentino.

Esta questão de desconformidade do modo de vida de Alga com os desejos do concílio será determinante para a alteração do seu carisma fundacional, que apenas conhecerá uma efetiva oposição entre os Cónegos Lóios. Não é possível perceber se as alegações de crise interna dos Cónegos de Alga se sustentam numa realidade de facto, o certo é que encontramos algumas disposições pontifícias que sugerem uma tentativa de reforma da Congregação e que culminam na imposição de votos solenes, conjugando deste modo numa mesma questão as duas questões que aqui se formularam.

Assim, após o breve de abril de 1567, vamos encontrar o registo de um outro breve, de 28 março de $1568^{1122}$, que o papa Pio V dirige ao Reitor Geral da Congregação de S. João Evangelista de Portu-

\footnotetext{
${ }^{1121}$ A suspensão a divinis, ou seja, para o serviço divino, é uma pena eclesiástica aplicada aos eclesiásticos e que implica, entre outras coisas, a suspensão do exercício do seu múnus litúrgico, sacramental e pastotal, conforme ao que estabelecem os cânones 1331 e seguintes (cf. Código de Direito Canónico, 1983) e cuja doutrina se poderá ver resumidamente em BOUDINHON, 1910.

${ }^{1122}$ ASV - Segreteria dei Brevi, Registra Brevium, SEC. BREV. REG. N. ${ }^{\circ}$ 10, fl. 213. O mesmo texto do breve está transcrito pelo cronista Francisco de Santa Maria, e segue em geral a lição do documento conservado no registo dos breves (cf. SANTA MARIA, 1697: 291, 292).
} 
gal, ordenando o envio a Itália de 6 ou 8 cónegos idóneos para reformarem a Congregação matricial italiana, e a expensas desta.

Penso não ser necessário expor o alcance deste breve: considerando em estado de crise a Congregação de S. Jorge em Alga, o Papa reconhece nos Lóios um modo de vida que se manteria minimamente exemplar, pelo menos considerando-os capazes de reformar a instituição que lhes servira de base carismática. Estamos perante a reversão dos papéis desempenhados pelas duas instituições no século precedente, um reconhecimento de ligação carismática entre as duas instituições, e um momento de particular partilha.

A cronística Lóia não deixou de salientar este facto prestigiante para a Congregação portuguesa $^{1123}$ (ainda que certamente menos para a sua matriz italiana). Francisco de Santa Maria deixou registado este encargo reformador no cap. 27 do Liv. I da sua crónica ${ }^{1124}$, onde dá conta que o breve papal foi recebido em junho desse ano de 1568, e que o geral P.e Diogo da Ressurreição determinou enviar a Itália o seu antecessor no cargo (a quem o breve viera dirigido), o P.e António do Espírito Santo, acompanhado dos Padres Francisco da Madre de Deus ${ }^{125}$, Pedro de S. João e Gil da Conceição, a quem deveria juntar-se o P.e Francisco de Santa Maria ${ }^{1126}$ que então servia de procurador da Congregação na cúria romana.

Não escreve o cronista Santa Maria, sobre a missão reformadora daqueles padres, mais do que umas parcas referências ao bom exemplo que os cónegos italianos teriam recebido dos seus congéneres portugueses, o que unido à ausência de outras fontes que não as de natureza cronística faz suspei$\operatorname{tar}$ (como acontece com outros eventos descritos em crónica mas sem suporte documental ${ }^{1127}$ ) que o determinado por Pio V no seu breve não tivesse alcançado efetiva execução.

\footnotetext{
${ }^{1123}$ Como o entendia o padre Santa Maria quando escreve «mas a mayor gloria da nossa Congregação nesta parte [actuação de Lóios como reformadores de ordens religiosas e dioceses], he a visita, que os nossos Conegos fiserão em Venesa, por ordem do Santo Pontifice Pio V» (cf. Idem, ibidem: 290).

${ }^{1124}$ Idem, ibidem: 290 e segs.

1125 Sobre Francisco da Madre de Deus escrevia Jorge de S. Paulo, em capítulo dedicado aos religiosos ilustres por virtudes, que era «natural de Lamego Theologo irmão do Doutor Antonio da Cunha Dezembargador do Paço que por sua virtude e zello da Congregação foy chamado pello Sumo Pontifice Pyo $5 .{ }^{\circ}$ com outros companheiros para reformar a Congregação de S. Jorge d'Alga em Veneza. Com ser de 80 annos nunqua perdeo missa nem hora de choro dizendoa quada dia com notável devação detendosse largo quarto de hora no $2 .^{\circ}$ memento contemplando na real assistência de Christo senhor nosso sacramentado. Fazendo a barba em hum dia veyo pella cella do Prelado, e lhe pedio bênção pera morrer naquele dia, e assy socedeo» (cf. ADB - Manuscritos, ms. 924, fl. 710).

1126 Trata-se do futuro bispo titular de Fez e auxiliar de Braga. Natural de Vila do Conde, filho de um escudeiro da Casa da Bragança, Álvaro Fernandes. Terá entrado jovem na Congregação, onde assumiria diversas prelazias, atribuindo-lhe Francisco de Santa Maria o generalato cerca de 1540, em cujo exercício teria promovido a impressão das Constituições dos Lóios, o que no entanto poderá ser confusão com outro religioso do mesmo nome, já que tal significaria que este prelado falecido em 1596 teria exercido o generalato em idade jovem. Terá exercido funções de procurador da Congregação na cúria romana na década de 1560, ofício que exerceria em 1568, quando é escolhido para integrar o grupo de Lóios encarregues de reformar a Congregação de Alga. Regressado a Vilar de Frades terá sido eleito em 1583, a instâncias do Arcebispo de Braga D. João Afonso de Meneses, bispo titular de Fez e auxiliar do Primaz, tendo ocupado os cargos de Provisor, Vigário Geral e Governador do Arcebispado. Terá sido preconizado Arcebispo de Goa por Filipe I de Portugal e terá recusado (cf. Idem, ibidem: 1002 e segs.). ${ }^{1127}$ Como é o caso da missão dos Lóios ao Congo em 1490, vd. cap. 4.4.
} 
Esta ideia torna-se mais sólida quando se tem em consideração que Tomasini na sua crónica não menciona uma visita da sua Congregação por cónegos portugueses, mas regista a nomeação pelo Papa, a 13 de novembro do ano anterior de 1567, dos dominicanos Fr. Paulo Emanuel de Verona e de Fr. Arcângelo de Soncino como visitadores da Congregação de Alga, com poderes para reduzirem e reformarem ${ }^{1128}$; visitação essa que podemos ter certeza de execução, já que no Arquivo do Vaticano se conservam as «Instruttione à Fra Paolo Emanuelle da Verona per la Visita dei padri della Congregatione di S. Giorgio in Alga $^{1129}$ ", as quais no entanto se reduzem em essência aos termos comuns de uma visita ${ }^{130}$, ainda que com ênfase no estado moral da comunidade e na verificação do cumprimento do breve de Pio V de 1567 e do que se dirigia às eleições na Congregação.

Será a primeira das cartas enviadas de Roma por Pêro de S. João Garcês, em 1595, que nos dá a primeira prova documental que confirma que a visita reformadora dos cónegos Lóios a Itália teve efetivamente lugar, quando escreve, sobre o bom acolhimento que teve em S. Salvador em Lauro, que se devia à carta do Geral mas também ao:

grande nome do Bispo Dom Francisco e os padres Francisco da Madre de Deos e os mais daquelle tempo qua deixarão. O padre Prior he daquelle tempo e alguns outros e os outros tem grande noticia das virtudes e prudente modo de proceder dos padres que digo ${ }^{1131}$.

Francisco de Santa Maria foi também lacónico sobre o resultado final da visita empreendida pelos padres Lóios. Por compreensíveis razões, e ainda mais em cronista que tão ardentemente assumiu o dever de promover a sua Congregação, Santa Maria não tira a ilação óbvia sobre o resultado desta missão: apesar dos Lóios terem sido chamados a reformar a sua matriz italiana, a sua visita não logrou manter intacta a Congregação de Alga e o seu carisma.

O parco resultado da visita (porque algum há de ter tido, pela impressão duradoura que deixou), com a maior das probabilidades, deve-se assacar não à incapacidade dos Lóios em reformar ou dos Cónegos de Alga em serem reformados, mas da especificidade do seu modo de vida que então se considerava incompatível com algumas das determinações de Trento.

De facto, depois de fazer visitar os cónegos de Alga por dois teólogos dominicanos e por um conjunto de cónegos portugueses da mesma matriz carismática, o Papa acabará por impor a Alga a profissão solene sob a regra de St. ${ }^{\circ}$ Agostinho. Tratou-se de um processo longo e complexo e que marca, no universo das duas congregações seculares, a gradual passagem para um sistema eclesial pós-tridentino, de regras mais estritas e com menor espaço para a variedade institucional.

A 17 de novembro de 1568 uma bula de Pio V determina, de acordo com as normas conciliares, que as congregações de vida comum sem profissão de votos e sob obediência voluntária (menciona

\footnotetext{
${ }^{1128}$ TOMASINI, 1642: 529 e segs.

${ }^{1129}$ ASV - Miscellanea, Armadio II, n. ${ }^{\circ} 34$, fl. 26 e segs.

${ }^{1130}$ Verificar as condições em que se cumpria o culto divino, o estado moral dos membros da comunidade, o seu estado material.

${ }^{1131}$ ANTT - Congregação de S. João Evangelista, Convento de S. João Evangelista de Xabregas, mç. 22, doc. 6, não numerado; $v d$. anexo documental A, doc. A2.
} 
especialmente a Congregação de Alga e os Eremitas de S. Jerónimo do beato Gambacorta ${ }^{1132}$ ), sejam forçadas a professarem os três votos solenes em prazo determinado ${ }^{1133}$.

A 29 de outubro de 1569, e seguindo em essência o que era o teor da bula, reuniu-se em Roma um capítulo da Congregação, onde em obediência à vontade do Papa, mas sem consenso interno, é emitida a sua profissão coletiva. Não deixa Tomasini de mencionar o sofrimento de alguns religiosos mais velhos por ver alterada a estrutura carismática da Congregação, bem como o facto de alguns cónegos terem preferido deixar os claustros de Alga como alternativa à profissão ${ }^{1134}$.

No seu esforço normativo para reformar e promover o estado clerical, o concílio de Trento acentuou não só a necessidade de restringir o acesso às ordens sacras a homens de comprovadas virtudes e suficiente mérito formativo, mas também procurou assegurar que nenhum clérigo se ordenasse sem dispor de uma garantida fonte de rendimentos consentânea com a dignidade que alcançava por via da ordenação.

Neste pressuposto determinou o concílio, na sua sessão XXI, que os ordinandos só pudessem receber as ordens maiores (mesmo que reunissem os demais requisitos) se possuíssem essa garantia de digna sustentação, que se traduzia em serem ordenados sob um de três títulos de ordenação: título de benefício, em que o ordinando era detentor de um benefício eclesiástico e do rendimento respetivo (é, segundo as normas eclesiásticas, o título natural para ordenação); título de património, quando por falta de benefício eclesiástico era estabelecido um património dotal que garantisse o digno sustento do ordinando; título de pensão, que similarmente ao anterior supria a falta de benefício por obtenção de uma pensão vitalícia ${ }^{1135}$.

Determinações conciliares sobre o título de ordenação aplicam-se aos clérigos seculares, já que o universo regular, a quem pertencia professar a pobreza evangélica ${ }^{1136}$ por voto solene (acompanhado dos votos de obediência e de castidade), se ordenava a título da sua ordem ou congregação, ou seja, tendo por garante da sua sustentação a própria instituição em que professara e da qual não poderia desligar-se sem especial mandato pontifício ${ }^{1137}$.

\footnotetext{
${ }^{1132} \mathrm{O}$ beato Pietro Gambacorta de Pisa, terceiro franciscano e eremita, foi o fundador dos pobres eremitas de S. Jerónimo, uma fraternidade de estrita vida comum, que se transformará em congregação no decurso do pontificado de Eugénio IV, o que é natural quando se sublinha a participação do grupo de Gambacorta com o universo reformista veneziano, nomeadamente com o movimento da observância beneditina de Barbo, e testemunhando a implementação do modelo de congregação sem votos solenes que se encontra em aplicação nos Cónegos de Alga e nos Lóios (cf. GIORDANO, 1999).

1133 TOMASINI, 1642: 537 e segs.

${ }^{1134}$ Idem, ibidem: 535, 536.

${ }^{1135}$ Veja-se Sacrosanctum Oecumenicum Concilium Tridentinum..., 1769: 135 e segs. Sobre a questão da sustentação do clero ao longo da História, nomeadamente a exigência de património beneficial para ordenação, veja-se OLIVEIRA, 2006.

${ }^{1136}$ Neste ponto, aliás, os decretos conciliares (na sua sessão XXV) são incisivos ao proibir aos membros de ordens e congregações religiosas a possibilidade de possuírem quaisquer bens a título pessoal (cf. Sacrosanctum Oecumenicum Concilium Tridentinum..., 1769: 328).

${ }^{1137}$ Note-se que a dispensa de solene profissão religiosa era caso reservado à Sé Apostólica, ou seja, só o Papa a poderia conceder. A profissão religiosa era perpétua e obrigava a pessoa à forma de vida religiosa, mesmo em caso de expulsão da Ordem ou Congregação a que pertencia ou de obtenção da Santa Sé de indulto de perpétua secularização (que colocava a pessoa sob o controlo do seu prelado diocesano) (cf. VEERMEERSCH, 1911 e VEERMEERSCH, 1912).
} 
Por definição, a profissão solene de vida religiosa criava mútuas obrigações entre o religioso e a instituição em que professava: ao primeiro cabia o cumprimento dos votos professados e a perseverança na vida religiosa ao longo de toda a sua vida, a que estava estritamente vinculado; à instituição cabia a obrigação de sustentar o religioso, integrá-lo como membro da sua estrutura de pleno direito e o dever de apenas o expulsar em caso de faltas graves e persistentes ${ }^{1138}$.

Nesta lógica de sistema patrimonial para ordenação a cúria romana não conseguia enquadrar as congregações de clérigos seculares, a quem pertencia a posse comum de bens e a proibição de posse individual, típica dos regulares ${ }^{1139}$, mas que mantinham a liberdade do clero secular para abandonar as fileiras da sua congregação, passando a ser um clérigo secular sem congregação nem património (de que abdicara quando entrara nos claustros) e sem prelado que o dirigisse e controlasse ${ }^{1140}$.

Os termos da bula de 1568 não afetaram apenas a Congregação de Alga, aos padres Lóios procurou-se igualmente impor a mesma obrigação de profissão solene. Sendo uma importante marca carismática e fundacional, a liberdade de que gozavam os cónegos (e a que Francisco de Santa Maria dedica três capítulos da sua crónica ${ }^{1141}$ ), por seculares e sem votos solenes, levará à resistência dos claustros portugueses.

O cronista Santa Maria colocou a profissão como a terceira das grandes tribulações porque a Congregação passou no decurso da sua história ${ }^{1142}$. A sua descrição faz supor que para os Cónegos Lóios o processo teve algumas variantes em relação ao que vimos em prática em relação aos Cónegos de Alga.

Se aos cónegos de Alga foi a profissão imposta diretamente por breve papal, aos Lóios a questão da profissão terá nascido das determinações conciliares sobre o património para ordenação e de um outro breve de Pio V que trata da mesma matéria.

Conforme descreve Santa Maria ${ }^{1143}$, e de acordo com os termos do breve de Gregório XIII ao Cardeal D. Henrique, de 1 de junho de 1573 (em que lhe delega o julgamento de toda a questão ${ }^{1144}$ ), os Lóios representaram ao Papa que, nos termos do concílio de Trento e da normativa de Pio V que impedia a ordenação sem património para os clérigos seculares, a sua Congregação encontrava-se

\footnotetext{
${ }^{1138}$ Cf. VEERMEERSCH, 1911.

${ }^{1139}$ Que, como visto em nota anterior, a sessão XXV do concílio de Trento proibia terminantemente aos regulares, norma que estas congregações, apesar de não professas, seguiam e que, na Congregação de Alga, está já perfeitamente patente na executória do bispo Barbarigo de 1404 ( $v$ d. cap. 2.1). Entre os Lóios pode-se encontrar a sua menção nos Estatutos (Statutos e Constituyções dos virtuosos e reverendos padres Conegos azuys..., 1540: cap. XXI, fl. XXI, XXIv.) e com alguma frequência nas determinações do capítulo geral da Congregação.

${ }^{1140}$ Pois se ordenado a título da sua congregação estava fora do sistema de incardinação dos clérigos diocesanos. Deste modo se compreende a determinação do breve de abril de 1567 (cf. ASV - Fundo Veneto I, n. ${ }^{\circ}$ 1353) em que suspende os cónegos que deixarem a congregação, obrigando-os a pedir o levantamento dessa suspensão, permitindo à Santa Sé incardiná-los, fazendo funcionar a ampla máquina de controlo do clero que Trento quis impor.

${ }^{1141}$ Os quais constituem ainda uma defesa do modo de vida da Congregação, mesmo que passado mais de um século sobre a questão da forçada profissão. Assim, o cronista dedica um capítulo ao valor específico da liberdade (considerado teológicamente) um segundo ao facto de os cónegos genericamente, e mesmo sem votos, perseverarem na Congregação, e o terceiro dedicado a expor os fins infelizes dos padres que decidiram deixar as fileiras Lóias (cf. SANTA MARIA, 1697: 241 e segs.).

1142 Idem, ibidem: 317.

${ }^{1143}$ Idem, ibidem: 327 e segs.

${ }^{1144}$ Transcrito no Livro dos Privilegios concedidos pellos Summos Pontifices..., 1594: fl. 73 v. e 74.
} 
impedida (aparentemente pelos próprios bispos portugueses, argumentando com a aplicação das novas normas) de fazer ordenar os seus cónegos, pois o seu modo de vida não só os impedia de possuírem benefícios ou bens próprios como, em simultâneo, não integrava na sua estrutura carismática a profissão solene que lhes permitiria serem ordenados a título da congregação. As determinações eram assim contraditórias com o seu modo de vida, e a adaptação da Congregação às normas conciliares iria necessariamente ferir a sua base carismática.

Na sua exposição, os Lóios dariam ainda conta ao Papa das numerosas obrigações de alma das suas Casas, que exigiam sacerdotes que as cumprissem; o bom estado material das comunidades, que permitia que sustentassem os ordinandos; o bom exemplo da sua vida ${ }^{1145}$ e a perseverança dos cónegos na Congregação; com o que se desejava convencer o Pontífice a prover na matéria e a preservar a particularidade do modo de vida dos padres Lóios.

Gregório XIII comete então a questão ao Cardeal D. Henrique, legado a laetere em Portugal, para que verifique as premissas (nomeadamente nunca terem sido professos, que vivam em obediência voluntária, que não tenham benefício ou património), com poder para, em caso de confirmarem-se verdadeiras, determinar que os prelados continuassem a ordenar os Lóios a título da Congregação, sem imposição de votos ou obrigação de benefício ou património pessoall ${ }^{1146}$.

O Cardeal Infante D. Henrique, que teve com os Lóios alguma proximidade (apesar do seu grande apoio ter depois transitado para a Companhia de Jesus), declara na sua sentença que o breve lhe foi apresentado pelos Lóios, tendo o purpurado aceitado a causa. Fazendo correr o processo, o cardeal ordenou à Congregação que apresentasse justificação, o que esta cumpriu nos termos em que apresentou a súplica ao Papa, e para prova dos quais apresentou testemunhas ${ }^{1147}$.

Sentenciou, a 13 de agosto de 1573, o Cardeal D. Henrique que os «conegos da dita congregaçam, que ora sam, e pollo tempo em diante forem que posto, que nam façam profissam solemne, e vivam voluntariamente na obediencia de seus Prelados, inda que nam tenham beneficio, nem património possam ser promovidos a ordens sacras, e de missa pellos ordinários, ou outros Prelados de sua licença» ${ }^{1148}$.

Pelas mãos do futuro Rei estava assim a Congregação de S. João Evangelista, e em contradição do que acontecera com a Congregação de Alga, isenta nesta matéria dos efeitos da estrita normativa tridentina, preservando intacta (e doravante solitariamente) a intenção original do carisma de uma congregação de clérigos seculares de vida comum.

Não terá ficado a questão inteiramente por aqui, já que Francisco de Santa Maria refere ainda que o padre Pêro de S. João, na sua missão romana, foi questionado do motivo porque os Lóios não emitiram profissão solene nos termos do breve de Pio V de 17 de novembro de 1568, no qual se acharia compreendido ${ }^{1149}$.

\footnotetext{
${ }^{1145}$ Afirmando mesmo que em Portugal haveria poucas comunidades de regulares que vivessem em tão estrita clausura e observância como eles (cf. Idem, ibidem: fl. 73v.).

${ }^{1146}$ Idem, ibidem, e o resumo de SANTA MARIA, 1697: 327, 328.

${ }^{1147}$ Livro dos Privilegios concedidos pellos Summos Pontifices..., 1594: fl. 74-75.

${ }^{1148}$ Idem, ibidem: fl. 75v.

${ }^{1149}$ Cf. SANTA MARIA, 1697: 329.
} 
A resposta do procurador, registada por Santa Maria em linhas gerais, teria por base uma das duas razões que podemos imaginar possíveis para os diferentes tratamentos das duas Congregações: afirma que as Congregações não estavam, em 1568, no mesmo estado moral, decadente a de Alga e prístina a dos Lóios, que inclusive era chamada pelo Papa para reformar a sua matriz ${ }^{1150}$.

Podemos ainda questionar-nos se a proximidade da Congregação de Alga ao centro do poder pontifício e aos grandes movimentos da Igreja conciliar não terá também desempenhado um papel na sua forçada regularização.

Santa Maria afirma que o Papa teria respondido através do seu secretário, que teria passado declaração escrita em que afirmava que Clemente VIII louvava o modo de vida da Congregação e confirmava a sua isenção da profissão solene ${ }^{1151}$.

Ainda assim é de registar que, em carta de 7 de novembro de 1599, Pêro de S. João Garcês sugeria que «não me parece tempo de tratar da materia de herdar a Congregação, porque he entrar outra vez a [... na profissão» ${ }^{1152}$. Aparentemente a questão não estava assim tão solidamente resolvida em Roma.

A quebra carismática existente da Congregação de S. Jorge em Alga, que pensada como Congregação secular, sem constrangimentos de votos solenes mas com vida comunitária partilhada, desprovida de posse particular de bens, permanente e voluntariamente aceite em liberdade pelos cónegos, não tornou inteiramente estranhas as duas Congregações, nem colocou em causa a necessidade recorrente dos Lóios de se relacionarem com a Cúria Romana.

Os capítulos gerais continuam a mencionar a necessidade de obter de Roma as necessárias confirmações, concessões e aprovações, e será precisamente a partir desta necessidade que vamos encontrar o capítulo geral de 1594 a enviar o P.e Pêro de S. João como seu procurador-geral.

A decadência da Congregação de S. Jorge em Alga parece ter acelerado com a sua regularização. Perdendo a sua especificidade institucional carismática, tornando-se mais uma congregação de cónego regulares agostinhos, os Cónegos de Alga parecem ter-se tornado redundantes.

A crise de Cândia será o argumento para extinguir a Congregação, e apesar de serem exclaustrados pela Santa Sé, parece que os cónegos terão passado pelo mesmo processo traumático que sofrerão os Lóios em 1834: a documentação da Sagrada Congregação Particular para a supressão conserva ainda hoje os múltiplos pedidos de cónegos de Alga por pensões ou benefícios que os possam sustentar.

Os exclaustrados de S. Salvador em Lauro, Casa de Alga com que os Lóios terão tido relações mais intensas, aparecem a pedir ao Papa que lhes permita terminar os seus dias no mosteiro, pedem ainda uma côngrua ou a nomeação para capelães da sua igreja, de modo a «che possano finire la Vita senl'andare mendicando» ${ }^{1153}$.

\footnotetext{
${ }^{1150}$ Idem, ibidem: 329, 330.

${ }^{1151}$ Idem, ibidem.

${ }^{1152}$ ANTT - Congregação de S. João Evangelista, Convento de S. João Evangelista de Xabregas, mç. 22, doc. numerado como 43, transcrito em anexo documental A, doc. A6.

${ }^{1153}$ ASV - Miscellanea, Armadio VIII, n. ${ }^{\circ} 41$.
} 


\section{A REFORMA ENTENDIDA PELOS LÓIOS: DO CLAUSTRO E DO SÉCULO}

\subsection{CARISMA E ESPIRITUALIDADE NA CONGREGAÇÃO DE S. JOÃO EVANGELISTA}

Penso que tem ficado bem claro, no desenrolar das páginas deste livro, o papel absolutamente central que o carisma assume na vida de uma ordem ou congregação religiosa, entendido como espírito fundacional, gerado no percurso do(s) fundador(es) e nos seus contextos, que orienta em teoria e prática a nova fundação e se mantém como elemento estrutural ao longo da sua história.

Carisma é pois o espírito da instituição, nos próprios termos definidos pela Igreja ao defender que o carisma das ordens e congregações religiosas é um dom de Deus, transmitido pelo poder do Espírito Santo e que se associa ao dom (ou carisma) da vida consagrada, que pertence ao dom mais vasto da vocação (vocatio, o chamamento) ${ }^{1154}$.

Nestes termos tem-se procurado demonstrar até que ponto se pode considerar que o carisma fundacional mais relevante da Congregação de S. João Evangelista (como antes dela da Congregação de S. Jorge em Alga) é o da reforma consubstanciado na reforma do universo clerical pela adoção de um modo de vida comunitário que se pretendia fundado nos tempos apostólicos da Igreja.

Como já se teve a oportunidade de salientar, no tempo das reformas in capite et in membris, modelo vertical de reforma, o carisma dos clérigos seculares de vida comum situa-se numa conceção distinta, a da reforma entendida pela base, a partir da reforma de um clero secular que se considera indigno e pouco (ou nada) preparado para um bom desempenho do seu múnus pastoral.

Foi este o modelo que a Congregação de Alga idealizou e implantou, que Eugénio IV seguiu estruturalmente no seu difícil pontificado, e que os fundadores Lóios reconheceram e adotaram como seu, transpondo-o a Portugal e ao universo eclesiástico português.

A consciência da dimensão reformista do seu modo de vida, por eles assim entendido e à luz da ideia de reforma teorizado por Ladner, está presente desde os seus primeiros dias, e é vincado em momentos de afirmação.

Recorrendo ao Novo Memorial de Paulo de Portalegre, como obra mais antiga traçável da cronística lóia, é patente na descrição que faz da fundação da Congregação italiana (a qual será certamente inspirada no Memorial de Alga que Afonso Nogueira trouxera de Itália) que as duas Congregações de Cónegos Seculares alicerçavam o seu modo de vida no modo de vida original das primeiras comunidades cristãs, cujos termos são recuperados num processo que é declaradamente descrito como uma reforma.

semdo ja ha ordem sacerdotal e o abito de Sam Pedro em pouqua estima avido, quis Christo noso Redentor que ha nave de Sam Pedro nam se alaguase [...] renovando e segumdariamente

${ }^{1154}$ Cf. FOLEY, 2003. 
aprazemdo-lhe instimtuir, e por milhor dizer reformar a Regra e estado apostólico, que per muitos tempos fora oculta em ho mundo ${ }^{1155}$.

Estamos, numa penada, perante a afirmação da direta correlação entre o modo de vida dos Cónegos no modo de vida original do cristianismo, o estado apostólico ${ }^{1156}$, apresentado como naturalmente pertencente ao clero secular («ordem sacerdotal e o abito de Sam Pedro»), afirmação clara de supremacia do estado sacerdotal e do clero secular em contraposição ao que fora o entendimento mais difundido na Idade Média, que identificava a perfeição de modo de vida e a proximidade ao modelo apostólico com o modo de vida dos regulares.

A crise do clero secular, nesta leitura, colocava em perigo a Igreja («ha nave de Sam Pedro», numa referência clara à crise cismática), levando à intervenção da Divina Providência (agente histórico com presença muito significativa na cronística religiosa), que teria inspirado o movimento de clérigos seculares de vida comum, cujo aparecimento assumiria dupla dimensão: se por um lado têm como principal função renovar e reformar o modo de vida dos Apóstolos, para o tornar possível vão «segumdariamente» instituir novo modo de vida, que é o da Congregação propriamente dita.

Em suma, o modo de vida dos Cónegos Seculares de vida comum é em simultâneo antigo e novo, antigo porque é visto como herdeiro direto do modo de vida da comunidade apostólica de Jerusalém dos primeiros anos do cristianismo, novo porque (depois deste modo de vida apostólico ter estado como suspenso) é retomado por meio de uma nova fundação institucional que o recupera. Saltando séculos de vida eclesial, Cónegos de Alga e Lóios vão filiar-se diretamente nos Apóstolos.

De facto, esta curta afirmação do primeiro memorialista Lóio tem ainda um outro alcance, o da recusa de validade aos demais movimentos reformistas, anteriores ou coetâneos, que são descartados enquanto movimentos inseridos na tradição dos Apóstolos, já que esta «per muitos tempos fora oculta em ho mundo».

Não sendo inovadores nesta filiação direta, os Cónegos Seculares são-no quando afirmam a supremacia do clero secular nesta questão de pureza de modo de vida e sua proximidade à origem, firmando no plano do clero secular, na noção de uma vida comum sem votos solenes mas de partilha de bens e de obediência voluntária, a base da reforma do clero e por ele da nave de São Pedro, símbolo não apenas do Papado ou da Igreja institucional, mas também do conjunto Eclesial.

Profundamente comprometidos com o seu modo de vida particular, os padres Lóios não parecem ter tido dúvidas de que o seu modo de vida era de carácter reformista e fundado sobre as próprias

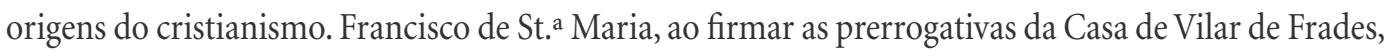
escreve que «Logra este convento a notavel prerogativa de haver sido o primeiro da nossa Congrega-

\footnotetext{
1155 PORTALEGRE, 2007: 69.

${ }^{1156}$ O mesmo que D. Manuel I informa a D. Miguel da Silva, com base na informação do Geral dos Lóios «que a sua regra e ordem de vida fora instytuida por Nosso Senhor Ihesus Chrispto e seus Apostollos segundo que he escrito que era a elles huma avontade e querer e todallas cousas lhe eram communhas e se dava a ca $<\mathrm{da}>$ hum segundo sua necessidade, e per esto modo se nomeava esta Comgregaçam estado apostollicall» (cf. ANTT - Congregação de S. João Evangelista, Convento de S. João Evangelista de Xabregas, mç. 15, doc. n. ${ }^{\circ}$ ).
} 
ção, e o primeiro de Portugal, onde viverão Clerigos reformados, fazendo vida comum à maneira de Christo Senhor Nosso com seus sagrados Apostolos» ${ }^{1157}$.

\section{Carisma e Liturgia}

Este carisma fundado no modo de vida não se esgota apenas na fórmula institucional da Congregação, mas passa também (e com grande acento no caso dos Lóios) pela afirmação do elemento mais distintivo de uma comunidade de clérigos: o culto divino solenemente celebrado pelo colégio de clérigos que constitui a comunidade.

Trata-se de um elemento que é carismático na medida que advém da própria natureza das comunidades e da forma como estas se entendem, colégios de clérigos seculares com título de cónegos com vida comum e dedicados, como é norma para as comunidades colegiadas de clérigos e conforme já aqui se explanou, ao solene e perpétuo culto litúrgico.

Os Lóios assumiram esta sua dimensão identitária de um modo constante, significativo e reconhecido ao longo dos quatro séculos da sua existência, mesmo para além dos tempos fundacionais e mesmo num período de manifesta crise para as ordens e congregações religiosas ${ }^{158}$. Saltando séculos sobre a fundação da Congregação, e já numa época de crise das comunidades e próxima ao tempo da exclaustração e extinção, encontramos os Lóios a trabalhar e publicar em liturgia ${ }^{1159}$.

Isabel Pina, ao analisar a vivência das práticas religiosas na Congregação ${ }^{1160}$, inserida precisamente na análise do carisma da Congregação e da forma como este se materializou institucionalmente e em espiritualidade, localiza os Lóios nesta matéria entre as linhas de observância com que a Congregação contactava mais diretamente, descrevendo os elementos que sobre esta matéria são identificáveis nos Estatutos e livros de atas capitulares. De facto a normativa oferece, sobre esta questão, uma perceção alargada da importância do culto divino ${ }^{1161}$ entre os Lóios.

\footnotetext{
${ }^{1157}$ SANTA MARIA, 1697: 385.

${ }^{1158}$ Para dar um exemplo pessoal, e apenas para demonstrar de algum modo o alcance da atividade dos Lóios nesta matéria, tive a oportunidade, no período em que estive empenhado no inventário dos Bens Culturais da Diocese do Porto, de encontrar em diversas paróquias da Diocese, algumas delas das mais remotas e humildes do seu território, exemplares de obras produzidas no séc. XVIII e inícios do séc. XIX no seio da Congregação, todas elas ligadas à liturgia e em que se inserem, por exemplo, diretórios litúrgicos. Saliente-se que nos casos em que pude identificar estas obras no espólio paroquial não estava perante paróquias que tivessem pertencido ao padroado de uma Casa Lóia.

${ }^{1159}$ Ainda em 1797 se imprimia um Ordo officii divini recitandi ac missa sacraticii celebrandi, iuxta breviarium missaleque romanum indultaque specialia servatis SER decretis ad usum Congregationis Canonicorum Secularium S. Joannis Evangelistae in Regno Lusitanus Pro Anno Domini 1798, e dois anos depois um Manuale Chori ad usum Canonicorum Praeclarae Congregationis S. Joannis Evangelistae (cf. ANTT - Manuscritos da Livraria n. ${ }^{\circ}$ 159; ANTT - Manuscritos da Livraria n. ${ }^{\circ}$ 157).

${ }^{1160}$ PINA, 2011: 199, 200, 239 e segs.).

${ }^{1161}$ Por ofício divino (ou liturgia, palavra de origem grega que precisamente significa ofício) compreende-se a liturgia laudativa da Igreja, que com a liturgia sacrifical (que compreende a Eucaristia) e a liturgia sacramental (na qual se compreende a celebração dos sete sacramentos da Igreja, incluindo o da administração da Eucaristia, que se distingue da sua consagração, que pertence ao universo da liturgia sacrificial) formam o conjunto da liturgia da Igreja. A liturgia laudativa, ou ofício divino, define-se então como o conjunto organizado e dirigido de orações e leituras dos livros sagrados recitado pela comunidade de crentes, em particular pelos clérigos e pelo universo monástico (para quem se tornará futuramente obrigatório), organizado para ser celebrado em diversos momentos de cada dia (as denominadas horas canónicas) e organizadas de
} 
Com os seus 109 capítulos $^{1162}$, os Estatutos e Constituições dos Lóios dedicam os seus primeiros 13 capítulos a historiar os elementos centrais das fundações das duas Congregações; seguindo-se 10 capítulos sobre o capítulo geral da Congregação, a sua mais alta instância de poder; 37 capítulos dedicados ao governo das Casas, do provimento e funções dos seus oficiais superiores, de diversas normas que regulam a vida da comunidade e a sua disciplina, da aceitação e formação dos noviços e até matérias de natureza sacramental ${ }^{1163}$, que por isso poderiam sem grande erro colocar-se entre as normas de natureza litúrgica.

Após explanar a memória fundadora da Congregação e de dispor sobre os elementos mais significativos do seu governo, os Estatutos entram então na segunda parte, de 27 capítulos (capítulos 48 a 74), dedicada ao Ofício Divino, precisando os diversos aspetos litúrgicos da vida da comunidade: o ofício divino propriamente dito celebrado pela comunidade em coro, os oficiais do serviço do coro (hebdomadário, antifonário, coreiro, cantores), as missas (de que insiste a assistência diária para os habitantes das Casas lóias ${ }^{164}$ ) e os sufrágios pela comunidade e benfeitores, bem como outras formas de devoção ou o modo como deveriam rezar os leigos que vivessem nas comunidades como comissos ${ }^{1165}$.

O facto da terceira parte das constituições, com 22 capítulos, se dedicar aos ofícios que devem existir em cada Casa para o seu bom funcionamento (excluem-se os ofícios maiores de reitor e vice-reitor que foram compreendidos na primeira parte, e compreende-se o de sacristão, que poderia também ser entendido na parte dedicada ao Ofício Divino), bem como de algumas normas operativas de carácter geral, permite-nos perceber que hierarquicamente os Lóios davam à função litúrgica de uma normal comunidade de clérigos um papel estrutural no seu modo de vida que se seguia de imediato à sua própria estrutura como Congregação, ou seja, em primeiro a forma institucional, em segundo o propósito de vida, e por fim a gestão interna das comunidades.

O capítulo geral foi também um espaço de produção normativa em matérias de natureza litúrgica e espiritual, com uma presença muito clara nos mandados capitulares, nas provisões das Casas e em rubricas das contas por elas apresentadas.

Sendo a liturgia por natureza e definição eclesiástica a expressão material da dimensão espiritual da religião, assegurando através do culto público da Igreja a ligação entre imanente e transcendente, e sendo

acordo com o calendário anual litúrgico. Existe entre as três vertentes da liturgia uma próxima conexão, com primazia da sacrificial, aquele que se considera ser a matriz de toda a liturgia da Igreja. Como o seu nome faz supor de imediato, à liturgia laudativa pertence antes de mais o perpétuo louvor de Deus em vista à sua Glória, e secundariamente o bem e salvação das almas (cf. COELHO, 1950: vol. I, 4 e segs., 18 e segs., 53 e segs., 211, 212).

${ }^{1162}$ Numerados de 1 a 13 na primeira parte de carácter memorialístico, e de 1 a 96 na segunda parte, que contém o que se pode propriamente apelidar (como o faz a própria obra no prólogo às constituições, fl. XI) das Constituições da Congregação (cf. Statutos e Constituyções dos virtuosos e reverendos padres Conegos azuys..., 1540).

${ }^{1163}$ Caso dos caps. 34 e 35 dedicados à confissão na comunidade (para que os Lóios tinham, pelos cónegos de Alga, privilé-

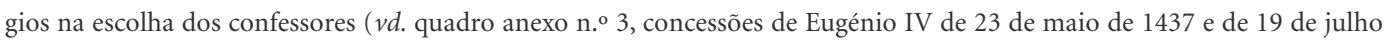
de 1440), o cap. 36 sobre a administração da comunhão, cap. 37 da pregação e pregadores e o cap. 38 sobre a ordenação dos cónegos nas ordens sacras (cf. Idem, ibidem).

1164 Statutos e Constituyções dos virtuosos e reverendos padres Conegos azuys..., 1540: fl. XLIv. («Todos os que em casa estam ouçam cada dia missa»).

${ }^{1165}$ Para quem se prescreve um conjunto simplificado de orações a rezar na igreja (cf. Idem, ibidem: fl. XLII). 
naturalmente este o fito fundamental de uma congregação de clérigos, é expectável que esta dimensão material da Fé seja alicerçada entre os Lóios por um conjunto de determinações e provimentos capitulares destinados a assegurar o seu funcionamento e a dirigir o sentido com que o culto é prestado.

O elevado número de menções e o interesse relativo de uma análise que seria muito longa e descritiva, com resultado pouco relevante para o argumento geral deste trabalho, desaconselham uma análise sistemática dessas referências; salientam-se apenas alguns dados que permitem perceber tendências.

A organização das contas apresentadas em capítulo geral, que nitidamente se aprofunda com a passagem do tempo ${ }^{1166}$, com diferença notória entre os dois livros de atas capitulares que se utilizam, têm nas contas para os anos de $1538-45^{1167}$ informações mais precisas nesta matéria, apresentando como rubrica própria as contas de sacristia.

Uma análise desta rubrica permite ver que são sistemáticos os gastos com consumíveis correntes de uma igreja (cera, sobrepelizes, conserto de paramentaria e alcatifas, além de «coisas miúdas», como surge nas contas de St. ${ }^{\circ}$ Elói de 1538, ou nas do Porto do mesmo ano ${ }^{1168}$ ). Encontra-se igualmente despesas com alfaias litúrgicas, como é o caso da custódia da Casa de Xabregas, para que se juntava dinheiro em 1538, e que estava feita em 15391169; ou paramentaria, como as dalmáticas de veludo preto que Vilar de Frades comprou em 1539, a que em 1540 acrescentou dois pluviais e frontal, bem como um cálice e galhetas ${ }^{1170}$. Surgem ainda gastos com outros utensílios com direta ligação com a vida litúrgica, como os dois sinos que Vilar de Frades mandou fazer, para si e para a Casa do Porto ${ }^{171}$, ou toalhas para todos os altares que St. ${ }^{\circ}$ Elói compra em $1540^{1172}$.

São exemplos que demonstram, na materialidade das práticas correntes da atividade litúrgica, o cumprimento da dimensão carismática de comunidades profundamente ligadas ao solene culto divino.

Para além dos dados fornecidos pelas contas das Casas, as atas capitulares dão-nos, nas determinações capitulares ${ }^{1173}$ relacionadas com a organização da liturgia, numerosos e diversificados exem-

\footnotetext{
${ }^{1166}$ Que aparecem registadas nas atas capitulares apenas a partir de 1486, ano em que o capítulo inclui uma constituição em que manda ao capítulo geral que tome a conta da receita e despesa das Casas, de modo a prover nas necessidade das Casas pelo mútuo apoio (cf. ANTT - Manuscritos da Livraria n. ${ }^{\circ}$ 523, fl. 23).

${ }^{1167}$ ANTT - Manuscritos da Livraria n. ${ }^{\circ} 186$.

${ }^{1168}$ Idem, ibidem: fl. 15, 18.

${ }^{1169}$ Idem, ibidem. fl. 10, 37. Trata-se de um cálice custódia de prata dourada, com imagens aplicadas de S. João e S. Bento.

${ }^{1170}$ Idem, ibidem: fl. 38, 61v.

${ }^{1171}$ Idem, ibidem: fl. 11v.; mas também a determinação que manda que o sino do oratório de Óbidos seja entregue à nova Casa de Arraiolos em 1540 ( cf. fl. 97v.). Ainda para o séc. XV destaque-se a provisão de 1482 em que se manda que a Casa de Xabregas faça um campanário solene, para os sinos, garrida e relógio (cf. ANTT - Manuscritos da Livraria n. ${ }^{\circ}$ 523, fl. 5v.). 1172 ANTT - Manuscritos da Livraria n. ${ }^{\circ} 186$, fl. 65v.

1173 Segundo o sistema capitular dos Lóios as definições eram as determinações que o capítulo geral tomava em matérias de interesse coletivo, e passavam por um triplo crivo: elaboradas num determinado capítulo geral eram designadas por «mandados» do capítulo. Por obrigação normativa tinham de ser revistas nos dois capítulos seguintes, no primeiro eram confirmadas, sob a designação de «louvadas», ou eram cassadas e nem eram registadas. No segundo capítulo se fossem novamente aprovadas entravam na categoria de «confirmadas» e passavam a integrar o corpo normativo permanente da Congregação, pelo menos até serem revogadas por um qualquer outro capítulo geral ou caírem em desuso (cf. Statutos e Constituyções dos virtuosos e reverendos padres Conegos azuys..., 1540: capitulo IIII, fl. XIIII, De ordinandis difinitionibus et ceteris agilibus). Sobre esta questão veja-se o artigo de Pedro Tavares sobre a legislação capitular dos Lóios (TAVARES, 2001c).
} 
plos da centralidade litúrgica na vida da Congregação. Podemos assim encontrar determinações em áreas como:

- Inovação ou aclaração em matéria litúrgica, bem como gestão do calendário litúrgico (com naturais consequências nas devoções cultuadas nas Casas), como quando se determina que se continue a fazer a comemoração de S. João Evangelista nas Casas (como era desejo de D. João III e costume Lóio ${ }^{1174}$ ), quando se introduzem festas de determinados santos (como quando se manda rezar de S. João Crisóstomo, ou solenizar os Santos Cosme e Damião, ou celebrar solenemente a festa do Nome de Jesus ${ }^{1175}$ ), ou se determina a forma como se deve cumprir com o calendário ${ }^{1176}$;

- Determinações de natureza cerimonial, como quando se proíbe uso de pluviais e dalmáticas como ornamento nos degraus do sepulcro nas Endoenças ${ }^{1177}$, se determina a forma do canto solene ${ }^{1178}$ ou as posturas na celebração da missa ${ }^{1179}$. Neste particular deve-se salientar a definição do capítulo geral de 1540, louvado e confirmado nos seguintes, em que se determina que nas Casas da Congregação se usasse o missal que o Bispo Ortiz elaborara, em uso na Capela Real, pelo facto de estarem de acordo com o costume romano ${ }^{1180}$. Aparentemente, e desejando garantir melhor a conformidade litúrgica na Congregação, em 1544 o capítulo manda ao P.e João de S. Paulo que faça um caderno com as cerimónias a usar pelos Lóios, para ser seguido em todas as Casas da Congregação ${ }^{1181}$.

Testemunhando a centralidade da liturgia na vida da Congregação está, entre outras histórias que se podiam avocar, o episódio em que o cronista St. ${ }^{a}$ Maria dá conta como quando o Cardeal Lencastre, então Arcebispo de Braga, visitou de surpresa a Casa de Vilar de Frades, encontrou a igreja vazia de povo mas onde os cónegos celebravam solenemente a missa de terça, com tal dignidade que o prelado «ficou justamente admirado (como elle ao depoes referia), formando grande conceito de quem assim se empenhava nos obséquios de Deos, sem fazer caso dos olhos, nem dos applausos do mundo» ${ }^{1182}$.

Os exemplos não são exaustivos, mas demonstram suficientemente o papel que a liturgia ocupou na vida desta Congregação, que teve no culto solene uma das suas principais marcas carismáticas, herdada aliás da Congregação matricial de Alga, já que aos Lóios se poderia aplicar o resumo, já citado, que de Alga fez Tramontin:

\footnotetext{
${ }^{1174}$ ANTT - Manuscritos da Livraria n. ${ }^{\circ}$ 186, fl. 96v. e 97.

${ }^{1175}$ Idem, ibidem: fl. 19v., 95v., 114v.

${ }^{1176}$ Idem, ibidem: fl. 21. Manda respeitar a data da festa dos santos que se comemoram solenemente.

${ }^{1177}$ Idem, ibidem: fl. 19v.

${ }^{1178}$ Idem, ibidem: fl. 20.

${ }^{1179}$ Idem, ibidem: fl. 20v.

${ }^{1180}$ Idem, ibidem: fl. 103.

${ }^{1181}$ Idem, ibidem: fl. 177.

1182 SANTA MARIA, 1697: 392.
} 
La sua originalità stava [...] nella sintesi della vita devota, umile e solitaria [i.e. o modo de vida de clérigos reformados, dirigida sob um conceito de exemplaridade], unita alla solennità della vita corale, dell'ufficiatura e della liturgia ${ }^{183}$.

Não se esgotava nas horas canónicas e na celebração da missa o serviço pastoral de uma Congregação que o era estruturalmente de homens ordenados de ordens sacras. Funções próprias dos clérigos eram a pregação e a direção de consciência (esta aliás reservada aos sacerdotes, por concretizar-se por via do sacramento da penitência).

São funções de particular relevo pastoral, por se dirigirem à instrução e correção da comunidade cristã: «Assaz manifesto quam proveitosa e necessaria he a confissam e quanto bem naçe dela: porque em ela se recebe a saude spirituale caridosa justificaçam ${ }^{1184}{ }^{2}$, «...antre as cousas que sam mais necessarias ao serviço de Deos e aa salvaçam das almas he a pragaçam e palavra de Deos» ${ }^{1185}$; e tiveram nos Lóios os seus cultores.

Dos pregadores deixaram a memória possível (que nestas matérias nem sempre é fácil) os cro-

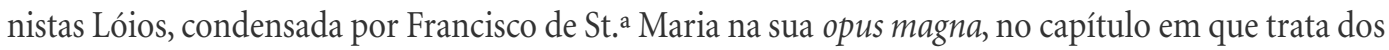
sujeitos insignes em letras ${ }^{1186}$, associando-os aos doutores e mestres da Congregação, apresentando assim a clara noção que a prática da pregação estava, entre os Lóios, proximamente associada à ideia de elevação intelectual.

Modelo principal de pregador entre os Lóios foi Martim Lourenço, um dos padres fundadores, que (como ficou visto) Jorge de S. Paulo estabeleceu como a personificação, entre os três pilares fundadores da Congregação, da via perfectiva ${ }^{1187}$, o terceiro e mais perfeito dos passos para a união com Deus. O seu papel de pregador do Infante D. Fernando e o de intelectual e latinista coloca-o como uma figura paradigmática para o entendimento de pregador douto que vigorava na Congregação.

E de facto os Estatutos dos Lóios definem que o ofício de pregador apenas se poderá exercer por aqueles que forem determinados por capítulo geral, visitação ou pelo reitor geral, sendo escolhidos depois de exame que comprove serem de suficiente ciência, habilidade e gravidade «...pera que nom venha em perigo das almas e desprezo do povo» ${ }^{1188}$, e que uma vez escolhidos só poderão pregar livremente os que forem reitores (que pregam nas suas Casas por ser coisa pertencente à cura das almas), estando os demais pregadores sujeitos a mando do seu reitor para pregarem ${ }^{1189}$.

Não aprofundando em demasia esta questão, retenha-se a afirmação que Francisco de St. ${ }^{a}$ Maria faz sobre a Casa do Porto: «He, e foi sempre este convento, assistido, e frequentado do melhor

\footnotetext{
1183 TRAMONTIN, 1975: col. 155.

1184 Statutos e Constituyções dos virtuosos e reverendos padres Conegos azuys..., 1540: cap. XXXIV, fl. XXVII.

${ }^{1185}$ Idem, ibidem: cap. XXXVII, fl. XXVIII.

${ }^{1186}$ SANTA MARIA, 1697: 522 e seguintes.

${ }^{1187}$ Cf. ADB - Manuscritos, ms. 924, p. 202 e segs.

1188 Statutos e Constituyções dos virtuosos e reverendos padres Conegos azuys..., 1540: cap. XXXVII, fl. XXVIII.

${ }^{1189}$ Idem, ibidem.
} 
da Cidade, ao que atende a Congregação, pondo nelle Conegos de letras, e virtude, para inteira satisfação do pulpito, e confessionario» ${ }^{190}$.

Descontando algum possível exagero por parte do cronista, não deixa de salientar a importância que as atividades de pregação e direção de consciência teriam na vida das comunidades, cujo prestígio moral e espiritual (particularmente mais forte nos primeiro 150 anos de vida da Congregação) atrairiam certamente os fiéis.

Retenha-se que a esta Casa do Porto esteve ligado o cónego Lóio P.e Pedro de St. ${ }^{a}$ Maria, formado Teólogo por Salamanca, público doutrinador pelas ruas do Porto e com pregação que terá reverberado fortemente na cidade, autor de obra catequética relevante, que mereceu diversos estudos de Pedro Tavares ${ }^{1191}$.

\section{Outras formas de culto: relíquias}

Para além do normal culto litúrgico, da pastoral parenética e da direção de consciência, e seguindo a tradição comum da Igreja de veneração das relíquias de santos, também as igrejas Lóias foram com o tempo tentando afirmar-se como centros agregadores de relíquias.

A prática foi, como comummente é conhecido, um dos pontos da tradição eclesial que mais duramente foi criticado pelo universo da reforma protestante do séc. XVI, tanto em polémica literária como na sistemática destruição de relíquias de santos. O concílio tridentino irá reforçar dogmaticamente o culto das relíquias dos santos, intensificá-lo, a par do fomento de outros elementos de natureza similar, como o Agnus Dei ${ }^{1192}$, sacramental ${ }^{1193}$ com origem na Idade Média e cuja produção (que tinha lugar na cúria romana) e utilização vemos ser intensificada a partir de finais do séc. XVI e cuja veneração se mescla com o universo das relíquias ${ }^{1194}$.

A maioria dos dados que vamos encontrando nesta matéria para os Lóios será já para períodos mais tardios da história da Congregação, fora da cronologia que baliza este trabalho, registada na memória cronística da Congregação, em particular em Francisco de St. ${ }^{a}$ Maria que elenca, para finais do séc. XVII, as relíquias existentes nas Casas Lóias.

Algumas delas terão tido algum culto mais intenso, como terá sido o caso da relíquia da cabeça santa ${ }^{1195}$ da Casa do Porto, cultuada na festa do martírio de S. João Baptista, a 24 de junho, quando era exposta à veneração dos fiéis, que pacientemente esperavam para terem as suas cabeças

\footnotetext{
${ }^{1190}$ SANTA MARIA, 1697: 510.

${ }^{1191}$ TAVARES, 1984; TAVARES, 1986; TAVARES, 1988.

${ }^{1192}$ Aos Agnus Dei, placas ovais ou circulares de cera benzidas pelos Papas com água benta e óleo crismal, eram reconhecidos pela sua natureza, que se fazia equivaler a relíquia, um conjunto de virtudes espirituais que se obtinham pela sua veneração e pelo seu uso taumatúrgico. Acerca destas virtudes veja-se o quinhentista Sumario das virtudes da Sancta relíquia AGNUS DEI, segundo o Ceremonial Romano, impresso em Lisboa em 3 de junho de 1585 (exemplar em BNP - Reservados, RES.4532V.); bem como o artigo de Herbert Thurston (THURSTON, 1907).

${ }^{1193}$ Sobre a natureza dos sacramentais veja-se o que diz Dom António Coelho (COELHO, 1950: vol. I, 637 e segs.).

${ }^{1194}$ Sobre relíquias e o seu culto veja-se a tese de doutoramento de Rosa Capelão sobre o assunto (CAPELÃO, 2011).

${ }^{1195}$ Que Francisco de St. ${ }^{a}$ Maria considerava a mais importante relíquia desta Casa (cf. SANTA MARIA, 1697: 509).
} 
tocadas pelo relicário de prata e serem curados, taumaturgicamente, dos males de cabeça que os afligiam $^{1196}$.

Mas entre as relíquias documentadas para os Lóios, as mais antigas serão as que a rainha D. Isabel, mulher de D. Afonso V, lhes lega testamentariamente:

Item se faça huma crus douro meaã bem obrada $p$ [ar] a se poerem em ella toda a Vera Crus que tenho e emcastoarem nella os robins que tenho soltos e as esmeraldas que sam por todos vinte e quatro, e esta crus seja oferecida neste moesteiro [de S. João Evangelista de Xabregas] que mando fazer e mais the dou todaslas outras minhas reliquias. ${ }^{1197}$

Não se conhecendo as demais relíquias que a Rainha possuía na sua capela ${ }^{1198}$, foquemo-nos na relíquia da Vera Cruz, ou Santo Lenho, tipo de relíquia sobejamente conhecida no universo cristão e apreciada pela sua imediata associação à crucificação de Cristo, cerne do mistério da Encarnação e do projeto salvífico para a humanidade ${ }^{1199}$.

A rainha demonstra com esta doação querer aprofundar o dotamento da casa conventual que, em honra de S. João Evangelista, determinava no seu testamento fundar para os cónegos de Santo Elói ${ }^{1200}$, dotando-a com parte do conteúdo material da sua capela e permitindo ao novo convento erguer o seu prestígio enquanto centro de relíquias com a posse de base de uma relíquia de particular relevo.

O desejo da rainha terá sido (pelo menos parcialmente) cumprido, como se poderá depreender da leitura do cronista Santa Maria quando diz que, na Casa de Xabregas, e tendo incluso um viril de cristal com uma relíquia do espinho da coroa de espinhos oferecido pelo arcebispo de Lisboa D. Martinho da Costa:

huma cruz de prata sobredourada, na qual se ve também huma fermosa relíquia do Santo Lenho: a Cruz he peça requissima, e com summa veneração, e estimação se guarda no sacrário da cappella do Crucifixo ${ }^{1201}$.

\footnotetext{
${ }^{1196}$ ADP - Monásticos, Convento de Santo Elói do Porto, lv. do Compêndio do cartório, K/19/6-57, fl. 901e segs.

${ }^{1197}$ Da cédula do testamento da Rainha, datada de 5/2/1452 (ANTT - Congregação de S. João Evangelista, Convento de S. João Evangelista de Xabregas, mç. 17, doc. 7), transcrita como documento anexo n. ${ }^{\circ}$.

${ }^{1198}$ Nesta matéria a biógrafa recente da rainha apenas menciona o trecho do testamento que aqui se citou (cf. RODRIGUES, 2012: 339).

1199 Acerca da preeminência das relíquias ligadas à morte de Cristo veja-se a preeminência litúrgica de que gozam o Santo Lenho e os Instrumentos da Paixão de nas procissões serem transportados debaixo de pálio, o que expressamente se proíbe a relíquias de santos, entre outras disposições no mesmo sentido (cf. COELHO, 1950: vol. I, 651, 681 e segs.).

${ }^{1200}$ Note-se que a rainha na verba do testamento que trata desta questão, transcrito em anexo como supra mencionado, prefere designar a Congregação pela casa lisboeta de St. ${ }^{\circ}$ Elói, certamente não só pela proximidade de St. ${ }^{\circ}$ Elói à Corte, mas também pelo facto de os Lóios deverem esta Casa ao apoio do Infante D. Pedro, pai da rainha, que ela tentava reabilitar e cujas ossadas estariam sepultadas na Igreja de St. ${ }^{\circ}$ Elói antes de serem sepultadas no panteão familiar da Batalha. Veja-se o que sobre isto diz a biógrafa da Rainha, RODRIGUES, 2012: 305 e segs., em particular a p. 316.

${ }^{1201}$ SANTA MARIA, 1697: 487. Difícil não fazer paralelo com o célebre relicário da sucessora de D. Isabel como rainha de Portugal, a rainha D. Leonor, em que se reúnem numa mesma peça (neste caso não de estrutura cruciforme mas em representação de arquitetura) um viril de cristal com um espinho da coroa de espinhos e um pedaço do Santo Lenho. Acrescente-
} 
Nesta matéria uma especulação, certamente perdoável, de modo a tentar situar mais claramente o valor desta doação da Rainha: poder-se-á aventar alguma hipótese da origem da relíquia do Santo Lenho que Dona Isabel lega aos Lóios? Talvez.

Luís Miguel Duarte, na sua biografia do Rei D. Duarte, não deixa de relatar com certo pormenor, na tradição do cronista Zurara, a morte da Rainha D. Filipa de Lencastre. Retoma o relato de como a Rainha, estando no leito de morte e desenganada do seu próximo destino ${ }^{1202}$, reparte pelo marido João e pelos três filhos Duarte, Pedro e Henrique a sua mais preciosa relíquia, a do Santo Lenho ${ }^{1203}$.

Zurara menciona os destinos destes fragmentos: Duarte usou sempre o seu e foi sepultado com ele, posteriormente exumado e entregue à sua viúva D. Leonor de Aragão; o do Infante D. Henrique acompanhá-lo-á ao longo de toda a sua vida e passará depois ao seu sobrinho Afonso V; o do Infante D. Pedro não é mencionado por Zurara ${ }^{1204}$.

Filha de D. Pedro, aquela entre os seus filhos que maior papel alcançou pelo seu casamento com o seu primo Afonso V e a quem coube, por via desta ligação, promover a possível recuperação da Casa de Coimbra, poderá a rainha D. Isabel ter herdado o fragmento da relíquia do Santo Lenho que sua avó, no leito de morte, deixara a seu pai?

É uma hipótese plausível, não documentalmente comprovável (pelo menos assim parece) mas que tem apesar disso o mérito de se pensar que também os Lóios tiveram um lugar no esquema mecenático da Coroa em promover centros religiosos por si fundados ou patrocinados, pela doação de relíquias que os tornarão mais procurados pelos fiéis, crescendo em riqueza e poder.

A tratar-se do fragmento herdado de D. Filipa, vemos a rainha D. Isabel ceder aos Lóios uma relíquia que congrega em si não só o peso religioso e espiritual como a simbólica da dinastia que, como é sabido e Luís Miguel Duarte tão bem salienta quando menciona a forma como Zurara descreve a morte da rainha, procura afirmar-se como dinastia exemplar também no plano de santidade.

O que Leonor de Lencastre fará com amplitude na Madre de Deus de Xabregas ${ }^{1205}$ já a sua tia, prima e sogra Isabel de Coimbra, décadas antes, fazia em S. João de Xabregas.

\section{A consequência do carisma litúrgico: as obrigações de alma}

É sabido a importância e o peso que as obrigações de alma tiveram no universo cristão medieval e católico moderno. Forma de economia transcendental, por via de um legado destinado à prática de

\footnotetext{
-se que a peça, hoje conservada no Museu Nacional de Arte Antiga, foi legado pela rainha ao mosteiro da Madre de Deus que fundou em Xabregas, vizinho portanto daquele dos Lóios. Teríamos assim num curto espaço geográfico a reunião de dois relicários tipologicamente similares.

1202 Escapando-se assim por fim à máxima que diz nada ser mais certo que a morte e mais incerto que a sua hora, «Mors certa, hora incerta».

${ }^{1203}$ DUARTE, 2005: 51, 52.

${ }^{1204}$ Idem, ibidem.

${ }^{1205}$ Sobre a rainha D. Leonor de Lencastre e a sua proteção à sua fundação da Madre de Deus de Xabregas, bem como a sua constituição como centro de relíquias, veja-se a tese de Ivo Carneiro de Sousa (SOUSA, 2002).
} 
boas obras ou a garantir um sufrágio litúrgico, esperava o dotador vir a ser creditado por essa ação na contabilidade divina ${ }^{1206}$.

Foram grandes beneficiários, nesta matéria, as comunidades religiosas, instituições que se acreditava idóneas para o eficaz cumprimento das determinações dos legados, pela sua condição de religiosas e pela durabilidade temporal de que pareciam estar institucionalmente dotadas. Também os Lóios, mesmo que congregação de clérigos seculares e não de regulares professos, tiveram o seu papel nesta matéria.

Os documentos sobreviventes dos cartórios Lóios estão repletos de documentos relacionados com os numerosos legados da Congregação, testemunhando a sua dupla dimensão: a material, que constitui o legado em si mesmo, ou seja, os bens que vão sustentar o cumprimento das obrigações de alma que estão associadas; e a espiritual, traduzida nas missas e sufrágios previstas pelo legado, e cujo efeito propiciatório é o seu objetivo último.

O livro 11 do cartório de St. ${ }^{\circ}$ Elói ${ }^{1207}$, por exemplo, dá-nos uma imagem do que era, em 1694, o mapa das obrigações de alma celebradas em todas as Casas da Congregação. O seu estudo, bem como da numerosa documentação associada a estes legados que se poderá ainda traçar, sustentará um estudo profundo, quando alguém se deliberar a tal.

Para a Casa Lóia de Santa Maria da Feira existe, nesta matéria, um estudo circunstanciado de Pedro Tavares ${ }^{1208}$, em que analisa a dimensão material e espiritual das obrigações de alma inseridas no contexto próprio daquela que foi a última Casa fundada pelos Lóios.

Em relação à Casa Lóia do Porto tive, na dissertação de mestrado, a oportunidade de fazer uma aproximação ao assunto. Concluí pela maior importância da dimensão espiritual destes legados, ou seja a dinâmica litúrgica e cerimonial que gerariam e a que obrigariam a comunidade, do que propriamente pela sua importância material, pois se em 1538-45 os legados (compreendidos na rubrica sacristia) correspondiam a 15\% dos rendimentos da comunidade (contra 74\% das igrejas anexas), em 1641 representavam apenas 9\% dos rendimentos (compreendendo rendimento da sacristia e dotação das capelas) contra $91 \%$ do rendimento gerado pelas igrejas anexas ${ }^{1209}$. Estamos nos antípodas, por exemplo, dos franciscanos do Porto onde o peso material dos legados era elevadíssimo na contabilidade da comunidade, forçando a importância do seu lado material ${ }^{1210}$.

Na senda do papel destacado que se acredita que os Cónegos Lóios tiveram na vivência carismática de comunidades dedicadas antes de mais ao digno e piedoso culto divino, as Casas da Congregação afirmaram-se como escolhas idóneas para o garante do cumprimento de legados de alma. Apro-

\footnotetext{
${ }^{1206}$ Sobre a questão teórica e a sua aplicabilidade em casos práticos veja-se o artigo sobre S. Francisco do Porto (SOUSA, 1982), e o ponto 4.2. da minha dissertação de mestrado sobre a Casa Lóia do Porto (cf. FALCÃO, 2009. 115 e segs.).

${ }^{1207}$ ANTT - Congregação de S. João Evangelista, Convento de St. ${ }^{\circ}$ Elói de Lisboa, lv. 11, Livro de todas as Obrigações das missas assi rezadas como cantadas de todas as Cazas da Congregação e dos Officios e Nocturnos e mais sufragios. O qual mandou fazer o Reverendissimo Padre Mestre Diogo dos Anjos no anno de Mil e Seiscentos e noventa e quatro, sendo segunda ves Geral da Nossa Congregação.

1208 TAVARES, 2008.

${ }^{1209}$ FALCÃO, 2009: 113-115.

${ }^{1210}$ SOUSA, 1982.
} 
funda esta noção o facto de os legados terem um peso mais relevante na determinação do quotidiano litúrgico da comunidade do que propriamente na sua vida económica já que, ainda que fossem materialmente significativos, as obrigações de alma não eram determinantes para o sustento das Casas.

Um possível exemplo desta realidade, da escolha dos Lóios pela seriedade da forma como celebravam o culto divino, está patente na doação do padroado da Igreja de S. Leonardo de Atouguia, com os seus benefícios anexos, que a condessa de Atouguia D. Guiomar de Castro fez aos padres Lóios de Xabregas.

Pretendendo instituir um legado pela alma de seu marido, o $1 .^{\circ}$ conde D. Álvaro de Ataíde ${ }^{1211}$, a Condessa pediu ao rei D. Afonso V, que renovara este padroado no $2 .^{\circ}$ conde, D. Martinho de Ataíde, que aceitasse a sua renúncia ao padroado e consentisse em anexá-lo aos Lóios de Xabregas, para sustentar o legado de alma pelo seu marido e pai D. Álvaro, que fora aio do Rei, que lhe concedera o título condal.

D. Afonso V aceita a renúncia e concede a união por carta régia de julho de 1463, confirmada pelo arcebispo de Lisboa (e fundador Lóio) D. Afonso Anes Nogueira, tomando os Lóios posse em 23 de setembro desse ano ${ }^{1212}$.

Uma memória setecentista, retirada dos documentos do cartório de Xabregas, identifica como motivo da escolha da Condessa, o facto de esta considerar que o cabido formado pelo prior e beneficiados da Atouguia não garantiam o bom cumprimento do legado de alma que instituía, transferindo a sua confiança nesta matéria aos Cónegos da Casa generalícia ${ }^{1213}$.

Note-se ainda que a Casa de Atouguia estava então fortemente ligada à Casa de Bragança. Não desprezando as alianças do Conde D. Álvaro, que se fazem com o Infante D. Pedro ${ }^{1214}$ mas essencialmente com D. Afonso $\mathrm{V}$ de quem foi aio, que o faz conde e ao lado de quem está em Alfarrobeira ${ }^{1215}$, atenhamo-nos sobretudo na figura da própria doadora, a condessa D. Guiomar de Castro.

Tia da duquesa D. Joana de Castro, mulher do Duque D. Fernando I e mãe do Duque D. Fernando II (que teve por confessor o Lóio P.e Paulo de Portalegre, que deixou um relato da sua morte ${ }^{1216}$ ), era portanto irmã de D. João de Castro, o já mencionado colaço de mestre João Vicente.

Somando os dados genealógicos que colocam, simultaneamente, os primeiros conde e condessa da Atouguia na órbita Lóia e da Casa de Bragança, à proximidade que estes titulares tiveram com os seus Reis, podemos ler esta escolha da Casa da Atouguia no âmbito dos círculos sociais que se geram em torno dos príncipes de Avis e da Casa de Bragança, de que os Lóios são participantes desde os seus dias fundacionais e em que são reconhecidos enquanto proposta reformista credível.

\footnotetext{
${ }^{1211}$ Sobre o 1. ${ }^{\circ}$ Conde de Atouguia, suas ligações políticas e carreira cortesã veja-se o que diz Baquero Moreno na sua obra (MORENO, 1980: 720 e segs.).

${ }^{1212} \mathrm{Vd}$. o instrumento de posse com a carta régia e confirmação arquiepiscopal em doc. não numerado inserto no ANTT Congregação de S. João Evangelista, Convento de S. João Evangelista de Xabregas, mç. 5.

${ }^{1213}$ ANTT - Congregação de S. João Evangelista, Convento de S. João Evangelista de Xabregas, lv. 12.

${ }^{1214}$ Como o afirma Rita Costa Gomes (cf. GOMES, 1995: 228, 229).

${ }^{1215}$ MORENO, 1980: 720 e segs.

1216 Sobre o relato da morte do Duque D. Fernando II de Bragança da autoria do P.e Paulo de Portalegre, e as significantes deste texto, veja-se o artigo de Cristina Sobral (SOBRAL, 1997).
} 
Outro exemplo: em associação ao patronato da rainha D. Isabel de Coimbra, podemos situar as instituições de alma que membros da sua família e do seu séquito estabelecem entre os Lóios, colocando-se na dupla posição de apoiarem uma fundação Lóia e em simultâneo de por ela honrarem a memória da Rainha que, por testamento, pretendia fazer em S. Bento de Xabregas a sua fundação de alma, dedicada ao Apóstolo S. João ${ }^{1217}$.

Assim nos documentos sobreviventes do cartório da Casa de Xabregas ${ }^{1218}$ encontramos registadas doações e fundações de alma que podemos relacionar diretamente com a rainha e com o seu desejo fundacional.

O primeiro dos casos é o do irmão de D. Isabel, o condestável D. Pedro, registado como rei de Aragão ${ }^{1219}$, que em 1457 terá doado bens de raiz à Casa de Xabregas com a intenção de a sua igreja servir de seu panteão e da sua descendência, tendo determinado que o rendimento desses bens fosse aplicado às obras da Casa ${ }^{1220}$ durante 10 anos, após os quais serviria para manter duas capelas de missa quotidiana, por si e pela Rainha sua irmã ${ }^{1221}$.

O valimento deste príncipe, segundo o que escreve Jorge de S. Paulo e o cronista Santa Maria ${ }^{1222}$, não se confinaria a este apoio material traduzido na assunção do padroado de uma das suas Casas, mas teria passado pela escolha de um cónego Lóio, o P.e Pedro Gonçalves, 3. ${ }^{\circ}$ Geral dos Lóios, para seu confessor e capelão-mor.

Outro caso de que ficou registo é o de uma das donzelas da Rainha, D. Isabel de Sousa que, segundo a prática corrente de casar as donzelas da Rainha com fidalgos da Casa do Rei ${ }^{1223}$, foi casada com Vasco Martins de Resende ${ }^{1224}$, corregedor de Entre Douro e Minho. Dona Isabel fez testamento em junho de 1459 em que doou 360 mil réis à nova Casa Lóia de Xabregas, por intenção de alma da Rainha e pelas 3 mil dobras de ouro com que a mesma a dotara para casar ${ }^{1225}$.

A memória da rainha D. Isabel, e do Duque de Coimbra seu pai, perdurou longamente numa Congregação que lhes estava certamente grata pelas duas Casas que tinha em Lisboa. Ainda em 1694, uma listagem das obrigações de missa existentes na Congregação, coloca em posição cimeira as missas que na Casa Lóia de Xabregas se celebravam pelos dois ${ }^{1226}$.

\footnotetext{
1217 Sobre a Casa de Xabregas veja-se TAVARES, 1999: 16, 17; PINA, 2011: 137-140.

${ }^{1218}$ Segue-se aqui em particular o Livro trese que contem varias noticias do Cartorio desta Caza e debaixo deste titulo l. ${ }^{\circ} 13$ se achara citado em varias partes (cf. ANTT - Congregação de S. João Evangelista, Convento de S. João Evangelista de Xabregas, lv. 12), bem como o [...] Tombo das Cappellas (ANTT - Congregação de S. João Evangelista, Convento de S. João Evangelista de Xabregas, lv. 18). ${ }^{1219}$ Acerca de quem veja-se a tese de Doutoramento de Luís Adão da Fonseca (FONSECA, 1982).

${ }^{1220}$ Em particular na abóbada da igreja.

${ }^{1221}$ ANTT - Congregação de S. João Evangelista, Convento de S. João Evangelista de Xabregas, lv. 12.

1222 Cf. ADP - Monásticos, Convento de Santo Elói do Porto, lv. do Compêndio do cartório, K/19/6-57, lista dos Gerais dos Lóios, fl. 1055 e segs; SANTA MARIA, 1697: 783 e segs.

${ }^{1223}$ Como afirma, com exemplos, Ana Maria Rodrigues na sua biografia sobre D. Isabel (cf. RODRIGUES, 2012: 335).

${ }^{1224}$ Sobre este fidalgo, com larga folha de serviços à coroa, veja-se o que diz Baquero Moreno (MORENO, 1980: 931-933).

${ }^{1225}$ Cf. ANTT - Congregação de S. João Evangelista, Convento de S. João Evangelista de Xabregas, lv. 18. Registada nas doações livres à Casa de Xabregas (fl. 112-135). O treslado deste testamento pode-se ver em ANTT - Congregação de S. João Evangelista, Convento de S. João Evangelista de Xabregas, mç. 17, doc. n. ${ }^{\circ} 11$.

${ }^{1226}$ Cf. ANTT - Congregação de S. João Evangelista, Convento de St. ${ }^{\circ}$ Elói de Lisboa, lv. 11.
} 


\section{Os livros nos Lóios e em Alga: uma aproximação a linhas comuns de espiritualidade}

A aproximação às linhas de espiritualidade seguidas por uma ordem ou congregação religiosa não é matéria simples de pesquisa, até porque quanto mais avançamos no recuo temporal exponencialmente mais difícil se torna a abordagem.

Algumas destas linhas seguidas pelos Cónegos Lóios estão associadas a ordens e congregações que se têm apontado como suas influências (Jerónimos, Serra de Ossa, Observância Franciscana...), propostas por Silva Dias, Freitas Carvalho ou Pedro Tavares, tendo sobre elas Isabel Pina feito uma reflexão circunstanciada ${ }^{1227}$, pelo que será de escusar o repisar do assunto.

Apesar disso será de propor, pela relação com um dos principais vetores deste trabalho, o de comprovar a proximidade carismática e espiritual dos Lóios à sua matriz italiana, uma análise superficial (porque para profunda se exigiria tempo, meios e páginas) que aproxime o universo das leituras Lóias, que Isabel Pina apresenta na sua tese ${ }^{1228}$, com os dados revelados pelo P.e Napoleão Barbato no seu estudo sobre as fontes de S. Lourenço Justiniano, e que analisa a livraria de S. Jorge em Alga ${ }^{1229}$.

Da biblioteca de Alga, que para Barbato é a forma possível de aproximação às fontes inspiradoras e formadoras de Lourenço Justiniano e da sua obra, não é possível um conhecimento material, pois terá ardido em 1716, quando o mosteiro de Alga estava já em posse dos Carmelitas Descalços, não se conhecendo o seu arrolamento aquando da supressão da Congregação de Alga.

Uma aproximação à livraria dos Cónegos de Alga é no entanto possível, como o faz Barbato, pelo recurso a uma obra que Tomasini, bispo e cónego de Alga, dedicou às coleções de manuscritos das mais importantes bibliotecas públicas e privadas de Veneza ${ }^{1230}$, entre os quais se inseriram os fundos manuscritos da biblioteca de $\mathrm{S}$. Jorge em Alga por recurso a quatro listagens associadas a doações de livros que a Casa recebera no séc. XV e inícios do séc. XVI.

Registam-se em primeiro lugar livros doados pelos fundadores da Congregação: uma listagem das obras doadas por António Correr, registados a par com os volumes existentes em 1481 (44 volumes); uma doação de livros feita pelo Papa Eugénio IV em 1443 (14 volumes); uma listagem dos livros que em 1444 o Cardeal Correr entregara para a Congregação na pessoa de Maffeo Contarini (futuro 2..$^{\circ}$ patriarca de Veneza) então reitor da Casa de S. João Degolado de Pádua, onde o cardeal se recolhera (126 volumes), concluindo-se com uma listagem dos manuscritos que tinham depois destas doações vindo ao mosteiro ( 85 volumes), em que se inseriria a importante doação de livros feita pelo humanista Cardeal Girolamo Aleandro ${ }^{1231}$ à Casa de St. ${ }^{a}$ Maria

\footnotetext{
${ }^{1227}$ PINA, 2011: 229 e segs.

${ }^{1228}$ Idem, ibidem: 242 e segs. Neste ponto salienta precisamente a proximidade dos Lóios a Itália nesta matéria, $v d .256,257$. 1229 BARBATO, 1959.

1230 TOMASINI, 1650.

${ }^{1231}$ O Cardeal Aleandro foi um importante intelectual e humanista italiano, formado em Pádua e Veneza, pertencente ao círculo veneziano de Aldo Manuzio, tendo contactos privilegiados com Erasmo de Roterdão (que lhe chega a entregar cartas de apresentação para uma sua estadia em Paris, onde estudou e onde chegou a ser reitor da Universidade), foi bibliotecário da Santa Sé. Foi-lhe entregue a missão de publicar na Alemanha a bula de condenação de Martinho Lutero, missão após a qual se tornou uma das peças principais na oposição entre católicos e luteranos, já que influenciado pelo Cardeal Carafa, depois Papa Paulo IV (e fundador dos clérigos regulares Teatinos), irá abraçar os esforços reformadores internos da Igreja,
} 
in horto, e que o Papa Paulo III consentira em 1546 que fosse transferida à Casa generalícia de S. Jorge ${ }^{1232}$.

Da análise deste conjunto de obras manuscritas, Barbato salienta que predominam (em ordem decrescente de representatividade) as obras dos santos Doutores da Igreja Agostinho, Tomás de Aquino, Jerónimo, Ambrósio, Bernardo de Claraval, e Beda o venerável, com clara tendência para a tradicional Teologia Escolástica.

Pelo Cardeal António Correr, Alga terá recebido um conjunto de obras dedicadas ao cultivo da vida espiritual interior, de que existe alguma aproximação espiritual à devotio moderna, contando-se com uma carta de Ruysbroek, para além de obras de S. Gregório, Ugo de S. Vítor, Cassiano, Dionísio, e os santos doutores Bernardo e Agostinho.

Barbato defende que a aproximação dos Cónegos de Alga à devotio se faz não por uma direta relação com o movimento norte-europeu, mas por uma partilha de um mesmo substrato espiritual que vicejaria pelos movimentos reformistas que se desenvolviam na Europa dos séc. XIV e XV.

Particularmente, os dois movimentos partilhariam o interesse, patente nesta biblioteca de Alga, pelas obras de St. ${ }^{\circ}$ Agostinho, S. Bernardo (pela sua preferência pela meditação e pela ideia da Imitatio Christi), por Boaventura e a escola franciscana (e o seu método de oração), e em que se destaca particularmente a figura de Ubertino da Casale, já que foi o criador do método de oração seguido em Alga (cuja biblioteca possuía mais do que uma das suas obras) e por ser um autor com obra centrada na vida espiritual interior, tanto lida e seguida em Itália, como apreciada nos círculos reformadores dos países Baixos.

A análise para os Lóios ${ }^{1233}$, baseando-se nas leituras recomendadas pela normativa da Congregação e nas listagens de livros que foi possível obter por menções documentais, referencia 51 obras que, analisadas em paralelo com o artigo de Cristina Sobral dedicado aos Lóios e aos livros no séc. $\mathrm{XV}^{1234}$, permitiu a Isabel Pina concluir pela importância da patrística (Gregório, Agostinho, Isidoro) a par com autores dos séculos finais da Idade Média, o cónego de Alga Lourenço Justiniano, Raimundo Lúlio, Ludolfo da Saxónia, Tomás de Aquino, entre outros.

Se em termos estruturais podemos considerar que existe uma presença forte, nos dois ramos da mesma árvore carismática, das leituras tradicionais dos Padres e Doutores da Igreja (característica aliás comum com o restante universo eclesiástico), já no que se refere a autores mais recentes é notório entre os cónegos de Alga uma presença mais forte de autores do próprio universo italiano (em que se destacaria Ubertino da Casale ${ }^{1235}$ ), enquanto os Lóios demonstrariam ter a influência (forte em Portugal naquele período) de Lufolfo da Saxónia ${ }^{1236}$ e principalmente de Raimundo Lúlio, de que não encontramos aparentemente vestígios entre os padres de Alga.

ocupando um lugar de primeiro plano na organização do concílio e dos esforços reformistas associados a partir da sua criação cardinalícia, em 1538. Morre em 1542 (cf. ALBERIGO, 1960).

${ }^{1232}$ Como se pode ver em TOMASINI, 1642: 482.

${ }^{1233}$ PINA, 2011: 242 e segs.

${ }^{1234}$ SOBRAL, 2003b.

${ }^{1235}$ Sobre a obra de Ubertino da Casale $v d$. POTESTÀ, 1980.

${ }^{1236}$ NASCIMENTO, 1999; SILVA, 2006. 
Esta circunstância não significa que houvesse, nesta matéria de espiritualidade livresca, um divórcio entre Lóios e Alga já que, como Castro Pina salienta ${ }^{1237}$, Itália foi o principal mercado de importação de obras para os Lóios, incluindo os incunábulos identificados na Congregação, mas também porque uma das principais obras de espiritualidade entre os Lóios, a Regra e perfeição da conversação de monges, de Lourenço Justiniano, entra rapidamente na vida dos Lóios, é traduzida pela Infanta D. Cata-

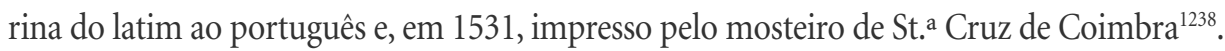

Pelos livros e pela espiritualidade desenvolvida no claustro de Alga sob a liderança de Lourenço Justiniano, elementos de um universo espiritual em transformação que renova as formas de piedade a par da reforma de vida do clero, as duas Congregações aparecem-nos como a partilhar de um mesmo substrato espiritual geral e, por via da espiritualidade Laurenciana, de um referencial próprio do seu carisma comum.

\subsection{OS LÓIOS E A ADMINISTRAÇÃO HOSPITALAR}

Como Pedro Tavares salienta, no seu percurso histórico os Lóios averbaram «importante folha de serviços ao país, nomeadamente no campo assistencial» ${ }^{1239}$, afirmação historicamente acertada mas que, no entanto, não nos deve levar a supor que a Congregação tivesse um carisma assistencial, como aconteceu com outras ordens e congregações religiosas, como os Hospitalários na Idade Média $^{1240}$ ou, no séc. XVI, os Hospitaleiros do português S. João de Deus ${ }^{1241}$.

A prática caritativa entraria na vida dos Lóios, como na vida de qualquer cristão, sustentada sobre os mandatos evangélicos que a mandam observar, que se aplicava internamente no cuidar dos irmãos ${ }^{1242}$ e externamente em auxiliar os mais necessitados. Tal se poderá supor numa simples análise às atas dos capítulos gerais dos Lóios em que se registam, nas contas das Casas, as despesas com enfermaria ${ }^{1243}$, e na disposição que ordena a distribuição de esmolas ${ }^{1244}$.

\footnotetext{
${ }^{1237}$ PINA, 2011: 256, 257.

${ }^{1238}$ JUSTINIANO, 1531. Da versão manuscrita, e já traduzida ao português, utilizada nas Casas Lóias, existe um exemplar em ANTT - Manuscritos da Livraria, n. 513.

1239 TAVARES, 1999: 1.

${ }^{1240}$ COSTA, 2000.

${ }^{1241}$ FILIPE, 2000.

${ }^{1242}$ Nesse ponto os Statutos e Constituyções dos virtuosos e reverendos padres Conegos azuys..., 1540: cap. LXXXVIII, fl. XLVIII, no capítulo respeitante ao enfermeiro, relembram-lhe que «esguarde que esta obra he sobretodas as obras de misericordia, e ho que elle faz ao enfermo faz a Chrispto».

${ }^{1243}$ Como normal em mosteiros, conventos e casas de religião, as Casas Lóias tinham enfermarias onde eram tratados os religiosos, para o que os Estatutos dispunham que cada Casa tivesse um enfermeiro, com ajudante de tal fosse necessário (cf. Idem, ibidem). As contas das Casas inscritas nas atas capitulares de 1538 a 1545 (ANTT - Manuscritos da Livraria, n. ${ }^{\circ}$ 186), mencionam gastos com enfermaria, com relevo tal que nas provisões das Casas do capítulo geral de 1538 se consigna uma renda anual de 12 mil reis para a enfermaria da Casa de St. ${ }^{\circ}$ Elói, cf. fl. 22.

${ }^{1244}$ Ainda que de modo muito incipiente, o primeiro livro de atas que se conhece para os Lóios (ANTT - Manuscritos da Livraria, n. ${ }^{\circ}$ 523), com registos que vão de 1481 a 1500, começa gradualmente a incluir as contas das Casas, em que a expressão esmola aparece algumas vezes, mas podendo-se duvidar da sua aplicação externa à Congregação. A leitura das contas das Casas inseridas nas atas seguintes que se conhecem, de 1538-1545 (ANTT - Manuscritos da Livraria, n. ${ }^{\circ}$ 186) não fazem referências a outras esmolas que não as que as Casas recebem e as que trocam entre si. No entanto é seguro supor que entre
} 
Isabel Pina, que a esta matéria (porque externa à cronologia que baliza a sua tese) dedica apenas alguns parágrafos ${ }^{1245}$, define o trabalho dos Lóios neste campo como uma natural consequência do seu carisma de pastoral ativa e da tradição assistencialista que se podia encontrar entre os cónegos regulares.

A importância recente dos estudos sobre a assistência hospitalar e caritativa (em que os estudos sobre as misericórdias têm dominado) impõe a omnipresença deste conceito global de "assistência», no qual se enquadram um sem número de questões históricas, e na qual se tem, como visto, situado a atuação hospitalar dos Lóios.

Não entrando de forma alguma no debate sobre a natureza e limites deste conceito globalizante, propõe-se no entanto que a análise da atuação hospitalar dos Lóios lhe seja subtraída, pelo menos na interpretação de atividade caritativa dirigida para o «bem-fazer» ${ }^{1246}$, situada num contexto religioso marcado pela ideia que a ação caritativa de uma pessoa sobre a outra (ou outras) se repercutiria na relação do agente caritativo com a divindade, assumindo-se como uma das formas privilegiadas do fiel cristão participar na economia da sua salvação ${ }^{1247}$.

É certo que os Lóios, como Congregação religiosa, se inserem na construção teológica e doutrinal que a Igreja faz em torno da questão das boas obras, que se situam como a forma prática de exercício da virtude teologal da caridade, e cuja realização coloca o cristão na relação com Deus, já que a Igreja crê que esta é infundida entre os homens, pela ação do Espírito Santo, como uma graça de Deus ${ }^{1248}$.

Apesar da pertença doutrinal dos Lóios a um universo em que a ação caritativa consubstanciada em prática assistencial tem um importante lugar, a sua atuação no universo hospitalar parece-me que deve ser lida e entendida externamente a esse enquadramento, e situada na sua atuação palatina, ou seja, entre as atividades que assume no contexto do universo de apoios e relações que estabelece com os dois mais importantes poderes existentes em Portugal, a Casa Real e a Casa Ducal de Bragança.

Será a imagem do cónego Lóio cortesão que iremos encontrar, numa lógica relacional de corte e em que se presta serviços por contraponto aos apoios recebidos, a administrar hospitais régios e da Casa de Bragança. De resto será nestas lógicas que se firmará a sua atividade educativa extra claustral, e que se constituirá como uma atividade a que se sujeitam no serviço régio.

\footnotetext{
os Lóios se praticaria a esmola aos mais pobres, pois o cap. LXXXVII dos Statutos e Constituyções dos virtuosos e reverendos padres Conegos azuys..., 1540: fl. XLVIII e XLVIIIv, dedicado aos porteiros das Casas, determina que dê esmola e bom conselho àqueles que o procurassem.

1245 PINA, 2011: 194.

${ }^{1246}$ Como Maria José Tavares entende ser a base mais notável da ação assistencial medieval (cf. TAVARES, 2000 : 136 e segs.). ${ }^{1247}$ Economia de salvação é o termo patrístico para o conceito Paulino de economia do mistério, com que se nomeia o desígnio de Deus para a humanidade, processo em que se insere o mistério da Encarnação divina, que coloca no cerne de um projeto salvífico para a humanidade. Neste sentido a economia da salvação é o meio pelo qual a divindade propõe a salvação da humanidade, e por aproximação os meios a que essa humanidade recorre para se aperfeiçoar e situar nesse percurso salvífico. Deste modo se entende que as práticas de boas obras, que na tradição católica está a par da fé como condições para a salvação, são elemento de participação deste processo de Economia de Salvação (cf. Catecismo da Igreja Católica, 1993: \$1066). ${ }^{1248}$ Cf. Compêndio do Catecismo da Igreja Católica, 2005: n.o 384 e segs.
} 
Nesta chave de leitura a atuação assistencialista dos Lóios (se assistencialista a poderemos considerar, o que nos parece duvidoso) irá circunscrever-se a um campo muito específico, que é o da administração hospitalar, e que nos leva a vê-los, sem anacronismo imperdoável, como umas das primeiras formas estruturadas de múltipla administração hospitalar que se pode encontrar em Portugal.

Recorrendo a um plebeísmo, poder-se-á dizer que no campo da administração hospitalar os Lóios estariam mais próximos da imagem atual de um gestor hospitalar, considerado como um profissional da área da gestão e coordenação de pessoas e meios, do que dos corpos gerentes de uma qualquer instituição de solidariedade social que, num contexto de trabalhos assistencial voluntário, dedicam algum do seu tempo a gerir as atividades da sua instituição.

É certo que os Lóios não foram os primeiros a gerir hospitais ou instituições congéneres, que como se sabe assumiam nos finais da Idade Média uma imagem algo distinta da visão contemporânea de uma instituição hospitalar.

Afinal «os hospitais medievais e do Renascimento eram, antes de mais, casas religiosas, orientadas por matrizes espirituais bem definidas e pontuadas pelos conceitos de pobreza e de caridade» ${ }^{1249}$.

Mais do que espaços de assistência na saúde (como hoje os entendemos), os hospitais na transição da medievalidade para a modernidade eram (ainda) espaços de assistência material caritativa, que quer fossem estabelecidos por razões de natureza puramente religiosa, quer se enquadrassem como estruturas que garantissem o equilíbrio social e atenuassem as desigualdades (ou, com probabilidade, tendo ambos os fitos), dedicavam-se a recolher, alimentar, vestir e tratar os mais pobres.

Implicavam, consoante a sua dimensão, uma estrutura material mais ou menos complexa para garantir o desenvolvimento da sua atividade, com os meios correspondentes, e cuja gestão foi crescendo em complexidade, acentuada no séc. XV com os movimentos de reforma das instituições hospitalares $^{1250}$.

Num contexto internacional em que os hospitais tardo-medievais e proto modernos serão essencialmente instituições piedosas seculares, administradas por elites locais (confrarias ou municípios), e num contexto nacional em que as ordens religiosas e a Igreja em geral estiveram na prática afastados da instituição de hospitais e da sua administração ${ }^{1251}$, a administração dos Lóios não deve assim ser entendida para além da sua natureza específica de gestão e controlo de meios.

A escolha dos Lóios, pelo rei D. João III, para assumir a direção de hospitais da órbita régia insere-se ao cabo de um longo processo de reforma hospitalar em Portugal.

\footnotetext{
${ }^{1249}$ RODRIGUES, 2013: 11.

${ }^{1250}$ Idem, ibidem. A Tese de Lisbeth Rodrigues, ainda que tratando de um hospital específico, que aliás foi da administração dos Lóios por cerca de 2 séculos, faz no entanto um trabalho de análise de conceitos em torno do fenómeno hospitalar da primeira modernidade e dos processos de reforma das instituições hospitalares que então se operaram, acabando por estabelecer um «estado da arte» para a produção nacional e internacional mais recente.

${ }^{1251}$ Idem, ibidem: 20, 21.
} 
Ante um universo vasto de pequenos hospitais medievais existentes, com ação que andava entre ajuda material aos mais pobres e a assistência na saúde, e a dificuldade em garantir que estas instituições, fundadas em legados pios, fossem corretamente geridas e o legado cumprido (seja pela gestão pouco escrupulosa dos administradores, ou pela insuficiência material dos seus bens dotais para cumprir integralmente os objetivos da fundação), vamos encontrar a Coroa, desde os inícios do séc. XV, a promover uma reforma gradual que procurava concentrar e fundir este número alargado de instituições, garantindo unidades hospitalares de maiores dimensões, com rendimentos suficientes e uma gestão a que os poderes régios, pelo menos na supervisão, não seriam alheios ${ }^{1252}$.

No decurso deste processo de reforma hospitalar promovido pela coroa vão surgir unidades hospitalares que se definem como modernas e que marcam uma alteração em relação ao padrão de hospital do período medieval. Isabel Sá, ao trabalhar a questão, menciona três hospitais nesta situação: o real de Todos os Santos, o das Caldas da Rainha e o da Misericórdia de Lisboa. Os dois primeiros virão a conhecer a administração dos Lóios.

O primeiro, e mais relevante, hospital que os Lóios receberam foi o Hospital Real de Todos os Santos, o qual é o epítome da reforma hospitalar pensada e desejada pela coroa portuguesa, particularmente por D. João II que sobre ela trabalhou, e que se viria a converter em exemplo para outros hospitais geridos na órbita régia. Criado a partir da agregação de mais de quatro dezenas de hospitais medievais lisboetas, assume-se como a maior instituição hospitalar do reino. Nas palavras do cronista Lóio:

invento acertadíssimo del-Rey D. João o II porque considerando, que havia em Lisboa muito hospitais dedicados a differentes Santos, e com differentes administradores, e para differentes enfermidades, se resolveo em redusir todos a hum, entendendo, que se fazia por este modo mais certa a boa administração da fazenda, reduzido a menos mãos o manejo della ${ }^{1253}$.

Além da dimensão, o hospital real de Todos-os-Santos incorpora um conjunto de inovações no entendimento do que é um hospital, sendo portanto a todos os níveis uma instituição marcante no domínio da assistência na saúde em Portugal ${ }^{1254}$.

Será por ele que a Coroa terá iniciado a lista dos hospitais que se entregam à administração dos Cónegos Lóios, e cujo elenco se segue, elaborado com recurso ao cronista e à crónica dos Lóios, ainda que com a recomendável cautela que as informações veiculadas pelo P.e Santa Maria nos pedem, por ser maior o seu compromisso com a promoção da Congregação do que com a verdade documental ${ }^{1255}$.

\footnotetext{
1252 SÁ, 1996: 87, 93.

1253 SANTA MARIA, 1697: 279.

${ }^{1254}$ Não entrando pormenorizadamente neste assunto, que é marginal ao tema da tese, remete-se para a leitura de obras em que se faça essa reflexão (SÁ, 1996; SÁ, 1998; RODRIGUES, 2013; CARMONA, 1954).

${ }^{1255}$ O P.e Francisco de Santa Maria parece ter seguido na sua obra a máxima de que uma boa mentira tem sempre um fundo de verdade. Para além do que Isabel Pina menciona como «variantes» introduzidas pelo cronista a documentos que transcreve na sua crónica (cf. PINA, 2011: 33), encontramos a completa alteração de um documento original para compor um dado histórico. Explique-se: em 12 de abril de 1541 o Duque de Bragança D. Teodósio escreve ao capítulo geral a pedir-lhe que o reitor de Évora tome a provedoria do seu hospital de Portel, como a Congregação já tinha a do seu hospital de Arraio-
} 
Segundo o cronista, o rei D. João III teria entregado aos Lóios, a partir de 1530, os seguintes hospitais: em Lisboa o hospital real de Todos-os-Santos; o hospital de Jesus Cristo de Santarém; o hospital de St. ${ }^{\circ}$ André de Montemor o Novo; o hospital do Espírito Santo de Évora; o hospital das Caldas da Rainha; o hospital real de Coimbra; os hospitais das vilas de Vimieiro e de Castanheira, a que se juntariam os hospitais da Casa de Bragança de Portel e Arraiolos em $1541^{1256}$.

Ainda segundo o cronista, desde os princípios que esta ocupação na gestão hospitalar seria encarada como um pesado encargo pela Congregação, da qual obteria em grande parte escusa em 1563, quando apenas mantém debaixo da sua administração os hospitais régios de Coimbra e das Caldas da rainha, e os dois hospitais da Casa de Bragança ${ }^{1257}$, informação que no caso do hospital de Santarém se tem de aceitar com alguma cautela e atirar cronologicamente para a frente, porque ainda encontramos provimento de provedor e almoxarife para o hospital de Santarém no final do séc. XVI ${ }^{1258}$.

Documentalmente vamos encontrar, datado de 8 de março de 1530, o alvará de D. João III dirigido ao Geral dos Lóios em que lhe dá conta da má gestão do hospital de Todos-os-Santos, que atribui ao desinteresse do provedor em exercício, e de como se determinara a entregar a gestão do hospital à Congregação, a quem pede que aceite em capítulo geral e que nomeie para provedor do hospital padres que trabalhem caridosamente em prol dos doentes ${ }^{1259}$.

A partir desta data, e em atenção ao trabalho que tenha sido efetuado pelos padres Lóios na administração do hospital lisboeta, foram sendo entregues pela coroa os hospitais já mencionados.

A atividade de administração hospitalar entra rapidamente na vida da Congregação, como se torna patente por uma leitura das atas capitulares de $1538-1545^{1260}$.

Logo em 1538 é louvada a definição feita no ano anterior em que o capítulo manda:

que os almoxarifes e mordomos dos espitaes não se vão deles ate não fazerem primeiro entrega aos que de novo vierem e emformados primeiro nas cousas necesareas antes que se partão so[b] pena de serem por isso bem pinitemciados. E os provedores farão também pessoallmente sua entrega $a^{1261}$.

\footnotetext{
los e outros hospitais do reino. Desta carta ducal, cujo original se conserva na Torre do Tombo (cf. ANTT - Congregação de S. João Evangelista, Hospital de S. João de Portel, lv. 1, fl. 25) e está transcrita em anexo a esta tese, o cronista dos Lóios elabora uma carta que imprime na sua crónica, que se converte na oferta única e simultânea dos dois hospitais (cf. SANTA MARIA, 1697: 282, 283), de que um confronto será muito interessante para ajuizar o modo como o cronista oficial dos Lóios elaborou a sua crónica.

1256 SANTA MARIA, 1697: 280 e segs.

${ }^{1257}$ Idem, ibidem.

${ }^{1258}$ Conforme se pode observar pelo provimento destes oficiais no livro de atas capitulares que se conhece posterior ao de 1538-45, que é o que concentra os registos de 1589 a 1604 (cf. ANTT - Congregação de S. João Evangelista, Convento de St.o Elói de Lisboa, lv. 15.

${ }^{1259}$ ANTT - Hospital de São José, lv. 940, fl. 147. Transcrito em anexo documental.

${ }^{1260}$ ANTT - Manuscritos da Livraria, n. ${ }^{\circ} 186$.

${ }^{1261}$ ANTT - Manuscritos da Livraria, n. ${ }^{\circ}$ 186, fl. 20. Confirmado no ano seguinte, fl. 46.
} 
Percebe-se no capítulo a preocupação por garantir que a transição entre gestores nomeados pela Congregação ocorra sem dificuldades, insistindo numa "passagem de testemunho» informada.

No mesmo capítulo é louvada a prescrição que ordena ao contador dos hospitais ${ }^{1262}$ que só os visite para fazer contas durante a visita do Geral, ou conforme ao que este determinar, procurando que a gestão e tomada de contas se faça em moldes que não escapem ao controlo do Geral ${ }^{1263}$.

Nas eleições, e logo a seguir aos reitores, vêm eleitos os provedores dos hospitais: Gaspar dos Reis para Santarém, Luís da Conceição para as Caldas e Jacob de Santa Maria para Montemor ${ }^{1264}$. Também na lista dos padres mudados encontramos uma referência, ao P.e João de Santa Maria que de Recião passa para Santarém onde será almoxarife do hospital ${ }^{1265}$. À pergunta lógica do motivo porque não aparecem as eleições dos almoxarifes dos hospitais nas atas do capítulo geral, e sem dados objetivos, parece que se poderá supor que nesta fase os almoxarifes dos hospitais seriam os padres que eram dados como companheiros aos padres provedores, como o faz pensar este registo de mudado.

As eleições para provimento dos hospitais são então uma constante anual, e percebe-se a existência de alguma estabilidade no exercício desses ofícios ${ }^{1266}$, ainda que em 1542 o capítulo geral disponha que os padres destacados para os hospitais não estejam a serviço mais do que um triénio ${ }^{1267}$.

Esta decisão interna de fazer rodar os provedores e almoxarifes dos hospitais a exemplo do que acontecia com os cargos da própria Congregação, leva a que em maio de 1544 os oficiais do hospital de Todos os Santos representem ao Rei pedindo-lhe que obste com a alteração regular de provedores e almoxarifes do hospital pelo capítulo geral dos Lóios, por a considerarem nefasta para a gestão do hospital $^{1268}$.

Em resposta, D. João III envia uma carta ao Geral dos Lóios dando-lhe conta do seu desejo que o provedor e almoxarife do hospital de Todos os Santos que estavam em exercício, pessoas recomendáveis por virtuosas e pelo conhecimento que já tinham da gestão da instituição, não sejam mudadas no capítulo desse ano, cumprindo com um outro triénio ${ }^{1269}$.

No capítulo geral da Congregação de 1541 já tinha aparecido a eleição para provedor do hospital de Lisboa, ou seja o de Todos-os-Santos, a somar-se às eleições dos três hospitais mencionados ${ }^{1270}$, e que nos permite supor que a eleição do provedor do hospital de Lisboa não ia anualmente a capítulo, mas apenas em triénio, e cuja ausência dos registos de 1544 se explicará pelo desejo expresso

\footnotetext{
${ }^{1262}$ Personagem que não pertence ao universo institucional da Congregação, pelo que se supõe tenha sido cargo criado internamente pela Congregação para fiscalizar, em contexto de visitação, a gestão material que os padres provedores e almoxarifes dos hospitais desenvolviam nas instituições.

${ }^{1263}$ ANTT - Manuscritos da Livraria, n. ${ }^{\circ}$ 186, fl. 20v. Confirmado no ano seguinte, fl. 46.

${ }^{1264}$ Idem, ibidem, fl. 25.

${ }^{1265}$ Idem, ibidem, fl. 26v.

${ }^{1266}$ Caso de Gaspar dos Reis que se pode observar no governo de Santarém de 1538 a 1542 e nas Caldas de 1542 a 1544 , e de Luís da Conceição nas Caldas de 1538 a 1541, em 1541 transferido para o hospital de Lisboa onde substitui o padre João de Santiago, onde fica até 1544 (cf. Idem, ibidem, eleições de 1538 a 1544).

${ }^{1267}$ Idem, ibidem, fl. 132v.

${ }^{1268}$ ANTT - Corpo Cronológico, parte I, mç.. 74, n. ${ }^{\circ} 96$.

${ }^{1269}$ ANTT - Corpo Cronológico, parte I, mç.. 75, n. ${ }^{\circ} 115$.

${ }^{1270}$ ANTT - Manuscritos da Livraria, n. ${ }^{\circ}$ 186, fl. 116.
} 
pela carta de D. João III, que como vontade régia terá encontrado compreensível eco entre os padres capitulares.

Não surgem menções às eleições para provedor dos restantes hospitais que então já estariam na órbita dos Lóios, mas em que o cargo estava adstrito ao reitorado de uma Casa: ao reitor de Évora caberia o do hospital do Espírito Santo da mesma cidade, bem como o do hospital de Portel, enquanto o de Arraiolos seria do reitor da Casa da mesma vila, exceção no ano de 1545 em que o cargo de provedor vem a eleição de capítulo ${ }^{1271}$, o que se compreende pelo facto de nesse ano a Casa de Arraiolos estar descolegiada, por causa das obras, e apenas ter nela a residir o Padre Marcos da Consolaçãa ${ }^{1272}$, que além do encargo das obras assegurou a provedoria do hospital.

Do hospital de Montemor, de que não conhecemos ao certo o gestor mas que supomos estar adstrito à casa de Évora, sabemos estar na órbita Lóia antes de 1540, ano em que o capítulo, na lista dos irmãos a mudarem de Casa, envia-lhe o Padre Álvaro da Cruz, em substituição do Padre Jorge do Salvador, que regressa à Casa de Évora ${ }^{1273}$.

Como Isabel Sá salienta, a regência do Cardeal D. Henrique e o reinado de D. Sebastião marcam o fim da escolha régia dos Lóios como opção para administração hospitalar, claramente uma solução do reinado de D. João III, e do seu apoio às congregações de carisma ativo, e triunfa a opção pela administração hospitalar nas mãos das irmandades de Misericórdia, cujo papel nesta matéria será central nos séculos seguintes.

O que importa salientar claramente, até para obstar à leitura totalizante que pretendem fazer os historiadores que se dedicam às Misericórdias, é que como se percebe pelo historial dos Lóios nesta matéria, a gestão dos hospitais por irmandades de Misericórdia não foi no Portugal quinhentista escolha única, nem escolha primeira, nem sequer escolha contínua (houve hospitais, como o de Portel, em que se alternaram as administrações, se bem que claramente com preferência dos Lóios), mas apenas foram a escolha que acabou por vencer e tornar-se dominante ${ }^{1274}$.

A diferença de dimensão institucional entre estas irmandades, em que se concentram as diversas elites seculares do reino, e uma ordem canonical com poucas centenas de religiosos acaba por se impor, não deixando apesar disso de ser notável a capacidade dos padres Lóios em atuarem nesta área de um modo muito relevante durante 3 décadas, e numa posição mais periférica por séculos, pois mantêm-se como administradores dos hospitais das Caldas e de Coimbra até ao séc. XVIII e às reforma de Pombal, enquanto os da Casa de Bragança serão por eles providos até à forçada extinção da Congregação em 1834.

Para além das eleições dos padres provedores dos hospitais da administração da Congregação, o capítulo geral, demonstrando o empenho institucional dos Lóios nesta sua nova atividade, vai legislar

\footnotetext{
${ }^{1271}$ Idem, ibidem, fl. 210.

${ }^{1272}$ Idem, ibidem, fl. 213.

${ }^{1273} \mathrm{Idem}$, ibidem, fl. 74 e seg. A suposição feita de estar ligado à Casa de Évora sustenta-se no facto de os padres mencionados em mobilidade saírem e retornarem à Casa de S. João de Évora.

${ }^{1274}$ SÁ, 1998: 51 e segs. Marta Lobo de Araújo chama precisamente atenção, na sequência da atuação lóia, da necessidade de se matizar a ideia de um domínio absoluto das misericórdias na administração hospitalar (cf. ARAÚJO, 2001).
} 
pontualmente em matérias que se consideram relevantes para a eficaz gestão, e de modo a garantir que esta não conflitua com a sua normal vida claustral.

Nos mandados de 1539, e no aprofundamento das determinações para uma eficaz gestão dos hospitais, decide-se a escolha de um padre para servir de procurador na Corte, a residir nas Casas das terras onde esta estiver, para que trate dos assuntos que respeitam aos hospitais, bem como aos da própria Congregação «por evitarmos as sobejas saídas que se fazem poor causa dos spritaes». Decisão que no entanto revertem no ano seguinte ${ }^{1275}$.

Precisamente visando evitar as saídas excessivas dos padres vamos encontrar um mandado de 1542 a ordenar aos padres destacados nos hospitais que não saiam sem os seus companheiros a visitar os hospitais ou a tratar dos seus negócios, o que recomenda particularmente ao de Arraiolos ${ }^{1276}$.

Em 1540 louva-se o mandato do ano anterior (de que no entanto não se encontra registo nas atas) que define que os provedores dos hospitais tenham lugar de reitores, como eles ordenados pela sua antiguidade e que sejam eleitos pelos definidores do capítulo ${ }^{1277}$. Decidem também que o «provedor das Caldas seja escuso de hir a capitulo e isto por o el Rey nosso senhor o mandar pedir porque então he necessário estar em o dito sprital» ${ }^{1278}$.

Estas decisões de 1540 revelam dois dados interessantes: o primeiro é que a Congregação reconhece aos provedores dos hospitais uma posição institucional relevante, a mais alta que a Congregação conhece e que é o reitorado; o segundo é que se nota que a Coroa acompanha interessada o desenrolar da atividade de gestão dos padres, não se coibindo de requerer ao seu capítulo geral providências em matérias que interessam à boa gestão dos hospitais.

Por este pedido do Rei, e relacionando-o com o que D. João III formulará em 1544, percebe-se que, nas matérias que concernem à gestão dos seus hospitais, a Coroa deseja que a Congregação adapte as suas práticas institucionais às exigências da administração hospitalar sempre que estas pareçam não coincidir.

Encontramos pontualmente disposições do capítulo que visam a gestão financeira das instituições; é o caso de um mandato de 1545 que é taxativo em proibir os almoxarifes dos hospitais em emprestar dinheiro do hospital sem licença dos provedores, e ordenando a estes que só consintam estes empréstimos sob penhores de prata ou ouro ${ }^{1279}$.

\footnotetext{
${ }^{1275}$ ANTT - Manuscritos da Livraria, n. ${ }^{\circ}$ 186, fl. 46v. e 69.

${ }^{1276}$ Idem, ibidem: 131.

1277 Os definidores eram o colégio eleitoral da Congregação que se reunia depois da eleição geral dos reitores das Casas (em que se incluía o Geral, a quem cabia o reitorado de S. João de Xabregas), e que era constituído pelos reitores e seus companheiros e pelo escrivão da visitação. Cabia-lhes eleger os vice-reitores, procuradores, deputados e confessores das Casas, bem como decidirem quem será promovido às ordens sacras. Além disso cabia-lhes decidir as mudanças de religiosos entre Casas e fazer novas definições para a normativa da Congregação (cf. Statutos e Constituyções dos virtuosos e reverendos padres Conegos azuys..., 1540: cap. X, fl. XVI. Por este mandado do capítulo os provedores dos hospitais passam a ser eleitos integrados no sistema eleitoral da Congregação.

${ }^{1278}$ ANTT - Manuscritos da Livraria, n. ${ }^{\circ}$ 186, fl. 70.

${ }^{1279}$ Idem, ibidem: fl. $212 \mathrm{v}$.
} 
Na mesma senda, e pelas contas de Arraiolos de 1539, ficamos a saber que o padre responsável pelo hospital recebia salário pelo seu trabalho, que se regista entre os rendimentos da comunidade ${ }^{1280}$.

Outro exemplo é o do mandato do capítulo geral de 1541 que dispõe o uso no Oratório de Alentejo $^{1281}$ de parte de cem mil réis que o Rei dera em esmola à Congregação do hospital de Santarém $^{1282}$. Estas informações pontuais dão-nos algumas pistas para responder uma pergunta que naturalmente se coloca: qual o ganho material obtido pela Congregação com o exercício das provedorias hospitalares, entendendo-se para além da satisfação moral e espiritual que possa obter da prática caritativa ou da honra e proveito que advém do serviço régio.

As atas capitulares revelam explicitamente benefícios financeiros em algumas das gestões; já Marta Lobo considera que na gestão dos hospitais da casa de Bragança os ganhos não seriam financeiros mas apenas adviriam das recompensas espirituais e da participação em redes de poder ${ }^{1283}$.

Um dado é notório na consulta das atas capitulares em relação à administração dos hospitais: a atividade de gestão é externa à atividade própria da Congregação. A sua administração corre por delegação de uma autoridade, é controlada pelo reitor geral e por um contador, é fiscalizada em visita da Congregação, mas não é apreciada pelo capítulo geral como é a gestão das Casas Lóias.

O capítulo geral apenas trata dos hospitais para nomear os provedores e almoxarifes (ato normal de gestão dos seus recursos humanos) e para aceitar encargos de hospitais ou para legislar pontualmente em matérias que têm por finalidade garantir que a gestão recorra sem sobressaltos assacáveis à Congregação.

Em 1541 o número de hospitais administrados pelos Lóios foi aumentado com a aceitação do hospital de Portel, a pedido do Duque de Bragança, a cujo senhorio pertencia, e na sequência da prévia integração do hospital de Arraiolos, que também pertencia ao universo senhorial da Casa de Bragança ${ }^{1284}$.

Posterior a 1545, porque ausentes da documentação Lóia antes disso, terão sido as incorporações dos hospitais de Coimbra, Castanheira e de Vimieiro à administração dos Lóios, dos quais apenas o de Coimbra, entregue à gestão dos Lóios em $1548^{1285}$, perseverará na sua administração para além de 1563/64, e isto até à reforma pombalina da Universidade.

Pesado encargo assumido pelo ónus contraído pela Congregação junto de D. João III, a quem os Lóios estariam obrigados pelo seu apoio, e de que estariam isentos pela morte do Rei, é a justificação de Francisco de Santa Maria para a desistência que a Congregação faz da administração da maior parte dos hospitais ${ }^{1286}$.

\footnotetext{
${ }^{1280}$ Idem, ibidem: fl. 45.

${ }^{1281}$ Sobre o oratório de Alentejo, no termo de Óbidos, que de experiência eremítica acabará por passar aos Lóios, e onde depois disso se tentarão várias experiências de vida (FONTES, 2009).

${ }^{1282}$ ANTT - Manuscritos da Livraria, n. ${ }^{\circ} 186$, fl. 114v.

${ }^{1283}$ ARAÚJO, 2003: 346.

${ }^{1284}$ ANTT - Manuscritos da Livraria, n. ${ }^{\circ}$ 186, fl. 115.

${ }^{1285}$ De que foi primeiro provedor o P.e Diogo da Ressurreição, como se poderá ver em AUC - Hospital Real, est. 7, tab. 3, lv. 11.

1286 SANTA MARIA, 1697: 280 e segs.
} 
Versão diferente lemos da pena do secretário da visitação de 1651, que acompanhou os visitadores da Congregação na fiscalização anual do hospital real de Coimbra, da sua administração. Aí afirma taxativamente, ao mencionar o costume dos provedores dos hospitais usarem uma bengala em símbolo de autoridade:

por ser este o custume dos nossos religiosos provedores, feitos pellos senhores Reis de Portugal assim no Hospital de todos os Santos de Lisboa como o de Santarem, e os mais que largamos por se nos não apremiar como se devia o grande serviço que a Deos e aos senhores Reis fazíamos nestas tão charidozas ocupacois pera que nos rogarão ${ }^{1287}$.

O secretário da visitação deixou, nesta nota, bem expresso o sentimento de insatisfação (que certamente não seria apenas seu, mas vox populi na Congregação) perante o que considerava ser o desequilíbrio entre o trabalho desenvolvido e o proveito obtido. Aparentemente nem sempre bastariam as recompensas espirituais, e ante um esforço excessivo que se entende mal recompensado a Congregação optou por apenas conservar parte das suas administrações hospitalares, garantindo assim que não perde de uma só vez todo um espaço de intervenção social.

Para a administração hospitalar dos Lóios sobrevivem corpos documentais suficientes que permitem um trabalho aprofundado, o que é mais importante ainda se tivermos em conta que existem trabalhos, de maior ou menor dimensão e profundidade e que aqui já se têm vindo a citar, que se têm dedicado ao estudo de algumas das instituições hospitalares geridas pelos Lóios, ainda que nunca na perspetiva da sua gestão. Este é pois um tema ainda por aprofundar sistematicamente, repto que aqui se deixa lançado.

Como estudos de caso que sustentem a análise que aqui se foi fazendo, e como subsídio para um futuro estudo alargado do tema, deixa-se uma análise breve de duas das instituições hospitalares que mais tempo estiveram sob a administração dos Lóios.

Uma das instituições é régia e esteve sob administração Lóia de 1548 até ao consulado pombalino. A outra pertencia ao universo da Casa de Bragança, sobre administração dos Cónegos Azuis de 1541 até 1834 e que já foi alvo de um estudo breve na perspetiva da instituição pensada a partir dos Arquivos da Casa de Bragança e da Misericórdia de Portel (instituição que acabará por ter a sua posse depois de séculos de tentativas), e que aqui se pretende, pela leitura dos documentos de fundos documentais ligados aos Lóios, apresentar na perspetiva do seu processo de gestão.

\section{Hospital Real de Coimbra}

Fundado em 1508 pelo Rei D. Manuel I e, de acordo com a prática de concentração de pequenas instituições hospitalares, constituído pela reunião de um conjunto de albergarias e confrarias coim-

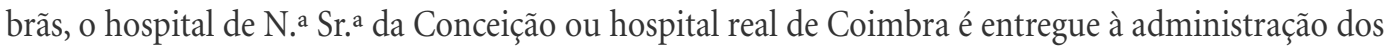
padres Lóios por carta régia de D. João III, datada de 29 de junho de $1548^{1288}$.

\footnotetext{
${ }^{1287}$ AUC - Hospital Real, est. 7, tab. 3, lv. 6, fl. 13v.

${ }^{1288}$ AUC - Hospital Real, est. 7, tab. 3, lv. 2.
} 
Terá estado sobre a administração prévia da Misericórdia de Coimbra, como se supõe da leitura de uma petição do prior de St. ${ }^{a}$ Justa $^{1289}$, sendo mais um caso em que a administração dos Lóios e da Misericórdia concorreram entre si, com preferência dos Lóios sobre a Irmandade, tendo administração de provedores singulares a intermediar.

Em 1568 a Coroa une-lhe as rendas em sobra dos hospitais de Montemor o velho, Tentúgal e Pereira, para aumentar a sua capacidade de atendimento ${ }^{1290}$.

A instituição gozou de diversos privilégios, liberdades e isenções concedidas pela Coroa, tendo em vista o cumprimento da sua função institucional, concedidos antes e depois da sua entrega à Congregação dos Lóios, e dos quais os volumes do seu arquivo, hoje unido ao da Universidade de Coimbra, dão satisfatório testemunho.

Para a Congregação o hospital de Coimbra teve um outro papel que não apenas o de mais um hospital na sua gestão.

No contexto da transferência da Universidade de Lisboa para Coimbra, e com o aparecimento nesta cidade de um conjunto de colégios das ordens religiosas que visavam garantir a inserção dos seus religiosos num universo de formação superior e num contexto eclesial de reforma em que se insiste no aprofundamento da formação clerical ${ }^{1291}$, os Lóios vão procurar também ter o seu colégio coimbrão. Afinal, como escrevia o P.e Jorge de S. Paulo:

São os Doutores da Igreja, e os Mestres das religiões sagradas, e os Pregadores da ley evangélica as colunas principaes em que se sustenta o edifício spiritual de toda a christandade, o bom governo do eclesiástico [...], e a boa doutrina pera a salvação das Almas, alem de serem as estrellas que com seus resplandores desterrão a obscuridade dos ignorantes, e lucernas que com suas luzes aperfeiçoão os entendimentos humanos ${ }^{1292}$.

Enquanto a Congregação não se decide a construir o seu próprio colégio, o que só acontecerá em 1631, ao cabo de um longo processo constitutivo ${ }^{1293}$, o hospital real vai funcionar como a residência coimbrã dos religiosos que frequentam os estudos superiores, segundo Francisco de Santa Maria por licença de D. João III ${ }^{1294}$, o que não deverá estar longe da verdade, porque de outro modo dificilmente se poderia compreender a utilização de uma estrutura da Coroa.

\footnotetext{
${ }^{1289}$ AUC - Hospital Real, est. 7, tab. 3, lv. 1, fl. 62. Petição sobre o pagamento de uma obrigação de missas instituído em 1370 e que caberia à confraria de St. ${ }^{a}$ Maria e S. João de Santa Cruz de Coimbra, a qual foi depois anexada ao hospital e Misericórdia de Coimbra, e que com a separação entre os dois organismos passou o hospital à administração da coroa e desta à dos Lóios. ${ }^{1290}$ AUC - Hospital Real, est. 7, tab. 3, lv. 1, fl. 25.

${ }^{1291}$ FONSECA, 2000.

${ }^{1292}$ ADB - Manuscritos, ms. 924, p. 713.

${ }^{1293}$ Este processo pode-se perceber pelas informações das atas capitulares de 1598-1604, que já mencionam o esforço da Congregação para obter meios para esta fundação de Colégio em Coimbra, que será exclusivamente sua (cf. ANTT - Congregação de S. João Evangelista, Convento de St. ${ }^{\circ}$ Elói de Lisboa, lv. 15). Também Jorge de S. Paulo ao mencionar no seu Epílogo a missão romana do P.e Pedro de S. João Garcês informa que este obteve diversas concessões materiais para o Colégio (cf. ADB - Manuscritos, ms. 924, p. 712).

${ }^{1294}$ SANTA MARIA, 1697: 517.
} 
O colégio de Coimbra teve alguma importância na vida da Congregação como espaço por onde passou a formação universitária da Congregação, ainda que só se assuma como relevante no final do período temporal que delimita esta obra, e que será um período em que a Congregação não possui já a dinâmica que conhece na dinastia de Avis. Deste mundo universitário Lóio deixa Jorge de S. Paulo uma imagem patente no seu Epílogo, quando no capítulo 72 trata Dos religiosos que florecerão insignes em letras, e dos Doutores e Mestres que houve na Congregação ate o ano de $1658^{1295}$.

Sobre o hospital real de Coimbra, e sua natureza institucional específica, há uma reflexão que importa não deixar por fazer. Numa conferência, em 2011, designei este hospital como um «hospital universitário», o que causou incómodo numa académica coimbrã ligada aos estudos de assistência, que sustentou então publicamente que o hospital real de Coimbra não era, nem nunca fora, um hospital universitário, e que tal instituição só surgirá com o organismo que substituirá (e herdará) o hospital real, e que é o hospital da Universidade de Coimbra instituído no consulado Pombalino.

O reparo, porque me pareceu despropositado na relação com a pesquisa efetuada, mereceu-me um aprofundamento da reflexão, e a tentativa de perceber se este hospital, que de facto não levou nunca no nome a designação de hospital da Universidade, teve ou não alguma função de hospital universitário.

Não querendo entrar num longo debate sobre a natureza do que é um hospital universitário, socorro-me do decreto-lei ${ }^{1296}$ que estabelece o regime jurídico dos hospitais que servem a formação universitária pré-graduada, e nos quais se define como instituição desta natureza (entre outras) as instituições prestadoras de cuidados de saúde em que se desenvolvam atividades práticas de formação.

Neste conceito podemos ler modernamente que o hospital real de Coimbra foi um hospital universitário, ficando à discussão apenas se os padres Lóios e a comunidade que servia, e era servida, pelo hospital real de Coimbra se entendiam como parte de um hospital universitário. A resposta parece-me claramente que é sim.

Não sendo o hospital real de Coimbra um hospital da Universidade, foi no entanto um hospital universitário, pois era nele que estava previsto que os professores e alunos de Medicina da Universidade de Coimbra desenvolvessem a sua atividade prática formativa.

Em petição do provedor do hospital ao Rei, de 1597, este menciona que os estatutos da Universidade mandam que os lentes de medicina das cadeiras de prima, vésperas e de Avicena visitem os doentes do hospital em presença dos estudantes de medicina, para que estes possam acompanhar os processos de cura e para que os lentes lhes falem das doenças e dos remédios e modo da sua aplicação. Esta atividade era remunerada anualmente com 12 mil réis, e as suas obrigações nem sempre cumpridas, pelo que se queixa o provedor e lhe dá razão a Mesa de Consciência e Ordens ${ }^{1297}$.

\footnotetext{
${ }^{1295}$ ADB - Manuscritos, ms. 924, p. 712.

${ }^{1296}$ Decreto-Lei n. ${ }^{\circ}$ 206/2004. «D. R. I Série A. 195» (2004-08-19).

${ }^{1297}$ AUC - Hospital Real, est. 7, tab. 3, lv. 1, fl. 74v. e 75.
} 
Já em carta régia datada de Lisboa a 6 de fevereiro de 1562, ao provedor do hospital, tinha-se concedido a alteração da prática que no hospital faziam os lentes de medicina com os seus alunos, de acordo com os estatutos da Universidade, para o que se emite um alvará com a nova forma, considerada em melhor proveito dos alunos e dos enfermos.

Acentuando a ideia de que o hospital real tinha um papel importante na formação médica da universidade de Coimbra, a carta régia ordena ainda que se faça no hospital uma casa para as aulas de anatomia, à custa da universidade, no lugar e maneira que melhor parecer ao seu reitor e ao provedor do hospital ${ }^{1298}$.

O primeiro livro de visitações que se conhece para o hospital, já do período de 1633 a 1694, revela igualmente o papel do hospital na vida formativa da Universidade, e acentua a importância que lhe era atribuída em sede de visitação $0^{1299}$.

Importa pois salientar que, sob a administração dos Cónegos de S. João Evangelista, o hospital real de Coimbra prestou um relevante serviço científico e pedagógico à Universidade portuguesa, servindo de instituição hospitalar de formação prática dos futuros médicos. Em suma, um hospital universitário.

\section{Hospital do Espírito Santo de Portel}

Entre os hospitais da Casa de Bragança administrados pelos Lóios conta-se o hospital do Espírito Santo da vila de Porte ${ }^{1300}$, instituído como confraria no tempo e com o apoio do senhor desta vila, D. João Peres de Aboim, confirmado pelo seu genro D. João Fernandes de Lima ${ }^{1301}$.

Do tempo em que D. Nuno Álvares Pereira detinha o senhorio de Portel foi feito treslado dos documentos principais do cartório e que nos informam desta fundação, dos bens e apoios concedidos pelos senhores da Vila, e que nos indica ser hospital associado ao senhorio ${ }^{1302}$, que passará à Casa de Bragança.

A entrega deste hospital à Congregação de S. João Evangelista dá-se em 1541, onze anos depois da entrega do primeiro hospital à sua administração, por pedido expresso do Duque de Bragança D. Teodósio I em carta datada de Lisboa a 12 de maio, e dirigida ao capítulo geral dos Lóios desse ano, reunido em S. João de Évora, dizendo:

\footnotetext{
${ }^{1298}$ Idem, ibidem, doc. avulso inserto.

${ }^{1299}$ Como se poderá ver nas visitas de 1646, 1648 e 1649, em que se menciona a queixa generalizada dos lentes de medicina não visitarem diariamente os doentes com os seus alunos, fazendo-se substituir por médicos mais novos e inexperientes, com prejuízos graves para alunos e pacientes (cf. AUC - Hospital Real, est. 7, tab. 3, lv. 6).

${ }^{1300}$ Este hospital conta já com um artigo, da autoria de Marta Lobo, publicado em 2003, que o aborda pelo prisma da documentação da Casa de Bragança e da Misericórdia de Portel, a quem pontualmente esteve entregue a provedoria do hospital, e a quem será definitivamente entregue em 1834, aquando da extinção da comunidade lóia de Évora (cf. ARAÚJO, 2003). A abordagem que faço vai pela documentação que sobre este hospital se conserva no cartório dos Lóios de Évora.

${ }^{1301}$ Será interessante notar que a sua mulher D. Maria Anes, filha de D. João Peres de Aboim e herdeira do senhorio de Portel, foi fundadora de um hospital em Lisboa, para 10 merceeiras pobres, que viria a ser incorporado no reinado de D. João II no novo hospital de Todos os Santos (cf. CORREIA, 1941; FERRO, 1973). Assim se começa a perceber os padrões e as redes existentes nestas fundações pias.

${ }^{1302}$ Está integrado no volume de agregação documental respeitante a este hospital, que se conserva na Torre do Tombo, sob a cota ANTT - Congregação de S. João Evangelista, Hospital de S. João de Portel, lv. 1, fl. 63 e segs. A existência deste documento é mencionada por Marta Lobo a partir das referências que encontra num cronista setecentista de Portel (cf. ARAÚJO, 2003: 342).
} 
Na minha villa de Portel há hum Esprital de onesta remda [...] o qual eu muito desejo que seja governado e regido por padres dessa vosa Casa de Sam Joam asy como o he o Esprital da Villa de Arraiolos e o sam outros Espritaes neste reino, porque da maneira que ele agora amda hei que nam se faz nisso muyto serviço a Nosso Senhor, como se faria semdo regido por padres dessa vosa Hordem. E porque a dita villa estaa dessa cidade seis legoas posto que seja alguum trabalho em hirem padres dela a prover no que comprir ao dito Esprital e governo dele, asi se fará nisso muito serviço a Nosso Senhor porque as remdas dele seram milhor aproveitadas e amdara tudo em boa hordem [...] e pera menos trabalho podeis ordenar e enleger huum padre ou dous nesa Casa a que deis o cuidado do governo do dito Esprital nam pera que estem continos se nam pera que tres ou quatro ou cinquo vezes no anno vão prover nelle como vos parecer que milhor se podera fazer pera as remdas se arrecadarem e despemderem no necessareo comforme aa hordem que tem no Esprital d'Arraiolos ${ }^{1303}$.

Tendo o capítulo-geral dos Lóios determinado aceitar o encargo que o Duque lhes oferecia, fá-lo em termos que deixam bem claro a que título a Congregação toma posse da superior administração do hospital:

Haa por bem o capitulo de aceitar ao duque de Braguança ho regimento do ospital de Portel. E o rector da casa d'Évora ho proveraa quando e como se contiver nas suas provisoens ${ }^{1304}$.

A 22 de agosto o Duque comunica aos juízes e oficiais da Vila de Portel a sua decisão de entregar a provedoria do hospital aos padres Lóios ${ }^{1305}$. Um alvará de 22 de novembro desse mesmo ano de 1541, novamente dirigido aos juízes e oficiais de Portel, bem como ao seu ouvidor, dando licença para alienar umas cabeças de gado dos bens do hospital, revela que não só se tinha levantado oposição local à tomada de posse («algumas pessoas lhe forão aa mão [do provedor] polo qual não acabara de asemtar as cousas como comprian a serviço de Deus e bem do dito Esprital» ${ }^{1306}$ ), como o estado do hospital por altura da posse era tal que obrigava à alienação das cabeças de gado para seu provimento ( «achara tudo muito destruído e danificado e de maneira que hera muito necessareo proverse» ${ }^{1307}$ ). Fica assim justificado, pela pena ducal, a decisão tomada de chamar os Lóios para a administração deste hospital.

O objetivo do Duque de Bragança é claro, estando insatisfeito pelo modo como decorre a administração do hospital da sua vila, e estimulado pelo exemplo dos outros hospitais administrados pelos Lóios (incluindo do seu senhorio, como o de Arraiolos), pretende que estes assumam o encargo da superior gestão do hospital de Portel, substituindo-se aos provedores escolhidos entre o poder local e

\footnotetext{
${ }^{1303}$ ANTT - Congregação de S. João Evangelista, Hospital de S. João de Portel, lv. 1, fl. 25. Documento completo transcrito em anexo documental.

${ }^{1304}$ ANTT - Manuscritos da Livraria, n. ${ }^{\circ}$ 186, fl. 115.

${ }^{1305}$ ANTT - Congregação de S. João Evangelista, Hospital de S. João de Portel, lv. 1, fl. 11.

${ }^{1306}$ Idem, ibidem: fl. 21. Alvará transcrito no anexo documental.

${ }^{1307}$ Idem, ibidem.
} 
que, aparentemente, não teriam o desempenho mais eficaz. Para o Duque seria garantia de uma eficaz gestão de meios humanos e de recursos, pelo controlo da boa cobrança de rendas e do seu correto dispêndio.

Aos Lóios caberá, como define o regimento que em 1592 o Duque D. Teodósio II concede ao hospital ${ }^{1308}$, o cargo máximo da instituição, o de provedor, que será ocupado doravante pelo reitor de S. João de Évora.

No texto do regimento distingue-se claramente entre os ministros que devem servir no hospital para atender aos pobres e enfermos (mordomo, escrivão, médico, capelão, sangrador, enfermeiros e boticário) e o provedor, a quem caberá dirigi-los, e que deve ser pessoa de capacidades intelectuais e morais $^{1309}$.

Uma leitura do regimento aliás faz perceber que o provedor em momento algum intervinha ou participava nos atos curativos ou caritativos, apenas lhe caberá (até pelo óbvio motivo de residir em Évora e não em Portel) o governo superior da casa, em que se entende a gestão mais relevante ${ }^{1310}$, o controlo da atuação dos demais envolvidos na vida do hospital, a escolha da maioria dos «ministros» que nela servem, com exceção do mordomo e do escrivão, a quem cabe o controlo e a direção quotidiana ${ }^{1311}$ da instituição e cuja escolha o Duque reserva para si.

O papel do Provedor do hospital, o reitor da Casa Lóia de S. João de Évora, aparece assim como um nível intermédio de poder entre o senhor de Portel (e por inerência padroeiro do hospital) e a instituição que servia a população da vila e de passagem, e tinha os seus lugares providos entre as gentes da elite local ${ }^{1312}$.

Como forma de enrobustecer a posição destes seus representantes no governo dos seus hospitais (e possivelmente pelo seu estado clerical e pelo facto de serem isentos e imediatos à Santa Sé), bem como em atenção ao respeito do seu próprio poder e autoridade, o Duque obtém da Coroa carta régia, datada de 11 de abril de 1554, para o provedor dos resíduos da comarca de Évora, com ordem

\footnotetext{
${ }^{1308}$ Idem, ibidem, fl. 1. Está publicado por Marta Lobo em anexo ao seu artigo (cf. ARAÚJO, 2003), a partir do exemplar que se conserva no arquivo da Casa de Bragança. As duas versões diferem na data, enquanto o exemplar dos Lóios está datado de 2 de abril de 1592, a versão utilizada por marta Lobo está datado de 2 de abril de 1593.

${ }^{1309}$ ANTT - Congregação de S. João Evangelista, Hospital de S. João de Portel, lv. 1, fl. 1 e segs.

${ }^{1310} \mathrm{O}$ regimento reserva que todos os atos principais de gestão, seja na administração dos bens e rendas, seja na gestão do pessoal, tenham a sua intervenção, como agente principal ou para confirmar a atuação do mordomo, que nem poderia gastar somas superiores a 100 reis sem consentimento do provedor ou seu representante (Idem, ibidem).

${ }^{1311}$ A presença do mordomo no quotidiano no hospital depreende-se desde logo pela determinação do Regimento para que visite o hospital duas vezes por dia, uma de manhã e outra à tarde (cf. Idem, ibidem: determinação 9).

${ }^{1312}$ Como Marta Lobo menciona brevemente, sustentando que se escolhiam entre os notáveis da terra e entre pessoas afetas ao serviço da Casa de Bragança (cf. ARAÚJO, 2003: 346), como de facto parece ter sido. Assim se poderá supor com mais certezas da provisão da duquesa Infanta D. Catarina (filha do Infante D. Duarte e como tal neta do rei D. Manuel I, por via de quem entrou a sucessão régia na Casa de Bragança), datada de Vila Viçosa a 18 de outubro de 1586, em que manda ao provedor tomar como fornecedor do hospital o boticário da Vila de Portel, que era irmão do boticário do Duque seu filho (D. Teodósio II) (cf. BPE - Hospital de Portel, Cod. CLXVI/2-42, doc. avulso). No mesmo conjunto documental encontram-se outras nomeações que um estudo aturado poderia certamente situar entre as elites locais e de serviço da Casa de Bragança.
} 
para que não tome conta aos padres Lóios da gestão dos hospitais de Portel e Arraiolos, bem como não entenda em nada que a estes religiosos respeite ${ }^{1313}$.

A gestão não parece ter sido sempre fácil, e Marta Lobo regista no longo tempo (1541-1834) diversos momentos em que o desempenho da provedoria pelos Lóios levantou problemas, dúvidas e críticas $^{1314}$, sobretudo entre os poderes locais.

Destacam-se as questões em torno da Misericórdia e do seu desejo de tomar em mãos a direção do hospital, o que segundo a autora poderá ter acontecido por duas vezes, por períodos curtos, a primeira das quais em 1578 e no contexto de crescimento do Irmandade. Em 1581 os Lóios já estavam novamente no exercício da provedoria hospitalar ${ }^{1315}$.

Estas duas notas episódicas que menciona integram-se num contexto de longo tempo de ações da Misericórdia de Portel para tomar posse do hospital e da sua provedoria ${ }^{1316}$, que não passaria apenas pelo confronto direto, mas também pelas tentativas diplomáticas.

Uma carta da Misericórdia de Portel ao reitor dos Lóios de Évora, de 17 de setembro de 1596, permite supor que a primeira administração do hospital pela Misericórdia tivera conhecimento e aval dos Lóios, pois afirma colocarem-se ao serviço do provedor e religiosos Lóios para por eles exercerem as obras de Misericórdia no hospital de Portel, tendo grande sentimento em ver a pouca boa vontade que o reitor lhes mostrava em usar seus serviços. Afirmam que tinham devolvido ao Duque os alvarás e cartas que ele lhes tinha concedido e que este lhos enviara de volta com indicação de que se entendessem com o Reitor de S. João de Évora sobre o assunto ${ }^{1317}$.

Por esta carta se supõe os dinamismos destes processos, o interesse da Misericórdia (sempre uma instituição representativa dos poderes locais) na gestão do Hospital, o papel dos Lóios como intermediário entre a gestão local do hospital e a Casa de Bragança (note-se que o Duque indica o reitor como instância com quem tratar).

Malgrado as circunstâncias ocasionais que se possam ter gerado nos quase 3 séculos de administração Lóia sobre o hospital de Portel, fique o registo da gratidão ducal de D. João, futuro rei do Portugal Restaurado como D. João IV, do terceiro mês do seu ducado:

He tão antigua a vontade e devação que todos os religiosos desse convento tem as cousas desta Casa, que com muita confiança podem esperar de mim que lhe saberei meresser todas as demonstrações de afeição que me fizerem [...] Deos o guarde. Escrita em Vila Vicoza a 18 de Janeiro de 1631.

[ASS]: O DUQUE $E^{1318}$

\footnotetext{
${ }^{1313}$ BPE - Hospital de Portel, Cod. CLXVI/2-42, doc. avulso. Treslado da carta régia original, datado de Vila Viçosa a 27 de julho de 1627.

${ }^{1314}$ Veja-se, como exemplo, uma carta do Duque D. Teodósio II, de 13 de outubro de 1602, pedindo ao reitor de Évora que faça visita ao hospital brevemente, como tinha prometido, porque havia tempo que não a fazia e o Duque fora informado de que era necessário prover (cf. Cf. BPME - Hospital de Portel, Cod. CLXVI/2-42, doc. avulso).

${ }^{1315}$ ARAÚJO, 2003: 343e segs.

${ }^{1316}$ Idem, ibidem.

${ }^{1317}$ Cf. BPE - Hospital de Portel, Cod. CLXVI/2-42, doc. avulso.

${ }^{1318}$ BPE, Hospital de Portel, Cod. CLXVI/2-42, fl. Não numerado. Transcrito em anexo documental, doc. n. ${ }^{\circ} 9$.
} 


\subsection{UM CARISMA INVOLUNTÁRIO: OS LÓIOS E A EDUCAÇÃO}

Confessa-se que o título deste ponto colocou algumas dúvidas sobre se deveria ser formulado como afirmação ou interrogação, ou seja, será que a atividade educativa foi, entre os Lóios, um carisma involuntário? Mais importante ainda, teve a atividade educativa da Congregação um papel de relevo no Portugal de Avis?

Ponto prévio: a educação não é um elemento carismático da Congregação de Alga ou dos Lóios, e isto como é entendido em instituições de vida consagrada de carisma especificamente educativo, como o são, por exemplo, as Doroteias (Congregação das Irmãs de St. ${ }^{a}$ Doroteia) ou os Lassalistas (Instituto dos Irmãos das Escolas Cristãs).

Uma leitura dos Estatutos dos Lóios permite perceber rapidamente que o seu mais importante documento normativo não dedicava ao tema dos estudos e formação na Congregação mais do que uns poucos capítulos e de carácter meramente interno, essencialmente dedicados à formação no contexto do noviciado.

Determina-se que preferencialmente se recebam na Congregação noviços com mais de 18 anos e dotados de pré-requisitos relevantes para o serviço do culto divino (saber cantar e tocar, conhecer profundamente as horas canónicas) mas também que sejam bem preparados na escrita e gramática $^{1319}$, idade e preparação que nos permite supor que se espera que os futuros cónegos venham à Congregação dotados de alguma maturidade e conhecimentos.

Os jovens aceites para noviciado eram entregues ao mestre de noviços (por inerência o vice-reitor de cada Casa), a quem cabia a obrigação de examinar os noviços em vida e costumes, bem como de os ensinar, aconselhar e castigar ${ }^{1320}$. O ano de noviciado era destinado ao que chamaríamos hoje discernimento vocacional, estabelecendo-se que os noviços começassem por ser preparados em matéria de confissão, no cerimonial da Congregação e nas suas constituições; ao mestre de noviços caberia induzir os jovens a um ambiente propício de oração e meditação e aprendizagem da virtude da humildade.

Sendo um período dedicado à transição à vida em comunidade era vedado aos noviços, e enquanto durasse o ano de noviciado, a frequência de outro tipo de formação, como aprender ou ensinar gramática ou qualquer outra disciplina ${ }^{1321}$, ainda que se determinasse que apenas aprendessem os cónegos a quem o reitor e deputados assim o determinassem ${ }^{1322}$.

Apesar das poucas especificações normativas sobre o ensino nas Casas, não deixam os Estatutos de determinar o privilégio de um lugar, no tempo de inverno, junto ao lume aceso «pera as pessoas que aprenderem e ouverem de tomar lição» ${ }^{1323}$.

Já os irmãos comissos (aqueles considerados inábeis para se ordenarem de ordens sacras, e como tal impedidos de serem cónegos de pleno direito) eram obrigados a conhecer as constituições e

\footnotetext{
${ }^{1319}$ Cf. Statutos e Constituyções dos virtuosos e reverendos padres Conegos azuys..., 1540: cap. XXVI, fl. XXIIIv. e XXIV.

${ }^{1320}$ Para o mestre de noviços $v d$. Idem, ibidem: cap. XXV, fl. XXIIIv.

${ }^{1321}$ Idem, ibidem: cap. XXVII, fl. XXIV, XXIVv.

${ }^{1322}$ Idem, ibidem: cap. XXXVIII, fl. XXVIIIv.

${ }^{1323}$ Cf. Idem, ibidem: cap. XXIII, fl. XXIIv.
} 
cerimónias da Congregação $0^{1324}$, o que nos permite supor um período de formação durante o seu ano de provação ${ }^{1325}$.

Para além destas poucas referências à formação no seio dos Lóios exaradas no seu principal instrumento normativo, podem-se ainda encontrar na mesma fonte referências ao universo da escrita, ou seja, aos livros existentes nas Casas da Congregação: condições de acesso e uso ${ }^{1326}$ (entre os quais poderemos incluir o capítulo que determina as leituras escolhidas para o refeitório ${ }^{1327}$ ), e a instituição do ofício de livreiro ( «hum irmão que seja latino se se poder fazer» ${ }^{1328}$ ), particularmente dedicado à gestão da livraria de cada casa e a garantir o digno tratamento dos seus livros.

As referências dos Estatutos demonstram a existência de uma atividade intelectual na Congregação, bem como de atividade educativa entre os padres situada aparte da formação base para a vida comunitária, compreendida no ano de noviciado.

Apesar da ausência de uma dedicação carismática ao ensino, os Cónegos Seculares italianos e portugueses devem ter tido, desde os primeiros dias, uma necessidade estrutural de ação educativa, imprescindível dada a natureza própria de uma instituição de clérigos seculares, dedicados ao solene culto divino, à pregação e ao acompanhamento espiritual das comunidades, inseridos num contexto reformista que baseava a sua linha de reforma na promoção de um clero digno e preparado.

É de supor que a primeira e mais básica necessidade educativa dos Lóios foi a de formar os seus padres (apesar da norma que mandava procurar noviços que já viessem à Congregação dotados de alguns estudos), não se distinguindo os Lóios substancialmente das práticas educativas das restantes ordens e congregações religiosas que, de um modo mais ou menos aprofundado, estabeleciam alguma forma de formação dentro dos seus claustros ${ }^{1329}$. Mas os Cónegos Seculares acabariam por não se cingir a educar aqueles que vestiam o seu hábito talar, e em dado momento abriram as portas do seu estudo a elementos exteriores à comunidade.

Podemos, em matéria de ensino, situar os Lóios num sistema educativo que combinará, pelo menos para o período desta obra em que dispomos de fontes capitulares ${ }^{1330}$ (ou seja, em termos de

\footnotetext{
${ }^{1324}$ Cf. Idem, ibidem: cap. XIX, fl. XXv. Como se pode supor para os comissos quando se define que têm de se comprometer a cumprir com as constituições e cerimonial, o que implicará pelo menos o conhecimento destes documentos.

${ }^{1325}$ Idem, ibidem.

${ }^{1326}$ Idem, ibidem: cap. XXIII (que determina como se podem ter e aceder a livros, que livros deve haver nos coros das Casas, e que os lóios não possam escrever livros sem licença do reitor).

${ }^{1327}$ Em latim liam-se os Antigo e Novo Testamentos, em português legendas de santos, o Vita Christi (tratar-se-á certamente da tradução portuguesa da obra de Ludolfo da Saxónia, $v d$. NASCIMENTO, 1999), uma Vida dos Santos Padres e a tradução que a Infanta D. Catarina fez de Ho Livro da regra e perfeyçam da conversaçam dos monges, de Lourenço Justiniano e que viria a ser impresso por iniciativa do prior de Santa Cruz de Coimbra (cf. JUSTINIANO, 1531) (cf. Statutos e Constituyções dos virtuosos e reverendos padres Conegos azuys..., 1540: cap. XXXIX, fl. XXVIIIv., XXIX). Para além desta determinação, o cap. XCII estabelece que os Estatutos e Constituições sejam lidos mensalmente no refeitório, nas quatro têmporas do ano, nas visitações, no capítulo geral e ad libitum dos reitores de cada Casa, seguindo a ordem da sua redação nesta versão impressa: primeiro o fundamento da Congregação de Alga, seguido do da Congregação dos Lóios.

${ }^{1328}$ Idem, ibidem: cap. XCI, fl. L.

${ }^{1329}$ ANTUNES, 2000; FONSECA, 2000.

${ }^{1330}$ ANTT - Manuscritos da Livraria, n. ${ }^{\circ}$ 523; ANTT - Manuscritos da Livraria, n. ${ }^{o} 186$.
} 
datas extremas, entre 1481 e 1545), as duas dimensões fundamentais do ensino da Época Moderna: o ensino específico dirigido para a preparação do clero (de que Trento apresenta como novidade a criação de seminários diocesanos para formar o clero secular) e o ensino público dirigido à formação académica dos mais jovens, em que se notabilizarão, a partir do séc. XVI, os Jesuítas e os Oratorianos ${ }^{1331}$.

Se no primeiro ponto é de salientar a educação entre os Lóios, na primeira metade do séc. XVI, de jovens africanos, de que uma parte estaria destinada à ordenação sacerdotal (funcionando assim como instituição de formação de futuros clérigos seculares, suprindo as funções que serão futuramente atribuídas a seminários diocesanos) ${ }^{1332}$; já no segundo deve ter-se em consideração que a tendência inicial da atividade educativa extraclaustral dos Lóios se situa não no novo sistema escolar que a 2. ${ }^{a}$ metade do séc. XVI irá introduzir, mas no sistema de ensino associado a comunidades religiosas que, em Portugal, se encontra em atividade para os séculos finais da medievalidade, entre Franciscanos e Dominicanos, em Alcobaça, nos mosteiros de cónegos regulares de St. ${ }^{a}$ Cruz de Coimbra e de S. Vicente de Fora, e entre os Lóios de St. ${ }^{\circ}$ Elói de Lisboa e Vilar ${ }^{1333}$.

Os Lóios, como estas comunidades, situam-se no cabo de uma tradição de ensino claustral que perpassou a Idade Média, mas a leitura dos dados aduzidos pelas fontes que aqui se apresentam permite ver os Cónegos Seculares como estando na transição entre as duas conceções (a medieval e a moderna) de ensino extra-claustral ministrado por ordens e congregações religiosas.

Exercendo-se nas suas Casas esta atividade de ensino segundo moldes pré-existentes, vão os Lóios (a pedido da Coroa) ver as suas Casas lisboetas assumirem a função de colégios que recebem jovens para formar academicamente, mas também para preparar para a ordenação sacerdotal, e que como se tal se pode considerar na linha dos colégios de clérigos instituídos no séc. XV (de que já se deram exemplos para o pontificado de Eugénio IV) e que objetivavam uma melhor formação do clero, base para a reforma da Igreja.

Deve-se ainda tomar em consideração a natureza própria da Congregação, de clérigos de vida comum, bem como a apetência para o ensino demonstrada pelas congregações de clérigos, sejam seculares ou regulares (ao primeiro grupo pertencem os Oratorianos, tal como os Lóios, ao segundo os Jesuítas), entendido não como uma extensão da atividade educativa aplicada aos membros da comunidade, nem como um mero encargo destinado a angariar rendimento ou a gerar prestígio social, mas também como forma de pastoral à comunidade cristã e promotor da espiritualidade praticada por estas congregações ${ }^{1334}$.

\section{Escolas e Curricula}

Afirma o cronista Santa Maria que entre os Lóios se ensinou, antes da abertura do Colégio de Coimbra em 1548 (e que continuaram mesmo depois desta abertura), nas Casas Lóias de St. ${ }^{\circ}$ Elói de Lisboa e de Vilar de Frades. Aqui seriam ministrados «cursos de Artes», cujos curricula se centrariam

\footnotetext{
${ }^{1331}$ FONSECA, 2000: 118.

${ }^{1332}$ Sobre esta questão $v d$. o ponto 4.4 .

${ }^{1333}$ MARQUES, 1987: 406, 407.

${ }^{1334}$ Sobre esta questão do ensino entre Jesuítas e Oratorianos veja-se a síntese suficiente em GONÇALVES, $2001 ;$ SANTOS, 2001.
} 
em estudos de Gramática e de Moral, pois Teologia e Filosofia só teriam começado a ser ensinados entre os Lóios quando estabelecem a comunidade coimbrã ${ }^{1335}$.

Não terão sido as únicas Casas da Congregação onde foram ministrados os cursos de Artes. A documentação permite-nos saber que outras Casas tiveram funções educativas: a Casa generalícia de S. João Evangelista de Xabregas é mencionada com St. ${ }^{\circ}$ Elói como Casas Lóias que receberam congoleses para educar, e nela deu, entre 1608 e 1610, o Padre Belchior da Graça um curso de matéria penitencial ${ }^{1336}$; e na Casa de Recião, pouco antes da sua transferência para Lamego, ordenou o capítulo geral de $1590^{1337}$ que ministrasse um curso o P.e Pêro de S. João ${ }^{1338}$.

Ainda que possamos elencar quatro comunidades da Congregação como Casas onde houve estudos, uma destas destaca-se claramente pelo número de referências e pela importância que teve enquanto escola de gramática, e escola de formação dos nobres africanos vindos para Portugal a educar: St. ${ }^{\circ}$ Elói de Lisboa. Isabel Pina ${ }^{1339}$ já teve a oportunidade de salientar este facto, que se pode situar na dupla qualidade de instituição fundada para acolher estudantes ${ }^{1340}$ e pela sua localização privilegiada na capital, junto aos paços da alcáçova de Lisboa, morada dos Reis até D. Manuel I, não longe da Universidade quando esta residia em Lisboa (onde se mantém até $1537^{1341}$ ).

Como ficou visto, a D. João III deve-se a constituição de um primeiro colégio Lóio em Coimbra, aparente contrapartida régia aos padres por aceitarem a administração do hospital real de Coimbra, entre outras. De facto, no capítulo geral de 1543 regista-se a vontade régia de querer dotar a Congregação de um colégio em Coimbra:

Acepta ho capitulo a merce e esmola que el Rei nosso senhor quer fazer a Congregaçam em the dar collegio pera os irmãos nos estudos de Coimbra da maneira que Sua Alteza ouver per bem ${ }^{1342}$.

O cronista Francisco de Santa Maria coloca esta oferta como uma manobra do rei D. João III para convencer os padres Lóios a aceitar a administração dos hospitais das vilas de Vimieiro e Castanheiro, mas que segundo o mesmo cronista se concretizaria na licença régia para os Cónegos Lóios

\footnotetext{
${ }^{1335}$ SANTA MARIA, 1697: 517. No entanto contraria-se o próprio cronista quando menciona a Livraria da Casa de Vilar de Frades, que também servia de aula onde se liam Artes e Sagrada Teologia, cf. p. 385.

${ }^{1336}$ Como se pode ver pelo códice que recolhe a matéria que leu neste curso «Materia do sacramento da penitencia, a qual leo o Rdo. Padre Belchior da graça em Lixboa em são Bento de enxobregas no anno de 1608 e 609 e 610» (cf. BPE - Col. Manizola, Cod. 410 .

${ }^{1337}$ Cf. ANTT - Congregação de S. João Evangelista, Convento de St. ${ }^{\circ}$ Elói de Lisboa, lv. 15, fl. 32v.

${ }^{1338}$ Que deverá ser o padre Pêro de S. João, o «letrado», e não Pêro de S. João Garcês que foi a Roma (cf. ADB - Manuscritos, ms. 924, p. 712).

${ }^{1339}$ PINA, 2011: 135-137, 244 e segs.

${ }^{1340}$ A Casa de St. ${ }^{\circ}$ Elói de Lisboa tem por base o hospital dos Santos Paulo, Clemente e Elói, que D. Domingos Jardo, bispo de Lisboa e chanceler de D. Dinis, instituiu como legado de alma com objetivo de sustentar estudantes pobres. A crise da sua administração, e o desejo de apoiar os Lóios (supõe-se), levou o regente Infante D. Pedro a entregá-lo aos Lóios que o convertem numa das suas Casas (cf. ANTUNES, 2000: 116; SANTA MARIA, 1697: 423 e segs.; vd. quadro anexo n. ${ }^{\circ} 4$.

${ }^{1341}$ GOMES, 2001.

${ }^{1342}$ ANTT - Manuscritos da Livraria, n. ${ }^{\circ}$ 186, fl. 158.
} 
habitarem no hospital real até terem um edifício próprio ${ }^{1343}$. Assim, o colégio dos Lóios passa a funcionar nas instalações deste último, a título precário, logo em 1548, e de onde só sairá quando a Congregação construir por fim o seu colégio de S. João Evangelista, inaugurado na década de $1630^{1344}$.

O Colégio de Coimbra permitirá à Congregação aprofundar as matérias lecionadas no seu seio e a frequência universitária facilitada dos seus padres, pois como Jorge de S. Paulo ${ }^{1345}$ faz notar antes dos cónegos se formarem em Coimbra, diversos são os casos dos formados na Universidade de Lisboa (o que a partir de 1537 se torna impraticável), e também por universidades estrangeiras (menciona-se Roma, Bolonha, Salamanca e Cuenca), com uma sua referência a um cónego formado em Évora ${ }^{1346} \mathrm{e}$ fazendo supor a existência de outros formados na instituição alentejana. Na listagem dos doutores da Congregação, Francisco de Santa Maria junta ainda à listagem das instituições cursadas pelos Lóios um doutor da Universidade de Paris ${ }^{1347}$.

Da consulta destes dois autores apercebemo-nos que em matéria de frequência universitária os Lóios formaram-se em Direito, civil e canónico (mas esmagadoramente neste último, e no outro caso sempre na versão in utroque), em Teologia, em Medicina (o fundador João Vicente), Filosofia e Matemática. Naturalmente pendia-se para os estudos naturais numa congregação de clérigos, ou seja, para os Cânones e para a Teologia.

A falta geral de informação sobre os curricula seguidos pelos Lóios não permite uma aproximação muito profunda ao conteúdo do ensino ministrado nas suas Casas. Note-se a referência recorrente a Artes em geral, e em particular o ensino da Gramática, e recorde-se a tradição de ensino destas matérias em escolas conventuais e por mestres individuais, já que estas constituíam a base da hierarquia dos estudos.

É de ter em conta que, na transferência da Universidade de Lisboa para Coimbra, o rei D. João III manda que as aulas da Artes e Gramática sejam ministradas pelos docentes que já as ensinavam no mosteiro de St. ${ }^{\text {a }}$ Cruz, por encargo dos cónegos Agostinhos ${ }^{1348}$, demonstrando a tradição das escolas ligadas a instituições regulares de algum fôlego académico em ministrarem cursos destas matérias.

Não estamos longe da determinação do capítulo geral dos Cónegos de S. Jorge em Alga de 1487, em que se tratou da forma como o mestre de noviços os deveria educar, ensinando-lhes gramática, costumes e estatutos da Congregação, harmonia eclesiástica (liturgia), estando aberto aos laicos os estudos de gramática e dos livros ${ }^{1349}$.

Não se deve deixar de salientar a similitude de padrão: estudos de base desenvolvidos nas Casas, em que as matérias académicas gerais estão abertas para dentro e fora do claustro, restringindo-se apenas a formação de carácter interno.

\footnotetext{
${ }^{1343}$ SANTA MARIA, 1697: 281, 517.

${ }^{1344} \mathrm{Vd}$. o que se diz no ponto anterior, bem como Idem, ibidem: 516 e segs.

${ }^{1345}$ Cf. ADB - Manuscritos, ms. 924, p. 712, 713.

${ }^{1346}$ Sobre a universidade de Évora, $v d$. LAVAJO, 2001.

${ }^{1347}$ SANTA MARIA, 1697: 522 e segs.

${ }^{1348}$ Idem, ibidem: 315; MARQUES, 1998; FONSECA, 2000.

1349 TOMASINI, 1642: 381, 382.
} 
As restantes disciplinas que se mencionam como ensinadas entre os Lóios: Moral, Teologia e Filosofia, apontam para estudos mais aprofundados, vitais para aqueles que seguindo a via clerical e da ordenação de ordens sacras, vivendo numa Congregação que tem por base carismática a prática digna e informada do múnus sacerdotal, se vêm na contingência de serem pregadores ${ }^{1350}$ e diretores de consciência.

Estas matérias serão cursadas no Colégio da Congregação (Teologia também em St. ${ }^{\circ}$ Elói, como já se mencionou) e aprofundadas nas Universidades, sendo asseguradas por cónegos academicamente preparados que serviam de leitores (lentes na expressão universitária). Em data que se desconhece o Colégio de S. João Evangelista de Coimbra será incorporado e privilegiado na Universidade ${ }^{1351}$.

\section{Mestres ou Leitores: quem ensinava nas Casas Lóias?}

A identidade dos docentes que ensinavam nas Casas Lóias é, nesta matéria do ensino, uma questão básica. Estando no âmbito de uma congregação religiosa poder-se-ia pensar à partida que o ensino fosse integralmente assegurado pelos cónegos da Congregação, pensamento que a ser formulado induziria em erro.

A mais antiga menção que podemos encontrar para atividade educativa no universo Lóio é a que Paulo de Portalegre deixou no seu Novo Memorial, quando relata a vida e morte de seu tio P.e Batista, no século Fernão Álvares.

Tendo estudado, das artes liberais, a Gramática e a Lógica, dedicou-se depois à Teologia, que terá cursado em Salamanca. Regressado a Portugal terá ensinado Gramática no Porto e em Lisboa ${ }^{1352}$, onde teve escola junto à igreja de S. Brás. Decidindo-se pelo estado clerical acabou por ordenar-se sacerdote.

Apesar de contactos com Jerónimos, Dominicanos, e Eremitas da Serra de Ossa, inclinou-se pelos Lóios e pela Casa de St. ${ }^{\circ}$ Elói de Lisboa (segundo o seu sobrinho pelo desejo de perseverar como clérigo secular), onde não entrou logo como irmão, tendo-se inicialmente dedicado a ensinar e a aprender, certamente como mestre de Gramática que já era. Depois de tomar grau de bacharel em Teologia acabará por ingressar na Congregação, não voltando o seu sobrinho a mencionar qualquer atividade sua de ensino no seio da Congregação ${ }^{1353}$.

Cristina Sobral, na leitura do testemunho de Paulo de Portalegre e ao fixar a cronologia da sua vida, determina que o P.e Fernão Álvares entrará nos Lóios em $1449-50^{1354}$, pelo que teremos de concluir que a atividade de mestre de Gramática do futuro padre Lóio na Casa de St. ${ }^{\circ}$ Elói terá de situar-se entre a entrega da Casa aos Lóios e a sua entrada na Congregação, ou seja, entre 1442 e 1450.

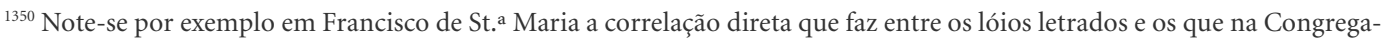
ção se destacaram como pregadores (cf. SANTA MARIA, 1697: 522 e segs.).

${ }^{1351}$ Conforme se depreende da carta régia do príncipe regente D. João, datada de 14 de dezembro de 1809 em que, em resposta ao requerimento do reitor e padres do Colégio dos Lóios, confirma que o Colégio era incorporado e privilegiado da Universidade de Coimbra (cf. AUC - Colégio de S. João Evangelista, mç. 1, doc. avulso).

${ }^{1352}$ Certamente como um daqueles mestres de gramática que se dedicavam a ensinar quem os procurava, e de que existira um número razoável no Portugal do séc. XV e XVI, em particular na capital (cf. MARQUES, 1987: 407; MARQUES, 1998: 468). 1353 PORTALEGRE, 2007: 127 e segs.

${ }^{1354}$ Idem, ibidem: 23 e segs.
} 
Revela-se assim que o estudo em St. ${ }^{\circ}$ Elói, que recorde-se era instituição fundada por legado de alma e dedicada a prover sustento a escolares e merceeiros, estava em funcionamento nos anos em que era transferido para a Congregação dos Lóios (se não antes), e que eram ministrados estudos de Gramática por um professor secular e externo à Congregação, característica que parece manter-se futuramente, e como tal será estrutural no ensino praticado entre os Lóios.

Sobre esta matéria as atas capitulares oferecem alguma informação, seja nos mandados, seja nas contas apresentadas pelas Casas. As menções frequentes aos mestres de gramática em St. Elói, e em outras Casas, bem como as determinações para os estudos, permitem supor um modelo de ensino assegurado essencialmente por mestres seculares (clérigos ou laicos) e regulares externos à Congregação para o ensino de Gramática, sobretudo quando se tem em conta que a este ensino acederiam elementos externos às comunidades Lóias.

Aos cónegos Lóios caberia ensinar em matérias mais avançadas de Teologia e Moral, que se sabem terem sido ministradas, mas cujos docentes nunca se mencionam em atas capitulares como remunerados, logo seriam pertencentes às comunidades, mas também em matérias de natureza cerimonial litúrgica, próprias do universo clerical.

O capítulo geral de 1481 (primeiro ano em que temos registos capitulares) menciona o bacharel de Gramática de St. ${ }^{\circ}$ Elói, elemento externo à comunidade, a quem se concede licença para circular em certos cómodos da Casa ${ }^{1355}$, mas que em 1485 é proibido de comer no refeitório da comunidade, exceto quando convidado pelo reitor, por ocasião de alguma festa ${ }^{1356}$.

Em 1482 o capítulo proíbe (o que indicará uma prática existente) que se recebam religiosos de outras ordens e congregações religiosas nas Casas Lóias para desempenho de atividades de alguma duração, incluindo-se o ensino de qualquer ciência ${ }^{1357}$.

Em 1484 um mandado determina que nas aulas de Gramática só se leia o que for determinado pelo reitor da Casa com o mestre ${ }^{1358}$, demonstrando que os Lóios, mesmo que com mestres estranhos aos seus claustros, não deixam de controlar o ensino ministrado nas suas Casas, orientando-o certamente de acordo com o seu modo de vida e a sua própria espiritualidade.

O capítulo de 1485 inclui um mandado que revela mais pormenorizadamente a organização dos estudos na Congregação. Menciona estar ordenado que entre os Lóios só houvesse mestre de Gramática em St. ${ }^{\circ}$ Elói. Nas outras Casas só se estudaria esta matéria se houvesse um cónego capaz para começar a ensinar algum irmão, preparando-o para mais rapidamente avançar quando estivesse no estudo de gramática em St. ${ }^{\circ}$ Elói. Manda-se ainda que os Lóios que terminem os estudos sejam mudados de Casa e que aqueles que forem determinados para aprenderem sejam mudados para a Casa de St. ${ }^{\circ}$ Elói ${ }^{1359}$.

\footnotetext{
${ }^{1355}$ ANTT - Manuscritos da Livraria, n. ${ }^{\circ}$ 523, fl.1v.

${ }^{1356}$ Idem, ibidem: fl. 20v.

${ }^{1357}$ Idem, ibidem: fl. 5.

${ }^{1358}$ Idem, ibidem: fl. 12.

${ }^{1359}$ Idem, ibidem: fl. 17v.
} 
Esta determinação não só demonstra a importância de St. ${ }^{\circ}$ Elói nesta matéria, como revela claramente que a frequência do estudo era de decisão superior (capitular), entendida num processo de obediência e abandono individual, que leva a que no final do seu articulado se ordene não enviar ao estudo os religiosos que o requeressem.

Até 1497 mantêm-se mudas as atas capitulares sobre esta matéria, e neste ano um longo mandado determina a suspensão da escola de Gramática de St. ${ }^{\circ}$ Elói, ordenando que nessa Casa aprendam os irmãos esta disciplina por livro, como nas demais Casas, dada por Lóio que para tal seja apto e a quem seja ordenado. Veda-se a frequência dessa aula a noviços (conforme a determinação dos Estatutos já mencionada), aos moços da Casa e de fora e a qualquer outra pessoa ${ }^{1360}$.

Esta suspensão, que claramente se destina a interromper a atividade de uma escola que acolhia elementos externos à própria comunidade (já que os cónegos continuaram a ter o ensino de Gramática assegurado internamente), tem a sua decisão fundada nas obras que a Casa de St. ${ }^{\circ}$ Elói então sofreria ${ }^{1361}$, "polla endesposiçam em que ora esta e dasseseguo (sic) e honestidade da dicta casa se reformar ${ }^{1362}$ », que certamente acrescentava perturbação a uma comunidade já perturbada pela dinâmica escolar.

Mas o peso e importância que esta escola de St. ${ }^{\circ}$ Elói parece ter tido leva a que no ano seguinte se determine mestre de Gramática em Vilar de Frades e St. ${ }^{\circ}$ Elói para ensinar somente os irmãos ${ }^{1363}$. Esta determinação, que o capítulo geral do ano seguinte de 1499 sublinhará ${ }^{1364}$, estaria no entanto destinada a fracassar, com as exceções a começarem no mesmo capítulo e exaradas na mesma página das atas, quando se decide receber os três moços («no modo que for mais onesto») indicados pela rainha D. Leonor, por sua irmã Isabel, duquesa de Bragança, e por D. Beatriz da Silva, pessoas a quem a Congregação era obrigada, e que se crê não errar muito ao interpretar como três moços para frequentarem o estudo de Gramática ${ }^{1365}$.

O reconhecimento que nesta matéria os Lóios terão alcançado perante a Coroa (Leonor e Isabel, além de viúvas de D. João II e de D. Fernando II de Bragança, eram irmãs do rei D. Manuel I), será a base da decisão manuelina de lhes entregar a educação dos nobres congoleses vindos a Lisboa ${ }^{1366}$.

A fama de educadores dos Lóios não se restringia à Coroa ou à Corte, como se depreende da proibição que o capítulo geral de 1499 faz de se receber entre os Lóios religiosos que viessem dos Ere-

\footnotetext{
${ }^{1360}$ Idem, ibidem: fl. 92.

${ }^{1361}$ Em 1496 não só se registavam gastos com obras no valor de 162.600 réis, como determinava-se a forma de construção do dormitório, com licença para a Casa se endividar para obras até 100 mil réis (cf. Idem, ibidem: fl. 85, 87). Para auxílio destas obras deve ter estado destinada a esmola que o Cardeal D. Jorge da Costa deu a St. ${ }^{\circ}$ Elói, Casa onde começou a sua carreira eclesiástica e onde tinha pousada (cf. o que diz MENDONÇA, 1991, bem como a referências no capítulo geral de 1481 às dependências habitadas pelo cardeal e que se guardavam para quando regressasse de Roma, cf. ANTT - Manuscritos da Livraria, n. ${ }^{5}$ 523, fl. 1v.), que se regista nas contas de 1498 (cf. Idem, ibidem: fl. 95v.).

1362 Idem, ibidem: fl. 92.

${ }^{1363}$ Idem, ibidem: fl. 97.

${ }^{1364}$ Determinando-se que não se consinta que leigos de fora, mesmo que familiares ou amigos dos Lóios, aprendam Gramática nas Casas Lóias, em escola ou fora dela (cf. Idem, ibidem: fl. 102).

${ }^{1365}$ Idem, ibidem: fl. 97.

${ }^{1366} \mathrm{Vd}$. o ponto seguinte.
} 
mitas da Serra de Ossa, que então passavam pelo processo de institucionalização que conduzirá à sua solene profissão religiosa ${ }^{1367}$, e que era prática ocasional na Congregação como patente nos capítulos gerais anteriores.

Esta determinação tem por base o facto de estes noviços virem apenas com intuito de aprender e não de perseverarem na vida religiosa como clérigos seculares, o que gerava conflitos entre os superiores das duas instituições. Estamos perante mais um exemplo, para os Lóios, da efetiva consciência da especificidade do seu modo de vida carismático, e a sua forte radicação nele ${ }^{1368}$.

Entrando nas atas capitulares de 1538-45, continuamos a encontrar referências aos mestres de Gramática e ao ensino entre os Lóios, ainda que a maioria das referências esteja exarada entre as contas que as Casas apresentavam anualmente. Assim, Vilar de Frades contabiliza despesas com o salário do mestre de Gramática nos anos de 1538 a 1540, entretanto este passa à lista de devedores de 1541 a 1543, está ausente das contas em 1544, mas é mencionado nos mandados desse ano na determinação para que nos dois anos seguintes ensine em Recião ${ }^{1369}$.

Já esta última Casa tem em 1538 uma entrada de 10 mil réis do Comendador de Poiares para o mantimento do seu filho e que se supõe educando entre os Lóios desta Casa onde neste ano se ensinaria Gramática, como se depreende da determinação desse ano para que o filho de Rui de Melo fosse de Xabregas para Recião para aprender esta disciplina. Em 1545 aparece nos gastos desta Casa de Recião o pagamento do mestre de Gramática, que ensinava em curso determinado no ano anterior ${ }^{1370}$.

Mais surpreendente são as parcas menções nas contas de St. ${ }^{\circ}$ Elói de Lisboa, onde surgem em 1539 e 1540 menções ao pagamento do mestre de gramática, menção que se renova em 1542 quando se menciona um pagamento que lhe deveriam de muitos anos ${ }^{1371}$.

Aparte as menções em contas, os estudos apenas aparecem nas definições e mandados capitulares em 1543, quando o capítulo determina aceitar do Rei a oferta de um colégio para os Lóios nos Estudos de Coimbra (de que já se fez menção) ${ }^{1372}$; e em 1544, quando o capítulo geral dedica um longo mandado a esta questão. Estabelece que haja mestre de gramática em St. ${ }^{\circ}$ Elói de Lisboa (que de facto estava ausente dos pagamentos correntes desde 1541), e que nos dois anos seguintes a Casa de Recião tenha mestre de gramática, Casa para onde era mudado (vindo de Vilar) D. Afonso ${ }^{1373}$, sobrinho do Marquês de Ferreira, Dom Leonis [Pereira] ${ }^{1374}$ filho do Conde da Feira e um rapaz que

\footnotetext{
${ }^{1367}$ Sobre os Eremitas da Serra de Ossa, incluindo a sua relação com os Lóios, veja-se FONTES, 2012.

${ }^{1368}$ ANTT - Manuscritos da Livraria, n. ${ }^{\circ} 523$, fl. 101v., 122v.

${ }^{1369}$ Cf. ANTT - Manuscritos da Livraria, n. ${ }^{\circ}$ 186, fl. 11, 38v., 62, 106, 145v., 192v.

${ }^{1370}$ Idem, ibidem: fl. 12v., 26v., 203v.

${ }^{1371}$ Idem, ibidem: fl. 41v., 65, 125v.

1372 Idem, ibidem: fl. 158.

${ }^{1373}$ Sobrinhos do Marquês de Ferreira, em $1 .^{\circ}$ grau, poderiam ser D. Afonso de Portugal, 2. ${ }^{\circ}$ Conde de Vimioso (o que será pouco provável, já que neste ano recebia carta do Conselho do rei, como afirma D. António Caetano de Sousa, cf. SOUSA, 1946-1955: tomo X, 405) ou D. Afonso de Lencastre comendador-mor da Ordem de Santiago, filho do Duque de Aveiro (cf. SOUSA, 1946-1955: tomo XI, 47, 48).

${ }^{1374}$ Com toda a probabilidade o filho do conde da Feira D. Manuel Pereira, que foi cónego Lóio (como se pode ver em TAVARES, 1991: 6), sendo certo que este $3{ }^{\circ}$ Conde da Feira terá tido dois filhos Leonis, um legítimo e um bastardo, como indica Felgueiras Gaio (cf. GAIO, 1940: tomo XXII, 173), que identifica o legítimo como capitão de Tânger, e o bastardo como o
} 
fora apresentado pelo Arcebispo de Braga. Determina por fim que terminados os dois anos deveria o mestre regressar a Vilar de Frades, onde portanto estava a ensinar «...e ahi se sostente a escola quanto possível for por ser excertio necessario e proveito e honra da Congregaçam» ${ }^{1375}$.

Mas o ensino não se ficaria pelas Artes e pela Teologia, conforme ao determinado pelos Estatutos, e como necessário numa congregação de clérigos que se preparam para os ministérios sagrados.

O ensino de cariz litúrgico (aquele mais específico e técnico no contexto da formação nas instituições destinadas a preparar o clero) tem de ter tido um papel não negligenciável, ainda que a sua dimensão não seja facilmente apreensível, porque praticado internamente e constantemente renovado, como poderemos supor pelas inúmeras menções que as atas capitulares fazem, nos seus mandados, a determinações, aclarações, correções e inovações em matéria cerimonial e litúrgica. A única referência direta que encontramos a ensino neste universo é uma determinação do capítulo geral de 1484 que manda promover o ensino de canto a par com o ensino de gramática em cada uma das Casas Lóias, quando possível ${ }^{1376}$.

A atuação dos Lóios na educação por incumbência régia, de que encontramos vestígios já em 1498 e o amplo recurso nas primeiras décadas do séc. XVI, não se esgota inteiramente no séc. XVI. Apenas como nota de curiosidade, deixa-se a referência que em 1779 a rainha D. Maria I, em atenção aos bons serviços prestados pela Congregação, concede-lhe na sua Casa de Xabregas, que tenha uma escola de ler, escrever e contar com ordinária de 50 mil réis, e uma cadeira de gramática latina com ordinária de 70 mil réis, a serem providas em cónegos $\operatorname{Lóios}^{1377}$. E, também já fora dos limites temporais desta tese, relembre-se o compromisso da mais jovem Casa dos Lóios, a de Vila da Feira, em dar mestre público de latim à população do concelho, que os compensava da finta que a Câmara da Vila obtivera de D. Pedro II para ajudar às obras da igreja ${ }^{1378}$.

Não sendo, nos termos em que se constituiu, uma experiência extraordinária em relação ao que coetaneamente se fazia em outras ordens e congregações religiosas, a atividade educativa dos padres Lóios na passagem do séc. XV para o XVI, em particular aquela que se desenvolveu na sua Casa de St. ${ }^{\circ}$ Elói de Lisboa, teve o reconhecimento da Coroa e das elites, que aos Cónegos Seculares recorriam para fazer educar (mesmo quando a Congregação a tal não parecia inclinada) membros da sua família e pessoas da sua proteção.

Em particular, a educação ministrada pelos Lóios ganha foros de diferença e de relevância quando se atende a que foi a escolhida pelo Rei Venturoso para acolher a elite africana que veio a Portugal para ser educada, sendo recolhida em St. ${ }^{\circ}$ Elói e Xabregas, onde se preparou e formou o primeiro clero africano e onde foi educado, nos inícios do séc. XVI, o primeiro Bispo católico originário do continente africano.

\footnotetext{
futuro capitão de Malaca onde se celebrou por defender a praça de um ataque particularmente grave por parte do sultanato de Achém (cit. em CRUZ, 2006: 137, 138), cargos que se deverão ter concentrado no irmão ilegítimo, já que o legítimo será o que se ordenou na Congregação dos Lóios.

${ }^{1375}$ ANTT - Manuscritos da Livraria, n. ${ }^{\circ}$ 186, fl. 192v.

${ }^{1376}$ ANTT - Manuscritos da Livraria, n. ${ }^{\circ}$ 523, fl. 12v.

1377 ANTT - Congregação de S. João Evangelista, Convento de S. João Evangelista de Xabregas, mç. 16, doc. avulso.

${ }^{1378}$ Cf. TAVARES, 1999: 22.
} 


\subsection{ATUAÇÃO MISSIONÁRIA EM ÁFRICA: DEBATES E DISPUTAS}

Entre as diversas primazias que o cronista Francisco de Santa Maria tenta estabelecer para a sua Congregação encontra-se aquela em que afirma terem sido os Cónegos Lóios os primeiros missionários que converteram o Rei e reino do Congo ${ }^{1379}$.

Como todas as primazias que se estabelecem entre as ordens e congregações religiosas, o lugar de proto missionários da «cristandade do Congo» é disputada por outras instituições religiosas. O P.e António Brásio analisa num seu artigo, e para além dos Lóios, as pretensões dos Franciscanos, Dominicanos, Trinitários e Cistercienses, dedicando-se a desmontar as propostas das três teses que mais sistemática e consistentemente se têm defendido pelos cronistas das Congregações, e na sua senda pelos historiadores que os seguem ${ }^{1380}$.

Brásio sugere ainda, timidamente, que os padres que foram nesta viagem seriam eventualmente clérigos seculares (e entenda-se que sem pertença a nenhuma Congregação, porque clérigos seculares foram os Lóios), hipótese que se afigura viável perante a impossibilidade aparente dos contendentes na matéria conseguirem comprovar documentalmente o seu proto missionarismo congolês.

A sugestão de um proto missionarismo secular poderá reforçar-se ao ter em consideração o testamento do primeiro donatário da Ilha de S. Tomé, Álvaro de Caminha, escrito pouco antes da sua morte em 1499 (e publicado pelo próprio Brásio), onde este revela estar acompanhado de um único padre secular que, sozinho, procedia a todo o trabalho pastoral. $\mathrm{O}$ mesmo documento revela que o donatário preparava um mosteiro para servir de base ao trabalho pastoral e educativo a desenvolver, e que nesta fase de construção ainda não tinha qualquer comunidade adstrita, revelando Álvaro de Caminha que gostaria de o entregar a franciscanos da observância ${ }^{1381}$.

Dada a proximidade geográfica e institucional entre S. Tomé e o reino do Congo (que estará enquadrado na diocese de S. Tomé desde a fundação desta e até ser constituída diocese própria do Congo em $1596^{1382}$ ), poder-se-á supor uma similitude de processos, em que alguns padres seculares antecedem, como que numa fase de experimentalismo, missões mais organizadas, naturalmente desenvolvidas pelas ordens e congregações.

\footnotetext{
1379 SANTA MARIA, 1697: 256 e segs. As designações de Rei e reino do Congo, bem como os nomes próprios e as titulaturas nobiliárquicas e cortesãs portugueses que os monarcas e os membros principais da elite adotam, pelo menos nas relações com Portugal, e pelos quais são mencionados na documentação portuguesa depois dos processos de conversão desenvolvidos a partir de 1490, são naturalmente formas relacionais de dominação impostas pela Coroa portuguesa e pelos poderes associados, a que parte das elites africanas serão recetivas e de que participarão, integrando-as em estratégias internas e externas de poder. São como tal estranhas à tradição e à cultura Bakongo a que se referem e colocam ao historiador problemas complexos sobre a sua análise e utilização. Neste trabalho, e porque trata da Congregação dos Lóios e não do universo dos Bakongo, utiliza-se a formulação que a própria Congregação utilizou, e que é a que está plasmada na documentação histórica deste período, como se poderá ver nas fontes que se citarão.

1380 BRÁSIO, 1973.

${ }^{1381}$ BRÁSIO, 1952: doc. 40.

${ }^{1382}$ Conforme o pedido que D. João III apresentara em Roma, em 1532, pelo futuro Arcebispo D. Martinho de Portugal, e que será deferido pelo Papa Clemente VII, com nomeação de D. Diogo Ortiz de Villegas como primeiro bispo (cf. BRÁSIO, 1953: doc. 2, 15).
} 
Atente-se na carta do rei do Congo D. Afonso ao rei D. Manuel I, datada de 1514, em que ao relatar o período da sua sucessão no trono menciona ter tido apoios e companhia de dois padres, Rodrigo Anes e António Fernandes, dos quais não menciona qualquer qualificativo de religião, o que nos leva a supô-los seculares. O peso do seu apoio aliás viria a ser compensado pelo Rei congolês, no seu regresso a Portugal, pela oferta de 50 escravos, demonstrando todo o régio agrado ${ }^{1383}$.

Estes dados esparsos permitem qualificar a validade da hipótese tímida de Brásio, pelo menos dando-lhe espaço na liça do debate histórico.

Após o trabalho do P.e Brásio, que se pretendia definitivo a resolver o debate de proto missionarismo ao arrasar as pretensões das ordens e congregações envolvidas, Pedro Tavares ${ }^{1384}$ fez sobre a questão uma importante reflexão na qual sustenta, depois de avaliada a questão, que mais importante do que saber se os Lóios foram ou não os primeiros missionários do Congo, aqueles que acompanharam a viagem de Gonçalo e Rui de Sousa em 1490-91 (e cuja identidade dificilmente se poderá alguma vez estabelecer com certeza), importa sim perceber onde a Congregação de S. João Evangelista se situa nas relações entre Portugal e o reino do Congo, e o papel dos Lóios enquanto educadores da elite congolesa transposta à Corte de Lisboa.

Mais recentemente Isabel Pina toca brevemente no assunto na sua tese, mas centra a sua hipótese apenas na atividade dos Lóios «na retaguarda, isto é, na preparação do clero autóctone que regressaria depois aos territórios de origem» ${ }^{1385}$.

\subsubsection{Os Lóios na missionação africana: um problema por resolver?}

A crónica Lóia de 1697 apresenta, sobre a hipotética missão de 1490 que os Cónegos Azuis teriam realizado ao reino do Congo (onde se incluiria o batismo do Rei, Rainha e principais figuras da elite congolesa), uma descrição rica em pormenores.

Francisco de Santa Maria não nos elucida sobre as suas fontes, mas uma leitura comparativa permite perceber que a descrição do cronista dos Lóios se assemelha muito à das Décadas de João de Barros $^{1386}$, substituindo aos seis frades dominicanos liderados por um Fr. João que propõe o humanista quinhentista (ou à versão de Rui de Pina que apresentava um número não especificado de franciscanos liderados por Fr. João ${ }^{1387}$ ), os cinco Cónegos Azuis (que inclusive nomeia ${ }^{1388}$ ) liderados por um P.e João de Santa Maria que propõe o cronista seiscentista dos Lóios ${ }^{1389}$.

\footnotetext{
${ }^{1383}$ Idem, ibidem: doc. 83.

1384 TAVARES, 1989.

${ }^{1385}$ PINA, 2011: 193, 194.

${ }^{1386}$ BARROS, 1778: 224 e segs.

${ }^{1387}$ Rui de Pina, Croniqua del Rey Dom Joham II, cap. LVIII, citado em BRÁSIO, 1952: 56 e segs. A lição de Rui de Pina seguiu também Garcia de Resende na sua Chronica del Rey Dom Ioam II (cf. RESENDE, 1798: 221 e segs.).

1388 SANTA MARIA, 1697: 256 e segs. Seriam os padres João de Santa Maria, João de Portalegre, António de Lisboa, Rodrigo de Deus e Vicente dos Anjos. Diz que foram escolhidos como melhores entre os cónegos dos dois conventos de Lisboa, já que em grande alvoroço todos os padres dos conventos a quem a idade e saúde permitia se teriam oferecido em tão importante missão. ${ }^{1389}$ Curiosa esta concordância geral num único nome, o de João de Santa Maria, que se faz frade ou padre consoante os casos. Note-se que entre os alvarás régios de D. João II respeitante ao embaixador D. Pedro do Congo, sua mulher e três congoleses que os acompanhavam um destes é citado como João de Santa Maria (cf. BRÁSIO, 1952: doc. 37 e 39, é o único que tem um
} 
Seria no entanto manifestamente injusto assacar a Francisco de Santa Maria a autoria de uma versão Lóia dos proto missionários no Congo, já que este apenas vai seguir a versão que o P.e Jorge de S. Paulo estabelecera anteriormente no seu Epílogo $0^{1390}$.

Historiando o processo de descoberta do Congo, do estabelecimento das primeiras relações e vinda do nobre Caçuta, afirma que D. João II ao determinar-se a reenviar o nobre congolês (agora batizado como D. João da Silva) ao seu reino e a enviar uma sua embaixada ao Rei do Congo, decidira que esta fosse acompanhada por religiosos que fossem ao reino africano servir pastoralmente, para o que teria pedido ao geral dos Lóios, Paulo [de Portalegre], que a Congregação aceitasse este encargo.

O Geral dos Lóios teria apresentado ao capítulo geral o pedido régio e colhido a adesão dos padres capitulares, formando-se um grupo de 5 religiosos integrado pelos Padres João de Portalegre, Rodrigo de Deus, João de Santa Maria, António de Lisboa e Vicente ${ }^{1391}$.

Depois de descrever a missão nos termos que depois utilizará Francisco de Santa Maria, Jorge de S. Paulo critica os cronistas Garcia de Resende (que seguiu Rui de Pina) e João de Barros por defenderem a primazia de franciscanos e dominicanos, oferecendo como prova da primazia Lóia um alvará de D. João II, datado de 1492 e que se conservaria em Xabregas, em que o Rei concedia aos Lóios o direito de pedirem uma mercê em paga dos serviços prestados na conversão do Congo ${ }^{1392}$, provisão que Brásio afirma ter procurado longamente sem encontrar ${ }^{1393}$.

Os artigos já mencionados deixam bem clara a improbabilidade dos padres Lóios terem estado presentes nesta viagem de 1490 (no caso de Brásio defendendo a mesma improbabilidade para os Dominicanos de João de Barros e para os franciscanos de Pina e Resende) aduzindo em contraponto ao triunfalismo descritivo de Francisco de Santa Maria o indesmentível dado documental.

Não existe documento da Congregação anterior a 1500 que mencione a participação dos Lóios em qualquer atuação missionária. Esta afirmação poderá parecer algo contundente, por isso aprofundemos com recurso aos registos da mais alta instância da Congregação, o capítulo geral anual, e que para o período deste trabalho encontramos os dois livros de atas já mencionados e amplamente citados $^{1394}$. Pedro Tavares menciona mesmo uma memória da Congregação que situa a primeira missão Lóia no Congo já no reinado de D. Manuel I ${ }^{1395}$.

Na leitura do mais antigo dos livros de atas sobreviventes, com registos que vão de 1481 a 1500, seria de esperar (a confirmar-se o cenário proposto por Jorge de S. Paulo e Francisco de Santa Maria) um qualquer registo sobre a matéria, seja do capítulo a aceitar o envio de irmãos, seja na distribuição

nome com uma invocação religiosa, relembrando um nome de religião). Será que existiu efetivamente um João de Santa Maria ligado a estes primeiros contactos com o Congo, cujo nome foi dado a um dos congoleses vindos a Portugal?

${ }^{1390}$ Cf. ADB - Manuscritos, ms. 924, cap. 50, p. 216 e segs.

${ }^{1391}$ Idem, ibidem: 219, 220.

1392 Idem, ibidem: 222.

${ }^{1393}$ BRÁSIO, 1973: 182 e segs.

${ }^{1394}$ Para o período de 1481 a 1500 (ANTT - Manuscritos da Livraria, n. ${ }^{\circ}$ 523; para o período de 1538 a 1545 ANTT - Manuscritos da Livraria, n. ${ }^{\circ}$ 186).

${ }^{1395}$ Cf. TAVARES, 1989: 562. 
de padres feita entre as Casas (e em que seria expectável encontrar, no capítulo de 1490, o envio dos padres para o Congo), seja até nas contas; em suma, um qualquer vestígio do reino do Congo ou até dos nobres congoleses. Mas o silêncio é absoluto e ensurdecedor.

As atas dos capítulos gerais, bem como a ausência de outras referências no cartório dos Lóios ${ }^{1396}$, abrem-nos uma janela temporal para balizar as ligações entre os Lóios e o Congo a partir da documentação capitular da Congregação, e que se pode situar num período nunca anterior a 1500 e nunca posterior a $1589^{1397}$.

Trata-se, ainda assim, de uma janela temporal muito ampla, e que tentaremos firmar com alguma certeza entre 1508, ano em que Damião de Góis regista, na Crónica do rei D. Manuel, um envio de uma primeira missão dos Lóios ao reino do Congo, e 1545, ano que não se coloca como uma janela temporal definitiva, mas que se propõe por situar-se no termo da documentação Lóia que menciona congoleses sob os cuidados educativos da Congregação.

Ainda que Francisco de Santa Maria defenda que aos Lóios coube já, e ainda antes da missão de 1490, a formação pastoral e educativa dos primeiros congoleses vindos a Portugal, nomeadamente Caçuta, afirmando que estiveram dois anos recolhidos em St. ${ }^{\circ}$ Elói de Lisboa por ordem de D. João II, onde se prepararam ao batismo ${ }^{1398}$, o certo é que as primeiras referências aos congoleses transportados a Portugal para serem educados referem «Joham de Samta Maria e a Caravelinha e a Joham Gomçallvez e a Symam e a dom Françisco negros [... q que Martim Afomso emsyna a leer e a escrepver» ${ }^{1399}$, fazendo-nos supor que neste período inicial da transposição de jovens africanos das elites a Portugal para serem catequizados e educados segundo os modelos portugueses e servirem futuramente como intermediários entre os seus dois universos de pertença (o original e o de formação), a sua educação passaria por mestres individuais a quem eram entregues e não por uma instituição que se vocacionasse para os receber.

Se nenhum documento, aparte as afirmações da cronística da Congregação, coloca os Lóios a colaborarem com D. João II na formação dos congoleses ou com qualquer outra atividade missionária, o caso será completamente distinto com o seu sucessor.

Na sua crónica, Damião de Góis regista o envio que em 1508 D. Manuel I faz, para o Congo, de treze padres Lóios dirigidos pelo P.e João de Santa Maria, com o objetivo de fazerem uma igreja, de ensinarem e de pregarem a Fé, os quais iriam na sequência de uma outra missão dirigida para a pastoral e para o ensino que o Rei se decidira a enviar em $1504^{1400}$.

\footnotetext{
${ }^{1396}$ Ainda que esta não seja determinante, porque geral a todas as relações com o Congo, e mesmo em períodos em que sabemos terem os padres Lóios estado efetivamente presentes no Congo.

${ }^{1397}$ Anos que se situam entre o fim dos registos do já mencionado ANTT - Manuscritos da Livraria, n. ${ }^{\circ} 523$, e o ano em que se situa o início do registo do $3 .^{\circ}$ volume sobrevivente (por ordem cronológica) das atas capitulares, e em cujos registos já não se encontram menções ao Congo e aos congoleses (cf. ANTT - Congregação de S. João Evangelista, Convento de St. ${ }^{\circ}$ Elói de Lisboa, lv. 15).

1398 SANTA MARIA, 1697: 258.

${ }^{1399}$ Alvará de D. João II datado de 10 de dezembro de 1493 (transcrito em BRÁSIO, 1952: 157).

${ }^{1400}$ Damião de Góis, Chronica do Felicissimo Rei Dom Emanuel, parte II, cap. XXX (apud BRÁSIO, 1952: doc. 53, 59).
} 
Esta informação parece concordar com a longa carta que o rei D. Afonso do Congo envia ao rei D. Manuel I em 1514, e na qual situa a chegados dos padres Lóios antes da embaixada de Simão da Silva, que se sabe enviada pelo rei português em $1512^{1401}$ :

e emtam dahy a pouco tenpo cheguaram os padres de Santa loya [Santo Elói] que nos Su'Allteza mandara e nos tanto que soubemos que elle [s] chegaram a nosso reyno mandamos apergoar que todos nossos fydallguos os fossem a receber ao camynho ${ }^{1402}$.

A escolha que D. Manuel faz dos padres Lóios para esta missão estará, com grande probabilidade, relacionada com a sua atuação anterior enquanto educadores dos nobres congoleses, pois conforme ao teor da mesma carta do rei do Congo somos informados que este enviara a Portugal, para serem educados, o seu filho D. Henrique e o seu sobrinho Rodrigo de Santa Maria ${ }^{1403}$, com toda a probabilidade em data anterior a 1508, já que o desenrolar da narrativa sugere uma natural sequência temporal, em que o rei do Congo situa a partida do seu filho e sobrinho após a sua subida ao trono, em $1506^{1404}$.

Depois do envio do seu filho Henrique, o Rei do Congo terá enviado ainda para Lisboa um outro seu sobrinho, D. Gonçalo, tudo viagens que se deverão ter situado anteriormente à chegada dos cónegos Lóios ao Congo, que se dará cerca de 1508-1509, se correto o testemunho de Damião de Góis.

É no entanto o mesmo Damião de Góis que afirma que D. Henrique e D. Emanuel, filho e irmão do Rei do Congo, só vieram para Portugal depois de os missionários Lóios estarem no Congo e antes da embaixada de Simão da Silva (ou seja entre 1508 e 1512) ${ }^{1405}$; enquanto Jorge de S. Paulo afirma mesmo que só em 1512, depois da embaixada de Simão da Silva, é que Afonso I do Congo envia seu filho Henrique, seu irmão Manuel e outros jovens, todos em companhia do seu embaixador, e primo, D. Pedro de Sousa ${ }^{1406}$.

O envio destes jovens estava respaldado nos recorrentes pedidos régios, mencionados na crónica de Damião de Góis, para que a Coroa congolesa enviasse jovens das principais famílias para serem catequizados e educados em «philosophia, boas artes e costumes, ho que tudo mandou [o rei D. Manuel] fazer à sua custa, repartindo estes moços per mosteiros e casas de pessoas doctas e religiosas» ${ }^{1407}$.

\footnotetext{
${ }^{1401}$ Como se vê amplamente em documentação citada em Idem, ibidem: doc. 63 e segs.

${ }^{1402}$ ANTT - Corpo Cronológico, parte I, mç. 16, doc. 28, fl.2 não numerado. Seguindo uma cronologia dos factos (ainda que não os datando) será posteriormente que a carta relata a chegada da embaixada de Simão da Silva, e os diversos problemas que lhe estiveram associados (transcrita em BRÁSIO, 1952: 294 e segs.).

${ }^{1403}$ Idem, ibidem: 295.

${ }^{1404}$ Cf. GONÇALVES, 1990: 7 (não numerada).

${ }^{1405}$ Transcrito em BRÁSIO, 1952: doc. 63

${ }^{1406}$ ADB - Manuscritos, ms. 924, cap. 50, p. 224.

${ }^{1407}$ BRÁSIO, 1952: doc. 53.
} 
Entre estes jovens contou-se, como visto, D. Henrique, filho do rei congolês Afonso I, que sabemos educado pelos Lóios em St. ${ }^{\circ}$ Elói de Lisboa ${ }^{1408}$, mas também o seu irmão D. Francisco ${ }^{1409}$, que na sequência da embaixada de Simão da Silva o rei do Congo se determinou a enviar ao rei D. Manuel I, acompanhado por 21 moços de prosápia régia (bem como de 530 escravos, que D. Francisco deveria apresentar como presente régio do monarca congolês para o monarca português ${ }^{1410}$ ), e de outros membros da família real que são constantemente citados na documentação que António Brásio publica no $1 .^{\circ}$ volume da sua Monumenta Missionaria Africana.

Mas não fugindo ao que nos ocupa neste livro, a questão que subjaz é se as Casas Lóias se assumem como instituições formativas de jovens congoleses antes ou depois da missão da Congregação ao Congo em 1508, que antecederá outras viagens e uma relação com o reino africano que se manterá pelo menos até finais da década de 1530.

A contradição temporal dos testemunhos não permite uma resposta definitiva, mas seguindo a lógica de uma Congregação que já se afirmara como instituição educativa a quem a Coroa recorria, podemos supor os acontecimentos numa sequência cronológica em que a coroa portuguesa sente a necessidade de dar uma estruturação mais efetiva aos cuidados educativos que eram tributados aos jovens das elites que vinham para Portugal ser educados, decidindo-se a escolha de uma instituição que tome esse encargo.

Salvo melhor opinião, parece-me que a entrega de congoleses aos Lóios para serem educados deve ser atribuída ao reinado de D. Manuel I (já que nenhuma evidência documental apontará para o seu antecessor) e que a hipótese apresentada por Isabel dos Guimarães Sá na sua recente biografia da rainha D. Leonor de Lencastre ${ }^{1411}$ se afigura como possível e provável; isto é, que a irmã de D. Manuel possa ter tido um papel importante na escolha da Congregação.

Apresenta a autora um conjunto de evidências circunstanciais acerca da proximidade da Rainha aos padres Lóios, mas não aduz o dado mais concreto em defesa desta hipótese que se pode encontrar. Mais do que os factos da Rainha viver em proximidade à Casa de St. ${ }^{\circ}$ Elói de Lisboa, ser irmã leiga da Congregação e de nesta ter iniciado a sua carreira eclesiástica o Cardeal da Costa (próximo da Rainha), são dois mandados do capítulo geral dos Lóios de 1498 que demonstram como a rainha D. Leonor tinha a Congregação como uma escolha educativa já nesse ano.

Tendo o capítulo geral de 1497 determina a suspensão do estudo na Casa de St. ${ }^{\circ}$ Elói de Lisboa, pelas obras em curso na Casa, vemos que foi ordenado no ano seguinte que fosse retomado, com mestre de gramática que ensine apenas os irmãos. Mas depois de circunscrever a atividade educativa da comunidade aos da Casa, acrescenta o mesmo capítulo geral o mandado, escrito na mesma página inclusive, em que os padres capitulares:

\footnotetext{
${ }^{1408}$ Conforme ao que expressamente afirma o rei Afonso I do Congo na sua carta a D. João III, de 18 de março de 1526 (cf. Idem, ibidem: 463).

${ }^{1409}$ Este D. Francisco será um dos quatro congoleses a quem D. Manuel I, por alvará de 30 de agosto de 1516, manda dar roupa e 2 mil reais para a viagem de regresso que iam empreender, grupo em que pelo menos um dos congoleses estaria em St. ${ }^{\circ}$ Elói de Lisboa (cf. Idem, ibidem: 366, 367).

${ }^{1410}$ Como afirma da carta de 1514 (cf. Idem, ibidem: 312).

1411 SÁ, 2012: 207 e segs.
} 
Despensarom polla muita obrigaçam que a Congregaçam teem aa Rainha Dona Lianor e a Duquesa sua irmãa e a Dona Briatriz da Silva ${ }^{1412}$ que lhes tomem cada huma seu moço no modo que for mais onesto e isto por serem pessoas que nos nom podemos escusar ${ }^{1413}$.

A correlação entre a decisão do mestre de gramática apenas ensinar os religiosos da Congregação, e a sua contravenção ao aceitar três moços apresentados pela rainha D. Leonor, pela Duquesa de Bragança e pela cunhada do fundador da Casa de Évora, demonstra não só a proximidade das relações estabelecidas entre a Congregação e as Casas Real e de Bragança, mas também que a atividade educativa nas Casas Lóias era já de reconhecido mérito entre estas personagens ${ }^{1414}$.

Se D. Leonor instava a Congregação a receber jovens para educar, mesmo em períodos que a Congregação declaradamente decidia não aceitar, será de supor que a Rainha tenha estado associada à escolha que o seu irmão irá fazer.

Perspetivando St. ${ }^{\circ}$ Elói de Lisboa como uma Casa em que se educavam jovens a pedido da Coroa já em 1498, será lógico que em sequência temporal o Rei D. Manuel se tenha determinado a enviar os jovens congoleses a educar entre os padres Lóios, e que por essa mesma circunstância tenha decidido enviar os cónegos seculares ao Congo, à frente de uma missão que visaria, antes de mais, estabelecer um espaço para a educação e formação religiosa da juventude da elite congolesa, a exemplo do que fariam em Lisboa, e não apenas uma missão de natureza estritamente pastoral e catequizante.

É de salientar na política de D. Manuel I o não estar exclusivamente focada em obter conversões nominais de cristãos, mas em preparar de modo estruturado a adesão dos congoleses, a começar pela sua elite, a um universo lusófono e cristão, sustentáculo de um relacionamento em que se pretendia, numa lógica relacional vassálica, situar o reino do Congo como um elemento estrutural da política portuguesa para a região.

É uma política que Custódio Gonçalves definiu como «convergência de culturas» (ainda que exercido sob a tentativa de predomínio de uma sobre a outra), com um papel consequente na reordenação política do reino do Congo, baseada numa pertença ao cristianismo e na relação com Portugal, que atribuiu aos reis do Congo instrumentos políticos com que pretenderam reforçar o seu poder, estruturando-o num sistema de hierarquização vertical, distinto do tradicional sistema político congolês, de estruturação horizontal. Como é sabido acabará por não funcionar e o reino do Congo irá desagregando-se a partir do séc. XVII ${ }^{1415}$.

O grupo de padres Lóios enviados cerca de 1508 à cidade de S. Salvador (M’Banza-Kongo, que vira o seu nome alterado com a conversão dos seus reis), capital do reino do Congo, é mencionado

\footnotetext{
${ }^{1412}$ Mulher de Manuel de Melo, alcaide-mor de Olivença, irmão de D. Rodrigo de Melo, Conde de Olivença e fundador do convento dos Lóios de Évora. O casal envolveu-se na fundação do convento de Évora, instituindo uma capela (cf. GAIO, 1939c: tomo XVIII, 142; PINA, 2011: 180-181).

${ }^{1413}$ ANTT - Manuscritos da Livraria, manuscrito n. ${ }^{\circ}$ 523, fl. 97.

1414 Sobre esta questão, das relações da rainha D. Leonor com a Congregação, pude já escrever um curto artigo (cf. FALCÃO, 2012: 95-106).

${ }^{1415}$ Cf. GONÇALVES, 1990.
} 
por Jorge de S. Paulo e por Francisco de Santa Maria como a segunda missão Lóia, dirigida pelo mesmo P.e João de Santa Maria que teria liderado a hipotética missão de $1490^{1416}$.

Parece que estamos perante a prática, não inteiramente desconhecida ao cronista oficial dos Lóios, da reformulação de memória pela utilização de dados verdadeiros que se reorganizam de modo a comprovar algo, neste caso a primazia dos Lóios na missão congolesa. A construção dos cronistas terá sido tal que mesmo os nomes dos cónegos que foram à missão de 1508 não serão inteiramente verdadeiros, pois se a carta do rei D. Afonso I menciona os padres João de St. a Maria e Aleixo, que encontramos nos textos dos cronistas Lóios ${ }^{1417}$, menciona igualmente os padres António de Santa Cruz e Diogo de Santa Maria, nomes ausentes da descrição desta missão.

Jorge de S. Paulo (que nesta matéria foi, manifestamente, a fonte de Francisco de Santa Maria) deixa-nos uma descrição elogiosa da dimensão pastoral e educativa da missão de 1508, com tal agrado de D. Manuel que este teria enviado a João de St. ${ }^{a}$ Maria uma carta, por um cavaleiro da sua casa, oferecendo-lhe o bispado de Viseu ${ }^{1418}$.

Estas informações divergem um pouco do único testemunho direto desta missão, a já mencionada carta de Afonso I, uma longa missiva em que o soberano do Congo faz ao seu homólogo português um resumo histórico do seu reinado e descreve todas as dificuldades que encontrara até então nas suas relações com os portugueses.

Ao falar dos Lóios, cuja chegada anunciara a todos os nobres do seu reino para lhes dispensarem um bom acolhimento, relata como ele próprio publicamente dera conta da chegada dos padres, dizendo aos seus súbditos:

apremdey as cousas da sua fee e tomai emxempro destes que sam seus servos [de Deus], os mantem muyta castidade e vive $[\mathrm{m}]$ em muyta avestyne $[\mathrm{n}] \mathrm{ca}^{1419}$ e jeguns e fazem muyto santa vida ${ }^{1420}$

Descreve ainda como, por ocasião da chegada dos padres, juntou cerca de quatro centenas de jovens provenientes da família Real e da elite congolesa, para os quais mandou preparar um recinto fechado junto ao qual estavam as casas destinadas a residência comunitária dos cónegos Lóios.

Pelos termos da carta percebe-se que estes padres Lóios iriam, na capital do Congo, estabelecer uma comunidade colegiada dedicada a ensinar estas quatro centenas de jovens, em suma um colégio de cónegos dedicado a manter um colégio de estudantes.

\footnotetext{
${ }^{1416}$ Cf ADB - Manuscritos, ms. 924, cap. 50, p. 223; SANTA MARIA, 1697: 264 e segs.

1417 Jorge de S. Paulo elenca o grupo como constituído por João de St. a Maria (superior), Rodrigo de Deus, Vicente do Manicongo, Aleixo de Viseu, Luís de S. Miguel, João de St. ${ }^{\circ}$ Estevão, Simão de Montemor, João de S. Vicente o moço, António de Cristo, Pêro dos Santos, Fernão de S. João, Bastião do Salvador e António de S. João (ou de S. Jerónimo, como diz Francisco de Santa Maria) (cf. ADB - Manuscritos, ms. 924, cap. 50, p. 223, 224).

${ }^{1418}$ Idem, ibidem: 224.

${ }^{1419}$ Brásio lê como «austyue era», mas uma leitura do original (ANTT - Corpo Cronológico, parte I, mç. 16, doc. 28) permite sugerir esta alternativa.

${ }^{1420}$ BRÁSIO, 1952: 299.
} 
O resultado da presença Lóia na capital congolesa não terá, no entanto, tido o grau de exemplaridade moral que Jorge de S. Paulo sugeriria 150 anos depois. A carta do Rei do Congo de 1514 afirma

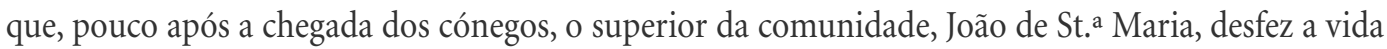
comunitária.

Estabeleceram-se os cónegos autonomamente, cada um em sua casa, ensinando um grupo de jovens. Afirma Afonso I que o importunariam constantemente com pedidos de dinheiro com que se dedicavam ao comércio. Logo no início da crise comunitária os padres António de St. ${ }^{a}$ Cruz e Diogo de St. ${ }^{a}$ Maria teriam pedido ao Rei para regressarem a Portugal, evitando assistir à decadência que pareciam adivinhar ${ }^{1421}$.

O exemplo de vida da comunidade terá sido tal que a carta resume deste modo:

lhe roguámos [aos Lóios] por amor de nosso Senhor Ihesus Christo que se comprassem algumas peças que fosem esprivos [i.e. escravos] e que nom conprasem nhuma molher, por nam darem mão emxenpro nem Nos fazerem ficar em mentyra com nosa gente do que lhe tynhamos pregado, e sem embarguo começaram a emcher as casas de putas, em tall maneyra que ho padre Pero Fernandez $z^{1422}$ emprenhou huma molher em sua casa e pario huum mulato, pollo quall os moços que emsynava e tynha em sua casa lhe fugyam e yam no contar a seus paes e mãis e parentes; pollo [que] todos começaram a zombar e escarnecer de Nós ${ }^{1423}$.

É nítido na descrição que o Rei faz desta missão o seu incómodo com o comportamento dos padres, que não estaria de acordo com o padrão que o próprio monarca apresentara publicamente, acarretando (como claramente se descreve no excerto transcrito) o ridículo, sempre tão perigoso em matéria de política.

Lamentavelmente a inexistência de outras fontes que não as cronísticas (omissas sobre a questão) tornam impossível o confronto das acusações do Rei do Congo, o que nos permitira perceber se a nota dominante da presença dos padres Lóios no Congo, nesta missão de 1508, foi a da prática do comércio de escravos e da mancebia clerical, que os cânones e as leis do reino claramente lhes vedavam, e que iam frontalmente contra o espírito reformador da sua Congregação.

Esta é a única documentação específica que descreve uma missão Lóia no Congo. Jorge de S. Paulo menciona, no acompanhamento do bispo D. Henrique no seu regresso a África em 1521, uma nova missão composta por quatro padres: Sebastião de Santa Maria, Fernão de S. João, Bartolomeu de S. João e António de S. João, tendo por superior o próprio Bispo, conforme provisão do Geral dos Lóios.

A morte de Bartolomeu reduziria o grupo a 3 padres, os quais seriam bem recebidos no Congo, mas dedicando-se rapidamente os padres Fernão e António a comerciar; Fernão de S. João teria mesmo estabelecido feitoria em S. Tomé e mercador correspondente em Lisboa. Esta atividade, que

\footnotetext{
${ }^{1421}$ Idem, ibidem: 299, 301.

1422 Provavelmente o P.e Pêro dos Santos de que fala Jorge de S. Paulo.

${ }^{1423}$ BRÁSIO, 1952: 300, 301.
} 
feria o modo de vida da Congregação (pela acumulação de bens próprios) teria chocado Afonso I e o seu povo, e sido alvo de censuras do Bispo e dos Gerais Lóios $^{1424}$.

Esta descrição de Jorge de S. Paulo, que pela primeira vez assume que a atuação Lóia em África nem sempre se realizou dentro dos parâmetros próprios do modo de vida da Congregação, coincide parcialmente com os termos de uma carta do rei do Congo a D. João III, datada de 18 de março de 1526, em que afirma que o seu filho bispo D. Henrique fora acompanhado no seu regresso por três Lóios dos quais, quando a carta foi escrita, um já tinha regressado a Portugal e os outros dois partiriam brevemente ${ }^{1425}$.

A carta de 1526 pedia o envio de seis cónegos Lóios «pera estarem com nosso filho o bispo, por que se cryou em elles e reçebe muita consolaçam tellos em sua companhia» ${ }^{1226}$, mas nem documentos futuros, nem a cronística Lóia, mencionam presenças posteriores de Lóios no Congo.

Dos padres comerciantes diz Jorge de S. Paulo que, em 1532 e 1535, os Gerais da Congregação teriam mandado embargar na Casa da Índia e em S. Tomé as suas fazendas, que D. João III mandaria por provisão entregar à Congregação e que passados a dinheiro seriam despendidos em obras de St. ${ }^{\circ}$ Elói de Lisboa e de Arraiolos.

Fernão de S. João, privado da sua fazenda, regressa aos claustros Lóios e é enviado para Arraiolos, Casa onde ainda em 1658 se dizia por sua alma um aniversário de três lições e vésperas, pelos 300 mil reis da sua fazenda gastos na Casa ${ }^{1427}$, se bem que tenha sido em St. ${ }^{\circ}$ Elói e Xabregas que o capítulo geral de 1542 tenha mandado celebrar ano e meio de missas por sua alma e pelas almas da sua obrigação, o que nos indica que já estava morto neste ano ${ }^{1428}$.

Os capítulos gerais dos Lóios de 1538 a 1545, de que se conservam as atas, dão-nos algumas pistas sobre esta questão, confirmando algumas das afirmações de Jorge de S. Paulo. Assim, as contas de St. ${ }^{\circ}$ Elói de Lisboa de 1538 incluem mesmo uma rubrica «Do dinheiro de comgo», com três parcelas: uma que indica terem sobrado 41.920 réis do primeiro dinheiro que veio do Congo, a segunda afirmando ter pago Francisco Paes do Amaral 96.000 réis, e a terceira que diz ter vindo por uma letra aos Henriques, que mandara Simão Cosme, 200 mil réis, perfazendo a soma de 337.920 réis, essencialmente gastos em obras da Casa ${ }^{1429}$.

No mesmo ano de 1538 manda o capítulo que o reitor de St. ${ }^{\circ}$ Elói dê a Arraiolos 16 mil réis do dinheiro do Congo, bem como a terça parte de tudo o que vier da fazenda do Congo, como teria já sido ordenado por outros capítulos (de que não existem livros de atas), determinação que se entenderá da fazenda que vier de Fernão de S. João ${ }^{1430}$.

\footnotetext{
${ }^{1424}$ ADB - Manuscritos, ms. 924, cap. 50, p. 227-229.

${ }^{1425}$ BRÁSIO, 1952: 463, 464.

${ }^{1426}$ Idem, ibidem: 463.

${ }^{1427}$ ADB - Manuscritos, ms. 924, cap. 50, p. 229.

${ }^{1428}$ Cf. ANTT - Manuscritos da Livraria, n. ${ }^{\circ} 186$, fl. 131v.

${ }^{1429}$ Idem, ibidem: fl. 15-16.

${ }^{1430}$ Idem, ibidem: fl. 22.
} 
Em 1539 o capítulo geral determina que com o dinheiro que vier do Congo se paguem todas as dízimas da Congregação, se tiverem de ser pagas (questão que estava por determinar, e que em caso negativo seria o valor respetivo dividido por todas as Casas Lóias), sendo o remanescente dividido em três partes: uma para St. ${ }^{\circ}$ Elói, outra para Arraiolos e outra para pagar as dívidas das restantes Casas da Congregação ${ }^{1431}$. Em 1543 a Casa de St. ${ }^{\circ}$ Elói ainda recebe 60 mil réis vindos da Ilha de S. Tomé ${ }^{1432}$.

Os termos capitulares não só parecem corroborar as afirmações de Jorge de S. Paulo, como a divisão dos valores, privilegiando as Casas de St. ${ }^{\circ}$ Elói e Arraiolos, demonstra o desejo de apoiar a mais recente fundação da Congregação (Arraiolos) e a remuneração da Casa Lóia que mais destacadamente se dedicou ao serviço educativo de nobres congoleses, St. ${ }^{\circ}$ Elói de Lisboa.

Fica apenas desmentido o rigor com que a Congregação veria, segundo o próprio Jorge de S. Paulo, a atividade mercantil dos seus cónegos, em particular Fernão de S. João. É o que se depreende do modo diligente como aplica o dinheiro obtido nesse comércio (e que vai recebendo parceladamente, fazendo supor uma liquidação faseada de interesses comerciais), bem como do facto de pagar ao seu cónego Fernão de S. João (o tal com quem o capítulo geral teria procedido com rigor) essa vasta soma de dinheiro com importantes sufrágios por alma ${ }^{1433}$.

Mas não era apenas dinheiro que de África vinha à Congregação, mandando o capítulo de 1538 ao reitor de St. ${ }^{\circ}$ Elói de Lisboa que dê um negro à Casa de Évora se vier algum (do Congo presume-se $)^{1434}$, entendendo-se por tal um escravo.

A realidade da Congregação como proprietária de escravos seria corrente por estes anos, já que encontramos o capítulo geral de 1544 a proibir reitores e vice-reitores de darem licença a escravos para casarem, sob pena de excomunhão ${ }^{1435}$, e isto no mesmo ano em que a Casa de Arraiolos dá um escravo em pagamento de um moio de renda numa herdade (valendo apenas 16 dos 43 mil réis do custo desse moio $)^{1436}$. Em 1545, último ano para que temos atas capitulares, as contas de Arraiolos declaram a venda do escravo Damião, por 16 mil réis (aparentemente o valor de um escravo no Alentejo da década de 1540), dos quais 12 mil já estavam aplicados nas obras da comunidade ${ }^{1437}$.

Poderia a posse de escravos, o seu comércio, a proibição estrita de que se casem, parecer um pouco a contrassenso do acolhimento que os Lóios fazem dos nobres congoleses, a educação que estes obtêm nas suas Casas, uma proximidade que se revela até na instituição de obrigações de missa por membro da família real congolesa num dos conventos Lóios ${ }^{1438}$.

\footnotetext{
${ }^{1431}$ Idem, ibidem: fl. 47.

${ }^{1432}$ Idem, ibidem: fl. 147.

${ }^{1433}$ Seria por considerarem que os sufrágios que a Congregação fazia pela alma de todos os seus cónegos falecidos não eram suficientes para a magnitude dos pecados de um cónego comerciante, e logo de escravos.

${ }^{1434}$ ANTT - Manuscritos da Livraria, n. ${ }^{\circ}$ 186, fl. 24.

${ }^{1435}$ Idem, ibidem: fl. $178 \mathrm{v}$.

${ }^{1436}$ Idem, ibidem: fl. $174 \mathrm{v}$.

${ }^{1437}$ Idem, ibidem: fl. 207.

${ }^{1438} \mathrm{Idem}$, ibidem: fl. 22v. Manda o capítulo ao reitor de St. ${ }^{\circ}$ Elói que pela esmola que à Casa deu D. Manuel irmão do Rei do Congo, se celebre anualmente uma missa em N. ${ }^{\text {a }}$ Sr. ${ }^{a}$ de Setembro, a qual depois da morte do doador se decidirá o que fazer.
} 
Parece patente que os «pretos», designação coletiva aplicada aos estudantes africanos que estudavam na Congregação ${ }^{1439}$, eram considerados como «um outro» que não inteiramente «um outro eu». Reconhecendo a hierarquia própria das elites africanas (afinal, como escrevia João de Barros em relação aos nobres congoleses, «todalas nações tem seus termos de nobreza, e honra, causa dos maiores trabalhos da vida» ${ }^{1440}$ ), e colocando-a a par da portuguesa, o que o próprio Rei D. Manuel desejava ${ }^{1441}$, não deixam naturalmente de os hierarquizar dentro das dinâmicas sociais e raciais que se construíam em relação aos africanos ${ }^{1442}$, nomeadamente num contexto de uma sociedade esclavagista, na qual se reconhecia ainda a diferença de posições entre a elite africana e os demais degraus da sua pirâmide hierárquica, até ao nível mais baixo que era ocupado pelos escravos.

Trata-se de um processo histórico que conheceu uma construção dilatada no tempo e foi participado pela própria elite africana, como se percebe pelas ofertas de escravos que eram feitas pelo Rei do Congo à Coroa portuguesa e a diversos dos súbditos desta ${ }^{1443}$, e que seguia as dinâmicas próprias do reino do Congo.

Francisco Bethencourt, que sobre estas matérias publicou recentemente uma importante síntese, refere que «o projecto de evangelização partia do pressuposto da boa natureza dos nativos. A erosão da presença europeia e cristã no Congo veio alterar essa perspetiva. Se compararmos os primeiros relatos, de finais do século XV, com relatos publicados um século e meio depois, é notória a mudança profunda da proximidade para a distância, de uma imagem espelhada para uma estranheza inultrapassável» ${ }^{1444}$.

\footnotetext{
${ }^{1439}$ Por exemplo nas contas da Casa de St. ${ }^{\circ}$ Elói de Lisboa de 1538, onde se regista na receita o mantimento dos pretos (cf. Idem, ibidem: fl. 14).

${ }^{1440}$ BARROS, 1778: 228.

${ }^{1441}$ Como se poderá ver pelo Regimento que em 1512 o rei D. Manuel I deu ao seu embaixador ao Rei do Congo, Simão da Silva, em que se ordena que transmita a ideia a Afonso I que o seu congénere português o considera entre os demais reis cristãos, pelo que the envia brasão de armas e selo para uso da chancelaria, bem como lista dos ofícios de corte para serem replicados na corte congolesa. Transcrito em BRÁSIO, 1952: doc. 65. Como Isabel Sá chama a atenção «estas instruções constituem um verdadeiro manual do perfeito colonizador» (cf. SÁ, 2009: 318 e segs.). Apenas erra a Prof.a Isabel dos Guimarães Sá quando diz que a estadia de nobres congoleses nas Casas Lóias que alguns historiadores aventariam é pouco documentada e essencialmente assente na crónica de Francisco de Santa Maria, que se basearia em documentos que nunca se encontraram. Mesmo excluindo a Crónica de 1697, existem dados documentais suficientes para sustentar a presença dos jovens entre os Lóios, como Pedro Tavares já enunciou (TAVARES, 1989), e como aqui se demonstra.

${ }^{1442}$ Um caso paradigmático é o dos alvarás de D. João II para entrega de peças de roupa a D. Pedro embaixador do Rei do Congo e aos três «negros» que o acompanham (cf. BRÁSIO, 1952: doc. 37 e segs.). Num outro nível encontramos indícios similares, como o que descreve a carta do rei D. Afonso do Congo ao rei D. Manuel I, de outubro de 1514, em que diz que Fernão de Melo, no contexto das difíceis relações que mantinha com o soberano congolês, lhe chegara a dizer «que por quanto tesouro suallteza tynha, nem quanta ryqueza avya em Portugall, elle nom vyveria com nosquo e que agora má ora avia elle de viver com huum negro» (citado em Idem, ibidem: 319).

${ }^{1443}$ Veja-se, apenas como um exemplo entre outros possíveis, o que ficou dito supra sobre os 50 escravos oferecidos aos padres, ou o alvará de D. Manuel I que menciona a oferta de 70 escravos que lhe foi feita pelo Rei do Congo (cf. Idem, ibidem: doc. 90). ${ }^{1444}$ BETHENCOURT, 2015: 126.
} 


\subsubsection{Evangelizar ou Educar: o modelo Lóio para o Congo e os congoleses}

Sendo certo que o processo de evangelização é em si um processo de educação (educa-se para um referencial religioso, mas educa-se), entenda-se o título deste ponto como um questionamento ao cerne da atuação dos Lóios em relação ao Congo: dirigia-se a um processo religioso de aproximação de populações não-cristãs ao cristianismo, pela catequização, tendo em vista a sua adesão por via do batismo, ou aos Lóios coube um papel mais profundo na relação com o Congo e os congoleses?

A resposta é rápida e simples: mesmo quando os Lóios, por iniciativa da Coroa portuguesa, enviam uma missão ao Congo, a principal atividade que se regista dos cónegos que a integravam não é a da catequização, mas a de educarem um conjunto de jovens da elite congolesa entregues aos seus cuidados, para que neles aplicassem os processos e padrões educativos que tinham em uso nas Casas Lóias. Esperava-se dos padres que formassem as elites congolesas à imagem dos cortesãos portugueses, mas também certamente que preparassem o futuro clero africano.

Nesta medida o estudo que funcionou em St. ${ }^{\circ}$ Elói de Lisboa assemelhou-se, na primeira metade do séc. XVI, não só a um colégio onde se educavam elites do Congo, mas também a um primeiro seminário formador do clero africano de rito latino ${ }^{1445}$, ideia que já Pedro Tavares sugeria no seu artigo dedicado à participação Lóia nas primeiras missões africanas ${ }^{1446}$.

A inexistência de dados muito precisos não permite afirmar contundentemente as datas de início e fim da atividade educativa de congoleses nas Casas de St. ${ }^{\circ}$ Elói de Lisboa ou de S. Bento de Xabregas, e dos fins específicos a que se destinava, mas permite no entanto uma aproximação à questão.

Entre a documentação própria da Congregação, é o já citado livro de atas capitulares de 1538-45 que encerra a esmagadora maioria das menções aos congoleses que se educavam entre os Lóios e ao dinheiro que vinha do Congo, revelando a existência, tipologia e constância destas relações, que no entanto não se alargaram por muito mais tempo, já que se encontram totalmente ausentes das atas capitulares seguintes, temporalmente situadas logo após o termo cronológico desta obra $^{1447}$.

Além das menções ao dinheiro que, da fazenda de Fernão de S. João, vinha do Congo, as atas referem nas contas da Casa de Xabregas de 1540 e 1541 a entrada de dinheiro das contas dos netos do Rei do Congo ${ }^{1488}$; enquanto as contas de St. ${ }^{0}$ Elói de 1540 declaram a entrada de 48 mil réis do «man-

\footnotetext{
${ }^{1445}$ Importa nunca perder de vista que o séc. XV e XVI marcam a expansão do cristianismo de rito latino em África, mas não a génese do cristianismo no continente, pois além da existência de Igrejas cristãs tradicionais como a Copta ou a Etíope, o norte de África teve, nos primeiros séculos do cristianismo e antes do advento do Islão, uma forte rede de dioceses cristãs, e uma importante cultura cristã, de que Santo Agostinho, bispo de Hipona (Argélia), foi um dos expoentes.

1446 Cf. TAVARES, 1989.

${ }^{1447}$ Para o período de 1589 a 1604 (cf. ANTT - Congregação de S. João Evangelista, Convento de St.o Elói de Lisboa, lv. 15.

${ }^{1448}$ ANTT - Manuscritos da Livraria, n. ${ }^{\circ}$ 186, fl. 59v., 104v. Entre estes netos podemos situar D. Manuel, neto de Afonso I, que este em 1539 enviou a Portugal (com cinco sobrinhos seus), para que com seu primo D. Pedro de Castro (que já estivera em Portugal na companhia do bispo de Útica), fossem aprender a ler, escrever, e as coisas do serviço de Deus, enquanto os outros estavam destinados a ir a Roma dar obediência ao Papa (D. Mateus e D. Henrique) e a receberem ordens menores e se prepararem para as sacras (D. Gonçalo e D. Francisco) (cf. BRÁSIO, 1953: 73-75).
} 
timento dos indios e pretos», de que a Casa ainda teria a haver algum valor ${ }^{1449}$, menção renovada nas contas de 1542 e 1543, mas em relação apenas a «indios» ${ }^{1450}$.

O pagamento destes «mantimentos» era feito pela Casa da Índia ${ }^{1451}$, demonstrando claramente a natureza de incumbência régia que a educação dos africanos tinha nas Casas da Congregação, de acordo aliás com o que afirmava já um alvará de D. Manuel I ao tesoureiro da moeda Garcia Moniz, de janeiro de 1514, que manda pagar o mantimento devido e prover de roupas os «pretos no Manycomguo que estam em Santaloy e Sam Bento [de Xabregas]» ${ }^{1452}$.

Este alvará é de particular interesse porque revela claramente que estes congoleses são enviados aos Lóios para serem educados, pois além do seu sustento, a Coroa surge a provê-los de «tinta, papel, calçado, camas e livros», e manda mesmo comprar «livros que ouverem mester pera seu ensyno» ${ }^{1453}$, revelando o objetivo da sua presença nas duas Casas lisboetas da Congregação dos Lóios e onde, na prática (e com financiamento da Coroa), se montava colégio.

Por estes anos somos informados da presença do futuro bispo de Útica nos claustros Lóios, bem como de outros congoleses, como os que são mencionados em alvará de D. Manuel, de agosto de 1516, e que estavam de partida para o Congo ${ }^{1454}$.

Do processo educativo em si, quais os curricula seguidos pelos padres Lóios, não encontramos informação disponível, apenas o podemos situar dentro do que já seria a tradição escolar da Congregação e particularmente da Casa de St. ${ }^{\circ}$ Elói de Lisboa, que os indícios apresentados parecem situar como instituição preferencial nesta matéria.

Para além da formação base em gramática e nas artes liberais, que se ensinavam a membros da Congregação e de fora, terão recebido formação específica no campo teológico e litúrgico aqueles que, como D. Henrique, estavam destinados a tomar ordens menores e maiores, entrando para o estado clerical.

A educação dos jovens congoleses (i.e., os das suas elites) parece ter sido encarado pelas duas Coroas, portuguesa e congolesa, como assunto de estado de elevada importância, para a primeira como forma de alicerçar a aproximação do reino de Congo ao universo lusófono e constituir-se como uma unidade política privilegiada para ajudar a sustentar os interesses portugueses na região; para a segunda como forma de mais efetiva adoção do modelo político, social e religioso europeu e cristão que se integrava no processo de afirmação política da monarquia congolesa.

\footnotetext{
${ }^{1449}$ ANTT - Manuscritos da Livraria, n. ${ }^{\circ}$ 186, fl. 64v. e 65v.

${ }^{1450}$ Idem, ibidem: fl. 124v., 147. Resta saber qual o efetivo alcance da supressão da expressão «pretos», se estamos perante a ausência de africanos entre os educandos de St. ${ }^{\circ}$ Elói ou se é apenas uma abreviação do registo.

${ }^{1451}$ Idem, ibidem: fl. 124v. Um alvará de D. Manuel de setembro de 1514, que manda dar roupa a «om Framçisquo e a dom Pedro e a dom Symão e a dom Myguell e a dom Amtonyo, pretos que ora vam a Manycomgo» e determinando que para a receberem apresentem certidão da Casa da Índia em que se indique estarem riscados dos registos dos que recebem mantimento daquela instituição (cf. BRÁSIO, 1952: 289).

1452 Transcrito em Idem, ibidem: 281.

${ }^{1453}$ Idem, ibidem.

${ }^{1454}$ Idem, ibidem: 366, 367.
} 
Tal pode-se depreender do esforço material de décadas empreendido pela Coroa portuguesa ${ }^{1455}$ e pelo seu pedido de envio de jovens nobres congoleses para serem educados em Portugal, mas também o próprio esforço da coroa congolesa, em que certas ofertas de escravos que acompanhavam os jovens educandos permitem supor uma forma de participação material na sua formação, ou o declarado desejo de enviar marfim para Portugal, como paga das despesas dos estudantes congoleses em Portugal ${ }^{1456}$.

Além do envio dos jovens e do apoio material, Afonso I tentou ver criadas no seu reino instituições escolares, de que a espécie de colégio preparado para os Lóios foi um exemplo, mas de que também o é o seu pedido (de 1515) de pedreiros e carpinteiros para construir uma escola ${ }^{1457}$, ou a carta do vigário Rui de Aguiar (que estava no Congo onde se dedicava a educar jovens congoleses ${ }^{1458}$ ) ao rei D. Manuel, em que dava conta de Afonso I ter a funcionar escolas dos dois sexos no seu reino, em que ensinavam congoleses já educados, e pedindo o envio de livros para ajudar a sustentar esse movimento $^{1459}$.

A importância estratégica para as duas Coroas desta ação educativa dá-nos a medida da incumbência atribuída aos Lóios, e permite perceber de um modo muito claro o reconhecimento e prestígio de que a Congregação gozava nos corredores do poder.

A Coroa reconhecia nos Lóios uma capacidade educativa que se prestava a uma missão que não se reduzia a um mero ato formativo, já que tinha uma dimensão política e eclesial (ao formar clérigos africanos) de grande relevância dentro da política ultramarina da monarquia portuguesa.

Reconhece-se mérito educativo, reconhece-se com toda a probabilidade o mérito de vida de uma Congregação reformista, que visava a melhor preparação e santificação do clero secular, tendo em vista a melhor formação, vivência e santificação da comunidade cristã.

Apesar dos múltiplos esforços, o resultado nem sempre terá sido o que os monarcas dos dois reinos desejariam, facilmente compreensível quando atendemos às dificuldades que o processo de aculturação dos jovens congoleses a uma realidade que lhes era estranha e/ou desconhecida certamente acarretaria.

A 27 de maio de 1517, ainda nas primeiras décadas do maciço esforço educativo empreendido pela coroa portuguesa, Afonso I escrevia ao seu homólogo português a resposta a uma carta que este lhe remetera, onde lhe dera conta do pouco proveito educativo dos seus parentes em Portugal e de como era sua intenção terminar com o projeto de educar os nobres congoleses em Portugal ${ }^{1460}$.

\footnotetext{
${ }^{1455}$ Não podendo estabelecer datas precisas para esta política régia, atenhamo-nos apenas às datas mais estremas mencionadas nesta obra: 1493 em que se encontram os jovens africanos educados por um mestre de gramática em Lisboa a mando de D. João II, e 1544, ultima menção sobre a questão nas atas capitulares dos Lóios.

${ }^{1456}$ Como declara Afonso I na carta que envia a D. João III, datada de 25 de agosto de 1526 (cf. BRÁSIO, 1952: 483, 484).

${ }^{1457}$ Cf. Idem, ibidem: 335-338. Carta datada de 31 de maio de 1515.

${ }^{1458}$ Educava-os a ler, escrever e em gramática, bem como dava-lhes catequese, conforme ao que descreve Damião de Góis (citado em Idem, ibidem: 373-375).

${ }^{1459}$ Carta transcrita por Damião de Góis na sua Crónica de D. Manuel e que por sua vez é transcrita pelo P.e Brásio na sua Monumenta (Idem, ibidem: 361-363).

${ }^{1460}$ Idem, ibidem: 406, 407.
} 
O Rei do Congo, manifestando a sua tristeza com essa informação e as implicações políticas de um regresso desses nobres (que seria contrário ao apoio político português que Afonso I propagandeava no seu reino), pede a D. Manuel que faça castigar os educandos, os separe e espalhe pelo reino «per esas Casas de Relegiam ${ }^{1461}$, das quais infelizmente não refere se são umas casas de religião genéricas ou se especificamente (como será provável) se refere às restantes quatro Casas Lóias fora da capital que existiam neste período ${ }^{1462}$.

Esta determinação do Rei de Portugal, como se sabe, não foi avante, porque ainda encontramos congoleses a estudar em Portugal nas décadas seguintes. Um ano depois da carta de Afonso I um dos principais frutos da educação dos Lóios atinge o seu apogeu, ao ser eleito Bispo pelo Papa Leão X.

\section{O clero congolês: D. Henrique, Bispo de Útica}

Em breve datado de 7 de maio de $1518^{1463}$, o Papa Leão X anuncia a D. Henrique, filho de D. João rei do Congo ${ }^{1464}$, e em resposta à súplica que lhe fora apresentada pelo rei de Portugal D. Manuel I e pelo rei seu pai, que o elevava à dignidade episcopal, na Igreja titular de Útica.

No mesmo breve afirma o Pontífice que, pelas cartas do Rei de Portugal e pelas palavras do seu embaixador D. Miguel da Silva, recebera notícia da suficiência do novo prelado, e que o nomeava bispo confiante de que os seus costumes morais e bons atos seriam ornamento da sua nova dignidade, e que do seu múnus pastoral esperava a exaltação da Fé e aumento da glória de Deus.

Recomenda ainda particularmente, o Pontífice ao novo Bispo que mantenha e promova a paz. Termina com um conselho e uma promessa: «In omnibus etiam quae episcopali conveniunt officio ita te exhibeas circunspectum et gloriam sempiternam in caelis aquirere et apud nos merito comendari valeas» ${ }^{1465}$.

O alcance deste breve é bem patente, pela primeira vez na história moderna da Igreja Romana um homem nascido em África é elevado ao episcopado. É certo que esta eleição não marca o início de uma tendência, tendo-se singularizado durante os séculos seguintes da modernidade; malgrado o desejo do cronista Francisco de Santa Maria de fazer de D. Pedro de Sousa, parente de Afonso I do Congo, seu embaixador em Portugal e homem próximo à rainha D. Leonor de Lencastre ${ }^{1466}, \mathrm{o}$

\footnotetext{
${ }^{1461}$ Idem, ibidem: 407.

${ }^{1462}$ Vilar de Frades, Recião, Évora e Porto. Para a listagem das Casas Lóias vd. quadro anexo n. ${ }^{4}$.

${ }^{1463}$ O P.e António Brásio data este breve do dia 8 de maio, de acordo com a transcrição de Eugen Weber, que utiliza para a sua publicação no I volume da sua Monumenta Missionaria Africana (BRÁSIO, 1952: 417). No entanto, uma consulta do original no Arquivo do Vaticano permitiu perceber que a carta não é datada de 8 das nonas de maio (data aliás incoerente com o sistema de datação romano), mas das nonas de maio de 1518, que nesse mês cairia no dia 7 (cf. ASV - Armadio XL, vol. 3, doc. n. ${ }^{\circ}$ 309).

${ }^{1464}$ Aqui equivoca-se o Papa, já que D. Henrique era filho do rei Afonso I, e neto de João I, como fica patente pelas múltiplas referências que seu pai lhe faz em cartas trocadas com o rei de Portugal, e que Brásio transcreve no $1 .{ }^{\circ}$ volume da Monumenta Missionaria Africana, aqui já amplamente citada.

${ }^{1465}$ Idem, ibidem.

${ }^{1466}$ Como o apresenta Isabel dos Guimarães Sá (SÁ, 2012: 208). Erra apenas em afirmar que o dado histórico de que D. Pedro do Congo morrera no hospital das Caldas da Rainha deve-se a um recente artigo de Lisbeth Rodrigues, datado de 2009,
} 
segundo bispo africano da Igreja, e logo como bispo diocesano de S. Tomé, afirmando-o sagrado com seu primo Henrique em Roma pelo próprio Papa Leão $\mathrm{X}^{1467}$.

De um segundo bispo africano encontra-se também menção em João de Barros ${ }^{1468}$ sem referir nomes de titulares nem dioceses, que Francisco de Santa Maria personaliza no bispo que se sabe que foi bispo e no bispo que se sabe que não foi bispo ${ }^{1469}$.

De Henrique e Pedro do Congo faz também Francisco de Santa Maria, na senda da afirmação de Damião de Góis ${ }^{1470}$, os primeiros embaixadores do seu reino à Santa Sé.

A confirmar a existência da ideia de uma embaixada congolesa ao Papa está o texto do regimento de 1512 a Simão da Silva, em que o Rei de Portugal encarrega o seu representante de sugerir ao rei Afonso I que este deveria enviar uma embaixada de obediência ao Papa, conforme ao costume em prática entre os reis cristãos, sugerindo que envie o seu primo D. Pedro que tinha enviado a Lisboa como seu representante, bem como o seu filho D. Henrique que:

estaa bem ensynado e doctrynado nas cousas da fee [...] e que sabe já latim e que a oraçam da embaixada da dita obidiencia fará em latim ao santo Padre ${ }^{1471}$.

Para dar resposta a esta sugestão, Afonso I vai enviar uma carta dirigida ao Papa Júlio II, em que dá conta da sua conversão e em que diz desejar dar sua obediência à Sé Apostólica como os demais reis cristãos, para o que envia como seus representantes seu primo D. Pedro de Sousa e

o meu muito amado e prezado filho dom Henrique, ho qual elrei dom Emanuel de Portugal meu muito amado irmão, em seus regnos mandou ensinar, e instituir na Sagrada Escriptura, e costumes da Fe catholica ${ }^{1472}$.

Podemos supor que foi sobre estes documentos que se alicerçou a hipótese de uma embaixada congolesa de obediência ao Papa nos anos de 1513 ou de 1514 (integrada na embaixada liderada por Tristão da Cunha), para o que no entanto não se encontra fundamentação em documentação de arquivo portuguesa ou romana.

\footnotetext{
quando a questão já fora documentalmente levantada, em 1947, num artigo do P.e António Brásio, e era já mencionado por Jorge Cardoso no seu Agiológio Lusitano (cf. BRÁSIO, 1973: 305).

${ }^{1467}$ SANTA MARIA, 1697: 264.

${ }^{1468}$ BARROS, 1778: década I, liv. III, cap. X, p. 244.

${ }^{1469}$ O P.e Brásio, ao tratar da questão e não querendo afirmar perentoriamente que D. Pedro do Congo não foi Bispo (apesar de nenhum documento não cronístico comprovar este episcopado) demonstra que no entanto nunca foi bispo de S. Tomé, diocese criada em 1533 e que teve como primeiro bispo em 1534 a D. Diogo Ortiz (cf. BRÁSIO, 1973: 303-307).

${ }^{1470}$ No cap. 39 da III parte da sua Crónica de D. Manuel (citado em BRÁSIO, 1952: 273, 274).

${ }^{1471}$ Citado em Idem, ibidem: 242.

${ }^{1472}$ Da versão em língua portuguesa inserida na Crónica de D. Manuel, de Damião de Góis, que com a versão original desta carta em língua latina (e que se conserva no fundo Corpo Cronológico da Torre do Tombo) está transcrita em Idem, ibidem: $270-273$
} 
É o que se conclui da análise que António Brásio faz da questão, com a particularidade de, entre 1947 e 1971 e numa série de 3 artigos $^{1473}$, passar da afirmação da embaixada congolesa a Leão X em 1513 à negação total da embaixada («um sonho lindo, mas, enfim, um sonho») em 1513 ou integrada na de Tristão da Cunha em 1514, passando por um estado intermédio em que passa da certeza da embaixada à possibilidade de ela nunca ter acontecido, depois de ter encontrado um silêncio absoluto nos arquivo e biblioteca do Vaticano, inexplicável em caso de efetivamente ter sido cumprida tal embaixada.

Deve-se atribuir a eleição de D. Henrique do Congo ao episcopado inteiramente ao rei D. Manuel I, que por ela propugnou em Roma e que a obteve de um Papa Leão X no mínimo renitente, que faz saber ao rei de Portugal que deseja que o novo bispo seja rodeado de teólogos e canonistas que o auxiliem e, em última análise, garantam a ortodoxia da sua fé quando for cumprir com o objetivo da sua promoção episcopal, a propagação da Fé no Congo ${ }^{1474}$.

O novo bispo, que fora ordenado clérigo na diocese do Funchal ${ }^{1475}$ (aquela que então tinha jurisdição eclesiástica sobre o reino do Congo ${ }^{1476}$ ), era eleito bispo titular com direito de celebrar pontificalmente em toda a diocese em que fora ordenado, com consenso do prelado ordinário.

Tinha D. Henrique 24 anos de idade, menos que os 26 necessários para receber a consagração, no que o Papa dispensa-o, bem como em caso de irregularidade de nascimento, caso precisasse dessa graça ${ }^{1477}$; no entanto a 1 de dezembro de 1520 D. Manuel escrevia ao seu representante em Roma, D. Miguel da Silva, queixando-se que ainda não viera a bula de dispensa da idade para poder ser sagrado, já que entretanto fora ordenado do presbiterado (como se pode depreender da notícia de já ter cantado missa nova) e dando o Rei bom testemunho da formação académica e eclesiástica dos Lóios ao dizer que o novo bispo «estaa muy boom latyno e muyto ensynado nas cousas da igreja» ${ }^{1478}$.

Em 1526 D. Henrique estava sagrado e regressado ao reino de seu pai, residia na sua corte acompanhado de dois padres Lóios que com ele tinham ida para o Congo, número que Afonso I desejava ver aumentado em mais seis efetivos, pelo apego do prelado aos cónegos com que se educara.

Escreve o Rei do Congo que o Bispo desejava fazer visita pastoral pelo reino com os quatro padres que tinha consigo (dois dos quais seriam os tais padres Lóios), exíguo número que como salienta não chegava sequer para celebrar dignamente um pontifical «que pera ofiçyar huma myssa nam abastam», e que ele ainda não consentira por medo que os seus inimigos o pudessem envenenar ${ }^{1479}$. Afonso I dá nesta carta particular conta da falta de padres para atuarem no seu reino, pedindo

\footnotetext{
${ }^{1473}$ De 1947, 1953 e de 1971 (republicados em BRÁSIO, 1973: 267-307).

${ }^{1474}$ Conforme se pode ver nos termos da bula de Leão X de 3 de maio de 1518, dirigida a D. Manuel I e em que lhe dá conta de ter aceite a sua súplica nesta matéria (transcrita por BRÁSIO, 1952: 414, 415).

1475 Conforme à cédula consistorial da sua eleição de 5 de maio de 1518 (transcrita em Idem, ibidem: 416).

${ }^{1476}$ Criada diocese em 12 de junho de 1514, tinha jurisdição eclesiástica em todo o ultramar português até à criação de novas dioceses ultramarinas em 1534 (cf. VIEIRA, 2000).

${ }^{1477}$ Conforme aos termos do breve que dirige ao bispo eleito, datado de 22 de maio de 1518 (transcrito em BRÁSIO, 1952: $419,420)$.

${ }^{1478}$ Citado em Idem, ibidem: 447.

${ }^{1479}$ Cf. carta do Rei do Congo a D. João III, de 18 de março de 1526 (apud Idem, ibidem: 463).
} 
um total de 50 sacerdotes (para além dos 6 cónegos Lóios para acompanharem o seu filho) para distribuir pelo seu reino ${ }^{1480}$.

Em nova missiva, de 25 de agosto desse ano de 1526, Afonso I demonstra o seu desejo de ver o filho não como Bispo titular sujeito ao ordinário funchalense, mas como Bispo diocesano de uma nova diocese do Congo, ao pedir a D. João III «por mercê a V.A. o queira prover do bispado deste Reyno, pois ho tam bem mereçe, e asy por seer nosso fylho».

Na mesma carta informa sobre a contínua da falta de saúde de D. Henrique e pede que o seu sobrinho Afonso, que estudava há muitos anos em Lisboa, seja ordenado para regressar ao Congo e auxiliar o Bispo seu primo, com o objetivo último de o também fazer aceder ao episcopado ${ }^{1481}$.

Em 1529 D. João III escreve ao rei do Congo dizendo que vira o seu pedido da diocese do Congo para D. Henrique, e que tal seria o objetivo principal para o mandar chamar a Portugal, de acordo com o que lhe fora recomendado por D. Manuel I, desejando ainda enviá-lo a Roma para dar obediência do reino do Congo ao Papa, argumentando com a necessidade dos reis cristão desafrontarem o Pontífice depois do episódio do saque de Roma com o envio do mais alto eclesiástico de cada reino, e oferecendo para que D. Henrique fosse a Roma na companhia do seu irmão Cardeal Infante D. Afonso ${ }^{1482}$.

Podemos supor, nos termos em que D. João III escrevia em 1529, alguma duplicidade por parte do monarca português, que sugere que uma vinda de D. Henrique a Portugal e a Itália, para dar obediência ao Papa integrado na embaixada portuguesa, e como tal demonstrar ao Papa a importância do processo de expansão portuguesa na propagação da Fé, poderia ter por resultado a criação da requerida diocese do Congo.

Se esta diocese estaria ou não na intenção de D. Manuel I (como seu filho afirma) não sabemos, no entanto parece certo que não estaria na de D. João III, que dois anos depois, a 20 de maio de 1532, suplicava ao Papa a criação de uma diocese de S. Tomé, em que se integraria o reino do Congo, e com sede na ilha que fazia já parte dos territórios coloniais portugueses ${ }^{1483}$, e cujos donatários e outros agentes coloniais criavam constantemente problemas à Coroa congolesa, como a documentação torna bem patente ${ }^{1484}$.

Nada indica que D. Henrique tenha regressado a Portugal, e menos ainda tenha ido a Roma, onde Clemente VII concederia a criação da diocese de S. Tomé, que o seu sucessor Paulo III, em breve

\footnotetext{
${ }^{1480}$ Idem, ibidem: 460-463.

${ }^{1481}$ Transcrito em Idem, ibidem: 483, 484. Este D. Afonso, segundo o que supõe o P.e Brásio, será o sobrinho do Rei do Congo que preteriu as ordens sacras e uma possível mitra por um casamento e o ofício de mestre-escola em Lisboa (cf. BRÁSIO, 1973: 308 e segs.).

1482 Transcrita em BRÁSIO, 1952: 524, 525.

1483 Transcrito em BRÁSIO, 1953: 6, 7.

${ }^{1484}$ Basta para tal percorrer a Monumenta de António Brásio e os testemunhos que regista, de uma parte e da outra, mas com destaque para as numerosas cartas com queixas de Afonso I do Congo (cf. Idem, ibidem; BRÁSIO, 1952). Os problemas gerados pela comunidade portuguesa de S. Tomé nas relações entre Portugal e o Congo são já salientados por Pedro Vilas-Boas Tavares (TAVARES, 1989: 559).
} 
de 17 de março de $1535^{1485}$, relembra a Afonso I, ao mesmo tempo que lhe recomenda o seu primeiro bispo, D. Diogo Ortiz, Deão da Capela-Real, que D. João III preconizara para esta mitra ${ }^{1486}$.

Sobre D. Henrique, o primeiro africano sagrado bispo católico, e educando dos Cónegos Lóios, que nunca deixou de amar os padres com que se formara, desce o véu da história, e regista-se que em 1539 estava já morto ${ }^{1487}$, sem que da sua mitra tenha o reino do Congo tirado proveito profundo que ficasse inscrito na memória histórica.

Podemos questionar-nos se com D. João III assistimos a uma política de fechamento em relação à preparação de um clero africano, sobretudo tendo em conta o que foi o reinado de seu pai nesta matéria. Esta sensação fica-nos do seu comportamento em relação à questão da diocese do Congo, mas sobretudo se tivermos em conta os instrumentos pontifícios de que seu pai se muniu e de que o filho pouco uso terá feito.

De facto, e ligado à eleição episcopal de $\mathrm{D}$. Henrique e à ordenação de outros clérigos não europeus, encontramos um breve de Leão X, de 12 de junho de 1518 (mês sequente ao da eleição de D. Henrique), em resposta a súplica de D. Manuel I sobre os etíopes, indianos e africanos que em Lisboa eram batizados e educados na Fé, e que D. Manuel desejaria enviar às suas terras para anunciarem o Evangelho e converterem os povos, mas ordenados de sacerdócio para maior força e autoridade do seu ministério pastoral.

Por este breve o Papa concede ao Bispo de Lamego, capelão-mor da Capela-Real, e aos seus sucessores e a outros prelados em comunhão com a Sé Apostólica, a faculdade de ordenarem africanos e indianos, mesmo que convertidos do paganismo ou do islamismo, idóneos e suficientemente preparados, suprindo defeitos de nascimento e ausência de benefício ou património para ordenação de ordens maiores e do presbiterado, e concedendo licença para o exercício do pleno múnus sacerdotal nas suas regiões de Etiópia, África e Índia onde não existisse quadro paroquial ${ }^{1488}$.

A eleição de D. Henrique do Congo ao episcopado e este breve com licença da ordenação de africanos e indianos, suprindo defeitos e faltas e permitindo o livre exercício do ordinário múnus pastoral nas regiões de missão, em que não existe uma administração paroquial estabelecida, tudo concedido pelo Papa Médicis em resposta a súplicas de D. Manuel, dão em duas pinceladas uma mostra clara da política deste Rei no efetivo e declarado desejo de preparar um clero africano e indiano a quem caiba a atuação pastoral nos seus territórios de origem, certamente enquadrados numa política de padroado da Coroa portuguesa e tendo por referente a hierarquia eclesiástica portuguesa, mas que permite pensar numa política dirigida para a constituição de um clero local atuante, em expansão (daí a necessidade de obter a sua regularização por via deste breve papal) e que deveria constituir a base de uma Igreja própria destes territórios.

\footnotetext{
${ }^{1485}$ BRÁSIO, 1953: 41, 42.

${ }^{1486}$ Como se infere desde logo pela oferta que o Rei faz, para dotar esta diocese, do benefício abacial de S. João de Tarouca, pertença do dito Deão, que dela renunciaria (cf. Idem, ibidem: 7).

${ }^{1487}$ Conforme afirma carta de Afonso I, de 25 de março de 1539, em que menciona o seu filho Bispo "que santa gloria aya...» (cf. Idem, ibidem: 73).

${ }^{1488}$ Transcrito em BRÁSIO, 1952: 421, 422.
} 
Esta política manuelina não terá alcançado a dimensão que o Rei possa ter desejado, e sobre o clero da África ocidental deixou Charles Boxer uma análise resumida, que parece ainda não ultrapassada, e que aos esforços desenvolvidos na primeira metade do séc. XVI contrapõe os parcos resultados e a escassez de números e de relevância do clero africano nos séculos seguintes ${ }^{1489}$, leitura de que ainda recentemente faz eco Bethencourt ${ }^{1490}$.

Apesar de tudo podemos ainda encontrar exemplos de clérigos africanos a alcançarem postos de relevância no ordenamento eclesiástico. Como exemplo atente-se na nomeação que, em 10 de abril de 1553, o Papa Júlio III concede por sua letra apostólica ao Mestre Henrique do Manicongo, clérigo da diocese de S. Tomé.

De sangue nobre e de prosápia régia congolesa, entende o Sumo Pontífice promovê-lo a protonotário apostólico do número participante, com todos os privilégios, isenções, prerrogativas, honras, preeminências, etc., a tal cargo pertencentes ${ }^{1491}$.

Ainda que o protonotariado apostólico componha o colégio não episcopal de mais alta posição na Igreja ${ }^{1492}$, e representar uma posição que demonstra a clara intenção do Papa em honrar o promovido $^{1493}$, a eleição ao episcopado de D. Henrique, bispo de Útica, manteve-se como um caso singular.

A sua educação entre os Lóios, a preparação que entre eles terá tido para as ordens sacras e para o episcopado, situou-o numa linha de clérigos seculares de vida comum, dedicados à preparação de um clérigo digno, que desse exemplo ao povo cristão e fosse o garante do bom serviço de Deus por uma liturgia digna e cuidada.

Certamente que Eugénio IV, que no decurso do concílio de Florença se preocupou em trazer à união da cristandade as igrejas orientais mais longínquas, incluindo a cristandade dos etíopes ${ }^{1994}$, não

\footnotetext{
${ }^{1489}$ Cf. BOXER, 1989: 14 e segs.

${ }^{1490}$ BETHENCOURT: 2015: 126.

${ }^{1491}$ ASV - Camera Apostolica, Diversi Camera, n. ${ }^{\circ}$ 175. fl. 175v. Trata-se do processo de promoção a protonotário apostólico do número participante, de Henrique do Manicongo, feito em nome do Camerlengo Guido Ascânio, Cardeal Sforza, e onde se inseria a letra apostólica de Júlio III.

${ }^{1492}$ A designação e função de protonotário aparece em uso na cúria romana a partir do séc. XIV, reservada aos notários da chancelaria apostólica, como forma de os distinguir dos demais notários constituídos por autoridade apostólica. No séc. XV surge a distinção entre os protonotários participantes (os que exerciam função na cúria romana) e os que tinham este título honorificamente. Em 1586 são-lhes concedidos numerosos privilégios como os de criar notários apostólicos, conferir (depois de exame) doutoramentos em Direito e Teologia, legitimar filhos de casamentos ilegítimos, usar pontifical. Até à reforma de Paulo VI dividiam-se em: protonotários do número participantes (os que exerciam funções efetivas na cúria romana); supranumerários (em que se compreendem os membros dos capítulos das basílicas de Latrão, S. Pedro do Vaticano e St. ${ }^{a}$ Maria Maior); ad instar participantium, a quem eram concedidos os mesmos privilégios dos participantes (ad vitam, os nomeados por Breve papal, como o caso em apreço, e os durante munere, clérigos que gozam dos privilégios enquanto detiverem determinada posição em igrejas a quem o Papa concedeu esse privilégio); Protonotários titulares ou honorários, a quem eram concedidos alguns dos privilégios dos participantes (cf. RABIKAUSKAS, 1994).

${ }^{1493}$ A estes clérigos eram concedidos numerosos privilégios, de diversa natureza, incluindo jurídica e de dignidade, podendo mesmo usar de algumas insígnias pontificais pertencentes à dignidade episcopal, e celebrar missas pontificais (cf. Idem, ibidem; ASV - Camera Apostolica, Diversi Camera, n. ${ }^{\circ}$ 175. fl. 175v., o final do processo inclui uma elencagem pormenorizada de todos os privilégios).

${ }^{1494}$ Cf. CERRULLI, 1933.
} 
deixaria de reconhecer na educação e preparação de futuros clérigos africanos feita nas Casas Lóias de Lisboa o seu entendimento de reforma, horizontal e de base, situada entre os degraus mais baixos de uma hierarquia eclesiástica reformada e que sustentasse a reforma da Igreja no seu conjunto.

A formação do clero africano quinhentista não logrou converter-se em tendência, mas marcou o ponto de partida do que virá a ser, no séc. XX, o efetivo estabelecimento de uma Igreja Católica local em África, patente nas suas dioceses e na constituição de uma hierarquia eclesiástica africana.

Neste ponto aos Lóios, fossem ou não protomissionários no Congo, caberá uma primazia como formadores do clero africano, e às Casas de St. ${ }^{\circ}$ Elói e de S. João de Xabregas se poderá dar, sem grande erro ou doloroso anacronismo, o título de primeiro seminário católico para a formação do clero originário da África ${ }^{1495}$.

${ }^{1495}$ De facto a diocese de S. Tomé e Príncipe, onde desde 1533 está inserido o Reino do Congo, só terá um seminário diocesano em 1571 (cf. BOXER, 1989: 18). 
CONCLUSÃO 
Não pode existir muita dúvida do eixo central em torno do qual se quis construir esta obra. Por certo reforma foi a palavra mais vezes repetida ao longo destas páginas, e foi em torno desta ideia (como a designa Ladner) que se procurou focar toda análise que se desenvolveu. Espera-se que o seu uso não tenha sido nem aborrecido, nem abusivo.

Pensar os Lóios como reformadores, na sua própria natureza carismática e nos movimentos reformistas com que lidou e que o enformaram, é a base para perceber esta realidade específica que foi a Congregação de S. João Evangelista. E na verdade, mais do que serem reformadores, os Lóios foram reformistas por serem reformados. E esta afirmação que significa, para além de um aparente jogo de palavras? Nada mais simples do que os Lóios, como a sua matriz dos Cónegos de Alga, ao adotarem um modo de vida entendido por reformado, constituíam-se como agentes de reforma quanto mais não fosse pelo simples exemplo do seu modo de vida.

Como se procurou expor ao longo do $10^{\circ}$ capítulo, o aparecimento dos Lóios não está isolado num contexto reduzido a um retângulo do ocidente peninsular, mas situa-se num complexo período de transição da história europeia, que de uma sociedade tardo-medieval em crise(s) vai abeirando-se, a passos largos, dos limites de uma modernidade superadora dessas crises, ao mesmo tempo que avança para a primeira idade global, em que Portugal tem um papel destacado e em que os Lóios intervêm, como instituição que toma em mãos a formação de elites e clérigos africanos.

O contexto de crise foi, além de político, económico, social e demográfico, uma crise clara da Igreja institucional, onde um Papado enfraquecido, primeiro na sua transposição a Avinhão, depois ao longo de um doloroso cisma de quase quatro décadas, luta por sobreviver e recuperar poder e prestígio espiritual e político.

O cisma altera a tradicional balança de poderes dentro e fora da Igreja, e abre espaço ao debate e à emergência coletiva, sobretudo entre os teólogos e outros pensadores da Igreja, da consciência da necessidade de mudança, o tal consensus da necessidade de reforma de que fala Pierre Chaunu que, sem termos de esperar pelo final do séc. XV para ver formulado, é já patente nas primeiras décadas desse século (quando já não nos anos finais do século anterior).

Foi aliás no sentido de perceber essa realidade que se trabalhou duas dimensões deste problema:

1) Por um lado a dimensão teórica do conceito de reforma na história da Igreja, para que se concebeu o ponto 1.1, em que a partir de duas propostas de análise, distintas no enfoque mas complementares entre si, se procurou estabelecer um conceito de reforma que se entende, na proposta de Gerhart Ladner, estrutural a toda a história do cristianismo, com a particularidade de ser (na leitura deste académico) um conceito que é, na sua própria conceção e natureza, de origem cristã.

A sua proposta de uma reforma entendida como uma ideia que enquadre os esforços livre e conscientemente desenvolvidos em prol da recuperação de um substrato espiritual e material da humanidade (noção em que entra a instituição eclesial), reafirmando-o por meio de um processo de renovação que ao mesmo tempo que recupera a essência original vai enriquecê-la e aumentá-la, permite situar em linhas reformistas todos os movimentos cuja dinâmica possa ser lida no contexto desta definição, mesmo que fora dos períodos claramente identificados como de reforma, como é o séc. XVI. 
Associando este conceito teórico à análise prática que da questão das reformas fez Chaunu, temos um enquadramento teórico que nos permite olhar para a Congregação de Alga, para os Lóios e os movimentos em que se inserem como verdadeiros e plenos movimentos religiosos reformistas.

Como se pôde salientar em diversos pontos deste livro, o carisma de Alga, seguido nas duas Congregações, constitui-se como paradigmático de uma ideia traduzida em esforços (que são eles a própria constituição das Congregações) dirigido para a recuperação de um valor pré-existente na composição espiritual e material do mundo, que foi o ideal que norteou a instituição de um novo modo de vida comunitária que recuperava (assim acreditavam) o modo de vida original do cristianismo, o seguido pela primordial comunidade cristã, a dos Apóstolos na Jerusalém do séc. I.

2) A segunda dimensão foi a da prática dos conceitos reformadores que se encontraram no horizonte fundacional das duas Congregações. Aos enquadramentos dos complexos contextos políticos e sociais (ponto 1.2) contrapôs-se o contexto específico da Igreja, em particular do Papado do período pré-cismático e cismático (ponto 1.3), fulcral como contexto principal de origem do movimento canonical de Alga, cuja compreensão se considerou sempre basilar para uma correta e mais profunda compreensão da Congregação dos Lóios.

Particularmente relevante o ponto 1.3.3, por enquadrar, no contexto da superação cismática, toda a emergência de uma ideia generalizada de reforma, sintetizada nesse lema vago mas poderoso da reforma na cabeça (a cúria) e nos membros (a restante instituição eclesiástica e, em última análise, todo o povo cristão).

Procurou-se expor como, para além deste conceito geral e vago de reforma, consubstanciado na ideia de reforma vertical que a corrente conciliarista pretendia impor ao Papa e sua cúria, bem como a toda a Igreja, existia uma outra noção de reforma, de sentido horizontal, mais pessoal, com um entendimento de reforma iniciado na base, marcado pela ideia de conversão pessoal, seguida da promoção da reforma dos outros, que podemos encontrar no pensamento de homens como Nicolas de Clamanges, ou Johanes Nider, e cujo pensamento se poderá encontrar em prática nas iniciativas reformistas do pontificado de Eugénio IV, cuja figura se pretendeu recuperar de uma leitura crítica centrada na sua oposição ao movimento conciliarista, e como tal entendido como de oposição às grandes reformas gerais que facilmente se propunham, sem explicar muito bem como implementá-las.

Nos anos em que por todo o cristianismo ocidental se reclamava a reforma in capite et in membris, e apesar de as Congregações de Alga e dos Lóios terem estados muito próximas e suportadas pelas «cabeças» (entenda-se os Pontífices Romanos e a Coroa portuguesa), assumiram-se como estruturas de reforma in membris, baseados numa ideia de reforma pessoal em Congregação, que pelo seu exercício litúrgico e pastoral se apresentaria como exemplar às sociedades em que se inseriam.

Como se poderá perceber pelo capítulo 2, em particular pelos pontos que se referem ao Papa Eugénio IV e ao seu pontificado, é possível perceber como esta ideia de reforma enquadra a fundação da Congregação de Alga, de um grupo de jovens que procura reformar-se e reformar a Igreja por um processo de conversão individual, que passa a coletiva quando iniciam um modo de vida comum que acreditam como original e, como tal, perfeito. 
Influenciados pelo contexto do cisma, de que aliás participam de modo íntimo na obediência romana, influenciados pelo rico movimento reformista veneziano que clamava pela conversão pessoal e pela reforma de vida, os cónegos de Alga introduzem um novo modo de vida, o de uma congregação de clérigos seculares de vida comum, que combina o modo de vida de uma comunidade regular observante com a liberdade plena garantida pela ausência de votos solenes, associada à exigência litúrgica e ao serviço pastoral próprio de uma colegiada de cónegos.

Instituição tendencialmente sacerdotal, Alga (e por eles os Lóios), introduzem um modo de ser congregação que terá (na vertente regular e secular) grande sucesso no séc. XVI, em particular no desenvolvimento de instituições tão notáveis como os Jesuítas, os Teatinos ou os Oratorianos. Como se procurou sublinhar no ponto 2.5, o modo de vida de Alga introduz, a um século de distância, o modelo de vida das mais destacadas instituições da reforma católica do séc. XVI. Penso que nada mais se terá de aduzir em defesa do cariz reformista das instituições que introduzem, e com dimensão carismática, o modelo de vida comum de instituições que são, sem contradição, consideradas pilares do reformismo católico.

A preocupação de caracterizar pormenorizadamente o processo de nascimento e desenvolvimento da Congregação de Alga, a inserção dos seus principais agentes, a participação da congregação e seus cónegos nos esforços reformistas do pontificado de um Eugénio IV (não apenas por ser instituição por si fundada mas também pela partilha de uma mesma ideia de reforma) e a precisão das particularidades do seu carisma, tiveram por objetivo estabelecer claramente todo o quadro carismático de uma Congregação e do seu universo de pertença, na certeza de que teve um papel não secundário na construção identitária dos Lóios, não se circunscrevendo a uma simples transposição de hábito e normativa de Itália a Portugal.

Como se procurou estabelecer no capítulo $3 .^{\circ}$, existe no processo de fundação dos Lóios uma clara inserção em contextos reformistas similares e paralelos aos da Congregação de Alga; mais ainda, entre Alga e os Lóios existe partilha de mútuas ligações: a já conhecida relação com a reforma de St. ${ }^{a}$ Justina e com Luís Barbo por meio do abade D. Gomes, mas também a formulação de uma hipótese enriquecedora, a de uma possível relação do fundador Lóio João Vicente com o círculo reformista veneziano através de uma das suas principais figuras, o dominicano beato Giovanni Dominici, figura grada da observância dominicana, movimento com que João Vicente se relacionou (a ponto de ser citado na cronística Lóia e dominicana) e que poderá estar na origem de uma primeira aproximação ao carisma de Alga.

Independentemente do momento e da forma como se deu a primeira ligação com Alga, tudo parece indicar que os Lóios aderem a esta carisma de modo informado, consciente e em plena liberdade. Fazem-no num momento em que Eugénio IV ainda não era Papa, e como tal não é escolha de circunstância mas o reconhecimento de um entendimento comum de reforma pessoal e coletiva por parte dos fundadores portugueses em relação à sua matriz italiana.

O carisma de Alga torna-se estrutural na Congregação portuguesa, o que por si só justifica todo o trabalho de análise de Alga e dos seus agentes realizado no capítulo 2.

O diálogo entre as duas Congregações não ficou, como parecia, confinado aos anos fundacionais e a uma missão reformadora de 1568, por diversas vezes mencionada mas pouco analisada. 
Um conjunto de indícios puderam-se recolher para demonstrar que, apesar das dificuldades da distância e de percursos institucionais absolutamente autónomos, existiu um continuado relacionamento entre as duas Congregações, assente sempre num mútuo reconhecimento de partilha carismática, tendo por base genérica a recorrente necessidade dos Cónegos Lóios de fazerem despachar, na cúria romana, os mais variados assuntos de natureza eclesiástica.

Nesta relação, e da força da ligação que nitidamente existia entre a Congregação portuguesa e a sua estrutura carismática herdada de Alga, podemos situar o breve papal de 1568 que ordenava aos Lóios que enviassem cónegos a reformar as comunidades de Alga, então consideradas em crise, missão de que se conhecia a execução apenas pela cronística, mas que se pôde aqui, pela primeira vez, comprovar em documentação de arquivo, mais claramente insuspeita.

Se juntarmos a esta missão a desvirtuação carismática de Alga pela forçada profissão religiosa solene de 1569 , e a resistência dos Lóios que lograram manter intacta a pureza da primitiva instituição do modo de vida dos Cónegos Seculares, estamos perante um processo de encerramento circular, quando a filiada assume, em matéria de carisma, a pureza institucional fundacional da sua matriz.

Num período em que, como ficou visto, se tentava forçar as congregações de clérigos seculares a professarem votos solenes, poucos serão os resistentes, podendo-se somar, e na tradição mais antiga deste modo de vida, os padres Lóios.

Mas sendo por carisma uma Congregação reformista (e pensa-se que tal ficou demonstrado muito claramente), os Lóios deverão ter sido uma Congregação de atividade reformadora. Assim parece ter sido, não tanto pelas ocasionais missões de reforma extra-claustros Lóios a que alguns dos seus cónegos foram chamados (e que como tal não foram tratadas por já terem sido analisadas pelos autores que têm trabalhado os Lóios) mas pelo modo como terão vivido materialmente um carisma de comunidade de clérigos seculares dedicados ao culto divino e múnus pastoral, e cujo modo de vida terá encontrado eco junto dos poderes do reino, que lhe consignaram, ao longo da vigência da dinastia de Avis, alguns importantes serviços que tanto a Coroa como a Casa de Bragança procuravam entregar a instituições fidedignas.

Assim o $4 .^{\circ}$ capítulo dedicou-se, num primeiro momento, a enquadrar espiritual e materialmente a atuação carismática de uma Congregação que, sendo constituída por colégios de clérigos seculares de ordens sacras e com título de cónegos, estava naturalmente vocacionada para o culto divino, a primeira e mais importante função de todo o corpo eclesiástico na sociedade.

Num tempo em que a Coroa desejava ver reformada a Igreja portuguesa, e em que as instituições eclesiásticas nem sempre apresentavam a mais virtuosa das disposições, os príncipes da Casa de Avis, e os sereníssimos Duques de Bragança, vão ter nos Lóios colaboradores dignos de suficiente confiança para lhes confiarem duas importantes missões: de D. João III e do Duque de Bragança D. Jaime, terão os Lóios a incumbência da administração hospitalar, de D. Manuel I tinham tido o encargo de receber e educar os nobres congoleses que vinham ser educados em Portugal e, em alguns casos, ordenar-se de ordens sacras.

Se este último encargo teve por base uma atividade educativa prévia desenvolvida na Casa Lóia de St. ${ }^{\circ}$ Elói de Lisboa, já a administração de hospitais é encargo novo e demonstra a confiança que 
os príncipes em causa tinham na Congregação para uma eficaz e honesta administração da atividade assistencial e dos meios associados.

Estas atividades, mesmo as que não têm direta ligação ao carisma da Congregação, são a marca do seu prestígio entre os poderes, e muito particularmente com a Casa Real de Avis, dinastia que sempre demonstrou um particular interesse nos movimentos de reforma da Igreja, em particular nas décadas fundacionais dos Lóios.

Lamentavelmente, não foi possível desenvolver uma análise profunda das relações entre a Congregação e as Casas de Avis e de Bragança, bem como do restante círculo social da Congregação (em que se situam casas titulares como a de Linhares ou da Feira) por si só merecedoras de um estudo doutoral; do mesmo modo não foi possível a aproximação ao relacionamento com outras congregações e movimentos reformadores, também por si todo um tema autónomo. Das duas realidades existem já sínteses muito esclarecedoras, pelo que me escusei a acrescentar uma outra.

Foi todo o foco deste trabalho estabelecer um conceito operativo de reforma, analisar à sua luz o desenvolvimento carismático do movimento de S. Jorge em Alga e caracterizá-lo estruturalmente, situando-o no seu contexto eclesial. Procurou-se assim comprovar a existência de uma matriz reformista nos Lóios, perceber a sua essência, demonstrar como os Cónegos Seculares portugueses estão em perfeita comunhão com esse ideal de vida, como o praticam, defendem e sustentam, como se enquadram no contexto reformista português do séc. XV, como são reconhecidos pelos principais poderes e como, por esse reconhecimento, lhe são atribuídas determinadas funções com relevância política e social, mais até do que religiosa.

Deste modo acredita-se terem ficado respondidas as questões que nortearam todo este trabalho. Foram os Lóios uma Congregação de carisma reformista, um carisma herdado das correntes reformistas da Itália dos primeiros anos do séc. XV, cujo carisma se aplicou na normal prossecução do seu ideal de vida, com o qual claramente se identificaram e que defenderam intransigentemente mesmo quando o concílio tridentino legislou em oposição.

De facto, construído sobre um ideal reformista desenvolvido em oposição ao que era defendido pelos conciliaristas de Constança e Basileia, o carisma da Congregação encontrou na reforma tridentina uma reforma de tipo vertical, verdadeiramente desenvolvida in capite et in membris. A sua dinâmica, construída sobre todo o capital reformador do século XV, mas ultrapassando-o pela força das circunstâncias desse longo séc. XVI, empurra as Congregações de Alga e dos Lóios para as rígidas regras conciliares, excluindo a liberdade com que estas se tinham desenvolvido no século precedente, marcando, com a concorrência de novas experiências de vida consagrada e a reforma de ordens bem mais antigas, o início da decadência das duas Congregações.

Este facto não anula no entanto o papel que Alga e os Lóios tiveram, enquanto carisma e enquanto comunidades, na Igreja dos sécs. XV e XVI, promovendo e vivendo em reforma. 
FONTES 


\title{
FONTES MANUSCRITAS
}

\author{
- Arquivo Distrital de Braga \\ - Manuscritos \\ - Manuscrito $924^{1496}$. \\ - Monástico, Lóios, Mosteiro de Vilar de Frades, livros 11-15, 24
}

\author{
- Arquivo Distrital do Porto \\ - Monásticos \\ - Convento de Santo Elói do Porto \\ - Livro do Compêndio do cartório, K/19/6-57 1497
}

\section{- Governo Civil do Porto}

- Atividades Eclesiásticas, Comissão administrativa dos bens dos conventos extintos

- Livro de registo do inventário, C/4/1/3/4815

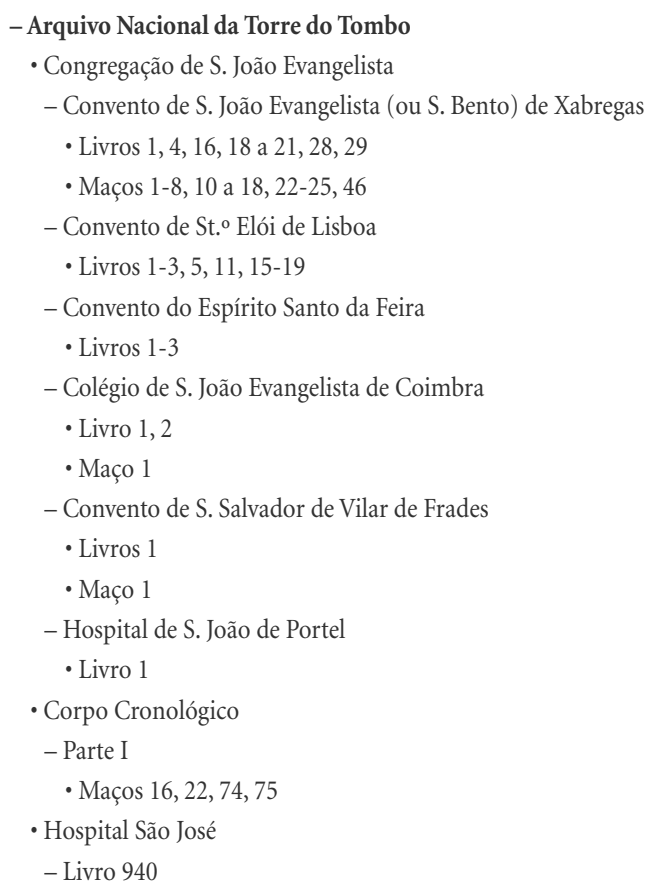

${ }^{1496}$ Título completo do manuscrito: Epilogo e compendio da origem da Congregação de Sam Joam Evangelista e do nacimento, vida e morte dos seus tres fundadores. Da fundação dos nove conventos; das suas rendas; encargos; e prelados; e dos onze hospitais da sua administraçaam; e de outras memorias. Composto, e escrito pello Padre Mestre Jorge de Sam Paulo (acerca dele veja-se MAGANO, 1956).

${ }^{1497}$ Título completo do manuscrito: Compendio do Cartório deste convento, das obrigações da sanchristia, da fazenda, e mais couzas neçessarias pera o bom governo dos prelados, e seus officiaes, feito cordenado pello padre mestre Jorge de S. Paulo sendo R.tor desta caza no anno de 1641 . 
- Mesa da Consciência e Ordens

- Hospitais, Hospital Real das Caldas

- Maço 2

- Manuscritos da Livraria

- Manuscrito 157, 159, 186, 399, 513, 523, 547, 625, 896

\section{- Arquivo da Universidade de Coimbra}

- Colégio de S. João Evangelista

- Maço 1

- Hospital Real

- Est. 7, tab. 3, lv. 1, 2, 6, 11

\section{- Arquivo Secreto Vaticano}

- Miscellanea

- Armadio II

- N. ${ }^{\circ}$ 2, N. ${ }^{\circ} 49$

- Armadio VIII

- N. ${ }^{\circ} 41$

- Armadio XL

- Livro 3 - Breves de Leão X (1516-1518)

- Fundo Veneto

- Documentos 951; 953; 969; 973; 978; 982; 988; 992; 994; 996; 1003; 1009; 1022; 1024; 1026; 1027; 1031; 1045; 1046; 1080; 1117; 1353; $1360 ; 1367 ; 1376$

- Indici Brevi

$-749$

- Nunziatura di Lisbona

- N. ${ }^{\circ} 94$ - Pasta com 3 maços de documentos, sendo os dois primeiros sobre os Lóios.

- Segreteria dei Brevi

- Registra Brevium - SEC.BREV.REG. N. ${ }^{\circ} 10$

- Camera Apostolica

- Diversi Camera - N. 175

\section{- Arquivo dos Viscondes de Vila Nova de Cerveira}

- Morgado de St. a Ana

- Caixa 1 - Documentos 11, 16, 22, 23, 25, 35.

- Caixa 3 - Documento 45

- Caixa 5 - Documento 32, 44

- Caixa 36 - Documento 1

\section{- Biblioteca Apostolica Vaticana}

- Manoscritti

- VAT.LAT.7167 - Diaria seu acta [Romanorum Pontificum] ab anno 1378 usque ad 1596 [...] Diaria Romae sub Bonifacio IX et Innocentio VII (fl. 40-44v.); [.. Diarium Romae] sub Eugenio IV (fl. 49 v.-59).

- VAT.LAT.12131 - Miscellanea - Registo de eleições Pontifícias e criação de Cardeais, do pontificado de Eugénio IV ao de Urbano VIII

- R.G.Dattil.158 


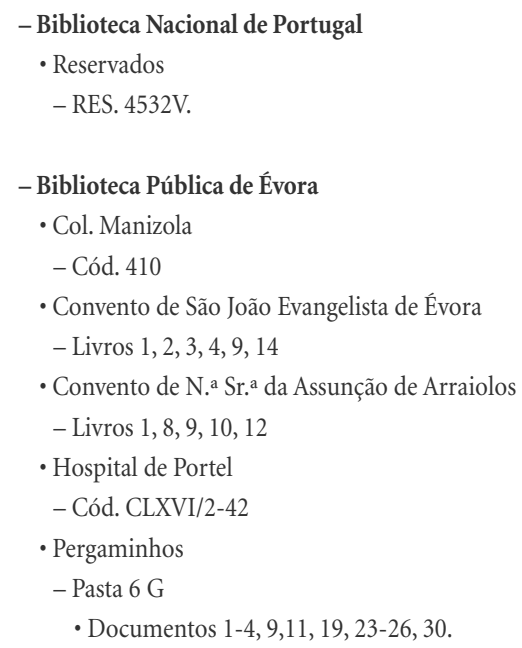

\section{FONTES IMPRESSAS}

ALMEIDA, Manuel Lopes et al. (1961) - Monumenta Henricina. Coimbra: Comissão Executiva das Comemorações do V Centenário da morte do Infante D. Henrique, vol. III.

AMBRÓSIO DE MILÃO, Santo (1842) - Sancti Ambrosii, Mediolanensis Episcopi, omnia quae extant Opera. Tomus Tertius: Tractatus de Scriptura: Apologiae David II - Enarrantiones in XII Psalmos Davidicos. Paris: Paul Mellier.

BARROS, João de (1778) - Da Asia de João de Barros e de Diogo do Couto. Lisboa: Regia Officina Typografica.

BASÍLIO MAGNO, Santo (1751) - Liber de Spiritu Sancto ad S. Amphilochium Iconii episcopum. In Sancti Patris Nostri Basilii Cesareae Cappadociae Archiepiscopi Opera Omnia. Ed. Juliano Garnier, OSB. Veneza: Typis Gasparis Girardi.

BISTICCI, Vespasiano da (1859) - Vite di Uomini illustri del secolo XV. Firenze: Barbera, Bianchi e Comp.

BRÁSIO, António, CSSp, compil. (1952) - Monumenta Missionaria Africana: África Ocidental (1471-1531). Lisboa: Agência Geral do Ultramar, vol. I.

__ (1953) - África Ocidental (1532-1569). Monumenta Missionaria Africana. Lisboa: Agência Geral do Ultramar, vol. II.

BULLARUM Privilegiorum ac Diplomatum Romanorum Pontificum... Tomus sextus pars sexta ab anno X Alexandri VII usque ad III Clem. IX scilicet ab anno MDCLXIV usque ad MDCLXIX. 1762. Roma: Typis Hieronymi Mainardi.

CARDELLA, Lorenzo, P.e (1793a) - Memorie Storiche de Cardinali della Santa Romana Chiesa. Roma: Stamperia Pagliarini, vol. 3.

(1793b) - Memorie Storiche de Cardinali della Santa Romana Chiesa. Roma: Stamperia Pagliarini, vol. 4.

CORNELIO, Flaminio (1749) - Ecclesiae Venetae antiquis monumentis nunc etiam primum editis illustratae. Veneza: Tipografia de Giovanni Battista Pasquali, vol. 12.

CORRER, Gregório, Patriarca de Veneza (1757) - Soliloquium ad Deum, De vita sua et de vita et obitu beatae Memoriae Antonii Episcopi Ostienses et Cardinalis Patrui sui. In Anedocta Veneta nunc primum collecta. Ed. João Baptista Contareno, OP, Veneza: Typis Petri Valvasensis, p. 12-24.

COSTA, Agostinho Rebelo da, P.e (1945) - Descrição topográfica e histórica da Cidade do Porto. Porto: Livraria Progredior. Ed. original 1788.

COSTA, António Domingues de Sousa, OFM (1970) - Monumenta Portugaliae Vaticana: Súplicas do Pontificado de Martinho V (anos 8 a 14). Braga: Editorial Franciscana.

DIVERSAE Concessiones et Gratiae Concessae a Sanctiss. D. N. Clemente Papa VIII Congregationi Canonicorum Saecularium S. Ioannis Evangelistae in Regno Portugalliae sub habitu et regula Congregationis S. Georgii in Alga Venetiarium institutae... Collectae à P. Petro de S. Ionne Portugallensi Procuratore generali eiusdem Congregat. apud eundem S.D. Clem. Oct. et Doctore Theologo. Roma: Typographia Marci Antonii de Valle. 
DOM PEDRO, Infante (1940) - O livro da virtuosa bemfeitoria do Infante Dom Pedro. Ed. Joaquim Costa. Porto: Biblioteca Pública Municipal do Porto.

ESTATUTOS e Constituições dos Cónegos Azuis da Congregação de S. João Evangelista. Lisboa: Oficina de Simão Thadeo Ferreira, 1804.

FIGUEIREDO, António Pereira de (1793) - João de Barros, exemplar da mais solida Eloquencia Portugueza. Dissertação academica de Antonio Pereira de Figueiredo, escrita e recitada no anno de 1781. In Memorias de Litteratura Portugueza, publicadas pela Academia Real das Sciencias de Lisboa. Lisboa: Officina da Academia Real das Sciencias de Lisboa.

FIORI, Agostino Romano, Er.Cam. (1729) - Vita del Beato Paolo Giustiniani, institutore della Congregazione de PP eremiti Camaldolesi di S. Romualdo, detta di Monte Corona. Roma: Antonio de Rossi.

GAIO, Manuel Felgueiras (1939a) - Nobiliário de famílias de Portugal. Ed. Agostinho de Azevedo Meirelles e Domingos de Araújo Affonso. Braga: Pax, vol. 7.

(1939b) - Nobiliário de famílias de Portugal. Ed. Agostinho de Azevedo Meirelles e Domingos de Araújo Affonso. Braga: Pax, vol. 8.

_ (1939c) - Nobiliário de famílias de Portugal. Ed. Agostinho de Azevedo Meirelles e Domingos de Araújo Affonso. Braga: Pax, vol. 9.

(1940) - Nobiliário de famílias de Portugal. Ed. Agostinho de Azevedo Meirelles e Domingos de Araújo Affonso. Braga: Tipografia Augusto Costa, vol. 11.

LOURENÇO JUSTINIANO, São, CSGA, (1531) - Ho Livro da regra e perfeyçam da conversaçam dos monges. Ho Livro da vida solitaria. Coimbra: Germão Galharde.

_ (1628) - Divi Laurentii Iustiniani Protopatriarchae Veneti, Opera Omnina. Lyon: Michaëlis Chevalier.

LIVRO dos Privilegios concedidos pellos Summos Pontifices, à Congregação de S. João Evangelista, assim per concessão, como per commissão; como em seus titulos se declararà. Lisboa: Impresso por Antonio Alvarez, 1594.

MACHADO, Diogo Barbosa, P.e. (1741) - Bibliotheca Lusitana. Historica, Critica, e Cronologica... Lisboa: Oficina de Antonio Isidoro da Fonseca, tomo I.

_ (1752) - Bibliotheca Lusitana: Historica, Critica, e Cronologica... Lisboa: Oficina de Ignacio Rodrigues, tomo III.

PAPADOPOLI, Niccolò Comneno (1726) - Historia Gymnasii Patavini post ea, quae hactenus de illo scripta sunt, ad haec nostra tempora plenius, et emandatius deducta. Cum auctario de claris cum Professoribus tum Alumnis eiusdem. Veneza: Apud Sebastianum Coleti, vol. II.

PORTALEGRE, Paulo de, CSJE (2007) - Novo Memorial do Estado Apostólico. Primeira crónica dos Lóios. Ed. Cristina Sobral. Lisboa: Roma Editora.

QUERINI, Angelo-Maria, OSB Cardeal (1761) - Tiara et Purpura Veneta ab anno MCCCLXXIX ad annum MDCCLIX. Bréscia: Joannes-Maria Rizzardi.

RESENDE, Garcia de (1798) - Chronica dos valerosos e Insignes feitos del Rey Dom Ioam II... Coimbra: Real Officina da Universidade.

ROSSI, Maffeo Urbano (1690) - Relazione delle Cerimonie et apparato fatto nella Basilica di S. Pietro nella Cannonizazzione de cinque Santi. Roma: Domenico Antonio Ercole.

SACROSANCTUM Oecumenicum Concilium Tridentinum additis declarationibus Cardinalium ejusdem Concilii interprettum. Madrid: Typographia Regia, 1769.

SANTA MARIA, Francisco de, CSJE (1689-1698) - Sermoens do padre Francisco de Santa Maria Conigo da Sagrada Congregaçam de S. Joam Evangelista, Cronista geral da mesma Congregação, Mestre jubilado na Sagrada Theologia, Qualificador do Santo Offici, Examinador das tres Ordens Militares, etc. Lisboa: Oficina de Manoel Lopes Ferreira, 3 vols.

— (1697) - O ceo aberto na terra. Historia das Sagradas Congregaçoens dos Conegos Seculares de S. Jorge em Alga de Veneza e de S. João Evangelista em Portugal. Lisboa: Officina de Manoel Lopes Ferreyra.

_ (1744) - Anno Historico, Diario Portuguez, noticia abreviada de pessoas grandes e cousas notaveis de Portugal. Lisboa: Oficina de Domingos Gonçalves, 3 vols.

SANTA MARIA, Pedro de, CSJE (1555) - Ordem e Regimento de vida christaam. Coimbra: em casa de João Alvarez.

SÃO PAULO, Jorge de, CSJE (1967/1968) - O Hospital das Caldas da Rainha até ao ano de 1656. Ed. Fernando da Silva Correia. Lisboa: Academia das Ciências de Lisboa, 3 vols.

SOUSA, António Caetano de, Dom, CR (1742) - Provas da Historia Genealogica da Casa Real Portuguesa. Lisboa: Regia Oficina Sylviana e da Academia Real, vol. II.

(1946-1955) - História Genealógica da Casa Real Portuguesa. Coimbra: Atlântida Livraria Editora, 1735-1749, 14 vols. 
SOUSA, Fr. Luís de, OP (1767) - Segunda Parte da Historia de S. Domingos particular do Reino e Conquistas de Portugal. Lisboa: Oficina de António Rodrigues Galhardo.

STATUTOS e Constituyções dos virtuosos e reverendos padres Conegos azuys, do especial amado discipulo de Chrispto e seu singular secretario Sam Ioam, apostolo e euãngelista e ho fundamento de sua apostolica e muy louvada congregaçãm da clerizia secular reformativa em a observância de sua vida. Lisboa: Germão Galharde, 1540.

TIRABOSCHI, Giovanni Carlo (1815) - La famiglia Picenardi ossia notizie storiche intorno alla medesima. Cremona: Giuseppe Feraboli.

TOMASINI, Iacobo Phillippo, CSGA, Bispo de Cittanova (1642) - Annales Canonicorum Secularium S. Georgii in Alga. Utini [Udine]: Typis Nicolai Schiratti.

_ (1650) - Bibliothecae venetae manuscriptae publicae et provatae. Utini [Udine]: Typis Nicolai Schiratti. 
BIBLIOGRAFIA 
AA.VV. (1970) - Les Memoires de l'Europe. Paris: Robert Laffont.

ABULAFIA, David, ed. (2006) - The New Cambridge Medieval History: V c.1198-c.1300. Cambridge: Cambridge University Press.

(2000) - The Italian South. In JONES, Michael, ed. - The New Cambridge Medieval History: VI c.1300-c.1415. Cambridge: Cambridge University Press.

ADDARIO, Arnaldo d' (1961) - Antonino Pierozzi, santo. In Dizionario Biografico degli Italiani. Roma: Istituto dell'Enciclopedia Italiana.

AGOSTINI, Giovanni Degli (1739) - Notizie Istoriche spettanti alla vita di Monsignore Vescovo Tommaso Tommasini Paruta dell'Ordine de Predicatori. In Raccolta di opuscoli scientifici e filosofici. Ed. Angelo Calogerà, OSBCam. Veneza: [s.n.].

AIT, Ivana (2000) - Urbano VI. In Enciclopedia dei Papi. Roma: Istituto dell'Enciclopedia Italiana.

ALBERIGO, Giuseppe (1960) - Girolamo Aleandro. In Dizionario Biografico degli Italiani. Roma: Istituto dell'Enciclopedia Italiana.

ALCE, Venturino (1984v.) - La riforma dell' ordine domenicano nel '400 e nel primo '500 veneto. In Riforma della Chiesa, Cultura e Spiritualità nel Quattrocento Veneto: Atti del convegno per il VI centenario della nascita di Ludovico Barbo (1382-1443). Ed. Francesco Giovanni Trolese, OSB. Cesena: Centro Storico Beneditino Italiano.

ALLMAND, Christopher, ed. (1998) - The New Cambridge Medieval History: VII c.1415-c.1500. Cambrigde: Cambridge University Press.

ALMEIDA, Fortunato de (1967) - História da Igreja em Portugal. Porto: Portucalense Editora, vol. I.

ANGIOLINI, Hélène (2001) - Giovanni da Capestrano. In Dizionario Biografico degli Italiani. Roma: Istituto dell'Enciclopedia Italiana.

ANTUNES, José (2000) - Ensino. I. Época Medieval. In AZEVEDO, Carlos Moreira, dir. - Dicionário de História Religiosa de Portugal. C-I. [Lisboa]: Círculo de Leitores, CEHR-UCP.

ARAÚJO, António de Sousa; SILVA, Armando Malheiro da (1985) - Inventário do fundo monástico-conventual. Braga: Arquivo Distrital de Braga.

ARAÚJO, Maria Marta Lobo de (2001) - Os regimentos quinhentistas dos hospitais de Arraiolos e Portel. «Biblos: Revista da Faculdade de Letras da Universidade de Coimbra». Coimbra: Universidade de Coimbra, p. 145-171.

__ (2003) - O hospital do Espírito Santo de Portel na Época Moderna. «Cadernos do Noroeste: Série História», vol. 3, n. 20. Braga: Universidade do Minho, p. 341-409.

AZEVEDO, Carlos Moreira, dir. (2000-2001) - Dicionário de História Religiosa de Portugal. [Lisboa]: Círculo de Leitores, CEHR-UCP, 4 vols.

(2000-2002) - História Religiosa de Portugal. [Lisboa]: Círculo de Leitores, CEHR-UCP, 3 vols.

BALARD, Michel (1997) - Le sfide esterne: La lotta contro Genova. In Storia di Venezia: La formazione dello stato patrizio. Roma: Istituto dell'Enciclopedia Italiana.

BARBALARGA, Donatella (1990) - Iacopino del Torso. In Dizionario Biografico degli Italiani. Roma: Istituto dell'Enciclopedia Italiana.

BARBATO, Napoleone, P.e (1959) - S. Lorenzo Giustiniani. Fonti Dottrina ascetica. Tese de Laurea, Pontificio Ateneo Internazionale «Angelicum», [s.l.].

BARBOSA, David Sampaio (2000) - Clero Regular. In AZEVEDO, Carlos Moreira, dir. - Dicionário de História Religiosa de Portugal. A-C. [Lisboa]: Círculo de Leitores/CEHR-UCP.

BARRACLOUGH, Geoffrey (1972) - Os Papas na Idade Média. Lisboa: Editorial Verbo.

BECK, H. G. J. (2003) - Antipope. In MARTHALER, Berard, OFM, ed. - New Catholic Encyclopedia. Detroit: Thomson Gale.

BELLITTO, Christopher; FLANAGIN, David Zachariah (2012a) - Introduction. In BELLITTO, Christopher; FLANAGIN, David Zachariah, ed. - Reassessing Reform. A historical investigation into Church renewal. Washington: The Catholic University of America Press.

_ (2012b) - Reassessing Reform. A historical investigation into Church renewal. Washington: The Catholic University of America Press.

BELLITTO, Christopher; HAMILTON, Louis, eds. (2005) - Reforming the Church before Modernity. Aldershot: Ashgate Publishing.

BELLITTO, Christopher (1999) - The spirituality of Reform in the Late Medieval Church: the example of Nicolas de Clamanges». «Church History Journal», vol. 68-1. [S.1.]: American Society of Church History.

_ (2008) - Councils and Reform: Challenging Misconceptions. In CHRISTIANSON, Gerald; IZBICKY, Thomas; BELLITO, Christopher, ed. - The Church, the Councils \& reform: The Legacy of the Fifteenth Century. Washington: The Catholic University of America Press.

_ (2009) - The Reform context of the Great Western Schism. In ROLLO-KOSTER, Joëlle, ed. - A companion to the Great Western Schism (1378-1417). Leiden: E. J. Brill.

BÉRENGER, Jean et al. (1996) - A Europa desde o início do séc. XIV ao final do século XVIII. In LIVET, Georges; MOUSNIER, Roland, ed. - História Geral da Europa: Do começo do século XIV ao fim do século XVIII. Mem Martins: Publicações Europa América, vol. II. 
BETHENCOURT, Francisco (2015) - Racismos: das cruzadas ao século XX. Lisboa: Temas e Debates/Círculo de Leitores.

BIANCA, Concetta (2000) - Martino V. In Enciclopedia dei Papi. Roma: Istituto dell'Enciclopedia Italiana.

BÍBLIA Sagrada (2001) - Ed. Herculano Alves. Lisboa: Difusora Bíblica.

BLACK, Antony (1998) - Popes and Councils. In ALLMAND, Christopher, ed. - The New Cambridge Medieval History: VII c.1415-c.1500. Cambrigde: Cambridge University Press.

BOLTON, Brenda (1986) - A Reforma na Idade Média. Século XII. Lisboa: Edições 70.

BONNET, Henry Marc (1968) - Histoire des Ordres Religieux (Que sais je?). Paris: Presses Universitaires de France.

BOUDINHON, Auguste (1910) - Interdict. In The Catholic Encyclopedia. Nova Iorque: Robert Appleton Company.

(1911) - Privilege. In The Catholic Encyclopedia. Nova Iorque: Robert Appleton Company.

BOXER, Charles (1989) - A Igreja e a Expansão Ibérica (1440-1770). Lisboa: Edições 70.

BRÁSIO, António, CSSp (1973) - História e missiologia. Inéditos e esparsos. Luanda: Instituto de Investigação Científica de Angola.

BROU, Alexandre, SJ (1937) - Associations pour la sanctification du Clergé. In VILLER, Marcel, SJ, ed. - Dictionnaire de Spiritualité. Paris: Gabriel Beauchesne et ses fils (col. 1037 a 1045).

BUCHOUD, Bernard, O.S.B. Oliv. (2009) - San Bernardo Tolomei. Fondatore della Congregazione Benedettina di Santa Maria di Monte Oliveto. Estrasburgo: Éditions du Signe.

BUESCU, Ana Isabel (2005) - D. João III: 1502-1557. [Lisboa]: Círculo de Leitores (Reis de Portugal).

_ (2010) - D. João III e D. Miguel da Silva, bispo de Viseu: novas razões para um ódio velho. «Revista de História da Sociedade e da Cultura», vol. 10, tomo I. Coimbra: CHSC-U. de Coimbra, p.141-168.

BULLMAN, Raymond (2010) - Aggiornamento. In FASTIGGI, Robert, ed. - New Catholic Encyclopedia. Supplement 2010. Detroit: Gale.

CAETANO, Marcelo (1965) - Recepção e execução dos decretos do Concílio de Trento em Portugal. Lisboa: Faculdade de Direito da Universidade de Lisboa.

CALATI, Benedetto (1984) - Dalla 'lectio' alla 'meditatio'. La tradizione benedettina fino a Ludovico Barbo. In Riforma della Chiesa, Cultura e Spiritualità nel Quattrocento Veneto. Atti del convegno per il VI centenario della nascita di Ludovico Barbo (1382-1443). Ed. Giovanni Francesco Trolese, OSB. Cesena: Centro Storico Beneditino Italiano.

CANZIAN, Dario (2007) - Francesco Malipiero. In Dizionario Biografico degli Italiani. Roma: Istituto dell'Enciclopedia Italiana.

CAPELÃO, Rosa Maria dos Santos (2011) - El culto de reliquias en Portugal en los siglos XVI-XVII: contexto, norma, funciones y simbolismo. Porto: Faculdade de Letras da Universidade do Porto. Tese de Doutoramento.

CARAVALE, Mario (1997) - Diritto, finanze, economia: Le Istituzioni della Repubblica. In Storia di Venezia: La formazione dello stato patrizio. Roma: Istituto dell'Enciclopedia Italiana.

CARMICHAEL, Montgomery (1908) - Clerks Regular of the Mother of God of Lucca. In The Catholic Encyclopedia. Nova Iorque: Robert Appleton Company.

CARMONA, Mário (1954) - O Hospital Real de Todos-os-Santos da Cidade de Lisboa. Porto: Imprensa Portuguesa.

CARNEIRO, Roberto, coord. (2005-2006) - Reis de Portugal. [Lisboa]: Círculo de Leitores. 34 vols.

CARPENTIER, Jean; LEBRUN, François, dir. (1990) - Histoire de l'Europe. Paris: Éditions du Seuil.

CARVALHO, Isabel da Conceição (1996) - O mosteiro de Arnóia, património e rendas de 1629 a 1822. Porto: Faculdade de Letras da Universidade do Porto. Dissertação de mestrado.

CARVALHO, José Adriano de Freitas (1995) - A Igreja e as reformas religiosas em Portugal no século XV. Anseios e limites. In Actas do Congresso Internacional de Historia «El Tratado de Tordesillas y su época». Madrid: Junta e Castilla y León, p. 635-660.

(1998) - Um «beato vivo»: o P. António da Conceição, C.S.J.E., conselheiro e profeta no tempo de Filipe II. «Via Spiritus: Revista de história da espiritualidade e do sentimento religioso». Porto: Centro Inter-Universitário de História da Espiritualidade da Universidade do Porto, p. 13-51.

(2016) - Antes de Lutero: A Igreja e as Reformas Religiosas em Portugal no século XV. Anseios e limites. Porto: CITCEM/Edições Afrontamento.

CATECISMO da Igreja Católica (1993). Coimbra: Gráfica de Coimbra.

CATTANA, Valerio (1984) - Ludovico Barbo e i monaci di Monte Oliveto. In Riforma della Chiesa, Cultura e Spiritualità nel Quattrocento Veneto. Atti del convegno per il VI centenario della nascita di Ludovico Barbo (1382-1443). Ed. Giovanni Francesco Trolese, OSB. Cesena: Centro Storico Beneditino Italiano. 
CERRULLI, Enrico (1933) - Eugenio IV e gli Etiopi al Concilio di Firenze nel 1441. In Rendiconti della Classe di Scienze morali, storiche e filologiche da Reale Accademia nazionale dei lincei. Roma: Giovanni Bardi, ser. VI, vol. IX.

CHAUNU, Pierre (1981) - Église, Culture et Société: Essais sur réforme et contre-réforme, 1517-1620. Paris: SEDES.

__ (2002) - O tempo das Reformas (1250-1550). Lisboa: Edições 70. (Lugar da História). Vol. I: A Crise da Cristandade. Edição original 1975. CHÉLINI, Jean (1982) - L’Église au temps des schismes, 1249-1449. Paris: Armand Colin.

CHOJNACKI, Stanley (1997) - Diritto, finanze, economia: La formazione della nobiltà dopo la Serrata. In Storia di Venezia: La formazione dello stato patrizio. Roma: Istituto dell'Enciclopedia Italiana.

_ (2002) - «The Most Serious Duty»: motherhood, gender and patrician culture in Renaissance Venice. In FINDLEN, Paula, ed. - The Italian Renaissance. The essential readings. [S.l.]: Blackwell Publishing.

CHORÃO, Maria José Biggote (2000) - Conventos. In AZEVEDO, Carlos Moreira, ed. - Dicionário de História Religiosa de Portugal, C-I. [Lisboa]: Círculo de Leitores/CEHR-UCP.

— (2001) - Mosteiros. In AZEVEDO, Carlos Moreira, ed. - Dicionário de História Religiosa de Portugal, J-P. [Lisboa]: Círculo de Leitores/ CEHR-UCP.

CHRISTIANSON, Gerald (2012) - Church, Bible, and Reform in the Hussite debates at the Council of Basel, 1433. In BELLITTO, Christopher; FLANAGIN, David Zachariah, ed. - Reassessing Reform. A historical investigation into Church renewal. Washington: The Catholic University of America Press.

CHRISTIANSON Gerald; IZBICKY Thomas; BELLITO Christopher, ed. (2008) - The Church, the Councils and Reform: The Legacy of the Fifteenth Century. Washington: The Catholic University of America Press.

CISTELLINI, Antonio, CO (1989) - San Filippo Neri. L'Oratorio e la Congregazione oratoriana. Storia e Spiritualità. Brescia: Morcelliana, 3 vols. CÓDIGO de Direito Canónico (1983) - Lisboa: Conferência Episcopal Portuguesa.

COELHO, António, Dom, OSB (1950) - Curso de Liturgia Romana. Singeverga: Edições «Ora et Labora», vol. I.

COELHO, Maria Helena da Cruz; HOMEM, Armando Luís de Carvalho, coord. (1996) - Portugal em definição de fronteiras (1096-1325): Do condado portucalense à crise do século XIV. Lisboa: Editorial Presença, vol. III. Nova História de Portugal.

COELHO, Maria Helena da (2001) - Os historiadores e a historiografia portuguesa. In FONSECA, Luís Adão da; CADEDDU, Maria Eugenia, ed. - Portogallo Mediterraneo. Cagliari: Consiglio Nazionalle delle Ricerche - Istituto sui rapporti italo-iberici.

COMPÊNDIO do Catecismo da Igreja Católica (2005). Roma: Libreria Editrice Vaticana.

CONSTABLE, Giles (1996) - The Reformation of the twelfth century. Cambridge: Cambridge University Press.

CORREIA, Fernando da Silva (1941) - Os Velhos Hospitais da Lisboa Antiga. «Revista Municipal», ano II, n. ${ }^{10}$. Lisboa: Câmara Municipal de Lisboa.

(1943) - A assistência médica em Portugal durante o século XVI. «Imprensa Médica». Lisboa: [s.n.].

CORREIA, Fernando da Silva (1961) - Um notável médico conselheiro do Infante D. Henrique. «Revista Ocidente». Lisboa: [s.n.], p. 51-67.

_ (1965) - Um grande administrador hospitalar de há três séculos (1656) - Jorge de S. Paulo - à memória do Prog. Francisco Gentil. «Jornal da Sociedade das Ciências Médicas de Lisboa». Lisboa: Sociedade das Ciências Médicas de Lisboa, p. 585-598.

COSTA, António Domingues de Sousa, OFM (1963) - D. Gomes, reformador da Abadia de Florença e as tentativas de reforma dos mosteiros portugueses no século XV. «Studia Monastica», n. . 5, fasc. 1. Monserrat: Abadia de Monserrat, p. 59-164.

_ (1975) - Lóios. In SERRÃO, Joel, ed. - Dicionário de História de Portugal. Porto: Livraria Figueirinhas, p. 48-50.

_ (1986) - Bispos de Lamego e Viseu no século XV (revisão crítica dos autores). Braga: Editorial Franciscana.

_ (1990) - Portugueses no Colégio de S. Clemente e Universidade de Bolonha durante o século XV. Bolonha: Publicaciones del Real Colegio de España.

COSTA, Avelino de Jesus da (1993) - Normas gerais de transcrição e publicação de documentos e textos medievais e modernos. Coimbra: Faculdade de Letras da Universidade de Coimbra.

COSTA, João Paulo Oliveira e (2005) - D. Manuel I: 1469-1521. Um Príncipe do Renascimento. [Lisboa]: Círculo de Leitores, vol. XIV. (Reis de Portugal).

COSTA, Manuel Gonçalves da, P.e (1982) - História do bispado e cidade de Lamego. Lamego: [s.n.], vol. III.

COSTA, Paula Pinto (2000) - A Ordem Militar do Hospital em Portugal: dos finais da Idade Média à Modernidade. Porto: Fundação Eng. António de Almeida. (Militarium ordinum Anacleta, 3/4). 
COSTA, Susana; LIMA, Francisco Pedroso (2009) - Retratos dos Bispos de Angra. Angra do Heroísmo: Museu de Angra do Heroísmo. Catálogo da exposição.

COSTANTINI, Attilio (1960) - Introduzione alle opere di San Lorenzo Giustiniani, primo Patriarca di Venezia. Veneza: Studium Cattolico Veneziano (Collana Laurenziana, 4).

CRACCO, Giorgio (1959) - La fondazione dei canonici secolari di San Giorgio in Alga. «Rivista di storia della Chiesa in Italia». Roma: Herder Editrice e Libreria, p. 70-88.

CRACCO, Giorgio (1960) - Riforma e decadenza nel monastero di S. Agostino di Vicenza. «Rivista di storia della Chiesa in Italia». Roma: Herder Editrice e Libreria, p. 203-235.

(1963) - Giovanni di Domenico Banchini. In Dizionario Biografico degli Italiani. Roma: Istituto dell'Enciclopedia Italiana.

(1997) - La vita civile e religiosa: Dinamiche religiose di uno Stato nascente. In Storia di Venezia: La formazione dello stato patrizio. Roma: Istituto dell'Enciclopedia Italiana.

CRUZ, Maria Augusta Lima (2006) - D. Sebastião. [Lisboa]: Círculo de Leitores. (Reis de Portugal, XVI).

CUNHA, Mafalda Soares da (1988) - A Casa de Bragança 1384-1483. Linhagem, parentesco e poder. Évora: Universidade de Évora. Ed. do autor.

_ (1990) - Linhagem, parentesco e poder. A Casa de Bragança (1384-1483). Lisboa: Fundação da Casa de Bragança.

CUNHA, Maria Cristina Almeida e (1989) - A Ordem Militar de Avis: Das origens a 1329. Porto: Faculdade de Letras da Universidade do Porto. Dissertação de Mestrado.

DAILEADER, Philip (2009) - Local experiences of the great western schism». In ROLLO-KOSTER, Joëlle, ed. - A companion to the Great Western Schism (1378-1417). Leiden: E. J. Brill.

DE VINCENTIIS, Amedeo (2000) - Innocenzo VII. In Enciclopedia dei Papi. Roma: Istituto dell'Enciclopedia Italiana.

DECALUWE, Michiel (2008) - Three ways to read the Constance decree Haec sancta (1415). Francis Zabarella, Jean Gerson, and the traditional Papal view of General Councils». In CHRISTIANSON, Gerald; IZBICKY, Thomas; BELLITO, Christopher, ed. - The Church, the Councils and reform. The legacy of the fifteenth century. Washington: The Catholic University of America Press.

DECRETO-LEI n. o 206/2004. «D. R. I Série A.» 195 (2004-08-19).

DEL TORRE, Giuseppe (2007) - Lorenzo Giustinian, santo. In Dizionario Biografico degli Italiani. Roma: Istituto dell'Enciclopedia Italiana.

DELUMEAU, Jean (1965) - Naissance et Affirmation de la Réforme. Paris: Presses Universitaires de France.

_ (1967) - La civilisation de la Renaissance. Paris: Arhaud.

DIAS, Geraldo José Amadeu Coelho, OSB (2001) - Quando os monges eram uma civilização: Beneditinos: Espírito, Alma e Corpo. Porto: CITCEM/Edições Afrontamento.

DIAS, José João Alves, coord. (1998) - Portugal do Renascimento à crise dinástica. Lisboa: Editorial Presença. Nova História de Portugal.

DIAS, José Sebastião da Silva (1960) - Correntes de sentimento Religioso em Portugal (séculos XVI a XVIII). Coimbra: Universidade de Coimbra, 2 vols.

DICIONÁRIO de Latim-Português (2001) - Porto: Porto Editora.

DINIS, António Dias, OFM (1956) - Quem era Fr. João Verba, colaborador literário de el-rei D. Duarte e do Infante D. Pedro. «Itinerarium: revista quadrimestral de Cultura». Braga: Editorial Franciscana, , p. 424-491.

_ (1957) - Ainda sobre a identidade de Frei João Verba. «Itinerarium: revista quadrimestral de Cultura» Braga: Editorial Franciscana, p. $479-490$.

DONAHUE, A. (2003) - Prior. In MARTHALER, Berard L. OFM, ed. - New Catholic Encyclopedia. Detroit: Thomson Gale, p. 716-717.

D'ONORIO, Joel Benoit (1994) - Congrégations Romaines. In LEVILLAIN, Philippe, ed. - Dictionnaire historique de la papauté. Paris: Librairie Arthème Fayard.

DONOVAN, Stephen (1908) - Conversi. In The Catholic Encyclopedia. Nova Iorque: Robert Appleton Company.

DOURMEC, Bernard (1997a) - Le sfide esterne: La difesa dell'impero In Storia di Venezia: La formazione dello stato patrizio. Roma: Istituto dell'Enciclopedia Italiana.

(1997b) - Diritto, finanze, economia: gli armamenti marittimi. In Storia di Venezia: La formazione dello stato patrizio. Roma: Istituto dell'Enciclopedia Italiana.

DUARTE, Luís Miguel (2005) - D. Duarte. Requiem por um rei triste. [Lisboa]: Círculo de Leitores. (Reis de Portugal, XI). 
ELBL, Martin Malcolm, ELBL, Ivana (2014) - The Private Archive (Carteggio) of Abbot Dom Fr. Gomes Eanes (Badia di Firenze) - An analytical catalogue, with commentary, of Codex Ashburnham 1792 (Biblioteca Medicea Laurenziana, Florence). Part One. «Portuguese Studies Review». Peterborough: Baywolf Press - Trent University.

_ (2015) - The Private Archive (Carteggio) of Abbot Dom Fr. Gomes Eanes (Badia di Firenze) - An analytical catalogue, with commentary, of Codex Ashburnham 1792 (Biblioteca Medicea Laurenziana, Florence). Part Two. «Portuguese Studies Review». Peterborough: Baywolf Press - Trent University.

ESCH, Arnold (2000) - Bonifacio IX. In Enciclopedia dei Papi. Roma: Istituto dell'Enciclopedia Italiana.

EVANS, G.R. (1999) - Catholic, Church as. In FITZGERALD, Allan D. OSA, ed. - Augustine through the Ages. Michigan: B. Eerdmans Publishing Company, p. 150-151.

FAGGIONI, Paolo Emilio (1986) - L' insediamento degli Olivetani al Tino nelle bole di Eugenio IV. In Memoria della Academia Lunigianese de Scienzia. [s.l.]: [s.n.].

FALCÃO, Manuel Franco, Dom. (2004) - Carisma. In Enciclopédia Católica Popular. Lisboa: Ed. Paulinas.

FALCÃO, Nuno de Pinho (2009) - Os Azuis no Porto. O convento Lóio de Nossa Senhora da Consolação (1490-1640). Porto: FLUP. Dissertação de Mestrado.

(2012) - Em torno da Rainha Velha: os Lóios e as Misericórdias. In Culto, Cultura e caridade. Atas do II Congresso de História da Santa Casa da Misericórdia do Porto. Porto: Santa Casa da Misericórdia.

(2016) - A reforma em carisma e ação: A Congregação de S. João Evangelista (Lóios). (Itália, Portugal e África - ca.1420/1580). Porto: Faculdade de Letras da Universidade do Porto. Tese de Doutoramento.

FALCIONI, Anna (2007) - Carlo Malatesta. In Dizionario Biografico degli Italiani. Roma: Istituto dell'Enciclopedia Italiana.

FARELO, Mário (2007) - Ao serviço da Coroa no século XIV: o percurso de uma família de Lisboa, os «Nogueiras». In KRUS, Luís, ed. - Lisboa Medieval - Os rostos da cidade. Lisboa: Livros Horizonte.

_ (2008) - A oligarquia camarária de Lisboa (1325-1433). Lisboa: Faculdade de Letras da Universidade de Lisboa.

_ (2012) - Os morgadios dos Nogueiras: entre a estratégia de poder e a lógica documental. In ROSA, Maria de Lurdes, ed. - Arquivos de famila, séculos XIII-XX: Que presente, que futuro. Lisboa: Instituto de Estudos Medievais.

FARINHA, Maria do Carmo (1997) - Mesa da Consciência e Ordens. Lisboa: Instituto dos Arquivos Nacionais/Torre do Tombo.

FAVERO, Angelo (1966) - Dio nella teologia di S. Lorenzo Giustiniani. Roma: Pontifícia Università Lateranense.

FERNANDES, Aires Gomes (2011) - Os Cónegos Regrantes de St. ${ }^{\circ}$ Agostinho no norte de Portugal em finais da Idade Média: dos alvores de trezentos à Congregação de Santa Cruz. Coimbra: Universidade de Coimbra. Tese de Doutoramento. Ed. do autor.

FERNANDES, Maria de Lurdes Correia (2000) - Da Reforma da Igreja à reforma dos cristãos. In AZEVEDO, Carlos Moreira, ed. - História Religiosa de Portugal. Humanismos e Reformas. [Lisboa]: Círculo de Leitores, CEHR-UCP.

FERREIRA, Maria Emília Cordeiro (1981) - Pedro, Infante D. In SERRÃO, Joel, ed. - Dicionário de História de Portugal. Porto: Livraria Figueirinhas, p. 29-31.

FERRO, Maria José Pimenta (1973) - Nótulas para o estudo da assistência hospitalar aos pobres, em Lisboa: os hospitais de D. Maria de Aboim e do Conde D. Pedro. In A pobreza e a assistência aos pobres na Península Ibérica durante a Idade Média. Actas das 1.as Jornadas Luso-Espanholas de História Medieval. Lisboa: Instituto de Alta Cultura da Universidade de Lisboa.

FILIPE, Nuno (2000) - Hospitaleiros de São João de Deus (Ordem Hospitaleira de São João de Deus). In AZEVEDO, Carlos Moreira, ed. Dicionário de História Religiosa de Portugal, C-I. [Lisboa]: Círculo de Leitores, CEHR-UCP.

FLECK, Cathleen (2009) - Seeking legitimacy: art and manuscripts for the Popes in Avignon from 1378 to 1417. In ROLLO-KOSTER, Joëlle, ed. - A companion to the Great Western Schism (1378-1417). Leiden: E. J. Brill.

FODALE, Salvatore (1991) - Giovanni de Primis. In Dizionario Biografico degli Italiani. Roma: Istituto dell'Enciclopedia Italiana.

FOIS, Mario (1984) - I movimenti religiosi dell'osservanza nel '400: i benedettini. In TROLESE, Giovanni Francesco, ed. - Riforma della Chiesa, Cultura e Spiritualità nel Quattrocento Veneto. Atti del convegno per il VI centenario della nascita di Ludovico Barbo (1382-1443), OSB. Cesena: Centro Storico Beneditino Italiano.

FOLEY, G. (2003) - Charisms in religious life. In MARTHALER, Berard L., ed. - New Catholic Encyclopedia, OFM. Detroit: Thomson Gale, p. 393-94. 
FONSECA, Cosimo Damiano (1984) - I canonici e la riforma di S. Giustina. In TROLESE, Giovanni Francesco, ed. - Riforma della Chiesa, Cultura e Spiritualità nel Quattrocento Veneto. Atti del convegno per il VI centenario della nascita di Ludovico Barbo (1382-1443), OSB. Cesena: Centro Storico Beneditino Italiano.

FONSECA, Fernando Taveira da 2000) - Ensino. II. Época Moderna. In AZEVEDO, Carlos Moreira, ed. - Dicionário de História Religiosa de Portugal, C-I. [Lisboa]: Círculo de Leitores, CEHR-UCP, p. 118-123.

FONSECA, Luís Adão da (1982) - O Condestável D. Pedro de Portugal. Porto: Instituto Nacional de Investigação Científica.

— (2005) - D. João II. [Lisboa]: Círculo de Leitores. (Reis de Portugal).

(2009) - Percursos de um antigo ermitério medieval: o oratório do Alentejo, no termo de Óbidos. In Olhares sobre a História. Estudos oferecidos a Íria Gonçalves. Lisboa: Edições Caleidoscópio, p. 233-251.

FONTES, João Luís Inglês (2010) - Inventário dos Fundos Monástico-Conventuais da Biblioteca Pública de Évora. Lisboa: Edições Colibri. (2012) - Da «pobre vida» à Congregação da Serra de Ossa: Génese e institucionalização de uma experiência eremítica (1366-1510). Lisboa: FCH-UNL.

FRAZEE, Charçes (1983) - Catholics and Sultans. The Church and the Ottoman Empire 1453-1923. Cambridge: Cambridge University Press. FREEDMAN, Paul (2000) - Rural Society. In JONES, Michael, ed. - The New Cambridge Medieval History: VI c.1300-c.1415. Cambridge: Cambridge University Press.

FREITAS, Eugénio de Andréa da Cunha e (1947) - O convento novo de Santa Maria da Consolação (padres Lóios). Porto: Publicações da Câmara Municipal do Porto. (Documentos e Memórias para a História do Porto, 16).

GASNAULT, Pierre (2000) - Innocenzo VI. In Enciclopedia dei Papi. Roma: Istituto dell'Enciclopedia Italiana.

GERHARDS, Agnès (1998) - Dictionnaire historique des ordres religieux. Paris: Fayard.

GILL, Joseph, SJ (1959) - The Council of Florence. Cambridge: Cambridge University Press.

GIORDANO, Silvano (1999) - Pietro Gambacorta. In Dizionario Biografico degli Italiani. Roma: Istituto dell'Enciclopedia Italiana.

GOMES, Joaquim Ferreira (2001) - Universidade de Coimbra. In AZEVEDO, Carlos Moreira, ed. - Dicionário de História Religiosa de Portugal, P-V, Apêndice. [Lisboa]: Círculo de Leitores, CEHR-UCP, p. 314-320.

GOMES, Rita Costa (1995) - A corte dos reis de Portugal no final da Idade Média. Lisboa: Difel.

GOMES, Saul António (2006) - D. Afonso V. o Africano. [Lisboa]: Círculo de Leitores. (Reis de Portugal, XII).

(2009) - Os dominicanos e a Cultura em tempos medievais: o caso português. «Biblos. Revista da Faculdade de Letras da Universidade de Coimbra». Coimbra: Imprensa da Universidade de Coimbra, p. 261-294.

GONÇALVES, António Custódio (1990) - A acção cultural e evangelizadora portuguesa em Angola e Congo (séc. XV-XVII). «Revista Eborensia». Évora: [s.n.], vol. 5-6.

GONÇALVES, Eduardo Cordeiro (1991) - O convento de St. Elói do Porto da congregação dos cónegos seculares de S. João Evangelista: património(s) e memórias. Porto: Universidade Portucalense.

GONÇALVES, Nuno da Silva (2001) - Jeuítas. In AZEVEDO, Carlos Moreira, ed. - Dicionário de História Religiosa de Portugal, J-P. [Lisboa]: Círculo de Leitores, CEHR-UCP.

GRANT, Ken A. (2012) - «He does not say 'I am custom'». Pope Gregory VII's Idea of Reform. In BELLITTO, Christopher; FLANAGIN, David Zachariah, ed. - Reassessing Reform. A historical investigation into Church renewal. Washington: The Catholic University of America Press.

GRIMAL, Pierre, et al. (1996) - A Europa das origens ao início do século XIV. In LIVET, Georges; Mousnier, Roland, ed. - História Geral da Europa. Mem Martins: Publicações Europa América, vol. I.

GUALDO, Germano (1964a) - Angelo Barbarigo. In Dizionario Biografico degli Italiani. Roma: Istituto dell'Enciclopedia Italiana.

_ (1964b) - Marco Barbo. In Dizionario Biografico degli Italiani. Roma: Istituto dell'Enciclopedia Italiana.

GUERREIRO, Jacinto Salvador (2001) - Vestes litúrgicas. In AZEVEDO, Carlos Moreira, ed. - Dicionário de História Religiosa de Portugal, P-V, Apêndices. [Lisboa]: Círculo de Leitores, CEHR-UCP.

GUILLEMAN, Bernard (1998) - Les papes d'Avignon. 1309-1376. Paris: Les éditions du CERF.

GULLINO, Giuseppe (2012) - Cristoforo Moro. In Dizionario Biografico degli Italiani. Roma: Istituto dell'Enciclopedia Italiana.

GUYOTJEANNIN, Olivier (1994) - Antipape. In LEVILLAIN, Philippe, ed. - Dictionnaire historique de la papauté. Poitiers: Librairie Arthème Fayard.

HAY, Denys (2000) - Eugenio IV. In Enciclopedia dei Papi. Roma: Istituto dell'Enciclopedia Italiana. 
HAYEZ, Michel (2000a) - Urbano V, beato. In Enciclopedia dei Papi. Roma: Istituto dell'Enciclopedia Italiana.

(2000b) - Gregorio XI. In Enciclopedia dei Papi. Roma: Istituto dell'Enciclopedia Italiana.

HERDE, Peter (2000) - From Adolf od Nassau to Lewis of Bavaria, 1292-1347. In JONES, Michael, ed. - The New Cambridge Medieval History: VI, c.1300-c.1415, Cambridge: Cambridge University Press.

HERLIHY, David (1999) - The Black Death and the transformation of the west. Massachusetts: Harvard University Press.

HITCHCOCK, Hellen Hull (2008) - Pope Benedict XVI and the «Reform of the Reform». In Antiphon. «A Journal for Liturgical Renewal», p. 179-197. Mundelein: Society for Catholic Liturgy.

HLAVÁCEK, Ivan (2000) - The Luxemburgs and Rupert of the Palatinate, 1347-1410. In JONES, Michael, ed. - The New Cambridge Medieval History: VI c.1300-c.1415. Cambridge: Cambridge University Press.

HOLMES, J. Derek; BICKERS, Bernard W. (2006) - História da Igreja Católica. Lisboa: Edições 70.

HOMEM, Armando Luís de Carvalho (1990) - O Desembargo Régio (1320-1433). Porto: INIC - Centro de História da Universidade do Porto.

(1991) - A história que nos fez e a história que se faz: da primeira à segunda fase da Faculdade de Letras do Porto. «Revista da Faculdade de Letras. História». Porto: Faculdade de Letras da Universidade do Porto, p. 227-240.

_ (2001) - Invicta Clio. «Revista da Faculdade de Letras. História». Porto: Faculdade de Letras da Universidade do Porto, p. 9-12.

_ (2010) - Prelados e clérigos régios no meio-século joanino (1384-1433): para uma reapreciação de situações. In Estudos em homenagem ao prof. Doutor Martim de Albuquerque. Lisboa: Faculdade de Direito da Universidade de Lisboa, p. 205-211.

HUDON, William (2012) - Black and White and re-read all over. Conceptualizing Reform across the Long Sixteenth Century, $1414-1633$. In BELLITO, Christopher; FLANAGIN, David Zachariah, ed. - Reassessing Reform. A historical investigation into Church renewal. Washington: The Catholic University of America Press.

HYLAND, William P. (2012) - Premonstratensian voices of Reform at the fifteenth-century councils. In BELLITO, Christopher; FLANAGIN, David Zachariah, ed. - Reassessing Reform. A historical investigation into Church renewal. Washington: The Catholic University of America Press.

INDICE dei Fondi e relativi mezzi di descrizione e di ricerca dell'Archivio Segreto Vaticano. Città del Vaticano: Archivio Segreto Vaticano, 2012. IPPOLITO, Antonio Menniti, coord. (2000) - Enciclopedia dei Papi. Roma: Istituto dell'Enciclopedia Italiana, 3 vols.

JEDIN, Hubert; ALBERIGO Giuseppe (1985) - Il tipo ideale di vescovo secondo la riforma Cattolica. Brescia: Morcelliana.

JONES, Michael, coord. (2000a) - The New Cambridge Medieval History: VI c.1300-c.1415. Cambrigde: Cambridge University Press.

(2000b) - The last capetians and early Valois Kings, 1314-1364. In JONES, Michael, ed. - The New Cambridge Medieval History: VI c.1300-c.1415. Cambridge: Cambridge University Press.

JULIA, Dominique (1990) - Religião. In LE GOFF, Jacques; CHARTIER, Roger; REVEL, Jacques, ed. - A Nova História. Coimbra: Almedina.

KAMINSKY, Howard (2000) - The Great Schism. In JONES, Michael, ed. - The New Cambridge Medieval History: VI c.1300-c.1415. Cambridge: Cambridge University Press.

KLAPISCH-ZUBER, Christiane (2000) - Plague and family life. In JONES, Michael, ed. - The New Cambridge Medieval History: VI c.1300-c.1415. Cambrigde: Cambridge University Press.

KOLLER, Alexander (2005) - Luigi Lippomano. In Dizionario Biografico degli Italiani. Roma: Istituto dell'Enciclopedia Italiana.

LABOA GALLEGO, Juan Maria (2010) - História dos Papas. Entre o reino de Deus e o poder terreno. Lisboa: A Esfera dos Livros.

LABOWSKY, Lotte (1967) - Bessarione. In Dizionario Biografico degli Italiani. Roma: Istituto dell'Enciclopedia Italiana.

LADNER, Gerhart Burian (1959) - The Idea of Reform. Its impact on Christian Thought an Action in the Age of the Fathers. Massachusetts: Harvard University Press.

LARNER, John (1971) - Culture and Society in Italy 1290-1420. Londres: B.T. Batsford.

LAVAJO, Joaquim Chorão (2001) - Universidade Henriquina de Évora. In AZEVEDO, Carlos Moreira, ed. - Dicionário de História Religiosa de Portugal, P-V, Apêndice. [Lisboa]: Círculo de Leitores, CEHR-UCP, p. 314-320.

LAW, John (2000) - The Italian North. In JONES, Michael, ed. - The New Cambridge Medieval History: VI c.1300-c.1415. Cambrigde: Cambridge University Press.

LAWLOR, F.X. (2003) - Schism. In MARTHALER, Berard L., ed. - New Catholic Encyclopedia, OFM. Detroit: Thomson Gale, p. 737-738.

LE GOFF, Jacques (1990) - A história nova. In LE GOFF, Jacques; CHARTIER, Roger; REVEL, Jacques, ed. - A Nova História. Coimbra: Almedina. 
LEGUAY, Jean-Pierre (2000) - Urban life. In JONES, Michael, ed. - The New Cambridge Medieval History: VI c.1300-c.1415. Cambridge: Cambridge University Press.

MAGALHÃES, Joaquim Romero, coord. (1997) - No alvorecer da Modernidade. In MATTOSO, José, ed. - História de Portugal. [s.1.]: Editorial Estampa, vol. III.

MAGANO, Fernando (1956) - A respeito, e em respeito, da Congregação de Vilar de Frades. O «Compêndio» do Padre Jorge de S. Paulo. In Studium Generale. Boletim do Centro de Estudos Humanísticos. Porto: Centro de Estudos Humanísticos, p. 5-50.

MANGUCCI, Celso (2013) - A iconografia de São Lourenço Justiniano nos azulejos dos conventos Lóios de Évora e Arraiolos. Évora: Centro de História da Arte e Investigação Artística da Universidade de Évora.

MANN, Jesse D. (1996) - The Devilish Pope: Eugenius IV as Lucifer in the Later Works of Juan de Segovia. «Church History». Cambridge: American Society of Church History/ Cambridge University Press.

MANSELLI, Raoul (1967) - Bernardino da Siena, santo. In Dizionario Biografico degli Italiani. Roma: Istituto dell'Enciclopedia Italiana.

MANUEL II, Dom, Rei de Portugal (1932) - Livros antigos portuguezes 1489-1600 da Bibliotheca de Sua Majestade Fidelissima. 1540 -1569. Londres: Imprensa da Universidade de Cambridge/Maggs Brothers, vol. II.

MARQUES, A. H. de Oliveira (1987) - Portugal na Crise dos séculos XIV e XV. In SERRÃO, Joel; MARQUES, A. H. de Oliveira, ed. - Nova História de Portugal. Lisboa: Editorial Presença, vol. IV.

_ (1998) - As instituições de Cultura. In DIAS, João José Alves, ed. - Portugal do Renascimento à crise dinástica. Lisboa: Editorial Presença.

MARQUES, João Francisco (1993) - Franciscanos e Dominicanos Confessores dos Reis Portugueses das duas Primeiras Dinastias. In Espiritualidade e Corte em Portugal (séculos XVI a XVIII). Porto: Instituto de Cultura Portuguesa.

MARQUES, José (1988) - A Arquidiocese de Braga no século XV. Lisboa: Imprensa Nacional - Casa da Moeda.

(2006) - Prof. Doutor José Amadeu Coelho Dias: obra histórica. In Estudos em homenagem ao Professor Doutor José Amadeu Coelho Dias,. Porto: Faculdade de Letras da Universidade do Porto, p. 7-20.

MARTINES, Lauro (1986) - Italy, 14th-15th centuries. In STRAYE, Joseph R., ed. - Dictionary of the Middle Ages. Nova Iorque: American Council of Learned Societies.

MATTOSO, José; SOUSA, Armindo de (1997) - A monarquia feudal. In MATTOSO, José, ed. - História de Portugal. [s.l.]: Editorial Estampa, vol. II.

— (1975) - Canonici Regolari di San Giovanni Evangelista. In PELLICCIA, Guerrino; ROCCA, Giancarlo, ed. - Dizionario degli Instituti di Perfezione. Roma: Edizione Paoline, col. 119-122.

MCGRATH, Alister E. (1988) - Reformation thougt. An introduction. Oxford: Basil Blackwell.

MEA, Elvira Cunha de Azevedo (1998) - A Igreja em Reforma. In DIAS, João José Alves, ed. - Portugal do Renascimento à crise dinástica. Lisboa: Editorial Presença.

MEEHAN, Andrew (1911) - Rector. In The Catholic Encyclopedia. Nova Iorque: Robert Appleton Company.

MENDONÇA, Manuela (1991) - D. Jorge da Costa, Cardeal de Alpedrinha. Lisboa: Edições Colibri.

MENEGHETTI, Francesca (1983) - Contarini, Maffeo. In Dizionario Biografico degli Italiani. Roma: Istituto dell'Enciclopedia Italiana.

MEYJES, G.H. M. Posthumus (1999) - Jean Gerson: apostle of unity. His Church politics and Ecclesiology. Leiden: E. J. Brill.

MODIGLIANI, Anna (2000) - Paolo II. In Enciclopedia dei Papi. Roma: Istituto dell'Enciclopedia Italiana.

MOMMSEN, Theodor (2002) - Petrarch's Conception of the «Dark Ages». In FINDLEN, Paula, ed. - The Italian Renaissance. The essential readings. [s.1.]: Blackwell Publishing.

MORENO, Humberto Baquero (1979) - A Batalha de Alfarrobeira: antecedentes e significado histórico. Coimbra: Biblioteca Geral da Universidade de Coimbra, vol. I.

(1980) - A Batalha de Alfarrobeira: antecedentes e significado histórico. Coimbra: Biblioteca Geral da Universidade de Coimbra, vol. 2.

(1997) - O Infante D. Pedro, Duque de Coimbra. Itinerários e Ensaios Históricos. Porto: Universidade Portucalense.

MURPHY, F. (2003a) - Creed. In MARTHALER, Berard L., ed. - New Catholic Encyclopedia, OFM. Detroit: Thomson Gale, p. $349-356$.

MURPHY, R. J. (2003b) - Rectors. In MARTHALER, Berard L., ed. - New Catholic Encyclopedia, OFM. Detroit: Thomson Gale, p. 957-958.

NASCIMENTO, Aires (1999) - A tradução portuguesa da Vita Christi de Ludolfo da Saxónia: obra de príncipes em «serviço de Nosso Senhor e proveito comum. «Didaskalia Revista da Faculdade de Teologia de Lisboa», vol. XXIX. Lisboa: Universidade Católica Portuguesa.

NEVES, Manuel Carreira das, OFM (1992) - Conceito de «Contemplatio» no «Cântico Espiritual» de S. João da Cruz. «Didaskalia Revista da Faculdade de Teologia de Lisboa», vol. XXII. Lisboa: Universidade Católica Portuguesa. 
NORA, Pierre (1990) - Memória colectiva. In LE GOFF, Jacques; CHARTIER, Roger; REVEL, Jacques, ed. - A Nova História. Coimbra: Almedina.

NUNES, Eduardo Borges (1963) - Dom Frey Gomez, Abade de Florença. 1420-1440. Braga: [s.n.]. Edição do autor.

O’NEILL, Charles, SJ (2001) - Diccionario Histórico de la Compañia de Jesus. Biográfico-Temático. Madrid: Universidad Pontificia Comillas, vol. I.

OAKLEY, Francis (2006) - Gerson as conciliarist. In MCGUIRE, Brian Patrick, ed. - A companion to Jean Gerson. Leiden: E. J. Brill.

OLIVEIRA, Aurélio de (1979) - A Abadia de Tibães 1630/80 - 1813. Propriedade, exploração e produção agrícolas no vale do Cávado durante $o$ Antigo Regime. Porto: Faculdade de Letras da Universidade do Porto. Tese de Doutoramento.

OLIVEIRA, Mário Rui de, padre (2006) - O direito a viver do Evangelho. Estudo jurídico-teológico sobre a Sustentação do Clero. Roma: Editrice Pontificia Università Gregoriana. Vol. 71, Tesi Gregoriana Serie Diritto Canonico.

OLIVIERI, Achille (1982a) - Francesco Condulmer. In Dizionario Biografico degli Italiani. Roma: Istituto dell'Enciclopedia Italiana.

_ (1982b) - Marco Condulmer. In Dizionario Biografico degli Italiani. Roma: Istituto dell'Enciclopedia Italiana.

O'MALLEY, John, SJ (2012) - «The hermeneutic of reform»; a historical analysis. «Theological Studies». Milwaukee: Marquette University, vol. 73 .

ORTALLI, Gherardo (2000) - Gregorio XII. In Enciclopedia dei Papi. Roma: Istituto dell'Enciclopedia Italiana.

PAIVA, José Pedro (2000) - Os mentores. In AZEVEDO, Carlos Moreira, ed. - História Religiosa de Portugal. Humanismos e Reformas. [Lisboa]: Círculo de Leitores, CEHR-UCP.

_coord. (2015) - Guia de fundos do Arquivo da Universidade de Coimbra. Coimbra: Imprensa da Universidade de Coimbra.

PASCOE, Louis B., SJ (1973) - Jean Gerson: Principles of Church Reform. Leiden: E. J. Brill.

(2012) - Gerhart Ladner's «The Idea of Reform». In BELLITO, Christopher; FLANAGIN, David Zachariah, ed. - Reassessing Reform. A historical investigation into Church renewal. Washington: The Catholic University of America Press.

PÀSZTOR, Edith (1960a) - Niccolò Albergati. In Dizionario Biografico degli Italiani. Roma: Istituto dell'Enciclopedia Italiana.

(1960b) - Louis Aleman. In Dizionario Biografico degli Italiani. Roma: Istituto dell'Enciclopedia Italiana.

PAVAN, Elisabeth (1997) - La vita civile e religiosa: Sviluppo e articolazione della città. In Storia di Venezia: La formazione dello stato patrizio. Roma: Istituto dell'Enciclopedia Italiana.

PELLEGRINI, Marco (2000) - Pio II. In Enciclopedia dei Papi. Roma: Istituto dell'Enciclopedia Italiana.

PENCO, Gregorio (1984) - Vita monastica e società nel Quattrocento italiano. In Riforma della Chiesa, Cultura e Spiritualità nel Quattrocento Veneto. Atti del convegno per il VI centenario della nascita di Ludovico Barbo (1382-1443). Ed. Giovanni Francesco Trolese, OSB. Cesena: Centro Storico Beneditino Italiano.

_ (1991) - Il monachesimo fra spiritualità e cultura. Milão: Editoriale Jaca Book.

PERRON, Anthony (2012) - The Bishops of Rome, 1100-1300. In RUBIN, Miri; SIMONS, Walter, ed. - The Cambridge History of Christianity - Christianity in Western Europe c.1100-c.1500. Cambridge: Cambridge University Press.

PESCE, Luigi (1984) - Ludovico Barbo vescovo riformatore. In TROLESE, Giovanni Francesco, OSB, ed. - Riforma della Chiesa, Cultura e Spiritualità nel Quattrocento Veneto. Atti del convegno per il VI centenario della nascita di Ludovico Barbo (1382-1443). Cesena: Centro Storico Beneditino Italiano.

PIAZZONI, Ambrogio Maria (1982) - Beato Giovanni Colombini. In Dizionario Biografico degli Italiani. Roma: Istituto dell'Enciclopedia Italiana.

PICOTTI, Giovanni Battista (1932) - Eugenio IV Papa. In Enciclopedia italiana di scienze, lettere ed arti. Roma: Istituto Treccani.

PIETRO Marcello. In Dizionario Biografico degli Italiani. Roma: Istituto dell'Enciclopedia Italiana, 2007.

PINA, Isabel Castro (2007) - Alterações na paisagem construída: os conventos dos Lóios no final do século XV. In Paisagens rurais e urbanas. Fontes, metodologias, problemáticas. Actas das terceiras jornadas. Lisboa: Centro de Estudos Históricos da Universidade Nova de Lisboa, p. 249-267.

_ (2009) - Documentos para a história dos Lóios em Portugal: o livro dos capítulos gerais da congregação (1478-1502). In Olhares sobre a História. Estudos oferecidos a Iria Gonçalves. Lisboa: Caleidoscópio, p. 469-474.

(2010) - Lóios. In FRANCO, José Eduardo et. al., ed. - Dicionário Histórico das Ordens e Instituições afins em Portugal . Lisboa: Gradiva, p. 211-213. 
_ (2011) - Os Lóios em Portugal: Origens e Primórdios da Congregação dos Cónegos Seculares de São João Evangelista. Lisboa: FCSH-Universidade Nova de Lisboa. Tese de Doutoramento.

PIÑEIRO, Manuel Vaquero (2000) - Benedetto XIII, antipapa. In Enciclopedia dei Papi. Roma: Istituto dell'Enciclopedia Italiana.

PISTILLI, Gino (2002) - Bernardo Giustinian. In Dizionario Biografico degli Italiani. Roma: Istituto dell'Enciclopedia Italiana.

POLÓNIA, Amélia (1994) - O Cardeal Infante Henrique: um prelado no limiar da viragem tridentina segundo o paradigma do «stimulus pastorum»? In Actas do Congresso Internacional do IV centenário da morte de D. Frei Bartolomeu dos Mártires. Fátima: Movimento Bartolomeano.

— (2005) - D. Henrique. O Cardeal-Rei. [Lisboa]: Círculo de Leitores. (Reis de Portugal).

POST, R. R. (1968) - The Modern Devotion. Confrontation with reformation and humanism. (Studies in medieval and Reformation traditions). Leiden: E. J. Brill, vol. 4.

POTESTÀ, Gian Luca (1980) - Storia ed escatologia in Ubertino da Casale. Milão: Università Cattolica del Sacro Cuore.

PRATESI, Alessandro (1964) - Ludovico Barbo. In Dizionario Biografico degli Italiani. Roma: Istituto dell'Enciclopedia Italiana.

PRETO, Paolo (1983) - Gregorio Correr. In Dizionario Biografico degli Italiani. Roma: Istituto dell'Enciclopedia Italiana.

RABIKAUSKAS, Paulius (1994) - Protonotaire. In LEVILLAIN, Philippe, ed. - Dictionnaire historique de la papauté. Poitiers: Librairie Arthème Fayard.

RANDO, Daniela (1992) - La societa e gli ordinamenti: le strutture della Chiesa. In Storia di Venezia: Eta Ducale. Roma: Istituto dell'Enciclopedia Italiana.

REUMONT, Alfredo (1880) - Saggi di Storia e Letteratura. Firenze: G. Barbèra, Editore.

RICHARDSON, Carol (2009) - Reclaiming Rome. Cardinals in the Fifteenth Century. Leiden: E. J. Brill.

RIGAUDIÈRE, Albert (2000) - The theory and practice of government in Western Europe in the Fourteenth century. In JONES, Michael, ed. The New Cambridge Medieval History: VI c.1300-c.1415. Cambridge: Cambridge University Press.

RIGON, Antonio (1997) - La vita civile e religiosa: i problemi religiosi. In Storia di Venezia: La formazione dello stato patrizio. Roma: Istituto dell'Enciclopedia Italiana.

RODRIGUES, Ana Maria (2000a) - Colegiadas. In AZEVEDO, Carlos Moreira, ed. - Dicionário de História Religiosa de Portugal. A-C. [Lisboa]: Círculo de Leitores, CEHR-UCP.

— (2000b) - Dignidades Eclesiásticas. In AZEVEDO, Carlos Moreira, ed. - Dicionário de História Religiosa de Portugal. C-I. [Lisboa]: Círculo de Leitores, CEHR-UCP.

_ (2012) - As tristes rainhas. Leonor de Aragão. Isabel de Coimbra. [Lisboa]: Círculo de Leitores. (Rainhas de Portugal, VII).

RODRIGUES, Lisbeth de Oliveira (2013) - Os hospitais portugueses do Renascimento (1480-1580): o caso de Nossa Senhora do Pópulo das Caldas da Rainha. Braga: Universidade do Minho. Edição do autor, 2 vols.

RUBIN, Miri; SIMONS, Walter, eds. (2012) - Christianity in Western Europe c.1100-c.1500. Cambridge: Cambridge University Press. (The Cambridge History of Christianity, IV)

RUSCONI, Roberto (1997) - Francesco d'Assisi, santo. In Dizionario Biografico degli Italiani. Roma: Istituto dell'Enciclopedia Italiana.

RYDER, Alan (1998) - The Papal States and the Kingdom of Naples. In ALLMAND, Christopher, ed. - The New Cambridge Medieval History: VII c.1415-c.1500. Cambrigde: Cambridge University Press.

SÁ, Isabel dos Guimarães (1996) - Os hospitais portugueses entre a assistência medieval e a intensificação dos cuidados médicos no período moderno. In Congresso Comemorativo do V Centenário da Fundação do Hospital Real do Espírito Santo de Évora: actas. Évora: Hospital do Espírito Santo, p. 87-103.

- (1998) - A reorganização da caridade em Portugal em contexto europeu (1490-1600). In «Cadernos do Noroeste», Série Sociologia, vol. 11, n. ${ }^{\circ}$ 2. Braga: Universidade do Minho, p. 31-63.

(2009) - Os rapazes do Congo: discursos em torno de uma experiência colonial (1480-1580). In O Império por escrito. Formas de transmissão da cultura letrado no mundo Ibérico (séc. XVI-XIX). São Paulo: Alameda.

_ (2012) - De princesa a rainha-velha. Leonor de Lencastre. [Lisboa]: Círculo de Leitores. (Rainhas de Portugal, VIII).

SANTOS, Cândido dos (1996) - Os Jerónimos em Portugal - Das origens aos fins do século XVII. Porto: Junta Nacional para a Investigação Científica e Tecnológica.

SANTOS, Eugénio Francisco dos (1982) - O Oratório no norte de Portugal - Contribuição para o estudo da história religiosa e social. Porto: Instituto Nacional de Investigação Científica. 
_ (2001) - Oratorianos. In AZEVEDO, Carlos Moreira, ed. - Dicionário de História Religiosa de Portugal, J-P. [Lisboa]: Círculo de Leitores, CEHR-UCP.

SARTORELLI, Pierluigi, Arcebispo Dom (1988) - Gabrielle Condulmer. Lume e ornamento della Chiesa. Roma: Città del Vaticano.

SCOTT, Tom (1998) - Germany and the Empire. In ALLMAND, Christopher, ed. - The New Cambridge Medieval History: VII c.1415-c.1500. Cambrigde: Cambridge University Press.

SCULLY, Vincent (1912) - Blessed John Ruysbroeck. In The Catholic Encyclopedia. Nova Iorque: Robert Appleton Company.

SESA, Rafael Sánchez (2006) - El Cisma de Occidente en la Península Ibérica: religión y propaganda en la guerra castellano-portuguesa. In Estudos em homenagem ao Professor Doutor José Marques. Porto: Faculdade de Letras da Universidade do Porto, vol. IV.

SILVA, António Martins da (2000) - Extinção das Ordens Religiosas. In AZEVEDO, Carlos Moreira, ed. - Dicionário de História Religiosa de Portugal, C-I. [Lisboa]: Círculo de Leitores, CEHR-UCP.

SILVA, Célia Taborda da (1993) - O Mosteiro de Ganfei - Propriedade, produção e rendas no Antigo Regime (1629-1683 e 1716-1822). Porto: Faculdade de Letras da Universidade do Porto. Dissertação de mestrado.

SILVA, Elsa Branco da (2006) - A Fortuna da «Vita Christi» no Medievo em Portugal: Pensar a espiritualidade à luz da tradição. Coimbra: Alma Azul.

SMITH, Aloysius (1953) - Chanoines réguliers. In BAUMGARTNER Charles, ed. - Dictionnaire de Spiritualité. SJ, col. 463 a 477. Paris: Gabriel Beauchesne et ses fils.

SOBRAL, Cristina (1997) - Um autor ignorado e a recepção da hagiografia no século XV. In O Género do Texto Medieval, ed. Cristina de Almeida Ribeiro e Margarida Madureira. Lisboa: Edições Cosmos, p. 271-281.

(2003a) - Decifrando o «Memorial» de Paulo de Portalegre. In Da decifração em textos medievais. Actas do IV Colóquio da secção portuguesa da associação hispânica de literatura medieval. Lisboa: edições Colibri, p. 163-178.

(2003b) - Os Lóios e os livros no séc. XV. «Românica. Revista de Literatura do Departamento de Literaturas Românicas da FLUL». Lisboa: Edições Colibri, p. 167-187.

SOUSA, Bernardo Vasconcelos, dir. (2005) - Ordens Religiosas em Portugal: das Origens a Trento: Guia Histórico. Lisboa: Livros Horizonte.

SOUSA, Ivo Carneiro de (1982) - Legados Pios do Convento de S. Francisco do Porto. As fundações de missas nos séculos XV e XVI. Porto: Arquivo Distrital do Porto. Separata do Boletim do Arquivo Distrital do Porto.

— (2002) - A Rainha D. Leonor (1458-1525). Poder, misericórdia e espiritualidade no Portugal do Renascimento. Lisboa: Fundação Calouste Gulbenkian/FCT.

SOVERAL, Manuel Abranches de (2004) - Os filhos e netos do «muj honrrado barom» Dom Frei Lopo Dias de Souza 8. ${ }^{\circ}$ mestre da Ordem de Cristo [visitado a 19-12-2015]. Disponível em <http://www.soveral.info/mas/SouzaArronches.htm.>

STIEBER, Joachim W. (1978) - Pope Eugenius IV the Council of Basel and the Secular and Ecclesiastical Authorities in the Empire. Leiden: E. J. Brill.

STUMP, Phillip (1994) - The reforms of the Council of Constance (1414-1418). Leiden: E. J. Brill.

_ (2009) - The Council of Constance (1414-18) and the end of the schism. In ROLLO-KOSTER, Joëlle, ed. - A companion to the Great Western Schism (1378-1417). Leiden: E. J. Brill.

TABACCHI, Stefano (2001) - Paolo Giustinian. In Dizionario Biografico degli Italiani. Roma: Istituto dell'Enciclopedia Italiana.

TASSI, Ildefonso, OSB (1948) - Un collaboratore dell'opera riformatrice di Eugenio IV: Giovanni de Primis. «Benedictinas», n. ${ }^{\circ}$ 2. Roma: [s.e.]. _ (1952) - Ludovico Barbo (1381-1433). Roma: Edizione di Storia e Letteratura.

TAVARES, Maria José Ferro (2000) - Assistência. I. Época Medieval. In AZEVEDO, Carlos Moreira, ed. - Dicionário de História Religiosa de Portugal. A-C. [Lisboa]: Círculo de Leitores, CEHR-UCP.

TAVARES, Pedro Vilas-Boas (1984) - Algumas notas sobre o «Catecismo Peninsular» no século XVI. De Constantino a Frei Pedro de Santa Maria. «Línguas e Literaturas: Revista da FLUP», série II, n. ${ }^{\circ}$ 1. Porto: Faculdade de Letras da Universidade do Porto.

(1986) - Os Lóios e a reforma religiosa nos meados do séc. XVI. A «Ordem e Regimento de vida cristã» de Pedro de Santa Maria (1555). Porto: Faculdade de Letras da Universidade do Porto. Síntese de provas de aptidão pedagógica e capacidade científica.

(1988) - Pedro de Santa Maria e o «Modus Orandi» de Frei Luís de Granada. Sugestões e hipóteses de uma aproximação. In Colóquio Comemorativo do IV Centenário da morte de Frei Luís de Granada: actas. Lisboa: Associção dos Arqueólogos Portugueses/Edições Távola Redonda. 
(1989) - Participação dos Lóios nas primeiras «missões» africanas. In Actas do Congresso Internacional Bartolomeu Dias e a sua Época, Porto 1988. Porto: Universidade do Porto/Comissão Nacional para as Comemorações dos Descobrimentos Portugueses.

- (1991) - A fundação e construção da Igreja e Convento da Congregação de S. João Evangelista de Vila da Feira (Breves apontamentos de arquivo). In «Humanistica e Teologia», n. ${ }^{\circ}$ 12. Porto: Faculdade de Teologia da Universidade Católica Portuguesa no Porto.

(1999) - Para uma revisitação dos cónegos Lóios. Porto: [s.n.].

— (2001a) - Lóios. In AZEVEDO, Carlos Moreira, ed. - Dicionário de História Religiosa de Portugal. [Lisboa]: Círculo de Leitores.

(2001b) - Jorge de S. Paulo (C.S.J.E.) e o seu Epílogo e Compêndio de Memórias: Traços de um padrão contra o esquecimento. In CARVALHO, José Adriano de Freitas, ed. - Quando os frades faziam história: de Marcos de Lisboa a Simão de Vasconcelos. Porto: Centro Interuniversitário de História da Espiritualidade.

—_ (2001c) - Legislação Capitular da Congregação de S. João Evangelista (séculos XV-XVI). In Estudos em homenagem a João Francisco Marques. Porto: Faculdade de Letras da Universidade do Porto.

_ (2003) - Em busca das virtudes primordiais do «Estado Apostólico»: os fundadores Lóios nas «Memórias» de Paulo de Portalegre ( $†$ 1510). «Línguas e Literaturas: Revista da Faculdade de Letras», série II, n. 20. Porto: Faculdade de Letras da Universidade do Porto.

(2008) - Espiritualidade e disposições perante a morte em Santa Maria da Feira: Capelas, legados e bens d'alma na matriz de S. Nicolau durante o Antigo Regime». «Via Spiritus. Revista de história da espiritualidade e do sentimento religioso». Porto: Centro Interuniversitário de História da Espiritualidade da Universidade do Porto, p. 195-248.

(2009) - Os Lóios em Terras de Santa Maria: do Convento da Feira à realidade nacional da congregação. Santa Maria da Feira: Município de Santa Maria da Feira.

TEIXEIRA, Vitor Gomes (2004) - O movimento da observância franciscana em Portugal (1392-1517): História, cultura e património de uma experiência de Reforma Religiosa. Porto: Faculdade de Letras da Universidade do Porto. Tese de Doutoramento.

THESEIDER, Eugenio Dupré (1979) - Caterina da Siena, Santa. In Dizionario Biografico degli Italiani. Roma: Istituto dell'Enciclopedia Italiana.

THURSTON, Herbert (1907) - Agnus Dei. In The Catholic Encyclopedia. Nova Iorque: Robert Appleton Company.

TOCH, Michael (2006) - Welfs, Hohenstaufen and Habsburgs. In ABULAFIA, David, ed. - The New Cambridge Medieval History: Vc.1198-c.1300. Cambridge: Cambridge University Press.

TRAMONTIN, Silvio (1956) - S. Lorenzo Giustiniani nella arte e nel culto della Serenissima, Collana Laurentiana. Veneza: Studium Cattolico Veneziano.

(1975) - Canonici Seculari di S. Giorgio in Alga. In PELLICCIA, Guerrino e ROCCA, Giancarlo, dir. - Dizionario degli Instituti di Perfezione, col. 154-158. Roma: Edizione Paoline.

(1984) - Ludovico Barbo e la riforma di S. Giorgio in Alga. In TROLESE, Giovanni Francesco, OSB, dir. - Riforma della Chiesa, Cultura e Spiritualità nel Quattrocento Veneto. Atti del convegno per il VI centenario della nascita di Ludovico Barbo (1382-1443). Cesena: Centro Storico Beneditino Italiano.

TROLESE, Giovanni Francesco, OSB (1984b) - Ricerche sui primordi della riforma di Ludovico Barbo». In TROLESE, Giovanni Francesco, OSB, dir. - Riforma della Chiesa, Cultura e Spiritualità nel Quattrocento Veneto. Atti del convegno per il VI centenario della nascita di Ludovico Barbo (1382-1443). Cesena: Centro Storico Beneditino Italiano.

__org. (1984a) - Riforma della Chiesa, Cultura e Spiritualità nel Quattrocento Veneto. Atti del convegno per il VI centenario della nascita di Ludovico Barbo (1382-1443). Cesena: Centro Storico Beneditino Italiano.

TUGWELL, Simon, OP (1996) - São Domingos. Estrasburgo: Éditions du Signe.

UGINET, François-Charles (1983) - Antonio Correr. In Dizionario Biografico degli Italiani. Roma: Istituto dell'Enciclopedia Italiana.

VALERI, Nino (1969) - L'Italia nell'età dei principati. Dal 1343 al 1516. Verona: Arnoldo Mondadori Editore, 1949.

VARANINI, Gian Maria (1997) - Le sfide esterne: Venezia e l'entroterra (1300 circa - 1420) In Storia di Venezia: La formazione dello stato patrizio. Roma: Istituto dell'Enciclopedia Italiana.

VARGAS, Michael (2012) - Administrative change in the fourteenth-century Dominican Order. A case study in partial reforms and incomplete theories. In BELLITO, Christopher; FLANAGIN, David Zachariah, ed. - Reassessing Reform. A historical investigation into Church renewal. Washington: The Catholic University of America Press.

VAUCHEZ, André (1985) - La espiritualidad del occidente medieval (siglos VIII-XII). Madrid: Ediciones Cátedra.

VEDOVA, Giuseppe (1836) - Biografia degli Scritori Padovani. Pádua: Tipografia Minerva, vol. II. 
VEERMEERSCH, Arthur (1911) - Religious Profession. In The Catholic Encyclopedia. Nova Iorque: Robert Appleton Company.

(1912) - Vows. In The Catholic Encyclopedia. Nova Iorque: Robert Appleton Company.

VENARD, Marc (1994) - Le Concile Latran V (1512-1517) et le Concile de Trente (1545-1563). In ALBERIGO, Giuseppe, ed. - Les Conciles Oecuméniques. L'Histoire. Paris: Les Éditions du Cerf.

VENTURA, Margarida Garcez (1997) - Igreja e Poder no séc. XV. Dinastia de Avis e Liberdades Eclesiásticas (1383-1485). Lisboa: Edições Colibri.

VIEIRA, Alberto (2000) - Funchal. In AZEVEDO, Carlos Moreira, ed. - Dicionário de História Religiosa de Portugal. C-I. [Lisboa]: Círculo de Leitores, CEHR-UCP.

VIGUEUR, Jean-Claude Maire (1982) - Cola di Rienzo. In Dizionario Biografico degli Italiani. Roma: Istituto dell'Enciclopedia Italiana.

VINHAS, Joaquim Alves (1998) - A igreja e o convento de Vilar de Frades: das origens da congregação dos cónegos seculares de São João Evangelista (Lóios) à extinção do convento. 1425-1834. Barcelos: Câmara Municipal de Barcelos.

WALSH, Katherina (1989) - Raimondo della Vigna. In Dizionario Biografico degli Italiani. Roma: Istituto dell'Enciclopedia Italiana.

WATANABE, Morimichi (2008) - Pope Eugenius IV, the Conciliar Movement, and the Primacy of Rome. In CHRISTIANSON, Gerald; IZBICKY, Thomas; BELLITO Christopher, ed. - The Church, the Councils and Reform. The legacy of the fifteenth century. Washington: The Catholic University of America Press.

WATRIGANT, Henry, SJ (1919) - Quelques Promoteurs de la Méditattion Méthodique au Quinzième siècle. Paris: Librairie P. Lethielleux. (Collection de la Bibliothèque des Exercices de saint Ignace, LIX).

WATT, J. A. (2006) - The Papacy. In ABULAFIA, Davida, ed. - The New Cambridge Medieval History: V c.1198-c.1300. Cambrigde: Cambridge University Press.

WINROTH, Anders (2012) - The legal underpinnings. In RUBIN, Miri; SIMONS, Walter, ed. - The Cambridge History of Christianity Christianity in Western Europe c.1100-c.1500. Cambridge: Cambridge University Press.

WITTERS, Willibrord (1984) - La legislazione monastica della Congregazione di S. Giustina nei suoi primordi (1419-1427). In TROLESE, Giovanni Francesco, OSB, dir. - Riforma della Chiesa, Cultura e Spiritualità nel Quattrocento Veneto. Atti del convegno per il VI centenario della nascita di Ludovico Barbo (1382-1443). Cesena: Centro Storico Beneditino Italiano.

ZAFARANA, Zelina (1964) - Bartolomeo da Roma. In Dizionario Biografico degli Italiani. Roma: Istituto dell'Enciclopedia Italiana.

ZUTSHI, Patrick (2000) - The Avignon papacy. In JONES, Michael, ed. - The New Cambridge Medieval History: VI c.1300-c.1415. Cambridge: Cambridge University Press. 
ANEXOS 


\section{ANEXO DOCUMENTAL}

Documento 1 - ADB - Monástico, Lóios, Mosteiro de Vilar de Frades, lv. 12, fl. 107.

Braga, 1425/02/28 - Carta do Arcebispo de Braga D. Fernando da Guerra de redução do mosteiro de S. Salvador de Vilar de Frades a igreja secular e sua entrega a Mestre João [Vicente]

«Dom Fernando per merce de Deos e da Santa Egreja de Roma Arcebispo de Bragaa e Primas. A quantos esta carta de reduçom e transfundaçom virem fazemos saber que visitando nos pessoalmente o moesteiro de Sam Salvador de Villar de Frades da hordem de Sam Beento do nosso arcebispado segundo a nosso ofiçio pastoral pertence, estando hy presentes o capellam e fregueses da capella do dicto moesteiro e outras muitas pessoas assi ecclesiasticas como seculares achamos que o dicto moesteiro ao presente era vago per morte d'Estevam Lourenço que delle foi poestumeiro abbade. E que outrossi em elle nom avia convento de monjes regulares conventuaaes avia bem trinta annos por quanto achamos per enquereçom que sobre ello tomamos per as dictas pessoas que as rendas do dicto moesteiro eram tam tenues e pequenas por o dicto moesteiro nom teer tantas nem taaes possesooes e daquellas poucas que avia eram hermas despovoadas e destruidas e dapnificadas per mingua de lavradores que hy nom avia pollas grandes pestellencias e guerras que em este regno foram e por que o dicto moesteiro pagava cada huum anno a nos e ao nosso cabidoo dos nossos e seos directos grandes encarregos em tancto que elles pagados por as dictas rendas do dicto moesteiro serem assi exulles e pequenas ficava tam pouco que se nom poderia manter convento de $<$ nom $>$ mendicante de nenhuma Ordem que fosse [...] penuria grande. E que o dicto abbade que ora delle fora per aquelle assi moesteiro vago vivera em elle muito pobremente sem tendo alguum monje por a grande pobreza do dicto moesteiro. E nós vista a pobreza delle e como per a rendas que ora ha se nom podia manter observancia regular, querendo que nom fosse defraudado do oficio divino que se em elle devia fazer por as almas daquelles que o fezerom e dotarom avendo sobre ello primeiramente conselho e trauctado com nosso cabidoo pera o que se adiante segue de seu acordo e conselho et de suo consensu ac sensu de nosso oficio pastorall auctoridade ordinaria reduzimos e fazemos do dicto moesteiro beneficio e egreja secular sem cura per o melhor modo e via que o com dicto podemos fazer. E porque em a freguesia da dicta egreja nom ha fregueses alguuns a que devam seer dados os ecclesiasticos sacramentos, ficando reguardados a nos e aa dicta nossa Egreja de Bragaa e ao dicto nosso cabidoo com nossos e seus directos que sempre ouvemos e avemos d'aver em cada huum anno per a dicta egreja que daqui em diante as ajamos per ella e per suas rendas livremente assi como ante desto aviamos sem outro algum embargo nem contradiçom que seja. E fecto assi per nos este auto como dicto he, veendo nos logo e consirando serviço de Deos e polla honrra da dicta egreja, e como Mestre Johane que presente estava era clerigo de missa e boo pregador e de boa e honesta vida e conversaçom e tall do quall e pello qual a dicta egreja loudabilitem seria servida e honrada no spiritual e o oficio divino seria em ella per elle acrecentado e nom minguado e outrosi a dicta egreja seria reparada e procurada no temporal segundo a ella compria, vistas e consiradas per nos todas estas razoens suso scriptas conferemos e provemos da dicta egreja sem cura ao dicto mestre Johane per emposiçam de nosso barrete que lhe posemos em sua cabeça e lhe cometemos o regimento no spiritual e temporal. E elle mestre Johane jurou aos Sanctos Avangelhos per suas maãos corporalmente tanjidos que a nos dicto arcebispo e a todos nossos socesores canonicamente instituitos pera sempre obediente e humildoso segundo deve e que nom sera em conselho nem em fecto ou assentamento que percamos a vida membro ou honrra, [...] alguum contra nos ou contra nosso estado alguum maao conselho e desejo conpeçar, logo per si se poder, ou per seu moesteiro nolo fara saber. E que a nos e aa dicta nossa Egreja de Bragaa sera fieel em todallas cousas. E as nossas dictas ordinárias e arcebispaaes e prometidos per a nossa clerezia pagara segundo os directos querem. $\mathrm{E}$ as dizimas de todallas terras que lavrar que sejam da dicta sua 
egreja enteiramente pagara a nos e aa dicta nossa Egreja de Bragaa e que os beens della nom alheara nem emprazara dem dara em teença nem em penhora nem as vendera nem arrendara ataam que sejam colheitos e ajuntados nos celeiros e adegas sem nossa licença e da dicta nossa Egreja de Bragaa. Mais as cousas que forem envalhoadas com todo seu poder e voontade as demandaram e tornara aa propriedade e direito da dicta egreja. E os nossos messenjeiros ou messenjeyro begninamente [sic] recebera em indo e vindo per sua egreja e que em ella fara residençia pessoal, senom for escusado per nos ou per nossos antecessores. E se for chamado per nossas leteras ou de nossos vigarios em lugares vizinhos e convinhavees ou per o dicto pera virem a nosso signodo ou kalendayro verra. E os nossos mandados e constituiçooes sinodaaes e da dicta nossa Egreja guardara e comprira. Porem mandamos a todollos fregueeses e caseeros da dicta egreja e a todollos outros que lhe obligados em alguma cousa forem, em virtude da santa obediencia e so[b]'pena d'escomunhom a qual em elles e cada huum poemos em estes scriptos se o contrairo fezerem, dandolhe pera ello tres dias de canonica amoestaçom se nom obedeçades inteiramente ao dicto mestre Johane vosso abbade verdadeiro e rettor com todollos directos dízimos e primiciaas foros e ofertas que a dicta egreja pertencerem, e os outros façaaes responder quanto com direito poderdes. E as sentenças que elle justamente der contra os reuees, nos as averemos por firmes e valedoyras polos directos da dicta sua egreja, e porem nós sobredicto senhor arcebispo, as faremos com ajuda de Deos guardar sem nenhum impiguamento ataa verdadeyra satisfacom. E per esta presente carta mandamos a quallquer clérigo ou religioso do dicto nosso arcebispado a que esta carta for mostrada em virtude de obediencia, e so[b] a dicta penna d'escomunhom que pessoalmente chegue aa dicta egreja sem cura e ponha em corporal possessom della o dicto mestre Johane ou seu dicto procurador com todollos seus directos e pertenças silicet per pedra terra telha altar livros calezes chaves vestimentas e per outros quaaesquer ornamentos e beens da dicta egreja sem cura segundo he de custume. E desque della for em posse ajudadooa manter em ella mandando da nossa parte e da dicta nossa Egreja de Bragaa aos sobredictos caseeiros e fregueses da dicta egreja sem cura que o ajam por seu verdadeiro abbade e reitor como dicto he, e lhe respondam bem e compridamente com as sobre dictas dizimas e primícias e foros rendas e directos que forem theudos dar e pagar aa dicta egreja, costrangendo os reuees e embargantes per censura ecclesiastica chamado pera ello da nossa parte e da dicta nossa Egreja de Bragaa ajuda de braço sagrall se comprir. E lhe façam fazer enventairo de todollos ornamentos e beens que assi em a dicta egreja sem cura forem achados. E em testemunho desto mandamos [...] fecta esta carta sygnada per nossa maão e sellada de nosso sello. Data em Bragaa vinte e oito dias do mes de fevereiro Bras Afonso a fez. Era do naçimento de de Nosso Senhor Ihesus Chrispto de mil IIIIc vinte e cinquo annos.

\section{[ASS]: F[ERDI]NA[N]DOS ARCHI[E]P[ISCOPU]S»}

Lugar do selo pendente, que falta.

Documento 2 - ADB - Monástico, Lóios, Mosteiro de Vilar de Frades, lv. 12, fl. 181.

Braga, 1439/05/01 - Carta do Arcebispo de Braga D. Fernando da Guerra concedendo aos cónegos de S. Salvador de Vilar de Frades licença para pregarem, e ao prior João de Arruda e seus sucessores comete os casos pontificais que lhe estão reservados, enquanto for de sua vontade.

«Dom Fernando per mercee de Deus e da Sancta Igreja de Roma Arcebispo de Bragaa e primas. A quantos esta nossa carta virem fazemos saber que o prior e coonigos da nossa egreja collegiada de Villar de frades nos disseram que por serviço de Deus elles entendiam preegar per nosso arcebispado, por edificaçom e salvaçom das almas do povoo, e que se temia que alguuns de nosso arcebispado lhes fazerem sobresto alguum embargo, por algumas 
nossas defesas que dizem que teem, ou por outra alguma razom, pidindinos que lhes dessemos pera ello licença e auctoridade $<$ a qualquer pessoa $>$ do dicto collegio que preegar saiba, que livremente e sem embargo de quaeesquer nossas defesas possam pregar per todo nosso arcebispado. E mandamos a todollos dom abbades e priores e beneficiados que os recebam begninamente sem [...] fezendo alguma sem razom. Outrossy confiado de Joham d'Arruuda prior que ora he do dicto collegio, e de quallquer outro que prior hi for, nos lhe cometemos nossos casos pontificaaes a nos em direito reservados, em quanto nossa mercee for. E porem lhe mandamos dar esta carta signada per nossa maão e seellada do nosso seello. Nom seja duvida hu diz a qualquer pessoa, porque assi ha de dizer. Data em Bragaa primeiro dia de Mayo, Bras Afonso a fez, anno do nasçimento de Nosso Senhor Ihesus Chrispto de mil IIII' XXXIX.

\section{[ASS]: F[ERDI]NA[N]DOS ARCHI[E]P[ISCOPU]S»}

No verso está o lugar do selo, de que só restam vestígios.

Documento 3 - ANTT - Mosteiro de S. João Evangelista de Xabregas, mç. 17, doc. 7.

Lisboa, 1452/02/05 — Excerto de cédula testamentária da rainha D. Isabel, mulher de D. Afonso V, em que determina a instituição de um mosteiro Lóio em honra de S. João Evangelista, onde manda sepultar as ossadas de seu pai, e ao qual faz algumas doações. Documento a partir do original conservado na Torre do Tombo, por treslado datado de 1769/11/02.

«[ $^{[3]}$ E porem eu Dona Izabel por graça de Deos Rainha de Portugal etc. em minha saude, e em aquelle entendimento que recebi do Senhor Deos, faço esta cedola de testamento na qual escrevo minha postumeira vontade atté o dia da sua feitura, e me pras que seja firme e dure, em quanto por outra parte, ou en todo nom for mudada. Primeiramente encomendo a minha Alma ao senhor Deos pedindo-lhe umildozamente que por merecimentos de sua amorosa encarnação e de sua dorida paixão e mui gloriosa Resurreicão, e por rogos e merecimentos da Bem aventurada //[3v.] Virgem Maria sua Madre e de Sam João Evangelista e de todolos Anjos e Santos e Santas ao postumeiro dia de minha morte a mandem receber em sua santa gloria onde viva em porduravel folgança amem. Item mando em quanto he a minha sepultura facasse como El Rey meu Senhor mandar, ou na Batalha ou no Moesteiro que mando fazer de São João segundo se mais compridamente a fundo declarará. Item peço por merce a El Rey meu Senhor que aquelas dividas que forem certo que eu devo mande pagar, e por ventura nom quizer que o mande descontar dos vinte e oito mil escudos de que me fes merce segundo se mostrara por o contracto. Item o que ficar destes vinte e oito mil escudos pagadas as dividas se as El Rey meu $/ /^{[4]}$ senhor nom quizer pagar que lhe pesso por merce que lhe apraza de fazer o Moesteiro de Sam João da Hordem dos de Santo [E]loy, certe se faça aqui em Santo [E]loy ou em Sam Bento de Emxabregas onde milhor parecer a El Rey meu Senhor, com concelho de Dom João Bispo de Vizeu e de Alvaro Gonçalves meu capelão mor e comfessor, aos quaes leixo cargo desolheitarem e requererem todas estas couzas a que elle der ordem segundo minha vontade. Neste moesteiro sera sepultado ha ossada do Senhor Infante meu Padre cuja alma Deos haja asy honradamente como pertence a huma tal pessoa como elle he. E estas duas pessoas tenhão carrego de ordenarem em que maneira seja, e se por ventura El Rey meu //[4v.] senhor nom quizer que se aly faça, ordene algum lugar ou Moesteiro onde se ponha secreto que seja onesto e bem pertencente para elle. [...] [5v.] Item se faça huma crus douro meaã bem obrada p[ar]a se poerem em ella toda a Vera Crus que tenho e emcastoarem nella os robins que tenho soltos e as esmeraldas que sam por todos vinte e quatro, e esta crus seja oferecida neste moesteiro que mando fazer e mais lhe dou todaslas outras minhas reliquias e hum dos meus missaes e o meu brebiario novo, e o dos livros dos auttos dos Apostolos, e dos Evangelhos, e os vestidos que me forem achados de 
pano douro e de sirgo facão em vestimentas para elle, e com esyas couzas nom será bolido em nenhuma maneira senom dados asy e o mando. $[. . .]^{[6]}$ Feito em Lisboa a sinco dias de fevereiro de mil e quatro centos sincoenta e dois.»

Documento 5 - ANTT - Hospital de São José, lv. 940, fl. 147.

Lisboa, 1530/03/08 — Treslado da provisão de D. João III, dirigida ao Geral dos Lóios, determinando a entrega da administração do Hospital Real de Todos-os-Santos à administração à Congegação de S. João Evangelista.

« ${ }^{[147]}$ Treslado da provisam porque el Rei nosso senhor mandou emtergar este espritall aos padres de Samto Eloy.

Padre Reitor da Comgregagaçam de Sam Joam Avamgelista e padres da dita Comgregaçam. Por ter sabido que os doemtes que se tomam no espritall de Todolos Samtos desta minha cidade de Lisboa nom sam curados com aquela caridade e limpeza que se requer para remedio de suas emfermidades, o que daa causa a emfermidade e maa desposissam do provedor pollo qual respeito elle nom pode niso olhar nem prover como fizera se fora milhor desposto. Assy por isso como por outras causas justas que me a isso movem e principalmente por saber que semdo o dito espital em mão vossa seria asy regido e guovernado como a serviço de Deus e meu compre e a boa cura dos ditos doemtes he necessário, ey por bem e me praz que sa feitura deste emdiamte em quoamto nom mandar o contrario essa Comgreguaçam tenha a guovernamça e reguimento do dito espritall e por tamto vos emcomendo muito assy a vos como aos outros Reitores que apos vos na dita Comgregaçam forem e padres della que por serviço de Deus queiraes tomar e açeptar a dita governamça e em voso capitollo com os padres de Samto'loy da dita cidade e de Sam Joam que esta jumto della ordeneis e nomeys os padres que virdes que sam necessários para guovernarem e ministrarem ho dito espritall, e os ponhais loguo nomeando hum que seja soprior dos que no dito espritall ouverem d'estar e a que os outros obedeçam. E agardecervos(sic) hei muito assy a vos como aos padres da dita comgregaçam que na enleuçam dos ditos padres sempre tenhais respeito aos mais caridoos e que souberdes que com toda caridade e amor curaram os ditos doemtes e amenistraram a dita casa como compre a serviço de Deus e meu e a bem della.

E este que assy ordenardes per soprior dos outros terá todos o carreguo que ate ora teve o provedor do dito espritall assy no que toqua ha arrecadaçam de suas remdas e aforamentos $/ /^{[147 \mathrm{v} .]}$ de suas eramças como cura dos doemtes e despesa da casa e todo ho mais que a guovernamça dela comprir com tall limitação que nam ha de fazer cousa alguma sem conselho e comsemtimento dos companheiros que lhe foren dados. E asy elle como os ditos companheiros que no dito espritall ouverem d'estar guoardaram acerqua da guovernança delle os reguimemtos e provisoens que acerqua disso sam dadas a dita casa per el Rei meu senhor e padre que samta gloria ajaa e per mim. E no em que teverem duvida e segundo a calidade de seu viver nom poderem comprir mo faram saber pera eu o prover como me bem parecer.

E porem no que toquar aos aforamentos ds eranças e propriedades do dito espritall despois de amdarem em pregam os dias decrarados no dito regimento e se guoardarem as outras solenidades que se requerem nom se arremataram sem vos dito Reitor Gerall ou os que pollos tempos forem serdes presemte e asy o reitor do moesteiro de Samto'loy ou ao menos hum de vos quando ambos nom poderdes ser presentes pera verdes os preguões que se lançaram e lanços que se fizeram e proverdes com o padre que no dito espritall ouver d'estar por soprior, e se guoardarão todas as outras solenidades e como se todo faça assy bem e verdadeiramente como se deve fazer.

E por que vos tendo jaa nomeados o padre Joam de Samt'amtonio por soprior do dito espritall e a Pero de San Migell e Luis de Samta Maria e Joam de Samtyaguo e Pero da Comsolaçam e Bernardo de Samta Maria por companheiros seus, eu ey por bem que a todos seja loguo emtrege a dita casa com todolas cousas que nela estam 
pera a guovernarem e menistrarem segundo virem que compre a serviço de Deus e guoardamdo os regimemto segundo acima he decrarado, aos quais e a cada huum delles e principallmente ao dito soprior emcomendo muito asy a elles como aos outros que ha ho diante na dira casa forem postos que queiram haceptar a dita guovernança e o façam asy bem $/ /^{[148]}$ e como se deles espera. E logo tanto que no dito espritall forem espidiram todolos oficiaees delle que lhe nom parecerem necessarios aos quoaees mando que loguo tanto que pello dito Joam de Samt'antonio lhes for dito e mandado que se sayam do dito espritall se vam loguo dele e cumpram inteiramente seu modo. e assy se sahiran todas as outras pessoas que das postas ademtro do dito espritall estiverem apousentadas a que ho dito padre disser que se sayam, nom daram mais ninhuma reçam a ninhuma pessoa das a que se ate aqui no dito espritall deram sem embarguo de quoaes alvarães e provisões minhas que tenham, salvo aos que aos ditos padres parecer que devem ficar por serem necessarios pera serviço da casa. E a estes que asy ficarem lhe seja dado reçam de mantimento ou em dinheiro ou comer em refeitouro segundo forem as calidades das pessoas e aos ditos padres milhor parecer.

E porem mando a todos os oficiaes do dito espritall e servidores e pessoas outras que nele ouverem de ficar que obedeçam ao dito Joam de Samt'amtonio soprior dos outros e asy aos outros sopriores que pollos tempos per essa comgregaçam forem dados a dita casa em todo o que a guovernança dela comprir e toquar assy e da maneira que obedeciam aos provedores que dele foram porque per este lhes dou os mesmos poderes que os ditos proveadores teveran.

E emcomendo a vos dito Reitor jerall e aos outros reitores que pellos tempos forem que em casa huum anno vesyteis o dito espritall no esprituall e temporal asy como fazeis as casas da dita comgregaçam e sem embarguo de vos asy per este cometer a dita amenistraçam governamça e regimento do dito espritall ficara a mim a superioridade de todo pera nisso emtender ou mandar emtender como me parecer bem. E esta minha provisam mandareis tresladar no livro do dito espritall e dar o trelado della aodito Joam de Samt'Amtonio e a vos outros sopriores que ha dita casa ouve dos de emviar assinada per vos dito reitor geral lho qual trelado mando que se cumpra como e propio, e este propio estara no cartorio do dyto mosteiro de Samta'loy o qual quero e me praz que valha e tenha tamta força e vigor como carta passada per minha escritura e posto que este nom pase per ella sem embarguo de minhas hordenações que mandam o contrairo e sem embarguo da ordenaçam que manda que se nom ajaa por derrogada ninhuma ordenaçam se da sustançia della nom fizer expressa mençam. Andre Pirez a fez em Lixboa a oyto dias de março de $\bar{I} V^{c} X X X$.

A quall provisam foy apresentada neste espritall pellos ditos soprior e padres aos X dias de Março de VcXXX e foi lhe dada a posse de toda a casa per Martim de Crasto escripvam que vai assentada nas costas da dita provisam de que aquy fyca o trelado coerçetado per mim Diogo Lobo escripvão e a propr[i]a foy dada ao reitor gerall.

\section{[ASS]: DIOGO LOBO»}

Documento 6 - ANTT - Cónegos de S. João Evangelista, Hospital de S. João de Portel, lv. 1, fl. 25.

Lisboa, 1541/05/12 — Carta do Duque de Bragança D. Teodósio ao capítulo geral dos Lóios em que demonstra o desejo que o hospital da sua vila de Portel seja administrado pela Congregação.

« ${ }^{[25]}$ Muito devotos e virtuosos geral e padres. Na minha villa de Portel há hum Esprital de onesta remda segumdo a calidade do luguar, o qual eu muito desejo que seja governado e regido por padres dessa vosa Casa de Sam Joam asy como o he o Esprital da Villa de Arraiolos e o sam outros Espritaes neste reino, porque da maneira 
que ele agora amda hei que nam se faz nisso muyto serviço a Nosso Senhor, como se faria semdo regido por padres dessa vosa Hordem. E porque a dita villa estaa dessa cidade seis legoas posto que seja alguum trabalho em hirem padres dela a prover no que comprir ao dito Esprital e governo dele, asi se fará nisso muito serviço a Nosso Senhor porque as remdas dele seram milhor aproveitadas e amdara tudo em boa hordem e se farama dellas esmolas mais aceitas a Deus como de tam virtuosos religiosos se espera polo que vos peço por caridade queiraes neste capitolo que aguora fazeis comonicar isto e aceitar o que aqui bos peço por serviço de Nosso Senhor e pera menos trabalho podeis ordenar e enleger huum padre ou dous nesa Casa a que deis o cuidado do governo do dito Esprital nam pera que estem continos se nam pera que tres ou quatro ou cinquo vezes no anno vão prover nelle como vos parecer que milhor se podera fazer pera as remdas se arrecadarem e despemderem no necessareo comforme aa hordem que tem no Esprital d'Arraiolos. E alem desto ser como diguo obra de serviço de Deus levarei eu disso muito contemtamento e prazer, e vos roguo que o que nesto determinardes de fazer mo escrevaes pera que aceitamdo vos isto como espero vos mandar as provisões necessareas e se dar hordem a como se faça . Nosso Senhor vossas muito devotas e vertuosas pessoas aja em sua spicial guarda. De Lixboa a XII de Maio de 1541.

\section{[ASS] HO DUQUE}

Pera o geral e padres da ordem de Santo Eloy no Capitolo de Sam Joam d'Evora sobre o Esprital de Portel.»

Documento 7 - ANTT - Cónegos de S. João Evangelista, Hospital de S. João de Portel, lv. 1, fl. 11.

Lisboa, 1541/08/22 - Carta do Duque de Bragança aos juiz e oficiais da sua Vila de Portel, e do hospital da mesma vila, ordenando que dêem posse do hospital ao reitor dos Lóios de Évora, e que lhe obedeçam na gestão da instituição.

«[11] Eu o Duque de Braguança e de Barcelos etc. faço saber a vos juízes e oficiaes da minha vila de Portel e asy ao juiz e oficiais do Esprital da dita vila ou a quem o conhecimento deste pertemçer que por Eu ho semtir asy por bem e serviço de Nosso Senhor e para que as remdas e beens do dito Esprital da dita villa se arrecadem e despemdam bem e como compre ey por bem que o padre Reitor que hora he do mosteiro de Sam Joham da cidade d'Evora ou qualquer outro que ao diamte o for tenha carguo do Esprital da dira vila de Portel, e de fazer arrecadar e despemder as rendas dele como lhe parecer serviço de Nosso Senhor, e por este mamdo aos ditos oficiais do dito Esprital que o metam delle em posse e lhe obedeçam em tudo o que acerqua do dito Esprotal mandar e asy poderá o dito padre ou quem seu poder tever no dito Esprital tirar e por os oficiaes que lhe bem parecer pelo que pera tudo lhe dou poder e mamdo que asy se cumpra. Feito em Lixboa a XXII dias d'Agosto Fernam Barbosa o fez de 1541.

\section{[ASS] HO DUQUE}

Ey per confirmado o alvará assima na forma delle. Baltasar Roiz o fes em Vila Vicoza a 18 de Janeiro de 631. [ASS] O DUQUE»

Documento 8 - ANTT - Cónegos de S. João Evangelista, Hospital de S. João de Portel, lv. 1, fl. 21.

Lisboa, 1541/11/22 - Alvará do Duque de Bragança aos ouvidor, juízes e oficiais da sua Vila de Portel, em que dá conta da dificuldade do reitor dos Lóios de Évora em tomar posse do hospital da vila como ele determinara, e do mau estado em que este se encontrava, dando ordem que lhe seja dada a posse e que possa alienar cabeças de gado pertença do hospital para prover o mesmo de diversos bens em falta. 
« ${ }^{[21]}$ Eu o Duque de Braguança e de Barcellos, etc. faço saber a vos meu ouvidor e juízes e oficiaees da minha Villa de Portel e a quaisquer outras pessoas da dita villa a que este meu alvará for mostrado e o conhecimento dele pertemcer que eu por o semtir asi por bem e serviço de Nosso Senhor hordenei que os padres de Samto Eloy do mosteiro de Sam Jhoão da cidade d'Evora tivessem carguo do Esprital dessa dita villa e do governo delle e que de sua mão fossem postos os oficiaes e posesem aqueles que o padre que disso carguo tiver vir qye são necessareos, etc. E ora me foi dito que himdo o padre Reitor do dito mosteiro a tomar a posse do dito Esprital pera ordenar as cousas dele conforme a minha provisão que pera isso levava algumas pessoas lhe forão aa mão polo qual não acabara de asemtar as cousas como comprian a serviço de Deus e bem do dito Esprital antes achara tudo muito destruído e danificado e de maneira que hera muito necessareo proverse polo <que > hei por bem e mamdo a vos dito ouvidor e aos juízes e oficiaes que loguo facaes meter em posse do dito Esprital e cousas dele ao dito padre comforme a minha provisão que pera isso lhe tenho passada, e nan lhe vades nem comsimtaes que se vaa comtra isso en cousa alguma. E acerqua do governo e regimento do dito Esprital o dito padre o fara asi e da maneira que se faz nos outros espritaes deste Reino de que padres da dita ordem de Samto Eloy then carguo e asy mamdo a vos dito ouvidor que loguo facaes fazer tombo novo de todas as heramças que a Casa do dito Esprital tiver asi e da maneira que o dito padre volo requerer e ordenar que se faça. E porque outrosy sou emformado que a igreja e casa do dito Esprital them muita necessidade das cousas seguintes $/_{/[21 \mathrm{v}]}$ de huum fromtal e huma vestimenta e de se fazer huma casa pera huum dormitório pera os emfermos por não seren homde sejam curados e perecen aa minguoa e asy de alguuma roupa pera os doentes e peregrinos, e que destas cousas ha gramde falta e sam mui necessareas, e por que a dita casa nan tem ao presemte donde se ysto possa fazer por tudo amdar mal hordenado e desbaratado e porque a dita casa tem aimda algumas cabeças de guado vacum que amtre gramdes e pequenas seram vimte cabeças de muitas que herão das quaes não se acha comta, hei por ben e mamdo que estas ditas vimte cabeças o dito padre as faça loguo vemder e do dinheiro delas mamde fazer as cousas acima decraradas de que ao presente a dita casa them necessidade. E mando que todas estas cousas acima decraradas se cumprão e asy as mais provisões que sobre isto tenho passado aos ditos padres. Que se alguuma pessoa quiser aleguar ou dizer comtra ysto alguuma cousa venhão aleguar e requerer peramte min pera o ouvyr e o prover como me bem parecer. Amtonio Gouvea o fez em Lixboa a XXII de Novembro de mil e quinhentos e coranta e huum annos.

\section{[ASS] HO DUQUE}

Alvara sobre se comprirem as provisões que VS tem passado pera se dar a posse do Esprital de Portel ao padre de Sam Joham d'Evora e sobre se comprirem outras cousas que acima sam decraradas pera VS ver.»

Documento 9 - BPE, Hospital de Portel - Cod. CLXVI/2-42, fl. não numerado.

Vila Viçosa, 1631/01/18 — Carta do Duque de Bragança D. João II (futuro rei D. João IV) ao reitor dos Lóios de Évora.

«He tão antigua a vontade e devação que todos os religiosos desse convento tem as cousas desta Casa, que com muita confiança podem esperar de mim que lhe saberei meresser todas as demonstrações de afeição que me fizerem e em particular fico estimando o que o Padre Bento de São Joze me disse da sua parte e dos mais religiosos ao negocio do hospitaleiro de Portel. Responderei mais devagar. Deos o guarde. Escrita em Vila Vicoza a 18 de Janeiro de 1631.

\section{[ASS]: O DUQUE}

[no verso]: a Miguel da Crus reitor de St. ${ }^{\circ}$ Eloi na Cidade Evora» 


\section{ANEXO DOCUMENTAL A - CARTULÁRIO DE ROMA}

Documento A1 - ANTT - Mosteiro de S. Bento de Xabregas, mç. 15, doc. 8.

Cotado com o treslado da Chancelaria de D. Manuel I da carta original, conservada em ANTT - Corpo Cronológico, I parte, maço 22, doc. 131.

Lisboa, 15/06/? (na versão do Corpo Cronológico data-se a carta de Lisboa a 7/12/1517) — Treslado de carta de D. Manuel I a D. Miguel da Silva, seu embaixador em Roma, sobre a confirmação dos privilégios dos Lóios.

«//1] Carta que el Rey dom Manuel mandou a Roma a dom Migyel que falasse ao Sancto Padre por ha confirmação de nossos privillegios.

Dom Mig<u $>$ ell Nos el Rey vos enviamos muyto saudar. O padre Jeronimo Reitor gerall que hora he da Comgregaçam de Sam Joham Avangellista em estes nossos reynos ao modo da Comgregaçam de Sam Jorge em Allgua de Veneza com os padres e irmãos da dita Comgregaçam nos fezeram emformaçam que a sua regra e ordem de vida fora instytuida por Nosso Senhor Ihesus Chrispto e seus Apostollos segundo que he escrito que era a elles huma avontade e querer e todallas cousas lhe eram communhas e se dava a ca $<\mathrm{da}>$ hum segundo sua necessidade, e per esto modo se nomeava esta Comgregaçam estado apostollicall, do quall estado per muitos tempos fora perdida a memoria delle e finalmente ${ }^{1498}$ hobra do Spiritu Sancto se viera a retromar ${ }^{1499}$ em as partes de Itallia em a Casa de Sam Jorge d'Allga de Veneza per Grabiell Comdallmario que despois foy Papa Eugenio quarto e per Lourenço Justiniano primeiro Patriarca de Veneza na era de Nosso Senhor de mil e quatrocentos e quatro e creçeram e crecem em numero de Casas e pessoas em vida llouvavell e depois aos mill e quatro centos e vinte e cimquo annos de Nosso Senhor em esta provimcia e em nossos reynos foy ynstituida pello reverendo padre mestre Joham que depois foy bispo de Lameguo e finalmente de Viseu dito dom Joham da boa memoria e por dom Afonso Nogeyra que depois foy Arcebispo de Lixboa que trouxe a forma do habito e regra daquelles padres de Itallia com outros padres reverendos e notavens que hordenaram ${ }^{1500}$ esta Comgregaçam ${ }^{1501}$ de Villar de Frades do arcebispado de Bragua creçendo // [1v.] em numero de Casas e de pessoas e de vida llouvavell ${ }^{1502}$ e depois foy allevantada em cabeça desta Comgregaçam Sam Joham Avangellista acerqua desta cidade pello Santo Papa Pio a suplicaçam da Rainha Dona Isabell movida de gram devaçam a honrra do dito bem avemturado Sam Joham per omde esta Comgregaçam se emtitulla e diz da Comgregaçam de Sam Joham Avangellista a qual sempre ate $<0>$ presente foy comfermada ${ }^{1503}$ per previllegios e isemtações dos Samtos Padres de todo domínio e jurdiçam dos hordenarios e em tall posse estava esta Comgregaçam ate ho presemte e per todos hos Reis nossos antessecores suas graças e previllegios e isemções sempre foram comservadas e defemdidas e guardadas e asy por nos por que sem estas graças sobreditas e isemções as Comgregações nom se podem comservar sobre a qual emformaçam do fundamento desta Comgregaçam nos disseram que viera hora aa sua noticia que ho Samto Padre nom semdo bem emformado no comcillio que fez devassou as Comgregações dos rellegiososo sometemdoos aos prellados e à sua jurdiçam, pedindo nos por merçee que nos quisésse-

\footnotetext{
1498 «e finalmente per obra» na versão do Corpo Cronológico.

1499 «reformar» na versão do Corpo Cronológico.

1500 «hordenaram e instituiram» acrescenta a versão do Corpo Cronológico.

1501 «em estes regnos em a casa de Sam Salvador» acrescenta a versão do Corpo Cronológico.

1502 «e sem escandallo do povo» acrescenta a versão do Corpo Cronológico.

1503 «conservada» na versão do Corpo Cronológico.
} 
mos llembrar ${ }^{1504}$ e prover ao escamdallo e $\mathrm{t}<0>$ rvaçam que desto $<$ se $>$ lhe seguia e por que nos somos bem emformados de seu modo de vida que he a serviço de Deus virtuoso e de bom exempro e que de semelhante cousa se fazer se siguira muito seu desserviço e pola ventura se dara azo a se perder cousa tam samta e tam virtuosa como esta Comgregaçam vos emcomendamos e mandamos que lloguo como esta vos for dada de nossa parte fales ao Sancto Padre e lhe fares rellaçam de todo ho que dito he e do fumdamento desta Comgregaçam e lhe certificay e afirmay que nas $/ / /^{[2]}$ Casas que estam nestes Reynos Nosso Senhor he muyto servido dellas e que todos sam pessoas de vida de toda honestidade e bom exemplo e que sam feytos hos hoficios divinos com grande devaçam e em tall modo que jerallmente toda a gemte he provocada a gramde devaçam e que por isso the pedimos e supllicamos com grande instancia que Sua Samtidade lhe queyra aprovar e comfirmar suas graças e privillejos isemçoes que lhe foram outorgadas pellos Samtos Padres as quaes ate aguora husaram e estam em posse sem embarguo dos mandados que Sua Samtidade tinha passados em comtrayro asy em ho comçillio passado como a quaes quer prelados outorgados e em spiciall da bulla e provisam que outorguou ao bispo d'Evora acerqua da Casa da Comgregaçam de Sam Joham da dita cidade por que pelas inimizades e deferemças que ha antre ho dito Bispo e o Comde de Temtuguall omde jazem os avos do dito Comde que a dita Casa fizeram de novo e a dotaram que estaa muy bem provida e em gramde prefeyçam ornamentada e sempre ho dito Bispo os vexa e mall trata como cousa própria do dito Comde e nom somente pidimos a Sua Samtidade que asy ho comfirme e corrobore e aprove mas que de novo isemte a dita Comgregaçam padres e casas della destes Reynos da jurdiçam dos prelados no que aja Sua Samtidade que fara gramde serviço a Deus e a nos muita merçe. E nas provisões que passarem fazey que sejam postas tais cllausullas de derogaçam ${ }^{1505}$ e quaisquer outras que dem emteyra força a esta nossa supllicaçam, e dizey a Sua Sanctidade que nos avemos por muy certo que aos prelados que a qu'isto tocar e em cujas dioceses as ditas Casas estam receberam gram desprazer desta trovaçam por que pera as suyas próprias comsollacões //[2v.] nom tem outras Casas sallvo estas. Somente ho dito bispo d'Évora pello respeyto que dito he. E muyto vos emcomendamos que trabalhes quamto possivell for por esta espidiçam por que ho receberemos com muyto prazer e serviço e tamto como se a causa fosse propria nossa e por tall ha havemos e nos cremos que vós estais também emformado ${ }^{1506}$ destas Casas e de quanto Nosso Senhor nellas he servido que se podera bem escusar tam llarga emformaçam e os padres mandaram requado pera se dar ho dinheiro que comprir pera expidiçam, e sede certo que nos nom poderes ${ }^{1507}$ em outra cousa mais servir, e ho mais em breve que poderdes nos emviar desto requado, e se com hos primeiros requeridos poder vir ho despacho muyto prazer e serviço nos fares. Escrita em Lixboa a XV dias de Junho. O secretario a fez ${ }^{1508}$ ».

Documento A2 - ANTT - Mosteiro de S. João Evangelista de Xabregas, mç. 22, doc. não numerado.

Roma, [1595, outubro] — Carta do Lóio P.e Pedro de S. João, enviado da Congregação à cúria romana, ao seu Geral, em que dá conta da sua chegada a Roma e das primeiras diligências desenvolvidas.

«//[1] Muito Reverendo Padre

Quinta feira 19 deste Outubro as 2 horas (que são as [...] de Italia) cheguei a esta cidade de Roma, muito bem desposto, e com tantas forsas aja Deos graças que se tevera negoçeado podera logo caminhar para esse Reino.

\footnotetext{
1504 «desta congregaçam» acrescenta a versão do Corpo Cronológico.

${ }^{1505}$ Palavra ausente na versão do Corpo Cronológico.

1506 «do bem» acrescenta a versão do Corpo Cronológico.

1507 «aguora» acrescenta a versão do Corpo Cronológico.

${ }^{1508}$ Esta frase de datação está ausente da versão do Corpo Cronológico.
} 
Vim com muito pressa e perque desejo servir a Congregação. Assi como vinha cheguei a este nosso mosteiro de S. Salvador, adonde não achei o padre Prior que era na cidade, mas os padres me receberão logo com tanta charidade que bem mostravam serem súbditos de tal prelado como depois achei, porque vindo de fora me agazalhou de sorte que parecia V. P., e assi lendo a carta ficou tão contente e edificado della que quasi com lagrimas me disse que me recebia e dava sella e lugar no refeitório sem querer disto couza algua e com tantas couzas que são largas de contar. E isto he mais de agradecer em tempo que por respeito [...] que se fez, não estão aqui senão doze dias que em tudo me favorecera, e sempre dará companheiro com que [...] ponto de meus negoceos, chamasse Dom Archangelo e foi já outra vez Prior deste mosteiro e Geral. A carta de V. P. fez estas couzas, e o grande nome do Bispo Dom Francisco e os padres Francisco da Madre de Deos e os mais daquelle tempo qua deixarão. O padre Prior he daquelle tempo e alguns outros e os outros tem grande noticia das virtudes e prudente modo de proceder dos padres que digo. Estão mui contentes sabendo que o principal negoçeo a que venho he a tratar de S. Lourenço N.P. do qual elles não rezão ainda senão no Estado de Veneza, e assi esta este negoçeo dificultoso, porque ja se pedio huma vez segundo qua me disseram, a instancia do padre Miguel do Spirito Sancto e sahio escuzo, mas avemos de ter bom despacho, e concluindo este capitulo, digo que me espanto tal e tanta charidade como vejo nestes padres, V.P. escreva ao padre Prior, e veja como me hei daver ou o que V.P. lhe há de mandar.//

$/^{[/ 1 v .]}$ 2. Na sexta feira estive em Casa e me fizeram de vestir conforme ao que qua uzão, no sábado fui visitar e dizer missa em hum dos dous altares que estão prope sepulchrum Apostolorum e ahi dei huma pequena oferta per a Congregação. Depois fui dar obediencia a S Mag.de em pessoa de seu agente e lhe dei a carta, mostrousse muito nosso amigo e muito satisfeito de meus princípios. E assi dis que o escrevrá a S. Mag.de.

3. Tenho grandes esperanças de todos nossos negoçeos terem o socesso desejado e espero em Deus que no outro ordinário mandarei novas de alguns. VP os mande encomendar a Deus porque como entramos por esta porta terão effeito. Relevante asaz muito hera carta do Senhor Arcebispo para S. S.de em que se trate da reformação em que esta a nossa Congregação e o proveito que seria aver muitos mosteiros no Reino, esta he a substancea da carta. Tãobem há VP de aver outra de João Gonçalves de Ataide em que como senhor da Atouguia peça a S. Sde. que consinta que se faça mosteiro.

4. O que toca ao mosteiro do Sr. Doutor Lourenço Mourão terá felice expedição pois elle quer fazer o que necessário, tem a saber carta de S. Mag.de em que peça a tal união, e carta do Bispo e cidade de Lamego, e porque Nosso Senhor faz merçe à cristandade de lhe dar muitas vitorias que o Turco sam feitas S. S.de [...] este verão as guerras pera o que he necessário dinheiro, pello que releva que com estremada brevidade me venhão estes papeis e descanse de minha prudencia.

5. Huma das cauzas que apontamos a S. Mag. foi a do Ceremonial que eu avia de fazer consultando muitas duvidas com os Cardeais a que isto pertence, e porque os padres Miguel do Spirito Sancto e Agostinho da Trindade tem escrito muito se me deve mandar primeiro todos seus escritos para eu fazer o que [...] he necessário o que se puder fazer nas noites grandes de Inverno. Venhão as constituições e privilégios, e tudo pode vir per via de Veneza, dirigindo ao Padre Geral ou por via de quem lá achar e parecer melhor.

6. S. S.de veo a 20 deste de sua Villa, ainda não tenho ordem de lhe beijar o pé, porque não foi ainda possível visitar o embaixador nem Cardeaes.

7. Manuel da Fonseca me mostrou boa vontade, e nos ajudara em tudo, e dará o dinheiro conforme ao credito e a necessidade.//

$/^{[2]} 8$. Avizeme VP quantos são os benefícios d'Atouguia, e se o vigário he por si, ou se se pagua do priorado, e o beneficio que está anexo ao priorado se há de ficar com o novo mosteiro, como parece que deve ser, e se há letras de União di tal beneficio ao priorado. 
9. Sendo caso que o Sr. Patriarcha queira proceder com sensuras por os quindénios do Cebal quanto ao que toca aos setenta mil reis de pensão, VP lhe peça de esperar ate o correo seguinte em que mandarei a resolução, e comece de se alegrar que tenho por certa a sentença por nós. A mim me offerecião espera ate se ver o caso mas confiado no Senhor Patriarcha que a dara per hum mês a não aceitei. E quanto assi remirem os quindemios não há que falar porque nem a S. Mag.de se excedeo pera huma igreja de hum seu lugar,

10. Não fica esta carta no livro que já tenho para todas as mais que eu escrever he receber de VP porque não estou ainda para muito tresladar, mas bem me lembrara o principal della para escrever no outro correo para que se este la não chegar saibão no outro o que passa, e sempre me responda a cada capitulo em particular para que eu entenda o que fis bem ou o que ei mester advertencia ou emenda.

11. Avizeme VP se se tratou neste capitulo de aceitarem as constituições novas e os termos em que isto está, porque huma das cauzas que apontamos as [...] foi que as constituições depois de acertadas avião de ser confirmadas por a Santa Sé Apostólica. E tudo o mais que se apontou vem no papel de VP. E assi me mande todas as duvidas que ouver ou nas ceremonias ou em outras cousas que todas decideremos nesta Curia Romana.

12. Soube que nesta capitulo se mandou aos reverendos padres reitores de Villar e do Porto que merquem certa contia (assaz pouca) de livros cada hum anno, se os ditos padres quiserem ser bons mercadores eu serei o agente, mandandome licença e o rol dos livros que querem e hirão ou daqui por Veneza ou de Veneza, mandando logo hir juntos os que lhes cabem no seu triénio, e assi mercão muito mais barato.

13. De Madrid fiz algumas lembranças a VP, e lhe pedi corresse com alguns juros [?], porque os não busquemos sempre no ponto que nos são necessários, VP aja paciencia e trabalhe que o officio isto pede, e não trate de ser continuo no choro que assaz tem bem que fazer em dar ordem do que he necessário aos negócios desta Corte. //

$/ /^{[2 v .]}$ 14. Releve fazer la o preço com o senhor Heitor Mendes dos ducados de Cameras, porque que me falou Manuel da Fonseca em [...] e eu ainda me não informei do que passa nesta Curia nesta materia o que farei logo; agora avizo para que saibamos como se há de proceder nesta materia.

15. VP me manda lhe escreva as cauzas que ouver notáveis, e porque ouve huma grande nova no mes passado a mando empressa com outras tãobem boas e frescas para que de graças a Nosso Senhor por tantas merces.

16. Da absolvição del Rei de França não sei dizer cousa alguma, veremos em que para este negoçeo que se deve muito encomendar a Deus.

17. Oje fui a casa de Gaspar Rivaldo sobcolleitor, o qual estava muito enfermo, mas achei la carta do Senhor Septimeo de Pas muito em nosso favor. Prometeome de escreverlhe que senão tratasse la deste quindénio ate eu não

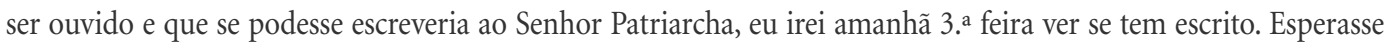
que sejamos absolutos deste quindénio do Cebal [...] toca à pensão, ainda que me disse que sabia que nunca se dá sentença $[. .$.$] a Camera Apostolica, senão que vem a alguma composição quando a [...] he tão clara como a nossa.$

18. Na mesma carta que digo se fala em S. Leonardo aserca da vigairia se he desmembrada do priorado, o qual não eu não entendo, avizeme VP delle para que não sejamos dous procuradores em Roma daqui adiante pois espero em Deus que eu hei de bastar.

19. Com carta do Senhor Dom Rodrigo de Lencastre visitei D. Paulo que he mui pratico e conhecido nesta Curia, e nella pode muito, promete fazer maravilhas, e assi fica a Congregação em maiores obrigações ao Senhor Dom Rodrigo.

20. O [...] de S.to Eloi ha de ter esta ordem, se tratão de prazos fateozins, não há que falar nisto ao Sumo Pontifice, por maiores cauzas que aja. Se tratamos de prazos em vidas como me declarou o Doutor Pero Barbosa farseha facilmente, mas há de vir hum instrumento publico para apresentar com a suplica, do qual conste que estes dinheiro se hade gastar no dormitório, e da falta que há de gazalhados, e como sera mais proveito o edifício 
que se faz, que ter mais de renda o que se poderá acrecentar nas propriedades senão se recebera o dinheiro que se da de entrada, isto venha logo. 21» [restante carta em falta].

Documento A3 - ANTT - Mosteiro de S. João Evangelista de Xabregas, mç. 22, doc. 38.

Roma, 06/01/1599 — Carta do Lóio P.e Pedro de S. João ao Geral da sua Congregação P.e Pedro da Assunção com diversos assuntos relacionados com diligências desenvolvidas na cúria romana, e dando conta de ter estado doente.

\section{$\ll^{[1]}$ Reverendissimo Padre}

A longa enfirmidade minha fez perecer que eu me esquecia de não comprir con minhas obrigaçõis na verdade a doença ao principio foi tal e tam perigosa que não era tempo de lembrar senão de como avia de morrer adoeci em Ferrara a 12 de 7 bro tive 74 dias febre passei muitos travalhos pello caminho e indo neste Roma fico en cama mais ja sem perigo e com esperanca de em poucos dias me alenvantar o que ja fizera senão fora o delubio que veo a esta cidade bespera de natal que deixou a cidade tan umida que os saons adoecem e os doentes tornão a peiorar. Foi grande parte pera eu ter saude achar aqui carta de VP R.ma en que me da licença que me vaya e me mostra hum desejo que tem de me eu ir logo tal é a vontade que tenho de me partir que se estas cartas me tornarão são me fora logo se bem não é ordem de partir de Roma senão en certos tempos e conjunçõis porque sen estas comodidades do tempo em embarcacão vai hum homen mui ariscado eu não tenho nenhum desejo de ver Africa ne $[\mathrm{m}]$ outra terra de moiros ou turcos. Logo tirei de minha mula e dei ordem con que Gonçalo João se fosse pera esse Reino e assi fico somente com a espera de minha pessoa que por ser a quatro meses doente não é pequena en tudo seguirei a ordem que VP.de me da com muito gosto e porque no seguinte correo espero teria forcas pera escrever por mão própria escreverei mais largo quanto ao cura de Sam Bertolameu se fara sem falta mais forão os tempos tais que se não pode espedir nada ate gora e VP.de pode $/ /^{[1 \mathrm{v} .]}$ pode affeituar a união porque nisto não havera defilculdade a qual ouve acai en alcançar que os nosso padres pudessem curara todas nossas igrejas e quanto a esta gracia emportasse a conservação de nosso estado em pessoa lho direi e a mostrarei. Comandei huma copia de hum breve acerca da moderação das missas de Sam Bertolameu pera me avisarem se erão tantas ou mais ou menos das que eu disse no memorial e pedi ao padre Geral passado me avesasse pera o acomodar o que não fez VP.de me avise porque certas cousas se as eu não fizer receo que ninguém as acave pello embaraco de despois ai embarcar os papeis e os por en ordem. Também muitas vezes escrevi que desem a execução do breve despedir en favor de Villar de Frades acerca do seminario e que se parecia que lhe faltavam clausulas ou tinha alguma cousa que não ouvisse me mandassem huma menuta de como o querião tornando-me o breve e que nessa mesma forma que os padres o pedissem o mandaria logo porque Sua S.de fez agora motu próprio et quibuscunque non obstantibus ate oje tive resposta a este particular e não sei pera que é perder cousa que importa e esta alcançada VP.de me avisse disto pera que se acomode.

Quanto a troca d'apresentação dos benefícios d'atouguia não á que falar porque o Papa nunca confirma padroados seculares antes quando é a preposito metem nas bullas citratamen approbationem iuris patronatos secularis quanto menos lhe concederia estes de novo e como digo segundo a enformação de todos os praticos da curia não é cousa en que se possa falar e quanto aos gastos pouco save de dataria e de componendis quem cuida que por averemos pago a composição dos benefícios aviamos de pagar menos se a troca com a parochial ouvesse effeitto antes ficavamos ja obrigados a pagar os quindénios dos benefícios ainda que o senhor Conde tivesse aprezentacão muitas outras rezoins à pera se não tentar isto mas como basta a de não ser fativel não à pera que as apontar. 
Pois o vigairo de Cambra por duvida ao breve peção a elle mesmo huma menuta e assi o mandarei nem aja cuidar que isto esta no ar nem pode aver perigo porque Pedro despois que em a Roma fundou $/ /^{[2]}$ sempre em pedras tam firmes como en todo tempo se vera.

Quanto a letra que eu passei en Novembro do anno passado e foi apresentada a VP.de R.ma esse Julho eu me queixei com o senhor Manoel da Fonseca pois era causa a VP.de entrar en sospeita que eu pasara letra entencio(?) nada mais elle como pratico e experimentado serio de quem tal emaginava dizendo que bem parecia que os padres não atendião mais que as cousas do serviço de Deus que vissem la enhitor mendes a carta de avisso que lhe foi o anno passado no mês de 9 bro e acharia que entonces lha mandara não dou mais rezão a isto porque me corro de desculparme de cousas que nunca emaginei.

De todas as mais cousas darei novas e conta no seguinte ordinairo agora baste saver VP.de que são vivo que é acaz porque não somente ouve ca gerais doencas mais muitas mortes e se temem com esta enundacão outras muitas o falecimento do p.re Miguel do Esperito Santo me causou grande desconcolacão e inda lhe não pude dezir missas mais com o me levantar comprirei com essa obrigacão e dos mais padres que Deus levou pera ssi ao p.re Geral passado me encomende VP.de muito e aos mais padres eu peco a bencão a VP.de R.ma en Roma en dia de Reis de 1599.

Subdito servo de Vossa paternidade Reverendissima

[ASS]: PERO DE SÃO JOÃO»

[no verso da carta] «A R.mo P.re Pero d’Asumcão [Reit]or Geral da Congrega[ção] de S. João Evangelista de Portugal meu p.de etc. Lisboa»

Documento A4 - ANTT - Mosteiro de S. João Evangelista de Xabregas, mç. 22, doc. n. ${ }^{\circ} 41$.

Roma, 20/09/1599 - Carta do Lóio P.e Pedro de S. João ao Geral da sua Congregação P.e Pedro da Assunção com diversos assuntos relacionados com a sua estadia em Roma.

«[1] Reverendissimo Padre

Arrivarão a esta cidade dous correos sem cartas de V.P R.ma e assi não tenho a que responder, nem foi o que há de ser de mim. Estive outra vez em cama tres vezes sangrado, e se bem ando fraco, arriscara me a hir nesta conjunção, e porque acerca de minha partida tenho escrito o quanto baste não direi mais nesta. E tres mezes passados forão muitos para negócios daqui avante se tratão e quanto dos senhores (?) d'atouguia não há que temer, e menos o vigário e de tudo tenho avizado o que baste. Tomei os 150 reis do credito que VP me mandou para me hir, porque depois que em Dezembro passado tornei a Roma de Ferrara gastei sincoenta e sete na botica como consta das contas autenticas que tenho. E como os gastos certos de doença tão comprida forão muitos e muito claros, estou oje em Roma sem ter de que viva, pello que he necessário proverme e sem comprar cavallo não posso negocear porque ainda que fora muito bem desposto, não se negocea a pe nesta cidade. VP [...] outro padre e pode ser com menos gastos servira a Congregação, he já tempo que eu deixe esta boa vida que qua tenho. Em bencão de VP R.ma encomendo de Roma em 20 de 7embro. A Deus os padres me encomendem em sua boa graça. 1599.

Subdito e mui particular servo de Vossa paternidade Reverendissima

[ASS]: PERO DE SÃO JOÃO

[no verso da carta] «Ao R.mo P.re Pero d’Assumpcão Reitor Geral da Congregacão de S. João Evangelista [de Portu]gal meu p.de. Lisboa» 
Documento A5 - ANTT - Mosteiro de S. João Evangelista de Xabregas, mç. 22, doc. 42.

Roma, 17/10/1599 - Carta do Lóio P.e Pedro de S. João ao Geral da sua Congregação P.e Pedro da Assunção com diversos assuntos relacionados com a sua estadia em Roma.

${ }^{[1]}$ Reverendissimo Padre

Ate oje 17 de Outubro não he vindo o correo, e assi não tenho cartas de VP desejandose muito por muitas rezões. A ultima que tive foi de Maio na qual me mandava de que me não partisse, sem outro recado seu, o qual esperava por horas, com esperança de ser oje partido com o senhor Cardeal de Guevara que daqui partio sesta feira na volta de Hespanha. E como sou muito doente desejo hirme porque queria morrer em Portugal. Os guastos são grandes e nem com os muitos remedeos me acho bem. Espero que VP R.ma me mande huma licença muito larga para me hir em fevereiro que já antes não pode ser, e o necessário para o caminho e para viver emtando em Roma porque este mosteiro não me da (nom he rezão) couzas de doente nem médicos nem botica, so o que se pousa aqui he d'aluguer da casa e pão, que ate o vinho compro. E porque ha dar contas, e [...] para as dar deante for(?) que sabe de Roma diguo a VP R.ma que me proveja porque o credito esta suspenso por carta de Heitor Mendes e eu passo mal. Não sofra VP.e e em seu tempo padeça necessidades quem padece tanto e a tantos annos em serviço da Congregação. Com isso me encomendo em bencão de VPe. R.ma de Roma em 17 de Outubro de 1599. Depois de amanhaa faz quatro annos que cheguei a esta Corte

Subdito e especial servo de Vossa paternidade Reverendissima

[ASS]: PERO DE SÃO JOÃO.

[no verso da carta] «Ao R.mo P.re Pero d'Assumpcão Reitor Geral da Congregacão de S. João Evangelista [de Portu]gal meu p.de. Lisboa»

Documento A6 - ANTT - Mosteiro de S. João Evangelista de Xabregas, mç. 22, doc. 43.

Roma, 07/11/1599 - Carta do Lóio P.e Pedro de S. João ao Geral da sua Congregação P.e Pedro da Assunção com diversos assuntos relacionados com a sua estadia em Roma.

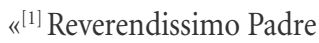

A carta de VP R.ma escrita em 2 de Agosto e recebida em 14 d'Outubro me deu a vida por me dar licença de partirme, o que farei como alcançar o santo jubileu tanto que em fevereiro ou março ouver conjunção. Há 14 mezes que sou doente e ainda este mês estive morrendo de dores de ilhargas e ventosidades [...] chegar a esse Reino eu cuido que em me partindo serei logo são. Fui forssado abrir duas fontes avera 20 dias, e já fazem tal operação que se ve a necessidade que avia. Basta que padeco há muito, e não tenho credito para dinheiro. VP R.ma me proveja asi para pagar os gastos e médicos destes mezes como para a jornada.

O senhor Duarte Manuel pagou os quindénios e mea anata. Tenho pareceres que o vigário d’Atouguia há de pagar este quindénio, tratarei isto, e com o seguinte ordinário avizarei. Por estar sempre doente não tratei as couzas deste vigário e outras, mas agora brevemente farei o possível, e VP se ria do vigário e de suas pretencoes. E peçolhe o cite por virtude da Bulla de Pio V [...] já lhe escrevi e apontei porque como demanda há de fenecer nesta corte. Temos certa a sentenca que não há de se mais que 40 mil reis ou cem escudos computatis omnibus emolumentis etc. Dos anniversarios o breve e [...] e se for necessário emendalo já escrevi que o mandasse e assi outros que indo se acomodara a nosso modo. As novas da elleicão dos padres reitores novos me alegram quanto 
VP sabe. Não me parece tempo de tratar a materia de herdar a Congregação, porque he entrar outra vez a [...] na profissão. Se VP quer que [...] a trate, avize, mas pareceme que sera bom deixar me hir a esse Reino, honde trataremos esta e outras couzas, porque se ingratidões ou palavras de quem falla la sem fundamento me não tirarem a vontade, espero fazer estando nessas partes muitos serviços a Ordem como se ainda estivera em Roma. E na somnana passada comprei huma opa azul por 15 escudos, porque ate oje não tive tenção de vestir outra cor, mas isto não digo a VP senão a essa Congregação para que se corra quem diz o que quer [...] isto fosse não saberia eu que escrever a VP ([...] limitados discursos). [...] a sua licença me esta prometida há dias, em bencao de VP R.ma me e[nco]mendo de Roma em 7 de 9embro 1599

Subdito e particular servo de [Vossa paternidade Reverendissima]

[ASS]: [PERO DE] SÃO JOÃO

[no verso da carta] «Ao R.mo P.re Pero d'Assumpcão Reitor Geral da Congregacão de S. João Evangelista de Portugal meu p.de. Lisboa»

Documento A7 - ANTT - Mosteiro de S. João Evangelista de Xabregas, mç. 22, doc. 44.

Roma, 18/12/1599 - Carta do Lóio P.e Pedro de S. João ao Geral da sua Congregação P.e Pedro da Assunção com diversos assuntos relacionados com a sua estadia em Roma.

«[1] Rmo P.e

A 14 de Xembro chegou correo de 9embro, e nelle tive duas cartas de VP R.ma de 7embro et d'Outubro, com ellas tiva muita consolação a qual me faltava de que chegou o outro dantes em que não tive novas de VP e como eu as estimo como de dignissimo Prelado meu e de fiel amigo a falta dellas me cauza muita tristeza.

Começando no vigário d'Atouguia, pella informação que VP me dá não he necessário emendar o breve de perpetuo silentio, e bem mostra elle dito vigário o pouco que sabe na resposta que da a elle. Tenha VP por certo que ninguém pode dizer nem alegar de subreptitio ou doutra [...] couza Breve de perpetuo silentio sem primeiro alcançar de S. S.de outro Breve que se chama Breve Aperiendi ps (o qual elle nunca alcansarà) e depois se começar a [...], e ate isto ser, sempre avemos de continuar nesta posse de aver vigarios, eVP hade recorrer ao juis do Breve ou ao senhor Conservador que os sentense na posse e em nada aja modo a este vigário porque eu lho [...] enquanto qua estiver e depois que la for muito mais.

$\mathrm{Na}$ quaresmo não the de preguador nem lhe pague e se dar nisso sentença contra nos appelle para esta Corte. Nem o contrato se julguara qua por simoníaco, porque dizem os que qua bem sabem que não foi contrato por mais que tevesse esse nome, e solenidade, sed fuit esplicatio et ratificatio eius quod inerat, conforme a sentença do cabido de Igreja ou de quem a deu. A qual stante duvidasse muito ser os podemos livrar de dar pregador quando não apresentanra os vigário letrado, pois consentira os e executamos a tal sentença dando-lhes preguadores os tempos passados. Isto cauza consentir em couza que ao prezente parecem pouco, e o discurso do tempo as mostra ou faz muito penosas. Mas o R.do Vigario há de pregar ou dar pregador, e a isto lhe faça contar de nos qua vencida, portanto se la o não entenderem assi não se enfade VP e appelle para esta Corte na qual sem falta seremos providos. //

${ }^{[1 v .]}$ Pois o dizer o dito R.do qye o beneficio que era unido a vigararia há de ser seu, he o maior desproposito que nunca se disse em materia beneficial. E não se falle nisto porque me envergonho aver quem cuide que isto pode ser, quanto o comuniquei com nosso avogado que he dos insignes desta Curia; entrou em cólera que eu lhe 
gastava o tempo com couzas empertinentes, e disse mais, quando elle tevera toda a justiça (quanto mais não tenho nem sombra della) quando e com que direito ouvera de acabar a tal demanda. Basta que nisto dos benefícios imponamos perpetuum silentium. Em nada lhe ajão medo, e deixem no esbrabejar que elle se enfadará.

O senhor Doutor nosso conservador attentou muito bem no que VP me aviza acerca da pensão do tal vigário porque quando VP me escreveo [...] que tinha(?) 20 mil reis em dinheiro e dous moios de trigo et [...] mas não falava em estar estimado por o Arcebispo quanto exigia a vicaria, porque senão fora estimado estava mais claro que o dia aver elle se tornar. Agora lhe a estão qua tão bem duvida. Estamos resolutos em o [...]ticar na primeira Congregação do Santo Concilio, e se os tres Cardeaes responderem logo, veremos o que se há de fazer, mais se disserem (como as vezes fazem) que informemos escrevendo in jure et in [...] o faremos com muita diligensia e ficara servindo para todos os mais vigarios como VP manda. [...] se poderemos la provar que quanto o arcebispo estimou e taxou a tal pensão valião comummente naquella villa as couzas mais e quanto mais valião. Em tudo o mais continue a posse em que estamos he não deixe perder huma mínima couza.

Por obviar a estes enfadamentos e pelas cauzas que VP R.ma me escreve ouve com muito trabalho o Breve de podermos apresentar padres nossos no qual vai também de se não aver de fazer concurso nas nossas vicarias. Eu quando trabalhei neste Breve e em outros de que la pode ser não fazem conta, foi com mais importante intento tocante a nossa liberdade, mas tãobem tive in respeito ao que relevava ao bem d'Atouguia, espantome não lerem todo o Breve e não o mostrarem a VP, eu lhe mando o duplicado assinte, pagando a metade do que se paga de [...] para que em tudo [...] que empata atentar nas cauzas. E então essa [...] que não falo mais por não dizer o que cuido.//

${ }^{[2]}$ Lembro outra vez que se elles [...] a VP [...] 30 ducados de Camera que se há de toomar conforme ao mandato de $[. .$.$] que lhe tocando não há de ser senão para esta Casa diante o senhor An[...] e se fosse cazo que$ algum juis quisesse conhecer disto, aja excepção declinatoria fari [...] isto he couza clara, mas as vezes nestas se embaracão nossas partes.

Em uniões de igrejas não há que fallar neste Pontificado. A de Valbom esta escrita [...] de S. S.de que a concedeo, e duas vezes a mandou sobreestar de moto que não esta feita e nisto não posso dizer mais em carta(?).

Quanto [à] minha ida ou premanensia nesta Corte, folguara eu muito de ser de precisão para servir mais sempre nella a Congregação, mas sou muito doente e guasto muito e aventuro(?) a vida que perdendosse não ganha nada a Congregação, e conservandosse espero em Deus que não perca. E porque certas variedades do mundo, e muitas diligensias que tenho uzado no particular principal me tem seguro que neste Pontificado não bullirão mais comnosco, $[\ldots]$ ao menos avendo couza nova e urgente senão decretara couza alguma ate não ser chamado hum procurador do habito desse Reino, he frossado que eu me parta na entrada de Abril sem falta se for vivo, porque [...] que os médicos chamarom [...] mago me cauzão ardentes [...]. VP R.ma aja por boa a licença que me tem dada da qual uzarei ainda que os padres rectores escrevão o contrairo, e lembresse que sirvo há 5 anos, e que dizem qua que sirvo bem. Já por vezes lembrei a VP que não avia dinheito, espero me proveja.

Acerva das indulgencias que pede VP para a Confraria etc. pezame não se poder servir a senhora D. Maria, porque nem em S. João Laterano que he caput urbis et orbis ha mais que hum altar privilegiado; e eu já mandei huma [...] o altar e capella de S. Sebastião do nosso mosteiro da Feira [...] de ser que [...] diguão que não he lá. E quanto as mais //[2v.] indulgencias não as pode porque Vespera de Natal ao abrir da Porta Sancta se sospendem quantas ha na cristandade por esto o anno Santo. Como eu la for verei [...] quem a dita [...] e tanto pode ser que farei em tudo estante em Portugal como em Roma, se o mundo não der volta totalmente.

VP R.ma advirta que em nossas igrejas não deixe publicar indulgencias porque como diguo não as há todo o anno santo. 
Em Ferrara expedi o officio próprio que fis de S. Lourenço Justiniano sobre o qual andei tres annos a se conceder. Com minhas doenças não o pude fazer imprimir a tempo que o mandasse para este anno [...] o estampão e assi a missa e $[\ldots]$ pouco qua a estampa

[...] me escreverão não já quem foi em 7embro a carta com os outros que são muitos, que o P. Miguel do Spiritu Santo era falecido, e eu logo lhe disse la muitas missas em altares priveligiados e sempre depois o encomendo a Deus particularmente como a defuncto, porque lhe tinha obrigação. Agora VP me escreve, preguntei por o Breve ao padre Bertholameu da Conceição e ao padre Miguel do Spiritu Santo, se elle he vivo sera hum dos grandes gostos que terei na vida e com mais gosto hirei a [...]. A todos os padres me encomendo, em Roma donde peço a bencão a VP R.ma em 18 de X.embro que he dia da Expectação mas qua não se faz officio nem se guarda. 1599

Subdito e mui particular servo e amigo

[ASS]: PERO DE SÃO JOÃO» 


\section{QUADROS}

\section{Quadro 1. Lista dos Reitores de S. Jorge em Alga e Gerais da Congregação, da fundação à morte de Eugénio IV (1404-1447)}

\begin{tabular}{|c|c|}
\hline Ano & Prior (até1425)/Reitor \\
\hline 1404-1409 & Luís Barbo ${ }^{1511}$ \\
\hline 1410 & Lourenço Justiniano $^{1512}$ \\
\hline $03 / 09 / 1410$ & Juliano de Manerbio (eleição) $)^{1513}$ \\
\hline $02 / 09 / 1413$ & Lourenço Justiniano (eleição) $)^{1514}$ \\
\hline $03 / 09 / 1414$ & Nicolau de Cremona (eleição) ${ }^{1515}$ \\
\hline ../09/1415 & Agostinho de Pavia (eleição) ${ }^{1516}$ \\
\hline $09 / 12 / 1416$ & Bassiano de Milão (eleição) ${ }^{1517}$ \\
\hline $02 / 04 / 1418$ & Luca de Este (eleição) ${ }^{1518}$ \\
\hline $27 / 04 / 1419$ & Romano de Milão (eleição) ${ }^{1519}$ \\
\hline $19 / 04 / 1420$ & Jerónimo de Piacenzza (eleição) ${ }^{1520}$ \\
\hline $07 / 04 / 1421$ & Lourenço Justiniano (eleição) ${ }^{1521}$ \\
\hline 1422 & Juliano de Manerbio $^{1522}$ \\
\hline 1424 & Lourenço Justiniano $\left(1^{\circ}\right.$ reitor Geral $\left.^{1523}\right)$ \\
\hline $20 / 04 / 1425$ & Luca de Este ${ }^{1524}$ \\
\hline $19 / 03 / 1427$ & Juliano de Manerbio $^{1525}$ \\
\hline
\end{tabular}

\footnotetext{
1511 TOMASINI , 1642.

${ }^{1512}$ ASV - Fundo Veneto I, doc. 969. Trata-se de uma procuração, datada de 8/07/1410, em que Lourenço Justiniano surge como prior da comunidade. Tomasini diz ter sido eleito a 2/9/1409.

${ }^{1513}$ ASV - Fundo Veneto I, doc. 973. Eleição para o ano seguinte.

${ }^{1514}$ ASV - Fundo Veneto I, doc. 978. Eleição para o ano seguinte.

${ }^{1515}$ ASV - Fundo Veneto I, doc. 982. Eleição para o ano seguinte.

${ }^{1516}$ ASV - Fundo Veneto I, doc. 988. Eleição para o ano seguinte.

${ }^{1517}$ ASV - Fundo Veneto I, doc. 992. Eleição para o ano seguinte.

${ }^{1518}$ ASV - Fundo Veneto I, doc. 994. Eleição para o ano seguinte.

${ }^{1519}$ ASV - Fundo Veneto I doc. 996. Eleição para o ano seguinte.

${ }^{1520}$ ASV - Fundo Veneto I, doc. 1003. Eleição para o ano seguinte.

${ }^{1521}$ ASV - Fundo Veneto I, doc. 1009. Eleição para o ano seguinte.

${ }^{1522}$ Segundo Tomasini (cf. TOMASINI, 1642: 108).

${ }^{1523}$ Tomasini afirma que neste ano, e devido ao aumento de número de casas religiosas entregues aos cónegos de Alga, foi necessário a criação de um Geral que presidisse aos destinos da congregação, cargo que estaria ligado ao reitorado da casa fundacional de S. Jorge em Alga. O primeiro foi Lourenço Justiniano, que junta ao protopatriarcado Veneziano o protogeneralato de Alga (cf. TOMASINI, 1642:110).

${ }^{1524}$ ASV - Fundo Veneto I, doc. 1022. Eleição para o ano seguinte. Eleito para substituir Lourenço [Justiniano] de Veneza (assim também chamado em ASV - Fundo Veneto I, doc. 1009) que renunciou. Será Luca de Este a parecer pela primeira vez documentado no cartório de Alga com a designação de reitor, ao ser designado numa admissão de Bartolomeu de Canalli, em que é designado como «reitor geral da sociedade de S. Jorge em Alga da diocese de Castelo» (cf. ASV - Fundo Veneto I, doc.1024). ${ }^{1525}$ ASV - Fundo Veneto I, doc. 1026. Tomasini di-lo eleito em 14/04/1426, cf. TOMASINI, 1642: 116).
} 


\begin{tabular}{|c|c|}
\hline Ano & Prior (até1425)/Reitor \\
\hline $12 / 05 / 1427$ & Lourenço Justiniano (eleição) ${ }^{1526}$ \\
\hline $26 / 04 / 1428$ & Maffeo Contarini ${ }^{1527}$ \\
\hline $23 / 10 / 1429$ & Lourenço Justiniano ${ }^{1528}$ \\
\hline 09/04/1430 & Juliano de Manerbio (eleição) $^{1529}$ \\
\hline 1431 & Lourenço Justiniano (eleição) ${ }^{1530}$ \\
\hline $10 / 05 / 1432$ & Luca de Este (eleição) $)^{1531}$ \\
\hline $23 / 04 / 1433$ & Maffeo Contarini (eleição) ${ }^{1532}$ \\
\hline 08/04/1434 & Juliano de Manerbio (eleição) ${ }^{1533}$ \\
\hline 09/05/1435 & Nicolau de Cremona (eleição) ${ }^{1534}$ \\
\hline $20 / 04 / 1436$ & Pedro Garzoni (eleição) ${ }^{1535}$ \\
\hline $24 / 05 / 1437$ & Maffeo Contarini ${ }^{1536}$ \\
\hline $12 / 05 / 1438$ & Juliano de Manerbio (eleição) ${ }^{1537}$ \\
\hline $17 / 04 / 1439$ & Maffeo Contarini (eleição) ${ }^{1538}$ \\
\hline $11 / 04 / 1440$ & Benedito de Veneza (eleição) ${ }^{1539}$ \\
\hline $12 / 05 / 1441$ & Juliano de Manerbio (eleição) ${ }^{1540}$ \\
\hline $30 / 11 / 1441$ & Maffeo Contarini ${ }^{1541}$ \\
\hline $23 / 04 / 1442$ & Luca de Este (eleição) $)^{1542}$ \\
\hline $02 / 05 / 1443$ & Maffeo Contarini (eleição) ${ }^{1543}$ \\
\hline
\end{tabular}

\footnotetext{
${ }^{1526}$ Idem, ibidem.

${ }^{1527}$ ASV - Fundo Veneto I, doc. 1027, como tal mencionado no documento. Segundo Tomasini terá sido eleito a 19 desse mês (cf. TOMASINI, 1642: 117). Maffeo Contarini, que sucede aqui a Lourenço Justiniano, e que com ele alternará algumas vezes no governo da Congregação, será seu sucessor imediato no patriarcado de Veneza, e por muitos considerado o seu principal discípulo (cf. MENEGHETTI, 1983).

${ }^{1528}$ ASV - Fundo Veneto I, doc. 1031, mencionado como tal no documento. Segundo Tomasini terá sido eleito a 15/04/1429 (cf. TOMASINI, 1642: 118).

${ }^{1529}$ Idem, ibidem.

${ }^{1530}$ Idem, ibidem: 121.

${ }^{1531}$ Idem, ibidem: 135.

1532 Idem, ibidem: 140.

${ }^{1533}$ Idem, ibidem: 177.

${ }^{1534}$ Idem, ibidem: 178.

${ }^{1535}$ Idem, ibidem: 179.

${ }^{1536}$ ASV - Fundo Veneto I, doc. 1046, mencionado como tal no documento. Segundo Tomasini terá sido eleito a 12/04/1437

(cf. TOMASINI, 1642: 179).

${ }^{1537}$ Idem, ibidem: 209.

${ }^{1538}$ Idem, ibidem: 220.

${ }^{1539}$ Idem, ibidem: 223.

${ }^{1540}$ Idem, ibidem: 235.

${ }^{1541}$ Sucedeu a Juliano de Manerbio, morto no exercício do seu reitorado (cf. Idem, ibidem: 245).

${ }^{1542}$ Idem, ibidem.
} 


\begin{tabular}{|c|c|}
\hline Ano & Prior (até1425)/Reitor \\
\hline $09 / 05 / 1444$ & Nicolau de Cremona (eleição) ${ }^{1544}$ \\
\hline $19 / 04 / 1445$ & Bandino de Veneza (eleição) ${ }^{1545}$ \\
\hline $11 / 05 / 1446$ & Maffeo Contarini (eleição) ${ }^{1546}$ \\
\hline $12 / 05 / 1447$ & Jacobelo de Murano $^{1547}$ \\
\hline
\end{tabular}

Quadro 1 A. Resumo do quadro 1

\begin{tabular}{|c|c|}
\hline Reitores de S. Jorge em Alga & No de reitorados \\
\hline Agostinho de Pavia & 1 \\
\hline Bandino de Veneza & 1 \\
\hline Bassiano de Milão & 1 \\
\hline Benedito de Veneza & 1 \\
\hline Jacobelo de Murano & 1 \\
\hline Jerónimo de Piacenzza & 7 \\
\hline Juliano de Manerbio & 7 \\
\hline Lourenço Justiniano & 4 \\
\hline Luca de Este & $7\left(10^{1548}\right)$ \\
\hline Maffeo Contarini & 3 \\
\hline Nicolau de Cremona & 1 \\
\hline Pedro Garzoni & 1 \\
\hline Romano de Milão & 1 \\
\hline
\end{tabular}

${ }^{1543}$ Idem, ibidem: 258.

${ }^{1544}$ Idem, ibidem: 259.

${ }^{1545}$ Idem, ibidem: 263.

${ }^{1546}$ Idem, ibidem.

${ }^{1547}$ ASV - Fundo Veneto I, doc. 1080, mencionado como tal no documento. Segundo Tomasini terá sido eleito a 11/05/1447 (cf. TOMASINI, 1642: 296).

${ }^{1548}$ Desde a morte de Eugénio IV até ser elevado ao episcopado, como 2o Patriarca de Veneza, em 1455, Maffeo Contarini foi Geral dos Cónegos de Alga por três outras vezes (1448, 1451 e 1454), tendo no espaço de 26 anos exercido o generalato da sua Congregação por 10 vezes, ou seja, quase $40 \%$ do tempo total de exercício desse cargo nos anos que medeiam o seu primeiro e último mandato anual como Geral. Para além do generalato terá desempenhado outros ofícios, nomeadamente reitorado de outras Casas da Congregação, caso do reitorado do convento de S. Pedro de Bréscia que exercia no momento da sua eleição episcopal (cf. TOMASINI, 1642: 296, 298, 306, 310). 
Quadro 2. Casas da Congregação de S. Jorge em Alga de Veneza

\begin{tabular}{|c|c|c|c|c|}
\hline Designação & Localização & Tipologia de Aquisição & $\begin{array}{l}\text { Data de } \\
\text { Aquisição }\end{array}$ & 之. \\
\hline $\begin{array}{l}\text { S. Jorge } \\
\text { em Alga }\end{array}$ & $\begin{array}{l}\text { Ilha de Alga, } \\
\text { Veneza }\end{array}$ & $\begin{array}{l}\text { Redução de priorado Agostinho por renúncia de Luís } \\
\text { Barbo. }\end{array}$ & $30 / 10 / 1404$ & 23 \\
\hline $\begin{array}{l}\text { S. João Decollato } \\
\text { (degolado) }\end{array}$ & Pádua & $\begin{array}{l}\text { Redução de mosteiro beneditino, sem vida claustral, por } \\
\text { Albano Micheli, Bispo de Pádua. }\end{array}$ & $12 / 07 / 1406$ & n.i. ${ }^{1549}$ \\
\hline St. ${ }^{\circ}$ Agostinho & Vicenza & $\begin{array}{l}\text { Priorado Agostinho sem vida claustral, entregue a Gabriel } \\
\text { Condulmer em comenda. Renuncia para a Congregação. }\end{array}$ & $1407^{1550}$ & 4 \\
\hline $\begin{array}{l}\text { S. Fermo } \\
\text { e Rustico }\end{array}$ & $\begin{array}{l}\text { Lonigo, } \\
\text { Vicenza }\end{array}$ & $\begin{array}{l}\text { Abadia beneditina sem vida claustral, entregue a Gabriel } \\
\text { Condulmer em comenda. Renuncia para a Congregação. }\end{array}$ & $1407^{1551}$ & 15 \\
\hline $\begin{array}{l}\text { St. }{ }^{\circ} \text { Anjo } \\
\text { (Gabriel) }\end{array}$ & Verona & $\begin{array}{c}\text { Mosteiro sem vida claustral, entregue a António Correr em } \\
\text { comenda. Renuncia para a Congregação. }\end{array}$ & $15 / 01 / 1419$ & 7 \\
\hline S. Gregório & Bolonha & $\begin{array}{l}\text { Redução de mosteiro Agostinho sem vida claustral, } \\
\text { por autoridade do beato Nicolau Albergati, Bispo de } \\
\text { Bolonha }{ }^{1552} \text {. }\end{array}$ & $22 / 04 / 1419$ & 13 \\
\hline S. Tiago & $\begin{array}{l}\text { Monselice, } \\
\text { Pádua }\end{array}$ & $\begin{array}{l}\text { Redução de mosteiro de religiosas beneditinas, por } \\
\text { autoridade de Pietro Marcello, bispo de Pádua. }\end{array}$ & $16 / 12 / 1420$ & 19 \\
\hline S. Tiago & $\begin{array}{l}\text { Mazzara, } \\
\text { Palermo }\end{array}$ & $\begin{array}{l}\text { Cedência do Rei da Sicília, Afonso V de Aragão, a cujo } \\
\text { padroado pertencia, a Henrico de Simeone }{ }^{1553} \text {. }\end{array}$ & $21 / 10 / 1436$ & 17 \\
\hline S. Calogero & $\begin{array}{l}\text { Naro, } \\
\text { Agrigento }\end{array}$ & n.i. ${ }^{1554}$ & n.i. & 7 \\
\hline $\begin{array}{c}\text { N. }{ }^{\text {a }} \text { Sr. }{ }^{\text {a }} \text { della } \\
\text { Serra }\end{array}$ & $\begin{array}{l}\text { Ravanusa, } \\
\text { Agrigento }\end{array}$ & n.i. ${ }^{1555}$ & n.i. & 4 \\
\hline
\end{tabular}

\footnotetext{
${ }^{1549}$ Não é mencionado no quadro sumário das casas da Congregação de Alga aquando da supressão. Terá saído da órbita da Congregação anteriormente.

${ }^{1550}$ Aprovado pelo Papa Gregório XII por carta ao Bispo de Vicenza datada de Siena a 2 dos Idos de Setembro, do 1 Ano do seu pontificado (1407).

${ }^{1551}$ Aprovado pelo Papa Gregório XII por carta ao Bispo de Vicenza datada de Siena a 2 dos Idos de Setembro, do $1^{\circ}$ Ano do seu pontificado (1407).

${ }^{1552}$ A entrega que Albergati faz deste mosteiro não estará longe do facto de neste período Gabriel Condulmer estar em Bolonha, como legado papal. Acerca de Albergati, próximo a Eugénio IV de quem foi muito importante colaborador, veja-se PÀSZTOR, 1960. Condulmer, como Legado, confirmará a comunidade por carta de 19/03/1424.

${ }^{1553}$ Fundador do ramo siciliano da Congregação, nascida por influência de Eugénio IV, que o aprovará por duas bulas de junho de 1437.

${ }^{1554}$ A crónica não menciona esta fundação, um dos três conventos do ramo siciliano mencionados no quadro sumário das casas da Congregação de Alga suprimidas.

${ }^{1555}$ A crónica não menciona esta fundação, um dos três conventos do ramo siciliano mencionados no quadro sumário das casas da Congregação de Alga suprimidas.
} 


\begin{tabular}{|c|c|c|c|c|}
\hline Designação & Localização & Tipologia de Aquisição & $\begin{array}{c}\text { Data de } \\
\text { Aquisiçãa }\end{array}$ & 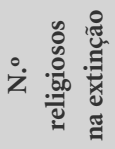 \\
\hline $\begin{array}{l}\text { S. Pedro de } \\
\text { Oliveto }\end{array}$ & Bréscia & $\begin{array}{l}\text { Redução de convento Agostinho, vago por morte do } \\
\text { comendatário, pelo Papa Eugénio IV. }\end{array}$ & $05 / 09 / 1437$ & 24 \\
\hline $\begin{array}{l}\text { S. Jorge em } \\
\text { Braida }\end{array}$ & Verona & $\begin{array}{l}\text { Mosteiro de religiosas beneditinas sem vida claustral, em } \\
\text { comenda, entregue por Eugénio IV à Congregação. }\end{array}$ & 1442 & 24 \\
\hline $\begin{array}{l}\text { St. }{ }^{\text {a }} \text { Maria in } \\
\text { Vanzo }\end{array}$ & Pádua & $\begin{array}{l}\text { Mosteiro beneditino, sem vida claustral, em comenda, } \\
\text { entregue por Eugénio IV à Congregação. }\end{array}$ & $1446^{1556}$ & 14 \\
\hline $\begin{array}{l}\text { St. }{ }^{\text {a }} \text { Maria do } \\
\text { Horto }\end{array}$ & Veneza & $\begin{array}{c}\text { Priorado dos Humiliati, expulsos pelo Patriarca por vida } \\
\text { licenciosa, entregue por Pio II à Congregação para o } \\
\text { reformar. }\end{array}$ & $28 / 10 / 1462$ & 21 \\
\hline $\begin{array}{l}\text { S. Salvador in } \\
\text { Lauro }\end{array}$ & Roma & Doação do cardeal Latino Orsini ${ }^{1557}$. & 1468 & 16 \\
\hline S. Roque & Vicenza & Fundação da comuna de Vicenza entregue à Congregação & $11 / 05 / 1486$ & 12 \\
\hline S. Juliano & Rimini & $\begin{array}{l}\text { Redução de abadia beneditina, sem vida claustral, pelo Papa } \\
\text { Alexandre VI, por renúncia do comendatário }\end{array}$ & $23 / 06 / 1496$ & 12 \\
\hline
\end{tabular}

Fontes: TOMASINI, 1642; ASV - Miscellanea, Armadio VIII, n. ${ }^{4} 41$.

\footnotetext{
${ }^{1556}$ Apesar da doação original do Papa Eugénio IV datar deste ano, problemas com o comendatário só a tornará possível no pontificado de Pio II, em 1458.

${ }^{1557}$ Tomasini atribui a doação à influência do Doge veneziano, que através do seu embaixador predispusera a cúria romana a favor da Congregação (TOMASINI, 1642: 338).
} 
Quadro 3. Privilégios eclesiásticos concedidos às Congregações de S. Jorge em Alga e de S. João Evangelista de Portugal (1404-1580)

\begin{tabular}{|c|c|c|c|c|}
\hline Data & $\begin{array}{l}\text { Tipo de } \\
\text { Privilégio }^{1558}\end{array}$ & Concessor & Beneficiário & Sumário \\
\hline $15 / 03 / 1404$ & Letra apostólica & $\begin{array}{l}\text { Bonifácio IX, } \\
\text { Papa }\end{array}$ & $\begin{array}{l}\text { Luís Barbo, Prior de } \\
\text { S. Jorge em Alga }\end{array}$ & $\begin{array}{l}\text { O Papa ordena ao Bispo de Kysamos que } \\
\text { verifique as premissas apresentadas em súplica } \\
\text { por Luís Barbo, que pede a reforma do seu } \\
\text { priorado de S. Jorge em Alga, procedendo da } \\
\text { melhor forma conforme às premissas. }\end{array}$ \\
\hline $30 / 10 / 1404$ & Executória & $\begin{array}{l}\text { Ângelo } \\
\text { Barbarigo, } \\
\text { Bispo de } \\
\text { Kysamos }\end{array}$ & $\begin{array}{c}\text { Marino Quirino } \\
\text { «et socios eius } \\
\text { clericos seculares }^{1559} »\end{array}$ & $\begin{array}{l}\text { Secularização do priorado Agostinho de } \\
\text { S. Jorge em Alga, constituído em colegiada de } \\
\text { cónegos seculares. }\end{array}$ \\
\hline $27 / 06 / 1407^{1560}$ & Confirmação & $\begin{array}{l}\text { Gregório XII, } \\
\text { Papa }\end{array}$ & $\begin{array}{l}\text { Luís, prior, e o } \\
\text { capítulo secular e } \\
\text { colegiada de S. Jorge } \\
\text { em Alga }\end{array}$ & $\begin{array}{l}\text { Confirmação da Letra Apostólica de Bonifácio } \\
\text { IX e da Executória do Bispo de Kysamos, com } \\
\text { supressão de qualquer defeito. }\end{array}$ \\
\hline $20 / 09 / 1407$ & Concessão & $\begin{array}{l}\text { Gregório XII, } \\
\text { Papa }\end{array}$ & $\begin{array}{l}\text { Cónegos de S. Jorge } \\
\text { em Alga }\end{array}$ & $\begin{array}{l}\text { Privilégio de, por um decénio, se ordenarem } \\
\text { com qualquer Bispo. }\end{array}$ \\
\hline $18 / 10 / 1414$ & Comissão & $\begin{array}{l}\text { Bento XIII, } \\
\text { Papa de } \\
\text { Avinhão }\end{array}$ & $\begin{array}{l}\text { Ordem de S. } \\
\text { Jerónimo }\end{array}$ & $\begin{array}{l}\text { Bula pela qual o pontífice determina a forma } \\
\text { de funcionamento do capítulo geral da Ordem } \\
\text { dos Jerónimos (a exemplo do capítulo da } \\
\text { Cartuxa), da forma de produzir normativa e } \\
\text { determinando a sua isenção do ordinário. }\end{array}$ \\
\hline 01/07/1424 & Comissão & $\begin{array}{l}\text { Martinho V, } \\
\text { Papa }\end{array}$ & $\begin{array}{l}\text { Prior e religiosos do } \\
\text { mosteiro Jerónimo } \\
\text { de Gualadupe }\end{array}$ & $\begin{array}{c}\text { Confirma a graça de Gregório XI aos } \\
\text { Jerónimos de Lupiana de não pagarem décimas } \\
\text { ou outros subsídios, considerando que a graça } \\
\text { abrangia toda a ordem. }\end{array}$ \\
\hline $7 / 08 / 1424$ & Comissão & $\begin{array}{l}\text { Martinho V, } \\
\text { Papa }\end{array}$ & $\begin{array}{l}\text { Fr. Lopo de Olmedo } \\
\text { e religiosos do } \\
\text { mosteiro Jerónimo } \\
\text { de Gualadupe }\end{array}$ & $\begin{array}{l}\text { Confirmação das constituições feitas pelos } \\
\text { Jerónimos, tratando da forma de governo e } \\
\text { estabelecimento de normas, eleição de superior, } \\
\text { bem como disposições sobre liturgia e modo de } \\
\text { vida (hábito, alimentação, etc.). }\end{array}$ \\
\hline
\end{tabular}

\footnotetext{
${ }^{1558}$ Aqui entende-se tipologia não pela origem do privilégio (que poderá ser pontifícia ou régia, e que ficará plasmado item concessor), mas pela sua tipologia documental e pela sua natureza na hierarquia dos privilégios concedidos, nomeadamente no que aos privilégios eclesiásticos respeita diferenciando os que são concedidos diretamente (e aí a sua tipologia será concessão) ou por comissão (a outra tipologia), quando se concede o usufruto de um privilégio que foi concedido a terceiros (cf. BOUDINHON, 1911).

${ }^{1559}$ Executória de 30 de outubro de 1404 transcrita em Livro dos Privilegios concedidos..., 1594:, fl. 1 e segs. Refere-se aos 17 cónegos fundadores que menciona.

${ }^{1560}$ Está datado do quinto dia das calendas de julho do primeiro ano do pontificado de Gregório XII (cf. Idem, ibidem: fl. 5).
} 


\begin{tabular}{|c|c|c|c|c|}
\hline Data & $\begin{array}{c}\text { Tipo de } \\
\text { Privilégio }^{1558}\end{array}$ & Concessor & Beneficiário & Sumário \\
\hline $26 / 04 / 1427$ & Confirmação & $\begin{array}{c}\text { Martinho V, } \\
\text { Papa }\end{array}$ & $\begin{array}{l}\text { Clérigos e presbíteros } \\
\text { que em Portugal } \\
\text { vivem segundo o } \\
\text { modo dos clérigos e } \\
\text { presbíteros de } \\
\text { S. Jorge em Alga }\end{array}$ & $\begin{array}{c}\text { Confirmação da concessão, sanando qualquer } \\
\text { defeito, do mosteiro de Vilar de Frades feita } \\
\text { pelo Arcebispo de Braga, bem como concessão } \\
\text { de indulgência plenária in articulo mortis } \\
\text { a todos os priores ou reitores, bem como } \\
\text { presbíteros da Congregação (commercio et } \\
\text { societate). }\end{array}$ \\
\hline $13 / 05 / 1427$ & Comissão & $\begin{array}{c}\text { Martinho V, } \\
\text { Papa }\end{array}$ & $\begin{array}{l}\text { Ordem de } \\
\text { S. Jerónimo }\end{array}$ & $\begin{array}{l}\text { Concessão, para sustento e aumento do bom } \\
\text { viver dos Jerónimos, de que possam receber } \\
\text { igrejas ou capelas, seculares ou regulares (se } \\
\text { desprovidas de observância), mesmo aceites } \\
\text { fora de capítulo geral, convertidas em casas da } \\
\text { Ordem e a ela incorporadas com usufruto de } \\
\text { todos os privilégios, etc., sem outra autoridade. }\end{array}$ \\
\hline $1 / 06 / 1427$ & Concessão & $\begin{array}{c}\text { Martinho V, } \\
\text { Papa }\end{array}$ & $\begin{array}{l}\text { Clérigos e presbíteros } \\
\text { que em Portugal } \\
\text { vivem segundo o } \\
\text { modo dos clérigos e } \\
\text { presbíteros de } \\
\text { S. Jorge em Alga }\end{array}$ & $\begin{array}{l}\text { Concessão de súplica apresentada, permitindo } \\
\text { que recebessem, para seu sustento, padroado } \\
\text { de paróquias, para que deputariam presbíteros } \\
\text { que curassem as almas e celebrassem o } \\
\text { culto divino, os quais seriam de cura anual e } \\
\text { amovível. Concede por biénio que o reitor, } \\
\text { durante o seu exercício, pudesse ouvir as suas } \\
\text { confissões e absolvê-los de todos os casos, } \\
\text { mesmo os reservados aos bispos. }\end{array}$ \\
\hline $18 / 10 / 1430$ & Concessão & $\begin{array}{c}\text { Martinho V, } \\
\text { Papa }\end{array}$ & $\begin{array}{l}\text { Presbíteros João } \\
\text { Vicente, Martim } \\
\text { Lourenço, Rodrigo } \\
\text { Amado, João } \\
\text { Rodrigues, bem } \\
\text { como clérigos } \\
\text { e laicos a eles } \\
\text { associados, residentes } \\
\text { em Vilar de Frades }\end{array}$ & $\begin{array}{l}\text { Concessão de súplica apresentada para que o } \\
\text { Arcebispo de Braga os recebesse a professar } \\
\text { como cónegos regulares de St. }{ }^{\circ} \text { Agostinho, com } \\
\text { prior eleito trienal e confirmação do ordinário. } \\
\text { Concede que possam receber candidatos à } \\
\text { profissão, bem como casas e igrejas concedidas } \\
\text { de modo canonicamente lícito; e que possam } \\
\text { fazer estatutos para seu governo. Concede os } \\
\text { privilégios, liberdades, isenções e imunidades } \\
\text { dos Jerónimos. Confirma a anexação que o } \\
\text { Arcebispo de Braga fizera da igreja da Várzea } \\
\text { a Vilar. }\end{array}$ \\
\hline
\end{tabular}




\begin{tabular}{|c|c|c|c|c|}
\hline Data & $\begin{array}{c}\text { Tipo de } \\
\text { Privilégio }^{1558}\end{array}$ & Concessor & Beneficiário & Sumário \\
\hline $20 / 01 / 1431$ & Concessão & $\begin{array}{c}\text { Martinho V, } \\
\text { Papa }\end{array}$ & $\begin{array}{l}\text { Presbíteros João } \\
\text { Vicente, Martim } \\
\text { Lourenço, Rodrigo } \\
\text { Amado, João } \\
\text { Rodrigues, bem } \\
\text { como clérigos } \\
\text { e laicos a eles } \\
\text { associados, residentes } \\
\text { em Vilar de Frades }\end{array}$ & $\begin{array}{l}\text { Concessão de súplica apresentada, em que } \\
\text { declaram viver sob regra evangélica no } \\
\text { mosteiro de Vilar de Frades, que estava há } \\
\text { mais de } 20 \text { anos sem observância regular } \\
\text { e que o Arcebispo de Braga entregara em } \\
\text { comenda a João Vicente, onde pretendem } \\
\text { viver colegiados. Confirma a anexação da } \\
\text { igreja da Várzea, e concede que o reitor possa } \\
\text { receber candidatos para viverem livremente } \\
\text { entre eles, que recebam igrejas concedidas de } \\
\text { modo canonicamente lícito, e os privilégios, } \\
\text { liberdades, isenções e imunidades dos } \\
\text { Jerónimos }{ }^{1561} \text {. }\end{array}$ \\
\hline $18 / 05 / 1431$ & Concessão & $\begin{array}{c}\text { Eugénio IV, } \\
\text { Papa }\end{array}$ & $\begin{array}{c}\text { Presbíteros João } \\
\text { Vicente, Martim } \\
\text { Lourenço, Rodrigo } \\
\text { Amado, João } \\
\text { Rodrigues, bem } \\
\text { como clérigos e } \\
\text { laicos viventes em } \\
\text { comum em Vilar de } \\
\text { Frades }\end{array}$ & $\begin{array}{l}\text { Declara que o seu precedessor confirmara } \\
\text { a colação de João Vicente a Vilar de Frades, } \\
\text { ordenando ao Bispo de Viseu e ao geral dos } \\
\text { Jerónimos Fr. Lopo de Olmedo para lhe darem } \\
\text { a posse pacífica e aos clérigos que lhe estavam } \\
\text { associados, o que executara Lopo de Olmedo, } \\
\text { conforme documento exarado, o que confirma } \\
\text { (em resposta a súplica), com supressão de } \\
\text { defeitos e direito a elegerem priores ad nutum, } \\
\text { a produzir normativa própria, e com concessão } \\
\text { dos privilégios dos Cónegos Seculares de } \\
\text { S. Jorge em Alga e dos Jerónimos. }\end{array}$ \\
\hline $6 / 12 / 1431$ & Confirmação & $\begin{array}{c}\text { Eugénio IV, } \\
\text { Papa }\end{array}$ & $\begin{array}{c}\text { Reitor e Capítulo } \\
\text { secular de S. Jorge } \\
\text { em Alga }\end{array}$ & $\begin{array}{l}\text { Confirma as secularizações e constituição em } \\
\text { colegiadas dos mosteiros de S. Jorge em Alga, } \\
\text { S. João Degolado, S. Tiago de Monselice, } \\
\text { St. }{ }^{\circ} \text { Agostinho e S. Rústico e Fermo de } \\
\text { Vicenza, St.o Angelo de Verona e S. Gregório de } \\
\text { Bolonha, feitas por autoridade de Bonifácio IX, } \\
\text { Gregório XII e Martinho V. Confirma tempo e } \\
\text { forma do reitorado, a reunião de capítulo geral } \\
\text { anual, a isenção do ordinário, e a possibilidade } \\
\text { de receber igrejas para colegiadas. }\end{array}$ \\
\hline $6 / 12 / 1431$ & Confirmação & $\begin{array}{c}\text { Eugénio IV, } \\
\text { Papa }\end{array}$ & $\begin{array}{c}\text { Reitor e Capítulo } \\
\text { secular de S. Jorge } \\
\text { em Alga }\end{array}$ & $\begin{array}{l}\text { Confirma todos os privilégios, liberdades, } \\
\text { imunidades e indulgências concedidas à } \\
\text { Congregação pelos seus predecessores, que } \\
\text { alarga às demais casas colegiadas ligadas a Alga, } \\
\text { e aquelas que o vierem a ser. }\end{array}$ \\
\hline
\end{tabular}

${ }^{1561}$ Resumo estabelecido a partir de COSTA, 1970: 596. O documento emitido a partir desta súplica está em Livro dos Privilegios concedidos..., 1594: fl. 19. 


\begin{tabular}{|c|c|c|c|c|}
\hline Data & $\begin{array}{c}\text { Tipo de } \\
\text { Privilégio }^{1558}\end{array}$ & Concessor & Beneficiário & Sumário \\
\hline $23 / 12 / 1431$ & Concessão & $\begin{array}{l}\text { Eugénio IV, } \\
\text { Papa }\end{array}$ & $\begin{array}{l}\text { Prior, prepósitos, } \\
\text { cónegos e pessoas } \\
\text { eclesiásticas da } \\
\text { Congregação de Alga }\end{array}$ & $\begin{array}{c}\text { Concede que os cónegos e religiosos da } \\
\text { Congregação possam ser ordenados nas ordens } \\
\text { por qualquer bispo católico em comunhão com } \\
\text { a Sé Apostólica, nos tempos devidos e nas suas } \\
\text { capelas e igrejas, ou qualquer outro lugar digno } \\
\text { onde estejam. }\end{array}$ \\
\hline $6 / 02 / 1432$ & Concessão & $\begin{array}{l}\text { Eugénio IV, } \\
\text { Papa }\end{array}$ & Congregação de Alga & $\begin{array}{c}\text { Concede à Congregação isenção das décimas } \\
\text { eclesiásticas. }\end{array}$ \\
\hline $23 / 05 / 1437$ & Concessão & $\begin{array}{l}\text { Eugénio IV, } \\
\text { Papa }\end{array}$ & $\begin{array}{c}\text { Cónegos da } \\
\text { Congregação de } \\
\text { S. Jorge em Alga }{ }^{1562}\end{array}$ & $\begin{array}{l}\text { Concede que os reitores da Congregação } \\
\text { possam dispensar de votos de peregrinação a } \\
\text { Compostela e Roma, bem como de votos de } \\
\text { entrar em religião, que podem ser suspensos } \\
\text { se entrarem e perseverarem na Congregação. } \\
\text { Estabelece que qualquer confessor possa } \\
\text { absolver os religiosos da Congregação in } \\
\text { articulo mortis, mesmo em casos reservados } \\
\text { à Santa Sé. Estebelece outros direitos } \\
\text { absolutórios, que especifica no articulado. }\end{array}$ \\
\hline $6 / 12 / 1437$ & Confirmação & $\begin{array}{l}\text { Eugénio IV, } \\
\text { Papa }\end{array}$ & Congregação de Alga & $\begin{array}{l}\text { Confirma à Congregação todos os privilégios } \\
\text { e imunidades que lhe foram concedidas, bem } \\
\text { como as que se concedem aos clérigos seculares } \\
\text { em geral. }\end{array}$ \\
\hline $21 / 01 / 1440$ & Concessão & $\begin{array}{l}\text { Eugénio IV, } \\
\text { Papa }\end{array}$ & Congregação de Alga & $\begin{array}{l}\text { Concede que os religiosos e leigos que vivem } \\
\text { na Congregação, atendendo ao seu modo de } \\
\text { vida exemplar, estejam isentos da autoridade } \\
\text { inquisitorial, seja ela da Santa Sé ou do } \\
\text { ordinário. }\end{array}$ \\
\hline $19 / 07 / 1440$ & Concessão & $\begin{array}{l}\text { Eugénio IV, } \\
\text { Papa }\end{array}$ & $\begin{array}{c}\text { Cónegos e Clérigos } \\
\text { da Congregação de } \\
\text { Alga }\end{array}$ & $\begin{array}{l}\text { Concede aos cónegos a liberdade de } \\
\text { escolherem confessor, que os possa absolver } \\
\text { de todos os casos e irregularidades, mesmo } \\
\text { os reservados à Santa Sé, com excepção de } \\
\text { homicídio voluntário, mutilação de membros } \\
\text { e bigamia. Concede que em tempo de interdito } \\
\text { possam celebrar os ofícios divinos, sem sino } \\
\text { e voz baixa. Suprime defeitos de nascença } \\
\text { na admissão à ordenação e aos reitorados. } \\
\text { Concede, quando seja para bom governo, que } \\
\text { possam ceder bens em enfiteuse ou aliená-los. }\end{array}$ \\
\hline
\end{tabular}

${ }^{1562}$ O Papa dirige esta Letra Apostólica a todas as pessoas da Congregação de S. Jorge em Alga de Veneza, bem como aos dos demais conventos que nomeia individualmente. 


\begin{tabular}{|c|c|c|c|c|}
\hline Data & $\begin{array}{c}\text { Tipo de } \\
\text { Privilégio }^{1558}\end{array}$ & Concessor & Beneficiário & Sumário \\
\hline $29 / 08 / 1440$ & Concessão & $\begin{array}{c}\text { Eugénio IV, } \\
\text { Papa }\end{array}$ & Congregação de Alga & $\begin{array}{l}\text { Concede, em resposta a súplica, que tenham } \\
\text { altar privilegiado nas suas igrejas, em que } \\
\text { possam usufruir das indulgências próprias das } \\
\text { igrejas estacionárias }{ }^{1563} \text { em Roma, segundo o } \\
\text { costume da cúria romana. }\end{array}$ \\
\hline $15 / 09 / 1440$ & Concessão & $\begin{array}{c}\text { Eugénio IV, } \\
\text { Papa }\end{array}$ & Congregação de Alga & $\begin{array}{c}\text { Concede, em resposta a súplica, faculdade } \\
\text { aos sacerdotes da Congregação para, nas suas } \\
\text { igrejas, ouvirem confissões e absolver, bem } \\
\text { como dispensar em casos de reserva episcopal } \\
\text { de foro de consciência. }\end{array}$ \\
\hline $28 / 09 / 1440$ & Concessão & $\begin{array}{c}\text { Eugénio IV, } \\
\text { Papa }\end{array}$ & $\begin{array}{c}\text { Sociedade de } \\
\text { Presbíteros Seculares } \\
\text { viventes em comum } \\
\text { em S. Salvador de } \\
\text { Vilar de Frades, } \\
\text { sob obediência e } \\
\text { correcção de D. João } \\
\text { [Vicente], Bispo de } \\
\text { Lamego }\end{array}$ & $\begin{array}{l}\text { Concede o que em súplica lhe pedia o duque } \\
\text { de Coimbra, Infante D. Pedro, governador do } \\
\text { reino de Portugal, sobre o hospital dedicado aos } \\
\text { santos Paulo, Clemente e Elói, de Lisboa, com } \\
\text { obrigação de alma pelo instituidor (Domingos } \\
\text { Jardo) e pelo rei D. Diniz (de que o instituidor } \\
\text { fora chanceler) celebrada por } 12 \text { capelães, e } \\
\text { com sustento de } 20 \text { estudantes pobres. Manda, } \\
\text { em letra dirigida ao Abade de Alcobaça, } \\
\text { que confirme as premissas e, se verdadeiras, } \\
\text { entregasse o hospital e todos os seus pertences à } \\
\text { Congregação de Vilar de Frades. }\end{array}$ \\
\hline $3 / 11 / 1440$ & Concessão & $\begin{array}{c}\text { Eugénio IV, } \\
\text { Papa }\end{array}$ & Congregação de Alga & $\begin{array}{l}\text { Concede, em resposta a súplica da Congregação } \\
\text { que excomungados ou interditos pudessem } \\
\text { celebrar os ofícios divinos nas suas igrejas sem } \\
\text { incorrerem em penas, desde que não estejam } \\
\text { denunciados. }\end{array}$ \\
\hline $7 / 06 / 1442$ & Concessão & $\begin{array}{c}\text { Eugénio IV, } \\
\text { Papa }\end{array}$ & Congregação de Alga & $\begin{array}{l}\text { Concede, atendendo à dedicação da } \\
\text { Congregação à liturgia e ao serviço pastoral, } \\
\text { bem como ao bom exemplo de vida dado pelos } \\
\text { religiosos, que os cónegos presentes e futuros, } \\
\text { seus conventos e demais bens, bem como os } \\
\text { seus servidores alargados e colonos, a isenção } \\
\text { perpétua de qualquer imposição ou subsídio } \\
\text { eclesiástico. }\end{array}$ \\
\hline $11 / 09 / 1443$ & Comissão & $\begin{array}{c}\text { Eugénio IV, } \\
\text { Papa }\end{array}$ & $\begin{array}{l}\text { Mosteiro de } \\
\text { Guadalupe, da } \\
\text { Ordem de } \\
\text { S. Jerónimo }\end{array}$ & $\begin{array}{l}\text { Concede ao mosteiro de Guadalupe a isenção } \\
\text { de pagar, ao ordinário paroquial, os direitos } \\
\text { funerários daqueles que se sepultam no seu } \\
\text { interior. }\end{array}$ \\
\hline $16 / 11 / 1443$ & Comissão & $\begin{array}{c}\text { Eugénio IV, } \\
\text { Papa }\end{array}$ & $\begin{array}{l}\text { Ordem de } \\
\text { S. Jerónimo }\end{array}$ & $\begin{array}{l}\text { Confirma ao mosteiro Jerónimo de Guadalupe } \\
\text { a isenção de qualquer subsídios ou imposições, } \\
\text { sejam pontifícias, régias ou outras. }\end{array}$ \\
\hline
\end{tabular}

${ }^{1563}$ Acerca das igrejas estacionárias e de altares indulgenciários veja-se o que diz COELHO, 1950: pontos 27, 889, 945, 946. 


\begin{tabular}{|c|c|c|c|c|}
\hline Data & $\begin{array}{c}\text { Tipo de } \\
\text { Privilégio }^{1558}\end{array}$ & Concessor & Beneficiário & Sumário \\
\hline $12 / 03 / 1445$ & Confirmação & $\begin{array}{c}\text { Eugénio IV, } \\
\text { Papa }\end{array}$ & $\begin{array}{c}\text { Cónegos da } \\
\text { Congregação de } \\
\text { S. Salvador de Vilar } \\
\text { de Frades }\end{array}$ & $\begin{array}{l}\text { Confirma aos Cónegos de Vilar de Frades a } \\
\text { união e incorporação do mosteiro que fizera } \\
\text { Martinho V a partir da colação de mestre } \\
\text { João Vicente na igreja de Vilar e na da Várzea } \\
\text { pelo Arcebispo de Braga. Confirma todos } \\
\text { os privilégios, isenções, etc., concedidos } \\
\text { à Congregação de S. Jorge em Alga e aos } \\
\text { Jerónimos, como se lhes fossem concedidos. } \\
\text { Atendendo ao que lhe fora dito por D. João } \\
\text { Vicente, Bispo de Viseu, e pela Congregação } \\
\text { sobre as disputas com o Arcebispo de Braga } \\
\text { por causa da isenção do ordinário e pagamento } \\
\text { das décimas, e ao que a rainha D. Isabel e os } \\
\text { cónegos suplicavam, determina a extinção das } \\
\text { causas e cancela penas e censuras eclesiásticas } \\
\text { aplicadas, anulando os capítulos feitos pelo } \\
\text { Arcebispo e qualquer determinação que } \\
\text { não esteja de acordo com a normativa e os } \\
\text { privilégios, de que para notícia manda fazer } \\
\text { uma cópia por notário e autenticada pelo Bispo } \\
\text { de Castelo (que então era Lourenço Justiniano). }\end{array}$ \\
\hline $19 / 03 / 1445$ & Concessão & $\begin{array}{c}\text { Eugénio IV, } \\
\text { Papa }\end{array}$ & $\begin{array}{l}\text { Sociedade de } \\
\text { Presbíteros Seculares } \\
\text { viventes em comum } \\
\text { em S. Salvador de } \\
\text { Vilar de Frades, } \\
\text { sob obediência e } \\
\text { correcção de D. João, } \\
\text { Bispo de Viseu }\end{array}$ & $\begin{array}{l}\text { Concede a súplica apresentada por Isabel, } \\
\text { rainha de Portugal, e anula a obrigação } \\
\text { existente no hospital de S. Paulo, S. Clemente } \\
\text { e St. }{ }^{o} \text { Elói de Lisboa de sustentar } 20 \text { escolares } \\
\text { pobres. }\end{array}$ \\
\hline $17 / 01 / 1446$ & Concessão & $\begin{array}{c}\text { Eugénio IV, } \\
\text { Papa }\end{array}$ & $\begin{array}{l}\text { Reitores e cónegos da } \\
\text { Congregação de Alga }\end{array}$ & $\begin{array}{l}\text { O Papa declara que a Congregação tem } \\
\text { estatuído a duração anual das prelaturas das } \\
\text { Casas e a eleição pelos cónegos em capítulo } \\
\text { geral, concedendo que se entre capítulos vagar } \\
\text { algum cargo possam o reitor e cónegos de Alga } \\
\text { nomear cónego para suprir a vacância, sem } \\
\text { necessidade de qualquer outra confirmação. }\end{array}$ \\
\hline $30 / 03 / 1446$ & Concessão & $\begin{array}{c}\text { Eugénio IV, } \\
\text { Papa }\end{array}$ & $\begin{array}{c}\text { Congregação de } \\
\text { S. Salvador de Vilar } \\
\text { de Frades }\end{array}$ & $\begin{array}{l}\text { Letra aos Arcebispo de Compostela, Abade } \\
\text { de Alcobaça e Prior de St. a Cruz de Coimbra, } \\
\text { em que diz que a pedido da Congregação } \\
\text { de S. Salvador de Vilar de Frades e para a } \\
\text { proteger, e aos seus bens, de qualquer pessoa } \\
\text { ou autoridade que os possa de algum modo } \\
\text { afetar, concede-lhes juízes conservadores nos } \\
\text { destinatários da Letra. }\end{array}$ \\
\hline
\end{tabular}




\begin{tabular}{|c|c|c|c|c|}
\hline Data & $\begin{array}{c}\text { Tipo de } \\
\text { Privilégio }^{1558}\end{array}$ & Concessor & Beneficiário & Sumário \\
\hline $22 / 09 / 1446$ & Concessão & $\begin{array}{l}\text { Eugénio IV, } \\
\text { Papa }\end{array}$ & Congregação de Alga & $\begin{array}{l}\text { Determina o pontífice, ante queixas da } \\
\text { Congregação contra ex-cónegos que } \\
\text { continuavam a usar o hábito e levavam vida } \\
\text { repreensível em seu descrédito, que aqueles } \\
\text { que abandonarem a Congregação deixem de } \\
\text { usar o hábito azul no prazo máximo de } 10 \\
\text { dias depois de tomarem conhecimento da } \\
\text { bula, e que no futuro os cónegos que deixem a } \\
\text { Congregação larguem logo o hábito, sob pena } \\
\text { de excomunhão. Se não o fizerem em } 15 \text { dias, } \\
\text { concede poder à Congregação para requerer } \\
\text { apoio das autoridades eclesiásticas e braço } \\
\text { secular para forçar a tal. }\end{array}$ \\
\hline $17 / 10 / 1446$ & Concessão & $\begin{array}{l}\text { Eugénio IV, } \\
\text { Papa }\end{array}$ & Congregação de Alga & $\begin{array}{c}\text { Concede à Congregação, por período de } 20 \\
\text { anos, a isenção das décimas eclesiásticas dos } \\
\text { bens que entrarem na sua posse, incluindo } \\
\text { as que estivessem em dívida, pondo fim } \\
\text { a controvérsia sobre se estes bens seriam } \\
\text { considerados na isenção de que a Congregação } \\
\text { gozava. }\end{array}$ \\
\hline $25 / 10 / 1446$ & Motu Propio & $\begin{array}{l}\text { Eugénio IV, } \\
\text { Papa }\end{array}$ & Congregação de Alga & $\begin{array}{c}\text { Perdoa à Congregação as taxas em dívida à } \\
\text { Câmara Apostólica. }\end{array}$ \\
\hline $23 / 01 / 1447^{1564}$ & Concessão & $\begin{array}{l}\text { Nicolau V, } \\
\text { Papa }\end{array}$ & $\begin{array}{c}\text { Congregação de } \\
\text { S. Salvador de Vilar } \\
\text { de Frades }\end{array}$ & $\begin{array}{c}\text { Referindo-se à concessão de Eugénio IV } \\
\text { de 30/03/1446, concede (a pedido de João } \\
\text { [Vicente] Bispo de Viseu e da Congregação) } \\
\text { que os conservadores, pela sua distância } \\
\text { em relação à Casa de Vilar de Frades, sejam } \\
\text { substituídos pelos Abade de Salzedas e priores } \\
\text { de S. Vicente de Fora e da Colegiada de } \\
\text { Guimarães. }\end{array}$ \\
\hline $20 / 04 / 1448$ & Confirmação & $\begin{array}{l}\text { Nicolau V, } \\
\text { Papa }\end{array}$ & $\begin{array}{l}\text { D. João [Vicente], } \\
\text { Bispo de Viseu, } \\
\text { reitor e cónegos da } \\
\text { Congregação de } \\
\text { S. Salvador de Vilar } \\
\quad \text { de Frades }\end{array}$ & $\begin{array}{l}\text { Confirma a graça de Eugénio IV, datada de } \\
\qquad 12 / 03 / 1445(v d \text {. supra). }\end{array}$ \\
\hline $20 / 04 / 1448$ & Concessão & $\begin{array}{l}\text { Nicolau V, } \\
\text { Papa }\end{array}$ & $\begin{array}{c}\text { Congregação de } \\
\text { S. Salvador de Vilar } \\
\text { de Frades }\end{array}$ & $\begin{array}{c}\text { Para cumprimento e salvaguarda da } \\
\text { confirmação anterior, o Papa nomeia por } \\
\text { conservadores da Congregação o Abade de } \\
\text { Alcobaça, o Abade de Sarzedas e o D. Prior da } \\
\text { Colegiada de Guimarães. }\end{array}$ \\
\hline
\end{tabular}

\footnotetext{
${ }^{1564}$ Data inscrita na versão impressa da bula (Livro dos Privilegios concedidos..., 1594: fl. 44v.), mas certamente errada, pois
} Nicolau V só foi eleito a 6 de março de 1447. 


\begin{tabular}{|c|c|c|c|c|}
\hline Data & $\begin{array}{c}\text { Tipo de } \\
\text { Privilégio }^{1558}\end{array}$ & Concessor & Beneficiário & Sumário \\
\hline $1 / 08 / 1451$ & Concessão & $\begin{array}{l}\text { Nicolau V, } \\
\text { Papa }\end{array}$ & $\begin{array}{l}\text { Congregação de } \\
\text { S. Salvador de Vilar } \\
\text { de Frades }\end{array}$ & $\begin{array}{l}\text { Depois de historiar o contexto dos diplomas } \\
\text { de Nicolau V de 20/04/1448, o documento } \\
\text { descreve como tendo os Cónegos de Vilar } \\
\text { estado na posse do seu mosteiro e nele } \\
\text { vivendo ao modo de Alga, o Arcebispo de } \\
\text { Braga manteve a contenda, sob o argumento } \\
\text { de os privilégios de que usavam eram sub- } \\
\text { reptícios, contra o que protestaram em Roma } \\
\text { os procuradores da Congregação P.e João de } \\
\text { Arruda e Fernando de Pombeiro, ouvidos os } \\
\text { quais e os testemunhos de Afonso e Isabel reis } \\
\text { de Portugal, decide o Papa avocar a si a causa, } \\
\text { extingui-la e impor sobre ela perpétuo silêncio. }\end{array}$ \\
\hline $23 / 07 / 1452$ & Concessão & $\begin{array}{l}\text { Nicolau V, } \\
\text { Papa }\end{array}$ & Congregação de Alga & $\begin{array}{c}\text { Exime a Congregação da perda dos feudos das } \\
\text { suas igrejas e mosteiros de que não tinha ainda } \\
\text { feito investidura. }\end{array}$ \\
\hline $29 / 07 / 1452$ & Confirmação & $\begin{array}{l}\text { Nicolau V, } \\
\text { Papa }\end{array}$ & Congregação de Alga & $\begin{array}{c}\text { Confirma todos os privilégios, liberdades, } \\
\text { isenções, etc., concedidos à Congregação por } \\
\text { Martinho V e Eugénio IV. }\end{array}$ \\
\hline $16 / 11 / 1458$ & Confirmação & Pio II, Papa & Congregação de Alga & $\begin{array}{l}\text { Confirma, a pedido da Congregação, a Letra } \\
\text { de Eugénio IV, datada de 19/07/1440, com } \\
\text { matéria absolutória concedida aos reitores da } \\
\text { Congregação, em casos reservados à Santa Sé. }\end{array}$ \\
\hline $9 / 03 / 1461$ & $\begin{array}{c}\text { Confirmação e } \\
\text { Concessão }\end{array}$ & Pio II, Papa & $\begin{array}{l}\text { Congregação de } \\
\text { S. João Evangelista de } \\
\text { Xabregas }\end{array}$ & $\begin{array}{l}\text { Confirma, a pedido do rei D. Afonso V e de } \\
\text { acordo com a vontade testamentária da rainha } \\
\text { D. Isabel, a ereção de um mosteiro de cónegos } \\
\text { da Congregação de Vilar de Frades, sob a } \\
\text { invocação e S. João Evangelista, no eremitério } \\
\text { de S. Bento de Xabregas, pertencente ao } \\
\text { mosteiro de Alcobaça, do qual é canonicamente } \\
\text { separado. Concede que seja a cabeça da } \\
\text { Congregação, que passará a designar-se de } \\
\text { S. João Evangelista de Xabregas. Concede ao } \\
\text { novo mosteiro gozar dos mesmos privilégios } \\
\text { de que gozava Vilar de Frades, bem como os } \\
\text { Jerónimos. }\end{array}$ \\
\hline $13 / 09 / 1466$ & Concessão & Paulo II, Papa & Congregação de Alga & $\begin{array}{c}\text { Concede, a pedido da Congregação, juízes } \\
\text { conservadores nas pessoas do Patriarca de } \\
\text { Veneza e no abade de S. Jorge Maior de Veneza. }\end{array}$ \\
\hline $18 / 05 / 1480$ & Sentença & $\begin{array}{l}\text { Guilherme, } \\
\text { Cardeal } \\
\text { d'Estouteville, } \\
\text { Camerlengo }\end{array}$ & $\begin{array}{c}\text { Congregação } \\
\text { de Alga }\end{array}$ & $\begin{array}{l}\text { Julga a matéria de precedências em procissões, } \\
\text { considerando que os Cónegos de Alga por } \\
\text { seculares podem nas procissões públicas } \\
\text { seguir com os clérigos seculares e não com os } \\
\text { regulares. }\end{array}$ \\
\hline
\end{tabular}




\begin{tabular}{|c|c|c|c|c|}
\hline Data & $\begin{array}{c}\text { Tipo de } \\
\text { Privilégio }^{1558}\end{array}$ & Concessor & Beneficiário & Sumário \\
\hline $18 / 03 / 1485$ & Confirmação & Inocêncio VIII & $\begin{array}{c}\text { Congregação } \\
\text { de Alga }\end{array}$ & $\begin{array}{l}\text { Confirma } 12 \text { privilégios concedidos por seus } \\
\text { antecessores em matéria eleitoral }{ }^{1565} \text {, judicial e } \\
\text { disciplinar }{ }^{1566} \text {, defesa de bens e direitos }{ }^{1567} \text {. }\end{array}$ \\
\hline $5 / 09 / 1495$ & Comissão & $\begin{array}{l}\text { Alexandre VI, } \\
\text { Papa }\end{array}$ & $\begin{array}{l}\text { Ordem de } \\
\text { S. Jerónimo }\end{array}$ & $\begin{array}{l}\text { Concede que os Jerónimos possam ordenar-se } \\
\text { com qualquer bispo católico em comunhão } \\
\text { com a Santa Sé, fora dos tempos prescritos, em } \\
\text { três dias domingos, ou santos, sucessivos. }\end{array}$ \\
\hline $7 / 04 / 1514$ & Confirmação & Leão X, Papa & Congregação de Alga & $\begin{array}{c}\text { Confirma o privilégio concedido por Eugénio } \\
\text { IV de os sacerdotes da congregação poderem } \\
\text { absolver de casos reservados aos bispos e } \\
\text { administrar a comunhão, que tinha sido } \\
\text { anulado pelas disposições do V Concílio de } \\
\text { Latrão (1512-1517) }\end{array}$ \\
\hline $20 / 08 / 1518$ & Concessão & Leão X, Papa & $\begin{array}{l}\text { Congregação de } \\
\text { S. João Evangelista }\end{array}$ & $\begin{array}{c}\text { Concede à Congregação isenção da obrigação } \\
\text { de participarem em procissões }{ }^{1568} \text {. }\end{array}$ \\
\hline $1 / 04 / 1519$ & Comissão & Leão X, Papa & $\begin{array}{l}\text { Mosteiro } \\
\text { portugueses da } \\
\text { Ordem de } \\
\text { S. Jerónimo }\end{array}$ & $\begin{array}{l}\text { Concede que, para os proteger de abusos } \\
\text { por parte de qualquer pessoa ou autoridade, } \\
\text { possam as comunidades escolher juízes } \\
\text { conservadores, e que não respondam perante } \\
\text { outras justiças que não eles. }\end{array}$ \\
\hline $26 / 11 / 1523$ & Confirmação & $\begin{array}{l}\text { Clemente VII, } \\
\text { Papa }\end{array}$ & $\begin{array}{l}\text { Reitor e Cónegos da } \\
\text { Casa de } \\
\text { S. João de Évora, } \\
\text { da Congregação de } \\
\text { S. Jorge em Alga (sic) }\end{array}$ & $\begin{array}{l}\text { Confirma-lhes a concessão dada por Leão X } \\
\text { aos reitores, cónegos, clérigos e demais pessoas } \\
\text { da Congregação de Alga, com privilégio de } \\
\text { não poderem ser forçados a participarem em } \\
\text { procissões, atendendo ao que a comunidade } \\
\text { suplicava, pois o bispo de Évora tentara forçá- } \\
\text { los a participar em procissões extraordinárias, } \\
\text { tendo-os excomungado. O Papa confirma o } \\
\text { privilégio e declara-os livres da excoumunhão } \\
\text { ou qualquer pena eclesiástica. }\end{array}$ \\
\hline
\end{tabular}

${ }^{1565}$ Que o reitor tenha poder ordinário espiritual e material sem mais solenidade que a eleição, que não possa ser imediatamente reeleito para o mesmo reitorado, não obstante possa ser eleito para outros reitorados ou interpoladamente para o mesmo.

${ }^{1566}$ Direito dos reitores excomungar, suspender e absolver os religiosos, proibição de qualquer juiz (mesmo os conservadores ou nomeados pela Santa Sé) de conhecerem de causas internas da Congregação, que pertencem ao capítulo geral ou em quem deputar, e que este possa reservar causas para si, que as suas causas sejam conhecidas rapidamente pelo conservadores ou por juízes que tenham por convenientes (direito de escolher foro), não obstante a constituição de Bonifácio VIII sobre o não recurso a juízes que distem da da cidade e diocese mais de um dia de distância, mantendo-se a impossibilidade de juízes fora desses limites poderem proceder contra eles, dispensando de duas decisões conciliares e constituições apostólicas que entravavam estes privilégios.

${ }^{1567}$ Obrigação dos religiosos que saírem da Congregação restituírem todos os bens desta em 15 dias.

${ }^{1568}$ Mencionada em letra de Clemente VII, de 26/11/1523 (cf. Livro dos Privilegios concedidos..., 1594: fl. 59). 


\begin{tabular}{|c|c|c|c|c|}
\hline Data & $\begin{array}{c}\text { Tipo de } \\
\text { Privilégio }^{1558}\end{array}$ & Concessor & Beneficiário & Sumário \\
\hline $4 / 12 / 1523$ & Confirmação & $\begin{array}{c}\text { Clemente VII, } \\
\text { Papa }\end{array}$ & Congregação de Alga & $\begin{array}{l}\text { Confirma verbalmente, ao reitor do mosteiro } \\
\text { de S. Salvador em Lauro e a seu pedido, os } \\
\text { privilégios da Congregação concedidos pelos } \\
\text { seus predecessores. }\end{array}$ \\
\hline $25 / 02 / 1533$ & Concessão & $\begin{array}{c}\text { António, } \\
\text { Cardeal Pucci }\end{array}$ & $\begin{array}{l}\text { Congregação de } \\
\text { S. João Evangelista }\end{array}$ & $\begin{array}{l}\text { Concede, com mandato do Papa Clemente VII, } \\
\text { a súplica que a Congregação apresentara, de } \\
\text { as suas casas poderem em tempo de interdito } \\
\text { celebrar missa e ofícios divinos com toques } \\
\text { de sino e portas abertas em algumas festas } \\
\text { principais }{ }^{1569} \text {, bem como celebrar os funerais } \\
\text { dos cónegos e seus familiares com a devida } \\
\text { pompa, e celebrar as missas e ofícios de } \\
\text { domingos e dias santos. }\end{array}$ \\
\hline $29 / 11 / 1533$ & $\begin{array}{l}\text { Concessão e } \\
\text { comissão }\end{array}$ & $\begin{array}{l}\text { Capítulo e } \\
\text { Cónegos de S. } \\
\text { João de Latrão }\end{array}$ & $\begin{array}{l}\text { Geral e cónegos da } \\
\text { Congregação de } \\
\text { S. João Evangelista }\end{array}$ & $\begin{array}{l}\text { Concedem a petição apresentada pelos cónegos } \\
\text { lóios de serem recebidos sob a protecção e } \\
\text { jurisdição do cabido de S. João de Latrão, com } \\
\text { todas as indulgências e privilégios de que esta } \\
\text { igreja e comunidades a ela ligadas gozam }{ }^{1570} \text {, } \\
\text { com obrigação de pagarem censo anual de um } \\
\text { ducado de ouro. }\end{array}$ \\
\hline $30 / 05 / 1534$ & Concessão & $\begin{array}{l}\text { Capítulo e } \\
\text { Cónegos de S. } \\
\text { João de Latrão }\end{array}$ & $\begin{array}{l}\text { Geral e cónegos da } \\
\text { Congregação de } \\
\text { S. João Evangelista }\end{array}$ & $\begin{array}{l}\text { Isenção do pagamento anual de censo de um } \\
\text { ducado de ouro, instituído em reconhecimento } \\
\text { de domínio na aceitação de } 29 / 11 / 1533 \text {. }\end{array}$ \\
\hline $23 / 01 / 1537^{1571}$ & Comissão & Paulo III, Papa & Congregação de Alga & $\begin{array}{l}\text { Concede, por comissão, que a Congregação } \\
\text { de Alga goze dos privilégios da Congregação } \\
\text { beneditina Cassinense (a de St. }{ }^{a} \text { Justina de } \\
\text { Pádua), que explicita }{ }^{1572} \text {. }\end{array}$ \\
\hline $13 / 02 / 1538$ & Comissão & Paulo III, Papa & Congregação de Alga & $\begin{array}{l}\text { Concede, por comissão e em viva voz segundo } \\
\text { declarava em carta o cardeal Giacomo } \\
\text { Simoneta, aos religiosos, laicos e familiares da } \\
\text { Congregação de Alga as indulgências plenárias } \\
\text { concedidas à Congregação Cassinense. }\end{array}$ \\
\hline $23 / 05 / 1547$ & Concessão & Paulo III, Papa & Congregação de Alga & $\begin{array}{l}\text { Concede, em viva voz e segundo declarava em } \\
\text { carta o cardeal protector Uberto Gambara, } \\
\text { que todas as igrejas da Congregação tivessem } \\
\text { altar privilegiado, conforme o pedido de antigo } \\
\text { reitor-geral. }\end{array}$ \\
\hline
\end{tabular}

${ }^{1569}$ As festas do Senhor, Anunciação, Conceição e Assunção, e os santos João Baptista, Pedro e Paulo, Tiago, André e João Evangelista.

${ }^{1570}$ Estes privilégios podem ver-se em Livro dos Privilegios concedidos..., 1594: fl. 63v. e segs.

${ }^{1571}$ Segundo a datação de Livro dos Privilegios concedidos..., 1594, já segundo TOMASINI, 1642, que transcreve o mesmo privilégio, a data seria 14/01/1537.

${ }^{1572}$ Desta bula foi pedido um treslado pelo Geral e cónegos Lóios, em Roma, representados pelo P.e Francisco Mauri, cónego de S. Salvador em Lauro, da Congregação de Alga. A impressão desta bula está em Livro dos Privilegios concedidos..., 1594 : fl. 68. 


\begin{tabular}{|c|c|c|c|c|}
\hline Data & $\begin{array}{c}\text { Tipo de } \\
\text { Privilégio }^{1558}\end{array}$ & Concessor & Beneficiário & Sumário \\
\hline $28 / 10 / 1554$ & Confirmação & Júlio III, Papa & Congregação de Alga & $\begin{array}{l}\text { Confirma os privilégios da Congregação } \\
\text { concedidos pelos seus predecessores. }\end{array}$ \\
\hline $25 / 02 / 1559$ & Concessão & $\begin{array}{c}\text { Rainúncio, } \\
\text { cardeal } \\
\text { Farnese }\end{array}$ & $\begin{array}{l}\text { Congregação de } \\
\text { S. João Evangelista }\end{array}$ & $\begin{array}{l}\text { Declara que por parte da Congregação fora } \\
\text { exposto que detinha o padroado de paróquias, } \\
\text { para cura das quais nomeava capelães aos } \\
\text { quais determinava salários, matéria na qual se } \\
\text { intrometiam os visitadores do ordinário, para } \\
\text { o que suplica fosse dado remédio. Concede, } \\
\text { por autoridade pontíficia, que a Congregação } \\
\text { possa livremente determinar o salário dos seus } \\
\text { capelães, com a cláusula de estes serem idóneos } \\
\text { e aprovados pelo ordinário. }\end{array}$ \\
\hline $15 / 03 / 1560$ & Confirmação & Pio IV, Papa & Congregação de Alga & $\begin{array}{c}\text { Confirma os privilégios da Congregação } \\
\text { concedidos pelos seus predecessores. }\end{array}$ \\
\hline $15 / 01 / 1563$ & Confirmação & Pio IV, Papa & Congregação de Alga & $\begin{array}{l}\text { Confirma, na sequência do fim do concílio de } \\
\text { Trento e de modo mais amplo,os privilégios } \\
\text { da Congregação concedidos pelos seus } \\
\text { predecessores, bem como a concessão por } \\
\text { comissão dos privilégios da Congregação } \\
\text { Cassinense concedida por Paulo III. }\end{array}$ \\
\hline $11 / 12 / 1569$ & $\begin{array}{l}\text { Concessão/ } \\
\text { confirmação }\end{array}$ & Pio V, Papa & Congregação de Alga & $\begin{array}{c}\text { Concede que, apesar de forçados a tomar votos, } \\
\text { os cónegos de Alga mantenham o título e } \\
\text { preeminência de cónegos seculares, bem como } \\
\text { os privilégios e imunidades concedidos pelos } \\
\text { Papas. }\end{array}$ \\
\hline $23 / 12 / 1569$ & Determinação & Pio V, Papa & Congregação de Alga & $\begin{array}{l}\text { Determina, ante a pretensão dos cónegos } \\
\text { Lateraneneses de que os cónegos de Alga pela } \\
\text { sua nova condição de professos deveriam } \\
\text { ocupar o lugar de congregação regular mais } \\
\text { recente na hierarquia de precedências, que a } \\
\text { Congregação mantivesse o lugar que ocupava. }\end{array}$ \\
\hline $22 / 05 / 1571$ & Confirmação & Pio V, Papa & Congregação de Alga & $\begin{array}{c}\text { Confirma, por motu proprio, que os cónegos } \\
\text { de Alga mantenham o título e preeminência } \\
\text { de cónegos seculares, precedendo sobre os } \\
\text { regulares. }\end{array}$ \\
\hline
\end{tabular}




\begin{tabular}{|c|c|c|c|c|}
\hline Data & $\begin{array}{c}\text { Tipo de } \\
\text { Privilégio }^{1558}\end{array}$ & Concessor & Beneficiário & Sumário \\
\hline $13 / 08 / 1573$ & Sentença & $\begin{array}{c}\text { Cardeal D. } \\
\text { Henrique; } \\
\text { Legado, juiz } \\
\text { deputado pelo } \\
\text { Papa Gregório } \\
\text { XIII }\end{array}$ & $\begin{array}{l}\text { Congregação de } \\
\text { S. João Evangelista }\end{array}$ & $\begin{array}{c}\text { Por letra de } 1 / 06 / 1573, \text { Gregório XIII encarrega } \\
\text { o cardeal D. Henrique de julgar o pedido dos } \\
\text { cónegos lóios para, apesar das determinações } \\
\text { de Pio V e do Concílio de Trento que } \\
\text { obrigavam os clérigos seculares a constituírem } \\
\text { património para ordenação, poderem manter } \\
\text { o seu modo de vida de clérigos seculares } \\
\text { viventes em comum, sem património próprio } \\
\text { nem votos solenes, podendo-se ordenar sem } \\
\text { património a título da Congregação. } \\
\text { Julgando o caso, o cardeal D. Henrique, tendo } \\
\text { ouvido os argumentos da Congregação, } \\
\text { considerou-os procedentes e determinou } \\
\text { quese mantivesse a norma da Congregação } \\
\text { e os seus religiosos se pudessem ordenar de } \\
\text { ordens sacras sem património, guardando o } \\
\text { seu modo de vida. }\end{array}$ \\
\hline $28 / 10 / 1579$ & Confirmação & $\begin{array}{c}\text { Gregório XIII, } \\
\text { Papa }\end{array}$ & $\begin{array}{l}\text { Congregação de } \\
\text { S. João Evangelista }\end{array}$ & $\begin{array}{l}\text { Confirma, a pedido da congregação, } \\
\text { determinações feitas no capítulo geral dos } \\
\text { Lóios: que os reitores e provisores no final } \\
\text { do seu triénio tivessem de estar um ano } \\
\text { a obediência sem poderem ser eleitos em } \\
\text { prelazias que não o generalato; que aqueles que } \\
\text { forem isentos de ofícios da Congregação por } \\
\text { capítulo geral ou visitação não possam depois } \\
\text { ser eleitos; que os reitores ou oficiais possam } \\
\text { dispor de alfaias ou paramentos litúrgicos. }\end{array}$ \\
\hline $3 / 12 / 1588$ & Concessão & Sisto V, Papa & $\begin{array}{l}\text { Congregação de } \\
\text { S. João Evangelista }\end{array}$ & $\begin{array}{l}\text { Declara o Pontífice que pelos Lóios fora } \\
\text { dado conta que pela determinação da } \\
\text { Congregação do Concílio, ao interpretar os } \\
\text { decretos de Trento, que mandava prover as } \\
\text { paróquias detidas por instituições regulares } \\
\text { em curas seculares, escolhidos por concurso } \\
\text { e examinados pelo ordinário, que servissem } \\
\text { como vigários perpétuos, tinha levado a que a } \\
\text { Congregação sofresse por parte dos ordinários } \\
\text { pressões para seguir estas directrizes. Concede } \\
\text { o Pontífice que possa a Congregação discernir } \\
\text { sobre o provimento de curas das suas } \\
\text { paróquias, podendo nomear entre os seus } \\
\text { religiosos, e podendo organizar o exame dos } \\
\text { candidatos e fazer a instituição dos curas por } \\
\text { bispo seu ou, caso não existindo nenhum, em } \\
\text { bispo exterior à Congregação. }\end{array}$ \\
\hline
\end{tabular}




\begin{tabular}{|c|c|c|c|c|}
\hline Data & $\begin{array}{c}\text { Tipo de } \\
\text { Privilégio }^{1558}\end{array}$ & Concessor & Beneficiário & Sumário \\
\hline $23 / 11 / 1596^{1573}$ & Concessão & $\begin{array}{c}\text { Clemente VIII, } \\
\text { Papa }\end{array}$ & $\begin{array}{c}\text { Congregação de } \\
\text { S. João Evangelista }\end{array}$ & $\begin{array}{c}\text { Concede que se possam ordenar de ordens } \\
\text { sacras por qualquer Bispo católico, fora das } \\
\text { contínuos, sem observar os tempos de espera } \\
\text { prescritos por Trento. }\end{array}$ \\
\hline
\end{tabular}

Fontes:TOMASINI, 1642; Livro dos Privilegios concedidos..., 1594; COSTA, 1970.

\footnotetext{
${ }^{1573}$ Apesar desta concessão se situar já fora do período cronológico da tese e deste quadro, inclui-se pelo facto de ser citada por TOMASINI, 1642: 631, que defende ser aplicável a Alga pela comunicabilidade entre as Congregações, sendo a primeira vez que se observa um privilégio lóio ser reinvindicado pela Congregação matricial.
} 
Quadro 4. Casas da Congregação de S. João Evangelista ${ }^{1574}$

\begin{tabular}{|c|c|c|}
\hline \multicolumn{3}{|c|}{ Fundações/Doações dos conventos dos Cónegos de S. João Evangelista } \\
\hline Convento & Fundador/Doador & Data \\
\hline S. Salvador de Vilar de Frades & $\begin{array}{l}\text { D. Fernando da Guerra, } \\
\text { Arcebispo de Braga }\end{array}$ & 1425 \\
\hline S. Jorge de Recião ${ }^{1575}$ & D. João Vicente, como Bispo de Lamego & 1436 \\
\hline Santo Elói de Lisboa & Infante D. Pedro, Regente de Portugal & 1440 \\
\hline S. João Evangelista de Xabregas & D. Afonso V, Rei de Portugal ${ }^{1576}$ & $>1455<1461$ \\
\hline S. João de Évora & D. Rodrigo de Melo, Conde de Olivença & 1485 \\
\hline Sta. Maria da Consolação do Porto & $\begin{array}{l}\text { D. Violante Afonso (sob inspiração do Bispo do Porto } \\
\text { D. João de Azevedo) }\end{array}$ & 1490 \\
\hline Na Sra. da Assunção de Arraiolos & $\begin{array}{l}\text { João Garcês, fidalgo da Casa de D. João II e sua mulher } \\
\text { D. Leonor de Abreu }\end{array}$ & 1526 \\
\hline Colégio de Coimbra & $\underbrace{1577}$ & 1548 \\
\hline Espírito Santo da Vila da Feira & D. Diogo Forjaz Pereira, Conde da Feira & 1560 \\
\hline
\end{tabular}

\footnotetext{
${ }^{1574}$ Este quadro foi retirado de FALCÃO, 2009, e elaborado com base em TAVARES, 1999.

1575 Transferido para o Convento de Santa Cruz de Lamego em 1595/1596, na sequência da doação do Dr. Lourenço Mourão Homem.

1576 Seguindo as indicações testamentárias da rainha D. Isabel, sua mulher.

1577 O colégio dos Lóios de Coimbra foi fundação da própria congregação, tendo funcionado provisoriamente anexo ao hospital de Coimbra e desde 1631 em Casa própria.
} 


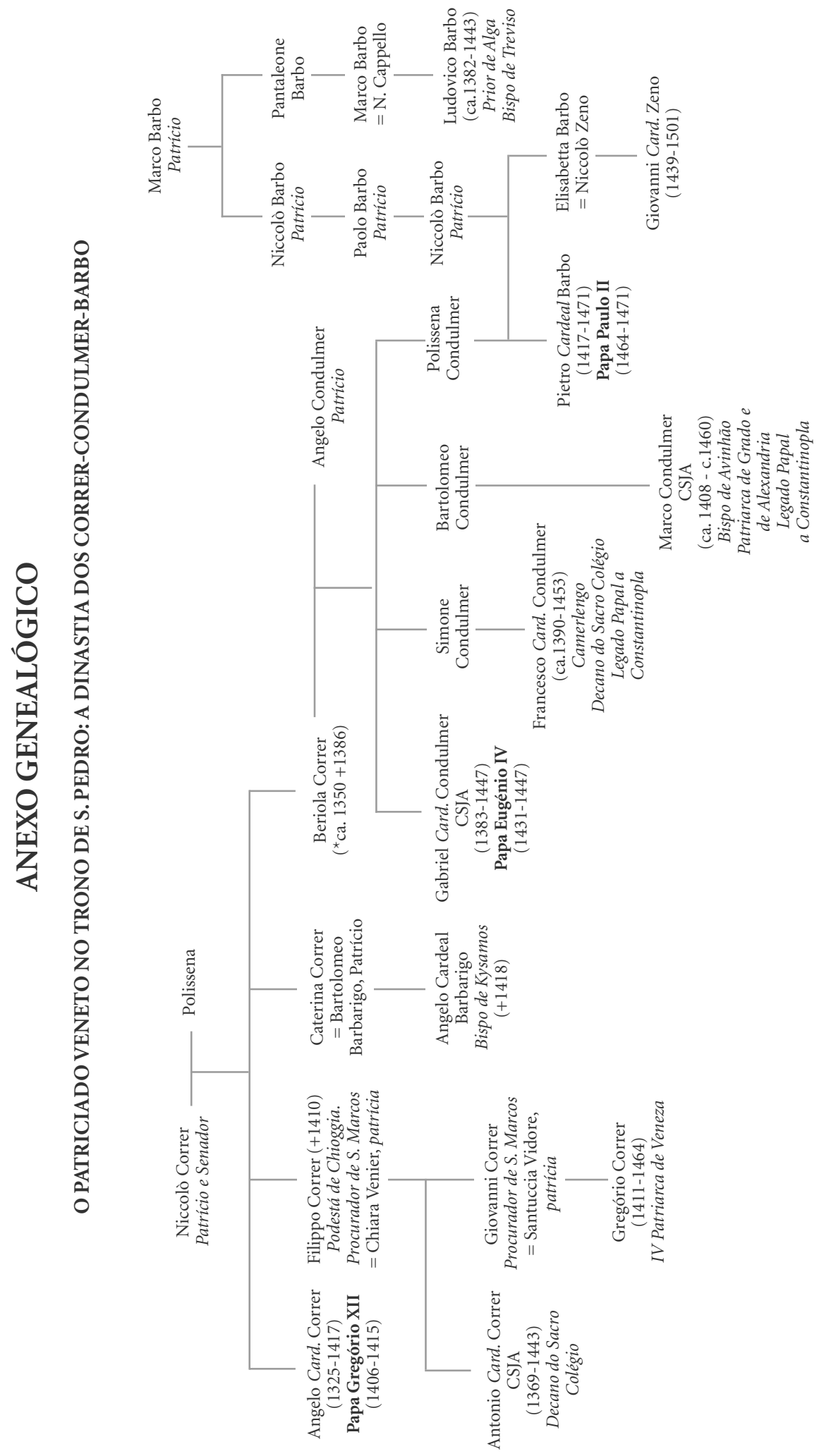

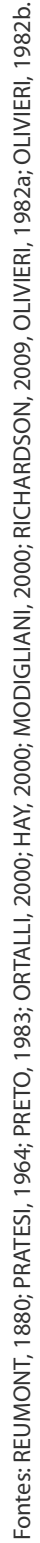




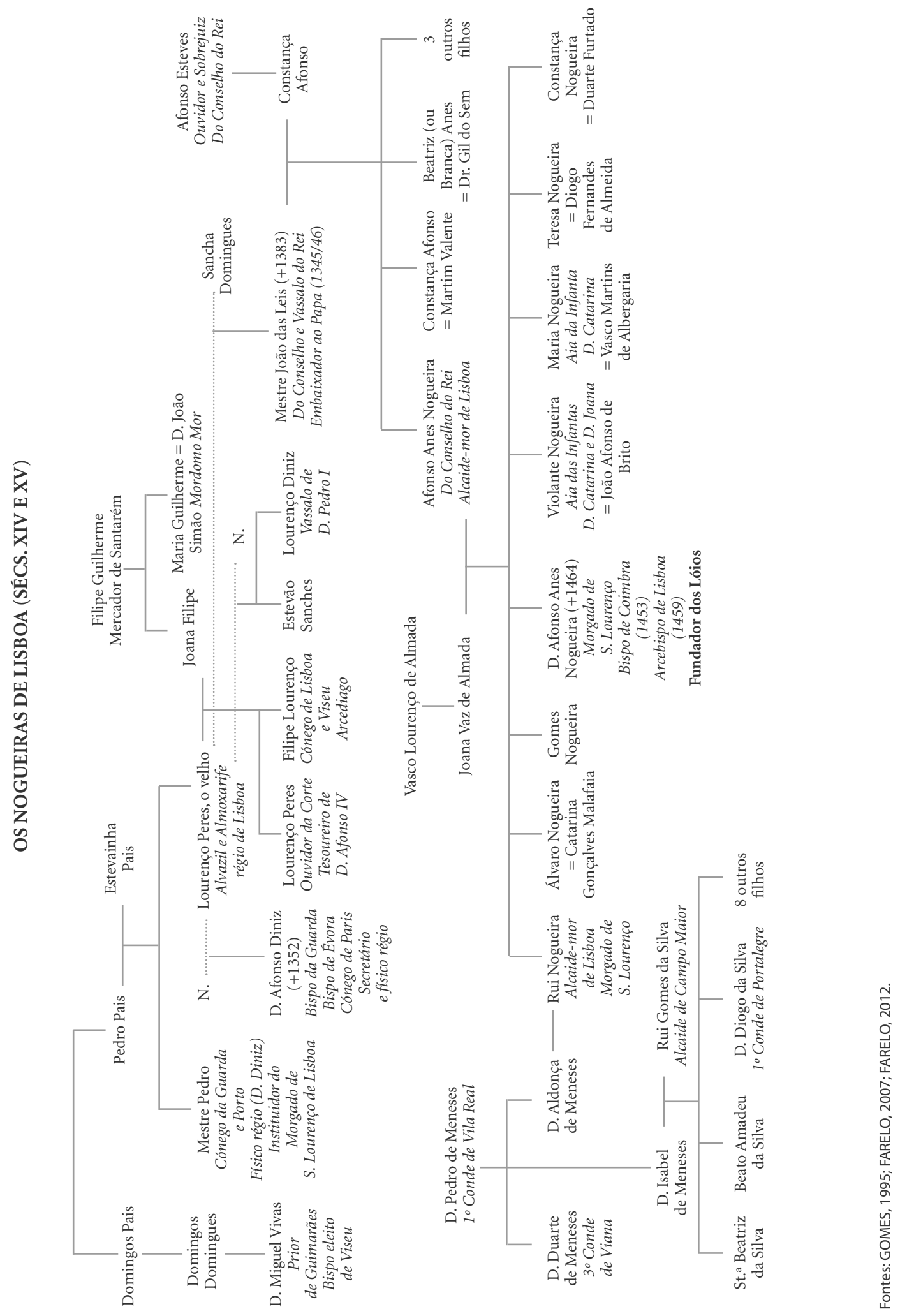




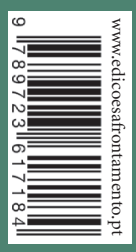

COLEÇÃO «TESES UNIVERSITÁRIAS», N.$^{\circ} 10$

PRÉMIOO CITCEM/AFRONTAMENTO 2017

\section{ECCLESIA SEMPER REFORMANDA \\ A CONGREGACẼO DOS LÓIOS \\ E A REFORMA DA IGREJA \\ (ITÁLIA, PORTUGAL E ÁFRICA - 1404-1580)}

NUNO DE PINHO FALCÃO

CITCEM

CENTRO DE INVESTIGACÁO TRANSDISCIPLINAR

CULTURA, ESPAÇO E MEMÓRIA ב $1 \begin{aligned} & \text { Fundação } \\ & \text { eara a Ciência }\end{aligned}$

\section{U.PORTO}

FLUP FACULDADE DE LETRAS

Cofinanciado por:

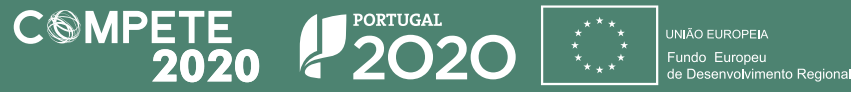

